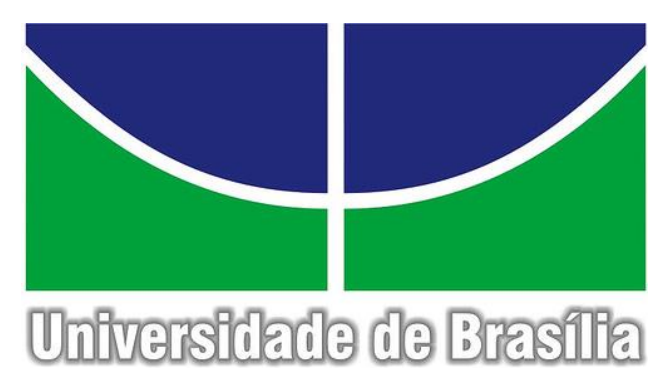

\title{
MESTRES ESTRANGEIROS; OPERARIADO NACIONAL: RESISTÊNCIAS E DERROTAS NO COTIDIANO DA MAIOR FÁBRICA TÊXTIL DO RIO DE JANEIRO (1890 - 1920)
}

Carlos Molinari Rodrigues Severino

Universidade de Brasília

Departamento de História

Professora Dra.:

Teresa Cristina de Novaes Marques 
MESTRES ESTRANGEIROS; OPERARIADO NACIONAL: RESISTÊNCIAS E DERROTAS

NO COTIDIANO DA MAIOR FÁBRICA TÊXTIL DO RIO DE JANEIRO (1890 - 1920)

\author{
Carlos Molinari Rodrigues Severino
}

Dissertação apresentada ao Departamento de História do Instituto de Ciências Humanas da Universidade de Brasília para a obtenção do grau de mestre em História.

Corrigida por:

Prof. Dra. Teresa Cristina Novaes Marques - Orientadora

Prof. Dra. Neuma Brilhante Rodrigues

Prof. Dr. Carlos Gabriel Guimarães

Brasília 
Dedico este trabalho

aos meus pais,

Silvia e Erivan, que sempre me apoiaram. 


\section{Agradecimentos}

Gostaria de agradecer a quem muito me ajudou na confecção desta dissertação.

À minha Orientadora, professora Teresa Marques, que demonstrou grande interesse e conhecimento no assunto, sempre sugerindo leituras, opinando, corrigindo e guiando a pesquisa, com toda a sua experiência acadêmica. Sem os seus conselhos e a sua atenção, seria impossível organizar este trabalho.

Ao sr. Benevenuto Rovere, grande amigo do Grêmio Literário José Mauro de Vasconcelos, em Bangu, que, desde que eu era menino, sempre me permitiu o acesso aos arquivos, às fotografias, permitindo que eu pesquisasse inicialmente o clube de futebol e, posteriormente, a vida social do bairro. Muitas das fotos aqui reproduzidas pertencem ao acervo desta instituição de memória. Além disso, ainda me emprestou o livro Rio de Janeiro operário - natureza do Estado, conjuntura econômica, condições de vida e consciência de classe, que foi de grande utilidade.

Ao jovem historiador Pedro Henrique Soares Santos que, ainda na época da graduação, quando regressava de Campinas, me presenteou com o livro Cadernos Arquivo Edgard LeuenrothImigração, volume $15, n^{\circ} 27$, de conteúdo bastante relevante para esta pesquisa.

Ao também historiador Nei Jorge dos Santos Júnior, que me enviou a sua dissertação de mestrado, impressa em formato de livro A construção do sentimento local: o futebol nos arredores de Bangu e Andaraí (1914-1923). Por mais que nossas pesquisas nunca tenham se cruzado, encontramos as mesmas fontes e chegamos às mesmas conclusões.

Ao banguense Gustavo Santos, formado em História pela Universidade Federal Fluminense (UFF), que gentilmente me enviou um livro em formato virtual: A insurreição anarquista no Rio de Janeiro e, também em PDF, a dissertação de mestrado A greve geral e a insurreição anarquista de 1918 no Rio de Janeiro: um resgate da atuação das associações de trabalhadores. Que o nosso Bangu continue vencendo!

Ao cavaleiro Rodrigo Estrella de Carvalho, que após muito esforço, conseguiu uma foto do seu trisavô, o temível Capitão Jorge Estrella, que tanto medo despertou nos operários de Bangu no século XIX.

Ao professor Francisco José Corrêa Martins, da Universidade Federal Rural do Rio de Janeiro (UFRRJ), que tive o prazer de conhecer em Assunção, no Paraguai. Suas dicas sobre sites que continham informações sobre o operariado britânico e leituras sobre a exploração das crianças na Grã-Bretanha foram únicas e imprescindíveis.

Ao pesquisador do Fluminense F. C., Carlos José dos Reis Santoro, que me enviou os documentos a cerca da família do mestre têxtil James Hartley, incluindo sua certidão de casamento, datada de 1898 . 
Ao curitibano Kevin Hall, que correu muito atrás e conseguiu documentos e certidões de casamento do escocês Andrew Procter e a carteira de trabalho do inglês James Stirling, seus antepassados aqui no Brasil.

À sra. Arilza Silva, sobrinha de Patrick Donohoe, que guardou por anos e anos alguns documentos relativos a seu tio e que, de bom grado, apresentou-me tais preciosidades em um encontro em 2014, em Bangu.

À arqueóloga Maria Fernanda Regis, que gastou seus conhecimentos em língua britânica para me ajudar na reta final do trabalho.

Ao sr. Rodrigo Guedes, do Arquivo da Memória Operária do Rio de Janeiro, situado no Instituto de Filosofia e Ciências Sociais da UFRJ que me enviou a edição digitalizada de $A$ Voz do Trabalhador, de 15 de novembro de 1909, justamente a que falava (mal) da Fábrica Bangu.

Ao genealogista Rod O’Donoghue, inglês, que me abriu os olhos, ainda em 2010, enviando o que encontrou nos censos britânicos sobre o técnico têxtil escocês Thomas Donohoe. Foi ali que todo esse projeto começou, com certeza.

Ao pesquisador escocês James McViccar, que foi me dando detalhes das viagens transoceânicas feitas por súditos de Vossa Majestade. Graças a seu minucioso trabalho de catalogação, foi possível descobrir em quais vapores saíram alguns dos homens que vieram desenvolver a indústria em Bangu.

À diretora da Biblioteca de East Refrenwshire, Amanda Robb, que me enviou algumas páginas do livro East Kilbride: the history of parish and village, com informações preciosas sobre a Busby Printworks, a fábrica onde trabalhou Thomas Donohoe, na Escócia.

À Biblioteca Nacional, no Rio de Janeiro, que fez um grande favor a todos os pesquisadores, ao digitalizar sua imensa coleção de periódicos, disponibilizando via internet, inclusive com um prático mecanismo de busca por palavras, este acervo precioso. Sem isso, seria impossível concluir a dissertação. Podendo consultar em casa, 24 horas por dia, inclusive em momentos em que a biblioteca física estava em greve, as edições dos diversos jornais, tudo ficou muito mais fácil.

E a quem me suportou nesses dois anos, quando estava com a cabeça no início do século XX bem mais do que nos tempos atuais... 
“Tenho ainda os ouvidos atordoados, numa vaga zoada importuna, guardando a ensurdecedora impressão do estridor daquelas máquinas e do confuso zumbir daquela colmeia humana. Só numa sala há mil e quinhentos teares em movimento: e ao barulho dessas gritadoras tecedeiras casa-se ao dos grossos pilões de madeira que batem as peças de morim, e o das pás de ferro que despolpam o algodão, e o dos cilindros que afinam os fios, e o dos carretéis que enrolam os cordões... Se há inferno, o inferno deve ser assim!"

Olavo Bilac, 1908 


\section{Resumo}

Esta dissertação se propõe a estudar o período de trinta anos, entre 1890 e 1920, desde a fundação da Companhia Progresso Industrial do Brazil até o arrefecimento do primeiro movimento operário brasileiro. A fábrica instalada no subúrbio do Rio de Janeiro, em Bangu, tornou-se a maior empresa têxtil da Capital Federal, empregando quase 3 mil trabalhadores de diferentes nacionalidades. De modo geral, os acionistas eram portugueses, o diretor-gerente era espanhol, os mestres de seção eram ingleses, os contramestres eram italianos e os tecelões, o "chão da fábrica", eram brasileiros. Uma análise micro-histórica do cotidiano fabril, utilizando como fonte principal as notícias de jornais, mostra que essa mistura étnica gerou muitos problemas, incluindo assassinatos e "paredes". Para acalmar esta população multifacetada, a Companhia investiu em benfeitorias na vila operária, incentivou o lazer e conseguiu passar anos sem conflitos mais sérios. No entanto, quando a “carestia de vida" invadiu os lares dos trabalhadores, a partir de 1917, as manifestações grevistas da classe operária voltaram a alarmar o patronato. Desta vez, foram necessárias intervenções repressivas da força policial e do Estado para acabar com as reivindicações não só dos banguenses, mas de todos os empregados nas diversas fábricas têxteis da cidade.
Palavras-chave:
1. Fábrica Bangu
2. Movimento operário
3. Indústrias têxteis
4. Primeira República
5. Imigrantes britânicos
6. Greves 


\begin{abstract}
This study aims to examine the thirty-year period between 1890 and 1920, from the foundation of the Companhia Progresso Industrial do Brazil to the weakening of the first labor movement of Brazil. This factory, installed in Bangu, on the outskirts of Rio de Janeiro, became the largest textile company at Brazilian capital, employing nearly 3,000 workers from different nationalities. In general, shareholders were Portuguese, the managing director was Spanish, the section masters were English, the foremen were Italian and the weavers - the most humble workers - were Brazilian. A micro-historical analysis of the factory daily life, having newspaper reports as the main source of research, shows that this ethnic blend generated many problems, including murderers and local strikes. To calm down this multifaceted population, the company invested in improvements at the workers' village and encouraged leisure activities. These measures guaranteed many years without serious conflicts. However, when the rising cost of living reached workers, especially from 1917 on, strikes and manifestations of the working class alarmed the patronage once again. Then, interventions carried out by the police and public authorities were necessary to stop the demands from the workers from Bangu, as well from the employees in the various textile factories of Rio de Janeiro.
\end{abstract}
Key-words:
1. Bangu Factory
2. Labor movement
3. Textile mills
4. First Republic
5. British immigrants
6. Strikes 


\section{Sumário}

Introdução

I A criação da Companhia Progresso Industrial do Brazil 12

1.1 - Brasileiros e estrangeiros na construção da Fábrica Bangu 19

1.2 - Desventuras dos primeiros trabalhadores 24

1.3 - A inauguração da fábrica 30

1.4 - Fotografias e representações dos primeiros operários 33

1.4.1 - O guardião da memória 40

II Mestres ingleses nos trópicos $\quad 42$

2.1 - As famílias britânicas em Bangu

2.1.1 - Os Donohoe 47

2.1.2 - Os Hartley

2.1.3 - Os Hellowell 66

2.2 - Uma elite fabril 72

2.2.1 - Outras opções de trabalho além da fábrica 75

III Greves e conflitos nos primeiros anos da Fábrica Bangu $\quad 80$

3.0.1 - Cinco dias de greve em 1894

3.1 - "Subdelegado da roça”, eleições fraudulentas e perseguição religiosa 85

3.2 - A greve de $1896 \quad 94$

3.3 - A derrota do Capitão 100

3.4 - Brasileiros vs. portugueses 104

3.5 - Brasileiros vs. italianos 110

3.6 - A "greve geral" de 1903

IV O Benemérito propugnador do progresso de Bangu 133

4.0.1 - O Bangu Athletic Club 134 
4.1 - Apogeu e queda de João Ferrer

4.1.1 - Decadência de João Ferrer

5.0.1 - A questão disciplinar

5.1 - Futebol como meio de ascensão profissional

5.1.2 - Roldão Maia: a trajetória de um jogador-operário

VI Greves: entre os fracassos e as conquistas de direitos

6.0.1 - Uma semana de greve em Bangu (1917)

6.1 - A epidemia e a greve andam juntas (1918)

6.2 - A maior greve e a jornada de 8 horas (1919)

6.2.1 - Comícios para inflamar o povo

6.3 - Mr. Schofield: "um macaco numa loja de louças"

6.4 - Arrefecimento do movimento operário (1920) 


\section{Introdução}

"Não é sem dificuldade que entramos no mundo desaparecido da classe operária nas primeiras décadas da história da República no Brasil" ${ }^{1}$ - assim, com esta frase, os historiadores Michael Hall e Paulo Sérgio Pinheiro iniciam seu livro, que transcreve documentos do movimento proletário no início do século XX. Esse "mundo desaparecido", em que milhares de pessoas viviam em casas iguais, praticamente enfileiradas, formando vilas e trabalhavam todas no mesmo lugar, em fábricas com pouca luminosidade interna, fachadas austeras, janelas bem no alto, aumentando ainda mais a sensação de calor, manuseando máquinas barulhentas e perigosas, em que qualquer descuido significaria um grave acidente, existiu simultaneamente em vários pontos do Rio de Janeiro.

Eram os chamados bairros operários, como Gávea, Jardim Botânico, Andaraí, Tijuca, Vila Isabel, Ponta do Caju, Deodoro e Bangu, que possuíam regras próprias de viver. Nestes locais, o tempo era determinado pelo apito que saía da chaminé da fábrica. Era ele que ditava o novo ritmo da vida urbana, acordando os operários às cinco da manhã, marcando o horário de entrada e alertando os retardatários que o portão já estava fechado. ${ }^{2}$ Noel Rosa, morador de Vila Isabel, onde existia a Companhia Confiança Industrial, lembrou-se de eternizar este momento no samba "Três Apitos", de 1933.

Mas as fábricas têxteis, construções gigantescas, eram mais que isso. Roberto Pompeu de Toledo vê no apito monocórdio das chaminés uma mensagem "de avanço, de progresso, de futuro". 3 O tempo não era mais controlado pelas badaladas dos sinos das igrejas, a incipiente industrialização brasileira chegava para ditar uma nova vida à população urbana e fazer rivalizar de forma desleal o ex-escravo recém-liberto com o imigrante branco, paupérrimo, vindo da Europa em busca de sonhos, na luta por um emprego na tecelagem.

Os principais estudos sobre movimento operário foram feitos entre o final da década de 1970 e meados dos anos 1980. Trabalhos elaborados por Boris Fausto, Sheldon Leslie Maram, Ângela de Castro Gomes, Margareth Rago, Edgard Carone, Edgar de Decca, Francisco Foot Hardman, Victor Leonardi, Michael Hall, Paulo Sérgio Pinheiro, Cláudio Batalha, Warren Dean, formam a base de um escopo de análise sobre a agitação social que a nova forma de trabalho gerou nas cidades. A leitura de suas obras evidencia o desconforto que o binômio exploração/má remuneração provocou nos diversos setores profissionais no início do século XX.

\footnotetext{
${ }^{1}$ HALL, Michael McDonald \& PINHEIRO, Paulo Sérgio. A classe operária no Brasil - documentos (1889 a 1930). Volume I - O movimento operário. São Paulo: Editora Alfa Ômega, 1979, p. 15.

${ }^{2}$ RABAÇA, Silvio. De pai para filho: imigrantes portugueses no Rio de Janeiro. Rio de Janeiro: Documenta Histórica, 2010 , p. 155.

${ }^{3}$ TOLEDO, Roberto Pompeu de. A capital da vertigem - Uma história de São Paulo de 1900 a 1954. Rio de Janeiro: Objetiva, 2015, p. 103.
} 
Atendo-se à visão macro dos acontecimentos, os historiadores mencionados retrataram a conjuntura social e econômica no âmbito das duas grandes cidades brasileiras - Rio de Janeiro e São Paulo - entendendo, claramente, que a exploração da mão-de-obra por capitalistas era idêntica em toda vila operária. No máximo, fazem uma exceção, concedendo ao industrial Jorge Street um pouco de generosidade no trato com o trabalhador, isso porque aplicava uma estratégia paternalista, onde o operário sequer percebia que era cerceado e, ao mesmo tempo, explorado.

Estes autores, de viés marxista, são unânimes em alertar aos leitores contemporâneos sobre a utilização em grande escala de menores, que cumpriam jornadas tão longas quanto os adultos e ganhavam uma verdadeira miséria. Todos nos contam sobre a participação feminina nas fábricas, uma força de trabalho que rivalizava, pelo menos em números gerais, com os homens, embora seus salários também fossem menores. E, claro, os autores também se preocuparam em mostrar o quanto o Estado brasileiro ignorou durante anos a existência dessas más condições, limitando a mediar conflitos através do Chefe de Policia na ocasião das greves e retardando ao máximo a criação de leis que viessem a melhorar a vida do trabalhador. Dentro de cada indústria reinava, absoluto, o regulamento interno e, muitas vezes, arbitrário do patrão. ${ }^{4}$

Trabalhos sobre fábricas específicas são mais escassos. Foram feitos por Elizabeth von der Weid e Ana Maria Rodrigues Bastos, que se debruçaram sobre a Companhia América Fabril; por Paulo Fernandes Keller, que analisou o cotidiano dos operários na Companhia Brazil Industrial, de Paracambi; e pela historiadora Gracilda Alves da Silva e pelo geógrafo Márcio Piñon de Oliveira, precursores nos estudos sobre a Companhia Progresso Industrial do Brazil, em Bangu. Gracilda Alves chegou a ter acesso às fichas funcionais - atualmente desaparecidas -, mas não se ateve a nomes, às pessoas que encontrava ali, preferindo realizar um trabalho de História Serial, tão em moda em meados dos anos 1980, e muito baseado nos relatórios da própria Companhia, formais e sem vida. Márcio Oliveira tinha outra preocupação: a utilização do espaço urbano, a construção de casas, a forma como a Companhia fez uso da imensa área que tinha à sua disposição. Novamente, os pequenos e ocultos personagens que caminhavam por esta região naquela época, pareciam ter menor importância.

Para suprir esta lacuna, esta dissertação irá focar espeficamente nas pessoas, trabalhadores ou mestres, que viveram esta fase da história do Brasil, moradores da vila operária da maior Companhia têxtil do período: a Fábrica Bangu, no subúrbio do Rio. Aqui, não iremos nos preocupar com os balanços financeiros da empresa, o lucro anual, quanto os acionistas ganhavam com suas ações. Nosso trabalho será sobre as questões sociais, o relacionamento entre homens de diversas

\footnotetext{
${ }^{4}$ SCHWARCZ, Lilia Moritz. "População e sociedade" in: SCHWARCZ, Lilia Moritz (org.). História do Brasil Nação - A Abertura para o Mundo (1889-1930). Rio de Janeiro: Editora Objetiva, 2012, p. 57.
} 
nacionalidades, de diferentes cargos na hierarquia do trabalho e como eram solucionados os conflitos, que invariavelmente ocorriam.

É claro que há várias outras formas de se abordar o tema da industrialização. As historiadoras Eulália Lobo e Maria Bárbara Levy elaboraram tabelas com índices de custo de vida e de salários pagos pelas empresas. Esses dados acabaram também sendo útil em diversos capítulos desta dissertação, mesmo este não sendo um trabalho de História Econômica.

Nosso intuito é, analisando uma vasta gama de notícias sobre a Companhia Progresso Industrial do Brazil, publicada tanto na grande imprensa diária, quanto nos jornais operários da época, reconhecer personagens, reconstituir trajetórias, para que possamos, através da microhistória, perceber como suas atitudes e ações estão bem próximas das conclusões que a historiografia sobre industrialização e cotidiano operário dos anos 1970 e 1980 chegou. Embora, os autores tenham escrito de forma bastante genérica, compreendendo que as mesmas características permeavam todas as fábricas do eixo Rio-São Paulo, com a análise micro será possível ver até onde o cotidiano desses trabalhadores era marcado pela opressão e por uma estagnação profissional. Não queremos limitar o raciocínio a uma dualidade: ou era péssimo ser operário na Primeira República ou era bom estar empregado na indústria numa época de excesso de mão-de-obra disponível. A vida desses homens, no dia a dia, tinha muitas outras tonalidades além do preto e branco.

Desta forma, o objetivo desta dissertação é entrar na intimidade de alguns personagens específicos; coincidentemente, todos homens (achar detalhes da vida de mulheres e crianças é bem mais difícil) e, através do que nos foi possível encontrar sobre suas vidas, tentar verificar em suas trajetórias as constatações dos historiadores do movimento operário dos anos 1970/1980. Para superar as dificuldades iniciais e entrarmos no "mundo desaparecido" da classe operária, os métodos da micro-história nos parecem ser os mais cabíveis para descobrirmos personagens obscuros, mas que podem ter deixados muitas pistas de como era a vida entre os teares nos primeiros anos da industrialização brasileira, justamente na fábrica que aglomerava o maior número de trabalhadores em toda Capital Federal. ${ }^{5}$

A partir de uma análise micro é possível conhecer o que estava ocorrendo ao redor desses personagens. Estudar a classe operária através de alguns de seus elementos não é uma tentativa inédita. O francês Jacques Revel nos mostra que o historiador italiano Maurizio Gribaudi já se utilizou da micro-escala para reescrever a forma de vida nas fábricas de Turim no início do século XX:

\footnotetext{
${ }^{5}$ Em 1919, um jornal chegou a fazer, por três vezes, a aferição de quantos operários tinham ido trabalhar após um longo período de greve. Na Companhia Progresso Industrial do Brazil, o número máximo alcançado foi 2.872 trabalhadores. A fábrica que mais perto chegava da Bangu era a Cruzeiro, no bairro do Andaraí, com 1.590 operários. Vide: O JORNAL, 27 de julho de 1919, p. 3; 5 de agosto de 1919, p. 2; 13 de agosto de 1919, p. 3.
} 
Numa situação em que se insistia essencialmente numa comunidade de experiências (imigração urbana, trabalho, luta social, consciência política) que constituiria a base da unidade, da identidade e da consciência da classe operária, o autor se restringiu a acompanhar itinerários individuais que fazem aparecer a multiplicidade das experiências, a pluralidade de seus contextos de referência, as contradições internas e externas das quais elas são portadoras. Ele as reconstrói a partir dos percursos geográficos e profissionais, dos comportamentos demográficos, das estratégias relacionais que acompanham a passagem do campo à cidade e à fábrica. Como muitos outros, Gribaudi partira da idéia de uma cultura operária homogênea ou, em todo caso, que homogeneizava os comportamentos. No meio do caminho (e especialmente ao recolher depoimentos orais sobre o passado familiar dos protagonistas da história que estudava), descobriu a diversidade das formas de ingresso e de vida na condição operária. ${ }^{6}$

Um dos principais nomes da micro-história, o italiano Carlo Ginzburg dá uma dica preciosa de como se deve fazer para esmiuçar a vida de um personagem, até então, desconhecido: procurar seu nome, repetidas vezes, em diversas fontes.

Se o âmbito da investigação for suficientemente circunscrito, as séries documentais podem sobrepor-se no tempo e no espaço de modo a permitir-nos encontrar o mesmo indivíduo ou grupos de indivíduos em contextos sociais diversos. O fio de Ariana que guia o investigador no labirinto documental é aquilo que distingue um indivíduo de um outro, em todas as sociedades conhecidas: o nome. (...) As linhas que convergem para o nome e que dele partem, compondo uma espécie de teia de malha fina, dão ao observador a imagem do tecido social em que o indivíduo está inserido. ${ }^{7}$

Portanto, iremos rastrear as pistas deixadas por nomes como o mestre têxtil britânico Thomas Donohoe, o Capitão Jorge Estrella, os malogrados Jacintho Telles de Moraes e Emygdio Barbosa, o diretor-gerente João Ferrer, o jogador-operário Roldão Maia, o impopular James Schofield, entre muitos outros homens que viveram em Bangu naquele período e tiveram ali suas experiências sócio-profissionais. Suas ações, apesar de únicas, são similares às de outros personagens minúsculos que viveram na mesma época, trabalhando em outras fábricas - todos eles ajudam a pintar o grande painel do cotidiano operário no início da industrialização brasileira. Como bem lembrou o historiador italiano Giovanni Levi:

Na micro-história a redução da escala se utiliza para compreender a história geral. Isto pode ser ilustrado se consideramos de que maneira se usa o microscópio. Através dele podemos ver as coisas anteriormente não visíveis, mas que existiam. A micro-história procura analisar como funciona a sociedade na sua base e, através desses dados, generalizar conclusões com o intuito de gerar perguntas e respostas capazes de serem comparáveis em outros contextos. ${ }^{8}$

O inglês Lawrence Stone adverte para os problemas que o historiador irá encontrar ao trabalhar com este método que lida diretamente com indivíduos "sobre os quais nada muito detalhado ou íntimo pode ser conhecido, pois estão mortos, e, portanto, indisponíveis para

\footnotetext{
${ }^{6}$ REVEL, Jacques. Jogos de Escalas - A experiência da microanálise. Rio de Janeiro: Editora Fundação Getúlio Vargas, 1998, pp. 22-23.

${ }^{7}$ GINZBURG, Carlo. A Micro-história e outros ensaios. Rio de Janeiro: Bertrand Brasil, 1989, pp. 173-175.

${ }^{8}$ Entrevista de Giovanni Levi a Juan José Marím (1999). Apud. OLIVEIRA, Luís Henrique de. Dos Annales à MicroHistória: alguns apontamentos sobre os avanços da História Social. In: Revista Virtú, Instituto de Ciências Humanas (ICH) da Universidade Federal de Juiz de Fora (UFJF) - $1^{\mathrm{a}}$ edição, $1^{\circ}$ semestre de 2005 . Disponivel no endereço eletrônico: http://www.ufjf.br/virtu/files/2010/03/artigo-1a4.pdf
} 
entrevistas". 9 Outra preocupação de Stone é a deficiência de dados. Evidentemente não há como termos uma ficha completa de cada morador de Bangu daquela época. Há, inclusive, alguns personagens importantes de que sequer se conhece a data de nascimento, por exemplo. "Em qualquer grupo histórico, é provável que quase tudo será sabido a respeito de alguns de seus membros e quase nada a respeito de outros; alguns itens faltarão para alguns e itens diferentes faltarão para outros". ${ }^{10}$

Para Stone, a quantidade documental fica sempre mais escassa quanto mais baixo se vai no sistema social. Por isso, muitos historiadores preferem fazer um estudo da história social das elites, onde há mais fontes. No caso do bairro de Bangu, muitas das fontes primárias já foram perdidas (caso das fichas funcionais), mas é possível "reencontrar" os moradores daquela sociedade analisando as notícias de jornais. Para isso, pesquisamos em 43 órgãos de imprensa diferentes, desde as pequenas publicações operárias às grandes folhas diárias, passando pelo Diário Oficial, buscando rastrear os personagens pelo nome nestas páginas e acompanhar, pelas notícias, os principais acontecimentos naquela vila.

As notícias publicadas nos jornais ao longo de 30 anos, passam muitas vezes imagens dúbias sobre o que realmente estava ocorrendo na fábrica. Durante a Belle Époque, por exemplo, os textos dos jornalistas elogiam a benemerência dos patrões e transformam a suada vida laboral dos milhares operários em um digno "paraíso". Concomitantemente, a pequena imprensa operária denuncia um verdadeiro "inferno" em que vivia o trabalhador têxtil não só em Bangu, mas em todas as Companhias da cidade. Em quem acreditar?

Por isso, utilizamos muitas outras fontes nesta pesquisa, incluindo fotografias, livros de atas do Bangu Athletic Club - agremiação esportiva criada no bairro pelos mestres têxteis britânicos -, os recenseamentos de 1890, 1906 e 1920, registros de chegada dos navios de imigrantes no porto do Rio, o código penal de 1890, os decretos-leis que foram sendo editados durante a Primeira República, um processo criminal (envolvendo o português Manoel Pinto Gaspar), além de documentos que pertenceram a algumas famílias de imigrantes (como o salvo-conduto recebido pela sra. Sarah Hellowell antes de viajar para o Brasil).

"Livros-monumentos", como o que comemora os 100 anos da Companhia, escrito pela historiadora Gracilda Alves e publicado em 1989, também são de grande utilidade para conhecer a memória que se desejou preservar daquela fábrica. As fotografias ali impressas, assim como as que foram guardadas pelo Grêmio Literário José Mauro de Vasconcelos - um centro de memória do

\footnotetext{
${ }^{9}$ STONE, Lawrence. Proposografia. In: Revista de Sociologia e Política, volume 19, no 39, junho de 2011, pp. 115137.

${ }^{10}$ Idem, ibidem.
} 
bairro - são extremamente generosas com a fábrica, redmindo-a de qualquer mal e tratando-a como responsável direta pela urbanização, progresso e desenvolvimento de Bangu.

Mas e a teoria marxista da "luta de classes", existiu ou não ali? Se formos analisar apenas pelos relatórios da própria Companhia, não. Em março de 1920, ao escrever sobre o ano anterior, os diretores sequer mencionam a existência de um greve que durou praticamente todo o mês de junho de 1919. Na seção "Operários" limitaram-se a agradecê-los. "A todos os nossos operários, que colaboram conosco no engrandecimento da Companhia, os nossos agreadecimentos; e os fazemos extensivos a todos os mestres, contramestres e chefes de seção que, de boa vontade, bem desempenharam as suas funções". ${ }^{11}$ Se formos analisar pela incrível gama de notícias dos jornais, Bangu viveu dias tensos no final dos anos 1910, com o ascenso do movimento operário no eixo Rio-São Paulo e a intensificação da repressão policial.

Mas é dessa dualidade entre a fábrica boa e a fábrica má que vamos extraindo a história que pretendemos contar. Em relação à dubiedade de informações, ninguém melhor que o político francês Georges Clemenceau para aumentar ainda mais a polêmica. Quando visitou a fábrica, em 4 de setembro de 1910, teceu elogios à Companhia. Porém, numa conferência pública, no dia seguinte, lamentou a condição das criancinhas e das mulheres. "Vi crianças de idade em que habitualmente devem ir à escola, já empregadas em diversos trabalhos da fábrica. (...) Outro fato que me contristou bastante durante a visita, foi ver mulheres em adiantado estado de gravidez trabalhando horas inteiras em pé. Não é necessário ser-se médico para se sentir o sofrimento dessas operárias". ${ }^{12}$

Porém, no livro que publicou em 1911, South America Today - A study of conditions, social, political and commercial in Argentina, Uruguay and Brazil, Clemenceau se esqueceu das criancinhas e das grávidas e enalteceu a Companhia: "O esplêndido desenvolvimento industrial de Bangu, entre muitos outros centros semelhantes, mostra o que está sendo feito no Brasil nesse sentido. Não vi nada mais marcante na Europa" e lembrou-se apenas dos rostos saudáveis: "A população ativa de Bangu está espalhada pela região em chalés que parecem ser admiravelmente higiênicos e todos possuem o aspecto dos melhores, de bem-estar físico e moral". ${ }^{13}$

Para complicar ainda mais, a memória dos moradores do bairro, baseada na história oral, lembra de um Clemenceau ingrato, que recusou a recepção que lhe prepararam na sede do Casino Bangu, "porque não podia admitir ver operários trabalhando 14 horas por dia, como era o caso da

\footnotetext{
${ }^{11}$ DIÁRIO OFICIAL, 23 de março de 1920, seção 1, p. 100.

12 O ESTADO DE SÃO PAULO, 7 de outubro de 1910, p. 5.

${ }^{13}$ CLEMENCEAU, Georges. South America Today - A study of conditions, social, political and commercial in Argentina, Uruguay and Brazil. Londres: The Knickerbocker Press, 1911, pp. 364-365.
} 
Fábrica Bangu, e considerou o trabalho escravo daquela casa uma hipocrisia". ${ }^{14}$ No entanto, nas páginas da imprensa diária, Clemenceau entrou no Casino, ouviu a execução da Marselhesa, pediu para que a banda dos operários tocasse um maxixe e degustou um lanche por lá. ${ }^{15}$

Embora este trabalho pretenda estudar apenas os desdobramentos das diversas ações dos diretores, mestres, contramestres e operários da Companhia Progresso Industrial do Brazil, a pesquisa nos mostra que as principais questões encontradas não se limitavam a Bangu. Com outros operários, outros diretores e outros imigrantes, processos semelhantes ocorreram nos demais bairros fabris do Rio de Janeiro naquele período. A criação de clubes de futebol em comunidades operárias - como o Andaraí, o Carioca, o Confiança e o Paracambi - por si só já indicam que uma das estratégias da Bangu foi seguida pelos industriais de outras fábricas da cidade.

Não foi sem rusgas, e sim com muitos conflitos que os brasileiros assimilaram a mudança de vida com a chegada da fábrica. O cotidiano industrial, onde todos trabalhavam trancados por horas e horas em seções como pouca ventilação e viviam num perímetro urbano restrito exigiu um período de assimilação. Esse "mundo novo", que transformava trabalhadores rurais em operários assalariados, que fazia encontrar nos subúrbios do Rio de Janeiro um imigrante italiano com um negro recém-liberto do cativeiro, não passou despercebido aos olhos do historiador Nicolau Svecenko:

\footnotetext{
Nunca em nenhum período anterior, tantas pessoas foram envolvidas de modo tão completo e tão rápido num processo dramático de transformação de seus hábitos cotidianos, suas convicções, seus modos de percepção e até seus reflexos instintivos. Isso não apenas no Brasil, mas no mundo tomado agora como um todo integrado. ${ }^{16}$
}

A convivência com os estrangeiros foi das mais espinhosas. O imigrante europeu branco, acolhido de portas abertas por dispor de maior conhecimento, acabou, com o tempo, assimilando-se ao bairro e a seus habitantes, através de práticas que se tornariam populares, como a criação de um clube de futebol ou o patrocínio a sociedades carnavalescas.

No caso de Bangu, a harmonia doce e amiga que pairava por aquelas bandas, ao ser analisada sob a ótica da micro-história, parece mais o fruto de um desejo civilizador do cronista da imprensa da Belle Époque do que uma realidade, que nunca se exprimiu na prática. Os crimes cometidos por estrangeiros contra brasileiros em 1899 e 1901 e as revoltas que se seguiram, são indicativos de que, em um curto espaço de tempo após a fundação da fábrica, já havia disputas de poder por indivíduos de nacionalidades diferentes naquele território.

\footnotetext{
${ }^{14}$ GAZE FILHO, Humberto. Casino Bangu - Um século em revista (1892-1992). Rio de Janeiro: Síntese Propaganda, 1992 , p. 23.

${ }^{15}$ GAZETA DE NOTÍCIAS, 5 de outubro de 1910, p. 2. A IMPRENSA, 5 de outubro de 1910, p. 1.

16 SEVCENKO, Nicolau. "O prelúdio republicano, astúcias da ordem e ilusões do progresso". In: SEVCENKO, Nicolau (org.), História da Vida Privada no Brasil - República: Da Belle Époque à Era do Rádio. Companhia das Letras. São Paulo, 1998, pp. 7-8.
} 
E mesmo quando todos os conflitos pareciam resolvidos pelas mãos do diretor-gerente daquele "pitoresco recanto", a carestia de vida trouxe de volta as greves e novas reivindicações num período de profunda agitação operária, entre 1917 e 1920.

As greves de outubro de 1894, fevereiro de 1896, setembro de 1901, agosto de 1903, julho de 1917, novembro de 1918, junho de 1919 e janeiro de 1920 são uma resistência contra a exploração do sistema fabril. Mas também havia outras causas em jogo, como o alto preço dos gêneros alimentícios no armazém, o cerceamento do direito de crença, a manipulação do voto nas eleições e a severa vigilância aos operários por parte de um capitão. As conquistas eram mínimas e evoluíram a passos lentos, mas mostram que, por mais receoso que o operariado da Fábrica Bangu fosse, sempre arrumavam um jeito de protestar.

O trabalho foi dividido em seis partes. Inicialmente, analisamos a criação da Companhia por capitalistas portugueses em 1889 e como a fábrica estava inserida num contexto de ampliação do investimento industrial na Capital Federal, numa época de fartos empréstimos bancários. As primeiras fotografias, ainda na época da construção, mostram negros brasileiros servindo como mão-de-obra no novo empreendimento. Logo, começam a surgir na imprensa diária notícias de acidentes, desavenças interétnicas, doenças envolvendo os primeiros operários, entre eles estrangeiros que encontravam na fábrica uma forma de conseguir emprego imediato no novo país. Relatamos a inauguração da empresa em 8 de março de 1893 e a pomposa recepção que ocorreu, para lembrarmos que, no dia seguinte, a primeira leva de operários - retratados em um conjunto de fotografias separadas por seções - já começava a sofrer com as condições pesadas do trabalho na indústria, especialmente as crianças, que formavam uma parte substancial dos empregados. A esses meninos e meninas paupérrimos, estampados nas imagens, restava oferecer ao mestre de sua seção, trabalho, obediência e lealdade em retribuição à suposta "proteção" que receberiam da fábrica. ${ }^{17}$

No segundo capítulo, abrimos espaço para as grandes e caras contratações feitas pela Companhia logo no seu início: técnicos têxteis britânicos que viriam ao Brasil para se tornarem mestres de seção. Diferentemente de trabalhadores contratados temporariamente, apenas para a instalação das máquinas, esse pequeno grupo de homens teria como obrigação se instalar no bairro, trazer suas famílias e ali, desenvolver a indústria local. Uma análise detalhada da trajetória de vida de três destes trabalhadores mostra que nenhum deles era mestre na Grã-Bretanha, lá eram operários que lutavam contra dificuldades como a baixa remuneração, o excesso de mão-de-obra e as demissões/falências das empresas. O escocês de Busby, Thomas Donohoe; o inglês de Preston, James Hartley; e o inglês de Yorkshire, Thomas Hellowell, deixaram pistas que nos permite analisar suas trajetórias individuais. O trabalho de pesquisa estende-se aos descendentes deles. A segunda

\footnotetext{
${ }^{17}$ GOMES, Ângela de Castro. Burguesia e trabalho - Política e legislação social no Brasil 1917-1937. Rio de Janeiro: Editora Campus, 1979, p. 32.
} 
geração de britânicos aqui no Brasil, apesar das vantagens que seus pais obtiveram trabalhando na Fábrica Bangu, normalmente procuravam outros empregos, aproveitando a oportunidade que tiveram de estudar e o fato de o imigrante inglês ser recebido de braços abertos por muitas companhias de capital estrangeiro. Nesta parte do trabalho, conseguimos dados financeiros, como o valor salarial, em Libras, pagos a estes mestres e convertemos esses valores em mil-réis. De fato, havia muita vantagem em se deslocar dos complexos fabris britânicos para o Rio de Janeiro, desde que, claro, viesse a ocupar o cargo de mestre de seção. A aceitação deles na comunidade de Bangu e a adaptação ou não aos costumes locais também é um dos temas abordados.

O terceiro capítulo apresenta um novo personagem: a trajetória do delegado da $3^{\mathrm{a}}$ circunscrição suburbana, Capitão Jorge Estrella. Figura das mais temidas na vila operária, Jorge Estrella representa os olhos da direção da Companhia sobre todos os trabalhadores. Naquele perímetro, ele dita as regras, impede cultos não-católicos e manipula os votos em dia de eleição. Convidado para ser o "gerente do movimento externo da fábrica", o capitão ilustra, de forma latente, o controle e a coação que a empresa procurou manter sobre quem vivia dentro do seu espaço urbano. A vigilância constante e as punições, incluindo expulsões do bairro em menos de 48 horas, são práticas comuns adotadas pelo capitão com a anuência da direção. Foram apenas cinco anos de domínio de Jorge Estrella, até que ele entrasse em rota de colisão com os mestres têxteis estrangeiros. Pode-se dizer que nestes primeiros anos, a Companhia optou claramente por uma política de opressão, tal qual os antigos senhores faziam com os escravos. Não deu certo. Espontaneamente, surgiram movimentos “paredistas” em 1894, 1896 e 1901. Em seções deste capítulo, analisaremos dois assassinatos, ocorridos em 1899 e 1901, envolvendo estrangeiros (português e italiano) que mataram dois brasileiros desempregados. Os acontecimentos, que deveriam interessar somente à polícia, revelam por trás uma grande xenofobia, disputa pelos melhores cargos e o ressentimento dos nacionais em relação aos imigrantes que chegavam para trabalhar na fábrica, onde preferencialmente alcançavam posições de destaque.

No quarto capítulo nos deparamos com outro personagem importante: o diretor-gerente João Ferrer. O espanhol foi uma espécie de prefeito da localidade entre 1903 e 1919, realizando diversas obras no bairro. Sua visão avançada permitiu dotar de conforto a pequena vila operária e propiciar várias formas de lazer à sua população. Certamente, influenciou uma geração de industriais, tal como Jorge Street, que aplicou os conceitos paternalistas em sua fábrica em São Paulo. Ferrer foi capaz de transformar o $1^{\circ}$ de maio - uma data determinada pelos sindicatos para o protesto da classe trabalhadora - em um dia festivo e de homenagens a si próprio e fazer a comunidade inteira ir às ruas comemorar com foguetório a inauguração de uma igreja, marcada para o dia de seu aniversário. Desta forma, manteve a Companhia isolada de greves por mais de uma década. Sua estratégia era, além de uma ótima convivência com a imprensa, convencer o trabalhador de que não 
havia fábrica melhor para se trabalhar, tal a quantidade de benefícios que se oferecia. Este tipo de "afago" ao operariado, pode ser visto como uma coação psicólogica bem eficiente, afinal, o tecelão poderia perder o pouco que tinha se não se conformasse à vida imposta pela Companhia.

É na quinta parte deste trabalho, dedicado à implementação de um clube de futebol dentro da fábrica (outra espécie de "afago" oferecido pela Companhia a seus empregados), que encontramos maiores distorções sobre o que pensam alguns historiadores contemporâneos e o que realmente ocorria no dia a dia da associação esportiva. Com o olhar da micro-história é possível compreender que o clube não se prestava a uma dominação do operariado até mesmo em suas horas de lazer, como pensava Joel Rufino dos Santos; que não havia uma norma clara de promoção profissional se o operário fosse também bom de bola, como acreditava Waldenyr Caldas; e que o clube não foi utilizado como uma entidade classista por seus sócios, como analisou Leonardo Affonso de Miranda Pereira. O futebol representava, naquele contexto, uma "válvula de escape" das tensões do dia a dia, servindo para unificar a coletividade em torno de um bem-comum. Torcer para o time do bairro passou a ser um ponto de identificação entre trabalhadores que tinham vindo de diferentes partes do mundo.

A sexta e última parte é a da maior maturidade do movimento operário, fortemente influenciado pelas "greves gerais". O tecelão carioca, incluindo os temerosos trabalhadores da Fábrica Bangu foram, aos poucos, reivindicando a redução da jornada para oito horas, o fim da contratação de menores, a igualdade salarial entre homens e mulheres, a diminuição do tempo do serão noturno, aumentos salariais que cobrissem a grande carestia de vida daquele período e o livre direito de se associarem em sindicatos. Entre 1917 e 1919, a elite dirigente se deparou com a mobilização e os esforços organizatórios dos trabalhadores de diversas categorias além dos têxteis. A resposta do Estado oligárquico para esta questão de ordem social foi aplacá-la com uma severa repressão policial, negando o reconhecimento dos mínimos direitos aos operários e escolhendo os anarquistas como inimigos públicos número 1. Apesar de fazer muito barulho e tomar as ruas da Capital, o operariado acabou sendo derrotado. A "classe" foi silenciada e entrou nos anos 20 sem qualquer força para continuar a série de reivindicações que vinha fazendo. Pode-se dizer que 1920 foi o "último suspiro de resistência". Até mesmo na Fábrica Bangu, as contingências de momento fizeram com que fosse trazido um diretor-gerente mais repressor - o inglês James Schofield -, que, diferentemente do espanhol João Ferrer, jamais caiu nas graças do operariado. Muito pelo contrário, são inúmeras as queixas contra seus procedimentos nas páginas dos jornais mais identificados com a classe trabalhadora, como A Razão e Voz do Povo.

Desta forma, restringindo a pesquisa a um limite cronológico (entre 1890 e 1920) e geográfico (o bairro proletário de Bangu) bem definidos, esperamos poder abranger os vários acontecimentos e os principais personagens que, a seu modo, construíram essa história do operariado na Primeira 
República. Nenhum tecelão poderia imaginar que ao obedecer ao apito da chaminé e entrar na fábrica para cumprir sua longa jornada diária, ao se filiar ao clube de futebol da localidade, ao mandar uma carta de repúdio aos jornais ou ao entrar em conflito direto contra algum imigrante, estaria deixando pistas, vestígios, sinais (como diz Carlo Ginzburg) de sua passagem por aquele mundo do trabalho fabril.

Ao lermos as várias notícias que encontramos nos jornais, estamos reconstruindo o cotidiano daqueles homens. Em alguns casos, é como se pudéssemos reconhecer a fisionomia deles em meio a um bairro com milhares de pessoas. Vasculhando o que a imprensa noticiava, buscando as particularidades dos personagens, acabamos cumprindo um dos desejos do historiador italiano Giovanni Levi, quando diz que ler um "maço de documentos heterogêneos cotidianos é semelhante à pesquisa de campo, como se estivéssemos na praça ouvindo, durante anos, tudo aquilo que aconteceu nas famílias". ${ }^{18}$ Ler aqueles jornais, relatórios oficiais e documentos pessoais equivale a estar na praça de Bangu assistindo, por trinta anos, tudo o que acontecia naquela vila - a chegada dos imigrantes, os assassinatos, as partidas de futebol, as visitas presidenciais, os comícios, as greves -, acumulando informações e construindo, pela observação, nossas impressões sobre o cotidiano dos diretores, mestres e operários do maior estabelecimento têxtil do Rio de Janeiro.

Teríamos que contar com a benevolência das autoridades, afinal, se ficássemos todos estes anos sentados no banco da praça, certamente, o delegado do $25^{\circ}$ distrito iria nos prender pelo crime de vadiagem, algo muito comum durante a Primeira República...

\footnotetext{
${ }^{18}$ LEVI, Giovanni. A herança imaterial: trajetória de um exorcista no Piemonte do século XVII. Rio de Janeiro: Civilização Brasileira, 2000, pp. 89-90.
} 


\section{I - A criação da Companhia Progresso Industrial do Brazil}

Durante todo o século XIX, muitos políticos discursaram sobre a "vocação agrícola" do Brasil, como se o investimento na agricultura fosse totalmente antagônico ao desenvolvimento da indústria. O próprio Visconde de Cairu, que colaborou diretamente com D. João VI para a abertura dos portos e a revogação do alvará que proibia a manufatura na colônia, datado de 1785, tinha uma visão receosa sobre a instalação de fábricas, deixando claro qual seria o papel que poderíamos esperar delas em alguns trechos do livro que publicou pela Imprensa Régia, em 1810, “Observações sobre a franqueza da indústria e estabelecimento de fábricas no Brasil”:

Não convém com privilégios distrair fundos de nossa agricultura, e ramos estabelecidos e assaz rendosos, e menos ainda com a mão do governo levantar fábricas rivais das estabelecidas no Reino, devendo as do Brasil ser antes filiais que inimigas, postas em desnecessária competição. ${ }^{19}$

Já na segunda metade do século XIX, políticos como o escritor José de Alencar (que foi deputado pelo Partido Conservador, representando o Ceará) e o Visconde de Itaboraí (que chegou a ser presidente do Conselho de Ministros, também pelo Partido Conservador) descartavam qualquer espécie de ajuda às manufaturas e indústrias; defendendo que os novos capitais deveriam ser aplicados na consolidação da lavoura. Ou seja, defendiam firmemente "a vocação agrícola do Brasil”. Mas, mesmo sob a condenação de altos políticos do Império, esse capital afluiu para atividades comerciais, manufatureiras, de transportes e principalmente para a especulação financeira, promovendo um primeiro surto de urbanização e de alargamento do trabalho livre. ${ }^{20}$

Por isso, no final do século XIX, o caminho para o investimento na implantação de grandes fábricas estava um pouco pavimentado, mesmo que com um atraso de mais de cem anos em relação ao início da revolução industrial na Inglaterra. Nos primeiros tempos da industrialização no Brasil dominou a indústria têxtil. Em 1889, ela era responsável por $60 \%$ do setor fabril, seguida da indústria de alimentos com $15 \%$, da indústria química com $10 \%$, da indústria de madeiras com 4\%, da indústria do vestuário com $3,5 \%$ e da metalurgia com $3 \% .^{21}$

A baixa dos preços do café, a crise da lavoura no último quartel do século XIX e o fim da escravidão, em lugar de contribuir para uma desaceleração industrial, colaborou para a reformulação da política econômica do governo e, para alguns autores, foram fatores decisivos para que ocorresse uma inversão de capitais a favor da indústria. ${ }^{22}$

\footnotetext{
${ }^{19}$ Apud. CALDEIRA, Jorge. "O processo econômico” in: SILVA, Alberto da Costa e (org.). História do Brasil Nação - Crise colonial e independência (1808-1830). Rio de Janeiro: Editora Objetiva, 2011, p. 188.

${ }^{20}$ NETO, José Miguel Arias. "Primeira República: economia cafeeira, urbanização e industrialização" in: DELGADO, Lucília de Almeida Neves \& FERREIRA, Jorge (orgs.). O Brasil Republicano: o tempo do liberalismo excludente - da Proclamação da República à Revolução de 1930. Rio de Janeiro: Civilização Brasileira, 2008, p. 200.

${ }^{21}$ PAULA, João Antônio de. "O processo econômico" in: CARVALHO, José Murilo de (org.). História do Brasil Nação - A Construção Nacional (1830-1889). Rio de Janeiro: Editora Objetiva, 2012, p. 217.

${ }^{22}$ LUZ, Nícia Vilela. A luta pela industrialização no Brasil. São Paulo: Difel, 1981, p. 59.
} 
Outros autores creem que o Rio de Janeiro sobreviveu de forma relativamente autônoma à série crise nas fazendas de café fluminenses porque a relação entre processo industrial e cafeicultura era pequena. Os recursos que ajudaram a formar as grandes indústrias têxteis vieram das atividades comerciais, em especial do comércio importador, atividade na qual predominavam ingleses e portugueses, e também do capital financeiro (bancos e mercado de ações). O Rio ganhava um novo perfil econômico e social e os primeiros capitalistas começaram a barganhar com o governo tarifas protecionistas para taxar os produtos importados que também pudessem ser feitos aqui, como os tecidos. ${ }^{23}$ Ao mesmo tempo, eles queriam facilidades para importar maquinário necessário para a implantação das primeiras indústrias têxteis.

A decisiva vantagem que a indústria carioca tinha sobre os demais centros urbanos decorria de sua grande população, que proporcionava excedente de mão-de-obra, de sua notória superioridade como centro comercial, da notável expressão do sistema financeiro, de seu porto relativamente bem aparelhado - o que lhe permitia acesso às matérias-primas e combustíveis provenientes de outras regiões - e o fato de estar cercado de quedas d'água de fácil aproveitamento para a produção de energia elétrica.

Assim, o decênio de 1885/1895 foi um período de intenso investimento em manufatura têxtil, seja pelo número de empresas fundadas, seja pelo aumento da capacidade instalada nas fábricas existentes. $^{24}$

Nesse contexto, o Rio de Janeiro poderia se orgulhar de ter constituído em um curto período de tempo a Fiação e Tecidos Aliança, fundada no bairro das Laranjeiras em 1880; a Confiança Industrial, situada em Vila Isabel, em 1885; a Fiação e Tecidos Carioca, instalada no Jardim Botânico, em 1886; a Fiação e Tecidos Corcovado, na Gávea, em 1889; a Fábrica São Cristóvão, no bairro de mesmo nome, em 1889; a Fábrica Cruzeiro, no Andaraí, em 1891; e a Fábrica Bonfim, na Ponta do Caju, também em $1891 .^{25}$

Foi neste cenário que surgiu a Companhia Progresso Industrial do Brasil, que viria a ser a maior fábrica têxtil do Rio de Janeiro. O projeto de criação de uma indústria que produzisse desde o fio cru até tecidos estampados, percorrendo todas as etapas do processo fabril, foi do engenheiro brasileiro Henrique De Morgan Snell, que tinha estudado na Inglaterra e montado uma empresa "De Morgan Snell \& Co.”, com sede em Londres. ${ }^{26}$

\footnotetext{
${ }^{23}$ LEOPOLDI, Maria Antonieta. Política e interesses na industrialização brasileira - as associações industriais, a política econômica e o Estado. São Paulo: Editora Paz e Terra, 2000, pp. 41, 56, 95.

${ }^{24}$ LEVY, Maria Bárbara. A indústria do Rio de Janeiro através de suas sociedades anônimas. Rio de Janeiro: Editora UFRJ, 1994, pp. 135, 143-144.

${ }^{25}$ SUZIGAN, Wilson. Indústria brasileira: origem e desenvolvimento. São Paulo: Editora Brasiliense, 1986, pp. 389390 .

26 SILVA, Gracilda Alves de Azevedo. Bangu 100 anos: a fábrica e o bairro. Rio de Janeiro: Sabiá Produções Artísticas, 1989, p. 21.
} 
Contado de forma simples pelo geógrafo Márcio Piñon de Oliveira, a construção da fábrica de tecidos parece quase uma obra do acaso, o encontro das ideias de um engenheiro anglo-brasileiro com o capital dos banqueiros luso-brasileiros.

Certo dia, no despontar do ano de 1889, o engenheiro Henrique de Morgan Snell sai por aí, em plena crise da economia agroexportadora, com um projeto de fábrica de tecidos embaixo do braço. (...) Na sua peregrinação capitalista, o engenheiro encontrou pela frente dois banqueiros, o Conde de Figueiredo e o Barão de Salgado Zenha, que após examinarem as plantas da fábrica, acompanhadas do cálculo de custos e demonstração de lucro provável, resolveram bancar a ideia do projeto fabril. ${ }^{27}$

Na verdade, nada se deu com tamanho grau de acaso, como escreveu o geógrafo. Henrique De Morgan Snell já tinha profundas ligações com os banqueiros Francisco de Figueiredo (o Conde de Figueiredo) e com o português Manoel Salgado Zenha (o Barão de Salgado Zenha). Em 27 de outubro de 1888, De Morgan Snell tinha inaugurado a Companhia Rio de Janeiro Flour Mills \& Granaries, para beneficiamento de cereais, como o trigo e a farinha, no bairro da Gamboa, tendo como principais acionistas o próprio Visconde de Figueiredo e o Conselheiro Zenha, além do Dr. Antônio de Siqueira, um profissional liberal, que também iria investir na fábrica têxtil a ser criada pelo engenheiro. ${ }^{28}$

Portanto, não foi uma surpresa encontrar banqueiros dispostos a investir em um segundo projeto. Assim, em 6 de fevereiro de 1889, foi fundada a Companhia Progresso Industrial do Brazil, tendo como incorporadores o Conde de Figueiredo e o Barão de Salgado Zenha pelo Banco Internacional do Brazil e os comendadores Estevão José da Silva e Manoel Antônio da Costa Pereira, ambos portugueses, pelo Banco Rural e Hypothecário do Rio de Janeiro. ${ }^{29}$ O objetivo era:

\footnotetext{
Organizar e fundar, nas proximidades desta Corte, uma fábrica para explorar a indústria de preparar, fiar, tecer, tingir e estampar algodão ou outros materiais têxteis, adquirindo, para esse fim, os mais aperfeiçoados maquinismos, e quanto for necessário ao aperfeiçoamento desta especialidade fabril. ${ }^{30}$
}

Na reunião pioneira, ocorrida no salão do Banco Rural e Hypothecário do Rio de Janeiro, à rua da Quitanda $n^{\circ} 105,1^{\circ}$ andar, foi escolhida a primeira diretoria, com mandato de três anos, permitida a reeleição. A presidência ficou com o comendador Estevão José da Silva, o secretário seria Antônio Xavier Carneiro (que também era diretor da Companhia Confiança Industrial, de Vila Isabel, um empreendimento do Barão de Salgado Zenha) e o tesoureiro foi o comerciante português Manoel Moreira da Fonseca. ${ }^{31}$

\footnotetext{
${ }^{27}$ OLIVEIRA, Márcio Piñon de. Bangu: de fábrica-fazenda e cidade-fábrica a mais uma fábrica da cidade. Instituto de Pesquisa e Planejamento Urbano e Regional (IPPUR) da Universidade Federal do Rio de Janeiro (UFRJ), 1991, p. 3.

${ }^{28}$ GAZETA DE NOTÍCIAS, 28 de outubro de 1888, p. 1.

${ }^{29}$ FARIA, Fernando Antônio. "Companhia Progresso Industrial do Brasil: empresa e empreendedores" in: História Revista - Revista da Faculdade de História e do Programa de Pós-Graduação em História da Universidade Federal de Goiás (Vol 4: Nos 1 e 2). Goiânia: Universidade Federal de Goiás, 1999, p. 37.

${ }^{30}$ COMPANHIA PROGRESSO INDUSTRIAL DO BRAZIL. Estatutos aprovados na Assembleia Geral de 14 de janeiro de 1889. Rio de Janeiro: Typografia Perseverança, 1889, pp. 3-4.

${ }^{31}$ FARIA (1999), pp. 37-38.
} 
A Confiança Industrial, de Vila Isabel, foi a primeira grande empresa têxtil no Rio de Janeiro a ser fundada como sociedade anônima, em 1885. A Companhia Progresso Industrial do Brazil foi a segunda a colocar suas ações no mercado, quatro anos depois. ${ }^{32}$

A nova Companhia foi constituída com um capital de 3.000:000\$ (três mil contos de réis), dividido em 15 mil ações de 200:000\$ (duzentos mil réis), sendo o Banco Internacional do Brazil, do Conde de Figueiredo e do Barão de Salgado Zenha, o maior acionista com 3.423 ações, injetando um valor de 684:600\$000 na empreitada. ${ }^{33}$ Do total, exatos 47,5\% do capital da empresa estavam vinculados ao capital bancário.

Outro aspecto interessante é que geralmente o valor unitário das ações era de duzentos mil-réis, muito alto para época, já que era um valor superior ao que recebiam, por mês, pedreiros, carpinteiros e enfermeiros; mais alto até que o aluguel de uma casa de dois ou três quartos, sala de visitas e jantar, quarto de banho, latrina e lavanderia. Por essa razão, o capital era fortemente concentrado entre os grandes acionistas, sendo insignificante a participação de pequenos capitais na constituição das empresas. ${ }^{34}$

Constituída a Companhia, buscou-se um lugar para a sua construção. Inicialmente, Henrique De Morgan Snell pensou em erguê-la na Tijuca, na chácara que pertencera, em vida, ao Duque de Caxias, na atual rua Conde de Bonfim. No entanto, os acionistas temerosos de depender do fornecimento público de água, sempre abalado por periódicas crises, incumbiram o engenheiro de buscar outro lugar para a instalação da fábrica, onde houvesse abundância de mananciais por perto.

Depois de diversas pesquisas, a diretoria foi informada pelo engenheiro de que na freguesia de Campo Grande, às margens da Estrada de Ferro Central do Brasil, havia terrenos com cachoeiras que podiam fornecer a quantidade de água suficiente para todos os trabalhos da fábrica. ${ }^{35} \mathrm{~A}$ água era um componente imprescindível para as indústrias têxteis nas seções de branqueamento, tinturaria, estamparia, para o resfriamento das máquinas e manutenção da temperatura. Enfim, a qualidade do tecido e a preservação do maquinário dependiam da água. ${ }^{36}$

Foram adquiridas, então, as Fazendas do Bangu e do Retiro, os Sítios do Agostinho e dos Amarais (que faziam parte da Fazenda Guandu do Sena), além das cachoeiras do Fundão e do Agostinho, pagando um preço total de 132:137\$910 (apenas 4\% do capital total da Companhia), ficando de posse de uma área imensa de $36.000 .000 \mathrm{~m}^{2}$, o que correspondia a uma área superior a de muitas freguesias do Rio de Janeiro de então. Para efeitos de comparação, toda a freguesia da Gávea, por exemplo, tinha uma área de $34.685 .000 \mathrm{~m}^{2}$. Ainda assim, o gigantesco terreno comprado pela Companhia era uma pequena parte da freguesia de Campo Grande, que tinha área total de

\footnotetext{
${ }^{32}$ MONTEIRO, Ana Maria Ferreira. Empreendedores e investidores em indústria têxtil no Rio de Janeiro (1878-1895): uma contribuição para o estudo do capitalismo no Brasil. Dissertação de mestrado em História na Universidade Federal Fluminense, 1985, p. 225.

${ }^{33}$ OLIVEIRA (1991), pp. 2, 266.

${ }^{34}$ LEVY (1994), p. 157.

35 OLIVEIRA (1991), p. 20.

${ }^{36}$ FREITAS, Adriana Oliveira de. A Fábrica Bangu e a República nascente (1889-1914). Dissertação de mestrado em História na Universidade Federal do Espírito Santo, 2005, p. 51.
} 
245.822.000 $\mathrm{m}^{2}$, ou seja, o futuro bairro de Bangu ocuparia, originalmente, 14,6\% da freguesia em que se encontrava. ${ }^{37}$

Segundo relatório da diretoria, se tivesse sido possível montar a fábrica na área urbana da Capital, só os terrenos custariam o dobro do que a Companhia despendeu, e sem a favorável circunstância de ser servida pela Estrada de Ferro Central do Brasil. ${ }^{38}$ Embora, estivesse situada a 31 quilômetros do centro da cidade e do porto do Rio de Janeiro, essa distância significava apenas uma hora de trem - quase o mesmo tempo que se levava da Gávea ou da Tijuca até o Centro pelo sistema de bondes, isto sem mencionar a redução dos custos de transportes proporcionados pela estrada de ferro, permitindo levar um volume de carga bem maior de uma só vez. ${ }^{39}$

No entanto, apesar de a ferrovia passar por aquelas terras, ligando a estação de Sapopemba (atual bairro de Deodoro) à estação de Santa Cruz, desde 1878, ainda não havia uma estação de embarque e desembarque de cargas na antiga Fazenda do Bangu. Só depois que o Barão de Itacurussá vendeu suas terras para a Companhia é que a Estrada de Ferro inaugurou ali a estação de Bangu em $1^{\mathrm{o}}$ de maio de $1890 .^{40}$ Uma parada que, segundo um cronista de $O$ Paiz, ficava muito a dever:

O aspecto exterior é o mais desagradável possível: um pequeno e sujo pavilhão de madeira, dividido em três compartimentos, cada qual mais acanhado. No primeiro fica a agência, o segundo serve de sala de espera e o terceiro é destinado a armazém de bagagens. Só há uma plataforma e esta mesmo tão curta que os passageiros, às vezes, são obrigados a fazer grandes esforços para tomar os últimos carros. ${ }^{41}$

Sem ela, porém, tudo era pior. No princípio das obras, os construtores ainda não podiam se beneficiar desta estratégica parada, provavelmente descarregando os materiais na estação de Realengo, a quatro quilômetros do local onde seria erguida a fábrica. Bangu ficava, portanto, entre as estações de Realengo (inaugurada em 2 de outubro de 1878) e a de Campo Grande (inaugurada em 2 de dezembro de 1879). ${ }^{42}$

Para erguer o edifício fabril, naturalmente, a diretoria da Companhia fechou contrato com a firma De Morgan Snell \& Co., do engenheiro idealizador do projeto. A construção da fábrica de tecidos se encaixaria no padrão da arquitetura conhecido por "Britânica Manchesteriana": fachada

\footnotetext{
${ }^{37}$ SENRA, Nelson de Castro. O Censo de 1906 do Rio de Janeiro. Rio de Janeiro: Publicações Pereira Passos, 2012 , p. 28.

${ }^{38}$ COMPANHIA PROGRESSO INDUSTRIAL DO BRAZIL. Relatório de 12 de março de 1890, p. 10.

${ }^{39}$ OLIVEIRA (1991), p. 31.

${ }^{40}$ RODRIGUEZ, Hélio Suevo. A formação das estradas de ferro no Rio de Janeiro - o resgate da sua memória. Rio de Janeiro: Memória do Trem, 2004, p. 68.

${ }^{41}$ O PAIZ, 11 de maio de 1906, p. 3.

${ }^{42}$ LETIERE, Róbson. Rio Bairros - Uma breve história dos bairros cariocas, de A a Z. Rio de Janeiro: edição do autor, 2013, pp. 37, 132.
} 
típica com tijolinhos vermelhos aparentes, estrutura sóbria e pesada, simetria de planos, paredes elevadas e janelas ao alto. ${ }^{43}$

A assinatura se deu em 21 de junho de 1889. Pelo contrato firmado entre as duas empresas, foi fixado o preço total da obra em 4.100:000\$ (4.100 contos de réis), valor que cobriria não apenas a construção do prédio, mas também a instalação de tanques, reservatórios e maquinário necessário para que ela iniciasse sua produção. Estavam excluídas do contrato as despesas com canalização das águas, com a Alfândega do Rio de Janeiro e com o transporte pela Estrada de Ferro Central do Brasil. $^{44}$

Ou seja, para um capital total de 3.000:000\$ (três mil contos de réis), a Companhia tinha firmado uma empreitada de $4.100 \$ 000$ (4.100 contos de réis). Acrescente-se a isto o custo de aquisição de vasta extensão de terras (a 132:137\$910), os juros de $7 \%$ ao ano, pagos a todos os acionistas durante o período de construção da fábrica (como constava nos Estatutos de 1889) ${ }^{45}$, além de gastos com questões judiciais - um morador da região, José Clemente Marques, acionou a Companhia na Justiça, em 1891, alegando também ter direito aos mananciais da Fazenda do Guandu do Sena ${ }^{46}$ - fora a canalização das águas, as taxas alfandegárias e o transporte do material pela estrada de ferro, que não constavam do contrato com a De Morgan Snell \& Co.

O prazo de execução da obra era de dois anos e meio, a contar da assinatura do contrato (em junho de 1889), mas as obras só se iniciaram em 26 de setembro de 1889 e não ficaram prontas, como deveriam, em dezembro de 1891. Quando, finalmente, a fábrica abriu as portas, em março de 1893, a Companhia já tinha gasto 7.436:051\$430, tendo pego um empréstimono Banco Rural e Hypothecário e no Banco Rio-Mato Grosso, ${ }^{47} \mathrm{em} \mathrm{1891,} \mathrm{que} \mathrm{deveria} \mathrm{começar} \mathrm{a} \mathrm{ser} \mathrm{pago} \mathrm{em} \mathrm{outubro}$ de $1895 .{ }^{48}$

Em junho de 1892, a fábrica passou a funcionar em fase de testes, e o parecer do engenheiro fiscal da Companhia, Arthur Alvim, parece ter sido escrito para acalmar os acionistas.

Até o presente, os trabalhos foram executados com todo o escrúpulo e posso desassombrada e imparcialmente afirmar que nenhuma outra fábrica terá sido construída no Brasil com mais cuidado e talvez nenhuma possa igualar a esta como conjunto de maquinismos aperfeiçoados, correta distribuição e de sólida construção. A Companhia pode ufanar-se de possuir uma instalação que dificilmente será igualada em qualquer parte do

\footnotetext{
${ }^{43}$ HARDMAN, Foot Francisco \& LEONARDI, Victor. História da Indústria e do Trabalho no Brasil (das origens aos anos 20) - $2^{a}$ edição. São Paulo: Editora Ática, 1991, p. 134.

${ }^{44}$ SILVA (1989), p. 23.

45 Todos os acionistas receberam juros de 7\% desde o desembolso do capital até 30 de junho de 1892 . "Ata da Assembleia Geral Extraordinária da Companhia Progresso Industrial do Brazil, de 20 de outubro de 1894”, publicada em O PAIZ, 19 de novembro de 1894, p. 4.

${ }^{46}$ OLIVEIRA (1991), pp. 63-64.

47 “O empréstimo no valor de 3.000:000\$000, representado por debêntures ao portador, a juros de 7\% ao ano negociadas através dos Bancos Rural e Hypothecário e Rio-Mato Grosso. O empréstimo era no valor do capital inicial, o que dá uma ideia da facilidade de crédito, que existia nessa época, para montar novas fábricas”. Vide: LOBO, Eulália Maria Lahmeyer. História do Rio de Janeiro. Do Capital Comercial ao Capital Industrial e Financeiro. $2^{\circ}$ Volume. Rio de Janeiro: IBMEC, 1978, p. 481.

${ }^{48}$ FARIA (1999), pp. 56-57.
} 
mundo. Assim seja ela bem conduzida, pois os resultados serão seguros e esses são os meus votos. $^{49}$

Mas, os acionistas duvidaram desses "resultados seguros" ainda em 1894. Uma assembleia geral extraordinária foi convocada em 20 de outubro daquele ano, a pedido do acionista Henrique De Morgan Snell, que tinha 105 ações, mas que somadas à da sua empresa, a De Morgan Snell \& Co., chegavam a 7.128 ações, ou seja, 47,52\% do capital da Companhia.

Durante a assembleia, cujo principal assunto era o afastamento ou não do diretor-gerente Antônio Xavier Carneiro, tido como responsável pelo "entorpecimento do desenvolvimento da Fábrica Bangu", o acionista Antônio de Siqueira, dono de 125 ações e ávido por lucros imediatos, sem compreender que ao investir na Companhia, tinha feito um investimento a longo prazo, declarou que:

Assistiu à organização desta empresa, feita sob o mais severo escrúpulo, em relação ao orçamento e aí influiu bastante o Sr. Carneiro. Tal era a época, que apesar da empresa ser patrocinada por dois importantes bancos desta praça, não pôde conseguir mais de 3 mil contos, sendo o orçamento de 6 mil contos. Acompanhou a construção da fábrica e teve ocasião de ver o zelo e interesse com que esse diretor dirigiu todo o serviço; entretanto não é acionista de outras empresas congêneres e inveja a sorte dos acionistas delas, por isso que há cerca de seis anos que esta empresa está organizada e ainda não teve dividendo $!^{50}$

No final, a proposta de demissão do diretor-gerente Antônio Xavier Carneiro, sugerida por Henrique De Morgan Snell e Antônio de Siqueira acabou sendo rejeitada por grande maioria de votos, especialmente porque a assembleia deliberou que a votação fosse individual e não por capital.

A De Morgan Snell \& Co. teve a possibilidade real de um controle acionário efetivo da Companhia. No entanto, uma reforma no artigo 18 dos Estatutos, que estabelecia a proporção de votos em relação ao número de ações, limitando ao máximo de 50 votos, mesmo que o acionista tivesse mais de 500 ações, manteve o controle da Companhia nas mãos do grupo de acionistas que tinham a hegemonia da empresa na época da fundação. Assim, de pouco adiantava o anglobrasileiro De Morgan Snell ter 7.128 ações se ele poderia ter apenas 50 votos em vez de 712 votos (como estava na versão de 1889 dos Estatutos, que dava direito a um voto a cada 10 ações).

$\mathrm{Na}$ impossibilidade de controlar a empresa, esta firma passou então suas ações para o Banco da República do Brazil, de propriedade do Visconde de Figueiredo, naquele mesmo ano de $1894 .{ }^{51}$

\footnotetext{
${ }^{49}$ JORNAL DO COMMERCIO, 8 de junho de 1892, p. 1.

${ }^{50}$ O PAIZ, 19 de novembro de 1894, p. 4.

${ }^{51}$ OLIVEIRA (1991), pp. 17-18.
} 


\section{1 - Brasileiros e estrangeiros na construção da Fábrica Bangu}

Redigidos seus Estatutos em 14 de janeiro de 1889; fundada a Companhia em 6 de fevereiro; assinado o contrato com o engenheiro Henrique De Morgan Snell em 21 de junho; foi só em 26 de setembro daquele ano que as obras para a construção da fábrica começaram, empregando, inicialmente, apenas 20 homens. Foram necessários quatro meses dedicados somente ao trabalho de terraplanagem e abertura de valas para o escoamento das águas pluviais. Finda esta primeira fase, entre dezembro de 1889 e janeiro de 1890, já se encontravam no canteiro de obras, 315 trabalhadores. ${ }^{52}$

Os dados gerais da obra são facilmente encontrados nos relatórios anuais da diretoria da Companhia, apresentados aos acionistas em 21 de março de 1891 e em 16 de março de $1892 .{ }^{53}$ No entanto, os relatórios não apresentam detalhes sobre quem era essa mão-de-obra que estava erguendo a nova fábrica, de onde vinham estas centenas de trabalhadores. Daí, torna-se necessário buscar indícios, pistas, vestígios da passagem desses homens pela região, como bem nos ensina o historiador italiano Carlo Ginzburg: "Se a realidade é opaca, existem zonas privilegiadas - sinais, indícios - que permitem decifrá-la". ${ }^{4}$

A historiadora Gracilda Alves de Azevedo Silva, que também se debruçou sobre a Companhia Progresso Industrial do Brasil, a partir de um estudo dos seus relatórios, não traz mais do que um parágrafo sobre quem foram os primeiros trabalhadores a chegarem a Bangu. Uma pista que pode ser aprofundada:

A mão-de-obra veio do Paraná, de Santa Catarina (principalmente, alemães e italianos), do estado do Rio de Janeiro e do Distrito Federal (principalmente portugueses). Utilizou-se também o braço escravo, recém-liberto, que lutava por uma oportunidade de abandonar a lavoura e acudira em massa para os centros urbanos. Na região, já existia um remanescente, deixado pelo Barão de Itacurussá. Foram estes escravos os primeiros colonos livres que ali se fixaram e se incorporaram à vida da fábrica nascente..$^{55}$

A única certeza demonstrada é que, já neste início, havia uma mescla entre mão-de-obra imigrante e brasileiros recém-libertos do trabalho escravo. O recenseamento feito em dezembro de 1890 pode ajudar a esclarecer quem era aquela população que vivia na região. Bangu ficava situado na freguesia de Campo Grande, uma das 21 freguesias em que era divida a Capital Federal. Na época, numa área total de $245.822 .000 \mathrm{~m}^{2}$, viviam apenas 15.947 pessoas, dentre os quais 14.899

\footnotetext{
52 FARIA, Fernando Antônio. "Companhia Progresso Industrial do Brasil: empresa e empreendedores" in: História Revista - Revista da Faculdade de História e do Programa de Pós-Graduação em História da Universidade Federal de Goiás (Vol 4: Nos 1 e 2). Goiânia: Universidade Federal de Goiás, 1999, p. 42.

${ }^{53}$ Idem, pp. 43, 45.

${ }^{54}$ GINZBURG, Carlo. Mitos, emblemas, sinais. São Paulo: Companhia das Letras, 2001, p. 177.

55 SILVA, Gracilda Alves de Azevedo. Bangu - a fábrica e o bairro: um estudo histórico, 1889-1930. Instituto de Filosofia e Ciências Sociais (IFCS) da Universidade Federal do Rio de Janeiro (UFRJ), 1985, pp. $774,777$.
} 
brasileiros $(93,5 \%)$ e 1.048 estrangeiros $(6,5 \%) .{ }^{56}$ Um índice bem menor de imigrantes do que no total da cidade do Rio de Janeiro que, entre 522.651 habitantes, concentrava 155.202 estrangeiros $(29,5 \%){ }^{57}$

Ainda baseado nos dados do recenseamento de 1890, dessas 15.947 pessoas que viviam no distrito de Campo Grande, 11.995 não sabiam ler, nem escrever, o que dava a cifra de $75 \%$ de analfabetos na região. Apenas 3.632 brasileiros (24\%) e 320 imigrantes (30,5\%) eram letrados. O número de brancos era de 5.654 (incluindo os 1.048 estrangeiros), contra 10.293 de "pretos, caboclos e mestiços". ${ }^{58}$ Os homens eram a maioria: 8.446 contra 7.501 mulheres (53\% a 47\%). No entanto, se entre os brasileiros este índice estava bem equilibrado: 7.593 pessoas do sexo masculino e 7.306 do sexo feminino ( $51 \%$ a $49 \%$ ); entre os 1.048 estrangeiros, a quase totalidade era formada por homens: 853 , havia apenas 195 mulheres $(81 \%$ a $19 \%),{ }^{59}$ o que mostra que a região parecia atrair imigrantes do sexo masculino, especialmente portugueses, sem família, que vinham buscar emprego nas obras da fábrica.

A presença de imigrantes na freguesia de Campo Grande, especialmente na antiga Fazenda do Bangu, já existia desde a época imperial, quando alguns colonos das Ilhas Canárias foram contratados para trabalhar na lavoura. A experiência, no entanto, foi a síntese do que ocorreria com diversos estrangeiros que vinham para o Brasil na esperança de melhorar de vida: "Uma turma de mais de 30 colonos das Ilhas Canárias, que se achavam na Fazenda do Bangu, abandonaram-na na noite passada, por falta de seus salários de três meses. Naturalmente... e muito tolos foram ainda". ${ }^{60}$

Ao longo das duas últimas décadas do século XIX, o número de entrada de imigrantes no país foi se acentuando. Se entre 1872 e 1879, entraram no país “apenas” 176.337 estrangeiros; no decênio entre 1880 e 1889 , exatos 448.622 imigrantes chegaram aos portos brasileiros; e um expressivo número de 1.198.327 veio para cá entre os anos de 1890 e 1899. Os dados de entrada, infelizmente, não são divididos por estados. No entanto, há a classificação por nacionalidade, evidenciando que, tanto na década de 1880, quanto na de 1890, os italianos representavam a grossa maioria deles com, respectivamente, $61,77 \%$ e $57,61 \%$ do total; os portugueses vêm logo em seguida com $23,34 \%$ e $18,30 \%$ nas duas últimas décadas analisadas. ${ }^{61}$

Vários trabalhos demonstram que esses imigrantes que vinham para o Brasil "fazer a América" estavam praticamente sendo expulsos de seus países de origem pela falta de emprego, de

\footnotetext{
${ }^{56}$ RECENSEAMENTO Geral da República dos Estados Unidos do Brasil em 31 de dezembro de 1890 - sexo, raça, estado civil, nacionalidade, filiação, culto e analfabetismo. Rio de Janeiro: Officina da Estatística, 1898, pp. $31,161$.

${ }^{57}$ CHALOUB, Sidney. Trabalho, lar \& botequim: o cotidiano dos trabalhadores no Rio de Janeiro da Belle Époque. $2^{a}$ edição. Campinas: Editora da Unicamp, 2001, pp. 43-45.

${ }^{58}$ Nomenclaturas utilizadas pelo recenseamento de 1890.

${ }^{59}$ RECENSEAMENTO (1898), pp. 31, 161, 389.

${ }^{60}$ A FOLHA NOVA, 30 de julho de 1883, p. 2.

${ }^{61}$ LEVY, Maria Stella Ferreira. "O papel da migração internacional na evolução da população brasileira (1872 a 1972)" in: Revista Saúde Pública, no 8. São Paulo, 1974, p. 71.
} 
terras para cultivar, pelo grande surto populacional, pela miséria e pela fome. Ingredientes suficientes para que os estrangeiros - muitos deles possuindo um capital modesto e sabendo realizar algum ofício - largassem sua pátria e atravessassem o Atlântico em busca de melhores oportunidades:

Muito antes de ter alcançado o campo, a fome atingira as cidades, onde vivia uma multidão expulsa da agricultura, sobretudo nos países já industrializados. (...) A diferença entre quem possuía algum tipo de ocupação e a multidão desempregada não passava de um prato de comida. ${ }^{62}$

O relato narrado por Carlos Urbin, que fez um minucioso trabalho sobre a saga da família Zamprogna, que partiu de Gênova em 1875 para o Rio de Janeiro e de lá para as colônias do sul do Brasil, mostra que todos os momentos da travessia eram repletos de incertezas. Em suma, um verdadeiro calvário:

A travessia do Atlântico dura mais de um mês, em navios sobrecarregados, passageiros recebendo alimentação precária, sem assistência médica nem camas. Luigi está indignado. Não há para quem reclamar, parece que os responsáveis pela viagem desapareceram. (...) Ana e Luigia choram, sem saber o que fazer. Há pouco, as duas rezaram junto com a família da Bréscia que perdeu a filha menor. A menina saiu da Itália com febre alta. Assim que morreu, os pais foram obrigados a jogar no mar o corpo enroladinho em um lençol. ${ }^{63}$

Depois da longa travessia, abarrotando a $3^{\text {a }}$ classe dos paquetes, esses imigrantes “maltrapilhos" chegavam ao porto do Rio de Janeiro, alarmando o cronista Luiz Edmundo:

Por vezes todo esse logradouro feio e imundo [o cais do porto] enche-se de homens que desembarcam, vindos das bandas do mar, sopesando canastras, baús, sacos, trouxas, pacotes, taramelando em voz alta, aos brados, em exclamações ruidosas, largando por onde passam um cheiro ativo e amorrinhado que fica entre o do suor humano e o do alho cozido. São imigrantes que chegam. Pobre e simpática gente que, pelas escadinhas do Pharoux, vomitam as lanchas, botes e saveiros. Trazem todos um ar medroso e parvo, os carões secos e tisnados pelo sol, metidos na moldura ampla e circular de enormes chapelões de Braga. Descem, como animais, de escantilhão, aos trotes (...) Por vezes, porém, os homens de ar asselvajado e triste entreolham-se e sorriem-se, cheios de enlevo, contentes e felizes. Batem com os pés no chão, para se convencerem. Olham o céu, com enternecimento, sentindo o azul, gozando a luz, beijando o ar! É o Brasil. Terra da promissão. Éden do bem-estar e da fartura. ${ }^{64}$

O governo republicano brasileiro tenta regularizar o serviço de introdução de imigrantes, publicando em 28 de junho de 1890 o decreto n ${ }^{\circ}$ 528. Assinado pelo Marechal Deodoro da Fonseca, ainda na época do governo provisório, a lei tem como objetivo trazer mão-de-obra europeia para as lavouras para substituir o braço escravo, recém-liberto. Além disso, é evidente a preocupação racial. Trazer o imigrante era também ajudar a contrabalançar a população, que possuía alto número de negros e mestiços. “A imagem do imigrante associava-se à ideia do 'melhoramento', seja pelo

\footnotetext{
${ }^{62}$ ALVIM, Zuleika. "Imigrantes: a vida privada dos pobres do campo" in: SEVCENKO, Nicolau (org.). História da Vida Privada no Brasil - República: Da Belle Époque à Era do Rádio. São Paulo: Companhia das Letras, 1998, p. 223.

${ }^{63}$ URBIM, Carlos. Zamprogna: a história da imigração italiana e a industrialização no Rio Grande do Sul. Porto Alegre: Nova Prova Editora, 2009, p. 31.

${ }^{64}$ EDMUNDO, Luiz. O Rio de Janeiro do meu tempo. Brasília: Edições do Senado Federal, 2003, pp. 69-70.
} 
branqueamento da população, seja a partir da divulgação ampliada de um éthos de trabalho"65, muito embora essa explicação se aplicasse mais ao imigrante italiano, que vinha com passagens custeadas, diferentemente do português, que não era "convidado" e por isso, não era bem recebido.

Por isso, desde o $1^{\circ}$ parágrafo do decreto republicano, já se demonstrava que essa nova "importação" de mão-de-obra seria controlada, impedindo assim a entrada de outros povos que não o branco europeu. De ex-escravos e descendentes de africanos, as ruas da Capital Federal já tinham 180 mil negros ou mestiços, compondo cerca de $34 \%$ da população em $1890{ }^{66}$

\footnotetext{
É inteiramente livre a entrada, nos portos da República, dos indivíduos válidos e aptos para o trabalho, que não se acharem sujeitos à ação criminal do seu país, excetuados os indígenas da Ásia ou da África, que somente mediante autorização do Congresso Nacional poderão ser admitidos com as condições que forem então estipuladas. ${ }^{67}$
}

Analisando o mesmo decreto, percebe-se que as condições de transporte daqueles imigrantes eram, realmente, precárias e alvo de um sem-número de reclamações. Tanto que o artigo 16 chega a incluir uma premiação para a companhia de navegação que não tivesse tido queixas, nem extravio de bagagens. Até onde se sabe, o governo republicano nunca precisou desembolsar nenhuma premiação: “As companhias de navegação, que houverem transportado durante o ano 10.000 imigrantes pelo menos, sem que tenha havido reclamação alguma a respeito das bagagens e do tratamento dado aos mesmos imigrantes, terão direito a um prêmio de 100.000 francos". ${ }^{68}$

Foi neste cenário de substanciosa chegada de mão-de-obra estrangeira aliada a uma grande quantidade populacional de ex-escravos que a Companhia Progresso Industrial estava recrutando trabalhadores para as obras da fábrica. Assim, encontramos na Gazeta de Notícias, de 22 de maio de 1890, o seguinte anúncio: "Alvenaria de tijolo - precisa-se de 20 bons oficiais pedreiros para as obras da Fábrica do Bangu. Paga-se bem". ${ }^{69}$ Como talvez, poucos tenham apresentado a especialização desejada, a Companhia republicou o anúncio no mesmo jornal em 27 de junho, desta vez, com significativas alterações na redação: "Pedreiros - precisa-se para trabalhar em tijolo na Fábrica do Bangu. Paga-se muito bem e dá-se casa. Trata-se na Rua do Rosário, 75, sobrado". 70

Uma fotografia, datada do final das obras, em 1892, retrata bem o perfil de quem aceitou o trabalho de pedreiro. A maioria era formada por negros, possivelmente ex-escravos, e até mesmo algumas crianças aparecem entre os tijolos da olaria, muitos deles descalços em meio ao entulho.

A fotografia, neste caso, serve como uma "imagem-documento" - para utilizarmos a classificação do historiador francês Jacques Le Goff -, na qual objetos, pessoas e lugares nos

\footnotetext{
${ }^{65}$ SCHWARCZ, Lilia Moritz. "População e sociedade" in: SCHWARCZ, Lilia Moritz (org.). História do Brasil Nação - A Abertura para o Mundo (1889-1930). Rio de Janeiro: Editora Objetiva, 2012, p. 36.

${ }^{66}$ CHALOUB (2001), pp. 43-45.

${ }^{67}$ DECRETO no 528, de 28 de junho de 1890. Brasília: Senado Federal, Subsecretaria de Informações. Texto integral da norma jurídica, localizado em: http://legis.senado.gov.br/legislacao/ListaTextoIntegral.action?id=75228.

${ }^{68}$ Idem.

${ }^{69}$ GAZETA DE NOTÍCIAS, 22 de maio de 1890, p. 4.

${ }^{70}$ Idem, 27 de junho de 1890, p. 4.
} 
informam sobre determinados aspectos do passado, no caso, as condições de trabalho. Simultaneamente, esta fotografia pode ser vista como uma "imagem-monumento", ou seja, um símbolo, aquilo que, no passado, a sociedade estabeleceu como a única imagem a ser eternizada para o futuro. ${ }^{71}$ No caso desses trabalhadores que serviram à construção da fábrica, esta é a única fotografia conhecida.

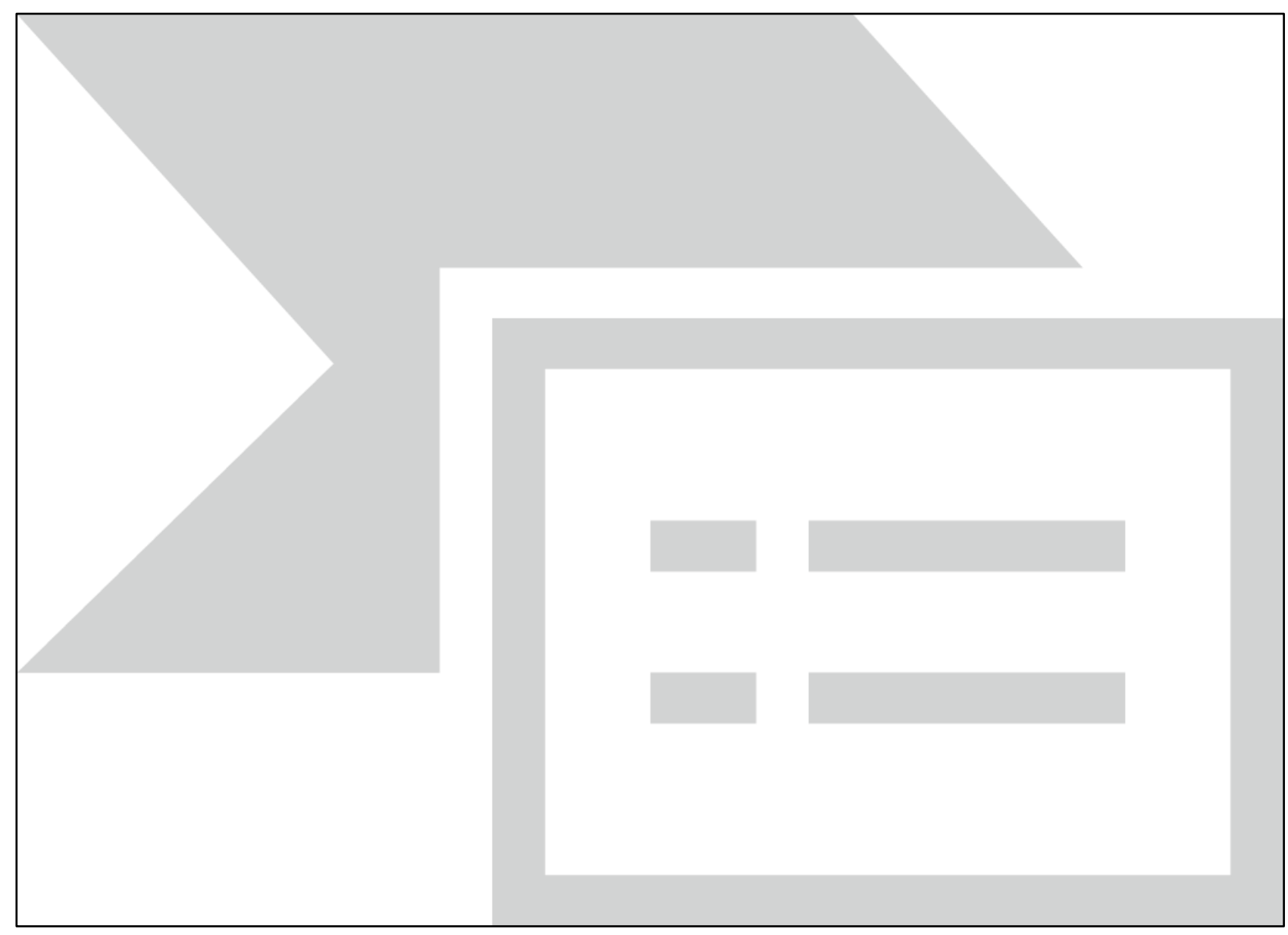

Figura 1 - Operários na olaria em 1892. Arquivo de Antenor Ferreira (Nonô).

\footnotetext{
${ }^{71}$ MAUAD, Ana Maria. Através da imagem: fotografia e história interfaces. Revista Tempo - volume $1, \mathrm{n}^{\circ} 2 . \mathrm{Rio}^{\mathrm{de}}$ Janeiro, 1996, p. 73-98.
} 


\section{2 - Desventuras dos primeiros trabalhadores}

É possível também que, além do grande contingente de brasileiros, alguns estrangeiros tenham aceitado a oferta da Companhia. Operários desconhecidos, cujos nomes só aparecem nas páginas dos jornais quando morrem, se acidentam ou quando se envolvem em alguma confusão. Assim, é possível encontrar informações precárias sobre a morte de um inglês chamado John Ockley, em $1^{\circ}$ de junho de 1891 , vítima de uma "congestão cerebral", ${ }^{72}$ de uma queda que feriu gravemente o operário alemão Frederico Old, em 10 de outubro de 1891, tendo que dar entrada na Santa Casa de Misericórdia ${ }^{73}$; de um acidente envolvendo o alemão William Metrupp, "empregado na Fábrica do Bangu", também recolhido à Santa Casa por ter caído de um bonde e fícado com a mão direita esmagada pelas rodas, em outubro de $1892 ;{ }^{74}$ de um conflito envolvendo dois italianos - Zanine Ettore e Roque Sevollelo -, no qual Ettore feriu gravemente o seu compatriota com um martelo. $^{75}$

Embora as notícias dos jornais não explicitem o motivo dos conflitos na região de Bangu, é possível encontrar choques entre trabalhadores de diferentes nacionalidades, como o que ocorreu entre um imigrante britânico e um alemão em novembro de 1891:

William John Fordyre, empregado da Fábrica de Tecidos do Bangu, foi agredido e ferido, em 14 do corrente mês, por seu companheiro de trabalho, o alemão Hermes Henrique Frederico Stives, que se julga ser desertor da brigada policial.

A autoridade local prendeu e lavrou auto de flagrante delito contra o ofensor, enviando o ferido para a Santa Casa de Misericórdia. ${ }^{76}$

Numa época de permissão incondicional ao trabalho infantil, deveria ser normal encontrar menores nos canteiros de obra da fábrica. Apesar de raramente aparecerem nos registros formando junto com as mulheres uma espécie de "população invisível" da história - dois meninos de cerca de 14 anos surgem nas páginas dos jornais, vítimas de um acidente "em uma fábrica do lugar denominado Bangu". A Gazeta de Notícias, porém, coloca a nota de forma a parecer que Eloy Agenor da Silva e Pedro José Maria estavam "brincando" com um troly de conduzir areia, quando esta máquina virou sobre Eloy, que faleceu instantaneamente, por ter ficado com a cabeça esmagada. Pedro, com um pouco mais de sorte, ficou ferido em uma das pernas. ${ }^{77}$

Fora os conflitos, os acidentes, a vida dos primeiros trabalhadores urbanos que chegaram à região também sofria o abalo das epidemias. A Gazeta da Tarde informava, em edição de 11 de

\footnotetext{
72 O TEMPO, 5 de junho de 1891, p. 2; GAZETA DE NOTÍCIAS, 5 de junho de 1891, p. 1.

73 JORNAL DO BRASIL, 11 de outubro de 1891, p. 2.

${ }^{74}$ O TEMPO, $1^{\circ}$ de novembro de 1892 , p. 1.

75 JORNAL DO BRASIL, 3 de fevereiro de 1892, p. 1.

${ }^{76}$ Idem, 18 de novembro de 1891 , p. 1

77 GAZETA DE NOTÍCIAS, 28 de março de 1891, p. 1. A mesma notícia, sem qualquer informação adicional, foi reproduzida nas páginas de O PAIZ, 28 de março de 1891, p. 1; DIÁRIO DO COMMERCIO, 28 de março de 1891, p. 1. e DIÁRIO DE NOTÍCIAS, 28 de março de 1891, p. 2.
} 
março de 1891, que "na estação de Bangu está grassando com intensidade a febre amarela" e justamente "onde a epidemia tem feito grande número de vítimas é em uma fábrica de tecidos que ali existe". ${ }^{78}$ Não só em Bangu, mas em todo o Rio de Janeiro, o verão de 1891 assistiu a um grande surto. Entre $1^{\circ}$ de janeiro e 14 de março, 817 pessoas tinham morrido da doença na cidade, ou seja, 11 mortes por dia. ${ }^{79}$

Sem especificamente falar sobre o lugarejo de Bangu, $O$ Paiz alertava que as maiores vítimas eram pessoas que moravam em estalagens insalubres, com espaço diminuto e com alta lotação. A febre amarela atingia principalmente estrangeiros, "chegados faz muito pouco tempo e que, por conseguinte, ainda não estão naturalmente aclimatados". ${ }^{80}$

Alarmado com a notícia divulgada pela imprensa, é provável que o engenheiro superintendente dos trabalhos, empregado da De Morgan Snell \& Co., Sigwald Müller tenha sido o redator da carta enviada ao jornal de língua inglesa The Rio News, desmentindo que a febre amarela venha ceifando vidas em Bangu. Segundo a carta, em março de 1891, havia 660 homens trabalhando nas obras, com apenas quatro mortes desde outubro de 1889. Além disso, os operários tinham feito uma subscrição entre si, para garantir um médico e um dispensário gratuito a todos. E para terminar a retificação, o seu autor garantia: "como um grande número de estrangeiros são empregados, o relatório da doença lá - o que parece ter surgido por motivos pessoais -, ocasionará muita ansiedade desnecessária e alarme entre os seus amigos". ${ }^{81}$

Seja como for, verídica ou inverídica, os principais engenheiros estrangeiros da De Morgan Snell \& Co., não moravam próximos do canteiro de obras. Encontramos nos jornais, vindos de Bangu e dando entrada no Freitas Hotel, situado no Largo da Lapa, os nomes de Sigwald Müller, J. H. Clark e David Mills. ${ }^{82}$

O hábito de Sigwald Müller de escrever para o The Rio News resultou na mais significativa contribuição para entender a história de como diversos imigrantes foram encontrar nas obras da Fábrica Bangu um emprego e porque não dizer, um abrigo seguro. O historiador Stanley Stein já tinha se deparado com o caso dos imigrantes da cidade inglesa de Bradford, que chegaram ao Brasil em 1891, e foram transferidos para o Sul. Segundo ele, não eram apenas italianos e portugueses que se deparavam com a penúria e eram obrigados a emigrar, os britânicos também foram vencidos pela depressão e a grande concorrência entre as indústrias têxteis fez com que muitas delas fechassem, obrigando seus operários a buscarem trabalho em outro continente.

Os tecelões de Bradford, Inglaterra, foram trazidos para Santa Catarina, em 1891, mas não encontraram trabalho; o cônsul inglês em Porto Alegre conseguiu emprego nas fábricas

\footnotetext{
${ }^{78}$ GAZETA DA TARDE, 11 de março de 1891, p. 1

79 THE RIO NEWS, 17 de março de 1891, p. 4.

${ }^{80}$ O PAIZ, 28 de fevereiro de 1891, p. 1.

${ }^{81}$ THE RIO NEWS, 17 de março de 1891, p. 4.

${ }^{82}$ NOVIDADES, 2 de setembro de 1890, p. 2
} 
Rehingantz de tecidos de lã e algodão para um homem e duas mulheres que estavam "quase morrendo de fome". Mas depois de seis meses de trabalho, o homem ganhava Rs $2 \$ 200$ por dia, o equivalente a dois shillings ${ }^{83}$, e as mulheres recebiam cerca de $2 £ 2$ s por mês, trabalhando por tarefa. "O homem embarcou de volta para a Inglaterra, via Rio de Janeiro e Estados Unidos, trabalhando de graça num navio a vapor como bombeiro, com a esperança de ser readmitido em sua antiga fábrica, com o seu antigo salário", informou o cônsul. ${ }^{84}$

Pelo menos, cinco desses imigrantes de Bradford, foram parar em Bangu. Inicialmente, saíram da cidade industrial situada no distrito de West Yorkshire e foram até o porto de Liverpool, distante 110 quilômetros. Lá, embarcaram no paquete Britannia, da Pacific Steam Navigation Company, no dia 4 de março de 1891, que fez escalas nos portos de Bordéus (França), Vigo (Espanha) e Lisboa (Portugal), antes de atravessar o Atlântico e chegar ao Rio de Janeiro, em 25 de março. Ao todo, segundo a lista apresentada pela Repartição Central das Terras e Colonização, assinada, inclusive, pelo Visconde de Figueiredo (grande acionista da Companhia Progresso Industrial e também membro da Comissão de Internação de Imigrantes ${ }^{85}$ ) desembarcaram 412 passageiros de $3^{\text {a }}$ classe, dos quais 96 vinham espontaneamente para o Brasil e outros 316 vieram por conta de contratos. ${ }^{86}$

Assinada por Robert Cummins, Loftus Hollywood, Thomas Flinn, John Connelly e Dominic Flinn e publicada no The Rio News sob o título "English Emigrant's Experience in Brazil”, traz uma pequena introdução, escrita pelo engenheiro Sigwald Müller, dizendo que os três últimos já tinham conseguido regressar a Yorkshire, enquanto os dois primeiros, com esposa e filhos, ainda permaneciam no Brasil, trabalhando em Bangu. Não há outras notícias sobre esses ingleses que ajudaram a construir a fábrica, mas é certo que penaram muito vagando desde a chegada ao porto do Rio de Janeiro, passando por São Paulo, porto de Santos, porto de Paranaguá, Rio Negro (PR) e Curitiba, até retornarem a Capital Federal:

\footnotetext{
Saímos de Liverpool no navio Britannia, no dia 4 de março de 1891, e desembarcamos no Rio, no dia 25. Um trem nos aguardava. Do porto do Rio de Janeiro fomos para São Paulo. Nós viajamos algumas horas antes paramos, quando, enfim, recebemos um pouco de água para beber. Seguimos então para um lugar chamado "Pinheiro"87, aonde chegamos às 8 horas da noite. Estava muito escuro. Fomos levados a uma casa, um edifício inacabado, que não tinha janelas e sem telhado. Nós ficamos lá três dias. Quando nossas caixas chegaram, elas estavam arrombadas e roubadas. No terceiro dia saímos de lá para São Paulo. Viajamos de $11 \mathrm{~h}$ de sábado pela manhã até às $6 \mathrm{~h}$ da manhã seguinte, sem um pouco de comida ou um copo de água. Muitos desmaiaram.
}

\footnotetext{
${ }^{83}$ A Libra Esterlina era fracionada em duas divisões até o início do padrão decimal, em 15 de fevereiro de 1971: o shilling e o pence. Para formar uma Libra eram precisos 20 shillings ou 240 pences. Para formar um shilling era preciso ter 12 pences. Ou seja, $1 £=20 \mathrm{~s}=240 \mathrm{p}$, sendo que $1 \mathrm{~s}=12 \mathrm{p}$.

${ }^{84}$ STEIN, Stanley Julian. Origens e Evolução da Indústria Têxtil no Brasil, 1850-1950. Rio de Janeiro: Editora Campos, 1979, p. 65.

${ }^{85}$ FARIA, Fernando Antônio. "Companhia Progresso Industrial do Brasil: empresa e empreendedores" in: História Revista - Revista da Faculdade de História e do Programa de Pós-Graduação em História da Universidade Federal de Goiás (Vol 4: Nos 1 e 2). Goiânia: Universidade Federal de Goiás, 1999, p. 51.

${ }^{86}$ Relação de passageiros do vapor Britannia. Arquivo Nacional, BR.AN.RIO.OL.0.RPV.PRJ 4447.

${ }^{87}$ Trata-se, naturalmente, da Hospedaria de Imigrantes de Pinheiros, para onde foram 255 dos imigrantes que desembarcaram do vapor Britannia.
} 
Quando chegamos à Hospedaria de São Paulo ${ }^{88}$, pudemos dividir meio-litro de café e um pão pequeno entre dois. Tivemos que vender nossas roupas para comprar comida, ou teríamos morrido de fome. Nós ficamos lá 17 dias. Havia alguns emigrantes na hospedaria quando chegamos lá; eles nos alertaram para não irmos para uma plantação de café, pois eles tinham ido. Eles estavam em uma condição chocante: coberto de chagas, de larvas de insetos e mal alimentados. Depois de terem trabalhado durante algum tempo, eles fugiram da plantação e vieram caminhando de São Carlos até São Paulo ${ }^{89}$, com suas mulheres e crianças. Uma pobre mulher levou o bebê morto nos braços por três dias, então tiveram que enterrá-lo na beira da estrada.

Então, todos nós assinamos para ir para o estado do Paraná, onde fomos informados que era uma colônia inglesa. Fomos de São Paulo a Santos, e ficamos lá por 21 dias, dormindo em um chão de pedra, e recebendo muito pouca comida. Os soldados entravam e saíam, insultando as mulheres, e se os homens interferissem, eles eram espancados e cortados com espadas. Fomos então até Paranaguá pelo barco Rio Pardo. Recebemos três refeições em quatro dias e fomos tratados com muita crueldade. Nós fomos mantidos no convés, à mercê das torrentes de chuva, sem lona. Uma mulher idosa, de 70 anos de idade, foi espancada por dois marinheiros negros. Eles tentaram ultrajar a mulher e as meninas.

Quando chegamos a Paranaguá, fomos colocados em um trem para o Paraná (um dia de viagem!). Chegamos a um pequeno lugar chamado "Barragem", onde recebemos a primeira refeição em quase dois dias - uma caneca de feijão preto e duas batatas doces cada. Nós ficamos lá três semanas e, durante esse tempo, 11 crianças morreram. Nenhum alimento era dado para qualquer criança com menos de 5 anos de idade. Uma senhora e um cavalheiro inglês (Sr. Balster e Sra. Withers) vieram e nos aconselharam a ir a Rio Negro, onde resolveriam nossa situação; teríamos uma casa, terras, gado e dinheiro para começar. Eram cinco dias de viagem, e nossa comida não era suficiente para quatro dias. Foi horrível ouvir as pobres crianças chorando por comida. Uma criança morreu na carroça, tendo tido o seu pescocinho quebrado pelos chacoalhões. Lá fomos colocados em outra "casa"90 e os homens nos prometeram um trabalho de construir estradas. Durante três meses, trabalhamos e não recebemos nenhum dinheiro. Em seguida, as epidemias começaram, e as pessoas começaram a cair doentes, com febre. Não havia nenhum médico e nenhum alimento para comer. De cinco a seis morriam em um dia; alguns foram enterrados assim que morriam, em lugares imundos. Dois homens solteiros foram colocados num quarto nos fundos, expostos ao tempo, e ninguém pôde fazer qualquer coisa por eles. Eles foram encontrados mortos juntos. Fomos levados para a floresta, pois um dilúvio derrubou a "casa" e nós tivemos que encontrar um abrigo da melhor maneira que podíamos. Em todo esse tempo, jamais tivemos um médico e estávamos sem pão, apenas comíamos feijão preto e um pouco de farinha de mandioca, o que não era suficiente. Minha mulher, com um bebê de três semanas de idade, teve que viver com isso ${ }^{91}$. Fui então acometido de uma febre na floresta, que durou 38 dias. Não havia um homem capaz de ajudar a carregar os mortos. Russos-poloneses levaram-nos amarrados em varas e corriam com eles até um túmulo, como se fossem cães, sem clérigo ou qualquer um para vê-los decentemente enterrados; 49 morreram em um mês. Ao intérprete foi fornecido um chicote para bater nas mulheres que queriam fugir à noite. E todos nós bebíamos a mesma água suja. Após a epidemia, 16 homens foram capazes de ir trabalhar de novo, e quando eles pediram o seu dinheiro, eles os enviaram para a polícia, que bateu neles com as suas espadas, e mandou todos para fora, mulheres, crianças e tudo mais. Alguns de nós já estávamos um pouco melhor da febre. Disseram-nos que se quiséssemos nosso dinheiro, teríamos que ir a um lugar chamado Curitiba, 25 quilômetros depois de "Barragem". Distava de Rio Negro, 96 milhas ${ }^{92}$. Não tínhamos nem comida, nem dinheiro. Levamos, com nossas crianças, de dez a 12 dias caminhando e vivendo de frutos silvestres. Tivemos que dormir no chão nu. Choveu e relampejou tão forte, que estávamos com medo de chegar perto das árvores para nos abrigar. Uma pobre mulher, a Sra. Carr, ficou pela estrada.

\footnotetext{
${ }^{88}$ Os livros de registros da Hospedaria dos Imigrantes de São Paulo apontam para o dia 29 de março de 1891 a data da chegada deste grupo de ingleses por lá.

${ }^{89}$ A distância de São Carlos até São Paulo é de, aproximadamente, 238 quilômetros.

${ }^{90}$ Provavelmente, outra hospedaria.

${ }^{91}$ Neste trecho, o relato parece ser escrito por John Connolly, um inglês de 26 anos, que aparece nos registros da Hospedaria dos Imigrantes de São Paulo, acompanhado de sua mulher, Mary, também de 26 anos, e o filho John, de apenas seis meses.

${ }^{92}$ A distância entre Rio Negro e Curitiba é de 112 quilômetros.
} 
Quando chegamos a Curitiba eles riram de nós, e não nos admitiram na "casa". Dormimos nas ruas, pedimos, fizemos reclamações e, enfim, fomos admitidos. A febre estava no auge neste lugar, e muitos mais morreram. Aqui, novamente, um chicote foi utilizado para bater nas mulheres e nas crianças, e se os homens falassem uma palavra, eles eram espancados e trancados em uma caixa com furos para respiração por 24 horas. Uma mulher foi espancada três noites seguidas, até que ela ficou muito doente. Um rapaz foi espancado, seu nariz e boca sangravam. Ele não tinha mãe nem pai, ambos tendo morrido com a febre. Vários dos homens, eu inclusive, passaram a trabalhar para o governador do Paraná $^{93}$. Ele tratou-nos como escravos e não pagou nenhum dinheiro, então, estávamos determinados a não trabalhar mais.

Então disseram que íamos ser mandados para casa. Certa manhã, fomos colocados em um trem, às 5 horas, para Paranaguá, sem comida. Quando chegamos lá à noite, fomos colocados em um barco, o Rio de Janeiro, quase mortos de fome. A conduta da polícia a bordo foi escandalosa; o engenheiro-chefe, um inglês, teve de esconder as mulheres e crianças em sua cabine. Em seguida, fomos colocados em uma ilha ${ }^{94}$, em que fomos tratados pior do que nunca. Tivemos que deixá-la e vir para o consulado britânico no Rio de Janeiro. Sr. Parks, o funcionário do consulado, foi muito gentil; também o Sr. Trout, que alimentou-nos e vestiu-nos. Ele pediu que eu, Joseph Hossman, Harry Ward e John Peyton viessem até Bangu para conseguir trabalho, o que obtivemos dos Srs. Müller ${ }^{95}$ e Jaffray ${ }^{96}$, que nos trataram com grande bondade. Este é o primeiro lugar em que temos recebido salários pelo nosso trabalho. ${ }^{97}$

Verídico ou exagerado em alguns pontos, o relato desses ingleses que chegaram até Bangu, após penosa odisseia, revela como era visto o novo imigrante europeu: apesar de responder às perspectivas da corrente "civilizatória" do Estado, promovendo uma espécie de "branqueamento" da nação, para os fazendeiros, eles eram apenas substitutos dos escravos. Segundo o relato do viajante Van Del den Laërne, “o fazendeiro, acostumado como está a lidar constantemente com escravos, facilmente considera os colonos totalmente seus dependentes". ${ }^{98}$

A explicação para tantos maus tratos e seguidas recusas de pagamento aos imigrantes ingleses, é que, mesmo tendo passado três anos após o fim da escravidão, os proprietários continuavam com a mesma mentalidade escravista, principalmente nas áreas rurais, independentemente da raça ou da cor da nova mão-de-obra que aparecia. Nas obras da Fábrica Bangu, um empreendimento tocado pela firma de um anglo-brasileiro, supervisionado diretamente por engenheiros britânicos, natural que seus compatriotas fossem recebidos "com grande bondade" e, pela primeira vez em território nacional, conseguissem receber - mesmo que fosse uma quantia modesta - pelos dias trabalhados.

Mesmo depois da abolição, a situação dos ex-escravos e dos trabalhadores imigrantes europeus não mudou muito. No século XIX, os proprietários das fábricas tratavam os seus operários diaristas da mesma forma que os fazendeiros de café ou os senhores de engenho

\footnotetext{
${ }^{93}$ É possível que o governador do Paraná em questão fosse Generoso Marques dos Santos, que administrou o estado entre 3 de junho de 1891 e 29 de novembro de 1891.

${ }^{94}$ Provavelmente, trata-se da Hospedaria da Ilha das Flores, em São Gonçalo, no Rio de Janeiro.

${ }^{95}$ Sigwald Müller, engenheiro-superintendente das obras da fábrica.

96 Thomaz Jaffray, comerciante, que possuía uma venda que "explorava os gêneros de estiva para prover os operários da Fábrica Bangu". Manteve-a até 31 de agosto de 1892, quando dissolveu a sociedade que tinha com Guilherme dos Santos. Vide: GAZETA DE NOTÍCIAS, 14 de janeiro de 1893, p. 6.

97 THE RIO NEWS, 3 de maio de 1892, pp. 3-4.

${ }^{98}$ Apud. SLENES, Robert. "Senhores e subalternos no Oeste Paulista" in: ALENCASTRO, Luiz Felipe de (org.). História da vida privada no Brasil - Império: a corte e a modernidade nacional. São Paulo: Companhia das Letras, 2010, p. 286.
} 
tratavam os seus escravos ou os poucos trabalhadores livres que recebiam pagamento por dia de trabalho. O mercado de trabalho era limitado. A possibilidade de se tornar um pequeno proprietário em áreas inexploradas ou já ocupadas era remota. ${ }^{99}$

A situação dos imigrantes permaneceria por muitos anos a mesma, apesar da farta quantidade de relatos e denúncias. O governo italiano, por exemplo, chegou a proibir a imigração para o Brasil em 1902. ${ }^{100} \mathrm{O}$ estadista francês Georges Clemenceau, em visita ao país, em 1910, expôs em uma conferência o que pensava do assunto:

O Brasil, que por todos os meios, procura atrair o emigrante, deve criar leis que assegurem o seu bem-estar. Não bastam as reclamas pomposas espalhadas por toda a Europa, gritando que aqui há trabalho em quantidade; necessário também que o Estado assegure com leis, o bem-estar e condições de segurança do imigrante. ${ }^{101}$

As leis de proteção ao imigrante foram poucas, basicamente restrita ao decreto $\mathrm{n}^{\circ} 528$, de 28 de junho de 1890, assinado ainda pelo Marechal Deodoro. Ao contrário, foi aprovado o decreto $\mathrm{n}^{\circ}$ 1.641, de 7 de janeiro de 1907, que versava sobre a expulsão de estrangeiros do território nacional, logo intitulada "Lei Adolpho Gordo", nome do deputado que a propôs. ${ }^{102} \mathrm{Em}$ 1912, a lei ficou ainda mais rigorosa, quando o Congresso revogou todas as isenções (artigos $3^{\circ}, 4^{\circ}$ e $8^{\circ}$ ) do decreto de 1907..$^{103}$

Na realidade, o estrangeiro só iria ser recebido com o máximo do bem-estar e viajando em condições seguras se fosse um trabalhador especializado, como os técnicos têxteis britânicos que seriam recrutados por firmas locais e contratados com numerosas vantagens pela nascente indústria carioca (iremos analisar as trajetórias de alguns desses "mestres" durante o segundo capítulo desta dissertação). As milhares de famílias, desprovidas, que vinham para o país abarrotando a $3^{\text {a }}$ classe dos navios, acreditando encontrar uma terra de fartura, sofreriam com a ausência do Estado, a crueldade dos seus novos patrões e logo viam ruir seus sonhos de prosperidade. O caso dos tecelões de Bradford, que se aventuraram pelo interior do Paraná e terminaram trabalhando na construção da Fábrica Bangu é típico. Muitos estrangeiros fugiam das áreas rurais, onde viviam em condições de semiescravidão e iam para os centros urbanos, onde mais habituados à lida cotidiana nas cidades, poderiam almejar colocar em prática as especializações profissionais que traziam de seus países de origem. ${ }^{104}$

\footnotetext{
99 STEIN (1979), p. 63.

100 SLENES (2010), p. 290.

101 O ESTADO DE SÃ̃ PAULO, 7 de outubro de 1910, p. 5.

102 LEAL, Cláudia Feienrabend Baeta. "De primos, cunhados e anarquistas perigosos: repressão a imigrantes italianos (São Paulo, 1893)” In: HALL, Michael McDonald (org.). Cadernos Arquivo Edgard Leuenroth - Imigração, volume 15, $n^{o}$ 27. Campinas: UNICAMP/IFCH, 2009, p. 111.

${ }_{103}$ MARAM, Sheldon Leslie. Anarquistas, imigrantes e o movimento operário brasileiro. Rio de Janeiro: Paz e Terra, 1979 , p. 41.

${ }^{104}$ SCHWARCZ, Lilia Moritz. "População e sociedade" in: SCHWARCZ, Lilia Moritz (org.). História do Brasil Nação - A Abertura para o Mundo (1889-1930). Rio de Janeiro: Editora Objetiva, 2012, pp. 43, 69-71.
} 


\section{3 - A inauguração da fábrica}

No dia 5 de junho de 1892, o presidente da Câmara dos Deputados, Bernardino de Campos; o presidente da Companhia, Estevão José da Silva; o diretor-gerente, Antônio Xavier Carneiro; os engenheiros Arthur Alvim, Sigwald Müller, W. F. Lieson e Eduardo Gomes Ferreira, além de vários acionistas foram visitar as obras. "A fábrica será entregue dentro de poucos dias à Companhia e estará pronta para funcionar com 2.000 operários”, resumia o Jornal do Commercio.

A reportagem ainda dizia que "o sr. Müller foi auxiliado por vários mestres ingleses, tendo sob suas ordens cerca de 500 operários". Na ocasião da visita, o edifício principal da fábrica (com 174,9m x 106,6m) e a chaminé de 55 metros de altura já estavam concluídos. As máquinas importadas também tinham chegado, incluindo os 1.221 teares.

Todos os aparelhos de fiação e os teares, que devem produzir cerca de 36.000 metros por dia, são dos fabricantes Platt Brothers \& Co., de Oldham, os maquinismos para alvejamento, tinturaria e estamparia foram fornecidos por Matter Platt \& Co., e os três motores saíram das oficinas de Buckley, Taylor \& Co. ${ }^{105}$

Ao que tudo indica, faltava apenas a conclusão das casas para os operários, que deveriam formar uma vila contígua ao terreno da fábrica.

Atualmente procede ativamente a construção de 300 casas para seus operários, colocando-os convenientemente em ruas de 20 metros de largura. Os diversos tipos adotados e as disposições das casas mostram que todas as condições higiênicas foram atendidas e que dentro de pouco tempo o local será transformado em florescente povoado. ${ }^{106}$

Quando a Companhia Progresso Industrial do Brasil, finalmente, assumiu o controle da fábrica, em 11 de julho de 1892, todas as “casinhas" ainda não estavam prontas. Das 300 previstas, apenas 95 saíram do papel. Segundo o relatório da Companhia, os motivos do atraso eram as “dúvidas do engenheiro encarregado da construção dessas casas e a falta de pessoal para executálas". 107

No entanto, a existência da vila operária, mesmo que incompleta, era fundamental para a Companhia se beneficiar de um decreto imperial de 9 de dezembro de 1882, que isentava de impostos aduaneiros e concedia outros benefícios às indústrias que construíssem "casas populares higiênicas, com fossas, dependências de cozinha e de lavanderia, elevadas do solo e com boa aeração" para seus operários. ${ }^{108}$

\footnotetext{
105 JORNAL DO COMMERCIO, 8 de junho de 1892, p. 1.

106 Idem, ibidem.

107 FARIA, Fernando Antônio. "Companhia Progresso Industrial do Brasil: empresa e empreendedores” in: História Revista - Revista da Faculdade de História e do Programa de Pós-Graduação em História da Universidade Federal de Goiás (Vol 4: Nos 1 e 2). Goiânia: Universidade Federal de Goiás, 1999, p. 44.

${ }^{108}$ ABREU, Maurício. Evolução Urbana do Rio de Janeiro. 4a edição. Rio de Janeiro: Instituto Pereira Passos, 2010, p. 57.
} 
Por isso, tentando se beneficiar da lei, a Companhia aparece nos despachos do Diário Oficial da União, pedindo para ser restituída pelo governo nos seus gastos aduaneiros:

Companhia Progresso Industrial do Brazil - pedindo restituição dos direitos de expediente que pagou na Alfândega do Rio de Janeiro, na importância de 113:945\$930, pelo despacho dos maquinismos e aparelhos importados com destino à primeira instalação de sua fábrica de tecidos, tinturaria e estamparia, em construção no lugar denominado Bangu, freguesia de Campo Grande. ${ }^{109}$

Entre julho de 1892 e fevereiro de 1893, a fábrica passaria por um período de experiência. O bom funcionamento das instalações era garantido, contratualmente, por seis meses. ${ }^{110}$ Era tamanha a certeza da construtora de que tudo iria correr bem que, em 16 de setembro de 1892, realizou um "leilão de materiais e ferramentas pertencentes aos empreiteiros da De Morgan Snell \& Co., nos terrenos da Companhia Progresso Industrial do Brazil, por terem concluído as obras na fábrica de chitas e morins, na estação do Bangu, ramal de Santa Cruz". ${ }^{111}$

Com a construção pronta, a Companhia precisava de mão-de-obra para tocar os teares. Assim, encontramos outro anúncio nos jornais, em outubro de 1892: “Tecelões - Precisa-se na Fábrica de Bangu, estação do ramal de Santa Cruz. Trens às 6 1/4 em S. Diogo e às 7 1/2 na estação Central”. ${ }^{112}$

Enfim, quando possuía 700 funcionários - "desde a criança de 9 anos até o velho de 60"113 -, que conseguiam mover 497 teares e produzir 9.500 metros de pano por dia, a Fábrica Bangu abriu as portas oficialmente em 8 de março de $1893 .^{114}$

Diferentemente do que o livro dos 100 anos da Companhia, publicado em 1989, informa, o presidente da República, Marechal Floriano Peixoto não esteve presente na inauguração ${ }^{115}$. O "Marechal de Ferro" foi representado pelo seu ajudante de ordens, alferes Aristides Villas Boas. E mesmo que a "Revolta da Armada" ainda não tivesse sido deflagrada, o que só ocorreria em setembro, Floriano parecia ter outras atribuições naquela quarta-feira do que prestigiar o empreendimento de alguns capitalistas portugueses. ${ }^{116}$

Em nome do sr. Vice-Presidente da República, o sr. Tenente Villas Boas, seu ajudante de ordens, declarou que $\mathrm{S}$. Ex. sentia que preocupações políticas criadas por maus patriotas o impedissem de comparecer a uma festa industrial como aquela, que representava o tipo de civilização que almejava a nossa pátria. ${ }^{117}$

\footnotetext{
${ }^{109}$ DIÁRIO OFICIAL, $1^{\circ}$ de julho de 1892, seção 1, p. 4.

${ }^{110}$ FARIA (1999), p. 47.

111 GAZETA DE NOTÍCIAS, 16 de setembro de 1892, p. 3.

112 Idem, 18 de outubro de 1892, p. 5.

${ }^{113}$ DIÁRIO DE NOTÍCIAS, 10 de março de 1893, p. 1.

114 JORNAL DO COMMERCIO, 9 de março de 1893, p. 1.

115 SILVA, Gracilda Alves de Azevedo. Bangu 100 anos: a fábrica e o bairro. Rio de Janeiro: Sabiá Produções Artísticas, 1989, p. 118.

116 Segundo informações dos jornais, no dia 8 de março de 1893, Floriano Peixoto esteve em conferência, até adiantada hora, com o Ministro da Guerra, Francisco Antônio de Moura, na sala do telégrafo, no Palácio do Itamaraty. Vide: GAZETA DE NOTÍCIAS, 9 de março de 1893, p. 1.

117 JORNAL DO BRASIL, 9 de março de 1893, p. 1.
} 
Mesmo sem a presença ilustre do presidente, quando o trem, que partiu da Central do Brasil às 8 horas da manhã, repleto de políticos, diretores, acionistas e jornalistas, chegou à estação de Bangu, houve festa: “Ao chegar o trem à fábrica, a banda de música da Sociedade Recreio do Bangu, sob a direção do professor Barbosa, e composta por operários, executou o hino nacional, sendo os convidados recebidos com vivas e foguetes pelo pessoal do estabelecimento". 118

A comitiva fez uma longa visita às seções da fábrica, obtendo explicações detalhadas do diretor-gerente Antônio Xavier Carneiro, que "nada absolutamente poupou para que todos os convidados trouxessem da visita à monumental fábrica a mais agradável e lisonjeira impressão". ${ }^{119}$

Como era dia de festa, aos 700 operários foi oferecido um almoço com vinho ${ }^{120}$. Aos 200 convidados, foi oferecido um banquete, encomendado à famosa Casa Castelões, situada à Rua do Ouvidor, 114. Pela opulência do menu daquele dia - publicado em francês pela Gazeta de Notícias , já se podia prever que estava surgindo "o mais grandioso estabelecimento da América do Sul"121:

Serviço de mesa: empadinhas à la financière, ostras, camarões recheados, suspiros de batatas, croquetes de lagostim, coxas de frango à la Béchamel, perna de porco com agrião, roast-beef à inglesa, cordeiro no espeto.

Serviço principal: Canja à brasileira, peixe fino ao molho Chambord, filé picado à la parisiense, perdiz recheada à la Perigueux.

Serviço de frios: língua escarlate à pás pic, maionese à la Progresso Industrial, recheado de peru em um espeto, presunto gelado à la prussiano.

Sobremesas: pudins variados, geleias de frutas da Baviera, sorvetes sortidos, sobremesas à escolha, café.

Vinhos: Madére, Xérés, Chablis, Sauterne, Collares, Bordeaux, Bourgogne; Champagne Porto Vieux, licores, conhaque, águas minerais, cervejas. ${ }^{122}$

\footnotetext{
118 JORNAL DO COMMERCIO, 9 de março de 1893, p. 1.

${ }^{119}$ GAZETA DE NOTÍCIAS, 9 de março de 1893, p. 1.

${ }^{120}$ DIÁRIO DE NOTÍCIAS, 10 de março de 1893, p. 1.

${ }^{121}$ JORNAL DO COMMERCIO, 9 de março de 1893, p. 1.

${ }^{122}$ GAZETA DE NOTÍCIAS, 9 de março de 1893, p. 1.
} 


\section{4 - Fotografias e representações dos primeiros operários}

Em contrapartida à fartura do banquete oferecido pela Companhia e alegremente noticiado pela imprensa, no dia seguinte é que as máquinas começariam a produzir tecidos para o mercado; o período experimental tinha acabado. A cobrança, certamente, recairia sobre os primeiros operários, que aparecerem retratados em algumas fotos, que mostram claramente que o grosso dos trabalhadores, a mão-de-obra barata, era composta por negros, mulheres e crianças.

Naquele final de século XIX, os empresários tinham a visão, amplamente difundida, de que os pobres eram uma classe dada à indolência se não fosse coagida a trabalhar. Esperava-se que os filhos e filhas das famílias pobres que habitavam as vizinhanças das fábricas de tecido encontrassem no trabalho fabril uma ocupação apropriada e satisfizessem todas as suas necessidades de vida. ${ }^{123}$

Assim como no caso dos operários da olaria, mais uma vez, recorremos às imagens datadas de 1892, para dar rostos a esse contingente de trabalhadores. Nelas, vemos um mundo fabril repleto de crianças - muitas delas ainda na tenra idade -, listadas como pertencentes à seção de cardas. Constata-se que a empresa utilizava em larga escala o trabalho do menor, em tarefas inicialmente simples como varrer as seções e limpar as máquinas, ou então, atuando diretamente na fiação, aproveitando o fato de serem pequeninos para substituírem as espulas cheias de fios por espulas vazias nos filatórios. ${ }^{124}$ Um jornalista, em visita à Companhia em 1900, passando pela seção de fiação, percebeu que, as máquinas eram, na sua maioria, manobradas por crianças de 10 a 15 anos. $^{125}$

Empregando esses menores, como se estivessem dando proteção a essas famílias, o estilo "paternalista" dos industriais do final do século XIX é visto pelos historiadores contemporâneos, como uma forma de exploração racional da mão-de-obra. ${ }^{126}$

Olhando atentamente para o rosto desses personagens anônimos da história da Fábrica Bangu, é difícil não perceber que as crianças possuem uma aparência de miséria, sofrimento e abatimento ${ }^{127}$, além de um semblante sisudo e embrutecido. Numa época em que ainda estava longe a regulamentação do trabalho dos jovens - o primeiro "Código de Menores" só iria surgir em $1^{\circ}$ de dezembro de 1926, no governo do presidente Washington Luís, com o decreto $\mathrm{n}^{\mathrm{o}} 5.083$-, eles

\footnotetext{
123 STEIN, Stanley Julian. Origens e Evolução da Indústria Têxtil no Brasil, 1850-1950. Rio de Janeiro: Editora Campos, 1979, p. 66.

124 BASTOS, Ana Marta Rodrigues \& WEID, Elisabeth von der. O Fio da Meada - Estratégia de expansão de uma indústria têxtil - Companhia América Fabril (1878-1930). Rio de Janeiro: Fundação Casa de Rui Barbosa, 1986, pp. 183-184, 229.

125 JORNAL DO BRASIL, 18 de agosto de 1900, p. 3.

${ }^{126}$ DEAN, Warren. A industrialização de São Paulo (1880-1945). São Paulo: Difel, 1986, p. 168.

127 ÁVILA, Fernando Bastos de. Antes de Marx. As raízes do humanismo cristão: textos e comentários. Rio de Janeiro: Ed. PUC-Rio, 2002, p. 135-140.
} 
representavam a mão-de-obra mais barata possível, afinal, eram aprendizes, o que justificava um salário menor, apesar de cumprir jornadas igualmente longas. ${ }^{128}$

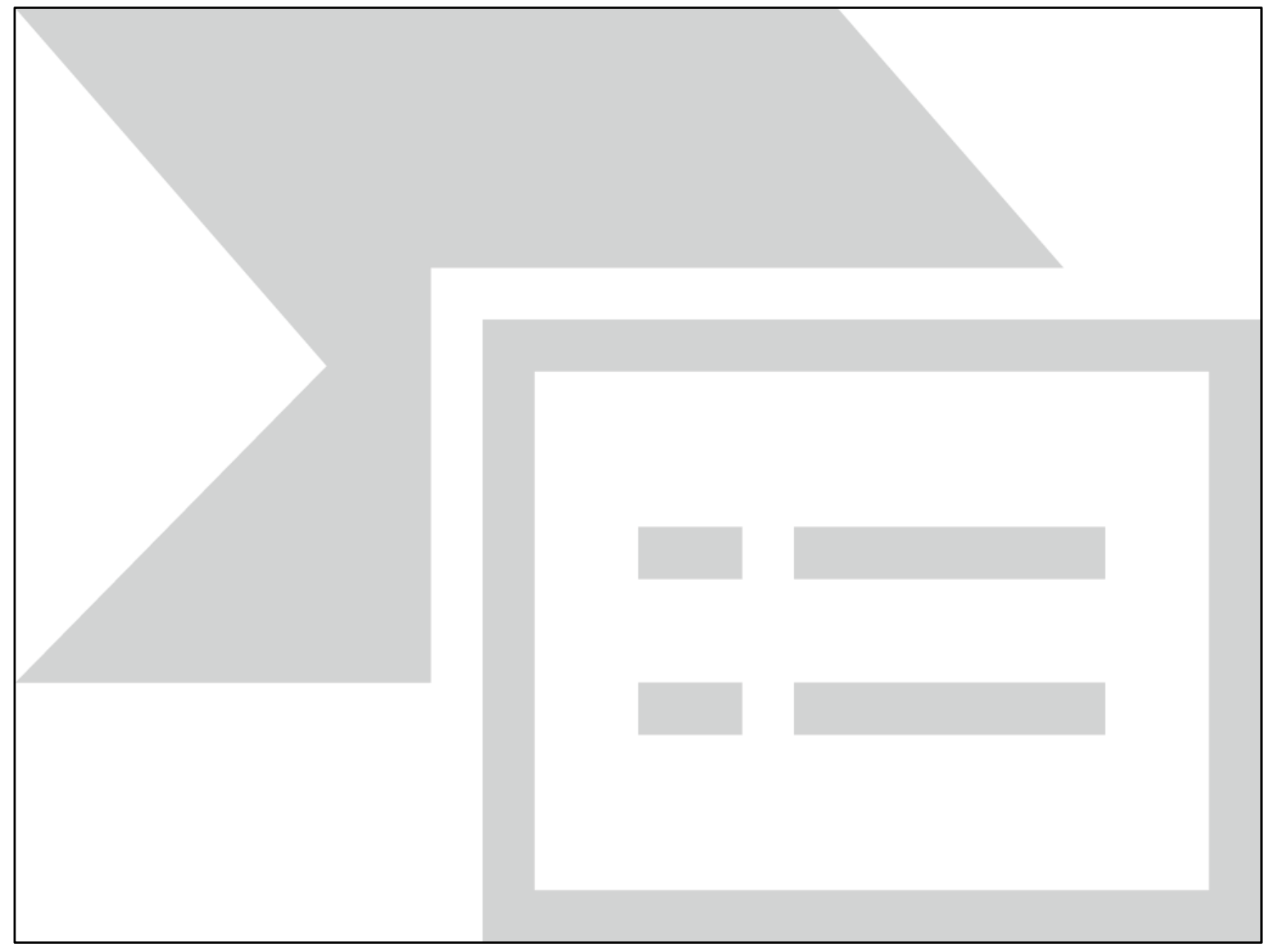

Figura 2 - Operárias da seção de cardas em 1892. Arquivo de Antenor Ferreira (Nonô).

Para uma fábrica que copiara modelos industriais britânicos desde a sua construção, a inclusão das crianças também seguia uma prática inglesa. Pesquisa feita pelo historiador Wade Tatcher mostrou que em Manchester e na vizinha Stockport na primeira metade do século XIX, 49,9\% dos operários tinham começado a trabalhar com idades inferiores a 10 anos e apenas 4,1\% tinham ingressado no ambiente fabril entre os 18 e os 20 anos. De acordo com a mesma fonte, as fábricas dessas duas cidades empregavam a proporção de 51,3\% de menores contra 48,7\% de maiores de 18 anos, de ambos os sexos. ${ }^{129}$

Esta série fotografias (uma com os operários das obras da construção da fábrica, uma das funcionárias e crianças da seção de cardas e outras duas de empregados de seções têxteis sem identificação) foi incluída no livro publicado pela Companhia para comemorar os cem anos de sua fundação, em 1989.

\footnotetext{
128 SILVA, Gracilda Alves de Azevedo. Bangu - a fábrica e o bairro: um estudo histórico, 1889-1930. Instituto de Filosofia e Ciências Sociais (IFCS) da Universidade Federal do Rio de Janeiro (UFRJ), 1985, pp. 764-769.

129 THATCHER, Wade. Child labor during the English Industrial Revolution.

In: http://wathatcher.iweb.bsu.edu/childlabor Acessado pela última vez em 13 de novembro de 2014.
} 
Para quem as vê com o olhar de hoje, elas podem depor contra a própria instituição, mostrando a crueldade do trabalho fabril, em que colocava crianças - muitas delas descalças - para cumprir longas jornadas nas diversas seções. No entanto, se olharmos com a ótica da época, o que se via era uma espécie de proteção, a fábrica dando um rumo na vida desses meninos pobres, ingressando-os desde cedo no mundo do trabalho. Não haveria lógica alguma em mandar retratar essas pessoas na época da fundação da Companhia, transformar essas imagens em "fotos oficiais", se não fosse para louvar o próprio estabelecimento.

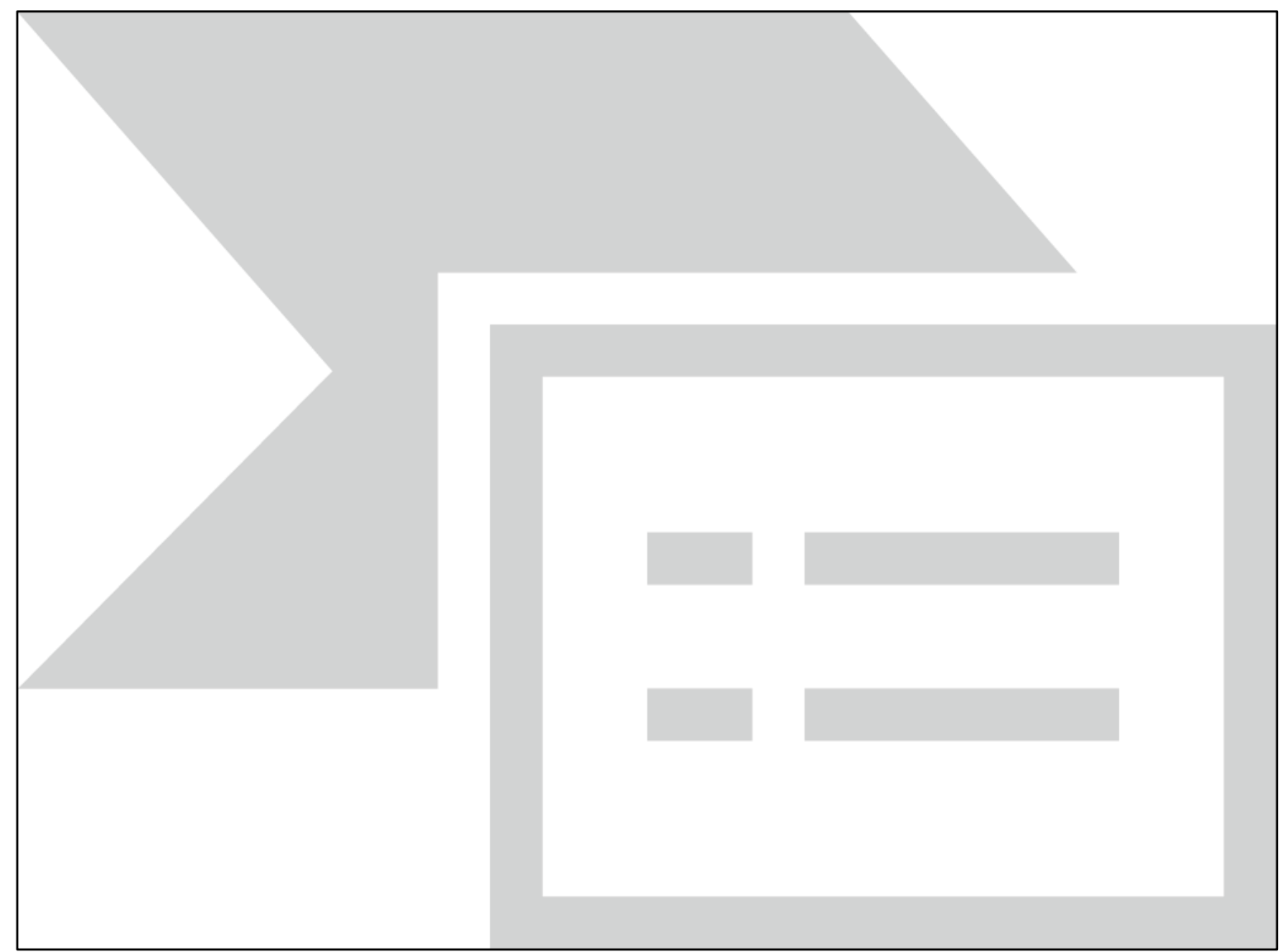

Figura 3 - Operários de uma seção não identificada da Fábrica Bangu, em 1892. Na imagem vemos 15 homens adultos, uma mulher, duas adolescentes (do sexo feminino), dois adolescentes (do sexo masculino) e seis crianças. Arquivo de Antenor Ferreira (Nonô).

Porém, logo se perceberia que o trabalho do menor era uma exploração do industrial à procura de uma mão-de-obra barata. Segundo os jornais, cada um deles ganhava a ninharia de $1 \$ 300$ a $2 \$ 000$ (mil e trezentos réis a 2 mil réis por dia) e trabalhavam das 6 horas da manhã até às 6 horas da tarde, com descanso apenas para o café e para o almoço. Uma reportagem do cronista Costa Rego para o Correio da Manhã, em 1907 (quinze anos após a confecção das fotografias dos primeiros operários da Fábrica Bangu), serviu como um alerta para quem defendia a inclusão das crianças no trabalho fabril. Apesar de não ter visitado a Companhia Progresso Industrial do Brasil, a 
realidade vista pelo jornalista nas duas fábricas da Gávea (a Carioca e a Corcovado) deveria ser idêntica na Aliança nas Laranjeiras; na Confiança Industrial, em Vila Isabel e também em Bangu.

As crianças trabalham com os corpinhos tenros já definhados. Eram meninos e meninas, sem distinção, empenhados todos no serviço. Tinham aspecto de tuberculosos. Magros, as faces encovadas e os olhitos sombreados de olheiras fundas, mais pareciam esqueletos a se mexerem tetricamente naquele amontoado de engrenagens, de máquinas possantes, que se moviam ruidosamente, numa vertigem formidável de trabalho. (...) Olhei as criancitas, que se empenhavam no serviço. Conservavam o mesmo aspecto tristonho e apegavam-se ao trabalho como a uma coisa de que não podiam fugir e a que estavam irremediavelmente ligadas. ${ }^{130}$

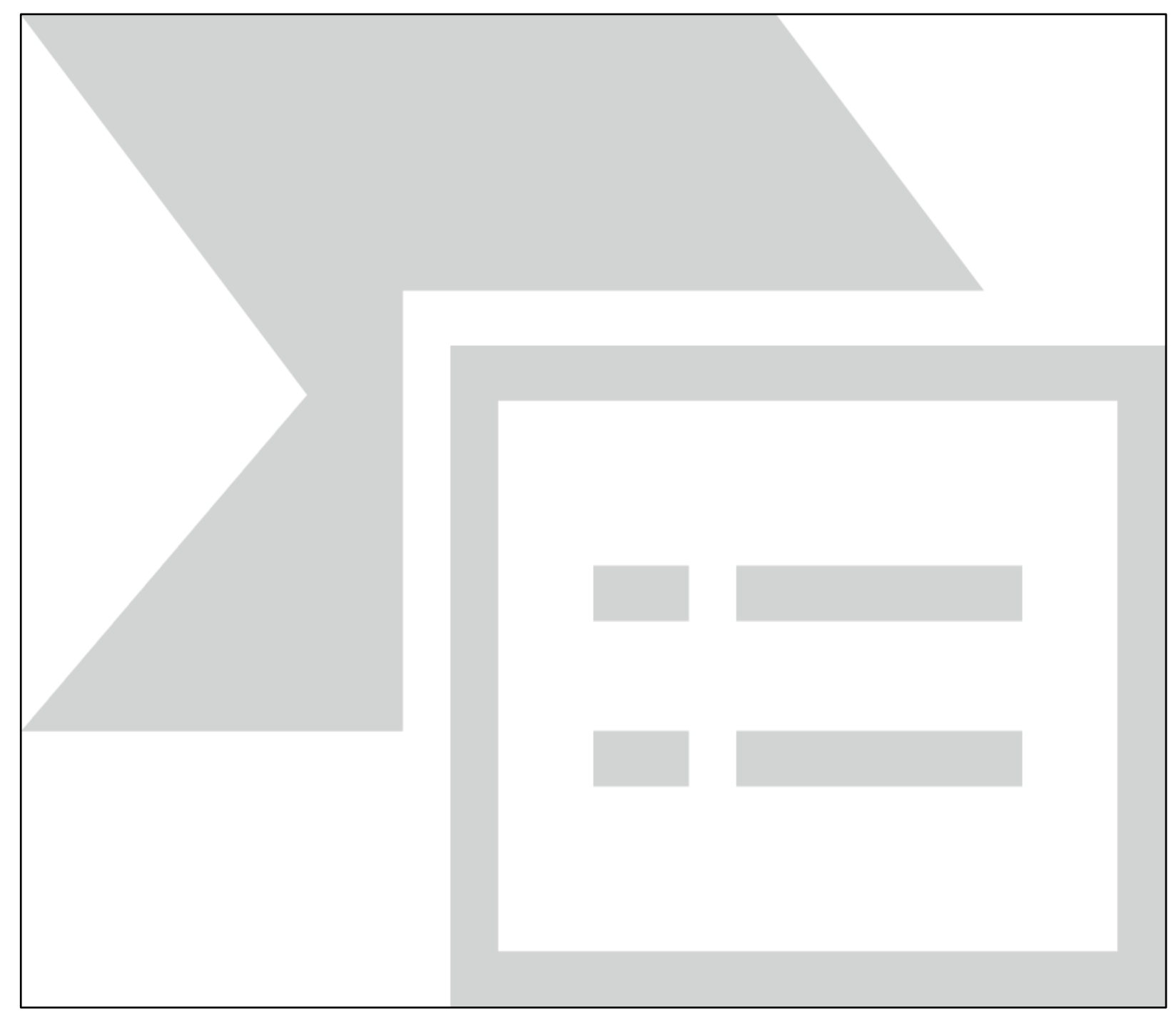

Figura 4 - Patrão de boina e bigode ao lado de algumas operárias e de 84 crianças. Baseando-se pelas imagens anteriores, inclusive por estar na mesma locação, também se tratavam de operários mirins da Fábrica Bangu, em 1892.

Arquivo da Organização Internacional do Trabalho (OIT).

Uma imagem, no entanto, não foi publicada no livro oficial do centenário da Fábrica Bangu, embora pertença à mesma série de fotografias de 1892. Foi encontrada apenas numa publicação recente da Organização Internacional do Trabalho, de 2001, e mostra um mestre têxtil cercado por 
vários "operários mirins". A cartilha foi produzida para combater o trabalho infantil contemporâneo, mas dedicou algumas páginas para lembrar que, no Brasil, esse tipo de mão-deobra era muito comum, principalmente nas fábricas de tecidos. ${ }^{131}$

É provável que já naquela época a fotografia fosse vista com algum mal-estar e poderia até indicar que a Companhia não cumpria o decreto $\mathrm{n}^{\circ} 1.313$, de 17 de janeiro de 1891 , assinado pelo Marechal Deodoro da Fonseca, que "atendendo à conveniência e necessidade de regularizar o trabalho e as condições dos menores empregados em avultado número nas fábricas existentes na Capital Federal e, a fim de impedir que, com prejuízo próprio e da prosperidade futura da pátria, sejam sacrificadas milhares de crianças", publicou dezessete artigos que visavam regularizar a mãode-obra infantil, especialmente na indústria têxtil. ${ }^{132}$ No artigo $2^{\circ}$ vinha logo a proibição de empregar menores de 12 anos, lei claramente infringida ao se analisar os mirrados meninos e meninas que aparecem na fotografia que, por mais de cem anos, permaneceu oculta.

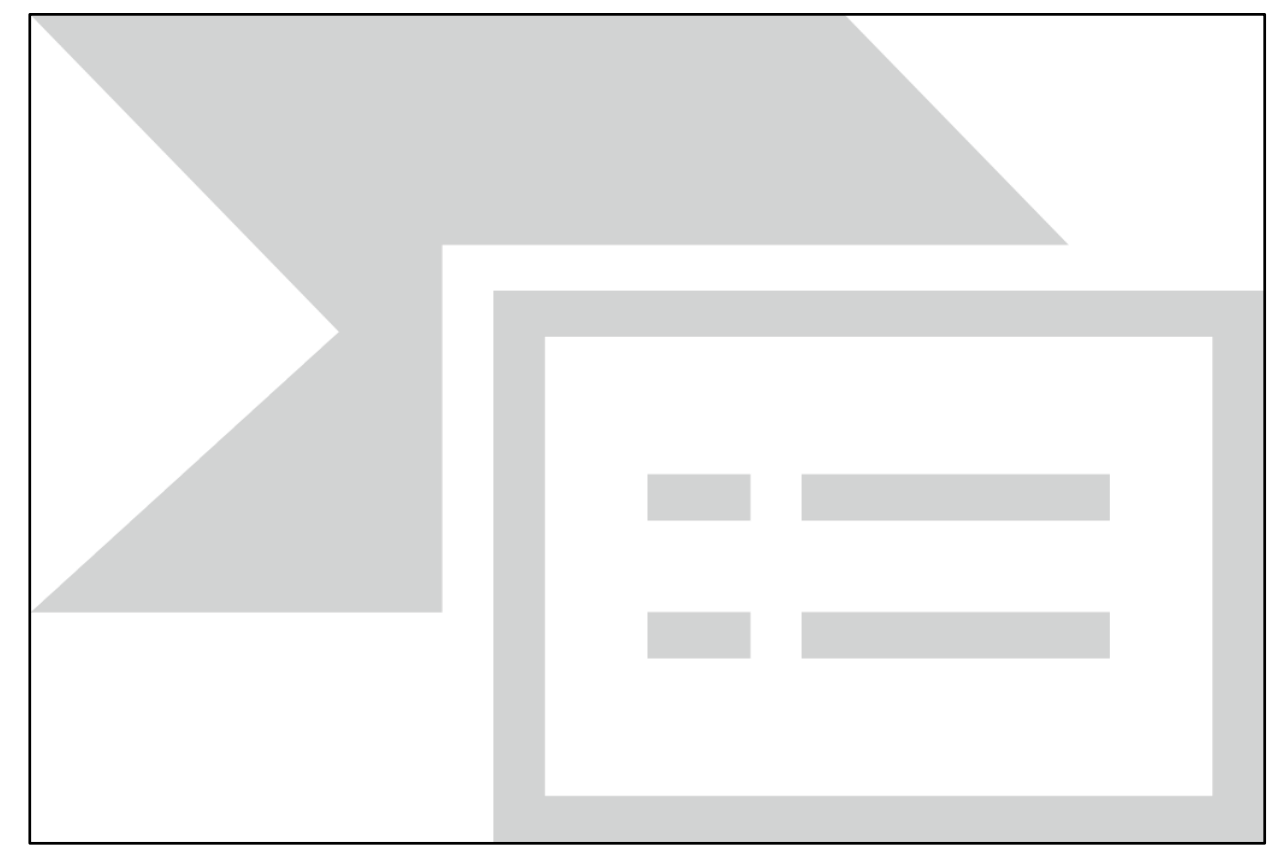

Figura 5 - Detalhe de onze crianças retratadas na fotografia anterior. Aproximando a imagem é possível ver o semblante entristecido e a aparência de miséria, sofrimento e abatimento no rosto dos pequenos operários. Arquivo do Museu do Futebol (SP).

Fotografias de operários, agrupados pela seção da fábrica em que trabalhavam, eram uma constante nas indústrias têxteis inglesas no século XIX. Muitas dessas fotos dividiam por fila quem

\footnotetext{
131 ORGANIZAÇÃO INTERNACIONAL DO TRABALHO. Combatendo o trabalho infantil - Guia pra educadores. Brasília: IPEC, 2001, pp. 24-28.

${ }^{132}$ Decreto $\mathrm{n}^{\circ} 1.313$, de 17 de janeiro de 1891. Brasília: Câmara dos Deputados. Texto integral da norma jurídica,

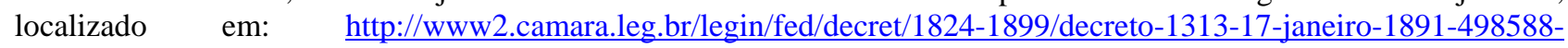
publicacaooriginal-1-pe.html
} 
estava no topo da hierarquia, separando assim chefes de subalternos. No exemplo abaixo, retratado na Fábrica Bangu, percebe-se que na primeira fila, sentados, encontram-se os mestres têxteis e os contramestres, enquanto o "grosso" dos trabalhadores - na quase totalidade negros - aparece em pé nas duas fileiras seguintes.

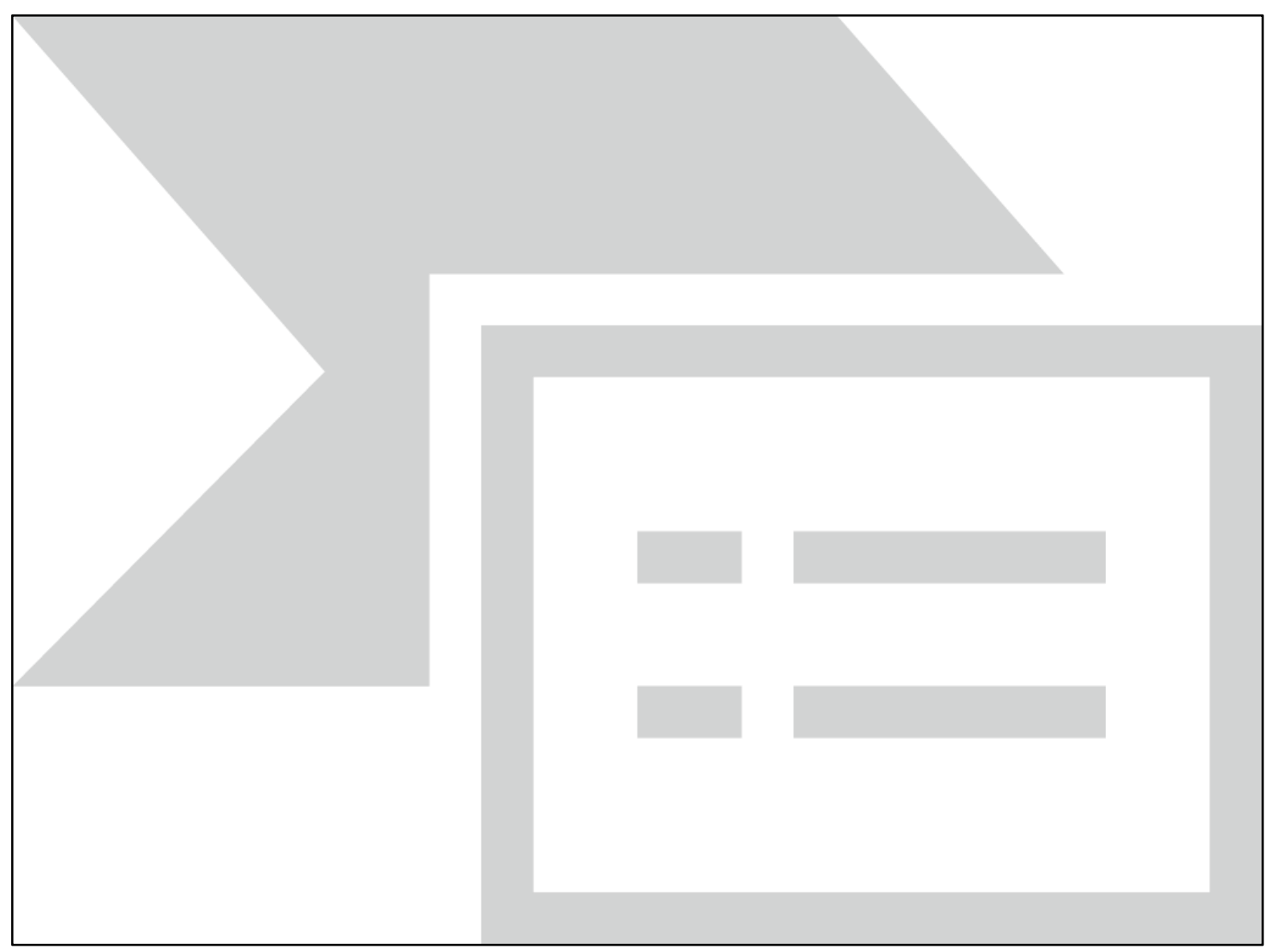

Figura 6 - Por mais que a imagem não indique qual a seção fabril, percebe-se que na primeira fileira estão os trabalhadores mais especializados daquele setor, sentados do lado esquerdo da fotografia. Arquivo de Antenor Ferreira (Nonô). ${ }^{133}$

Um anacronismo muito comum é olhar para a imagem e atribuir à época retratada impressões atuais. Daí, os mestres têxteis da primeira fila poderiam parecer senhores escravocratas que colocavam hordas de homens negros para trabalharem no pesado trabalho fabril, horas a fio, por um salário miserável. Quando a foto foi tirada, em 1892, essa imagem tinha, provavelmente, outra interpretação. Aquele grupo de operários, formado ordeiramente, deveria mostrar que a Fábrica Bangu estava acolhendo a mão-de-obra dos escravos recém-libertos após a Lei Áurea, sem qualquer

\footnotetext{
${ }^{133}$ As figuras reproduzidas do arquivo de Antenor Ferreira (figuras 1, 2, 3 e 6), mostrando diversos operários da Fábrica Bangu, foram retiradas do livro em homenagem ao centenário da Companhia. Vide: SILVA, Gracilda Alves de Azevedo. Bangu 100 anos: a fábrica e o bairro. Rio de Janeiro: Sabiá Produções Artísticas, 1989, pp. 26-27.
} 
resquício de preconceito, valorizando estes homens e dando-lhe a oportunidade de aprender um ofício fabril.

É claro que essas imagens de 1892 possuem diversos significados. Com o passar do tempo as interpretações sobre elas vão mudando. $\mathrm{Na}$ época, esses operários foram retratados para valorizar o trabalho fabril e a luta diária para a conquista do próprio pão, o que era uma prática comum na Inglaterra. Isso diferia totalmente da cultura portuguesa, que desde os tempos coloniais, nos segmentos mais abastados, via como positiva a ideia de se beneficiar do trabalho do outro, evitando assim ganhar a vida com o próprio suor.

Uma digna ociosidade sempre pareceu mais excelente, e até mais nobilitante, a um bom português, ou a um espanhol, do que a luta insana pelo pão de cada dia. O que ambos admiram como ideal é uma vida de grande senhor, exclusiva de qualquer esforço, de qualquer preocupação. E assim, enquanto povos protestantes preconizam e exaltam o esforço manual, as nações ibéricas colocam-se ainda largamente no ponto de vista da antiguidade clássica. $\mathrm{O}$ que entre elas predomina é a concepção antiga de que o ócio importa mais que o negócio e de que a atividade produtora é, em si, menos valiosa que a contemplação e o amor. ${ }^{134}$

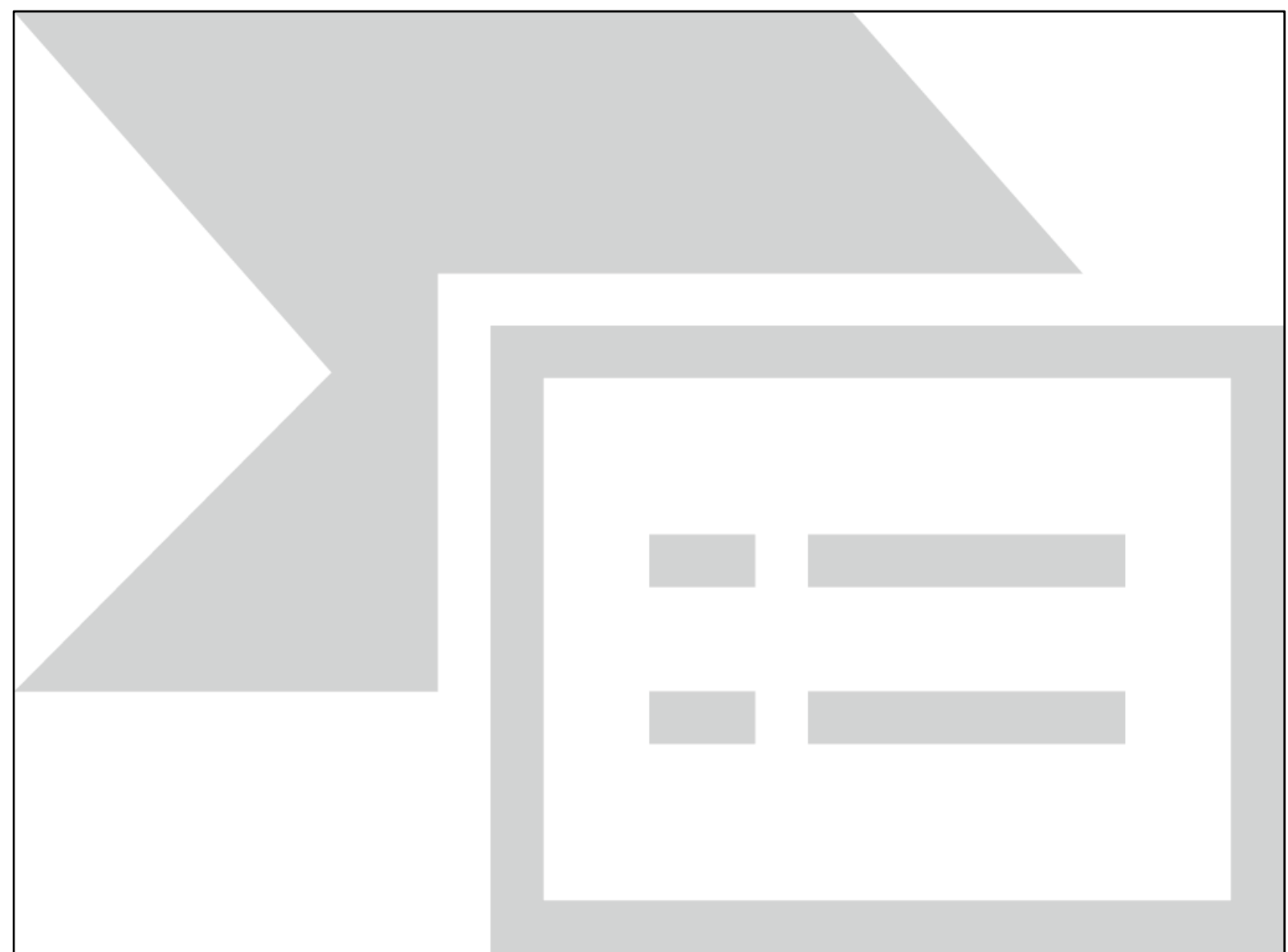

Figura 7 - Vários operários, incluindo nove crianças na primeira fila, circundam o mestre têxtil, vestido de terno e boina brancas, em 1892. Não há registro a qual seção pertencem. Fonte: Arquivo do Museu do Futebol (SP).

${ }^{134}$ HOLANDA, Sérgio Buarque de. Raízes do Brasil. São Paulo: Companhia das Letras, 2006, p. 28. 


\subsection{1 - O guardião da memória}

Curiosamente, o conjunto de imagens não foi guardado no arquivo da Fábrica Bangu, mas passou todo o século XX preservado graças aos cuidados de Antenor Ferreira, o "Nonô", um antigo morador do bairro.

Um simples tecelão da fábrica no final da década de 1910, quando também jogava futebol pelo time do Esperança - equipe das redondezas que disputava o Campeonato Carioca da $2^{\mathrm{a}}$ Divisão -, "Nonô" passa a defender as cores do $1^{\circ}$ time do Bangu A. C. entre os anos de 1921 e $1927^{135}$. Talvez por causa de seus méritos "futebolísticos", ele tenha passando para um trabalho mais leve, deixando a tecelagem e virando escriturário da Companhia já em 1921, como mostra o livro de registros de jogadores do clube, redigido a mão pelo secretário Guilherme Pastor entre 1911 e 1943.

Fora o futebol, Nonô também se envolveu com outra "paixão" dos banguenses: o Carnaval, o que certamente aumentou ainda mais sua popularidade no bairro. Durante toda a década de 20, ele aparece como mestre de canto da Sociedade Recreativa Prazer das Morenas de Bangu e lá ganhou outro apelido: “Antenor Ferreira, o célebre 'Garganta de Ouro', que há de assombrar as hostes adversárias, entre os justos e calorosos aplausos do povo desse soberbo arrabalde" - destacava o Jornal do Brasil, antes de mais uma apresentação do rancho, em 1927. ${ }^{136}$

Sua paixão pelo bairro, fez com que colecionasse muitas fotografias antigas, relativas ao trabalho fabril e ao clube de futebol, inclusive as dos primeiros operários, retratados em 1892, antes, portanto, de seu nascimento. Assim, "Nonô" se tornava o "guardião da memória".

Para a historiadora Ângela de Castro Gomes, o "guardião" ou o "mediador", como também pode ser chamado, tem como função primordial ser um narrador privilegiado da história do grupo a que pertence e sobre o qual está autorizado a falar. Ele possui as "marcas" do passado sobre o qual se remete, tanto porque se torna um ponto de convergência de histórias vividas por muitos outros do grupo (sejam eles vivos ou mortos), quanto porque é o "colecionador" dos objetos materiais que encerram aquela memória. Os "objetos de memória" são eminentemente bens simbólicos que contêm a trajetória e a afetividade do grupo. O "guardião", nesta perspectiva, é um profissional da memória. ${ }^{137}$

\footnotetext{
${ }^{135}$ Nos registros do Bangu Atlético Clube, Antenor Ferreira aparece pela primeira vez listado como "sócio prestante" (ou seja, o que presta algum serviço ao clube; no caso, jogando futebol) em $1^{\circ}$ de abril de 1920. No entanto, por não ter cumprido o acordo, Nonô foi desligado em 29 de julho do mesmo ano, reaparecendo novamente como "sócio prestante" em 24 de fevereiro de 1921, desta vez, realmente vestindo a camisa e defendendo as cores do clube nas disputas do Campeonato Carioca. Vide: "Atas das sessões de $1^{\circ}$ de abril de 1920, de 29 de julho de 1920 e de 24 de fevereiro de 1921". 6 Livro de Atas das Sessões da Diretoria do Bangu A.C., 13 de fevereiro de 1919 a 15 de dezembro de 1921.

${ }^{136}$ JORNAL DO BRASIL, 13 de janeiro de 1927, p. 12.

${ }^{137}$ GOMES, Ângela de Castro. "A guardiã da memória”. In: Acervo - Revista do Arquivo Nacional, Rio de Janeiro, volume $9, \mathrm{n}^{\text {os }} 1$ e 2, 1996, pp. 17-30.
} 
Por possuir essa preocupação com a história do bairro e ser ele mesmo parte integrante dessa história, Antenor Ferreira foi homenageado pela Câmara Municipal do Rio de Janeiro em 6 de setembro de 1985 com o título de cidadão benemérito do município do Rio de Janeiro, por proposta do vereador Aloísio de Oliveira, um político com bases eleitorais em Bangu.

Após o seu falecimento, o "guardião Nonô" continuou a receber homenagens do poder municipal. O nome de Antenor Ferreira batiza atualmente uma pequena rua no bairro vizinho de Senador Camará. 


\section{II - Mestres ingleses nos trópicos}

No Brasil do final do século XIX, época que alguns autores chamam de "nosso primeiro surto industrial", ${ }^{138}$ os fabricantes brasileiros dependiam das indústrias de máquinas da Grã-Bretanha, não só para a aquisição do equipamento, como também para a contratação de técnicos que vinham supervisionar a sua instalação e manutenção. ${ }^{139}$

Todo o maquinário da Fábrica Bangu tinha sido importado da Inglaterra. As companhias Platt Brothers \& Co., Matter \& Platt e Buckley \& Taylor Engineers, de Oldham, eram as responsáveis pelo aparelhamento da grande indústria. ${ }^{140}$ No entanto, só mesmo especialistas já familiarizados com tantos teares, motores, urdideiras, maçaroqueiras, poderiam auxiliar na operação dessas máquinas. Era como se, além do equipamento, a Companhia tivesse que importar um manual de instruções, em forma de um técnico têxtil britânico. Inicialmente, a diretoria conseguiu recrutar ingleses que moravam no Rio de Janeiro e trabalhavam em outras fábricas. O caso mais conhecido é o de Mark Sutton, que futuramente seria um dos grandes diretores da Companhia América Fabril dona de cinco empresas têxteis no Rio de Janeiro (a Cruzeiro, no Andaraí; a Bonfim e a Mavilis, no Caju; a Carioca, no Jardim Botânico e a Pau Grande, em Magé). O engenheiro, natural de Yorkshire, foi contratado pela Carioca em 1889, mudando-se para a Fábrica Bangu em 1892, ficando por apenas três anos e sendo o responsável pela instalação do primeiro lote de equipamentos. ${ }^{141}$

Mas, Mark Sutton, apesar de aparecer até no time de críquete montado pela Companhia em 1895, teve o mesmo destino breve de outros companheiros ingleses, que figuravam naquela equipe, como F. Smith, Edward Elkin, W. Jeakes e J. Harmond ${ }^{142}$ : nenhum deles fincou raízes no bairro. Realizaram seu trabalho, organizaram as seções da fábrica nos primeiros anos, colocaram os maquinismos em funcionamento e depois seguiram para outras Companhias, montaram suas próprias empresas de importação/exportação ou regressaram para a Inglaterra.

Se o primeiro grupo de britânicos não ficou por muito tempo, indo embora ao fim do contrato de dois ou três anos, a partir de 1893 a Companhia investiu pesado na contratação de mão-de-obra importada, trazendo da Grã-Bretanha técnicos têxteis para que se estabelecessem no bairro,

\footnotetext{
${ }^{138}$ HARDMAN, Foot Francisco \& LEONARDI, Victor. História da Indústria e do Trabalho no Brasil (das origens aos anos 20) - $2^{a}$ edição. São Paulo: Editora Ática, 1991, p. 21.

139 STEIN, Stanley Julian. Origens e Evolução da Indústria Têxtil no Brasil, 1850-1950. Rio de Janeiro: Editora Campos, 1979, p. 50.

140 SILVA, Gracilda Alves de Azevedo. Bangu 100 anos: a fábrica e o bairro. Rio de Janeiro: Sabiá Produções Artísticas, 1989, p. 25.

141 WRIGHT, Arnold. Impressões do Brazil no Século Vinte - Sua História, seo povo, commercio, indústrias e recursos. Londres: Lloyd's Greater Britain Publishing Company Ltd., 1913, p. 386.

142 THE RIO NEWS, 28 de maio de 1895, p. 8.
} 
trouxessem família e chefiassem as várias seções da fábrica. Oliveira (1991) sustenta que vieram, ao longo dos anos, 21 ingleses, com suas famílias. ${ }^{143}$

Mesmo sem se debruçar sobre quem eram especificamente os imigrantes da Fábrica Bangu, em linhas gerais, o sociólogo Gilberto Freyre traça um perfil da mão-de-obra inglesa que veio para o Brasil no século XIX. Para ele, esses operários britânicos eram "modestos transmissores de valores de uma cultura adiantada a outra ainda em formação, gente nada insignificante pelo que realizou". Acrescentando ainda que o brasileiro enxergava a Inglaterra como "um país de novos mágicos: os engenheiros, os técnicos, os mecânicos", apesar de reconhecer que "a mesma imigração foi sempre pequena em número, embora importante do ponto de vista técnico e econômico". 144

Essa comunidade especializada que se formou na Fábrica Bangu era contemplada com vantagens que nenhum outro imigrante recebia. Todos os mestres eram contratados com direito a passagem de volta e remuneração durante os dias da duração da viagem, tinham direito a toda ou metade da passagem da esposa, além do direito a passagens e ordenado se quisessem ir a Inglaterra, mesmo que à passeio. ${ }^{145}$ Fora isso, tinham prioridade na ocupação das casas da vila operária e recebiam seus salários em libra esterlina, de acordo com o número de dias trabalhados. Embora, analisando os pagamentos feitos aos chefes estrangeiros, no período de 1897 a 1900, não se encontre uma equivalência lógica entre a quantia em libras e o número de dias recebidos, o que reforça o fato de que cada contrato era específico, de acordo com a importância individual de cada um na produção fabril. ${ }^{146}$

A vinda desses especialistas deu-se, majoritariamente, na última década do século XIX, não aparecendo nos relatórios, a partir de 1903, nenhum registro de contratações feitas pela Companhia no exterior. Provavelmente, os que vieram depois desta data faziam parte das colônias de imigrantes que já se encontravam no Brasil. A exceção foi, em 1904, quando foram trazidos três ingleses para o conserto da chaminé de 56 metros, que se achava fendida em três partes. Segundo o relatório da Companhia, esses "Struple Jacks" eram "práticos nesses serviços" e o preço total do trabalho foi de 16:977\$950, "importância inferior à calculada", ${ }^{147}$ embora este valor significasse o equivalente a dois meses e meio de salários de todos os funcionários da fábrica em 1904.

Espécie de braço-direito dos diretores da Companhia, os ingleses ficavam com a administração da fábrica quando o gerente viajava, o que ocorreu em 1901. Além disso, quando

\footnotetext{
143 OLIVEIRA, Márcio Piñon de. Bangu: de fábrica-fazenda e cidade-fábrica a mais uma fábrica da cidade. Instituto de Pesquisa e Planejamento Urbano e Regional (IPPUR) da Universidade Federal do Rio de Janeiro (UFRJ), 1991, p. 99.

${ }^{144}$ FREYRE, Gilberto. Ingleses no Brasil. Aspectos da influência britânica sobre a vida, a paisagem e a cultura do Brasil. $3^{\text {a }}$ edição. Rio de Janeiro: UniverCidade Editora, 2000, pp. 29, 62, 87.

145 SILVA, Gracilda Alves de Azevedo. Bangu - a fábrica e o bairro: um estudo histórico, 1889-1930. Instituto de Filosofia e Ciências Sociais (IFCS) da Universidade Federal do Rio de Janeiro (UFRJ), 1985, pp. 774-775.

146 OLIVEIRA (1991), p. 100.

${ }^{147}$ DIÁRIO OFICIAL, 15 de abril de 1905, seção 1, p. 15-16.
} 
havia a necessidade de ir a Europa comprar novos maquinários, um deles ia junto para ajudar na escolha e, provavelmente, servir como um mediador das negociações. ${ }^{148}$

Desta forma, quando do recenseamento de 1906, encontravam-se na freguesia de Campo Grande, onde estava situada a Fábrica Bangu, o número significativo de 37 britânicos na região, com 28 homens e 9 mulheres (sendo que 11 eram crianças: 7 meninos e 4 meninas até 15 anos), superior ao número de alemães (35) e de franceses (26). ${ }^{149}$

No final do século XIX, a população inglesa parecia, aos olhos de Eça de Queirós, espalhada por todo o mundo. E de fato, onde havia a possibilidade de fazer negócios lá estavam eles. Ao encontrar uma comunidade de britânicos no Egito, o escritor português redigiu, alarmado, uma crônica que, bem poderia se referir à colônia de imigrantes que vivia em Bangu, um "obscuro canto do Universo" com marcante presença dos súditos de "Vossa Majestade":

Estão em toda parte esses ingleses! Porque por mais desconhecida e inédita que seja a aldeota onde se penetra, por mais perdido que se ache num obscuro canto do Universo o regato ao longo do qual se caminhe, encontra-se sempre um inglês, um vestígio de ingleses! Sempre um inglês! Inteiramente inglês, tal qual como saiu da Inglaterra, impermeável às civilizações alheias, atravessando religiões, hábitos, artes, culinárias diferentes, sem que se modifique num só ponto, numa só prega, numa só linha o seu protótipo britânico, querendo encontrar por toda parte o que deixaram em Regent Street, e esperando Pale-Ale e roastbeef no deserto da Pétrea; vestindo no alto dos montes sobrecasaca preta ao domingo, em respeito à igreja protestante, e escandalizados de que os indígenas não façam o mesmo; recebendo nos confins do mundo o seu Times ou o seu Standard e formando a sua opinião não pelo que veem ou ouvem ao redor de si, mas pelo artigo escrito em Londres; a alma voltada sempre para trás, para o home; abominando tudo o que não é inglês, e pensando que as outras raças só podem ser felizes possuindo as instituições, os hábitos, as maneiras que os fazem a eles felizes na sua ilha do Norte! ${ }^{150}$

Paschoal José Granado, um morador de Bangu, nascido em 1904, chegou a conviver, na sua infância, com alguns ingleses que trabalharam na fábrica. Ele encontrou "britânicos impermeáveis às civilizações alheias", como era o caso de William French, o mestre de máquinas e oficinas. Segundo as memórias de Granado, o "velho" French era "um inglês clássico que fumava cachimbo e falava pouco, quase taciturno e que nunca se familiarizou com a língua de nossa pátria". ${ }^{151}$ Ao mesmo tempo, conheceu um exemplo que era a antítese do padrão descrito por Eça de Queirós, o engenheiro eletricista William Procter $^{152}$ :

Foi o inglês mais brasileiro daqueles tempos. Nem sotaque tinha. Vivia somente entre brasileiros, não que desprezasse a companhia dos seus conterrâneos, mas se adaptara tão bem ao clima, a terra e aos homens que se esquecera da pátria-mãe. Nunca mais lá voltara. Era muito mais brasileiro do que inglês o nosso William. ${ }^{153}$

\footnotetext{
148 SILVA (1985), p. 775.

${ }^{149}$ SENRA, Nelson de Castro. O Censo de 1906 do Rio de Janeiro. Rio de Janeiro: Publicações Pereira Passos, 2012 , p. 346.

${ }^{150}$ QUEIRÓS, Eça de. Obra completa - volume 3. Rio de Janeiro: Editora Nova Aguilar, 2000, pp. 1172-1173.

${ }^{151}$ GRANADO, Paschoal José. O primeiro e o mais. In: Revista Comemorativa do $70^{\circ}$ aniversário do Bangu A.C., Rio de Janeiro, abril de 1974, p.7.

152 William Stewart Procter, nascido na Escócia em 20 de maio 1874, faleceu no Rio de Janeiro em outubro de 1923. “Ata da sessão de 11 de outubro de 1923". $7^{\circ}$ Livro de Atas das Sessões da Diretoria do Bangu A.C., 6 de janeiro de 1922 a 13 de novembro de 1930.

${ }^{153}$ GRANADO, Paschoal José. Retratos, espelho da vida. In: Bangu Notícias. Ano I - nº 1 - Novembro de 1970 , p. 17.
} 
Independentemente da adaptação ou não a terras tropicais, de certo modo, uma característica comum unia todos esses imigrantes britânicos. Recrutados de uma forma bem diferente daqueles primeiros tecelões de Bradford, que passaram por todo tipo de privações no Brasil, em 1891, esses técnicos foram escolhidos pela empresa Platt Brothers \& Co. - a mesma que fornecia máquinas para a Fábrica Bangu. No entanto, a história individual mostra que eles não eram mestres de seção em suas respectivas indústrias na Grã-Bretanha. Vieram indicados e fugindo de uma carestia de vida que afetava os empregados fabris naquele final de século XIX.

A situação, a princípio, pode parecer até simples: com um elevado número de mão-de-obra disponível, as fábricas têxteis inglesas pagavam salários baixos aos seus operários. Por isso, ao receberem uma proposta para serem mestres de seção, mesmo que em um país distante, esses trabalhadores viam na oportunidade uma chance de adquirir um status que jamais poderiam sonhar se estivessem ainda na Grã-Bretanha.

\footnotetext{
Naquela época, o Brasil era visto como uma terra de oportunidades, especialmente para profissionais treinados. Notícias sobre a qualidade de vida e custo de vida no Brasil foram publicadas na Inglaterra, os jornais anunciavam empregos e vagas de negócios aqui e mostravam nossos melhores aspectos da vida. O objetivo era atrair imigrantes com habilidades profissionais. ${ }^{154}$
}

Dados estatísticos, datados de 1881, mostram que um trabalhador assalariado inglês do século XIX gastava mais da metade de sua remuneração mensal $(56,9 \%)$ só com gêneros alimentícios, restando pouco para os gastos com vestuário (16,6\%), habitação/aluguel (13,5\%), lazer/educação (8\%) e para pagar os impostos (5\%). Vinte anos depois, em 1901, outra pesquisa realizada pelo Boardof Trade, estimava para uma família trabalhadora urbana composta por um casal e quatro filhos, exatos $75 \%$ da renda eram destinados à compra de alimentos. ${ }^{155}$

Por terem pertencido a um grupo, relativamente, de elite no bairro operário de Bangu, as famílias inglesas que mais tempo viveram na região são facilmente localizáveis em artigos de jornais, em relações de passageiros de navios, em registros censitários de seu país de origem, em certidões cartoriais de casamento e de nascimento quando ocorridos em território nacional, em atas de reunião do clube esportivo que fundaram, em relatórios da Companhia, em súmulas de jogos de futebol em que tomaram parte, enfim, em uma gama de documentos que nos ajudam a traçar a biografia dos membros dessa colônia, realizando, assim, um trabalho de "prosopografia", tal como nos sugere Lawrence Stone.

Para o historiador britânico que desenvolveu a ideia das biografias coletivas de pessoas simples da sociedade há alguns "limites e perigos", especialmente quanto à inexistência de correspondência pessoal íntima, que segundo ele, “é uma raridade entre os registros históricos”, já

\footnotetext{
${ }^{154}$ NEIRA, Luz Garcia \& WAIN, Sarah. Teaching arts and crafts or the technology transfer: Ernest Bower and textile design practice in Brazil. São Paulo: Editora Edgard Blucher, 2012, p. 103.

${ }^{155}$ VEIGA. José Eli da. O Desenvolvimento agrícola: uma visão histórica. São Paulo: EdUSP, 2007, pp. 41-42
} 
que é "usualmente destruída durante a vida ou na morte". Utilizada para "identificar a realidade social e descrever e analisar com precisão a estrutura da sociedade e o grau e a natureza dos movimentos em seu interior", a prosopografia irá sempre ser "limitada pela quantidade e pela qualidade dos dados acumulados sobre o passado". ${ }^{156}$ Graças a uma árdua busca pelos vestígios que deixaram, é possível dar rosto aos principais técnicos têxteis da Companhia e delinear a trajetória privada e profissional de, pelo menos, dez famílias ${ }^{157}$ que vieram e se fixaram em Bangu no final do século XIX.

Todos eles, operários lá na Grã-Bretanha, mestres aqui no Brasil, numa mudança de status bem assinalada por Gilberto Freyre:

Limito-me simplesmente a recordar a figura do trabalhador comum inglês no Brasil: operário de estrada de ferro, de minas ou de oficinas. (...) Pois não foi esse trabalhador comum uma figura desprezível em nossa vida, mas um portador de cultura, particularmente de técnica britânica, que contribuiu não só para o avigoramento do capital inglês no Brasil como para o desenvolvimento material do nosso país. E vários deles aqui constituíram família. Aqui se dissolveram na população brasileira. Aqui se elevaram socialmente, mudando de status. ${ }^{158}$

156 STONE, Lawrence. Prosopografia in: Revista Sociologia Política, volume 19, $\mathrm{n}^{\circ}$ 39. Universidade Federal do Paraná: junho de 2011, pp. 115-137.

${ }^{157}$ Algumas com mais, outras com menos informações, ainda assim é possível entrar na intimidade da vida privada e delinear as carreiras profissionais dos seguintes pioneiros britânicos que vieram para a fábrica têxtil: Thomas Donohoe, James Hartley, Thomas Hellowell, Thomas Stirling, John Stark, William French, Henry Bennett, Frederich Jacques, Clarence Sam Hibbs e os irmãos Andrew e William Procter. No entanto, a partir da página seguinte, limitaremo-nos a narrar a saga de três núcleos familiares, cujos documentos e fontes nos permitem traçar um panorama sobre a forma como chegaram a Bangu, quem eram as esposas e os filhos, quanto ganhavam por dia trabalhado e como interagiam com a população do bairro.

${ }^{158}$ FREYRE (2000), p. 112. 


\section{1 - As famílias britânicas em Bangu}

\subsection{1 - Os Donohoe}

A Escócia esteve em evidência no mundo inteiro em setembro de 2014. Um plebiscito decidiria se o país diria "sim" ou "não" para sua independência em relação à Grã-Bretanha. Os eleitores foram às urnas e tudo ficou como estava antes. O "Não" venceu com 55,3\% dos votos válidos. No entanto, o destaque na imprensa fez com que o jornal $O$ Globo entrevistasse o primeiroministro escocês Alex Salmond. Em uma das perguntas, respondendo sobre as relações BrasilEscócia, o líder nacionalista se lembrou de uma antiga história de um emigrante:

O Brasil é um país fantástico e vibrante, com o qual temos ligações históricas. Embora as nossas habilidades futebolísticas não sejam do mesmo calibre de uma Seleção Brasileira, temos orgulho de ter dado a vocês o jogo propriamente dito! Acredite ou não, foi um escocês que organizou o primeiro jogo de futebol da história do Brasil, em 1894! Foi um trabalhador da indústria têxtil, um certo senhor Donohoe, que se mudou da Escócia para o Brasil em 1894 para trabalhar numa fábrica no Rio de Janeiro. ${ }^{159}$

A história contada pelo primeiro-ministro faz sentido. Donohoe vem tendo sua trajetória de vida foi mais esmiuçada do que a dos outros mestres, justamente por ele ser o possível introdutor do futebol no Brasil. Nascido em 25 de janeiro de 1863 no pequeno vilarejo industrial de Busby, cidade a 8 quilômetros de Glasgow, Thomas Donohoe era o sexto filho do casal Patrick Donohoe e May Ann Sloan, ${ }^{160}$ irlandeses do Condado de Wicklow que haviam emigrado para a Escócia. Como todo morador da vila, Thomas teve como destino trabalhar na fábrica Printworks, lidando diretamente com o setor de tingimento de tecidos.

A Busby Printworks foi fundada em 1796 na região de East Renfrewshire e passou por muitas mudanças de donos ao longo do século XIX, chegando por algumas vezes - em 1803 e em 1828 - a fechar as portas, até que outro grupo assumisse o comando. A indústria era especializada no tingimento e estamparia de tecidos. Em 1883, a fábrica cobria uma área de 28.328 metros quadrados de terra, produzia 3.000 peças de tecido estampado por dia e empregava 600 trabalhadores. ${ }^{161}$

Thomas Donohoe era um desses 600 operários, aparecendo, inclusive, numa fotografia de 1884, com os demais trabalhadores da seção de tinturaria. Na ocasião, tinha 21 anos e era um dos subordinados de James Donohoe, seu irmão, dez anos mais velho e que já alcançara o posto de mestre.

\footnotetext{
${ }^{159}$ O GLOBO, 17 de setembro de 2014, p. 34.

160 Segundo informações do pesquisador escocês John McVicar, que se debruçou em buscar dados sobre a família Donohoe nos censos da Escócia, o casal Patrick e Mary Ann tinha respectivamente, 44 e 34 anos, no recenseamento de 1861. Naquela ocasião, o casal já tinha cinco filhos: James (8 anos), Patrick Jr. (7 anos), John (5 anos), Sarah (4 anos) e Ellen (4 meses).

${ }^{161}$ NIVEN, Thomas Eric. East Kilbride: the history of parish and village. Escócia: Wilson, Guthrieand Lang, 1965, p. 205.
} 


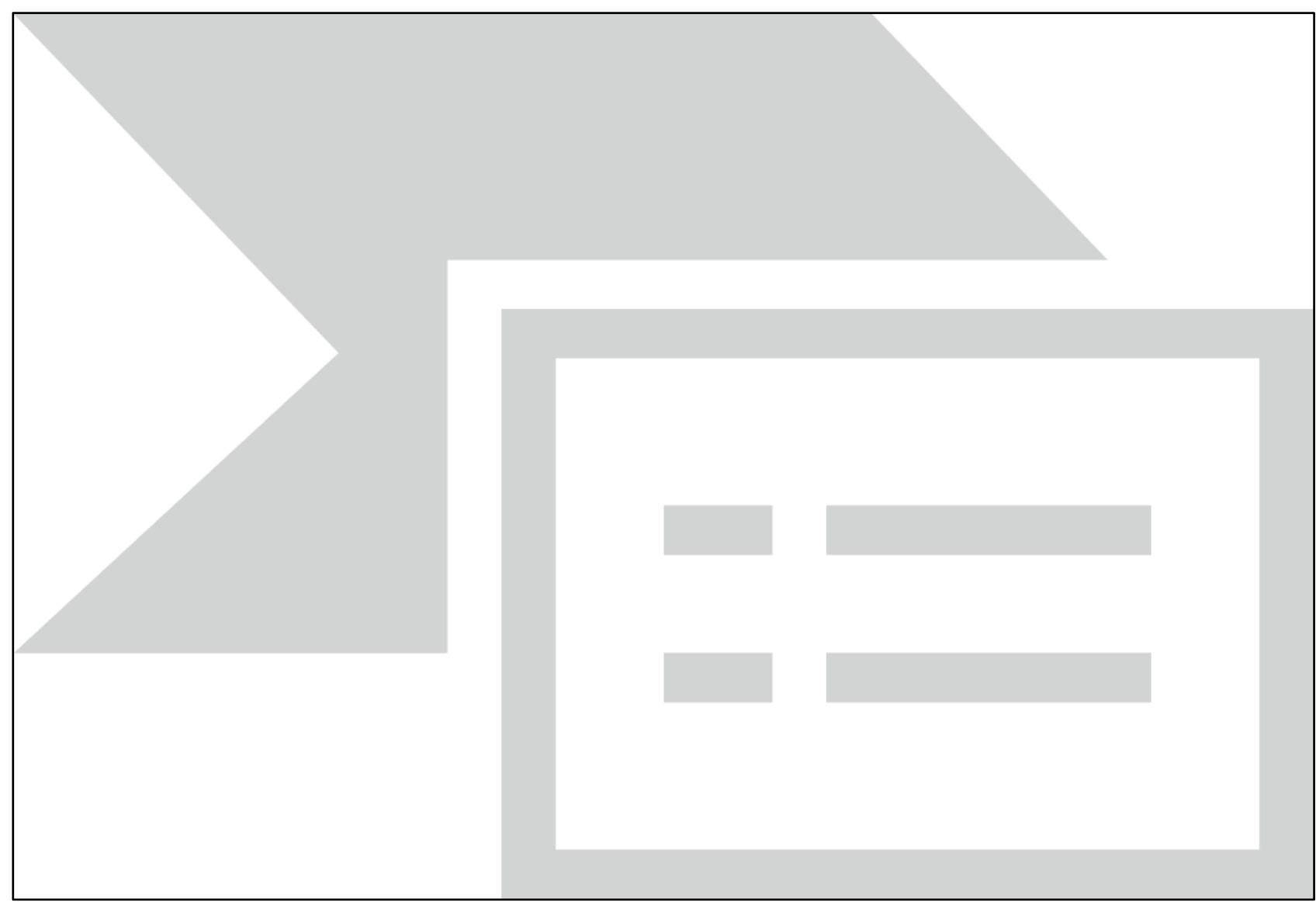

Figura 8 - Trabalhadores da seção de tinturaria da fábrica de Busby, na Escócia, em 1884. James Donohoe é o mestre do grupo e está na última fila, trajando seu chapéu coco, privilégio dos chefes. O jovem Thomas Donohoe, na ocasião com 21 anos, está à direita da fila de trás, com a mão na cintura e o já tradicional bigode que manteria por toda a vida. Percebemos na imagem, alguns jovens aprendizes na primeira fila - mostrando retalhos de tecidos - e duas mulheres na segunda fila, ladeadas de alguns operários barbudos. ${ }^{162}$

No recenseamento escocês de 1881, Thomas Donohoe, com 18 anos, ainda aparece morando na mesma casa que seus pais - Patrick e Mary Ann. A residência, situada em Busby, ficava na rua Burtons Land e tinha apenas dois quartos para uma família que comportava além do casal, o irmão John, a irmã Ellen, a caçula Mary Ann e a sogra Ellen Sloan.

Enfim, no dia 6 de junho de 1890, Thomas Donohoe, já com 27 anos, casa-se com Elizabeth Montagne, de 19 anos, também operária da vila de Busby. Com isso, no recenseamento de 1891, os recém-casados já aparecem morando em outro local, em Burnside Terrace, num sobrado, que dividia porta a porta com seu irmão Patrick Jr. - um bombeiro da fábrica Priestfield - que vivia com a esposa, a sogra e mais quatro filhos.

Numa família que tinha a tradição de ter muitos descendentes, Thomas não ficou para trás. Em 30 de junho de 1891 nascia o primogênito John Donohoe. Em 20 de fevereiro de 1894, nascia o

\footnotetext{
162 Acervo pessoal do historiador escocês John McVicar.
} 
segundo filho, Patrick Donohoe, ${ }^{163}$ batizado assim em homenagem ao avô. É provável que tenha sido nesta ocasião que os cálculos financeiros de Thomas tenham lhe alertado que a vida de um operário escocês não era das melhores. Por mais que fosse um trabalhador especializado, formado pelo Busby Mechanics Institute, Thomas sabia que não teria chances de chegar a ser mestre de seção. O cargo estava nas mãos de seu irmão James, que tivera que esperar que seu pai, Patrick, se retirasse do serviço, para assumir a tinturaria.

Além do mais, a própria Busby Printworks vivia seus últimos dias. Em meio a uma crise financeira, foi incorporada ao grupo Calico Printers Association em 1900, que administrava 32 fábricas na Inglaterra e 14 na Escócia, controlando 85\% da indústria de tingimento de tecidos na época. O que parecia ser um alívio para os operários de Busby, logo se tornou um pesadelo, já que os novos donos iniciaram uma política de fechamento das pequenas fábricas. A Busby foi uma das primeiras a acabar, encerrando suas atividades em 1901. ${ }^{164}$

Para sorte de Thomas Donohoe, uma nova fábrica têxtil no Brasil estava recrutando trabalhadores especializados para virarem chefes de seções. Quem fazia a contratação desses técnicos era a firma Platt Brothers \& Co., de Oldham, que era, ao mesmo tempo, a fornecedora de maquinário e equipamentos para a Fábrica Bangu. Tratava-se da mais conceituada empresa de máquinas têxteis do mundo. Fundada em 1821, a Platt Brothers podia se orgulhar de ter, em 1890, mais de 12 mil trabalhadores e era tão importante que $42 \%$ da população de Oldham, naquela época, vivia diretamente ligadas a essa potência. ${ }^{165}$

Assim, após ser bem recomendado pelo seu "patrão-irmão", Thomas Donohoe, aos 31 anos, deixaria pela primeira vez o vilarejo de Busby, na Escócia. Primeiro, foi de trem até Oldham, apresentar-se à Platt Brothers. Assinou um contrato, ganhou a passagem e partiu para o porto de Southampton, no sul da Grã-Bretanha, a porta de saída de muitos navios a vapor que cruzavam o oceano Atlântico. Fundado em 1843, o porto de Southampton tinha linhas regulares para os Estados Unidos e também para a América do Sul.

De lá, numa sexta-feira, 4 de maio de 1894, o futuro mestre de tinturaria da Companhia Progresso Industrial do Brazil embarcou para o Rio de Janeiro a bordo do paquete S.S. Clyde, junto com outros 48 passageiros.

\footnotetext{
${ }^{163}$ Os dados a respeito da vida privada da família de Thomas Donohoe foram fruto da generosidade do genealogista Rod O’Donoghue, criador da "The O'Donoghue Society". Foi ele quem enviou as páginas com o registro do nascimento de Thomas, em 1863; do recenseamento na casa de Patrick Donohoe, em 1881; do registro de casamento de Thomas e Elizabeth, em 1890; do nascimento de John Donohoe, em 1891; do recenseamento nas casas de Thomas Donohoe e Patrick Donohoe Jr., em 1891; e do nascimento de Patrick Donohoe, em 1894. Todos obtidos no site ancestry.com.

${ }^{164}$ FIFTY years of calico printing. A jubilee history of the C.P.A. Manchester: Calico Printers Association, 1949, p. 12.

165 Para maiores detalhes sobre a Platt Brothers \& Co., recomenda-se buscar no site "The NationalArchives", instituição do governo britânico, no fundo "Oldham Local Studies and Archives", a pasta "Platt collection".
} 


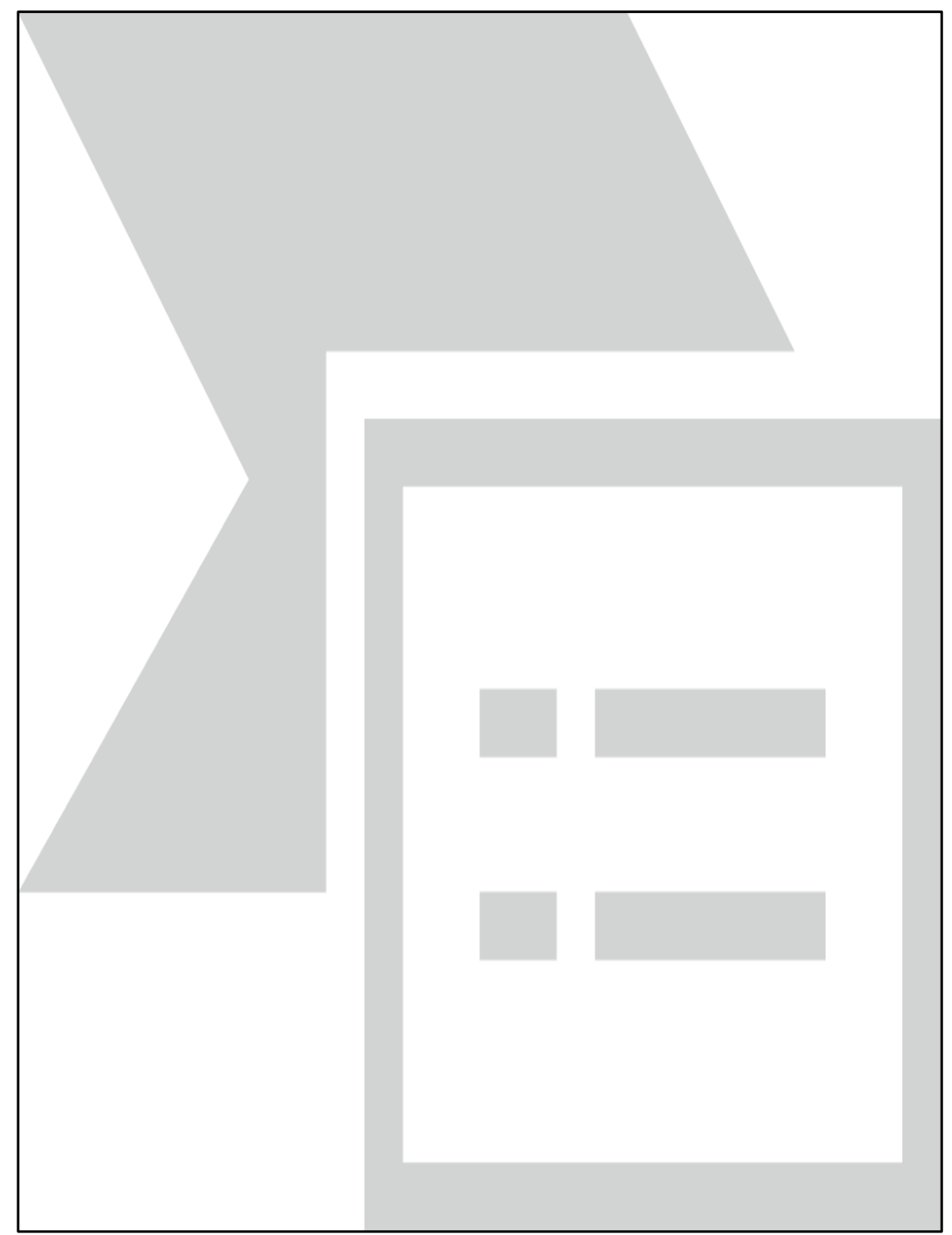

Figura 9 - O mapa apresenta o trajeto de Thomas Donohoe em 1894. O ponto A, próximo a Glasgow, representa a vila operária de Busby, na Escócia. O ponto B, próximo a Manchester, representa a sede da Platt Brothers, em Oldham. E o ponto C, próximo ao Canal da Mancha, refere-se ao porto de Southampton.

Durante 17 dias, com paradas para embarque e desembarque nos portos de Cherburgo (França), Vigo (Espanha), Lisboa (Portugal) até chegar ao Rio de Janeiro, as cabines do S.S. Clyde seriam a morada provisória de vários imigrantes, numa época em que "fazer a América" parecia ser um sonho possível para os europeus.

Thomas Donohoe seria um dos 60.182 imigrantes que desembarcariam no Brasil naquele ano de 1894. Os britânicos estavam longe de ser a maioria neste número. Italianos (34.872), portugueses (17.041) e espanhóis (5.986) puxavam a fila e até mesmo os alemães (790 registros de entradas) estavam à frente dos ingleses. ${ }^{166}$ Coletivamente, este êxodo de europeus rumo ao Brasil tornou-se um fenômeno já estudado por muitos historiadores, em que a vida de camponeses e simples operários mudava radicalmente com a travessia do Atlântico.

${ }^{166}$ LEVY, Maria Stella Ferreira. “O papel da migração internacional na evolução da população brasileira (1872 a 1972).” In: Revista Saúde Pública, nº 8. São Paulo, 1974, p. 71. 
O desembarque no porto do Rio de Janeiro ocorreu numa segunda-feira, 21 de maio. Dentro do navio, Thomas Donohoe, o futuro mestre de tinturaria, conheceu Clarence Sam Hibbs, um inglês natural de Derbyshire, 35 anos, e que também viria trabalhar na Fábrica Bangu como mestre da seção de estamparia. ${ }^{167}$

Enquanto o paquete navegava, é provável que os dois só vissem vantagens em vir para o Brasil. Emprego garantido como mestre de seção, uma boa casa na vila operária, passagens da viagem paga pela Companhia, salário pago por dia de trabalho de acordo com a cotação da Libra, eram as vantagens que os brasileiros ofereciam para os destemidos que cruzassem o Atlântico para desenvolver a nossa incipiente indústria têxtil. Porém, quando chegaram a Bangu, viram que a localidade tinha apenas uma rua e pouco mais de mil habitantes. Em 1894, trabalhavam 873 pessoas na fábrica. ${ }^{168}$

Depois de tomar posse, instalar-se na vila operária e começar a trabalhar, Thomas Donohoe pode providenciar com a diretoria da Companhia a vinda de sua família para o Brasil. Como os técnicos estrangeiros vinham sob contrato e não possuíam fichas individuais, infelizmente, esses contratos escritos nunca foram localizados por nenhum historiador, ${ }^{169}$ por isso não há como saber se a Companhia custeou parcialmente ou totalmente o translado de Elizabeth Donohoe e seus filhos. Sabe-se, porém, que ela embarcou no paquete S.S. Liguria, ${ }^{170}$ que saiu de Liverpool em 16 de agosto de 1894, com outros 39 imigrantes, incluindo sua irmã mais nova, Margareth Montagne.

Depois de fazer escalas em outros portos da Europa - La Pallice (França), La Coruña e Vigo (Espanha), Leixões e Lisboa (Portugal) -, Elizabeth desembarcou no Rio de Janeiro numa terçafeira, 4 de setembro, junto com outros 169 imigrantes. Na relação da Repartição Central das Terras e Colonização, o nome dela, o da irmã e o de um "baby" (naturalmente, trata-se de Patrick Donohoe) aparecem entre os 22 passageiros de $2^{\mathrm{a}}$ classe do navio (havia também 3 passageiros de $1^{\mathrm{a}}$ classe e 144 de $3^{\mathrm{a}}$ classe). ${ }^{171}$ Curiosamente, na listagem não aparece o nome do filho John Donohoe, de 3 anos.

A esperá-la, ao lado de Thomas Donohoe no cais do porto, estava o mestre de fiação Thomas Hellowell, inglês da cidade de Yorkshire. Ele chegara ao Brasil em 1893 e só agora, um ano depois,

\footnotetext{
${ }^{167}$ A lista dos passageiros que desembarcaram do S.S. Clyde aparece publicada em O PAIZ, 22 de maio de 1894, p. 5. $\mathrm{Na}$ mesma página, um anúncio da Real Companhia de Paquetes a Vapor de Southampton destaca que "os paquetes empregados no serviço durante este ano são todos grandes e rápidos".

168 OLIVEIRA, Márcio Piñon de. Bangu: de fábrica-fazenda e cidade-fábrica a mais uma fábrica da cidade. Instituto de Pesquisa e Planejamento Urbano e Regional (IPPUR) da Universidade Federal do Rio de Janeiro (UFRJ), 1991, p. 110 .

${ }^{169}$ SILVA, Gracilda Alves de Azevedo. Bangu - a fábrica e o bairro: um estudo histórico, 1889-1930. Instituto de Filosofia e Ciências Sociais (IFCS) da Universidade Federal do Rio de Janeiro (UFRJ), 1985, pp. 776, 783.

170 O S.S. Liguria, da Pacific Steam Navigation Company, sob os cuidados do Comandante Hamilton, tinha capacidade para transportar 4.676 toneladas. Segundo um anúncio publicado em O PAIZ, 13 de outubro de 1894, p. 4, "os paquetes desta linha são iluminados à luz elétrica" e o "vinho de mesa é fornecido grátis aos passageiros de todas as classes".

${ }^{171}$ Relação de passageiros do vapor Liguria. Arquivo Nacional, BR.AN.RIO.OL.0.RPV.PRJ 5212.
} 
veria sua mulher, Sarah Hanna Hellowell, e seus três filhos - William, John e Albert - novamente. Era praxe da Fábrica Bangu comprar passagens para que dois técnicos têxteis ou duas famílias de imigrantes viajassem juntas, o que serviria para afinar ainda mais os laços de união entre os britânicos.

No S.S. Liguria estava também um francês, Jean Labond, passageiro de $3^{\text {a }}$ classe, embarcado em La Pallice que pode ter feito amizade com o grupo de ingleses durante a viagem e, ao desembarcar, rumou até Bangu para procurar trabalho. Futuramente, ele apareceria como chefe da seção de reparação de panos da Companhia. ${ }^{172}$

Thomas Donohoe sempre trabalhou como "mestre de tinturaria". Os operários - com dificuldade para pronunciar seu nome -, logo o apelidaram de "seu Danau". ${ }^{173}$ Ele teria sido o responsável por trazer a primeira bola de futebol para o bairro, embora, não se saiba quando isso realmente ocorreu. No entanto, por ter chegado ao Brasil antes do paulista Charles Miller - que começou a desenvolver o esporte em São Paulo em 1895, depois de voltar de Southampton -, é possível que Thomas Donohoe tenha sido o pioneiro da prática esportiva, ainda em 1894. Daí é justificado o orgulho do primeiro-ministro escocês Alex Salmond de que um compatriota tenha introduzido o jogo no chamado "país do futebol". ${ }^{174}$

Morador da Rua Fonseca, $n^{\circ}$ 7, que ficava em frente ao terreno da fábrica, Thomas Donohoe jamais voltou para a Grã-Bretanha. Dos poucos registros trabalhistas da Fábrica Bangu que ainda restavam nos anos 80 e consultados pela historiadora Gracilda Alves, sabe-se que Donohoe recebia meia libra (10 shillings) por dia de trabalho. Assim, em junho de 1897 , recebeu $£ 4.0 .0$ por 8 dias. Em junho de 1898 , recebeu $£ 9.10 .0$ por 19 dias. E em dezembro de 1898 , ganhou 4 libras e 10 shillings (4.10.0) por 9 dias. ${ }^{175}$

Para efeitos de comparação, uma passagem de ida na $1^{\text {a }}$ classe do paquete S.S. Liguria para a Liverpool, custava em 1894, entre 24 e 30 libras. Se comprasse logo a ida e a volta, o viajante pagaria um valor entre 36 e 45 libras. Na $3^{\text {a }}$ classe, o preço despencava para 9 libras. ${ }^{176}$ Segundo cálculos do historiador John Schulz, 9 libras equivalia, naquele mesmo ano, a 270 mil-réis (270\$000), ou seja, o soldo de um capitão do Exército por mês. ${ }^{177}$

Seus ganhos na Companhia possibilitaram que, logo em 1897, pudesse enviar a esposa Lizzie Donohoe, a cunhada Maggie Montagne e o filho Patrick Donohoe para uma viagem de recreio à

172 GAZETA DE NOTÍCIAS, 12 de outubro de 1906, p. 2.

173 SILVA, Gracilda Alves de Azevedo. Bangu 100 anos: a fábrica e o bairro. Rio de Janeiro: Sabiá Produções Artísticas, 1989, p. 104.

174 Atualmente, a versão de que Thomas Donohoe é realmente “o pai do futebol brasileiro" vem ganhando força, tendo aparecido em algumas publicações a tese do seu pioneirismo. Vide: MENDES JR., Leonardo \& ROSSI, Jones. Guia politicamente incorreto do futebol. São Paulo: Leya, 2014, pp. 17-31.

175 SILVA (1985), p. 778.

176 O PAIZ, 13 de outubro de 1894, p. 4.

177 SCHULZ, John. O Exército na Política - origens da intervenção militar (1850-1894). São Paulo: EdUSP, 1994, p. 212. 
Escócia, alocados na $2^{\mathrm{a}}$ classe. Os três regressaram ao Rio de Janeiro, vindos de Liverpool, em 26 de outubro daquele ano, pelo paquete Oravia. ${ }^{178}$ É certo que nem sua esposa, nem seu filho precisavam trabalhar na fábrica, já que apareciam na lista de passageiros dos navios sempre com um traço ou um "none" no lugar destinado à profissão.

Em 1904, outra vez, Thomas Donohoe os envia a Europa. Na ocasião, a cunhada Margareth já casada com um outro técnico têxtil da Companhia não os acompanhou. Lizzie regressou com Patrick pelo vapor Victoria, no dia 2 de novembro, sempre na $2^{\mathrm{a}}$ classe. ${ }^{179}$

Aos 11 anos, numa idade em que muitas crianças brasileiras já estavam trabalhando na Fábrica Bangu, Patrick Donohoe ainda podia brincar. Seu nome aparece, em 1905, ao lado de outro inglesinho, Albert Hellowell, como um dos integrantes do time infantil do Esperança Football Club, "mais uma sociedade de petizes" fundada para a prática do esporte, situada na região do Marco Seis, contígua à estação de Bangu. ${ }^{180}$ É provável que se ainda vivesse na Escócia, o filhos de Donohoe, com esta idade, já teria que estar trabalhando em alguma fábrica de tecidos.

Por mais que para jogarem bola, ainda precisassem de outros 20 "coleguinhas", a escalação dos times do Esperança em 1905 traz sobrenomes portugueses, como Gomes, Ribeiro, Barbosa, Rocha, Pereira, Granado, Campos, Araújo, Silva, Figueiredo, Medeiros, Lobo, Lopes e Oliveira, crianças que, apesar de a revista indicar apenas os sobrenomes, dificilmente estariam entre os 205 meninos que trabalhavam na Fábrica Bangu, representando $17 \%$ da mão-de-obra empregada. ${ }^{181}$

O futebol parecia ser uma herança de família. O próprio Thomas Donohoe é encontrado em registros do Busby Football Club, atuando numa partida contra o Cartvale F. C., em 2 de março de 1889, tendo, inclusive, marcado um gol. Em Bangu, como não poderia ser diferente, além de jogar, Thomas ajudou na organização de um clube esportivo dentro da Companhia, em 1904. Mesmo sem comparecer à reunião de fundação, seu nome é lembrado pelos demais britânicos, que o elegem vice-presidente do recém-criado Bangu Athletic Club. ${ }^{182}$ Apesar de ter 41 anos, Thomas Donohoe fez questão de participar dos quatro primeiros jogos do novo clube, atuando como atacante e marcando um gol diante do Andarahy, que representava a Fábrica de Tecidos Cruzeiro. A partida, realizada em 31 de julho de 1904, nos jardins da Fábrica Bangu, terminou com a vitória dos banguenses por 6 a 0 . As escalações deste encontro, publicadas pelo Jornal do Commercio, demonstram bem que, na época, football ainda era um assunto quase que exclusivamente inglês.

\footnotetext{
${ }^{178}$ Relação de passageiros do vapor Oravia. Arquivo Nacional, BR.AN.RIO.OL.0.RPV.PRJ 5968.

${ }^{179}$ Relação de passageiros do vapor Victoria. Arquivo Nacional, BR.AN.RIO.OL.0.RPV.PRJ 8862.

${ }^{180}$ REVISTA DA SEMANA, nº $281-1^{\circ}$ de outubro de 1905, p. 2731.

181 THE RIO NEWS, 26 de dezembro de 1899, p. 8. As meninas, em número de 154, representavam $13 \%$ da mão-deobra empregada na fábrica.

182 “Ata da sessão de 17 de abril de 1904". 1 Livro de Atas das Sessões da Diretoria do Bangu A.C., 17 de abril de 1904 a 7 de fevereiro de 1905.
} 
Bangu: William Procter, James Hartley, José Villas Boas, Augusto Rosemberg, Clarence Hibbs, William Hellowell, Andrew Procter, Thomas Donohoe, John Stark, Francisco de Barros e Fred Jacques.

Andarahy: Tom Emery, Fred Geldeards, Fred Smith, Harry Softon, Jack Farrington, Tom Harrison, M. Smith, Anníbal Bebiano, Robert Cross, Geson Smith e Jack Walmsley. ${ }^{183}$

Em 1905, Thomas Donohoe já tinha pendurado as chuteiras, mas era constantemente chamado para ocupar postos na diretoria do clube. Assim, foi membro do Conselho Fiscal, ${ }^{184}$ membro do Ground Committee ${ }^{185}$ (que era uma espécie de comissão técnica da época, responsável por tratar dos jogos e até mesmo do campo) e Diretor Esportivo (equivalente aos atuais técnicos de futebol) por três anos consecutivos. ${ }^{186}$
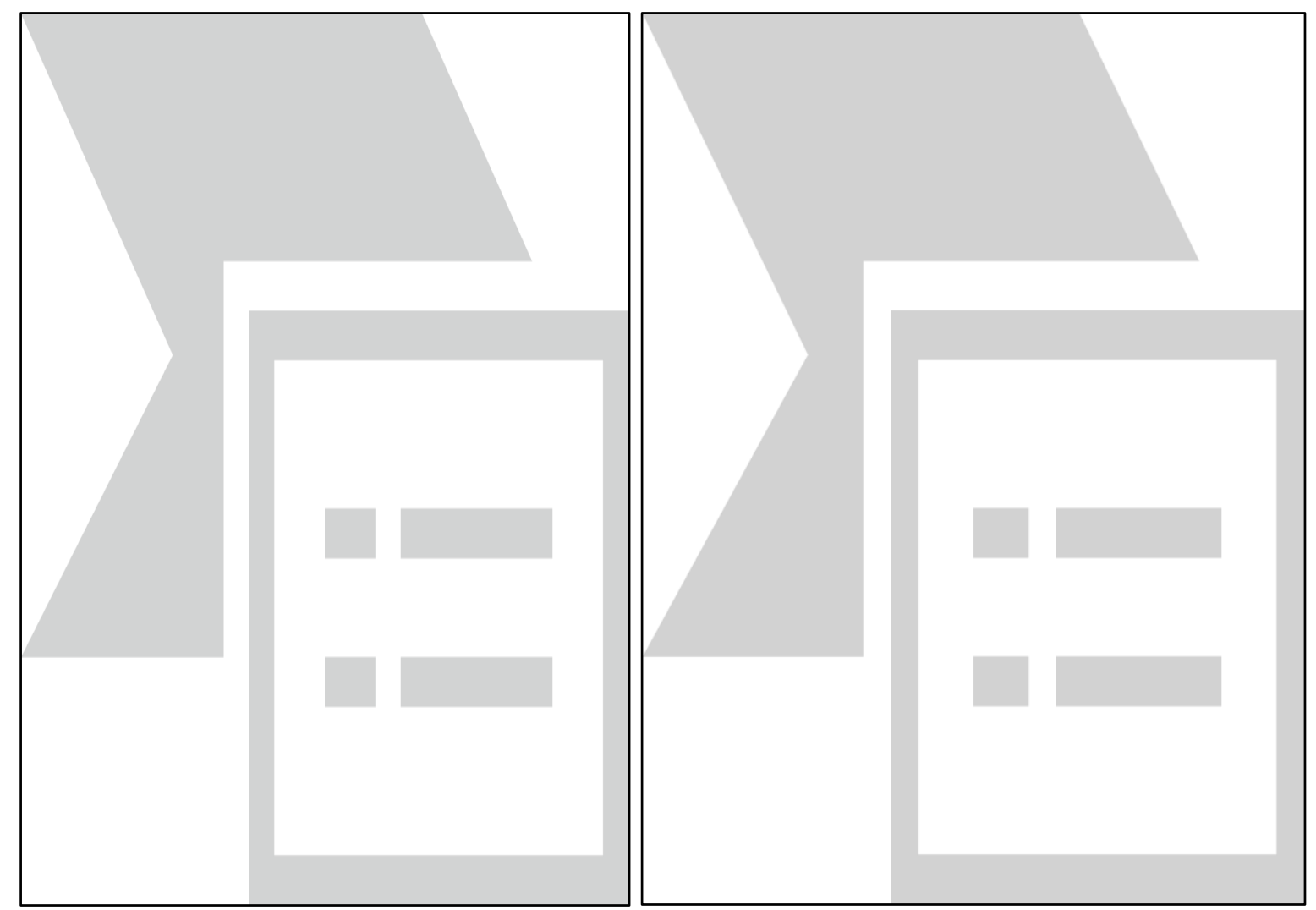

Figuras 10 e 11 - Thomas Donohoe. O escocês, ao lado da segunda esposa, Abigail da Silva Torres. Arquivo do Grêmio Literário José Mauro de Vasconcelos.

183 JORNAL DO COMMERCIO, 6 de agosto de 1904.

184 “Ata da sessão de 26 de março de 1906". 2 Livro de Atas das Sessões da Diretoria do Bangu A.C., 24 de fevereiro de 1905 a 23 de julho de 1908.

185 “Ata da sessão de 9 de julho de 1906". $2^{\circ}$ Livro de Atas das Sessões da Diretoria do Bangu A.C., 24 de fevereiro de 1905 a 23 de julho de 1908.

186 “Ata da sessão de 14 de setembro de 1917" e "Ata da sessão de 19 de abril de 1918". 5 Livro de Atas das Sessões da Diretoria do Bangu A.C., 14 de setembro de 1917 a 29 de janeiro de 1919. “Ata da sessão de 6 de março de $1919^{\prime}$. $6^{\circ}$ Livro de Atas das Sessões da Diretoria do Bangu A.C., 13 de fevereiro de 1919 a 15 de dezembro de 1921. 
Em 1924, aos 61 anos, foi novamente eleito vice-presidente do clube, ${ }^{187}$ mas não compareceu para tomar posse no prazo estipulado, ${ }^{188}$ o que causou um pequeno problema para o Bangu A.C, que teve que realizar outro pleito para escolher quem ficaria com a vaga do escocês.

Tendo ficado viúvo, apesar de ser nove anos mais velho do que sua primeira esposa, Elizabeth, Thomas Donohoe voltou a se casar no Brasil, agora com a portuguesa Abigail da Silva Torres, sendo os proclamas lidos na Catedral Metropolitana em 30 de maio de 1918. ${ }^{189}$

Tudo indica, então, que o escocês era católico (ou sua nova esposa era), em vez de ser protestante anglicano, a religião normalmente esperada dos imigrantes britânicos. A crença de Donohoe poderia estar ligada até mesmo a uma questão de lugar para professar sua fé. Em Bangu, a Igreja Católica foi oficialmente inaugurada em $1910^{190}$ e a primeira Igreja Evangélica só ficou pronta em 1919, quando o número de britânicos no bairro era bem menor.

Mostrando que o catolicismo prevaleceu em relação ao protestantismo, Thomas Donohoe aparece fazendo a maior doação da paróquia de Bangu no mês de outubro de 1923, no valor de 20\$, ao padre Alfredo de Vasconcellos em prol da construção do monumento ao Cristo Redentor. Abigail, sua segunda esposa, doou 10\$. Outro inglês da fábrica, Joseph Pellegrin, doou $3 \$ .{ }^{191}$

Com esta nova companheira, viveu por mais sete anos, até falecer em 2 de abril de 1925, aos 62 anos, no mesmo bairro que o acolhera em 1894, sem ver, portanto, a inauguração da estátua do Cristo, que só ocorreu em 1931. À noite, durante a reunião de diretoria do Bangu A.C., o secretário Guilherme Pastor informou aos presentes: "Fala o autor desta, que comunica haver falecido hoje o sr. Thomas Donohoe, introdutor do football em Bangu e um dos fundadores do Bangu A. C., onde é sócio benemérito. Propõe seja lançado em ata, por esse motivo, um voto de profundo pesar, o que é aprovado". ${ }^{192}$

\section{Filhos e netos}

Quanto a seus filhos, John e Patrick, o primeiro aparece pouco nos registros, de modo que pouco se sabe sobre sua vida profissional e privada. Sem aparecer nas listas de passageiros, quando da vinda da família ainda no século XIX, é possível que tenha ficado na Grã-Bretanha, sob os cuidados dos tios. Seu nome é encontrado no livro de atas do Bangu, tendo se filiado ao clube junto

\footnotetext{
${ }^{187}$ CORREIO DA MANHÃ, 10 de abril de 1924, p. 6.

188 “Ata da sessão de 21 de fevereiro de 1924". $7^{\circ}$ Livro de Atas das Sessões da Diretoria do Bangu A. C., 6 de janeiro de 1922 a 13 de novembro de 1930.

${ }^{189}$ O IMPARCIAL, 31 de maio de 1918, p. 6.

${ }^{190}$ REVISTA DA SEMANA, n 525 - 5 de junho de 1910, p. 20.

191 JORNAL DO BRASIL, 25 de outubro de 1923, p. 18. No total, a paróquia de Bangu já tinha recolhido, até aquele momento, a soma de 1:086\$000 em prol do monumento ao Cristo Redentor.

192 "Ata da sessão de 2 de abril de 1925". $7^{\circ}$ Livro de Atas das Sessões da Diretoria do Bangu A.C., 6 de janeiro de 1922 a 3 de novembro de 1930 .
} 
com seu irmão caçula, em novembro de 1912. ${ }^{193}$ John Donohoe aparece uma única vez jogando futebol, atuando pelo $2^{\circ}$ time (o dos reservas), em 1913, escalado para enfrentar a equipe da América Fabril, ${ }^{194}$ outra companhia têxtil do Rio.

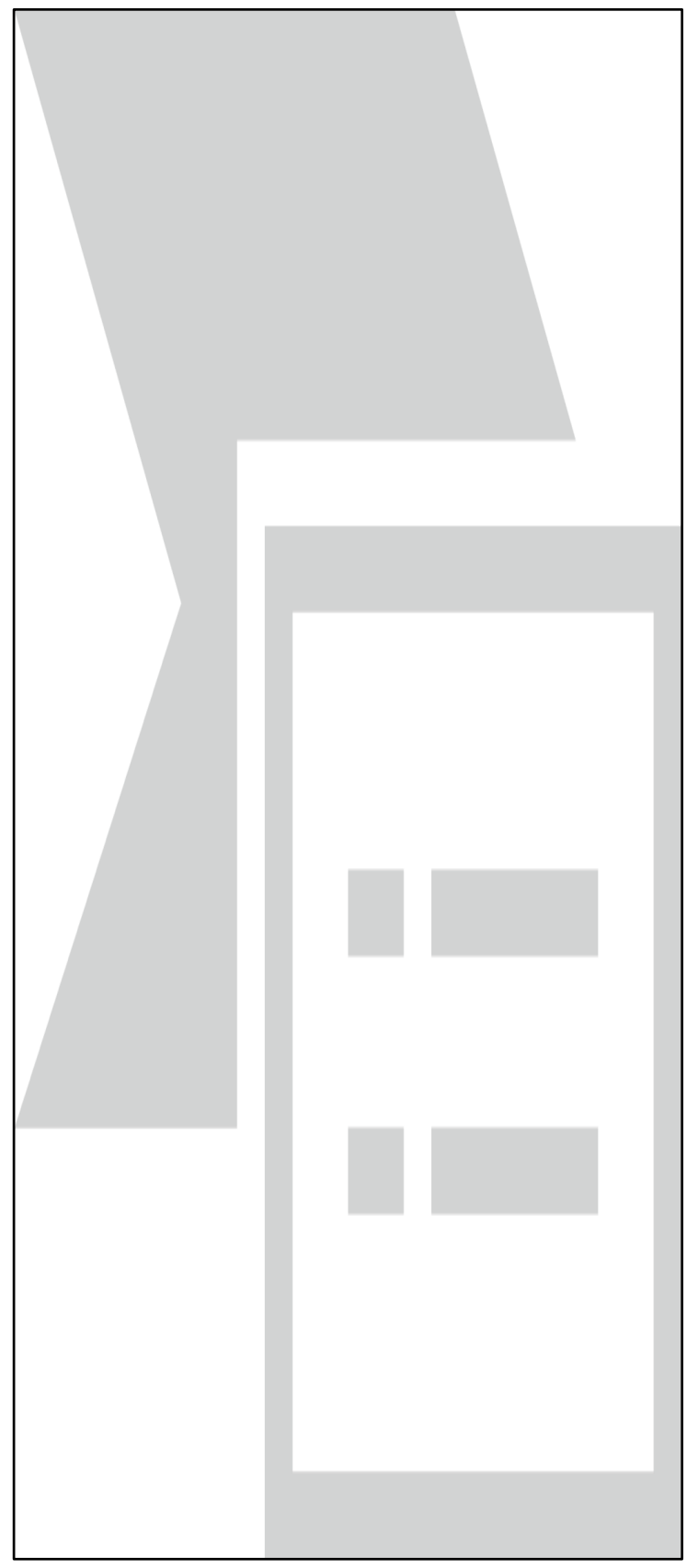

Figura 12 - Patrick Donohoe pronto para jogar pelo Bangu. A fotografia de corpo inteiro do atacante foi inaugurada na sede social do clube, como forma de homenageá-lo pelos serviços prestados, na noite de 24 de agosto de 1918, ocasião em que foram "oferecidos, como ficara combinado verbalmente entre a diretoria, um chá aos quadros do Bangu". ${ }^{195} \mathrm{No}$ dia seguinte, motivado, fez dois gols na vitória do Bangu sobre o Flamengo, por 4 a 2.

\footnotetext{
193 “Ata da sessão de 25 de novembro de 1912”. $3^{\circ}$ Livro de Atas das Sessões da Diretoria do Bangu A.C., 28 de fevereiro de 1909 a 12 de janeiro de 1915.

194 JORNAL DO BRASIL, 16 de fevereiro de 1913, p. 16.

195 "Ata da sessão de 28 de agosto de 1918". 5 Livro de Atas das Sessões da Diretoria do Bangu A.C., 14 de setembro de 1917 a 29 de janeiro de 1919.
} 
Fato curioso é que, logo após a associação dos dois filhos de Thomas Donohoe ao clube, uma nota apareceu nas páginas do Jornal do Brasil, alardeando que o Bangu tinha se reforçado com dois elementos vindos diretamente da Inglaterra, embora sem citar o nome dos novos craques: "O $1^{\circ}$ time do Bangu acaba de ser reforçado com dois bons elementos que militaram por um dos clubes concorrentes ao Campeonato do Norte da Inglaterra. Um deles é center-forward e o outro, inside". 196

É possível que os dois irmãos tivessem regressado juntos da Grã-Bretanha naquele ano de 1912, após terem se especializado por lá. Patrick Donohoe, justamente por jogar futebol, teve seus dados pessoais mais bem preservados. Em um livro de registro de jogadores do Bangu, que atuaram entre 1918 e 1923, preenchido à mão pelo secretário Guilherme Pastor, ele aparece como "Químico Industrial da Fábrica Bangu", passando a morar na Rua Ferrer no 110, a partir de 1920, ou seja, quando se casou com a brasileira Angelina Pinto de Azevedo.

O casal teve dois filhos, João e Hermínio, e ficou junto até o falecimento de Patrick, em 28 de abril de 1948, aos 54 anos, vítima de um "colapso cardíaco", como consta de sua certidão de óbito.

Faleceu ontem Patrick Donohoe, defensor do Bangu de 1913 a 1922 e, posteriormente, juiz de football. O antigo esportista era filho de Thomas Donohoe, introdutor do football em Bangu. O grêmio suburbano, prestando homenagem ao seu antigo defensor, tomará luto por oito dias, além de custear os funerais. O féretro sairá da rua Barão de Capanema para o cemitério do Murundu, em Bangu. ${ }^{197}$

Tido como um grande jogador em sua época, Patrick chegou a defender a Seleção Carioca, ${ }^{198}$ além de marcar 69 gols em 134 partidas pelo Bangu A.C. ${ }^{199}$

A fama de artilheiro e perigoso atacante continuou por algum tempo após sua morte, sendo encontrado nos jornais o relato de um banguense e secretário da Federação Metropolitana de Futebol, José Trocolli, que jurava ter sido o escocês o criador do chute de "bicicleta", popularizado posteriormente por Leônidas da Silva.

\footnotetext{
- Patrick Donohoe foi o inventor da bicicleta.

- Inventor ou precursor?

Trocolli ajeita-se abruptamente na cadeira. Toma posição e declara peremptoriamente:

- Inventor, inventor no duro! Ele é que, em verdade, criou a extraordinária jogada; não foi Leônidas da Silva, não!

Faz uma pausa e acentua, logo a seguir:

- E como jogava o fino o Patrick. Um colosso, um craque verdadeiro, autêntico. Tanto assim que integrou até a Seleção Carioca. E Seleção, antigamente, não era para qualquer um, não! Era preciso que o sujeito tivesse mesmo futebol. ${ }^{200}$
}

\footnotetext{
${ }^{196}$ Idem, 21 de novembro de 1912, p. 9. Ao mesmo tempo, a notícia pode ser um blefe para assustar os adversários quanto ao poderio do Bangu para a próxima temporada.

197 O GLOBO, 29 de abril de 1948, p. 13.

198 "Ata da sessão de 11 de setembro de 1918". 5 Livro de Atas das Sessões da Diretoria do Bangu A.C., 14 de setembro de 1917 a 29 de janeiro de 1919. Na época, qualquer jogador que atuasse em um time do Distrito Federal. poderia ser convocado para a Seleção Carioca, não sendo restrito apenas a jogadores nascidos na capital.

${ }^{199}$ MOLINARI, Carlos. Almanaque do Bangu. Brasília: Editora Kiron, 2011, pp. 17-31.

${ }^{200}$ DIÁRIO DE NOTÍCIAS, 9 de janeiro de 1955, Suplemento Esportivo, p. 8.
} 
A esposa de Patrick, Angelina Pinto, também trabalhadora na fábrica de tecidos (aparece como industriaria na certidão de óbito), faleceu aos 72 anos, em 23 de novembro de 1965, num centro psiquiátrico. Louca, acreditava que o marido tinha sido atropelado pelo trem ao atravessar a linha férrea que cortava o bairro de Bangu, ${ }^{201}$ o que contraria o laudo da certidão de óbito.

Seus filhos, Hermínio Donohoe - gravador da fábrica, falecido em 30 de abril de 1969, aos 45 $\operatorname{anos}^{202}$ - e João Pinto Donohoe - escriturário, falecido em 4 de janeiro de 1979, aos 58 anos ${ }^{203}$ não deixaram descendentes, encerrando-se desta forma a vida da família Donohoe no Brasil.

\footnotetext{
${ }^{201}$ Relato de Arilza Silva, sobrinha de Angelina Pinto, colhido em 31 de julho de 2014, em Bangu. Pertencem a ela, também, as certidões de óbito de Patrick Donohoe, Angelina Pinto de Azevedo, Hermínio Donohoe e João Pinto Donohoe.

${ }^{202}$ A certidão de óbito de Hermínio Donohoe revela que ele era solteiro, não deixou bens, nem deixou filhos, sendo vítima de um infarto do miocárdio.

${ }^{203}$ A certidão de óbito de João Pinto Donohoe revela que ele era solteiro, deixou bens, porém não fez um testamento e não deixou filhos, sendo vitimado por um acidente vascular cerebral. Em outro documento, a $2^{\mathrm{a}}$ via de seu título eleitoral, expedida em 1966, ele aparece como industriário e nos é fornecida a data de seu nascimento: 25 de agosto de 1920. Na ocasião, morava na mesma Rua Fonseca, onde viveu seu avô, Thomas.
} 


\subsection{2 - Os Hartley}

Houve uma pequena festa em Bangu, em maio de 1896. Os contramestres se reuniram, a banda de música da fábrica foi chamada e muitos discursos foram feitos em homenagem ao técnico têxtil Thomas Mills, ${ }^{204}$ um inglês que iria se despedir da localidade para "tomar uma posição mais importante em uma fábrica na Bahia”, depois de três anos na Companhia Progresso Industrial do Brazil.

O relato, extremamente positivo à imagem do britânico, mostra que havia uma perfeita interação entre o líder e seus subordinados, entre um estrangeiro e os operários brasileiros. Os contramestres (geralmente italianos ou portugueses) "foram para sua casa para expressar o pesar pela sua partida". No dia seguinte, "um grande número de tecelões saiu da fábrica para ver sua partida no comboio", afinal, Thomas Mills era descrito não só como um chefe, mas como um amigo: "Esta é certamente uma das manifestações mais marcantes que foi vista aqui, e mostra que, apesar de um estranho em uma terra estranha, um inglês que se assume como tal, será sempre aceito e tratado pelos nativos não apenas como um mestre, mas um amigo". ${ }^{205}$

Durante os discursos e os brindes que se sucederam na cerimônia de despedida, Thomas Mills lembrou-se de pedir aos operários que tratassem o seu substituto com a mesma estima, que por anos, dedicaram a ele.

Mr. Mills, na resposta ao brinde de sua saúde, disse que sempre tentou fazer o seu melhor, tanto para os empregadores e os operários; que ele nunca teve nenhum caso grave de denúncia contra qualquer um, e foi deixando-os com os sentimentos mais profundos de gratificação pelas amáveis palavras que haviam sido ditas. Ele esperava que a mesma atenção e respeito às ordens, que sempre tinha sido mostrado a ele, fosse repetido no caso de seu sucessor, James Hartley, de Preston, que havia sido escolhido pelos diretores da empresa para preencher o seu lugar. ${ }^{206}$

James Hartley, então, assumia o cargo com a grande responsabilidade de substituir um mestre tão amado pelos operários. O inglês, nascido em 19 de junho de 1871, em Preston, filho de James Willacy Hartley e Ann Hartley, teve seu destino fatalmente ligado à indústria têxtil. Um distrito do condado de Lancashire, Preston ficava a 39 milhas de Oldham, a cidade-sede da Platt Brothers \& Co.; a 34 milhas do pólo industrial de Manchester; e a 37 milhas do porto de Liverpool. É provável que ainda criança ele tenha começado a trabalhar em fábricas. Segundo um relato encontrado no jornal $A$ Época, ${ }^{207}$ Hartley veio para Bangu com 20 anos, ou seja, em 1891. Por mais que seu nome

\footnotetext{
${ }^{204}$ Após trabalhar por cinco anos como mestre de tecelagem na Companhia Carioca, no Jardim Botânico, Thomas Mills voltou para a Inglaterra e depois, regressou ao Brasil para assumir o cargo de mestre geral da tecelagem na Fábrica Bangu. Chegou no dia $1^{\circ}$ de setembro de 1893, pelo paquete Tamar, vindo de Southampton. Deixou o Rio de Janeiro no vapor Elmo, junto com a esposa e uma filha, no dia 20 de maio de 1896, para se empregar numa fábrica na Bahia.

${ }^{205}$ FIBRE \& FABRIC: A record of American textile industries in the cotton and woolen trade, volume $23, \mathrm{n}^{\circ} 592$. Boston, Massachusetts: 4 de julho de 1896, p. 860.

206 Idem.

${ }^{207}$ A ÉPOCA, 31 de maio de 1914, p. 9.
} 
não tenha sido encontrado nas inúmeras listas de imigrantes que desembarcavam no porto do Rio de Janeiro, a explicação pode estar nas falhas que a coleção do Arquivo Nacional apresenta em alguns meses daqueles anos. ${ }^{208}$

James Hartley não veio para ocupar um cargo de mestre, era ainda muito jovem para tal responsabilidade. Era um exemplo perfeito para compor a linha de pensamento formulada pelo historiador britânico David John Jeremy (1981), que dizia que:

A mais frequente forma de imigração da Inglaterra para o trabalho na indústria não envolvia profissionais bem qualificados. A imigração foi, em parte, causada pela crise econômica e social que afetou a região de Manchester, mas foi, principalmente, devido ao caráter corajoso e empreendedor dos trabalhadores. ${ }^{209}$

Coube a Hartley instalar os primeiros maquinários da Companhia, decidindo fixar residência no bairro, em vez de regressar. Talvez, tenha previsto que um inglês, na incipiente indústria brasileira, tivesse mais chances de crescer do que no já saturado mercado de trabalho de Lancashire.

\begin{abstract}
A instalação das máquinas continuou a ser, na maioria dos casos, uma tarefa reservada a trabalhadores especializados estrangeiros, sob a supervisão técnica dos montadores ingleses. (...) Era tão grande o número relativo de pessoal técnico inglês na indústria têxtil de algodão no Brasil que um observador das fábricas do Rio e de suas redondezas comentou, em 1898: "a aparelhagem em uso foi obtida quase exclusivamente no Reino Unido e os operários trabalham, via de regra, sob a direção dos mestres de Lancashire". ${ }^{210}$
\end{abstract}

Em 1896, com 25 anos, Hartley ganhou a grande chance na Companhia, galgando o posto de chefe geral da tecelagem, onde se manteria por 13 anos, mudando-se posteriormente para chefe geral da seção de fios. ${ }^{211}$ Diferentemente de Thomas Mills, o “amigo dos operários”, Hartley viria a ter problemas com seus subordinados por ocasião de uma greve em 1901, ganhando a antipatia dos brasileiros, que o acusavam de proteger em demasia os italianos da fábrica. "Por infelicidade, de todos os mestres ingleses, [é ele, James Hartley, que] acha-se colocado como $1^{\circ}$ mestre, o qual é o único culpado desta situação", diziam. ${ }^{212}$

No entanto, para a Companhia, James Hartley era uma peça fundamental, tendo seu nome citado de forma elogiosa no relatório da empresa a ser apresentado para a Assembleia Geral, em 1904, apontado como um dos "dignos auxiliares" da diretoria. ${ }^{213}$

Se sua vida profissional foi exitosa, sua vida privada não difere muito dos demais homens de seu tempo. Tendo chegado solteiro ao Brasil, só foi conhecer sua esposa em setembro de 1894, quando, como já vimos, desembarcou pelo paquete S.S. Liguria a Sra. Elizabeth Donohoe,

\footnotetext{
208 O Arquivo Nacional não tem os livros de desembarque de passageiros relativos aos meses de maio, julho, agosto e dezembro de 1891.

${ }^{209}$ Apud. NEIRA, Luz Garcia \& WAIN, Sarah. Teaching arts and crafts or the technology transfer: Ernest Bower and textile design practice in Brazil. São Paulo: Editora Edgard Blucher, 2012, p. 103.

210 STEIN, Stanley Julien. Origens e Evolução da Indústria Têxtil no Brasil, 1850-1950. Rio de Janeiro: Editora Campos, 1979, p. 52.

${ }^{211}$ A ÉPOCA, 31 de maio de 1914, p. 9.

212 GAZETA DE NOTÍCIAS, 27 de setembro de 1901, pp. 1-2. A greve de 1901 será mais bem detalhada em um capítulo específico, explicando os motivos da revolta dos brasileiros contra os italianos.

${ }^{213}$ DIÁRIO OFICIAL, 23 de abril de 1904, seção 1, pp. 15-16.
} 
acompanhada de sua irmã, Margareth Montagne. Cinco anos mais jovem que James Hartley, Margareth representava, praticamente, a única opção do mestre têxtil de se casar com uma mulher britânica na região de Bangu. Casamentos exogâmicos pareciam fora de cogitação naquele momento.

Assim, em 29 de outubro de 1898, no rancho do capitão Jorge Estrella, às 3 horas da tarde, na presença do sub-pretor, Arthur Ferreira de Mello, e servindo como testemunhas o diretor-gerente da fábrica, Eduardo Gomes Ferreira e o compatriota Thomas Stirling, James Hartley casou-se com Margareth Montagne.

Os filhos não tardaram a nascer. O primogênito foi Ellis Hartley; depois, outro menino, John Hartley, nascido a 19 de março de 1901; e enfim, uma menina, Sybil Hartley, que veio ao mundo em 10 de janeiro de $1906 .{ }^{214}$

Como todos os ingleses do bairro, James Hartley também teve participação ativa na fundação do Bangu Athletic Club, em 1904, figurando inicialmente como um membro do Conselho Fiscal, ${ }^{215}$ depois como vice-presidente em 1905 e 1906, ${ }^{216}$ instrutor de futebol em 1907, ${ }^{217}$ membro da comissão que redigiria o regulamento interno do clube em $1908,{ }^{218}$ membro da comissão de jogos atléticos em $1910^{219}$ e, por fim, presidente entre 1911 e $1914 .^{220}$

Além das funções de dirigente, James Hartley foi zagueiro, atuando em 36 partidas entre 1904 e 1908, quando já estava com $37 \operatorname{anos}^{221}$ e, posteriormente, árbitro de futebol, ganhando críticas da Gazeta de Notícias quando apitou um jogo do seu clube contra o Riachuelo, válido pelo Campeonato Carioca de 1909: "Atuou como referee o Sr. James, do Bangu, cavalheiro cuja obesidade o obrigava a ficar parado e cujo procedimento foi o mais incorreto possível. Pior referee jamais vimos em campo". 222 Ou seja, na hora de defender os interesses do seu clube, James Hartley colocava de lado seu caráter disciplinador, indo contra o que os jornais esperavam de um sportman britânico.

\footnotetext{
${ }^{214}$ As certidões de casamento de James Hartley e do batismo em cartório de seus filhos John e Sybil Hartley foram gentilmente enviadas pelo pesquisador do Fluminense F.C., Carlos José Reis Santoro.

215 "Ata da sessão de 17 de abril de 1904". 1 Livro de Atas das Sessões da Diretoria do Bangu A.C., 17 de abril de 1904 a 7 de fevereiro de 1905.

216 "Ata da sessão de 20 de dezembro de 1905", $2^{\circ}$ Livro de Atas das Sessões da Diretoria do Bangu A.C., 24 de fevereiro de 1905 a 23 de julho de 1908 .

217 "Ata da sessão de 6 de dezembro de 1907”, $2^{\circ}$ Livro de Atas das Sessões da Diretoria do Bangu A.C., 24 de fevereiro de 1905 a 23 de julho de 1908 .

218 "Ata da sessão de 9 de abril de 1908", $2^{\circ}$ Livro de Atas das Sessões da Diretoria do Bangu A.C., 24 de fevereiro de 1905 a 23 de julho de 1908.

219 "Ata da sessão de 29 de março de 1910", 3 Livro de Atas das Sessões da Diretoria do Bangu A.C., 28 de fevereiro de 1909 a 12 de janeiro de 1915.

220 "Ata da sessão de 16 de março de 1911", $3^{\circ}$ Livro de Atas das Sessões da Diretoria do Bangu A.C., 28 de fevereiro de 1909 a 12 de janeiro de 1915.

${ }^{221}$ MOLINARI, Carlos. Almanaque do Bangu. Brasília: Editora Kiron, 2011, pp. 7-12.

${ }^{222}$ GAZETA DE NOTÍCIAS, 8 de junho de 1909, p. 4.
} 

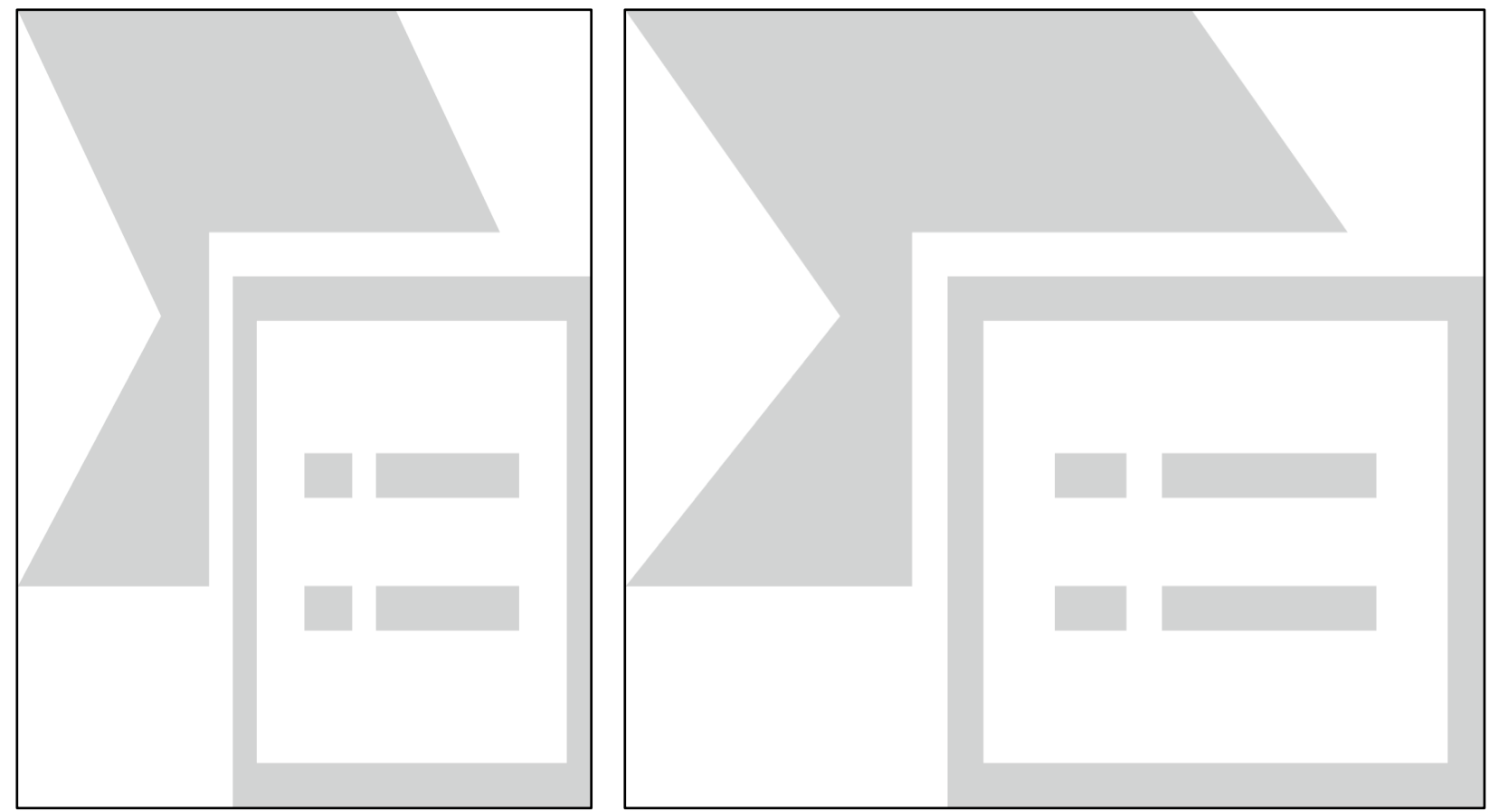

Figuras 13 e 14 - James Hartley. O inglês com sua família: o filho mais velho Ellis, a pequena Sybil, a esposa

Margareth e o filho John. ${ }^{223}$

Em julho de 1912, após mais de 20 anos de trabalho na fábrica, conseguiu fazer, pela primeira vez, uma viagem de recreio à Inglaterra, com sua família. Seu regresso, em novembro, foi extremamente festejado pela diretoria do Bangu A.C.:

Foi proposto pelo Sr. Paulo Vasconcellos fazer-se uma manifestação ao nosso Presidente por ocasião de sua chegada à localidade. A diretoria tomando em consideração tão simpática proposta aceitou por unanimidade de votos, ficando deliberado além da manifestação, dar uma soirée dançante aos associados em regozijo de sua chegada.

Foi proposto pelo Sr. João Fernandes ir a diretoria incorporada a bordo do vapor em uma lancha especial receber e dar as boas vindas ao nosso presidente, sendo posto a votos pelo Sr. Presidente Interino, foi aceito por unanimidade de votos. ${ }^{224}$

Porém, dois anos depois, em 11 de abril de 1914, Hartley teria que voltar à Inglaterra em condições bem menos felizes. ${ }^{225}$ Estava bastante doente e procurava tratamento, passando a presidência do Bangu A.C. ao secretário Guilherme Pastor e a gerência da seção de fios para o inglês Richard Dobson.

O Sr. Richard Dobson, mestre geral da seção de fiação da Fábrica Bangu, recebeu de Lisboa uma carta assinada pelo sr. James Hartley, que há pouco partiu para a Inglaterra em busca de melhoras para seus incômodos. Infelizmente, o estimado diretor da fábrica anuncia que está passando mal, o que vivamente causou pesar ao pessoal e amigos daquele digno cavalheiro. ${ }^{226}$

\footnotetext{
${ }^{223}$ Foto de James Hartley: arquivo do Grêmio Literário José Mauro de Vasconcelos. Foto da família: A ÉPOCA, 31 de maio de 1914, p. 9.

224“"Ata da sessão de 5 de novembro de 1912”, $3^{\circ}$ Livro de Atas das Sessões da Diretoria do Bangu A.C., 28 de fevereiro de 1909 a 12 de janeiro de 1915.

${ }^{225}$ A ÉPOCA, 12 de abril de 1914, p. 10.

${ }^{226}$ Idem, 11 de maio de 1914, p. 5.
} 
Assim, em 26 de maio de 1914, aos 42 anos, falecia em Oldham, o mestre têxtil James Hartley. Fato muito lamentado pelos diretores e sócios. ${ }^{227}$ No obituário dos jornais, Hartley aparecia com as mesmas características do antigo inglês Thomas Mills, generoso e benquisto:

Caráter firme e sem mácula, amigo de seu amigo, chefe de família exemplar, James Hartley tinha em cada banguense um admirador e em cada pessoa que trabalhava sob sua direção um amigo dedicado e satisfeito, porque ele sabia, pelos seus modos cativantes, pela sua criteriosa direção, prender-se à simpatia de todos que com ele tinham a ventura de privar. $^{228}$

Qual não foi a surpresa do redator do jornal A Época quando, na ocasião da missa de sétimo dia de James Hartley, na matriz de Bangu, estivessem presentes basicamente apenas a comunidade britânica do bairro e os diretores da fábrica, ausentando-se os operários brasileiros. É fácil compreender que, apesar de viver há 23 anos no bairro e ser o presidente do clube local, uma grande distância separava o inglês do proletariado em geral.

Causou-nos verdadeiro pasmo a ausência quase completa ali dos empregados da Fiação, Teares e Dobação da Fábrica Bangu, empregados esses que James Hartley sempre soube tratar tão bem, com distinção, protegendo-os, mesmo, muitas vezes.

Contudo, essa falta não pode ser atribuída à ausência de consideração e simpatia por James Hartley, pois na ocasião da missa em sufrágio de sua alma muitos foram os pedidos para serem paralisados os trabalhos da Fábrica, o que foi feito. ${ }^{229}$

Os filhos

Seus filhos, todos nascidos no Brasil, não permaneceram na Inglaterra e voltaram a morar em Bangu. Ellis aparece se alistando no Exército em 1922;230 John, que teve uma educação diversificada a ponto de não vincular seu futuro às atividades têxteis, tornou-se dentista, mantendo a residência na Rua Ferrer $n^{\circ} 84$ e tendo um consultório no no 33 do mesmo logradouro; ${ }^{231}$ Sybil aparece como órfã, necessitando de um tutor, quando da morte da mãe, Margareth Hartley, no início dos anos 20.

Inicialmente, em 1923, é um irmão de Margareth, William Montagne, que vem da Escócia para tutelar a órfã. ${ }^{232}$ No ano seguinte, é o próprio irmão John quem assume a tutela, por pouco tempo, já que logo Sybil, ao completar 18 anos, iria conseguir a emancipação, deferida em agosto de $1924 .{ }^{233}$

\footnotetext{
227 “Ata da sessão de 4 de junho de 1914", $3^{\circ}$ Livro de Atas das Sessões da Diretoria do Bangu A.C., 28 de fevereiro de 1909 a 12 de janeiro de 1915.

${ }^{228}$ A ÉPOCA, 31 de maio de 1914, p. 9.

${ }^{229}$ Idem, 2 de junho de 1914, p. 5.

${ }^{230}$ DIÁRIO OFICIAL, 17 de junho de 1922, seção 1, p. 64.

${ }^{231}$ Apontamentos feitos a mão pelo secretário do Bangu A.C., Guilherme Pastor, relativo aos jogadores do clube no ano de 1923.

${ }^{232}$ GAZETA DE NOTÍCIAS, 13 de setembro de 1923, p. 5.

${ }^{233}$ O PAIZ, 9 de agosto de 1924, p. 8.
} 
Para John Hartley ser tutor da irmã órfã e solteira parecia ser um bom álibi para fugir das obrigações militares. Sorteado para servir no Exército, o dentista tentou de todas as formas evitar o recrutamento. Inicialmente, alegou ser inglês, embora tivesse nascido em Bangu. Pelo artigo 69, parágrafo $1^{\circ}$ da Constituição Brasileira de 1891, eram considerados brasileiros "os nascidos no Brasil, ainda que de pai estrangeiro, não residindo este à serviço de sua nação". ${ }^{234}$ A justiça entendeu que, como James Hartley não estava no Brasil em missão militar, diplomática ou comercial britânica, sendo apenas um funcionário de um empreendimento particular, John não era inglês. Fora isso, como não tinha pedido a naturalização em país estrangeiro, não se enquadrava no artigo 71, parágrafo $2^{\circ}$ da Constituição. Então, teria que servir. ${ }^{235}$

As apelações chegarem até mesmo ao Supremo Tribunal Federal, mas foi negado provimento ao recurso, ${ }^{236}$ apesar de o advogado de John Hartley declarar que os seus finados pais "querendo que seu filho conservasse a nacionalidade deles, fizeram esta declaração ou registro no consulado britânico". 237

Paralelamente ao Exército, o anglo-brasileiro era disputado por dois clubes de futebol naquele ano de 1923: o Fluminense e o Bangu. O Fluminense, na época, o time mais elitista do Rio de Janeiro, e que só aceitava jogadores brancos, queria contar com o talento de John Hartley para a temporada de 1923. No entanto, numa batalha que chegou a parar nas páginas dos jornais, John acabando optando pelo time de seu falecido pai, ${ }^{238}$ porque estava "ligado a ele por laços de amizade". ${ }^{239}$ É bom lembrar que, na época, o futebol ainda era amador, os jogadores não recebiam remuneração e, por isso, poderiam decidir em qual clube ficar por questões mais emocionais do que financeiras, como luvas, salários e contratos, que só viriam a existir dez anos depois, com a profissionalização do esporte, em 1933.

Mesmo que John Hartley não fosse inglês de fato, para os dois clubes litigantes isso pouco importava. O sobrenome, a ascendência e, provavelmente, o estilo de jogar eram os de um inglês, numa época em que já eram escassos os jogadores britânicos nas escalações dos clubes cariocas.

Em carta à imprensa, um dos antigos ingleses fundadores do Bangu A. C., escondido sob um codinome, ironiza o compatriota Harry Welfare, capitão do Fluminense, por não conseguir manter John Hartley nas Laranjeiras.

O seu extinto pai, sr. James Hartley, foi fundador e jogador do Bangu nos bons tempos e muito estimado no meio esportivo, sendo essa, dentre muitas, uma das causas que levaram John Hartley a inscrever-se pelo club de sua predileção. O meu prezado amigo Harry

\footnotetext{
${ }^{234}$ CONSTITUIÇÃO da República dos Estados Unidos do Brasil, 24 de fevereiro de 1891, artigo 69, parágrafo $1^{\circ}$. Acessado pelo endereço virtual: http://www.planalto.gov.br/ccivil_03/constituicao/Constituicao91.htm

${ }^{235}$ DIÁRIO OFICIAL, 15 de maio de 1923, seção 1, p. 67.

${ }^{236}$ Idem, 28 de agosto de 1923, seção 1, p. 56.

${ }^{237}$ CORREIO DA MANHÃ, 2 de maio de 1923, p. 6.

238 "Ata da sessão de $1^{\circ}$ de março de 1923". $7^{\circ}$ Livro de Atas das Sessões da Diretoria do Bangu A. C., 6 de janeiro de 1922 a 13 de novembro de 1930.

${ }^{239}$ CORREIO DA MANHÃ, 18 de março de 1923, p. 5.
} 
Welfare que tenha a paciência: é inglês como eu sou, e devemos saber respeitar as leis do football. $^{240}$

Pelo Bangu, John Hartley fez 25 jogos e 9 gols entre 1923 e 1926. Aos 25 anos, largou o futebol e, em 1927, aparecia jogando tênis pelo clube, esporte preferido dos estrangeiros, como se pode perceber pelos nomes dos que disputaram o torneio daquele ano: além de John, Wilfred Harold, George Turner, Charles Hathaway, Dudley Clark e Richard Harrison. ${ }^{241}$ Por mais que a Constituição de 1891 o colocasse como brasileiro nato e que tenha vivido praticamente toda a sua vida em Bangu, John Hartley mostrava-se propenso a adotar as práticas e os hábitos da colônia britânica, como jogar de tênis e conviver com seus pares.

\footnotetext{
${ }^{240}$ Idem, ibidem.

${ }^{241}$ Com esta equipe de ingleses, o Bangu A. C. alcançou seu melhor resultado na prática do tênis, sendo vice-campeão carioca da $2^{\mathrm{a}}$ divisão, torneio promovido pela Associação Metropolitana de Esportes Athléticos, perdendo a decisão para o São Cristóvão. Vide: O IMPARCIAL, 28 de agosto de 1927, p. 11.
} 


\subsection{3 - Os Hellowell}

Em novembro de 1989, o jornal $O$ Globo encontrou uma espécie de "elo perdido" entre o passado e o presente: a última remanescente das famílias britânicas que ainda vivia em Bangu. Tratava-se de uma octogenária, Lilian Hellowell, nascida no bairro em 11 de março de 1905 e que, sem ter tido filhos, apesar de ter sido casada com o brasileiro João Felisberto de Macedo, vivia sozinha numa residência no antigo bairro operário. ${ }^{242}$

Lilian era filha de Thomas Hellowell, mestre de fiação da Fábrica Bangu ${ }^{243}$ que, segundo o relato da anciã, tinha vindo para o Brasil em 1893. O patriarca da família, nascido na vila de Triangle, West Yorkshire, em 29 de maio de 1863, desenvolveu-se profissionalmente na indústria têxtil, trabalhando diretamente para a poderosa Platt Brothers \& Co., de Oldham, cidade que fica a 17 milhas de sua vila natal. ${ }^{244}$

Não há informações adicionais sobre em qual vapor o sr. Hellowell chegou ao Rio de Janeiro, nem porque atendeu à proposta da Fábrica Bangu, deixando a vida na Inglaterra para trás. No entanto, tinha três filhos para criar. A família, composta da Sra. Sarah Hanna Hellowell (nascida em 1865) e dos meninos William Wallace, John e Albert, chegou ao Brasil em 4 de setembro de 1894, à bordo do S.S. Liguria, junto com os parentes do mestre de tinturaria, Thomas Donohoe. ${ }^{245}$

Quando eles chegaram ao bairro, só havia uma rua e menos de mil habitantes. Com a construção da fábrica, o bairro se expandiu, chegando inclusive a ser, durante um tempo, a capital da moda do país. No entanto, minha mãe, Sarah Hanna Hellowell, sentia muita saudade da Inglaterra. Ela sempre me mostrava um salvo-conduto que recebera da Rainha da Inglaterra quando eles se mudaram para o Brasil. ${ }^{246}$

Nas lembranças da única filha brasileira do mestre Thomas Hellowell aparece um documento tido como de fundamental importância para a mãe dela. Ao contrário do que a memória permite esclarecer, o "salvo-conduto" não era assinado diretamente pela Rainha Vitória e sim por John Woodhouse, o Conde de Kimberley, que era o Secretário de Estado dos Negócios Estrangeiros da Grã-Bretanha.

É provável que todos os ingleses que tenham emigrado para o Brasil recebessem um documento desses, porém, o único que restou foi justamente o da Sra. Sarah Hellowell, guardado pela filha Lilian por possuir um valor sentimental imenso para a família. A carta é uma espécie de segurança para que um cidadão inglês possa viver incólume em terras estrangeiras.

\footnotetext{
${ }^{242}$ O GLOBO, Jornais de Bairro - Zona Oeste, 26 de novembro de 1989, p. 24.

${ }^{243}$ GAZETA DE NOTÍCIAS, 12 de outubro de 1906, p. 2

${ }^{244}$ Os apontamentos sobre a família de Thomas Hellowell foram feitos pelo pesquisador Murillo Guimarães que, nos anos 1980, teve a oportunidade de conversar pessoalmente com a Sra. Lilian Hellowell, guardando nos arquivos do Grêmio Literário José Mauro de Vasconcellos, em Bangu, um pequeno relato de três páginas.

${ }^{245}$ Relação de passageiros do vapor Liguria. Arquivo Nacional, BR.AN.RIO.OL.0.RPV.PRJ 5212.

246 O GLOBO, Jornais de Bairro - Zona Oeste, 26 de novembro de 1989, p. 24.
} 


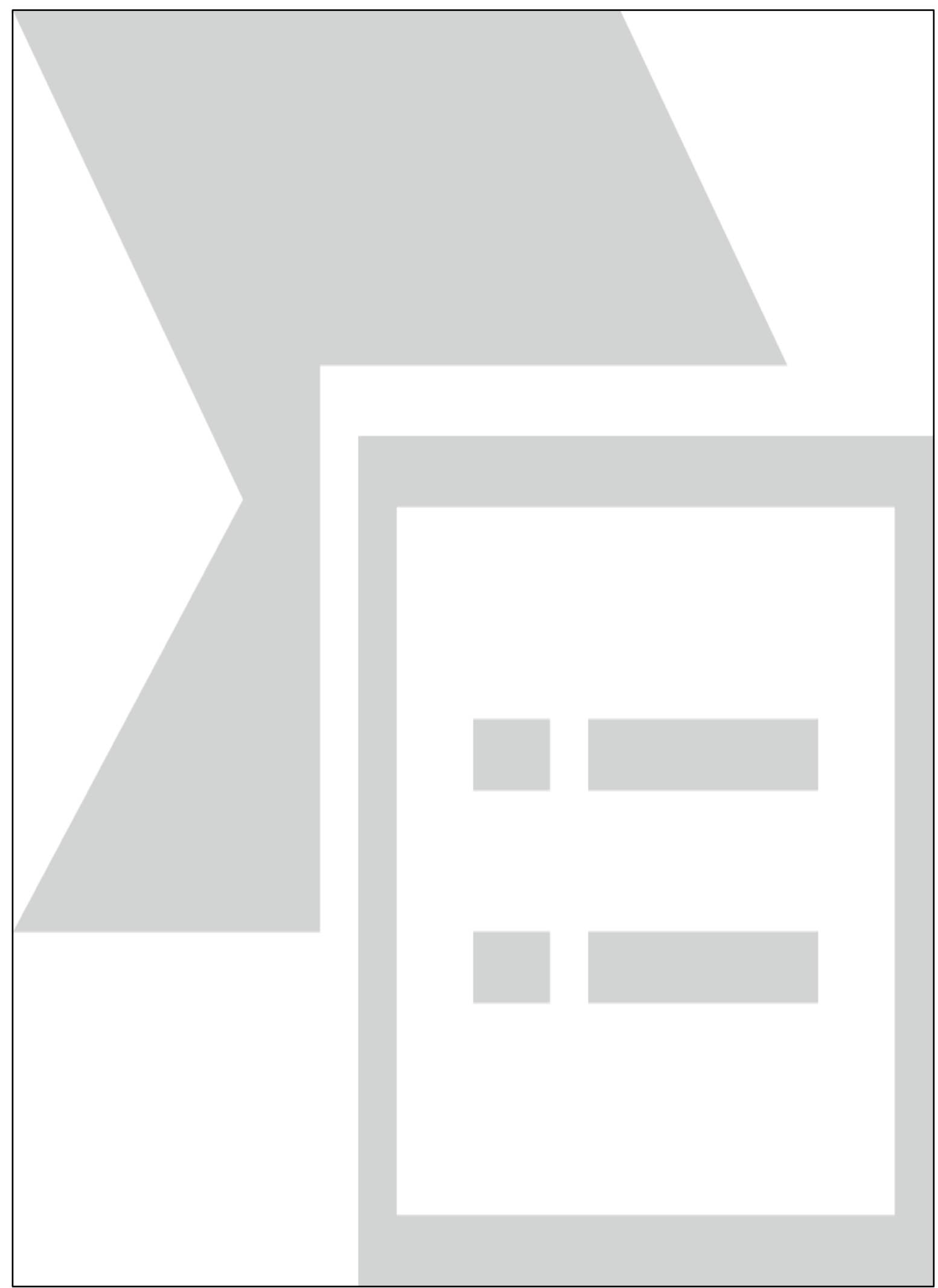

Figura 15 - O salvo-conduto assinado pelo Conde de Kimberley. Nele se lê: "Solicita e exige, em nome de Sua Majestade, a todos aqueles a quem possa interessar, para permitir que a Sra. Sarah Hannah Hellowell (súdita britânica), indo para o Brasil, acompanhada por três crianças, possa passar livremente sem impedimentos e lhe seja prestada toda a assistência e proteção de que ela possa ter necessidade. Dado pelo Ministério das Relações Exteriores. Londres, 8 de agosto de 1894."247

${ }^{247}$ Acervo do Grêmio Literário José Mauro de Vasconcelos. 
Pelas anotações relativas ao pagamento dos chefes estrangeiros da Fábrica Bangu, sabe-se que o mestre de fiação, Thomas Hellowell, recebeu em junho de 1897 por cinco dias trabalhados a quantia de 2 libras e 10 shillings (2.10.0), ou seja, ganhava 10 shillings por dia (meia libra). Em junho de 1898, ao que tudo indica, houve um aumento e ele aparece ganhando 17 libras (17.0.0) por ter trabalhado 24 dias. Depois disso, o valor recebido retorna a meia libra diária. Dessa forma, ganhou 15 libras por ter trabalhado 30 dias em dezembro de 1898; e 10 shillings por um único dia de labuta em dezembro de $1899 .{ }^{248}$

Como uma libra representava muitos mil-réis no final do século XIX, fazendo uma rápida conversão Thomas Hellowell ganhou em dezembro de 1898, com apenas 15 libras, o equivalente a 500 mil-réis. ${ }^{249}$ Em comparação, naquele mesmo ano, um operário da seção de tecelagem ganhava 211 mil-réis por mês. ${ }^{250}$

Tendo uma posição relativamente confortável no âmbito fabril, não foi difícil para o sr. Thomas Hellowell enviar sua esposa e os três filhos para a Europa em 1901, regressando ao Rio de Janeiro pelo vapor Oravia, em cabine de $2^{\text {a }}$ classe a 17 de julho daquele ano, após 19 dias de viagem desde Liverpool. ${ }^{251}$ Por mais que a Pacific Steam Navigation Company não divulgasse nos jornais o valor de uma passagem para a Europa, outras companhias cotavam em 14 libras um bilhete de $2^{\mathrm{a}}$ classe para a Lisboa ${ }^{252}$ e a 26 libras e 15 shillings um bilhete de $1^{\text {a }}$ classe para Paris. ${ }^{253}$

Como os demais ingleses do bairro, Thomas Hellowell participou ativamente da fundação do Bangu Athletic Club, em 1904, figurando nas primeiras diretorias como capitão do time de críquete, ${ }^{254}$ membro do conselho fiscal ${ }^{255}$ e integrante do Ground Committee. ${ }^{256}$ Além disso, atuou como goleiro do time de futebol em três partidas amistosas, apesar de já contar 41 anos.

Dois de seus filhos, William Wallace Hellowell (nascido em 1887) e John (nascido em 1890), na Inglaterra, também jogaram pelo clube do bairro. William fez 47 partidas e dois gols entre 1904 e 1908; enquanto John fez 60 partidas e 14 gols entre 1907 e $1913 .^{257}$

\footnotetext{
${ }^{248}$ SILVA, Gracilda Alves de Azevedo. Bangu - a fábrica e o bairro: um estudo histórico, 1889-1930. Instituto de Filosofia e Ciências Sociais (IFCS) da Universidade Federal do Rio de Janeiro (UFRJ), 1985, pp. 778-779.

249 "Entre 1889 e 1898, o câmbio passou de 9,07 mil-réis para 33,38 mil-réis por libra esterlina - uma alta de $268 \%$ ". Vide: BUESCU, Mircea. Evolução econômica do Brasil. Rio de Janeiro: APEC Editora, 1977, p. 153.

${ }^{250}$ LOBO, Eulália Maria Lahmeyer. História do Rio de Janeiro. Do Capital Comercial ao Capital Industrial e Financeiro. $2^{o}$ Volume. Rio de Janeiro: IBMEC, 1978, p. 665.

${ }^{251}$ Relação de passageiros do vapor Oravia. Arquivo Nacional, BR.AN.RIO.OL.0.RPV.PRJ 7540.

${ }^{252}$ GAZETA DE NOTÍCIAS, 6 de agosto de 1901, p. 3.

${ }^{253}$ Idem, 30 de julho de 1901, p. 3.

254“'Ata da sessão de 17 de abril de 1904”. $1^{\circ}$ Livro de Atas das Sessões da Diretoria do Bangu A.C., 17 de abril de 1904 a 7 de fevereiro de 1905 .

255 “Ata da sessão de 20 de dezembro de 1905". 2 Livro de Atas das Sessões da Diretoria do Bangu A.C., 24 de fevereiro de 1905 a 23 de julho de 1908.

256“'Ata da sessão de 6 de dezembro de 1907”. $2^{\circ}$ Livro de Atas das Sessões da Diretoria do Bangu A.C., 24 de fevereiro de 1905 a 23 de julho de 1908.

${ }^{257}$ MOLINARI, Carlos. Almanaque do Bangu. Brasília: Editora Kiron, 2011, pp. 7-17.
} 
Graças a um registro fotográfico, datado de 18 de março de 1928, às vésperas de uma nova viagem à Inglaterra, é possível ver que a família Hellowell foi criando raízes mais sólidas no Rio de Janeiro com o passar dos anos. Além dos pioneiros Thomas e Sarah Hanna, aparecem a filha Lilian (ainda solteira), o filho William Wallace com a esposa Frida Mathilde e a pequena Hanna; o filho John com a esposa Adalgisa Rodrigues e o pequeno Zahy; o filho Albert com a esposa Maria Julieta e a pequena Elsie, numa demonstração clara de que os casamentos entre ingleses e brasileiras passaram a ser uma constante para esta segunda geração de imigrantes, que já não dispunham mais de tantas opções na colônia britânica domicialiada na cidade.

Thomas Hellowell faleceu na sua própria residência, na rua Ferrer $n^{\circ}$ 5, em Bangu, a 20 de fevereiro de 1932, aos 68 anos. $^{258}$

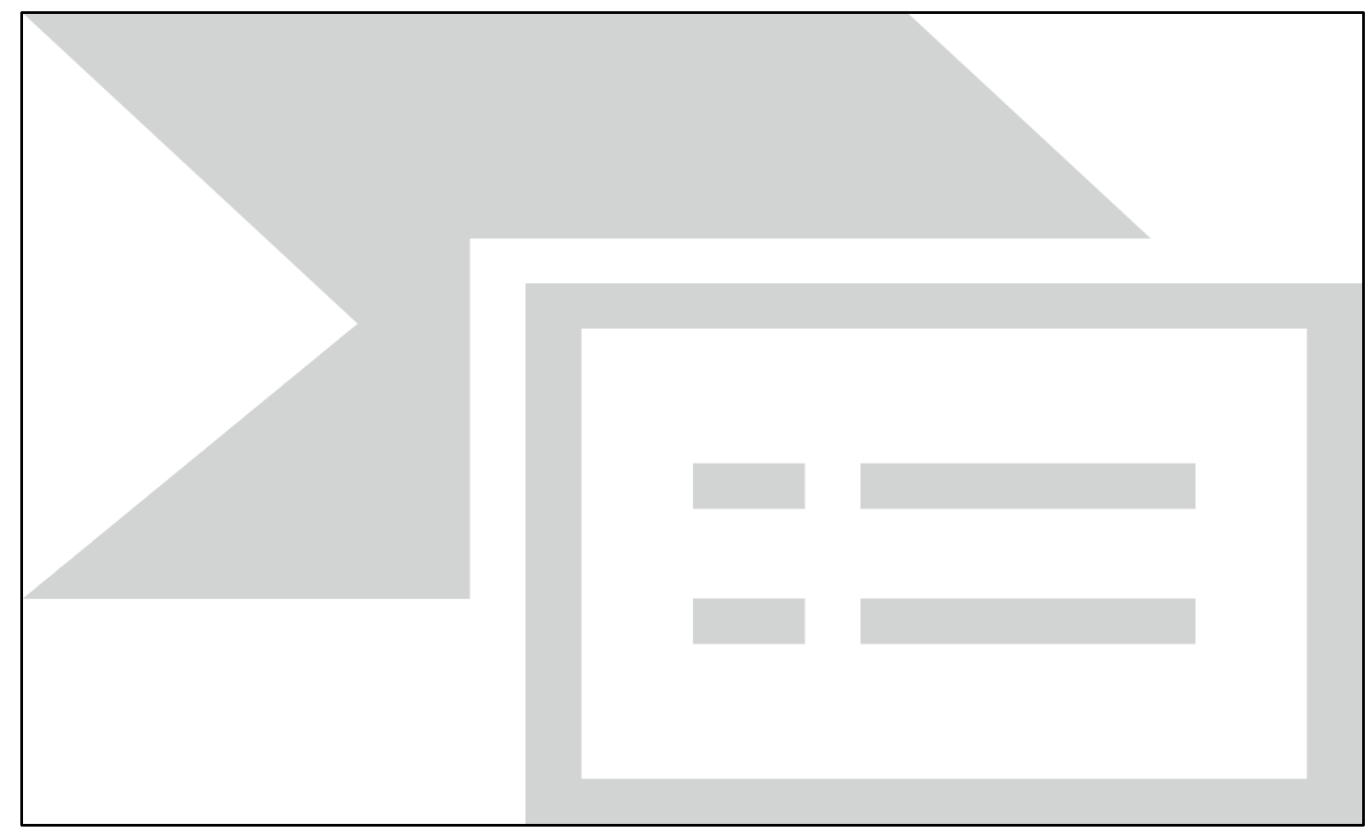

Figura 16 - Foto da família Hellowell na sala de estar da casa situada à Rua Ferrer no 5, em Bangu, em 18 de março de 1928.

Os filhos

Em 1932, John Hellowell vivia na rua Fonseca $\mathrm{n}^{\mathrm{o}}$ 5, em Bangu; ${ }^{259}$ Albert residia na rua Theóphilo Otoni $\mathrm{n}^{\mathrm{o}} 71$, no Centro; ${ }^{260}$ William Wallace morava na rua de São Pedro $\mathrm{n}^{\circ}$ 67, também

\footnotetext{
${ }^{258}$ CORREIO DA MANHÃ, 21 de fevereiro de 1932, p. 7; “Ata da sessão de 25 de fevereiro de 1932”. $8^{\circ}$ Livro de Atas das Sessões da Diretoria do Bangu A.C., 27 de novembro de 1930 a 12 de setembro de 1935.

${ }^{259}$ DIÁRIO OFICIAL, 6 de junho de 1930, seção 1, p. 84.

${ }^{260}$ Idem, 24 de agosto de 1932, seção 1, p. 57.
} 
no Centro, ${ }^{261}$ e mantinha fortes laços com o bairro proletário, pois fora vice-presidente do Bangu A. C. entre 1931 e $1932 .{ }^{262}$

Apesar de não trabalhar na Fábrica Bangu, o primogênito William mantinha uma empresa fabricante de aparelhos mecânicos no bairro, à rua Silva Cardoso no $69 .{ }^{263}$ Inicialmente, constituíra sociedade com o filho de alemães, Emílio Frambach que, assim como ele, também fora jogador do Bangu A.C. Os sócios se separaram em 1928, tendo Emílio levado metade do capital da empresa, uma quantia considerável de 38:533\$463 (38 contos, 533 mil e 463 réis). ${ }^{264}$

Além de perder o sócio, William Hellowell andou perdendo dinheiro no final da década de 20. Era credor de duas companhias têxteis que faliram na crise de 1929. Em setembro, com o fechamento da Companhia de Tecidos de Linho de Sapopemba, em Deodoro, William deixou de receber a quantia de 4:144\$600 (4 contos, 144 mil e 600 réis) ${ }^{265}$; e em novembro, com a falência da Companhia Nova Fábrica de Fiação e Tecidos Santo Aleixo, em Magé, perdeu 43\$200 (43 mil e 200 réis). ${ }^{266}$

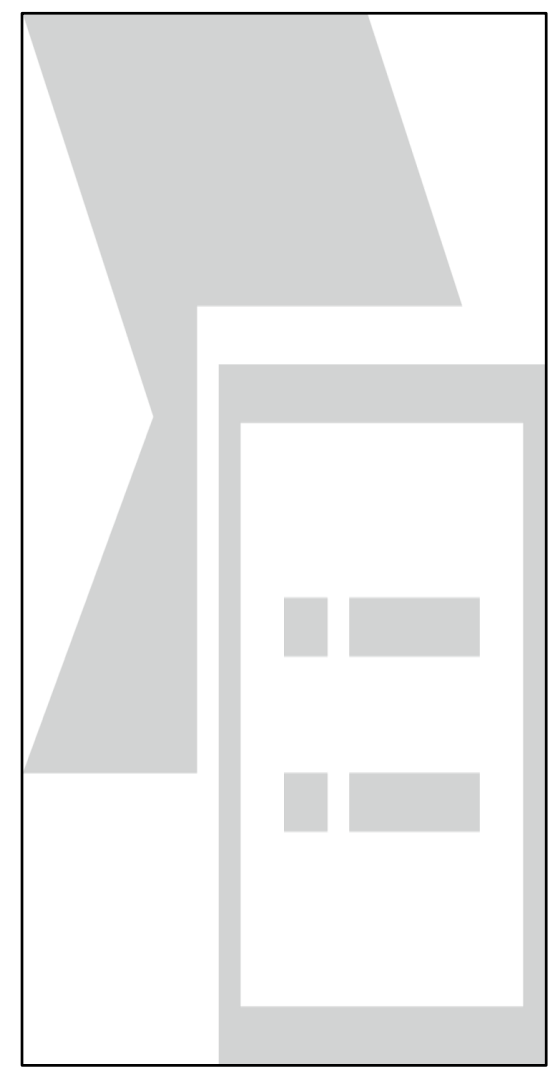

Figura 17 - William Hellowell, em 1905, aos 18 anos, defendendo as cores do Bangu, clube fundado por seu pai, Thomas. Acervo: Grêmio Literário José Mauro de Vasconcelos.

\footnotetext{
${ }^{261}$ Idem, 21 de maio de 1930, seção 1, p. 67.

262 JORNAL DO BRASIL, 7 de fevereiro de 1931, p. 16; O JORNAL, $1^{\circ}$ de março de 1932, p. 11.

263 DIÁRIO OFICIAL, 5 de novembro de 1935, seção 1, p. 55.

${ }^{264}$ Idem, 11 de outubro de 1928, seção 1, p. 49.

${ }^{265}$ GAZETA DE NOTÍCIAS, 29 de setembro de 1929, p. 6.

${ }^{266}$ Idem, $1^{\circ}$ de novembro de 1929, p. 6.
} 
Para enfrentar melhor as adversidades, William Hellowell decidiu diversificar sua renda, ingressando, nos anos 30, na White Martins S. A., empresa fundada no Rio de Janeiro, em 1912, pelo inglês George White e pelo brasileiro Domingos Bebiano Martins. ${ }^{267}$ Em 1931, já aparece nos jornais como "alto funcionário da S. A. White Martins", viajando constantemente a negócios para o Nordeste, especialmente Salvador, Aracaju e Recife, muitas vezes levando a esposa Frida Mathilde e chegando a negociar alguns amistosos interestaduais para o Bangu A. C. ${ }^{268}$

Fato curiosíssimo é que tal qual um moderno patrono das escolas de samba, mostrando que os ingleses acabaram por assimilar a cultura local e participaram ativamente da sociedade em que viviam, William Hellowell aparece como financiador da "Turma dos Esponjas", de Bangu, em 1927, ajudando a agremiação formada por operários do bairro a pôr o bloco na rua, ${ }^{269}$ com o enredo "Luís XV e sua corte em Versalhes”, recebendo por isso agradecimentos públicos dos foliões pelo "raro desinteresse e visível empenho" que fazia para "o brilhantismo da apresentação". 270

Seu irmão, John, também se embrenharia pelos caminhos da folia, ao se tornar vice-presidente do Bangu Club, agremiação verde e branca que existiu no bairro entre 24 de dezembro de 1930 e 7 de julho de 1939, 271 autointitulada "líder do recreativismo suburbano". 272

Curioso paradoxo, enquanto os irmãos Hellowell, nascidos em Yorkshire, iam se aproximando das tradições carnavalescas cariocas, afeiçoando-se às coisas da terra em que viviam, John Hartley, nascido no Rio de Janeiro, procurava manter hábitos e costumes que o aproximassem da Grã-Bretanha, negando até mesmo sua nacionalidade quando foi sorteado para o Exército.

William Wallace Hellowell faleceu, no Rio de Janeiro, em junho de 1954, aos 67 anos. ${ }^{273}$

\footnotetext{
${ }^{267}$ ARAÚJO, Marco Antônio de. Administração de produção e operações - uma abordagem prática. Rio de Janeiro: Brasport, 2009, p. 366.

${ }^{268}$ DIÁRIO DE NOTÍCIAS, 22 de junho de 1930, p. 10 e 12 de julho de 1931, p. 14.

${ }^{269} \mathrm{Na}$ concepção de alguns historiadores, o fato de imigrantes "endinheirados" financiarem sociedades carnavalescas poderia funcionar como um meio de reconhecimento, legitimação social e busca de prestígio. Vide: CUNHA, Maria Clementina Pereira. Ecos da Folia - Uma História Social do Carnaval Carioca entre 1880 e 1920. São Paulo: Companhia das Letras, 2001, p. 108.

270 JORNAL DO BRASIL, 17 de fevereiro de 1927, p. 13.

${ }^{271}$ Idem, 30 de dezembro de 1934, p. 21.

${ }^{272}$ Idem, $1^{\circ}$ de março de 1935 , p. 15.

${ }^{273}$ DIÁRIO DE NOTÍCIAS, 26 de junho de 1954, $2^{\text {a }}$ sessão, p. 2.
} 


\section{2 - Uma elite fabril}

Apenas o Jornal do Brasil trouxe a notícia de uma festa ocorrida na noite de 19 de junho de 1897 no Restaurante do Triângulo. Segundo o relato, "a corporação de ingleses que trabalham na Fábrica de Tecidos do Bangu, querendo provar o apreço, estima e gratidão que consagra aos diretores daquele estabelecimento, ofereceu-lhes um lauto banquete". ${ }^{274}$

Na ocasião, trabalhavam apenas oito mestres britânicos na fábrica: John Stark, Henry Bennett, Thomas Stirling, Clarence Hibbs, James Hartley, Thomas Hellowell, Thomas Donohoe e Fred Howard, cabendo a iniciativa da festa a John Stark, que dirigia a seção de fabricação de chitas. Tinha 26 anos e seu nome aparece nos relatos da Companhia, pelo menos, desde $1895 .{ }^{275}$ Dificilmente com esta idade seria mestre de seção na Grã-Bretanha. Em Bangu, sua ascensão fora mais rápida, daí demonstrar aos diretores toda sua gratidão num jantar.

Seu salário, inicialmente, girava em torno de 1 libra a cada três dias trabalhados, ganhando depois significativos aumentos na única série disponível entre 1897 e 1900.

Tabela I - Evolução salarial do mestre têxtil John Stark na C.P.I.B. (1897-1900) ${ }^{276}$

\begin{tabular}{|c|c|c|c|c|c|}
\hline Mês e ano & Câmbio & $\begin{array}{c}\text { Número de dias } \\
\text { trabalhados }\end{array}$ & Quantia recebida em libra & Total em Réis & $\begin{array}{c}\text { Média diária } \\
\text { em Réis }\end{array}$ \\
\hline Junho de 1897 & 7,69 & 7 & $\begin{array}{c}2.6 .8 \\
\text { (2 Libras, } 6 \text { shillings, } 8 \\
\text { pences) }\end{array}$ & $\begin{array}{c}72 \$ 821 \\
(72 \text { mil e } 821 \\
\text { réis) }\end{array}$ & $10 \$ 403$ \\
\hline Junho de 1898 & 7,30 & 18 & $\begin{array}{c}6.0 .0 \\
\text { (6 Libras) }\end{array}$ & $\begin{array}{c}197 \$ 260 \\
(197 \text { mil e } 260 \\
\text { réis) }\end{array}$ & $10 \$ 958$ \\
\hline $\begin{array}{c}\text { Dezembro de } \\
1898\end{array}$ & 7,77 & 8 & $\begin{array}{c}2.13 .4 \\
\text { (2 Libras, } 13 \text { shillings, } 4 \\
\text { pences) }\end{array}$ & $\begin{array}{c}82 \$ 368 \\
(82 \text { mil e } 368 \\
\text { réis })\end{array}$ & $10 \$ 296$ \\
\hline $\begin{array}{c}\text { Dezembro de } \\
1899\end{array}$ & 6,96 & 30 & $\begin{array}{c}11.0 .0 \\
\text { (11 Libras) }\end{array}$ & $\begin{array}{c}379 \$ 310 \\
(379 \text { mil e } 310 \\
\text { réis) }\end{array}$ & $12 \$ 643$ \\
\hline $\begin{array}{c}\text { Dezembro de } \\
1900\end{array}$ & 9,84 & 4 & $\begin{array}{c}3.6 .8 \\
\text { (3 Libras, } 6 \text { shillings, } 8 \\
\text { pences) }\end{array}$ & $\begin{array}{c}81 \$ 300 \\
(81 \text { mil e } 300 \\
\text { réis })\end{array}$ & $20 \$ 325$ \\
\hline
\end{tabular}

274 JORNAL DO BRASIL, 21 de junho de 1897, p. 2.

275 THE RIO NEWS, 28 de maio de 1895, p. 8.

${ }^{276}$ SILVA, Gracilda Alves de Azevedo. Bangu - a fábrica e o bairro: um estudo histórico, 1889-1930. Instituto de Filosofia e Ciências Sociais (IFCS) da Universidade Federal do Rio de Janeiro (UFRJ), 1985, pp. 778-779. 
John Stark teria outros motivos para saudar a diretoria da fábrica. No ano seguinte, conseguiu algo que nenhum outro técnico têxtil tinha obtido até então. Uma espécie de férias remuneradas, de forma bem peculiar. Solteiro, Stark vivia na vila operária, na casa $n^{\circ} 12$ da Rua Estevão (futuramente Rua Ferrer), a principal de Bangu, com seu pai, Jersey Stark. Desejando ir à Inglaterra, fez um acordo com a direção da fábrica, sendo-lhe concedida "permissão de, no correr do próximo semestre, ir visitar sua família, com passagens e ordenado durante os dias de viagem por conta da Companhia, que não suspenderia o fornecimento semanal de $£ 2$ a seu pai, conta a liquidar no seu regresso, que devia ser antes do fim do ano". 277

Stark embarcou rumo a Liverpool no dia 19 de julho de 1898, pelo vapor Oropesa, conforme notícias publicadas nos jornais. ${ }^{278}$ Ficou 81 dias fora do país, o que rendeu 27 Libras a seu pai (ou seja, ele ganhava 1 libra a cada três dias). Voltou pelo paquete Ibéria, em cabine de $1^{\mathrm{a}}$ classe, chegando ao porto do Rio de Janeiro no dia 9 de novembro de 1898. Detalhe: dos 229 passageiros daquele vapor, apenas 12 privilegiados viajaram de $1^{\mathrm{a}}$ classe. ${ }^{279} \mathrm{Com}$ o passar dos anos, seu prestígio continuava em alta junto à diretoria da fábrica. Em 1899, mudou de cargo e tornou-se "mestre da oficina das tinturarias". ${ }^{280}$ Em 1901, Stark acompanhou Eduardo Gomes Ferreira, diretor-gerente da Companhia, numa viagem a Europa para a compra de novas máquinas. ${ }^{281}$ Em 1904, é na sua casa que os demais ingleses se reúnem para fundar o Bangu A. C., ${ }^{282}$ tomando parte em 12 jogos do time de futebol até 1905 e sendo sempre o capitão da equipe.

Por mais que esses técnicos têxteis parecessem intocáveis em relação ao restante do operariado, que não poderia jamais competir com eles em conhecimento e, consequentemente, em remuneração; uma única vez, a grande imprensa publicou uma carta de um anônimo operário da Fábrica Bangu criticando o administrador português Eduardo Gomes Ferreira pelos altos salários pagos a estes britânicos, citando o caso do mestre de máquinas e oficinas, William French, que receberia 1:100\$ por mês e o diretor-mestre dos teares, James Hartley, que ganharia 1:000\$ (um conto de réis). Em 1901, num momento de cortes nos gastos, a Companhia tinha reduzido o salário dos "pobres trabalhadores que sofrem horrores e necessidades", mantendo as quantias fabulosas pagas a "homens sem habilitação alguma", na visão do operário que escreveu o protesto. ${ }^{283}$

\footnotetext{
${ }^{277}$ Idem, p. 777.

${ }^{278}$ GAZETA DE NOTÍCIAS, 20 de julho de 1898, p. 5 e THE RIO NEWS, 26 de julho de 1898, p. 7.

${ }^{279}$ Relação de passageiros do vapor Ibéria. Arquivo Nacional, BR.AN.RIO.OL.0.RPV.PRJ 6470.

280 JORNAL DO BRASIL, 27 de janeiro de 1899, p. 1.

${ }^{281}$ SILVA (1985), p. 775

282 "Ata da sessão de 17 de abril de 1904". 1 Livro de Atas das Sessões da Diretoria do Bangu A.C., 17 de abril de 1904 a 7 de fevereiro de 1905.

283 JORNAL DO BRASIL, 15 de junho de 1901, p. 2.
} 
“Os mestres mecânicos britânicos gozavam de uma invejável reputação no Brasil” e por isso ganhavam, em alguns casos, mais de 20 Libras por mês. ${ }^{284}$ Possuir nos seus quadros homens especificamente "importados", com um conhecimento único, era ao mesmo tempo um luxo e uma necessidade que uma Companhia têxtil, que pretendia ser a maior da cidade, não poderia abrir mão. ${ }^{285}$ Até por isso, em momento algum a Fábrica Bangu dispensou o conhecimento dos técnicos têxteis ingleses. Se bem que, até o final da segunda década do século XX, a participação deles na chefia das seções fosse bastante reduzida, jamais por demissões, e sim pela própria decisão do imigrante bretão de deixar a Companhia, mudando de empresa, deixando de trabalhar na indústria e investindo seu capital acumulado após anos de boas remunerações no comércio ou regressando à Europa.

Foi o que aconteceu com John Stark. Em 1906, sem maiores explicações nos registros da Companhia, "este verdadeiro gentleman e mestre da tinturaria de chitas" ${ }^{286}$ retorna a Southampton pelo paquete Aragon no dia 2 de março, ${ }^{287}$ contando com os maiores apreços por parte da colônia britânica de Bangu: “Ao seu bota-fora compareceram muitos amigos e coirmãos de lutas, a quem o sr. Stark ofereceu uma taça de champagne, trocando-se por essa ocasião amistosos e significativos brindes". 288

Deve ter sido uma decisão errônea, pois Stark acaba voltando ao Brasil durante a década de 10, aparecendo como um dos técnicos têxteis da Companhia Brazil Industrial de Paracambi, uma fábrica menor e mais antiga que a de Bangu. ${ }^{289}$ No interior do estado do Rio manteve seu gosto por esportes, fundando, em 16 de julho de 1912, o Paracamby Football Club, com as mesmas cores vermelha e branca da "matriz", junto com outros antigos mestres da Bangu, como Clarence Hibbs e Fred Jacques. ${ }^{290}$ Dessa forma, o Paracamby F. C. passa a reconhecer no Bangu A. C. um modelo a ser seguido. O teor de seus estatutos, inclusive, era uma cópia do regulamento banguense.

\footnotetext{
${ }^{284}$ GRAHAM, Richard. Grã-Bretanha e o início da modernização no Brasil. São Paulo: Editora Brasiliense, 1973 , pp. $143 ; 145$.

${ }^{285}$ A Companhia chega a despender só durante o mês de junho de 1898, a quantia de 84 Libras, 6 shillings e 8 pences, o equivalente a $2.698 \$ 660$ (quase 2,7 contos de réis), no pagamento a seis mestres britânicos. Apud: SILVA (1985), p. 778.

286 JORNAL DO BRASIL, $1^{\circ}$ de agosto de 1902, p. 2.

287 THE BRAZILIAN REVIEW, 6 de março de 1906, p. 18.

288 JORNAL DO BRASIL, 4 de março de 1906, p. 7.

${ }^{289}$ A Companhia Brazil Industrial, em Paracambi, tinha 1.000 teares, 31.500 fusos, empregava 1.220 operários e tinha o capital de 6:000\$000 em 1913. A Companhia Progresso Industrial do Brazil, em Bangu, tinha 2.000 teares, 53.168 fusos, empregava 2.569 operários e tinha o capital de 9:000\$000 no mesmo ano. Vide: WRIGHT, Arnold. Impressões do Brazil no Século Vinte - Sua História, seo povo, commercio, indústrias e recursos. Londres: Lloyd's Greater Britain Publishing Company Ltd., 1913, pp. 389-397.

${ }^{290}$ KELLER, Paulo Fernandes. Fábrica \& Vila Operária - A vida cotidiana dos operários têxteis em Paracambi-RJ. Engenheiro Paulo de Frontin: Editora Solon Ribeiro, 1997, pp. 93-94.
} 


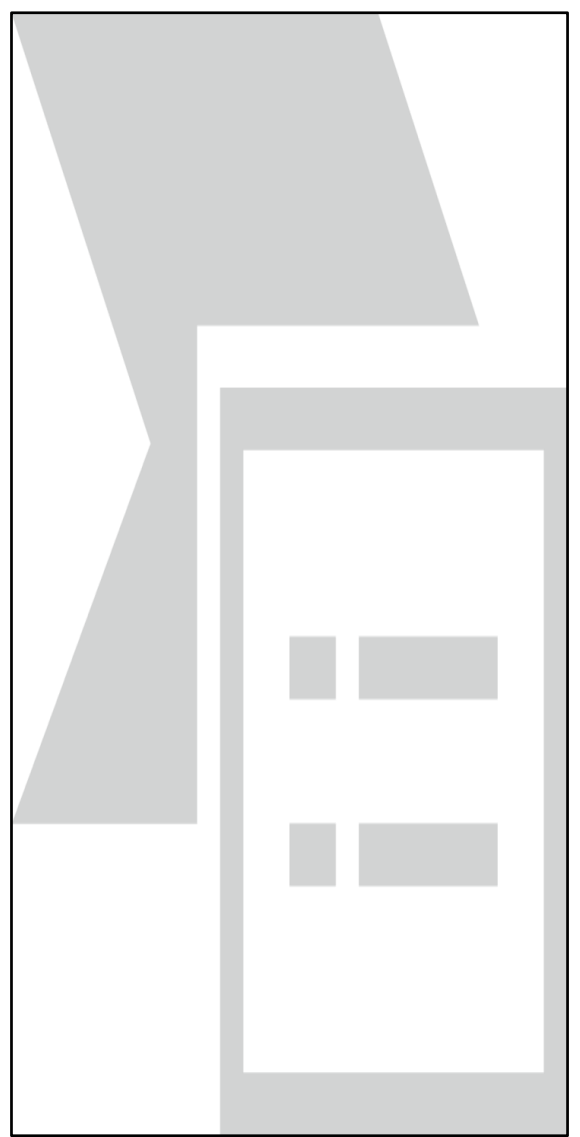

Figura 18 - O técnico têxtil John Stark, capitão e secretário do Bangu A. C., em 1905. ${ }^{291}$

\subsection{1 - Outras opções de trabalho além da fábrica}

As três histórias de família já apresentadas nos permitem encontrar pontos comuns entre elas. Por mais que recebessem por dia trabalhado, tal qual a maioria dos operários e, provavelmente, cumprissem uma jornada de muitas horas, a remuneração oferecida a esses técnicos têxteis compensava. A média de 10 shillings por dia (meia Libra) é significante, se comparado ao salário de qualquer outro trabalhador menos especializado da fábrica, que girava em torno de 4 mil réis por dia. Por isso, gastos relativamente altos, como a compra de passagens para a Europa em cabines de $2^{\mathrm{a}}$ classe para toda a família, era algo que esses britânicos poderiam dispor.

Além de gozarem de um conforto maior por terem acesso preferencial às melhores casas da vila operária, os pioneiros britânicos que chegaram a Bangu puderam dar a seus filhos um destino diferente do que teriam se continuassem nas fábricas inglesas. Nos casos analisados, vimos que o filho do sr. Donohoe especializou-se em químico industrial; o filho do sr. Hartley tornou-se dentista e o primogênito do sr. Hellowell galgou postos como um alto funcionário da White Martins.

Sinalizando que a segunda geração de britânicos poderia ter empregos menos penosos do que dentro de uma fábrica de tecidos, encontramos muitos outros exemplos. Archibald French, nascido

${ }^{291}$ REVISTA DA SEMANA no 286,5 de novembro de 1905, p. 19. 
em Liverpool em 8 de janeiro de $1896^{292}$ e vindo ainda criança para o Brasil com seu pai William French, mestre de máquinas e oficinas, ${ }^{293}$ era, em 1918, aos 22 anos, um promissor funcionário da The Texas Company (South America) Ltda. ${ }^{294}$ - a Texaco, implantada no país, em setembro de 1915. ${ }^{295}$ A carreira, no entanto, foi interrompida pela epidemia de gripe espanhola, que o vitimou em 29 de outubro de $1918 .^{296}$

Já Archibald Procter, nascido no Brasil em 1899, filho de Mary e Andrew Procter, ${ }^{297}$ este chefe do almoxarifado da fábrica, aparece em 1918 nos registros do Bangu A. C. como escriturário do Consulado Britânico e, futuramente, em 1934, como secretário e também acionista da Sociedade Anônima Pacheco Moreira, importadora de carvão de pedra, ${ }^{298}$ com sede na Avenida Rio Branco. ${ }^{299}$

Seu primo, André Procter, filho de William Procter, engenheiro eletricista da fábrica, também teve oportunidade de estudar e, logo cedo, aparece diplomado como radiotelegrafista pela Escola Marconi de Telegrafia sem fio, ${ }^{300}$ tornando-se oficial da Marinha Mercante brasileira. ${ }^{301}$

Os exemplos de que a vida dos filhos desses ingleses poderia prosseguir fora da Companhia, completa-se com James Stirling, ${ }^{302}$ filho do técnico têxtil Thomas Stirling. ${ }^{303}$ Apesar de jogar pelo clube de futebol do bairro entre 1913 e 1917, o jovem não morava mais em Bangu, aparecendo nos registros como domiciliado na Rua de Santa Luzia $n^{\circ}$ 69, no Centro do Rio, e trabalhando como escriturário da empresa inglesa City Improvement \& Co. Limited, ${ }^{304}$ contratado em $1^{\mathrm{o}}$ de abril de 1914.

\footnotetext{
${ }^{292}$ ASSAF, Roberto \& MARTINS, Clóvis. História dos Campeonatos Cariocas de Futebol (1906-2010). Rio de Janeiro: Maquinária, 2010, p. 76.

${ }^{293}$ GAZETA DE NOTÍCIAS, 12 de outubro de 1906, p. 2. William French veio originalmente para o Rio de Janeiro contratado para trabalhar com os maquinismos da Companhia Confiança Industrial, em Vila Isabel. Após algum tempo, mudou-se para Bangu, assumindo o cargo de mestre das oficinas e chefe das máquinas da Companhia Progresso Industrial do Brazil em $1^{\circ}$ de novembro de 1899, em substituição ao alemão Otto Fischer, que falecera no dia 18 de outubro de 1899.

${ }^{294}$ CORREIO DA MANHÃ, 17 de novembro de 1918, p. 11.

${ }^{295}$ GONÇALEZ, Márcio Carbaca. Publicidade e Propaganda. Curitiba: IESDE Brasil S.A., 2009, p. 13.

${ }^{296}$ O PAIZ, 31 de outubro de 1918, p. 6.

${ }^{297}$ DIÁRIO OFICIAL, 23 de maio de 1939, seção 1, p. 103.

${ }^{298}$ ALMANAK ADMINISTRATIVO, MERCANTIL E INDUSTRIAL DO RIO DE JANEIRO (1891 a 1940), Volume I, p. 945.

${ }^{299}$ DIÁRIO OFICIAL, 17 de março de 1934, seção 1, p. 83.

300 A ÉPOCA, 15 de agosto de 1915, p. 5.

${ }^{301}$ GRANADO, Paschoal José. "Retratos, Espelho da Vida" In: BANGU NOTÍCIAS, Ano I - No 2 - Novembro 1970, p. 17.

302 James Stirling nasceu na cidade de Prestwich, em Lancashire, no noroeste da Inglaterra, em 20 de maio de 1892, vivendo em Bangu quando era criança, entre 1897 e 1901. Regressou à sua terra natal com seus pais e voltou ao Brasil em 20 de dezembro de 1912.

${ }^{303}$ Thomas Stirling nasceu na vila de Oswaldtwistle, em Lancashire, em 1868. Entre 1897 e 1901, emprega-se como mestre na Companhia Progresso Industrial do Brazil. Depois desta data, retorna a seu país, trabalhando como simples tintureiro na Calico Printers. Os nomes dos três integrantes da família - o pai Thomas, a esposa Alice e o filho James aparecem nos Censos da Inglaterra e País de Gales, de 1911, vivendo na vila de Rainsough, em Prestwich. É certo que a família regressou ao Rio de Janeiro na década de 10.

${ }^{304}$ A City Improvement foi fundada em 1862 e era responsável pela construção e operação do sistema de águas e esgotos da capital. Vide: ALMEIDA, Paulo Roberto de. Formação da diplomacia econômica no Brasil - as relações econômicas internacionais no Império. $2^{a}$ edição. São Paulo: Editora Senac, 2001, p. 274.
} 
A diversificação de ofícios e a opção dos descendentes em não seguir o caminho do trabalho fabril podem significar que a segunda geração de britânicos possuía maior grau de instrução que os pioneiros e, para eles, assumir as longas jornadas numa fábrica, sem direito a uma aposentadoria ao final da carreira não era algo que lhes atraísse. Quando surgia uma oportunidade melhor, os filhos deixavam o bairro e se desobrigavam de seguir a carreira dos pais.

A evolução profissional dos filhos poderia significar dias melhores para os pais. O chefe do almoxarifado, Andrew Procter, ${ }^{305}$ que se tornou presidente do Bangu A. C. entre 1909 e 1910 e presidente do Esperança F.C. em 1917 e 1918, ${ }^{306}$ ao deixar a Companhia, muda-se também da localidade, inicialmente indo morar no Andaraí, ${ }^{307}$ e depois, adquire uma casa em Ipanema, na rua Visconde de Pirajá no 72, aonde vem a falecer em 1945, na "avançada idade de 81 anos". ${ }^{308}$ Muito embora Ipanema, naqueles idos, ainda fosse um "longínquo bairro", o qual, para se chegar, necessitava "de um deslocamento de bonde de pelo menos cinquenta minutosa partir do centro da cidade", ${ }^{309}$ os preços das residências nessa praia eram, com certeza, maiores do que uma casa em Bangu.

Evidente que cada um empregava o dinheiro ganho após tantos anos de fábrica como queria. Alguns se arriscaram a montar sociedades, mas como tinham passado a vida toda sendo empregados, não demonstraram maior tino comercial. Clarence Sam Hibbs e Fred. Jacques - que chegaram a Bangu em $1894^{310}$ e $1901^{311}$ para ocuparem, respectivamente, os cargos de chefe da seção estamparia e mestre em mecânica - organizaram uma firma em 1913 junto com o português Albino Monteiro da Costa Fontes, para o comércio de papéis pintados, situada à rua Desembargador Isidro $\mathrm{n}^{\mathrm{o}}$ 189, na Tijuca, com o capital inicial de 120:000\$ (cento e vinte contos de réis). ${ }^{312}$ Dez anos depois, em 1923, os dois ingleses desmancham a sociedade, recebendo Jacques a importância de 15:000\$ e Hibbs, a de 25:000\$, deixando Costa Fortes com o ativo e o passivo da empresa, no total de 150:000\$ (cento e cinquenta contos de réis). ${ }^{313}$

$\mathrm{Na}$ década de 1920, após trabalharem por mais de 25 anos na Companhia, os pioneiros ingleses já não faziam parte dos quadros da empresa. Na época, não havia ainda uma lei que

\footnotetext{
305 Segundo dados enviados pelo seu descendente, Kevin Hall, buscados no site ancestry.com, Andrew de Wolf Barss Procter, nasceu em 23 de junho de 1864 em Dundee, Angus, na Escócia. É certo que em 1898 já estava no Rio de Janeiro, trabalhando como empregado no comércio e morando na Travessa do Carneiro, no Estácio. Em 22 de janeiro

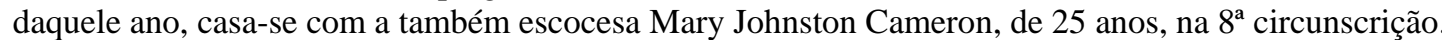

306 O IMPARCIAL, 21 de março de 1917, p. 12.

${ }^{307}$ Depois de morar em Bangu, Andrew Procter mudou-se para a rua Souza Cruz no 45, no bairro do Andaraí. É o endereço que consta na certidão de casamento de sua filha, Doris Procter, que contraiu matrimônio com James Stirling, em 22 de janeiro de 1923, na Igreja Protestante Episcopal do Rio de Janeiro.

${ }^{308}$ A NOITE, 3 de julho de 1945, p. 3.

${ }^{309}$ NETO, Lira. Getúlio - Da volta pela consagração popular ao suicídio (1945-1954). São Paulo: Companhia das Letras, 2014, p. 76.

310 O PAIZ, 22 de maio de 1894, p. 5.

311 A IMPRENSA, 6 de janeiro de 1901, p. 3.

312 O PAIZ, 16 de fevereiro de 1913, p. 10.

${ }^{313}$ DIÁRIO OFICIAL, 23 de janeiro de 1923, seção 1, p. 42.
} 
regulasse a aposentadoria - a primeira nesse sentido, que estendeu aos operários têxteis as vantagens da lei de aposentadorias e pensões dos ferroviários, foi proposta ao Congresso Nacional pelo deputado Pacheco de Oliveira em outubro de 1927. ${ }^{314}$ A solução para esses estrangeiros parecia ser a de investir o que conseguiram acumular durante toda a vida no comércio.
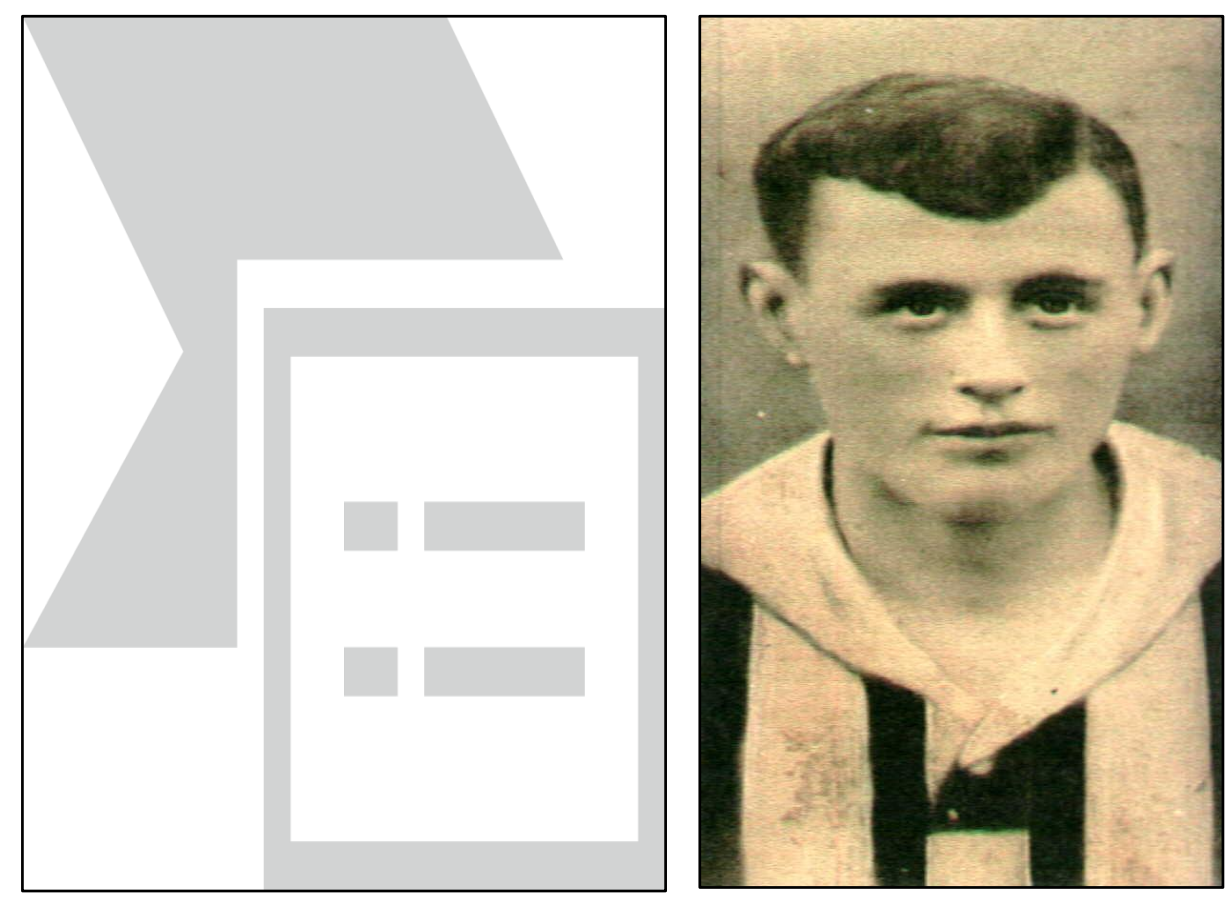

Figuras 19 e 20 - À esquerda, Andrew Procter (1864-1945), chefe do almoxarifado da fábrica, trocou Bangu por Ipanema. À direita, o jovem escriturário da City Improvement, James Stirling, filho do técnico têxtil Thomas Stirling.

Diferentemente do pai e apesar de ter jogado futebol no Bangu A. C., James nunca trabalhou na fábrica.

Foi assim que pensou o antigo mestre de máquinas e oficinas, William French, que acabou investindo 110:000\$ na compra de um botequim, confeitaria e comércio de bebidas em Madureira, de Madureira, à rua Domingos Lopes no 245. A aquisição demonstrou ser um desastre, pois French foi ludibriado pelos antigos donos, o espanhol Domingos Gonzalez e o português Manoel Antônio da Silva e também pelo sócio que o arranjaram, o português José da Fonseca Ferreira que, segundo informações, não entrara com um real na sociedade. ${ }^{315}$

O caso acabou ganhando certa notoriedade porque a esposa de William, Jessie Cameron French acionou a $3^{\mathrm{a}}$ delegacia auxiliar, alegando que o português Ferreira embebedava diariamente seu marido e, com isso, ia desviando mercadorias do botequim para outro, de sua propriedade, no bairro do Estácio. Segundo os jornais, "a fortuna de French foi toda dissipada aí nessa aventura!”.316

\footnotetext{
${ }^{314}$ SILVA, Gracilda Alves de Azevedo. Bangu - a fábrica e o bairro: um estudo histórico, 1889-1930. Instituto de Filosofia e Ciências Sociais (IFCS) da Universidade Federal do Rio de Janeiro (UFRJ), 1985, pp. 726-728.

${ }^{315}$ O PAIZ, 11 de dezembro de 1925 , p. 7

316 O JORNAL, 11 de dezembro de 1925, p. 6.
} 
Se compararmos os dados dos censos de 1906 e 1920 na freguesia de Campo Grande, iremos perceber um aumento do número de estrangeiros na região, passando de 2.989 para 5.061 pessoas vindas de outro país, um acréscimo de 69\%. Os portugueses expandiram sua colônia, elevando de 1.699 para 3.856 habitantes (um aumento de 126\%) em um período de apenas 14 anos. Os espanhóis passaram de 151 moradores para 281. E até mesmo os alemães passaram de 35 membros para 49. As únicas nacionalidades que diminuíram sua população na região foram a italiana (de 552 para 524, queda de apenas 5\%), a francesa (de 26 para 19, queda de 27\%) e a britânica (que caiu de 37 para 18 moradores, um decréscimo de 52\%), ${ }^{317}$ exatamente pelo campo de possibilidades que essa segunda geração de ingleses foi encontrando na cidade do Rio de Janeiro e também pelo capital acumulado após vários anos de trabalho, que lhes permitia mudar-se para bairros mais elitizados.
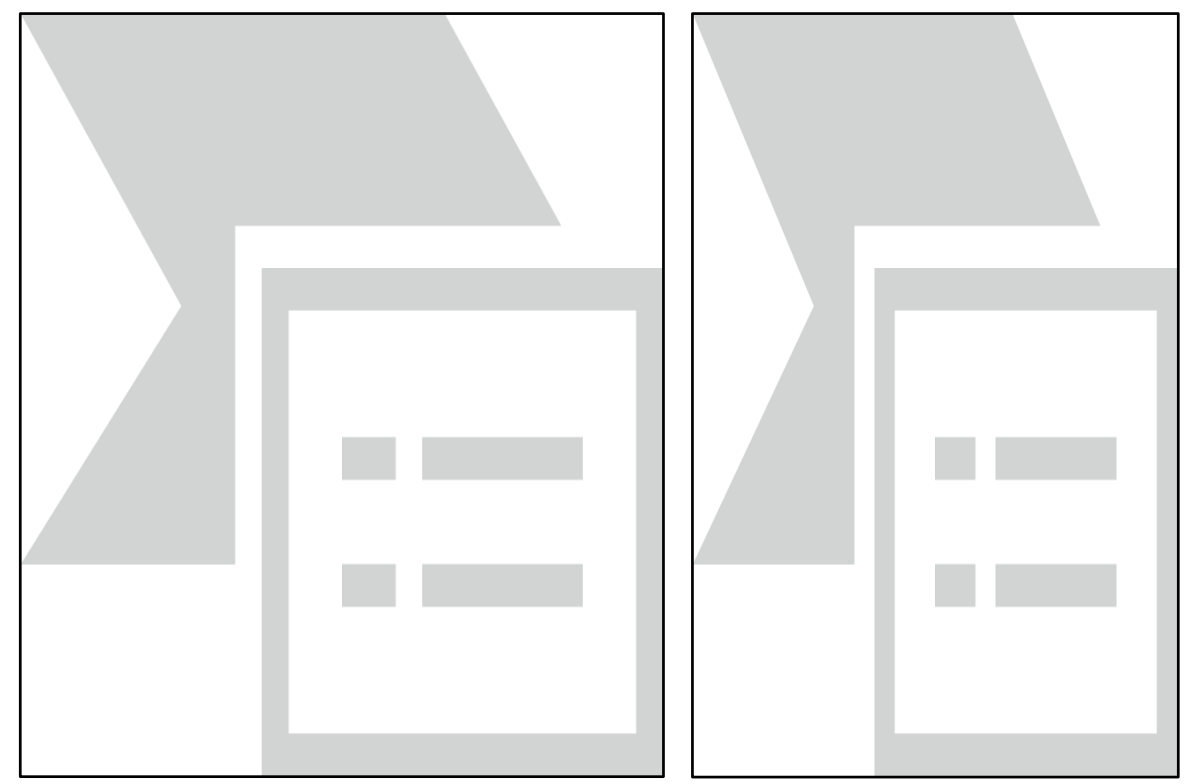

Figuras 21 e 22 - A família French teve pouca sorte no Brasil. O velho William French foi vítima de uma espoliação do seu patrimônio em 1924. Enquanto o filho, Archibald, faleceu durante a epidemia de gripe espanhola, em 1918.

Desta forma, quando a Companhia Progresso Industrial do Brazil coloca à venda seus terrenos, para que os moradores adquiram definitivamente as casas onde já viviam, nos anos 30, o maior número de interessados, além dos brasileiros, são os portugueses, que chegam a adquirir $30 \%$ das terras/imóveis. Os ingleses, cada vez mais distantes do bairro, compram apenas 0,9\% dos terrenos negociados. ${ }^{318}$

\footnotetext{
${ }^{317}$ SENRA, Nelson de Castro. O Censo de 1906 do Rio de Janeiro. Rio de Janeiro: Publicações Pereira Passos, 2012 , p. 347. RECENSEAMENTO DE $1920-4^{\circ}$ Censo geral da população do Brazil, $1^{\circ}$ da agricultura e das indústrias e $11^{\circ}$ da população da cidade do Rio de Janeiro (Districto Federal). Rio de Janeiro: Typographia da Estatística, 1926, pp. 98-105. ${ }^{318}$ O GLOBO, 30 de abril de 1938, p. 2.
} 


\section{III - Greves e conflitos nos primeiros anos da Fábrica Bangu}

"Fiam o fio no filatório de Bangu, mas quando o nó da concórdia se desata, não é brincadeira!". ${ }^{319}$ Em forma jocosa, o jornal satírico As Ocurrências da Semana queria mostrar aos seus leitores, em 1895, como eram delicadas as relações entre os trabalhadores no gigantesco empreendimento fabril, comparando-as a um fio tão fino que se rompia com imensa facilidade.

Nos primeiros anos após a fundação, Bangu ainda era um lugar remoto, com apenas duas ruas abertas, além da Estrada Real de Santa Cruz (existente há mais de um século para permitir a comunicação com as sesmarias dos Jesuítas, em Itaguaí): a Rua Estevão (em homenagem ao presidente da fábrica, Estevão José da Silva) e a Rua Fonseca (nome do primeiro diretor-tesoureiro, Manuel Moreira da Fonseca). ${ }^{320}$ Havia 95 casas de tijolinhos vermelhos constituindo a vila operária para as famílias mais privilegiadas dos mestres e contramestres, ${ }^{321}$ um grande número de ranchos, uma capela, uma escola subvencionada pela Intendência e uma sociedade recreativa: ${ }^{322}$ a Sociedade Musical Progresso, fundada em 24 de janeiro 1895. ${ }^{323}$

Segundo um relatório da própria Companhia apresentado na Exposição Industrial de 1895, trabalhavam ali aproximadamente mil "almas":

A fábrica ocupa atualmente cerca de 1.000 operários, sendo 400 homens, 300 mulheres e 300 crianças de ambos os sexos, na maior parte brasileiros, que vencem mensalmente cerca de $80 \$ 000$ e que produzem em algodões, morins e chitas mais de 30.000 metros diários, podendo subir a 40.000 quando todas as máquinas forem aproveitadas.

Os operários residem todos em terrenos da fábrica, quer nas 95 casas que a Companhia construiu, quer em pequenas casas (ranchos) que eles mesmos levantam e abastecem-se nos dois armazéns que sendo de negociantes alheios à Companhia, lhes fornecem os gêneros em condições vantajosas. Mediante uma pequena porcentagem dos salários, têm os operários: médico, enfermeiro, medicamentos, serviços fúnebres e auxílios pecuniários. ${ }^{324}$

Um cenário que parecia reproduzir fielmente o de outras duas fábricas têxteis instaladas em áreas rurais mais isoladas do Estado do Rio de Janeiro: a Fábrica de Tecidos Pau Grande, em Magé, fundada em $1878^{325}$ e a Companhia Brazil Industrial, na antiga fazenda dos Macacos, em Paracambi, fundada em $1871 .{ }^{326}$

\footnotetext{
319 AS OCURRÊNCIAS DA SEMANA, 17 de agosto de 1895, p. 1.

${ }^{320}$ ASSAF, Roberto. Bangu - Bairro operário, estação do futebol e do samba. Rio de Janeiro: Relume Dumará, 2001, p. 16.

321 “Como o número de casas nas fábricas urbanas jamais equivalia à demanda, era política da empresa fornecer moradias preferencialmente aos operários mais qualificados ou àqueles considerados imprescindíveis, incluindo-se nesse caso os que, por suas funções, deveriam estar por perto e em disponibilidade para qualquer contingência". Vide: BASTOS, Ana Marta Rodrigues \& WEID, Elisabeth von der. O Fio da Meada - Estratégia de expansão de uma indústria têxtil - Companhia América Fabril (1878-1930). Rio de Janeiro: Fundação Casa de Rui Barbosa, 1986, p. 167.

322 GAZETA DE NOTÍCIAS, 24 de novembro de 1895, p. 2.

${ }^{323}$ DIÁRIO OFICIAL, $1^{\circ}$ de janeiro de 1929 , seção 1, p. 33.

324 JORNAL DO COMMERCIO, 29 de novembro de 1895, p. 1.

${ }^{325}$ BASTOS \& WEID (1986), p. 31.

326 WRIGHT, Arnold. Impressões do Brazil no Século Vinte - Sua História, seo povo, commercio, indústrias e recursos. Londres: Lloyd’s Greater Britain Publishing Company Ltd., 1913, pp. 389-397.
} 
Em Bangu, no entanto, nada se deu com a calmaria das paragens rurais. Desde cedo, apareciam na imprensa sinais de que o operariado multiétnico ali empregado iria transformar a vila operária em uma área de tensões sociais e profissionais. ${ }^{327}$

Antes mesmo da inauguração oficial da Companhia, ocorrida em 8 de março de 1893, quando a fábrica ainda funcionava em caráter experimental, o jornal da colônia inglesa no Rio de Janeiro, The Rio News, foi o único a noticiar que 50 homens pararam de trabalhar na terceira semana de janeiro de 1893, embora o expediente não tenha sido afetado pela atitude dos grevistas. Os nomes dos envolvidos permaneceram eternamente no anonimato, assim como são desconhecidos os motivos que levaram a esta rápida paralisação. ${ }^{328}$

\subsection{1 - Cinco dias de greve em 1894}

No entanto, é fácil saber quais os motivos que levaram os operários a cruzarem os braços na segunda semana de outubro de 1894. Preservadas suas identidades sob o nome de uma "comissão dos operários da fábrica de tecidos de Bangu", eles foram às redações dos dois principais jornais da Capital à época - a Gazeta de Notícias e $O$ Paiz - protestar contra uma série de abusos da diretoria.

As quatro queixas principais eram as seguintes: a diminuição dos salários, querendo apenas que a diretoria restabelecesse o salário antigo; o aumento do aluguel das casinhas, propriedade da fábrica, e nas quais residiam os mesmos operários; reclamavam de um negociante ali estabelecido e que elevou o preço de todos os gêneros, desconfiando os operários que o fez de acordo com a administração da fábrica; e o atraso de quase dois meses no pagamento de seus vencimentos. ${ }^{329}$

No manifesto entregue aos jornais, os operários declararam que "resolveram essa greve pacífica como protesto ao tratamento que lhes dão os patrões, retardando vencimentos indispensáveis à sua subsistência de homens que vivem do trabalho"330 e que não se responsabilizariam "por quaisquer distúrbios que se possam dar", embora fizessem questão de frisar que "a atitude dos seus companheiros é toda pacífica e que nada pretendem obter à força". 331

Não consta que tenha havido violência policial e conflitos mais sérios. Na verdade, naquele momento, apesar de se reunirem sob o nome de "uma comissão de operários da fábrica de tecidos de Bangu", o operariado ainda estava longe de se ver como uma "classe" unida e forte. Ademais,

\footnotetext{
327 Naquele ano de 1895, já se computavam 50 famílias italianas, 50 portuguesas, dez inglesas e dez de outras nacionalidades vivendo na região. A precisão dos números, no entanto, pode comprometer a confiabilidade do dado estatístico colhido pela historiadora. Ver: SILVA, Gracilda Alves de Azevedo. Bangu - a fábrica e o bairro: um estudo histórico, 1889-1930. Instituto de Filosofia e Ciências Sociais (IFCS) da Universidade Federal do Rio de Janeiro (UFRJ), 1985, p. 293.

328 THE RIO NEWS, 24 de janeiro de 1893, p. 4.

${ }^{329}$ GAZETA DE NOTÍCIAS, 14 de outubro de 1894, p. 1.

${ }^{330}$ O PAIZ, 14 de outubro de 1894, p. 1.

${ }^{331}$ GAZETA DE NOTÍCIAS, 14 de outubro de 1894, p. 1.
} 
suas queixas eram extremamente locais - o que dificultaria o apoio e a solidariedade dos operários de outras Companhias - e bandeiras que futuramente seriam levantadas, como a diminuição da longa jornada de trabalho e a restrição ao trabalho infantil ainda estavam longe de ser mencionadas como temas a serem discutidos pelos grevistas.

No dia seguinte à publicação das queixas da comissão na primeira página dos dois principais jornais do Rio, o diretor-gerente Antônio Xavier Carneiro foi às duas redações rebater as informações prestadas pelos "paredistas". Primeiro, disse que a greve não era geral, "tomando parte nela simplesmente os tecelões". Ora, a tecelagem e os tecelões eram o "coração" da fábrica:

O setor de tecelagem possuía a maior concentração de operários especializados e representava o centro da produção da fábrica de tecidos, uma vez que todas as etapas anteriores convergiam para a tecelagem, de onde o produto era distribuído para as diferentes seções de beneficiamento e acabamento do pano. Constituía, por outro lado, o setor reivindicativo de ponta entre os têxteis, com perfeita noção de sua posição estratégica na fábrica, tendo-se notícia de greves específicas dos tecelões nos primeiros anos do século. $^{332}$

Na defesa da Companhia, Antônio Xavier Carneiro disse que não houve a diminuição geral dos salários, "houve apenas a diminuição no preço de uma qualidade de pano que se paga por metro, em tudo mais os salários são os mesmos". No caso do aumento do preço do aluguel das casas, o diretor informou que a Companhia tinha reduzido à metade os aluguéis por ocasião da última crise (onde é possível supor que tenha havido diminuição da jornada de trabalho semanal e, consequentemente, dos honorários pagos por dia, por hora trabalhada ou por metragem de pano) e que, agora, com o fim da crise e a regularização do trabalho, os aluguéis voltaram ao antigo valor. ${ }^{333}$ No caso do atraso salarial, o diretor-gerente justificou-se dizendo que:

Os pagamentos são feitos sempre no fim da quinzena subsequente ao mês vencido, e isso por não ser possível antes da organização das respectivas folhas. Há operários que trabalham por metro, variando ainda o preço conforme a qualidade de tecidos; outros têm abonos, aluguéis de casa, multas, descontos para a caixa de beneficência, e tudo isso reunido exige longo tempo para a confecção das folhas, que só ontem ficaram prontas, devendo começar hoje o pagamento. ${ }^{334}$

Não era uma desculpa inverídica, o sistema de pagamento fabril era extremamente diverso, fato que já foi constatado por outros historiadores que se debruçaram na pesquisa sobre fábricas de tecido: "a imensa maioria de trabalhadores era empregada por hora ou por empreitada, o que dificultava a previsão do total que deveria receber no final do mês". ${ }^{335}$

\footnotetext{
332 BASTOS \& WEID (1986), p. 252.

${ }^{333}$ GAZETA DE NOTÍCIAS, 15 de outubro de 1894, p. 1.

${ }^{334}$ O PAIZ, 15 de outubro de 1894, p. 2.

335 BASTOS \& WEID (1986), p. 275. A inconstância dos salários pagos pela Companhia compromete o minucioso trabalho da historiadora Eulália Maria Lahmeyer Lobo, que estipulou para o ano de 1894, uma média salarial mensal de um operário da fiação em 301\$200, com base em apenas duas fichas encontradas; o salário médio de uma operária das maçaroqueiras em 195\$840, com base em uma única ficha; e o de um operário dos teares em $184 \$ 800$ mensais, também tendo por base uma única amostra. Vide: LOBO, Eulália Maria Lahmeyer. História do Rio de Janeiro. Do Capital Comercial ao Capital Industrial e Financeiro. $2^{\circ}$ Volume. Rio de Janeiro: IBMEC, 1978, p. 664.
} 
A única questão que fugiu do controle da Companhia era em relação ao negociante que vendia gêneros aos operários. Segundo o diretor, ele tinha a "obrigação de vendê-los pelos preços correntes na Capital”, que há seis anos vinha fazendo e que jamais recebera protesto algum dos operários neste sentido. A cláusula de vender os gêneros ao preço corrente era uma das exigências básicas para que um negociante pudesse instalar um estabelecimento nas terras da Companhia.

A prática do preço justo foi estendida futuramente ao clube de futebol da localidade, quando este tratou de arrendar um botequim dentro de sua sede. A recomendação de "vender as bebidas pelos preços correntes" aparecia em todos os contratos, como uma forma de garantir aos sócios que o comerciante não estaria lucrando às suas custas. ${ }^{336}$

Numa comunidade ainda isolada das demais, onde era necessário esperar pelo incipiente sistema de trens para se deslocar ao Centro do Rio ou até mesmo a bairros próximos, como Campo Grande, "passou a ser quase impossível morar na fazenda ou na vila da fábrica sem comprar no armazém"337. Se o diretor Antônio Xavier Carneiro, na defesa do estabelecimento comercial, chega a concluir que "é lógico inferir-se que o abuso realmente não se deu", 338 é porque não estava a par da constante insatisfação dos moradores de Bangu com relação ao sr. Guilherme dos Santos.

Seu armazém de secos e molhados tinha se estabelecido no lugarejo desde o início das obras da fábrica. Inicialmente, era sócio do inglês Thomaz Jaffrey, que desfez a sociedade em 31 de agosto de 1892. Guilherme dos Santos, porém, continuou no bairro, com a missão de "explorar os gêneros de estiva para prover os operários da fábrica de Bangu (...), esperando merecer a confiança com que tem sido honrado o seu estabelecimento", dizia em um anúncio de jornal de 1893.339

O armazém de Guilherme dos Santos já tinha sido alvo de queixas dos operários em reclamações à imprensa. O comerciante utilizava-se de um engenhoso sistema de vales-troco em forma de cartões com valores impressos entre 100 e 800 réis para obrigar o comprador a voltar a consumir no estabelecimento emissor, já que esses vales não eram aceitos em nenhum outro lugar. ${ }^{340}$

Mesmo após a greve de cinco dias em 1894, as denúncias contra os vales-troco do armazém continuaram. A Gazeta de Notícias chegou a tomar parte em defesa dos trabalhadores, alegando que “a emissão é uma irregularidade e forçar os operários a fornecerem-se a custa de ela é um abuso que não deve continuar". ${ }^{341}$ Dois dias depois, na mesma folha, o guarda-livros do armazém, Lúcio Godoy, aparece declarando "que aquela casa não obriga de modo algum, os trabalhadores ali

\footnotetext{
336 “Ata da sessão de 21 de março de 1911”, “Ata da sessão de 6 de março de 1912” e "Ata da sessão de 18 de fevereiro de 1913". 3 Livro de Atas das Sessões da Diretoria do Bangu A.C., 28 de janeiro de 1909 a 12 de janeiro de 1915.

${ }^{337}$ BASTOS \& WEID (1986), p. 164.

${ }^{338}$ GAZETA DE NOTÍCIAS, 15 de outubro de 1894, p. 1.

${ }^{339}$ Idem, 14 de janeiro de 1893 , p. 6.

${ }^{340}$ O PAIZ, 10 de novembro de 1893 , p. 1.

${ }^{341}$ GAZETA DE NOTÍCIAS, 10 de janeiro de 1895, p. 1.
} 
existentes a fornecerem-se naquele estabelecimento". ${ }^{342}$ Um argumento que não se justifica, afinal, onde mais eles poderiam gastar os seus cartões de vale-troco?

A polêmica dos armazéns de gêneros alimentícios não era uma exclusividade da Fábrica Bangu. Em janeiro de 1895, uma semana depois de a reclamação aparecer nas páginas da Gazeta de Notícias, os operários da Fábrica de Pau Grande também encaminharam um abaixo-assinado à administração da empresa denunciando irregularidades que estariam sendo cometidas pelo arrendatário de um armazém local. Ao tomar conhecimento dos fatos, a diretoria autorizou o administrador da fábrica, Victor Guizard, a chamá-lo ao cumprimento das obrigações contratuais. ${ }^{343}$

A greve de 1894 não mereceu maiores comentários dos jornais. A forma como o diretorgerente Antônio Xavier Carneiro a contornou, indo à imprensa para rebater as críticas dos operários, fez com que não saísse uma única linha a respeito da "parede" nos dias posteriores. No ano seguinte, na data de seu aniversário, uma espécie de homenagem publicada por "um seu admirador", dá uma ideia da forma como este português administrava a fábrica e lidava com o operariado: era "um zelador consciencioso e justo, os companheiros e amigos o estimam pelas suas virtudes; os subalternos e operários o adoram, porque assim como ele é implacável no castigo, quando merecido, também é bom e caritativo para aqueles que sabem cumprir o dever". 344

A diretoria a que pertencia o presidente Estevão José da Silva, o diretor-gerente "implacável no castigo", Antônio Xavier Carneiro, e o tesoureiro Octaviano Pereira da Cunha foi substituída por outra em 18 de abril de 1895, ${ }^{345}$ quando a Assembleia Geral Ordinária escolheu os nomes do Comendador Manoel Antônio da Costa Pereira para presidente, Eduardo Gomes Ferreira para diretor-gerente e José Clemente de Carvalho para tesoureiro, todos de origem portuguesa. ${ }^{346}$

Com isso, Estevão José da Silva passou a se dedicar somente à presidência do Banco Rural e Hypothecário e Antônio Xavier Carneiro logo foi eleito presidente da Companhia Confiança Industrial, em Vila Isabel, numa amostra clara que os altos postos dessas empresas têxteis eram ocupados pelos mesmos grandes acionistas portugueses, que apenas faziam entre si uma espécie de "dança das cadeiras".

\footnotetext{
${ }^{342}$ Idem, 12 de janeiro de 1895 , p. 1.

${ }^{343}$ BASTOS \& WEID (1986), p. 163.

${ }^{344}$ GAZETA DE NOTÍCIAS, 26 de julho de 1895, p. 3.

345 Idem, 18 de abril de 1895 , p. 3.

${ }^{346}$ OLIVEIRA, Márcio Piñon de. Bangu: de fábrica-fazenda e cidade-fábrica a mais uma fábrica da cidade. Instituto de Pesquisa e Planejamento Urbano e Regional (IPPUR) da Universidade Federal do Rio de Janeiro (UFRJ), 1991, p. 10.
} 


\section{1 - "Subdelegado da roça", eleições fraudulentas e perseguição religiosa}

Naquela espécie de "fábrica-fazenda", que era o bairro de Bangu no final do século XIX, um elemento introduzido na pequena, mas crescente comunidade, fez bastante estardalhaço e, durante cinco anos, entre 1894 e 1899, foi alvo da ira, de algumas revoltas e provavelmente, do temor de muitos operários. Tratava-se do Capitão Jorge Estrella que, em junho de 1894 foi nomeado para ser o delegado da $3^{\text {a }}$ circunscrição suburbana, substituindo a Leonardo de Moraes e Souza, uma figura bem mais apagada na história da região. ${ }^{347}$

Em uma festa em homenagem ao médico da Fábrica Bangu, em abril de 1894 - antes de sua nomeação, portanto -, Jorge Estrella era descrito como "chefe político do lugar" pelo jornal $O$ Paiz. ${ }^{348}$ E é bem provável que sua nomeação para o cargo de delegado da $3^{\text {a }}$ circunscrição suburbana tenha vindo de seu apoio e lealdade ao presidente Floriano Peixoto.

Em 1895, quando o governo do "Marechal de Ferro" já tinha terminado e a imprensa poderia referir-se ao seu mandato como uma "ditadura", um anônimo morador do distrito de Campo Grande enviou uma carta para a Gazeta da Tarde reclamando da forma como era feito o recrutamento militar na região: "com todo o aparato da força intimidando a população laboriosa e ordeira". E lembrava que o próprio Chefe de Polícia da Capital Federal tinha mantido como delegado daquela freguesia uma "herança" da época da ditadura de Floriano: "O sr. Dr. André Cavalcanti é em parte culpado disso por ter conservado em cargo de confiança um dos servidores da ditadura do sr. Floriano - o delegado de Campo Grande, sr. Jorge Estrella. O sr. Estrella tem ainda saudades do belo tempo!"349

Se um insatisfeito morador via o delegado suburbano como um "florianista" ferrenho, outra nota publicada no mesmo jornal elevou, equivocadamente, Jorge Estrella à diretor-gerente da Companhia.

Tudo se deu numa visita da Gazeta da Tarde à Fábrica Bangu. Na pequena nota publicada no vespertino, saiu, por engano, que o capitão estava “à testa do serviço da fábrica". ${ }^{350} \mathrm{O}$ próprio Jorge Estrella correu para corrigir o erro e, em carta enviada à Gazeta de Notícias - um jornal com maior tiragem - tratou de colocar os pingos nos is: "A fábrica está não sob a minha gerência, mas sim sob a inteligente e criteriosa direção do sr. Eduardo Gomes Ferreira, sob cujas ordens trabalho"351 mostrando, claramente, que sua função na delegacia era, prioritariamente, servir ao patronato da Companhia.

\footnotetext{
${ }^{347}$ O PAIZ, 8 de junho de 1894 , p. 1.

${ }^{348}$ Idem, 6 de abril de 1894, p. 3.

${ }^{349}$ GAZETA DA TARDE, 5 de novembro de 1895 , p. 1.

${ }^{350}$ Idem, 15 de setembro de 1895 , p. 1.

${ }^{351}$ GAZETA DE NOTÍCIAS, 20 de setembro de 1895, p. 3.
} 
O equívoco rendeu boas risadas dos acionistas da Companhia que, também através dos jornais, publicaram uma nota jocosa, admirados com "a nova aptidão do nosso amigo Jorge Estrella, que pela mesma notícia soubemos com espanto ser o gerente da dita fábrica!”. No correr do texto, assinado pelos "pobres acionistas da Companhia Progresso Industrial do Brazil", vamos encontrar adjetivos e funções que podem nos dar uma pista sobre como os grandes negociantes e capitalistas viam aquele delegado da região:

Já o conhecíamos como cabo eleitoral, subdelegado da roça, fogueteiro, veterinário, sacristão, tocador de bumbo do Club Musical do Bangu, mas confessamos a nossa ingenuidade, nunca julgamos capaz o nosso amigo Jorge Estrella de descer da sua alta competência e ocupar um lugar tão ínfimo como o de gerente da fábrica do Bangu. ${ }^{352}$

"Cabo eleitoral" e "subdelegado da roça" talvez fossem os melhores adjetivos para definir a forma como o Capitão Jorge Estrella atuava no distrito de Campo Grande e, por conseguinte, na vila operária de Bangu.

As eleições para intendentes das freguesias rurais, em 6 de janeiro de 1895, foram uma verdadeira guerra, com feridos a tiros, alguns mortos, urnas roubadas e locais de votação destruídos. $\mathrm{Na}$ época, as 21 freguesias que compunham o Distrito Federal eram dividas em três distritos maiores, que escolhiam, por voto direto e para mandato de dois anos, quem seriam os seus cinco representantes no Conselho de Intendência (uma espécie de Câmara de Vereadores). Como a região suburbana era formada por nove freguesias - Campo Grande, Engenho Novo, Engenho Velho, Guaratiba, Ilha do Governador, Inhaúma, Jacarepaguá, Paquetá e Santa Cruz -, a disputa era intensa e eram poucos os eleitores que realmente tinham o direito de escolher. Se formos analisar a população existente apenas na freguesia de Campo Grande pelo censo de 1890, veremos que dos 15.947 habitantes, no máximo 2.446 (15\%) estariam aptos a votar. Afinal, representariam o seleto grupo de homens, brasileiros e alfabetizados. ${ }^{353}$ Some-se a isto o fato de a decisão de ir às urnas ser facultativa, o que aumentava as abstenções, principalmente por medo de confusões. ${ }^{354}$

A eleição em Campo Grande, em 1895, foi uma disputa entre o intendente, Dr. Augusto de Vasconcellos, ${ }^{355}$ que tentava eleger seus partidários, e o Dr. Francisco Alves Barbosa, que tentava

\footnotetext{
${ }^{352}$ Idem, 18 de setembro de 1895 , p. 3.

353 RECENSEAMENTO geral da República dos Estados Unidos do Brasil em 31 de dezembro de 1890 - sexo, raça, estado civil, nacionalidade, filiação, culto e analfabetismo. Rio de Janeiro: Officina da Estatística, 1898, p. 389.

${ }^{354}$ O PAIZ, 7 de janeiro de 1895, p. 1 analisou assim a eleição municipal: "Sucedeu o que prevíamos. As urnas na eleição de ontem foram pouco concorridas, já pela indiferença de muitos eleitores, já pela razão de que não houve publicidade conveniente das seções eleitorais, e ainda porque os mesários em muitos colégios deixaram de comparecer. Também não foi um modelo de verdade o escrutínio em muitas freguesias. A ordem pública alterou-se em diversos pontos. A $1^{\text {a }}$ seção da paróquia de Campo Grande teve o trabalho inutilizado, por intervenção de adeptos de uma das parcialidades".

355 O Dr. Augusto de Vasconcellos, médico, ligado ao Partido Republicano Federalista, ganhou as eleições para intendente de Campo Grande em outubro de 1892, sendo o intendente mais votado dentre todos os distritos da Capital Federal. Seu poder político na região era imenso e, segundo consta, obrigava seus eleitores a votarem em cédulas coloridas (vermelhas), diferenciadas das demais, para que, na hora da apuração, soubesse quantos votos realmente obteve para seus aliados. Como as eleições na zona suburbana eram, de fato, fraudulentas, Augusto de Vasconcellos ganhou também muitos inimigos, entre eles José do Patrocínio, dono do jornal Cidade do Rio, que logo lhe cunhou o
} 
impor os seus. Para termos uma ideia de alguns dos acontecimentos, um trecho de uma notícia publicada pelo jornal $O$ Paiz, de acordo com os autos do inquérito policial, já nos é suficiente para compreender o clima de pânico que se instaurou na localidade no dia das eleições:

(...) O referido grupo, armado de cacetes e revólveres, invadiu a casa onde se realizavam os trabalhos eleitorais e dando tiros, pondo em fuga os eleitores e mesários, conseguiu apoderar-se da urna e de todos os livros e papeis relativos ao processo eleitoral, objetos estes que destruiu em frente à casa onde antes se achava reunido. (...) Quando a sala da eleição foi invadida, o eleitor Augusto da Silva Gomes apoderou-se da urna e procurou salvá-la, com ela fugindo no momento em que foi gravemente ferido pelas costas por um tiro de revólver. ${ }^{356}$

O capitão Jorge Estrella, delegado na freguesia, apoiava o grupo do intendente Augusto de Vasconcellos. Seu pai, o Dr. Manoel Lourenço Estrella, era partidário de Francisco Alves Barbosa e chegou a depor contra o filho, confirmando a existência de rondas de capangas no dia da eleição, a fim de garantir a vitória dos aliados do Dr. Vasconcellos:

(...) Que no dia da eleição, achando-se às 7 horas da noite, no Santíssimo, aí foi com outras pessoas agredido e insultado por um grupo armado e capitaneado por José Rodrigues Quinhões, genro do delegado, grupo este que tinha vindo da $1^{\mathrm{a}}$ seção eleitoral e que se manifestava orgulhoso, declarando que sua obra não estava concluída, embora já tivesse feito na paróquia tudo quanto estava ao seu alcance, que era público e notório que o Dr. Vasconcellos dissera esperar reforço da capital para disputar as eleições. ${ }^{357}$

O Dr. Augusto de Vasconcellos realmente emplacou seus candidatos ao Conselho de Intendência naquele ano e, depois do inquérito policial, apenas dois homens - Josephino da Silva Oliveira e Gregório da Silva Oliveira - correligionários do rival Francisco Barbosa foram presos e, em 1898 já estavam soltos e tumultuando uma nova eleição. ${ }^{358}$ A acusação do pai do capitão Jorge Estrella não foi levada a sério, inclusive porque apareceram testemunhas para defender o delegado, dizendo que "tal acusação é feita pelo Dr. Estrella em consequência de ser o mesmo inimigo pessoal de seu filho Jorge Estrella e do genro deste, José Rodrigues Quinhões, amigo do Dr. Vasconcellos". ${ }^{359}$ Enfim, as divergências partidárias influíam na acusação do "velho" Dr. Estrella e acirravam os ânimos entre os próprios familiares. ${ }^{360}$

apelido nada lisonjeiro de "Dr. Rapadura", em alusão às origens rurais de sua família. Vide: FREIRE, Américo. Augusto de Vasconcellos, o Dr. Rapadura - Um estudo sobre liderança e negociação política na Capital Federal. Rio de Janeiro: Fundação Getúlio Vargas - Texto CPDOC nº 35, 1999, pp. 5-22.

356 O PAIZ, 22 de fevereiro de 1895, p. 2.

${ }^{357}$ Idem, ibidem.

${ }^{358}$ Idem, 11 de junho de 1898 , p. 3.

${ }^{359}$ Idem, 22 de fevereiro de 1895, p. 2.

${ }^{360} \mathrm{Em} 1913$, dezoito anos depois deste imbróglio eleitoral, novamente a população de Bangu vai aos jornais acusar o delegado local - na ocasião, não mais o Capitão Jorge Estrella e sim o Comissário João Odon - de tentar conseguir votos à força sempre a favor dos candidatos do Senador Augusto Vasconcellos, do Partido Conservador. "João Odon, indivíduo sem critério algum, que envergonha qualquer administração policial, andou procurando diversos cidadãos que tinham recebido cédulas no comício e tomando-as e rasgando-as, em altas vozes, escandalosamente, declarou que quem vencia era o Partido Conservador, que ninguém votasse nos "espoletas" que ali tinham estado [no caso, os candidatos do Partido Republicado Liberal] e que aqueles que não seguissem o seu conselho ele meteria na cadeia, pois contava com a proteção do Senador Vasconcelos". Vide: A ÉPOCA, 27 de outubro de 1913, p. 6. 
Naquele mesmo ano, ainda haveria tempo para o Capitão Jorge Estrella se envolver em outra polêmica, como numa violenta perseguição religiosa a evangélicos e espíritas que ousassem fazer cultos e reuniões na vila operária de Bangu. O caso dos protestantes é rumoroso e há versões dos dois lados na imprensa: tanto do pastor, quanto dos padres.

O certo é que, naquela localidade, os próprios imigrantes ingleses - que poderíamos supor serem protestantes - aparecem em diversos momentos indo a missas na igreja católica (como no caso da missa de $7^{\circ}$ dia do inglês James Hartley, em 1914) ou participando com doações (como no recolhimento feito em prol da construção da estátua do Cristo Redentor, realizado em 1923). Bem antes disso, um dos britânicos que foi para lá trabalhar de forma temporária, Charles William Ralph, na tentativa de evitar qualquer problema ou confronto com a Igreja Católica, aparece nas páginas do jornal A Estrella convertendo-se ao catolicismo de forma bastante veemente, em texto que, provavelmente, foi redigido pelo Vigário Victor Leonardo de Soledade, padre da freguesia de Campo Grande:

No grande estabelecimento da fábrica do Bangu, onde há uma capela, o vigário do Campo Grande celebra e administra sacramentos aos milhares de empregados que ali trabalham e residem, teve lugar, a esforços do mesmo vigário, a seguinte solene abjuração:

"Eu, abaixo assinado, natural de Londres, filhos de pais protestantes, nascido e criado na seita dos evangélicos, tendo reconhecido, em tempo, que só a religião católica apostólica romana é a única depositária da verdade, ensinada e instituída por Nosso Senhor Jesus Cristo, fora da qual não há salvação, faço completa abjuração do grande erro em que vivia; aceito tudo quanto a Igreja Católica ensina, creio e condeno tudo quanto ela crê e condena, sem que para isso fosse coagido ou violentado por alguém, mas por minha própria deliberação, no pleno uso de minhas faculdades, com a mente esclarecida e o espírito verdadeiramente convencido".

Bangu, 12 de agosto de 1894 - Charles William Ralph. ${ }^{361}$

O exemplo do inglês, com certeza, não foi seguido pelo brasileiro Alfredo Pires de Oliveira que abria sua casa todos os domingos, às 18 horas, para um culto evangélico. No dia 11 de agosto, no entanto, a residência foi invadida, depredada e os fiéis foram agredidos por um grupo de 16 homens. Os evangélicos, incluindo mulheres e crianças, tiveram que fugir pelos matos até chegarem à distante estação de Santíssimo, onde ficaram à espera do trem das 3 horas da manhã. Segundo o pastor da Igreja Evangélica Fluminense, a agressão era uma política da própria fábrica, que teria se utilizado da força policial do delegado Jorge Estrella para, enfim, expulsar os protestantes daquela região: “O delegado policial de Bangu, em vez de defender e proteger estes cidadãos pacíficos, é o próprio que disse que havia de acabar com aquilo, executando o seu dito pelo grupo de turbulentos no dia 11 deste mês”. Em carta ao jornal O Paiz, o pastor João Manoel Gonçalves dos Santos foi além e disse que a Companhia tinha iniciado uma política de demissões dos protestantes:

A diretoria da Companhia de Bangu despediu os operários evangélicos, homens pacíficos e conserva no trabalho da fábrica os turbulentos; ordenou aos operários evangélicos a deixarem as suas residências dentro de 24 ou 48 horas; intimou Alfredo de Oliveira a mudar-se ou por bem ou por mal, manifestando por estes atos apoio aos

\footnotetext{
${ }^{361}$ A ESTRELLA, 14 de outubro de 1884, p. 3.
} 
operários turbulentos e agressores, e perseguição aos operários evangélicos que, no gozo de suas consciências e da liberdade da Constituição, reuniam-se pacificamente para lerem e ouviram o Evangelho.

O delegado policial de Bangu e o inspetor nenhuma providência deram a favor dos perseguidos; antes, pelas informações que existem, eles são os motores desta agressão, cabeças do barulho. O delegado policial é administrador dos bens da Companhia em Bangu, e de acordo com o diretor-gerente da fábrica, causou essa agressão e despediram os operários evangélicos. ${ }^{362}$

Para o jornal católico $O$ Apóstolo, de fato, houve a arruaça e também as demissões. E sob o paradoxal título de "Liberdade Religiosa", um padre escreveu um artigo defendendo o fim dos cultos evangélicos em Bangu e justificou a atitude violenta tomada pelos operários - embora sem mencionar a ação efetiva do delegado - porque os protestantes estavam atrapalhando o bom andamento do trabalho fabril.

(...) Começou, porém, a ordem a ser perturbada, o próprio serviço da fábrica começou a ser desorganizado, porque os pregoeiros evangélicos entraram a arrebanhar de suas casas as mulheres e filhas dos católicos e das outras seitas; os chefes dessas famílias entraram muito louvavelmente a alarmar-se; já sobressaltados, muitos deixavam o serviço a qualquer hora, para irem em busca de suas mulheres e filhas, pois estas eram muitas vezes levadas para sítios desertos e ignorados.

Afinal a queixa subiu à zelosa administração da fábrica, que desde que a fábrica é sua, as casas são suas, o terreno é seu, usou do direito de que usa cada um em sua casa: intimou os sectários que já produziam tais perturbações no estabelecimento a que dali se retirassem; recalcitraram e reuniram-se em maior número, tomando aspecto de provocação.

Os pais, esposos e irmãos justamente indignados pelo mau caminho em que iam suas filhas, mulheres e irmãs, em uma noite em que os sectários ostentavam sua propaganda tão oposta à vontade livre dos chefes do estabelecimento e de cada família de operários ali domiciliados, foram estes, os operários, intimá-los a se retirarem, intimação que em bons termos já havia sido feita em seu pleno direito pelos diretores da fábrica. ${ }^{363}$

O caso ganhou certa projeção na imprensa naquele mês de agosto de 1895 e, embora todos os órgãos reprovassem a violência, de certo modo, deixavam transparecer um alívio pela "vitória" da religião católica. ${ }^{364} \mathrm{O}$ delegado Jorge Estrella, mais uma vez, estava do lado dos vencedores.

Os habitantes do Bangu têm um meio muito simples de impedir ali o progresso do protestantismo: é não frequentar as reuniões protestantes e pedir ao vigário da freguesia que evangelize o povo, ensinando-lhe a religião de seus pais. A agressão brutal, a violência essa não podemos senão condenar calorosamente em nome da liberdade e da lei. ${ }^{365}$

A questão envolvendo o espiritismo ganhou muito menos espaço nos jornais, até pela falta de abrangência desta prática, pela dificuldade em aceitá-la como uma religião e principalmente, por intitularem seus praticantes como pessoas que lidavam menos com a divindade e mais com o sobrenatural. E só pela carta de seu principal adepto, João Pereira de Lima, ao Jornal do Brasil que

\footnotetext{
362 O PAIZ, 23 de agosto de 1895, p. 3.

${ }^{363}$ O APÓSTOLO, $1^{\circ}$ de setembro de 1895 , p. 1.

${ }^{364}$ Em 1904, oito anos depois, nova perseguição aos evangélicos ocorreu em Bangu, já sem a ação do Capitão Jorge Estrella. Na ocasião, o pastor J. L. Kennedy e seu ajudante, Marcellino Affonso Adeala, foram agredidos ao final de um culto. Diferentemente de 1896, a imprensa se indignou e questionou a falta de investigação policial ao caso. "Se a liberdade de cultos e do pensamento é garantida pela Constituição, como deixa a polícia que se pratiquem atos como esse, que nos envergonham e deprimem? Não sabe ela que deve estar presente às reuniões públicas para manter a ordem e que, dada a intolerância que sempre existe nesses lugares afastados do centro, era de prever qualquer perigo para os que não seguem a crença geral da população?” Vide: CORREIO DA MANHÃ, 15 de fevereiro de 1904, p. 3.

365 GAZETA DE NOTÍCIAS, 13 de agosto de 1895, p. 2.
} 
ficamos sabendo o que ocorreu em Bangu, entre 23 de junho (data da reunião inaugural) e 30 de julho de 1895 (quando o capitão Jorge Estrella resolveu agir, poucos dias antes da ação contra os protestantes). Pelo relato, o delegado o intimou a não continuar com o grupo, sob o pretexto de estar “a enlouquecer a população de Bangu”.

Fazia apenas cinco anos que o decreto $\mathrm{n}^{\circ} 119-\mathrm{A}$, de 7 de janeiro de 1890, fora assinado pelo Marechal Deodoro da Fonseca. Nele, estava consagrada a plena liberdade de culto nos seus artigos $2^{\circ}$ e $3^{\text {o }}{ }^{366}$ Porém, em Bangu, a 40 quilômetros do Palácio do Itamarati, sede da presidência da República à época, a lei era "letra morta" tanto para o delegado, quanto para a direção da fábrica, sob responsabilidade de acionistas portugueses. Em Bangu, quem ditava as regras era a Companhia e isso parecia bem claro ao articulista do jornal católico quando afirmou que "a fábrica é sua, as casas são suas, o terreno é seu". ${ }^{367}$

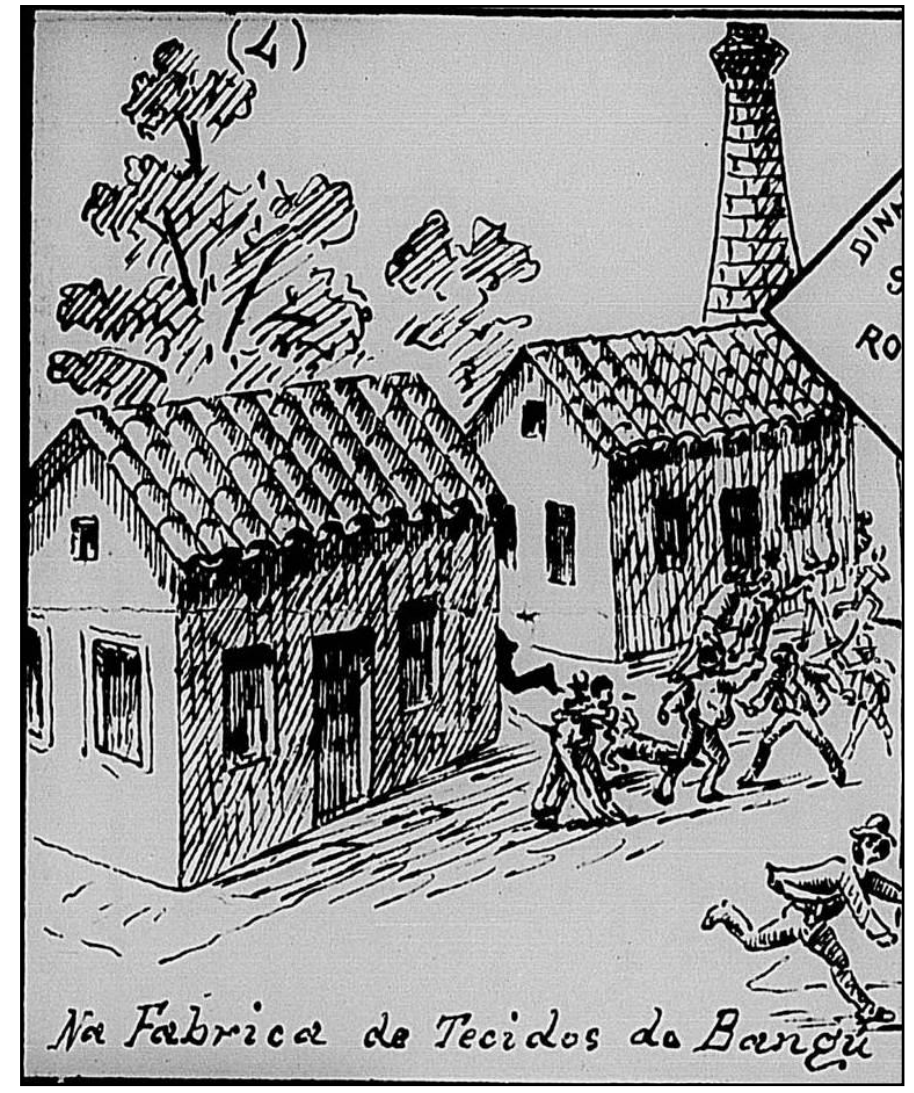

Figura 23 - Charge retratando a perseguição religiosa aos evangélicos. ${ }^{368}$

\footnotetext{
${ }^{366}$ Decreto no 119-A, de 7 de janeiro de 1890. Brasília: Palácio do Planalto. Texto integral da norma jurídica, localizado em: http://www.planalto.gov.br/ccivil_03/decreto/1851-1899/d119-a.htm.

Art. $2^{\mathbf{o}}$ - A todas as confissões religiosas pertence por igual a faculdade de exercerem o seu culto, regerem-se segundo a sua fé e não serem contrariadas nos atos particulares ou públicos, que interessem o exercício deste decreto.

Art. $3^{\circ}$ - A liberdade aqui instituída abrange não só os indivíduos nos atos individuais, senão também as igrejas, associações e institutos em que se acharem agremiados; cabendo a todos o pleno direito de se constituírem e viverem coletivamente, segundo o seu credo e a sua disciplina, sem intervenção do poder público.

${ }^{367} \mathrm{O}$ APÓSTOLO, $1^{\circ}$ de setembro de 1895 , p. 1.

${ }^{368}$ AS OCCURRÊNCIAS DA SEMANA, 17 de agosto de 1895, p. 2.
} 
A repressão policial, a perda do emprego na fábrica, a obrigação de se retirar da localidade em um curto espaço de tempo eram as práxis adotadas pelo capitão e pela Companhia e narradas pelo espírita João Pereira de Lima apenas em março de 1896:

Dirigi (...) ao sr. Dr. Chefe de Polícia uma petição para que me fosse concedido permissão para continuar a funcionar com o mesmo grupo. Em virtude de me ter dirigido ao Dr. Chefe de Polícia, fui no dia 3 de agosto chamado no escritório da fábrica e aí interrogado com referência ao fato. O sr. Jorge (...) dispensou-me do serviço da mesma fábrica e como delegado, intimou-me a que me retirasse em 48 horas daquele lugar. Como não me fosse possível em tão curto espaço de tempo retirar a minha família, fui perseguido, tendo de me ocultar, para escapar com vida. (...) Ainda hoje estou privado de ir ao Bangu, tendo lá parentes, aos quais não posso visitar, notando-se que isto me foi dito pelo mesmo Jorge. ${ }^{369}$

No caso do espiritismo, o delegado poderia se dizer amparado no Código Penal de 11 de outubro de 1890 que, contrariamente ao decreto n 119-A, incluía a prática do "espiritismo, da magia e seus sortilégios" como "crimes contra a saúde pública" em seu artigo 157. ${ }^{370}$ No entanto, segundo interpretação de historiadores, o alvo deste artigo não era o culto "espírita kardecista", mas sim as "casas de pretos", onde se praticava o "baixo espiritismo" (umbanda). O novo regime republicano, que primava pela ordem, progresso, modernização e higienização da Capital Federal não podia tolerar práticas que demonstravam "atrasos" e remetiam à indesejável lembrança da escravidão e heranças culturais dos descendentes de escravos. Mesmo assim, entre 1891 e 1900, apenas 30 pessoas foram processadas com base neste capítulo do Código Penal, ${ }^{371}$ uma delas vivia justamente em Bangu, o negro Benedicto Antônio Maria, de 30 anos, enquadrado por ser um "perigoso feiticeiro". 372

A perseguição religiosa, nesses dois casos, está configurada como uma política da própria empresa. O delegado Jorge Estrella não agiria dessa forma repressiva se não tivesse amparo do alto escalão da Companhia, especialmente do diretor-gerente, o português Eduardo Gomes Ferreira que, certamente, entendia que a única crença a seguir era o catolicismo, tal como aprendeu no seu país. A tentativa de isolar aquela parte do território do Rio de Janeiro de qualquer invasão de outras religiões foi eficaz em 1895. Mas em um lugarejo em que a população ia a cada dia aumentando, novos trabalhadores iam chegando, vindos de diferentes partes do país e até do mundo, é claro que a restrição era paliativa. Bastava o fiel ir a um bairro vizinho e continuar com sua crença, trazendo para dentro de Bangu as suas novas influências. No entanto, naquele instante, os diretores portugueses queriam seus operários ordeiros, obedecendo a um único rito e entenderam que qualquer forma de culto que fugisse do tradicional, poderia atrapalhar a boa convivência e acirrar as

\footnotetext{
369 JORNAL DO BRASIL, 31 de março de 1896, p. 2.

370 Art. 157 - Praticar o espiritismo, a magia e seus sortilégios, usar de talismãs e cartomancias, para despertar sentimentos de ódio ou amor, inculcar cura de moléstias curáveis ou incuráveis, enfim, para fascinar e subjugar a credulidade pública. Penas - de prisão celular de um a seis meses, e multa de $100 \$ 000$ a $500 \$ 000$.

${ }^{371}$ PRIORE, Mary del. Do outro lado - A história do sobrenatural e do espiritismo. São Paulo: Editora Planeta, 2014, pp. 155-158.

372 JORNAL DO BRASIL, 20 de outubro de 1900, p. 2.
} 
disputas entre os trabalhadores. Era melhor que todos fossem católicos dentro das terras da Companhia e que não sofressem influência de pessoas que professavam outra fé, que não a "oficial".

Antes que os "tais sectários" ampliassem sua "importuna pregação" em um lugar aonde "tudo ia muito bem, na melhor tolerância e geral harmonia", ${ }^{373}$ era melhor "deixar-se de evangelho e voltar aos teares que rendem mais" 374 - conselho que os diretores da fábrica certamente concordariam.

Utilizado como braço executor desta perseguição religiosa, o "anti-herói” Jorge Estrella, em janeiro de 1896, pediu exoneração do cargo de delegado da $3^{\text {a }}$ circunscrição suburbana, embora não apareça na imprensa os motivos de tal decisão. ${ }^{375}$ Curiosamente, houve lamentações por parte de alguns funcionários da fábrica e um abaixo-assinado com 70 nomes foi enviado à redação de $O$ Paiz:

\footnotetext{
Os abaixo assinados sentem profundamente que os seus muitos afazeres o impeçam de continuar como autoridade policial, pois não será fácil encontrar quem o substitua, empregando tanta atividade e zelo pelos interesses locais, e de todo coração lhe agradecem os serviços que sempre lhes dispensou com a melhor boa vontade. ${ }^{376}$
}

Apesar de 24 deles se intitularem operários - tal qual Américo José Ferreira, João Caetano de Oliveira e Manoel Donato Silva -, 28 se classificavam como eleitores - tal qual Justino José de Abreu, Domingos Francisco Baptista e Francisco de Simas Telles, o que nos parece sugerir um status a mais na sociedade banguense do período. Dezesseis deles não escreveram nada ao lado do nome - embora seja possível reconhecer entre eles o malquisto comerciante do armazém Guilherme dos Santos -; outro assina como "negociante" e um signatário representa a firma Silva, Almeida \& Cia, mostrando que quem iria sentir a falta do delegado era uma espécie de elite local, ligada ou à própria Companhia ou ao comércio.

O grosso da mão-de-obra, formado pelos mais simples operários, no entanto, não pôde sequer comemorar a saída do Capitão Jorge Estrella do cargo de delegado. Imediatamente, a diretoria da Companhia o nomeou para ser "administrador do movimento externo da fábrica", ganhando o privilégio de morar numa fazenda, situada num terreno um pouco distante do edifício fabril ${ }^{377} \mathrm{e}$ todo o direito de fiscalizar e vigiar diariamente a vida dos operários da Bangu. Para a historiadora Eulália Maria Lehmayer Lobo:

Os industriais de tecidos, além de terem a seu serviço as forças de repressão do Estado, mantinham uma constante vigilância sobre os operários. A presença de um grande número

\footnotetext{
${ }^{373}$ Para nos utilizarmos de algumas expressões encontradas na folha católica O APÓSTOLO, $1^{\circ}$ de setembro de 1895 , p. 1.

${ }^{374}$ Conselho dado pelo jornal satírico AS OCURRÊNCIAS DA SEMANA, 17 de agosto de 1895, p. 1.

375 GAZETA DA TARDE, 24 de janeiro de 1896, p. 1.

376 O PAIZ, 28 de janeiro de 1896, p. 4.

377 JORNAL DO BRASIL, 27 de janeiro de 1899, p. 1.
} 
de crianças, mulheres e recém-egressas da escravidão e do meio rural enfraqueciam o operariado de tecidos. ${ }^{378}$

No caso da Fábrica Bangu, a nomeação de Jorge Estrella rapidamente receberia uma enérgica resposta dos tecelões...

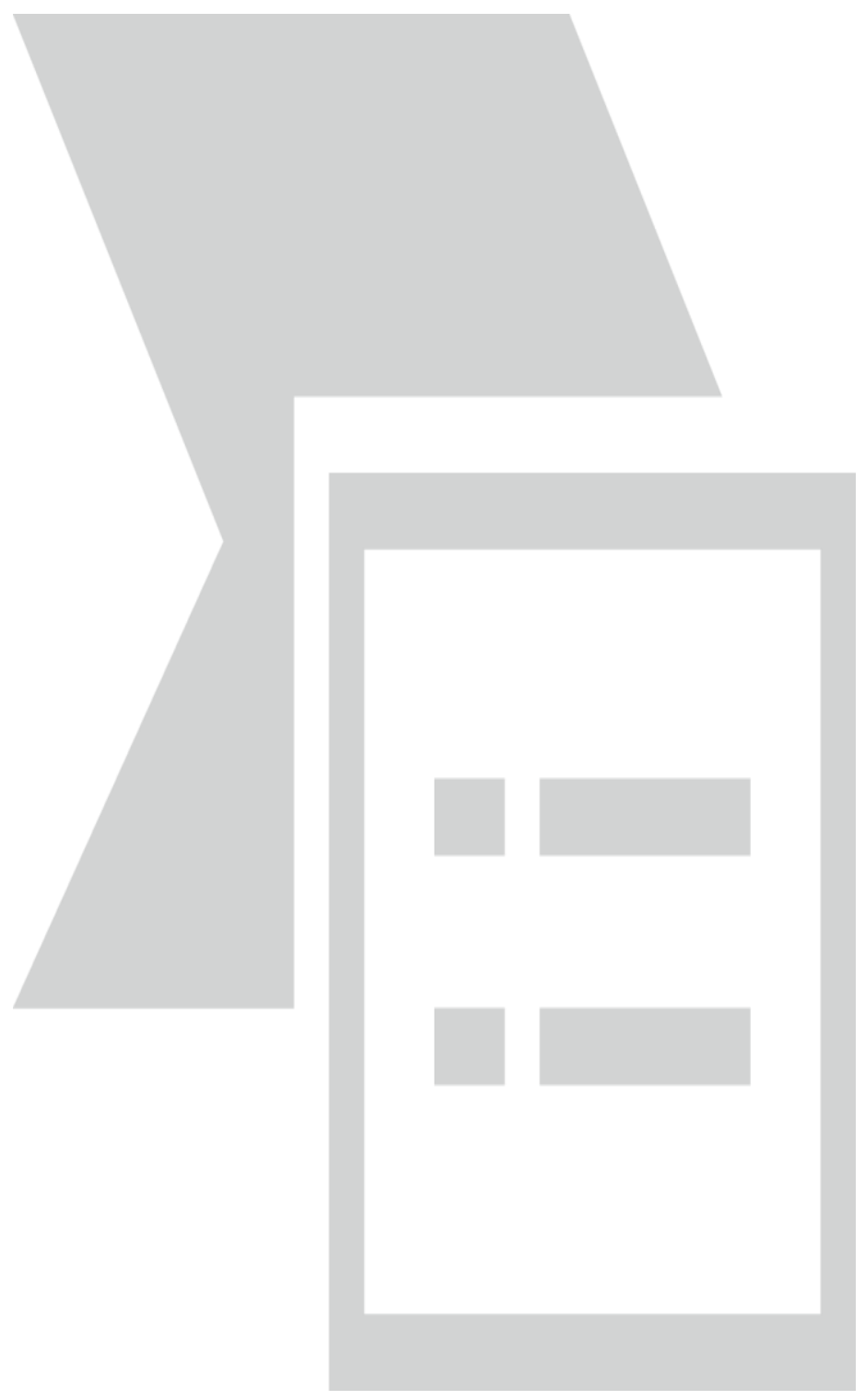

Figura 24 - O capitão Jorge Estrella. Fotografia sem data. ${ }^{379}$

378 LOBO, Eulália Maria Lahmeyer. História do Rio de Janeiro. Do Capital Comercial ao Capital Industrial e Financeiro. $2^{o}$ Volume. Rio de Janeiro: IBMEC, 1978, p. 530.

${ }^{379}$ Fotografia gentilmente oferecida pelo trineto de Jorge Estrella, Rodrigo Estrela de Carvalho, em março de 2015. 


\section{2 - A greve de 1896}

Em 1896, em função do aumento do número de operários empregados nos últimos três anos, que passou de 745 para 1.083, a Companhia resolveu construir outro grupo de casinhas no antigo local da olaria que existia na época da construção da fábrica. Assim, das 95 moradias originais da vila operária, este número pulou para 195 casas, o que abrigaria, no máximo, umas 750 pessoas, já que os cômodos possuíam dimensões mínimas (geralmente uma sala, dois quartos e uma cozinha de madeira ligada à parte posterior da casa; o banheiro ficava destacado da casa, nos fundos do terreno, acoplado a um sistema de fossas italianas). ${ }^{380}$

Pelos relatórios da Companhia, todo o conjunto de casinhas estava avaliado em 670:451\$. Valor pequeno se comparado ao volume de vendas apenas no primeiro trimestre daquele ano de 1896, que chegou à grandiosa marca de 1.140:000\$. ${ }^{381}$ Ainda assim, pelas séries analisadas por Lobo (1978), um operário das cardas via seu salário ser reduzido de $208 \$ 800$ em 1895 para $195 \$ 840$ em $1896 .^{382}$

É certo que a nomeação de Capitão Jorge Estrella para "administrador do movimento externo" em janeiro ajudou a aumentar a insatisfação dos operários, mas esse fato isoladamente não explica a turbulenta greve de cinco dias que foi deflagrada na Companhia entre 19 e 24 de fevereiro de 1896.

Uma leitura atenta dos jornais da época dá as diretrizes que nortearam a paralisação e ainda lista alguns "cabeças" do movimento. ${ }^{383}$ Às 4 horas da tarde de uma quarta-feira, 19 de fevereiro, a fábrica parou as máquinas. Um grupo de quarenta operários dirigiu-se à sala do diretor-gerente Eduardo Gomes Ferreira e entregou uma reivindicação: queriam a diminuição dos alugueis das casas que ocupavam, pertencentes à Companhia; ${ }^{384}$ queriam que o pagamento fosse feito sempre no segundo sábado de cada mês; e que dessem providências para não haver falta de carvão para as máquinas a vapor (sem carvão, operários que ganhavam por jornada, voltavam para casa e não ganhavam por aquele dia não trabalhado). ${ }^{385}$ Os jornais ainda acrescentaram o problema do

\footnotetext{
380 OLIVEIRA, Márcio Piñon de. Bangu: de fábrica-fazenda e cidade-fábrica a mais uma fábrica da cidade. Instituto de Pesquisa e Planejamento Urbano e Regional (IPPUR) da Universidade Federal do Rio de Janeiro (UFRJ), 1991, pp. 93, 98, 112.

${ }^{381}$ GAZETA DE PETRÓPOLIS, 17 de junho de 1896, p. 1.

${ }^{382}$ LOBO, Eulália Maria Lahmeyer. História do Rio de Janeiro. Do Capital Comercial ao Capital Industrial e Financeiro. $2^{\circ}$ Volume. Rio de Janeiro: IBMEC, 1978, p. 664.

${ }^{383}$ Curiosamente, duas autoras que se debruçaram em estudar a Fábrica Bangu para suas respectivas dissertações, escreveram não saber "as razões específicas que levaram os tecelões à greve" (FREITAS, Adriana Oliveira de. $A$ Fábrica Bangu e a República nascente, 1889-1914. Dissertação de mestrado em História na Universidade Federal do Espírito Santo, 2005, p. 76) e "nem como a mesma foi resolvida" (SILVA, Gracilda Alves de Azevedo. Bangu - a fábrica e o bairro: um estudo histórico, 1889-1930. Instituto de Filosofia e Ciências Sociais (IFCS) da Universidade Federal do Rio de Janeiro (UFRJ), 1985, p. 774).

${ }^{384}$ Segundo foi dito aos operários, o diretor-gerente da fábrica, Eduardo Gomes Ferreira, iria elevar os alugueis das casinhas para $35 \$$ mensais. Para um cardador, que ganhava $195 \$ 840$, isso representaria $18 \%$ do salário.

385 GAZETA DA TARDE, 21 de fevereiro de 1896, p. 1; GAZETA DE NOTÍCIAS, 21 de fevereiro de 1896, p. 1; JORNAL DO BRASIL, 21 de fevereiro de 1896, p. 1.
} 
aumento da metragem do pano (já que alguns trabalhadores ganhavam por metro de fazenda concluído sem falhas), no entanto, os próprios operários foram à imprensa dizer que esse motivo não os levou a manifestar-se em greve. ${ }^{386}$

Analisando as reivindicações, a mais problemática era a questão da pontualidade nos pagamentos: o salário do mês de dezembro de 1895, por exemplo, só foi pago em 31 de janeiro de $1896 .{ }^{387}$ O historiador Stanley Stein afirma que era praxe das fábricas atrasarem o pagamento dos salários até o segundo sábado do mês seguinte, ou até que pudessem reunir dinheiro suficiente. ${ }^{388}$ Já Gracilda Alves da Silva entende que a forma tão diversificada da empresa realizar os pagamentos por metragem, por jornada, por semana, por mês - era uma artimanha para:

não desembolsar uma quantia muito grande de dinheiro num determinado dia, e de diluir os pagamentos ao longo do mês, de tal modo que o recebimento das vendas e encomendas cobrissem tal despesa, além de manter uma determinada quantia em conta para qualquer eventualidade e ganhar juros por manter uma quantia de dinheiro em conta bancária. $^{389}$

Pego de surpresa, o diretor-gerente Eduardo Gomes Ferreira limitou-se a dizer que "nada podia resolver sem consultar à diretoria”, o que certamente irritou os operários. Uma hora depois, os grevistas voltaram ao escritório, capitaneados pelo tecelão espanhol Antônio Motta Salles, que entregou um novo papel dizendo que os seus companheiros não queriam mais ser gerenciados pelo atual diretor e exigiam também a demissão de alguns de seus auxiliares, como o Capitão Jorge Estrella e outros dois nomes. Formou-se um imbróglio e na discussão, o operário brasileiro Joaquim José da Silva, de forma agressiva, disse não admitir outra solução a não ser o cumprimento do que estava no papel. ${ }^{390}$

A liderança de um tecelão espanhol é sintomática, indo ao encontro às teses de historiadores de que muitos desses imigrantes eram anarcossindicalistas e, por isso, foram expulsos das fábricas têxteis da Catalunha, ${ }^{391}$ vindo se abrigar e se empregar na América do Sul, apesar da fiscalização em busca de "anarquistas perigosos" feita pelas autoridades brasileiras na lista de passageiros dos navios que chegavam diariamente aos portos do Rio de Janeiro e de Santos. ${ }^{392}$

Os operários menos privilegiados como os brasileiros e os imigrantes que não possuíam contrato apelavam para as greves para fazerem valer os seus direitos. É bom não esquecer

\footnotetext{
386 JORNAL DO BRASIL, 22 de fevereiro de 1896, p. 1.

${ }^{387}$ Idem, ibidem.

388 STEIN, Stanley Julien. Origens e Evolução da Indústria Têxtil no Brasil, 1850-1950. Rio de Janeiro: Editora Campos, 1979, p. 74.

389 SILVA (1985), p. 787.

${ }^{390}$ GAZETA DE NOTÍCIAS, 21 de fevereiro de 1896, p. 1.

${ }^{391}$ BUADES, Josep. A guerra civil espanhola - O palco que serviu de ensaio para a Segunda Guerra Mundial. São Paulo: Editora Contexto, 2013. Segundo este autor, as ideias anarquistas tinham entrado na Espanha em 1869.

392 LEAL, Cláudia Feienrabend Baeta. "De primos, cunhados e anarquistas perigosos: repressão a imigrantes italianos (São Paulo, 1893)" In: HALL, Michael McDonald (org.). Cadernos Arquivo Edgard Leuenroth - Imigração, volume 15, $n^{\circ}$ 27. Campinas: UNICAMP/IFCH, 2009, pp. 71-90.
} 
que os imigrantes vinham de países onde os conflitos trabalhistas industriais eram comuns nos últimos cinquenta anos. ${ }^{393}$

Ao mesmo tempo em que a Companhia preferia empregar imigrantes por já serem familiarizados com o trabalho fabril, também corriam o risco de admitir homens com um maior sentido de classe e dispostos a enfrentar a diretoria da fábrica em busca de melhores condições profissionais. Por outro lado, essa dualidade também se refletia na decisão do imigrante de atuar ou não à frente do movimento operário, o que poderia significar sua demissão, sua prisão ou até sua extradição, retornando assim para a pátria natal, de onde tinha saído justamente por falta de oportunidades, alta competitividade e em busca de maiores ganhos. ${ }^{394}$

$\mathrm{Na}$ quinta-feira, 20 de fevereiro, chegou em Bangu uma brigada com 50 policiais, que estavam na estação do Méier, sob o comando do Coronel Travassos. Além desses homens, o $1^{\circ}$ delegado auxiliar, Dr. Moura Carijó, seguiu com mais 60 praças para a vila operária. Com tantos reforços, logo após às 10 horas da manhã, depois que os grevistas conseguiram impedir os foguistas de acenderem as máquinas da fábrica, os três líderes do movimento - Joaquim José da Silva, Antônio Motta Salles e José Pereira Fernandes - foram presos em flagrante. ${ }^{395}$

Na época da Primeira República, a questão operária era um caso de polícia - para nos reportarmos a uma famosa citação atribuída ao futuro presidente Washington Luís quando ele ainda era Secretário de Justiça do Estado de São Paulo. Se ele realmente disse essas palavras, não há provas, mas a sentença era verdadeira. As reivindicações operárias eram sempre sufocadas pela polícia por serem consideradas obras de agitadores, especialmente de estrangeiros. ${ }^{396}$

As prisões continuaram na sexta-feira, 21 de fevereiro. O Dr. Moura Carijó enviou um telegrama ao novo delegado da $3^{\text {a }}$ circunscrição suburbana para que fossem presos todos os grevistas e convencesse os operários a voltar ao trabalho. Assim, outros seis grevistas de um grupo de quinze "mais exaltados" também foram detidos por impedirem que seus companheiros voltassem às máquinas. ${ }^{397}$

A opressão policial fez com que um grupo de quatro operários fosse até a sede do Jornal do Brasil fazer mais uma exigência: a greve só terminaria quando seus companheiros fossem soltos. Acrescentando que não voltariam ao serviço enquanto não saíssem da fábrica os srs. Leal, Francisco Gaspar de Oliveira e Jorge Estrella, sendo que este era tido como o pior inimigo dos grevistas, por dispor "abusivamente da força policial que ali está". Perguntados se os que estavam presos eram os "cabeças da greve", os operários responderam que "esta partiu espontânea de todos eles".

\footnotetext{
393 STEIN (1979), p. 75.

${ }^{394}$ MARAM, Sheldon Leslie. Anarquistas, imigrantes e o movimento operário brasileiro. Rio de Janeiro: Paz e Terra, 1979, p. 33.

395 JORNAL DO BRASIL, 21 de fevereiro de 1896, p. 1.

${ }^{396}$ LOPREATO, Christina da Silva Roquette. O espírito da revolta - a greve geral anarquista de 1917. São Paulo: Annablume, 2000, p. 209.

${ }^{397}$ GAZETA DE NOTÍCIAS, 22 de fevereiro de 1896, p. 1.
} 
Terminaram relatando que estavam todos aflitos para que terminasse logo essa anormalidade e dispostos a aceitar um acordo razoável.

Entre os quatro operários que foram até a sede do jornal - Antônio Pereira de Souza, Honorato José dos Santos, Manuel Francisco de Macedo e Francisco de Barros -, talvez, o menos privilegiado de todos era o português Francisco de Barros. Provavelmente via, como muitos de seus patrícios, o Brasil como um lar temporário, um lugar onde pudesse melhorar sua situação econômica o suficiente para retornar à sua terra natal. Sem instrução, o máximo que conseguiu foi ser "guarda da fábrica" e ganhar um apelido que o acompanhou por toda a vida: "Chico Porteiro". ${ }^{398}$ Se houve alguma melhora em sua vida, não foi devido à greve de 1896, foi à custa de muito trabalho. Treze anos mais tarde, em 1909, apesar de já ter virado operário - "o mais querido entre os seus companheiros", ainda mantinha o mesmo apelido dos velhos tempos e inaugurava um botequim-restaurante, onde "encontram os fregueses o melhor café, as melhores bebidas e comedorias preparadas à la minute", segundo uma notinha publicada nos jornais. ${ }^{399}$ Se havia um sonho de enriquecimento e retorno à Portugal, esse ficou para trás. Dez anos depois, encontramos Francisco de Barros e seu filho Júnior sendo excluídos de sócios do Bangu Athletic Club por deverem três meses de mensalidade. ${ }^{400}$

No sábado, 22 de fevereiro, 495 operários compareceram ao trabalho, o que representava $45 \%$ do pessoal da fábrica. Mesmo sem ver as suas exigências cumpridas, o medo de represálias por parte da diretoria, acelerou o regresso às máquinas.

No domingo, 23 de fevereiro, o Dr. Moura Carijó voltou ao bairro, reunindo-se com 200 operários no salão da Sociedade Musical Progresso de Bangu. Interessante assinalar que em um momento de crise, quem negociava com os grevistas não era a direção da Companhia e, sim, o $1^{\circ}$ delegado auxiliar da Capital. A autoridade policial prometeu por em liberdade os nove operários que por motivo da greve estavam detidos, assim que todos voltassem a trabalhar e "fez-lhes ver que não eram procedentes as suas reclamações". 401 Às 4 horas da tarde, "deixando os ânimos acalmados", o Dr. Moura Carijó pegou o trem de volta e deixou em Bangu o Capitão Lopes Filho com uma força de 25 praças postada em frente à fábrica. ${ }^{402} \mathrm{Em}$ suma: não resolveu nada.

À noite, o diretor-gerente foi conversar com o delegado na repartição central da polícia, alegando que "só depois de uma consulta à diretoria da Fábrica e ao presidente do Banco da

\footnotetext{
${ }^{398}$ FILHO, Mário Rodrigues. O Negro no Futebol Brasileiro. $4^{\text {a }}$ edição. Rio de Janeiro: Editora Mauad, 2003 , p. 32.

399 A IMPRENSA, 23 de maio de 1909, p. 4.

400 “Ata da sessão de 21 de novembro de 1919”. 6 Livro de Atas das Sessões da Diretoria do Bangu A.C., 13 de fevereiro de 1919 a 15 de dezembro de 1921.

${ }^{401}$ CIDADE DO RIO, 24 de fevereiro de 1896, p. 2.

402 GAZETA DE NOTÍCIAS, 24 de fevereiro de 1896, p. 1.
} 
República, Dr. Affonso Penna, onde a Companhia tinha "importantes transações comerciais, poderia resolver alguma das questões propostas pelos grevistas". 403

Na segunda-feira, 24 de fevereiro, o tesoureiro e o gerente da Fábrica enviaram um ofício ao delegado dizendo concordar que fossem postos em liberdade os nove grevistas presos e "declara que os mesmos podem apresentar-se a fim de continuarem seus trabalhos como anteriormente". ${ }^{404}$

A greve terminava sem nenhuma conquista trabalhista dos operários. A demissão do “temível” Capitão Jorge Estrella sequer foi ventilada pela diretoria da fábrica. É provável que neste dia, a insatisfação na hora de voltar aos teares tenha sido generalizada. As cicatrizes mal curadas desta curta greve de cinco dias se estenderiam até o mês de março, desta vez, com motivos reais para a polícia se intrometer na "questão operária".

No sábado, 14 de março, quis o destino (será mesmo?) que se encontrassem às 8 horas da noite, no bairro vizinho de Campo Grande, o ativista espanhol Antônio Motta Salles e o operário Manuel Gomes Carneiro que, durante os dias da greve, "pusera-se do lado da gerência da fábrica, defendendo-a contra os interesses dos grevistas". Os dois se odiavam e o espanhol jurara se vingar do português, "cujo comportamento durante a greve qualificou de traição aos companheiros". Depois da costumeira discussão, Antônio deu duas facadas no desafeto, uma que varou o peito de Manuel, do lado esquerdo, e outra que lhe atingiu o braço direito.

No momento em que se preparava para uma nova facada, o espanhol foi alvejado por Joaquim dos Santos, compatriota do português "fura-greves". ${ }^{405}$ Antônio Motta foi recolhido preso à $8^{\mathrm{a}}$ estação e Manuel Gomes, agonizante, ficou esperando por um trem que o levasse à Santa Casa de Misericórdia, aonde chegou vivo, embora mal falasse, "toda sua roupa estava embebida de sangue e a sua palidez era extrema". 406

Os operários de Bangu, ao saberem do crime, não se comoveram com o assassinato de Manuel Gomes, que para eles era "íntimo amigo do já conhecido Capitão Jorge Estrella”. Desta forma, a falta de consciência social do português, a amizade com o rejeitado Capitão e a pronta defesa dos interesses da Fábrica, fez com que sua morte não fosse lamentada. O mártir, para os trabalhadores, era o líder grevista Antônio Motta, que segundo a versão corrente entre o operariado, tinha sido vítima de uma emboscada (o que era justificado pelo tiro que levou de Joaquim dos Santos), tendo vibrado as facadas no português apenas para se defender.

\footnotetext{
${ }^{403}$ Idem, 25 de fevereiro de 1896, p. 1.

${ }^{404}$ Idem, 26 de fevereiro de 1896, p. 1.

405 A fama dos portugueses em serem costumeiros "fura-greves" era corriqueira na época, sendo os lusos atacados em um artigo do jornal anarcossindicalista paulista A Terra Livre, em 5 de fevereiro de 1907: "É bastante ridículo o papel que os portugueses vêm desempenhando. Esses pobres Manéis correm para a central de polícia e se tornam seus fantoches, enquanto aqueles que produzem todas as coisas e não possuem nada, estão pedindo somente mais um pedaço de pão”. Apud. MARAM (1979), p. 32.

406 A NOTÍCIA, 16 de março de 1896, p. 1.
} 
Numa petição enviada pelos operários ao $1^{\circ}$ delegado, Dr. Moura Carijó, argumentavam que “a prova mais evidente de que os tais senhores da Fábrica reuniram diversos capangas é quê e por que Joaquim dos Santos [estava] no mesmo lugar do conflito e, na mesma ocasião, estava armado de revólver?"407

Infelizmente, os jornais não acompanharam mais o caso. A gerência da Fábrica pode ter perdido um dos homens que mais lhe prestara serviços na época da greve, no entanto, ao mesmo tempo, se livrou definitivamente do "anarquista" espanhol que tantos problemas lhe causara em fevereiro daquele ano: o líder dos grevistas estava preso e não era mais uma ameaça.

${ }^{407}$ CIDADE DO RIO, 18 de março de 1896, p. 2. 


\section{3 - A derrota do Capitão}

Normalmente, Bangu pega "fogo" no verão. Situado em um vale, espremido entre a Serra do Mendanha ao norte e o maciço da Pedra Branca ao sul, o vento vindo do oceano não chega ao bairro, barrado por este último, que é o ponto culminante do município do Rio de Janeiro, com 1.024 metros de altura. Em suma, forma-se uma ilha de calor e as temperaturas ultrapassam facilmente os 40 graus. ${ }^{408}$

Por mais que a medição oficial do Observatório do Morro do Castelo informasse que naquele 25 de janeiro de 1899, a temperatura máxima na Capital Federal foi de 30,3 graus, ${ }^{409}$ é certo que em Bangu o clima estava bem mais quente que isso. Não só pelas características geográficas da localidade, mas principalmente pelos acontecimentos que tomaram vulto ali durante a semana, fazendo com que todos os mestres e operários ficassem sobressaltados.

Os eleitores da região já estavam alertas para as possíveis fraudes na eleição para o Conselho de Intendência, a ser realizada no domingo, 29 de janeiro. Sabiam que o Capitão Jorge Estrella, mais uma vez, iria querer fazer seu poder político, através da coação, para garantir maior número de votos para os partidários do Dr. Augusto de Vasconcellos. Sabiam também que o antigo abolicionista José do Patrocínio - dono do jornal Cidade do Rio - era o inimigo número 1 do político de Campo Grande - a quem apelidou de "Dr. Rapadura", já que seu pai tinha um engenho de cana-de-açúcar naquela área rural. ${ }^{410}$ Assim, dois moradores de Bangu, João Moreira da Silva e Manoel Miranda de Carvalho foram à redação e pediram providências ao poder público para que o “administrador dos assuntos externos da fábrica” não se envolvesse nas eleições municipais. 411

Os dois eleitores só não podiam prever que Jorge Estrella sequer gozaria do mesmo poder e regalias até o dia da eleição. Às 9 horas da manhã de uma quarta-feira explodiu um movimento na fábrica pela expulsão definitiva do Capitão do bairro. Desta vez, no entanto, os operários não estavam sozinhos - como ocorreu em 1896 -, contavam com o apoio dos mestres de seção, ou seja, dos intocáveis imigrantes britânicos e também do alemão Otto Fischer, chefe dos operários.

Em uma minuciosa reportagem, o Jornal do Brasil se preocupou em explicar aos leitores de outros bairros, quem era o Capitão e como ele agia politicamente na região e na fábrica, enfatizando que, ultimamente, seu método de captação de eleitores já estava em decadência.

Há cerca de quatro anos foi admitido na fábrica, como administrador do movimento externo, o sr. Capitão Estrella, que dispõe de alguma influência política no lugar, onde já havia ocupado vários cargos públicos, e entre eles o de delegado de polícia, chegando

\footnotetext{
${ }^{408}$ ASSAF, Roberto. Bangu - Bairro operário, estação do futebol e do samba. Rio de Janeiro: Relume Dumará, 2001, p. 48.

${ }^{409}$ GAZETA DE NOTÍCIAS, 26 de janeiro de 1899, p. 2.

${ }^{410}$ SÁ PINTO, Surama Conde. Só para iniciados - o jogo político na antiga Capital Federal. Rio de Janeiro: Mauad Editora, 2011.

${ }^{411}$ CIDADE DO RIO, 21 de janeiro de 1899, p. 2.
} 
mesmo a captar a simpatia de uns e antipatia de outros, por alguns de seus atos quase sempre violentos para com os adversários políticos.

Assim, pôde arregimentar o pessoal da fábrica, de modo que, em tempos eleitorais, conseguiu fazer "cabala" e muitas vezes "furar" a chapa de outros candidatos influentes, pois contava com o elevado número de 1.200 eleitores somente naquele lugar.

O capitão Estrella, porém, querendo exercer a sua ação política dentro da fábrica, fazendo valer o cargo que ali ocupava, ia muitas vezes ferindo princípio disciplinar dentro das oficinas, procurando proteger este ou aquele operário afeiçoado.

Com tal procedimento, os mestres e contramestres viam-se sempre desautorados, quase sempre e, por isso, mostravam-se a isso contrariados.

Daí o estado de decadência em que dia a dia foi caindo o Capitão Estrella, que já por último, dificilmente encontrava quem o auxiliasse nas urnas. ${ }^{412}$

Como já não conseguia converter os operários à sua vontade, depreende-se que o Capitão encontrou uma nova estratégia para continuar conquistando votos para os partidários do Dr. Augusto de Vasconcellos. Nos dois últimos anos, a Companhia, por conveniência do serviço, teve necessidade de dispensar alguns empregados que excediam do quadro. Daí que, em 1897 tinha 1.339 funcionários e em 1899 contava com apenas 1.155 , ou seja, 184 trabalhadores a menos. ${ }^{413}$ Foi justamente nesses demitidos que Jorge Estrella buscou apoio para se reerguer politicamente na região.

O capitão Estrella transformou-se em protetor dos despedidos, chegando a excitá-los a agredir os mestres e demais empregados superiores da fábrica, o que desde logo chegou ao conhecimento da diretoria.

Ultimamente, porém, o capitão Estrella principiou a admitir nos vários serviços da fábrica homens desordeiros, para, talvez, em um momento de rebelião, encontrar força necessária para qualquer resistência. ${ }^{414}$

É provável que a iniciativa do movimento contra Estrella tenha partido do mestre alemão Otto Fischer, afinal é ele quem encabeça uma comunicação ao Coronel José Casemiro da Silva Franco, delegado da $3^{\mathrm{a}}$ circunscrição suburbana, logo após os operários decretarem a "parede" na manhã de 25 de janeiro. ${ }^{415}$ Ao saber do levante, Jorge Estrella tomou o caso como gracejo, mas logo percebeu que a situação tinha escapado a seu controle.

Consta que 500 pessoas - incluindo crianças e mulheres -, armadas de cassetetes e outros objetos, exigiam da diretoria fabril a retirada do Capitão da vila operária. Alguns adeptos do exdelegado protestaram e houve atritos entre os dois grupos. ${ }^{416}$

A diretoria da fábrica ainda esperou a chegada da força policial de 30 homens, que só embarcou para Bangu no trem das $4 \mathrm{~h} 55$ da tarde e às 5h40, o guarda-livros Francisco da Rocha; o mestre geral das oficinas, Eustáquio da Rocha; e o inglês John Stark, mestre da oficina das

\footnotetext{
412 JORNAL DO BRASIL, 27 de janeiro de 1899, p. 1.

413 OLIVEIRA, Márcio Piñon de. Bangu: de fábrica-fazenda e cidade-fábrica a mais uma fábrica da cidade. Instituto de Pesquisa e Planejamento Urbano e Regional (IPPUR) da Universidade Federal do Rio de Janeiro (UFRJ), 1991, p. 110.

414 JORNAL DO BRASIL, 27 de janeiro de 1899, p. 1.

415 Idem, ibidem: "O sr. Otto Fischer e mais mestres de serviços, reunidos com diversos operários em atitude bastante pacífica, comunicam que começaram uma parede hoje, às 9 horas da manhã, a fim de expulsarem certos operários e indivíduos perturbadores da ordem. Neste sentido comunicam-lhe para que fique inteirado".

${ }^{416}$ Idem, 26 de janeiro de 1899, p. 1.
} 
tinturarias e um dos ingleses que mais trânsito tinha com a direção da Companhia, foram até a fazenda onde o Capitão residia e comunicaram a sua demissão, dando-lhe um prazo de sete dias para desocupar a propriedade.

$\mathrm{Na}$ manhã do dia seguinte, 26 de janeiro, também foi despedido "a bem da disciplina do serviço da fábrica o operário Francisco Carregal, por ficar provado que reunia alguns operários para um ataque à fábrica". E outros dois - Domingos Gaspar e Domingos Campello - foram presos "por se haverem portado inconvenientemente". Jorge Estrella ainda compareceu à Fábrica para entregar alguns papeis que estavam em seu poder ao guarda-livros Francisco da Rocha e logo se retirou, montado em um "cavalo tordilho" e acompanhado de seu cunhado, Francisco Gaspar de Oliveira. Os operários que presenciaram a retirada definitiva do Capitão "trataram-no com a devida consideração". ${ }^{417}$

Jorge Estrella foi a principal força de repressão da Companhia a qualquer tipo de insubordinação dos operários por três anos. A estratégia de contratar o ex-delegado para ser o administrador de assuntos externos mostrava que a diretoria fabril tinha a necessidade de exercer sua coação àquela comunidade, formada por trabalhadores (alguns deles tachados como desordeiros) das mais diversas origens. Em nome de uma desejada disciplina, a fábrica aceitou a livre ingerência do Capitão em manipulações eleitorais na região. No entanto, a partir do momento em que as críticas à sua conduta partiram dos bem pagos e altamente especializados mestres de seção, quase todos eles imigrantes, a diretoria optou rapidamente por ficar ao lado dos seus técnicos têxteis, que se não eram obrigatoriamente garantidores da ordem, eram a certeza de que a produção fabril continuaria em alta. Com eles no comando das diversas seções, a fábrica tinha obtido um volume de vendas inédito de 5.361:941\$680 em 1898. ${ }^{418}$ Perder esses homens que a peso de ouro foram importados da Europa era inadmissível. Jorge Estrella ao "influir no ânimo dos operários, aconselhando-lhes à desordem, em oposição aos mestres das oficinas"419 não compreendeu o poderio e a confiança que a empresa tinha nesses trabalhadores especializados e sequer compreendeu qual era sua função na localidade: o de um simples capataz, uma espécie de "subdelegado da roça", ${ }^{420}$ como o definiram alguns acionistas em 1895.

Contra as críticas de que era "amotinador" e "turbulento", o Capitão escreveu uma carta ao jornal $O$ Paiz reclamando que os seus "precedentes na vida pública e particular não autorizam tão caluniosa imputação"; relembrou seus áureos tempos de delegado, quando era responsável pela

\footnotetext{
${ }^{417}$ Idem, 27 de janeiro de 1899, p. 1.

418 THE RIO NEWS, 26 de dezembro de 1899, p. 8.

${ }^{419}$ O PAIZ, 26 de janeiro de 1899, p. 1.

${ }^{420}$ GAZETA DE NOTÍCIAS, 18 de setembro de 1895, p. 3.
} 
"manutenção da ordem no Distrito Federal" e disse que ainda mantinha "as mais cordiais relações com os diretores da fábrica". ${ }^{421}$

Curiosa ironia, quando Jorge Estrella faleceu, em 1920, na mais completa miséria e totalmente esquecido, apenas o jornal $A$ Razão - um periódico que apresentava postura crítica em relação à política dominante e que dedicava amplo espaço à divulgação das mobilizações operárias, que o Capitão tanto combateu - foi o único que noticiou sua morte:

Vitimado por uma disenteria mesentérica, finou-se ontem o capitão Jorge Estrella, residente na Praça Seca, em Jacarepaguá.

Antigo funcionário da polícia, onde exerceu o cargo de delegado em Campo Grande durante alguns anos, chefe político no $2^{\circ}$ distrito desta Capital, concorrendo junto aos velhos políticos, o capitão Jorge Estrella teve sua época, vivendo na opulência, donde lhe vinha todo seu prestígio.

Foi ainda gerente da Fábrica de Tecidos do Bangu, e após essa ocasião, deixou ele, nesse tempo, a política, retirando-se para o interior de Minas, a fim de tratar-se.

Pouco depois, veio ele a sofrer a perda quase total da sua fortuna, tendo falecido na mais extrema miséria, cercado de mulher e cinco filhos.

O seu enterramento efetuou-se ontem à tarde no Cemitério de Jacarepaguá, tendo sido seu enterro feito ás expensas dos amigos. ${ }^{422}$

${ }^{421}$ O PAIZ, 27 de janeiro de 1899, p. 2.

${ }^{422}$ A RAZÃO, 3 de dezembro de 1920, p. 6. 


\section{4 - Brasileiros vs. portugueses}

Durante a Primeira República a quantidade de imigrantes na cidade do Rio de Janeiro era tão grande que, provavelmente, um nacional não passasse um único dia sem se encontrar com um estrangeiro pelas ruas. Estatisticamente, era mais fácil encontrar com um português do sexo masculino. Pelo censo de 1890, dos 155.202 estrangeiros no Rio, 106.461 eram lusos (77.954 homens e 28.507 mulheres). Isso numa população total de 522.651 habitantes significava que $20,36 \%$ eram portugueses.

No outro censo do Rio de Janeiro, o de 1906, apesar da entrada maciça de imigrantes de outras nacionalidades no país, os portugueses ainda eram mais da metade dos estrangeiros na cidade: 133.393 dentre 210.515 estrangeiros, em uma população de 811.443 habitantes. Portanto, $16,43 \%$ eram lusos. $^{423}$

Na freguesia de Campo Grande, onde estava situada a Fábrica Bangu, pelo mesmo censo de 1906, havia 1.699 moradores portugueses na região (1.308 homens e 391 mulheres). ${ }^{424}$ Dentro da Companhia, porém, trabalhavam somente 71 lusitanos (57 homens e 14 mulheres) pela contagem que foi feita em 1903. ${ }^{425}$

A direção da fábrica já deveria estar atenta às rivalidades que surgiam entre nacionais e imigrantes. Em 1898, por exemplo, o brasileiro Antônio Lopes feriu com uma facada no rosto o espanhol Francisco Penno da Silva, num caso sem maiores repercussões. A Gazeta de Notícias, no entanto, advertia, repercutindo o episódio: “As desordens ali são constantes pela grande aglomeração de operários de diferentes nacionalidades e não seria mau que algumas praças fossem para ali destacadas". 426

A historiografia sobre o período reconhece que havia, na imigração, uma tentativa de ver surgir uma mão-de-obra disciplinada, com homens mais sóbrios que os nacionais, tidos como preguiçosos e indolentes, principalmente se estes fossem mulatos ou negros, sobre os quais ainda pesava o preconceito do recente fim da escravidão.

Dentre os imigrantes europeus, o português era considerado o menos qualificado culturalmente; entretanto, era europeu, leia-se, melhor do que o nacional, portador do elemento básico para a modernização da cidade: o trabalho. Portanto, tratava-se principalmente de substituir os negros e mulatos, ineptos, pelo português, branco, trabalhador e disciplinado. Com esta imagem formada, o português concorria com o nacional e acabava por ocupar parcela significativa do mercado de trabalho numa cidade do

\footnotetext{
${ }^{423}$ RABAÇA, Silvio. De pai para filho: imigrantes portugueses no Rio de Janeiro. Rio de Janeiro: Documenta Histórica, 2010, p. 39.

${ }^{424}$ SENRA, Nelson de Castro. O Censo de 1906 do Rio de Janeiro. Rio de Janeiro: Publicações Pereira Passos, 2012, p. 346.

${ }^{425}$ OLIVEIRA, Márcio Piñon de. Bangu: de fábrica-fazenda e cidade-fábrica a mais uma fábrica da cidade. Instituto de Pesquisa e Planejamento Urbano e Regional (IPPUR) da Universidade Federal do Rio de Janeiro (UFRJ), 1991, p. 103.

${ }^{426}$ GAZETA DE NOTÍCIAS, 9 de março de 1898, p. 2.
} 
início do século, com maior oferta de mão-de-obra do que colocações, com alto índice de inflação e custo de vida, bem como salários diminutos. Esta preferência dada ao imigrante português engendrava no seio das camadas populares um antilusitanismo que, se não era novo e vivera latente por toda a Colônia e Império, parece ter-se acirrado durante a República Velha. ${ }^{427}$

Esse antilusitanismo também se manifestou em Bangu, em setembro de 1899, num rumoroso caso que colocou frente a frente um gravador português da Companhia e um brasileiro desempregado.

Sábado, 23 de setembro, às 5 horas da tarde, o farmacêutico João Frederico de Figueiredo foi até a estação de trem receber duas vacas que vieram de Santos, uma dele, outra do português Manoel Pinto Gaspar, chefe da oficina de gravação. Para conduzi-las até o curral que ficava na casa do alemão Otto Fischer, chefe de máquinas da fábrica, o farmacêutico e o gravador contrataram quatro operários: Francisco José da Silva, Manoel de Medeiros, João Lourenço e João José da Silva.

No caminho até a casa de Otto Fischer, uma das vacas empacou, deu um pinote para frente e quebrou os chifres. Quando o farmacêutico e o gravador estavam indo até o curral ver se as vacas chegaram bem, encontraram-se com o brasileiro Jacintho Telles de Moraes que, da porta de uma venda, gritou assim: “Ó Gaspar, a tua vaca partiu os chifres! Antes os do dono da vaca do que os da mesma". Ao que tudo indica, Jacintho tinha jurado vingar-se de Gaspar porque atribuía a ele ter sido despedido da Fábrica Bangu.

Gaspar parou e ouviu ainda algumas vezes Jacintho repetir a frase insultuosa. Logo, estavam os dois brigando. O português com uma bengala e o brasileiro com um cacete. Um terceiro homem, Leonardo Telles, apareceu para ajudar a bater em Gaspar. $\mathrm{O}$ farmacêutico Figueiredo, que assistia à cena, foi buscar ajuda, mas a luta terminaria rapidamente:

Quando ele se retirava, porém, ouviu tiros de revólver; era Gaspar que, já tendo o antebraço esquerdo partido, o corpo cheio de contusões e o paletó em farrapos, sacara do bolso do colete um pequeno revólver bulldog e dera três tiros em Jacintho, tendo o terceiro acertado a nuca, indo alojar-se na massa encefálica, ficando o projétil achatado. ${ }^{428}$

Depois de atirar em Jacintho, o português Gaspar foi cercado por brasileiros que gritavam: “Mata! Mata!”. Foi salvo por Francisco José da Silva (um dos operários que guiaram as vacas até o estábulo), que acertou uma paulada em Leonardo Telles, quando este estava a ponto de dar uma facada em Gaspar. Nessa ocasião, o inspetor Felippe Mascarenhas apareceu e prendeu Gaspar, Francisco Borges, Leonardo Telles e Francisco José da Silva. Enquanto os detidos eram levados para o trem que os conduziria à delegacia de Campo Grande, Jacintho falecia às $8 \mathrm{~h} 30$ da noite na farmácia da fábrica.

\footnotetext{
${ }^{427}$ CHALOUB, Sidney. "Trabalho escravo e trabalho livre na cidade do Rio: vivência de libertos, galegos e mulheres pobres”. In: Revista Brasileira de História, v. 55, no 8/9. São Paulo, 1985, p. 98.

428 O PAIZ, 25 de setembro de 1899, p. 1.
} 
O único jornal que relatou o assassinato em Bangu fora $O$ Paiz, de propriedade do português João José dos Reis Júnior, o Conde de São Salvador de Matosinhos. ${ }^{429}$ Por isso, ao término da notícia, não era de se surpreender com a descrição dos dois principais envolvidos: assassinado e assassino. Mesmo morto, o brasileiro era "provocador e desordeiro", enquanto o português era "estimado e folgazão":

$\mathrm{O}$ assassinado era alto, corpulento e musculoso, era brasileiro, branco e tinha 35 anos, casado, com quatro filhos e foi durante algum tempo empregado como apontador da fábrica do Bangu. Telles era mal visto no lugar, pois era provocador e desordeiro, e era conhecido por Jacintho Caolho.

O assassino é baixo, corpo regular, bigode, trajava na ocasião do crime calça branca, paletó preto de alpaca, casado, 33 anos, português. Gaspar era muito estimado na fábrica e lugar, pelo seu bom comportamento, pelo seu gênio folgazão, tendo o crime causado profunda impressão no Bangu. ${ }^{430}$

Numa época em que a palavra impressa nos jornais tinha status de veracidade absoluta, principalmente por não existir outros meios de comunicação que pudessem desmentir uma notícia, um grupo de vinte brasileiros - muitos deles da própria família Telles -, ao ler as características dos envolvidos no crime, mandou um abaixo assinado para $O \mathrm{Paiz}$, pedindo uma retificação e, logicamente, invertendo a ordem. Para eles, o português Gaspar é que "sempre foi rixento, andando constantemente armado, e muito dado à politicagem, que infesta este bairro". Já o brasileiro Jacintho Telles de Moraes "sempre foi homem morigerado, trabalhador, chefe de família exemplar". Clamavam, por fim, que os redatores de O Paiz, tratados como "apóstolos da verdade", publicassem a retificação. ${ }^{431}$

Acompanhando o depoimento de uma testemunha-chave no caso, João José da Silva (brasileiro, casado, jornaleiro, 21 anos), e que era um dos homens que levavam as vacas até o curral, pode-se inferir que, por trás de uma simples rixa entre os dois, havia questões profissionais envolvidas na briga. O gravador português tinha subido de vida rapidamente, podia até mesmo darse o luxo de comprar vacas e contratar operários para conduzi-las, mesmo que fosse tido como um “adulador" da diretoria. O desempregado brasileiro era preterido em relação a qualquer português que chegasse na localidade e, provavelmente, era um dos antigos aliados do capitão Jorge Estrella:

(...) Que no dia e hora que a denúncia trata quando ele retirava-se do seu trabalho na Fábrica Bangu, fora chamado por José de Medeiros para que ele, Alfredo José da Silva, Daniel de tal, Francisco José da Silva, conduzissem duas vacas à casa de Otto Fischer, pertencentes as mesmas, uma a Manoel Pinto Gaspar e a outra a João Pinto, digo, João Felippe de tal. Em caminho, quando levavam as vacas próximo à Praça Mascarenhas, aí achavam-se reunidos Jacintho Telles Moraes e outros desconhecidos, nesta ocasião saíra Jacintho da venda onde se achava perguntando aos condutores a quem pertenciam as ditas vacas, respondendo-se nesta ocasião que as vacas pertenciam a Gaspar, gravador, dizendo Jacintho neste ato o seguinte: "Então aquele galego já tem dinheiro para comprar vacas...".

Respondeu neste ato Leonardo Telles de Moraes que aquela fábrica dava para tudo, só não, digo, "os aduladores dela só não têm o que não querem". Que em caminho, quando

\footnotetext{
${ }^{429}$ RABAÇA (2010), p. 183.

${ }^{430}$ O PAIZ, 25 de setembro de 1899, p. 1.

${ }^{431}$ Idem, 15 de outubro de 1899 , p. 3.
} 
conduziam as vacas, uma delas partiu os chifres, o que fez com que Leonardo dissesse que sentia menos que a vaca tivesse quebrado o chifre do que o acusado... que havia prevenção da parte de Jacintho para com o acusado, pois este segundo ele testemunha acredita, responsabilizava Gaspar pela saída da Fábrica não só do capitão Jorge Estrella como do ofendido; que depois que Jacintho e Leonardo perguntavam-lhe de quem eram as vacas que conduziam e tendo ele, testemunha, respondido que eram de Gaspar e Figueiredo, Jacintho proferiu as seguintes injúrias contra Gaspar: "Aquele filho da puta, antes fosse os cornos do gravador do que o da vaca". ${ }^{432}$

Manoel Pinto Gaspar conseguiu um habeas-corpus para esperar o julgamento fora da cadeia. ${ }^{433}$ A colônia portuguesa, contando com o apoio de nomes conhecidos da sociedade carioca como o repórter Gustavo de Lacerda, o caricaturista Calixto Cordeiro, o poeta Mário Pederneiras, o engenheiro Orozimbo do Nascimento, o escritor Gonzaga Duque - também foi aos jornais prestar solidariedade ao patrício. Publicou um documento com 38 assinaturas, em que defendia inclusive o direito de Gaspar andar armado em um lugar tão perigoso como era Bangu, "não policiado" e repleto de "população operária", naqueles idos de 1899:

Que tendo sido Manoel Gaspar agredido inopinadamente, sem provocação da sua parte, por um bando de indivíduos publicamente conhecidos como desordeiros e frequentadores de tavernas, teve de sustentar luta desigual e heroica, e só se serviu do revólver que trazia por precaução, aliás, vulgar em lugares não policiados e de condensada população operária; ainda mais, tendo usado dessa arma quando já tinha o braço quebrado e a cabeça ferida. ${ }^{434}$

A própria diretoria da Companhia - formada basicamente por portugueses, a começar pelo presidente Manoel Antônio da Costa Pereira e pelo diretor-gerente Eduardo Gomes Ferreira também tomou parte a favor de Manoel Gaspar, custeando seu processo e pagando seus salários pelo período em que estava preso. A discussão ganhou relativo espaço na Assembleia Geral Ordinária, de 28 de junho de 1901, tendo o acionista Carlos de Oliveira Soares, um general do Exército, feito pesadas críticas ao administrador Eduardo Gomes Ferreira. Sustentava o general que enquanto:

na fábrica reina descontentamento pelas injustiças e torpelias com que são tratados os operários e trabalhadores que não pertencem à privança ou simpatia do administrador, a diretoria despendeu mais de 10:000\$ com a defesa de um operário da sua privança que assassinou a outro e, ainda mais, pagou $800 \$$ mensais ao delinquente enquanto preso e processado. $^{435}$

Outro acionista, o Dr. Coelho Rodrigues, saiu em defesa do administrador da fábrica e explicou que por ser o gravador Manoel Gaspar um trabalhador especializado, a Companhia o protegeu, querendo mostrar que a questão estava acima dos interesses de cooperação mútua entre os portugueses, transferindo o cerne da discussão para o fato de Gaspar ser um operário com características únicas:

(...) a essas questões talvez se prenda também a morte do indivíduo que agrediu para matar a um empregado da fábrica dos mais necessários e dos de mais difícil substituição,

\footnotetext{
${ }^{432}$ PROCESSO CRIMINAL de Manoel Pinto Gaspar (réu), m 58, 1899, Arquivo do Primeiro Tribunal do Júri (APTJ).

${ }^{433}$ O PAIZ, 21 de outubro de 1899 , p. 1.

${ }^{434}$ GAZETA DE NOTÍCIAS, 11 de novembro de 1899, p. 3

${ }^{435}$ DIÁRIO OFICIAL, 17 de julho de 1901, seção 1, p. 27.
} 
cuja falta importaria, na ocasião, muito maior prejuízo à Companhia do que os 10 contos despendidos em sua defesa e livramento.

É certo que se lhe pagou, durante o processo, todo o ordenado, mas cumpre advertir que ele só esteve preso alguns dias antes do julgamento e duas ou três semanas durante a formação da culpa, e que todo o resto do tempo esteve sempre trabalhando no seu lugar. ${ }^{436}$

Deste crime ocorrido numa rua de Bangu em 23 de setembro de 1899 e de todo seu desdobramento nas páginas dos jornais e nos depoimentos na justiça, o português saiu vencedor. Inocentado por ter realmente agido em legítima defesa, o gravador Manoel Gaspar tinha outros atenuantes em sua conta. Era um operário qualificado - o que pelo discurso do acionista era algo difícil de encontrar -; era estrangeiro, portanto, mais propenso ao trabalho do que os brasileiros "indolentes"; tinha a mesma nacionalidade dos diretores da Companhia; e, por se enquadrar num modelo de imigrante que traria a modernização, buscado pelas elites da Belle Époque, contou até mesmo com o apoio de grandes nomes da imprensa da época.

Colocando na balança, tudo pesava a favor do português, chefe da oficina de gravação. Para o pensamento da época, Manoel Gaspar fora vítima de uma agressão injustificada de um desordeiro brasileiro, mesmo que este também fosse branco, como era o caso do lavrador Jacintho Telles de Moraes.

Os imigrantes vieram para um meio já preparado para recebê-los como gente operosa e de confiança, dotada de aptidões especiais para as exigências da vida urbana. O próprio meio parecia assegurar-lhe o êxito.

Em contrapartida, o trabalhador brasileiro parecia condicionado ao fracasso, devido ao preconceito existente no país. Os imigrantes portugueses, italianos e espanhóis também eram considerados ignorantes, fatalísticos e retrógrados pelas elites de seus países. Entretanto, no Brasil, os empregadores viam os europeus do sul como gente trabalhadeira, ambiciosa, muito mais adaptável à vida urbana que o próprio brasileiro. ${ }^{437}$

Não por acaso o comportamento dos imigrantes portugueses chamou a atenção do cônsul norte-americano em 1922, que comentou: "os trabalhadores portugueses, em particular, fazem qualquer coisa para preservar o seu emprego". Em outros termos, os imigrantes portugueses não contavam com outros membros da família para garantir o nível de renda pessoal. Eis aí uma razão possível para que se tivesse fixado entre os contemporâneos a imagem dessas imigrantes como trabalhadores incansáveis. ${ }^{438}$

A mesma visão que reinava no restante do Rio de Janeiro era reproduzida em Bangu. Nas palavras de um antigo memorialista do bairro, Paschoal José Granado:

O braço escravo, há pouco liberto, ainda "tatibitate", não sabia como começar a trabalhar na fábrica. Suas ocupações eram as mesmas que tinham antes da Lei Áurea. Urgia

\footnotetext{
${ }^{436}$ Idem, ibidem.

${ }^{437}$ MARAM, Sheldon Leslie. Anarquistas, imigrantes e o movimento operário brasileiro. Rio de Janeiro: Paz e Terra, 1979, pp. 14-15.

${ }^{438}$ MARQUES, Teresa Cristina de Novaes \& MELO, Hildete Pereira de. "Imigrantes portugueses no Brasil a partir dos recenseamentos populacionais do século XX: um estudo exploratório de gênero" In: Revista Gênero, volume 9 , $\mathrm{n}^{\circ} 1$. Niterói, 2008, p. 77.
} 
uma solução. O Brasil, àquela época, era o eldorado dos povos europeus. A imigração, portanto, resolveria de modo fácil o que parecia insolúvel. Os diretores da fábrica optaram por ela. ${ }^{439}$

Ingredientes mais que suficientes para que, em Bangu, onde apesar do alto número de estrangeiros, a maioria dos trabalhadores ainda fosse de brasileiros (à proporção de quatro para um), outro crime, agora envolvendo um italiano e um negro se tornasse o estopim para uma greve que paralisou a Companhia por uma semana, em 1901.

${ }^{439}$ GRANADO, Paschoal José. Histórias e estórias de Bangu. Material avulso mimeografado, s. d. 


\section{5 - Brasileiros vs. italianos}

Está registrada em uma página da Gazeta de Notícias, de 1907, a seguinte impressão sobre o operariado de Bangu e as relações entre pessoas de diversas nacionalidades que viviam no bairro. Ao contrário da linguagem jornalística como conhecemos hoje, o relato do anônimo cronista, repleta de visões pessoais, é um primor:

Bangu é uma pequena cidade operária, com uma população de seis mil e tantas almas aproximadamente.

Todo o seu território - enorme anfiteatro cujo recinto é demarcado pelos elevados cerros que se alteiam em redor - é de propriedade da fábrica de tecidos, e os seus habitantes, todos, são homens do trabalho, operários, que tiram os seus proventos desse grandioso estabelecimento, uma das glórias da nossa indústria.

São os modernos feudatários, mas sem a opressão das de outrora, gozando de todas as regalias do homem livre de hoje, com uma vida à parte, confortável e tranquila, ignorando o que sejam as agruras dos seus irmãos operários de outros estabelecimentos e países.

A palavra "operário", como modernamente se concebe - cortejada pelas dores, sofrimentos e miséria, que fazem o homem operário mau e feroz -, não pode ser aplicada ao operário brasileiro, máxime, ao que tem a felicidade de viver e trabalhar na fábrica de Bangu.

As diversões em Bangu são dadas pelos clubes que lá existem. Imagine-se, pois, o que é uma festa ali, onde se reúnem o inglês, o francês, o italiano e o brasileiro branco e de cor na mais ampla cordialidade, na mais encantadora harmonia, que não é perturbada pela distinção de posições sociais e de outros prejuízos abomináveis. Todos ali têm um fim, divertirem-se; tem um dever, portarem-se bem, porque lá estão os seus diretores solícitos e prontos, dispensando a todos eles amabilidades, atenções e tanta cousa, tanta, que até parecem seus companheiros de labor, quando são seus dirigentes. ${ }^{440}$

Por mais exagerado que o texto possa ser, enquadrando-se naquela política de vida edificante, adequada a princípios comportamentais da Belle Époque carioca, a introdução da reportagem sobre uma festa esportiva promovida pelo Bangu A. C., apenas três anos após a sua fundação, enaltece que, naquele domingo, reinava a paz na vila operária e, principalmente, entre as diversas etnias que compunham o quadro profissional da fábrica de tecidos. Seis anos antes desta festa, em 1901, ninguém ousaria falar em "ampla cordialidade e encantadora harmonia" entre brasileiros e italianos que conviviam na mesma faixa de terra.

Embora essa reportagem e muitas outras da Gazeta de Notícias sejam extremamente favoráveis ao ambiente fabril da Companhia, o fato é que o operariado da Bangu já se mostrava revolto nas greves de 1894, 1896 e nas confusões de 1899.

Ao mesmo tempo em que os operários estavam unidos para reivindicar, a comunidade italiana - crescente no bairro desde que os pioneiros chegaram em 1893 - mostrava-se coesa em ocasiões especiais, como em solidariedade à memória do Rei Umberto I, assassinado em Monza, na Itália, em 29 de julho de 1900. Após reunirem-se em comissão, os imigrantes resolveram realizar uma missa no dia 11 de agosto, antecedida de um préstito em que a Sociedade Musical Progresso de Bangu - regida por um maestro brasileiro - tocaria uma marcha fúnebre. O documento, publicado

${ }^{440}$ GAZETA DE NOTÍCIAS, 12 de setembro de 1907, p. 5. 
no jornal $O$ Paiz, é assinado por três italianos: Angello Troccoli, Eugenio Beltrame e Secondo Maffeo $^{441}$ (que, futuramente, viraria a ser sócio e jogador do Bangu A. C. entre 1904 e 1906, tendo seu nome abrasileirado para "Segundo Maffeu").

As estatísticas mostram que entre 1891 e 1900 entraram no Brasil 678.761 italianos, ${ }^{442}$ que fugiam da crise pela qual o país vivia. Não há uma distinção de quantos foram para cada estado. Mas, pelo censo do Distrito Federal de 1906, sabe-se que havia 25.557 vivendo no Rio de Janeiro (17.148 homens e 8.409 mulheres). ${ }^{443}$ No distrito de Campo Grande, onde estava situado o bairro de Bangu, o censo indica que viviam por aquela região 552 italianos ( 376 homens e 176 mulheres). ${ }^{444}$ Destes, 86 (55 italianos e 31 italianas) trabalhavam na fábrica de tecidos, segundo dados de 1903.445

A comunidade italiana no Rio podia não ser grande como a de São Paulo, mas era unida e animada. Faziam questão de comemorar a data de 20 de setembro, rememorando 1870, quando as tropas do rei Victor Emanuel II entraram em Roma e a declararam Capital do Reino da Itália, vencendo a resistência do Papa Pio IX, que considerava a "Cidade Eterna" como um estado pontifício independente. ${ }^{446}$

No ano de 1901, os italianos fizeram uma grande festa de três dias pelo Rio de Janeiro. As comemorações começaram na sexta-feira, 20 de setembro, às 10 horas da manhã, com um grande préstito que percorreu as principais ruas da cidade até irem cumprimentar o Presidente Campos Salles, no Catete. Às 5 da tarde, foi oferecido pela colônia um grande banquete às demais sociedades italianas do interior e à imprensa no Hotel Carson's. Enfim, às 8 da noite, houve uma festa no Parque Fluminense, no Largo do Machado.

Os festejos continuaram no sábado, 21 de setembro, com um pic-nic, um jantar e mais música e baile no Parque Fluminense. No domingo, 22 de setembro, os italianos, acompanhados de uma banda de música, foram até o cemitério de São Francisco Xavier inaugurar o "monumento aos mortos do Lombardia", um navio que, em novembro de 1895, chegou ao porto do Rio com 240 dos

\footnotetext{
${ }^{441}$ O Paiz, 9 de agosto de 1900, p. 1.

${ }^{442}$ CENNI, Franco. Italianos no Brasil: Andiamo in Merica. São Paulo: Edusp, 2003, p. 218.

${ }^{443}$ SENRA, Nelson de Castro. O Censo de 1906 do Rio de Janeiro. Rio de Janeiro: Publicações Pereira Passos, 2012 , p. 126.

${ }^{444}$ Idem, p. 346.

445 OLIVEIRA, Márcio Piñon de. Bangu: de fábrica-fazenda e cidade-fábrica a mais uma fábrica da cidade. Instituto de Pesquisa e Planejamento Urbano e Regional (IPPUR) da Universidade Federal do Rio de Janeiro (UFRJ), 1991, p. 103.

${ }^{446}$ Esses imigrantes saíam de diferentes partes da Itália e se identificavam prioritariamente com a região, a aldeia ou a província de origem - podendo ser "calabreses", "sicilianos", "lombardos", "vênetos". No novo país, a convivência forçada de italianos das mais diversas origens, a discriminação comum e a tendência das sociedades hospedeiras a vêlos e tratá-los todos como "italianos" ampliava seus interesses e a identidade comum de "italianos", em um período da história italiana em que essa identidade ainda não estava consolidada nem na própria Itália. Vide: BERTONHA, João Fábio. Os italianos. $2^{a}$ edição. São Paulo: Editora Contexto, 2005, pp. 113-114.
} 
249 passageiros sofrendo de um surto de febre amarela, que vitimou 134 deles, inclusive o comandante. ${ }^{447}$

Em Bangu, a colônia também reservou o final de semana para festejar, inclusive com um desfile, independente do que ocorreu no centro do Rio. Na sexta-feira, 20 de setembro de 1901, os italianos saíram pelas ruas do pequeno bairro para comemorar. No préstito, caberia aos italianos Felippe Júlio Chiara levar a bandeira brasileira e a João Andrioli carregar a da sua pátria natal. ${ }^{448}$

Ao que parece, ao passarem por uma localidade chamada Marco Seis (onde realmente há um marco de pedra, utilizado desde a época imperial para se contar as distâncias da Estrada Real de Santa Cruz), a bandeira nacional deveria ser empunhada por uma das moças da colônia italiana. Todas elas se recusaram e a bandeira ficou jogada ao chão. Então, um operário brasileiro resgatou-a e a levou até o final do desfile. Dissolvida a passeata, as bandeiras foram entregues na sede da Sociedade Musical Victor Emmanuel III. "Contam-nos os operários nacionais que ela havia sido rasgada e com os retalhos foram arrolhadas garrafas" - registrou o Correio da Manhã. ${ }^{449}$

À noite, para maior irritação dos brasileiros, a colônia italiana reservou o salão da Sociedade Musical Progresso de Bangu para uma festa íntima, somente para os imigrantes, sendo proibida a entrada dos nacionais. Pelos relatos da Gazeta de Notícias, a algazarra só terminou às 2 horas da madrugada de sábado e os italianos não se apresentaram ao trabalho nos dias 20,21 e 22.450

Evidente que os desdobramentos do desfile iriam ser o assunto do pequeno bairro nos dias subsequentes, com os ânimos exaltados por parte dos brasileiros. Então, na segunda-feira, 23 de setembro, pouco depois das 5h20 da tarde, o italiano Garibaldi Romanelli, de 36 anos, desceu do trem que o trazia desde o centro do Rio até Bangu, e foi tomar um vinho na venda do sr. Ângelo Mauro. Chegando lá, "encontrou um indivíduo desconhecido, que em companhia de outros tomava bebidas", segundo consta no depoimento que prestou à polícia.

"Você não é o patife que outro dia jogou bilhar com um barbeiro?" - reportou-se, assim, o brasileiro Emygdio Barbosa ao italiano. Deu-se uma discussão entre os dois, envolvendo, inclusive, o rumoroso caso do desfile. Por fim, Emygdio, "conhecido no local como homem valente e destemido", deu um pontapé que derrubou o italiano ao chão. ${ }^{451}$ Perdida a briga, Romanelli foi para sua residência e voltou à rua com um revólver. Bastante nervoso, dizia apenas que ia matar um homem. Reencontrando-se com Emygdio deu-lhe vários tiros, atingindo o braço direito, a região

\footnotetext{
${ }^{447}$ GAZETA DE NOTÍCIAS, 22 de setembro de 1901, p. 1.

${ }^{448}$ Idem, 26 de setembro de 1901, pp. 1-2.

${ }^{449}$ CORREIO DA MANHÃ, 26 de setembro de 1901, p. 2.

${ }^{450}$ GAZETA DE NOTÍCIAS, 26 de setembro de 1901, pp. 1-2.

${ }^{451}$ Idem, 25 de setembro de 1901, pp. 1-2.
} 
umbilical e o crânio. Emygdio morreu na hora, enquanto Romanelli fugiu, embrenhando-se nas matas. "Acabo de matar um macaco", teria dito. ${ }^{452}$

O italiano, descrito como "alto, reforçado, claro, bigodes e cabelos já um tanto grisalhos", iria se apresentar à repartição central da polícia na noite de terça-feira para confessar o crime e se entregar.

Coincidentemente, nem Romanelli, nem Emygdio eram operários da fábrica de tecidos. $\mathrm{O}$ italiano era sapateiro, morava no bairro de Bangu, mas trabalhava na Rua Senador Euzébio, no Centro, e estava separado da mulher, uma gaúcha, "a qual dava maus tratos". Emygdio tinha sido funcionário da seção de estamparia, mas fora demitido em 1898, por mau comportamento.

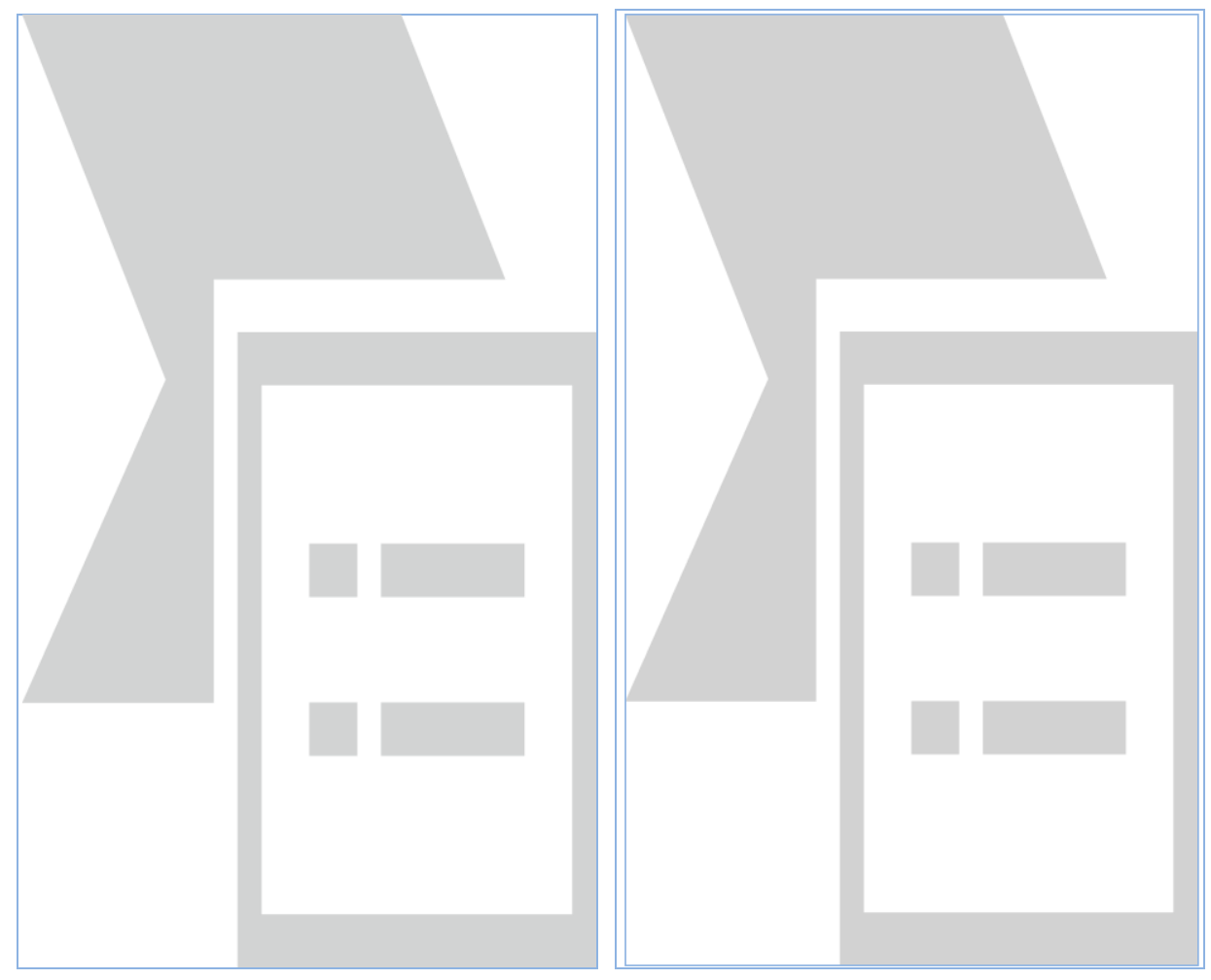

Figuras 25 e 26 - O italiano Garibaldi Romanelli, assassino confesso do negro brasileiro Emygdio Barbosa. ${ }^{453}$

Outras coincidências marcavam a vida desses dois homens de caráter duvidoso. Romanelli já tinha uma passagem pela polícia, em 1894, quando, no Passeio Público, dera sete facadas em um italiano, que comprara e não pagara um balcão de uma sapataria que ele tinha na Rua do Lavradio.

Emygdio, apelidado de "Crioulo", era tido como desordeiro em Bangu, já tendo agredido o sr. Jacintho Leite em uma venda, brigado com um francês em um café e na manhã do dia em que foi assassinado, teria esbofeteado uma senhora. Sem trabalho na fábrica há três anos, continuava

\footnotetext{
452 Idem, 26 de setembro de 1901, pp. 1-2.

${ }^{453}$ REVISTA DA SEMANA, nº 72, 29 de setembro de 1901, p. 12.
} 
residindo nas proximidades do Marco Seis, com dois filhos - Alfredo e Paulino - que trabalhavam na seção de fiação.

A notícia do crime correu rapidamente pelo bairro operário. A raiva que os brasileiros tinham dos italianos transformou-se em uma revolta generalizada e os trabalhadores nacionais decidiram, em 24 de setembro, iniciar uma greve. Não desejavam aumento de salários ou melhores condições de trabalho, queriam a demissão de todos os italianos da Companhia (aproximadamente 80 pessoas).

Analisando os jornais, é possível perceber que a morte do brasileiro foi o estopim para uma situação que já parecia insustentável dentro da fábrica. Colocados em cargos mais elevados, os italianos chefiavam os tecelões brasileiros. "Quando vaga algum lugar na mestrança, a diretoria da Companhia Progresso Industrial sistematicamente preenche por estrangeiros", relataram ao Correio da Manhã. ${ }^{454}$ Ou seja, não havia chances de um brasileiro ascender profissionalmente.

Normalmente, a Companhia reservava aos britânicos o cargo de mestres de seção, incumbindo a outros estrangeiros, no caso, italianos ou portugueses, a função de contramestres. Apesar disso, a grande maioria dos italianos trabalhava como tecelões, lado a lado com os brasileiros. O relatório publicado pela própria Companhia no início de 1903 revela onde os 86 italianos trabalhavam: 52 na tecelagem, nove nas obras, oito na oficina de motores, cinco nas cardas e fiação, quatro na conservação de imóveis, três na administração, dois no alvejamento, dois no preparo das chitas e um no preparo dos morins. ${ }^{455}$

Uma lista nominal com as ocupações dos italianos residentes em Bangu pode ser encontrada na Gazeta de Notícias, de 26 de setembro, que especificou quem participou do desfile comemorativo:

Antonio Gerevini, mestre de engomação e fios; Eugenio Beltrame, mestre da sala de branqueação (alvejamento); Sylvio Aldigheiri, contramestre dos teares; José Brangati, chefe da enfardação; Umberto Pastor, operário na branqueação; José Molica, empregado na sala de pano; Pio Bochialini, empregado na tinturaria; Attilio Batistelle, empregado na fábrica (sem especificar a seção); José Bartholomeu, Mariato Ângelo, Miguel Gartero, Bartholomeu Borges, Pietro Destri, Vicente Moretti, Carlos Aldigheiri, Moyses Beltrame, Natal Bresci, Achiles da Silva e Isidro Conti, tecelões; Fioravanti Zambonelli, mestre da banda de música; Raphael Pastor, negociante; Luigi Molica, negociante de secos e molhados no Marco Seis; Thiobaldi Molica, barbeiro no Marco Seis; Alexandre Bicego, sapateiro no Marco Seis; João Bicego e Júlio Batistelle, ocupação ignorada. ${ }^{456}$

\footnotetext{
${ }^{454}$ CORREIO DA MANHÃ, 26 de setembro de 1901, p. 2.

455 Apud. OLIVEIRA (1991), p. 103.

456 GAZETA DE NOTÍCIAS, 26 de setembro de 1901, pp. 1-2.
} 
Com o passar dos dias, outros trabalhadores italianos teriam seus nomes vinculados nas matérias dos jornais, entre eles, Francisco Maffeo e Pio Bochialini, operários, que foram até o correspondente do Correio da Manhã declarar que não era verdade que "o pavilhão brasileiro tivesse sido desconsiderado ali, nos festejos do dia 20 de setembro".

Com a greve, ou "parede pacífica", como insistiam em dizer os operários brasileiros, era fundamental que os italianos desmentissem o caso da bandeira. Uma comissão formada por Sylvio Aldigheiri, Bartholomeu Roggerio, Daniel Alberto, Giovanne Durso e Silvestre Bulzone informou ao Correio da Manhã que a bandeira tinha sido devidamente guardada, ao fim do desfile, pelo brasileiro Bento Marques. No entanto, o próprio Bento, um dia depois, ao mesmo jornal, declarou que "não tomou parte na manifestação de 20 de setembro".

Além do delegado de polícia da $3^{a}$ circunscrição suburbana, Meira Dantas, apareceu em Bangu o $1^{\circ}$ delegado auxiliar, Dr. Edmundo Muniz Barreto, que enviou uma força de 40 praças de infantaria no primeiro dia de greve, ampliada, em seguida, para 60 homens, tal os distúrbios que os operários faziam às portas da fábrica, impedindo a entrada de outros trabalhadores.

Em vez de negociarem diretamente com os dirigentes da Companhia, era com o Dr. Edmundo Muniz Barreto que os operários - representados por uma comissão de empregados - dialogavam em reuniões na sede da Sociedade Musical Progresso de Bangu, a mesma onde há poucos dias os italianos fizeram a "festa íntima". Na primeira reunião, em 25 de setembro, a comissão era formada por Manoel Pereira, Juvenal Pereira, Nicolau de Souza, Benedicto Silva, Isidro Godoy, João da Silva, José Praxedes e Renato dos Santos Ferreira (operário brasileiro que se queixava de ter sido afrontado, inclusive com uma arma, pelo italiano Isidro Conti, no dia 20 de setembro).

(...) Voltando para o salão da Sociedade Musical de Bangu, o sr. Chefe de Polícia novamente procurou dissuadir os grevistas de continuarem em "parede". Todos a uma vez respondiam que não continuavam trabalhando com os seus colegas italianos, em virtude destes injuriarem a nacionalidade brasileira. (...) A comissão de operários entregou ao chefe de polícia uma exposição escrita, onde são enumeradas as suas queixas. Entre elas, está o fato dos operários italianos trabalharem de revólver à cinta, tendo um deles, antes do assassinato de Emygdio, ameaçado um operário brasileiro. ${ }^{457}$

Sem encontrar uma solução para o impasse, o Chefe da Polícia voltou para o Centro às 18h15, encontrando-se à noite, na repartição central, com o Conde Rossi Toesca, secretário da legação italiana.

Fato raríssimo para o jornalismo da época era a coleta das chamadas "aspas" e "sonoras", ou seja, impressões das pessoas envolvidas no fato. As reportagens não abriam espaço para isso. No entanto, o Correio da Manhã publicou, em 27 de setembro, um vasto depoimento dado por dois operários brasileiros, que não quiseram se identificar. O discurso, baseado sempre no fato de que os nacionais eram homens do trabalho, honrados e que faziam apenas uma "parede pacífica", lançava

${ }^{457}$ CORREIO DA MANHÃ, 26 de setembro de 1901, p. 2. 
também profundas mágoas em relação aos problemas decorrentes da diversidade étnica da fábrica, que tinha chegado naquele ano de 1901 ao clímax:

A nossa questão não está em fazer guerra aos estrangeiros, nem tampouco a este ou aquele indivíduo. Precisamos todos ganhar a vida e assim como não queremos que tirem o pão aos nossos filhos, também não procuramos tirá-los aos dos outros. Ainda mais: entre os italianos temos alguns camaradas: o Achilles, por exemplo, é nosso amigo e dá boa vida a uma brasileira com quem mora; o Napoli não é mau sujeito e eu próprio que lhe falo, tenho um compadre italiano.

Pois bem. Mesmo com esses camaradas não queremos trabalhar! Já vê, vossa mercê, que a questão é muito séria, muito grave. E sabe por quê? É porque se trata da nossa bandeira, do nosso 'trapo', como um deles disse. Será 'trapo', será, mas é nosso e não o trocamos por outro qualquer. A polícia nada pode fazer contra nós. Somos homens do trabalho e não nos metemos em rolos. Respeitaremos a polícia. Lá quanto a tomar nomes dos cabeças, nada adianta, porque todos somos cabeças nessa questão. A nossa 'parede' é pacífica e se quiséssemos usar de insolências, já teríamos feito. Basta ver que somos mais de 500 e que toda gente da estação do Bangu é do nosso lado. Agora, deixar esses que nos insultam junto de nós, é querer provocar um conflito total.

E é isso que devemos evitar. Estamos com a razão. $\mathrm{O}$ caso da bandeira é verdadeiro e já começou no préstito de 20 de setembro. Foi preciso que um inspetor seccional se metesse no meio para colocar o nosso estandarte no lugar que lhe competia. Os nossos insultadores têm também gente a seu favor. Dois graúdos da fábrica - o 'Carne Seca' e o presidente de uma sociedade deles - protegem os italianos. Com esses dois, que são estrangeiros, é que eles contam. No mais, fiam-se nos protocolos e indenizações. Eu, decididamente, é que não voltarei à fábrica enquanto isso não endireitar com honra para nós. Operário não quer dizer escravo! ${ }^{458}$

Como a reunião com a polícia não teve resultado prático, no dia 26 de setembro, uma quintafeira, os operários brasileiros entregaram à diretoria da fábrica um manifesto, pedindo a imediata demissão dos 23 italianos que teriam "enxovalhado" a bandeira nacional e que os demais, deveriam ser dispensados no prazo de dois meses. Entre os trechos desse manifesto constavam três cláusula que são o cerne de toda a questão:

$1^{\circ}$ ) que ultimamente a fábrica tem dispensado em grande número o operariado nacional, admitindo, entretanto, o italiano, menos entendedor daquele serviço;

$2^{\circ}$ ) que não é pequena a perseguição ao operário brasileiro, que na fábrica é preterido pelo italiano e isso devido à influência do mestre Hygino;

$3^{\circ}$ ) que apenas propõem que os operários brasileiros sejam os substitutos dos estrangeiros na ocupação de cargos elevados da fábrica. ${ }^{459}$

Em suma, estava explicitada aí toda a causa da revolta do operariado nacional, que aproveitou a questão da bandeira e o assassinato de Emygdio "Crioulo" como pretextos para mudar uma situação de dominação e de dificuldade de acesso aos melhores cargos que já vinha desde o princípio da Companhia. Havia, claramente, uma divisão entre estrangeiros e brasileiros, com total predominância da mão-de-obra imigrante no acesso às melhores oportunidades.

A fábrica não cedeu e os brasileiros foram até as páginas da Gazeta de Notícias protestar contra o Mestre-Geral da Companhia, o inglês James Hartley. Na época, o diretor-gerente da fábrica

${ }^{458}$ CORREIO DA MANHÃ, 27 de setembro de 1901, p. 2.

459 JORNAL DO BRASIL, 26 de setembro de 1901, p. 3. 
era o português Eduardo Gomes Ferreira. Uma viagem de negócios à Europa no segundo semestre de 1901 fez com que ele não estivesse em Bangu na época dos distúrbios, deixando a fábrica nas mãos de três técnicos têxteis britânicos: William French, Thomas Stirling e James Hartley.

Mr. Hartley tinha negado peremptoriamente a proposta dos tecelões brasileiros, ganhando imediatamente a antipatia dos operários:

\begin{abstract}
"Os operários do Bangu levam ao conhecimento da briosa redação da Gazeta de Notícias que se conserva em 'parede' pacífica contra os operários italianos, os quais gozam de toda a simpatia do mestre James Hartley que, por infelicidade, de todos os mestres ingleses, acha-se colocado como $1^{\circ}$ Mestre, o qual é o único culpado desta situação. Fato este que não se daria se aqui estivesse o diretor Eduardo Gomes Ferreira, que se acha atualmente na Europa. Queríamos aqui para nos considerar, como sempre fez, não dando lugar a que nenhum operário tivesse motivo algum de queixa". ${ }^{460}$
\end{abstract}

James Hartley justificou ao corresponde da Gazeta de Notícias que queria agir com a razão, por isso indeferiu a proposta dos brasileiros, "porque trata-se de atirar à miséria não somente 50 ou 100 homens, mas sim dezenas de pessoas, que formam as famílias desses operários, de cujo trabalho eles nada têm a dizer". Enfim, mostrou dados estatísticos que, mais que defender, ratificavam a ideia de que ao operariado nacional cabiam às funções mais básicas da Companhia: dos 70 operários admitidos em 1901 na seção dos teares, 61 eram brasileiros.

Só na sexta-feira, 27 de setembro, é que a "parede" teria um fim. Às 11 horas da manhã, porém, dois operários foram presos pelo Dr. Meira Dantas. Eram eles João Luciano de Castro e Cândido Manoel, “que se achavam em frente ao portão da fábrica em atitude agressiva, sendo mais tarde postos em liberdade, em virtude de pedidos que fizeram alguns operários ao Dr. Chefe de Polícia".

Foi o mesmo Chefe de Polícia, Edmundo Muniz Barreto, quem teve que solucionar a "parede". Ele desembarcou do trem às 12 h05 e logo foi se reunir com uma comissão de empregados brasileiros, composta por Renato Ferreira dos Santos, Fernando João Machado, José de Araújo e Oscar Corrêa. Nas ruas, duas patrulhas de cavalaria tomavam as esquinas. Dentro do salão da Sociedade Musical Progresso de Bangu havia uma força de 20 praças.

Ao término da reunião, o Chefe de Polícia e os integrantes da comissão foram para a fábrica de tecidos. Lá, iriam se encontrar com os funcionários italianos.

Antônio Gerevini, Taurino Manfrenatti, Domingos Troccoli, Sylvio Aldigheiri, Fioravanti Zambonelli, Pio Bochialini, Francesco Maffeo, João Andreoli, Mariato Angelo, Daniel Alberto, Matheus Schiari, Achilles Scorsalli, João Degani, João Saísse, José Molica, João Chiarelli, Moyses Beltrame, Pedro Destri, Isidro Conti, Pedro Roggeri, Luigi Beltrame e Bartholomeu Rogério se fizeram presentes.

${ }^{460}$ GAZETA DE NOTÍCIAS, 27 de setembro de 1901, pp. 1-2. 
A diretoria da Companhia decidiu que, Isidro Conti e Pedro Roggeri, por medida disciplinar, seriam demitidos. A reunião durou apenas uma hora e a decisão imposta pelo Chefe de Polícia foi pelo fim da "parede":

Aceita friamente pelos operários a solução da questão, prometeram em consideração ao Chefe de Polícia, comparecer ao trabalho no dia seguinte. Eram $4 \mathrm{~h} 30$ da tarde. O mormaço que reinara durante o dia dissipara-se. $\mathrm{O}$ sol, num céu límpido, banhava a vasta campina onde está situada a fábrica, dissipando as últimas brumas.

O alferes Enéas Ferraz ficou comandando uma força de 20 praças, por ordem do sr. Chefe de Polícia. Os operários pretendiam acompanhar com sua banda de música o Dr. Chefe de Polícia à estação. À última hora resolveram o contrário, estando a estação pouco concorrida.

À hora em que nos retiramos, reinava absoluta calma no Bangu, sendo raras as pessoas que transitavam na rua. ${ }^{461}$

No sábado, 28 de setembro, o apito da fábrica soou, como era de costume, às 6 h30 da manhã. Era o sinal para o trabalho. Brasileiros e italianos voltariam a dividir as mesmas seções. Insatisfeitos ou resignados, mais uma vez o operariado nacional retornou aos teares sem conseguir sua maior reivindicação: a de ocupar as vagas de contramestres até então preenchidas pelos imigrantes.

Evidente que perderiam. O esforço de anos anteriores, em que a direção da fábrica se esmerou em trazer mão-de-obra estrangeira para Bangu não seria aniquilado assim, por causa de um movimento paredista. "Os estrangeiros eram considerados os operários mais adaptados ao sistema fabril e os mais especializados", ${ }^{462}$ gente valiosa aos olhos do patronato. Enquanto que o trabalhador nacional, "sem preparo técnico, analfabetos em sua grande maioria, sujeitavam-se aos mais baixos salários e a condições de trabalho as mais terríveis". 463

Em Bangu, no entanto, o grau de instrução dos operários brasileiros se equiparava no geral ao dos operários estrangeiros, uma vez que havia 57,95\% de nacionais analfabetos contra 51,29\% de estrangeiros. No total, a Companhia tinha 687 operários analfabetos, isto é, 56,68\% do total. ${ }^{464}$

Era essa mão-de-obra nacional - em sua grossa maioria negra ${ }^{465}$-, que na mentalidade das classes hegemônicas ainda não estava preparada para o trabalho fabril. "A maior ocorrência de brigas com companheiros e até com os chefes se deu entre os operários brasileiros, indicando uma reação espontânea contra a tensão do sistema de trabalho fabril, ao qual ainda não estavam adaptados". 466

\footnotetext{
${ }^{461}$ CORREIO DA MANHÃ, 28 de setembro de 1901, pp. 1-2.

462 BASTOS, Ana Marta Rodrigues \& WEID, Elisabeth von der. O Fio da Meada - Estratégia de expansão de uma indústria têxtil - Companhia América Fabril (1878-1930). Rio de Janeiro: Fundação Casa de Rui Barbosa, 1986, p. 232.

${ }^{463}$ BASBAUM, Leôncio. História sincera da República - De 1889 a 1930. $2^{a}$ edição. São Paulo: Edições L. B., 1962, p. 260.

${ }^{464}$ OLIVEIRA (1991), p. 105.

${ }^{465}$ Analisando 466 fichas dos operários brasileiros, que representavam o "chão de fábrica", Eulália Lobo chegou aos índices de 58,37\% de negros, $41,20 \%$ de mulatos e meros 0,43\% de brancos em Bangu. Vide: LOBO, Eulália Maria Lahmeyer. História do Rio de Janeiro. Do Capital Comercial ao Capital Industrial e Financeiro. $2^{o}$ Volume. Rio de Janeiro: IBMEC, 1978, p. 523.
}

${ }^{466}$ BASTOS \& WEID (1986), p. 245. 
Por mais que o Jornal do Brasil tenha, em determinado momento da "parede", publicado que os operários alemães, poloneses e portugueses estivessem ao lado dos brasileiros em sua reivindicação, é pouco provável que isso tenha ocorrido efetivamente. ${ }^{467} \mathrm{~A}$ unidade do movimento operário, o sentimento de pertencer à mesma classe não existia naquele momento. Muito pelo contrário, como vimos nos exemplos de conflitos entre portugueses e nacionais e italianos e brasileiros, a diversidade de etnias dentro da Fábrica Bangu fez com que os trabalhadores demorassem a se ver como um grupo unificado, como uma classe operária em si. Apesar de viverem no mesmo "campo de batalha", a diferença racial e cultural, acrescida de outros fatores, os distanciava. Cada operário queria obter o melhor para si e depois, para seus compatriotas.

Os operários são de diferentes nacionalidades, raças, religiões, encontrando-se embebidos de patriotismo e mostrando-se adversos aos homens de outros países. Na sua grande maioria têm como único pensamento ganhar algum dinheiro para voltar ao seu país de origem, do qual partiram acreditando poder ganhar facilmente uma boa quantia.

A desilusão, porém, logo os colhe e, querendo ou não, resignam-se a ficar aqui, procurando sempre, no entanto, melhorar individualmente as próprias condições econômicas. ${ }^{468}$

Como bem salientou Edgard Carone, nos primeiros anos de industrialização no Brasil, as primeiras greves eram, em geral, limitadas a uma fábrica, porque se tratava de uma reivindicação particular dos operários daquele estabelecimento e a manifestação ficava restrita a um número determinado de trabalhadores. Para o historiador, essas greves isoladas não serviam para mobilizar o operariado nacional por muito tempo, nem mesmo ajudavam a formar um sentimento de classe.

Em nenhum momento questões mais amplas são levantadas: o seu sentido político, a nova consolidação do movimento operário, a análise da estratégia de luta. É assim que, em vez de um leque amplo de ensinamentos sobre a luta, vemos uma eterna repetição da mecânica grevista: o descontentamento com a situação, a mobilização, a greve, os resultados positivo ou negativo, o fim do movimento e a consequente dispersão do operariado e, finalmente, a reação do patronato. ${ }^{469}$

Se na Grã-Bretanha, a "classe operária" se formou entre 1790 e 1830 com a "consciência de uma identidade de interesses entre todos esses diversos grupos de trabalhadores contra os interesses de outras classes", ${ }^{470}$ na visão de Edward Palmer Thompson; no Rio de Janeiro, no início do século XX, ela ainda não existia.

A análise micro nos faz perceber as divisões existentes dentro de uma única fábrica, entre homens que poderiam até fazer a mesma função, mas que jamais se viam como iguais ou pertencentes a um bloco único. Os conflitos não ocorriam só entre operários e patrões, mas principalmente entre os próprios trabalhadores, por questões de acesso aos melhores cargos e pelo

\footnotetext{
467 JORNAL DO BRASIL, 26 de setembro de 1901, p. 2.

${ }^{468}$ HALL, Michael McDonald \& PINHEIRO, Paulo Sérgio. A classe operária no Brasil - documentos (1889 a 1930). Volume I - O movimento operário. São Paulo: Editora Alfa Ômega, 1979, p. 114.

${ }^{469}$ CARONE, Edgard. Classes sociais e movimento operário. São Paulo: Editora Ática, 1989, pp. $42-43$.

470 THOMPSON, Edward Palmer. A Formação da Classe Operária Inglesa. Volume II - A maldição de Adão. São Paulo: Editora Paz e Terra, 2012, p. 17.
} 
xenofobismo existente num período de forte imigração. Se não havia coesão dentro de uma única Companhia, fica bem mais difícil pensar o conceito de uma classe homogênea que permeasse todos os operários de todas as fábricas têxteis. Essas tensões certamente não ajudaram a formar uma única "classe operária" no início da industrialização no Brasil, como era defendida pela historiografia marxista que vigorou durante o século XX. "Classe costumava ser a palavra de ordem dos que buscavam uma história do trabalho politicamente engajada", afirma o historiador britânico Mike Savage. ${ }^{471}$

Na própria "parede pacífica" de 1901, em momento algum os operários das outras fábricas do Rio de Janeiro aparecem nos jornais se mostrando solidários com o movimento dos tecelões banguenses. Uma reivindicação, tão pontual como aquela, não encontrava ressonância em outros trabalhadores, mais preocupados em garantir seu sustento diário e às vezes, brigando somente por causas particulares de suas próprias fábricas. Para o historiador britânico Neville Kirk: “As pessoas estavam, o mais das vezes, muito mais preocupadas com seus 'lugares' nas hierarquias de status locais - e em competição com outros membros da 'comunidade' na busca por tais lugares - do que interessadas na solidariedade operária". ${ }^{472}$

Podemos dizer que a análise desses dois conflitos internos entre brasileiros e imigrantes no âmbito da Fábrica Bangu - em 1899 e 1901 - corrobora com essa nova visão, de uma classe operária bem mais fracionada, tal como é defendida pelo historiador Cláudio Batalha:

Ao enfocar o ativismo e a consciência de classe, os estudos tenderam a idealizar as comunidades operárias, concebendo-as como coletividades realmente indiferenciadas e homogêneas, enquanto subestimavam os aspectos que indicavam dispersão e variabilidade de referências e comportamentos sociais. (...) Tendências atuais da historiografia têm-se voltado cada vez mais para a diversidade, a divisão e os conflitos internos à classe operária. (...) O resultado é a ampliação do leque temático da história do trabalho, compondo um quadro multifacetado da vida dos trabalhadores. ${ }^{473}$

\footnotetext{
${ }^{471}$ SAVAGE, Mike. "Classe e história do trabalho" in: BATALHA, Cláudio; FORTES, Alexandre; SILVA, Fernando Teixeira da (orgs.). Culturas de classe - identidade e diversidade na formação do operariado. Campinas: Editora da Unicamp, 2004, p. 26.

${ }^{472}$ KIRK, Neville. "Cultura: costume, comercialização e classe" in: BATALHA, FORTES \& SILVA (2004), p. 56.

${ }^{473}$ BATALHA, FORTES \& SILVA (2004), p. 13.
} 
Trabalhadores empregados em $1^{\circ}$ de janeiro de 1903 na Companhia Progresso Industrial do Brasil por nacionalidade

\begin{tabular}{|c|c|c|c|c|c|c|c|c|c|c|c|c|c|c|c|c|c|c|}
\hline \multirow[t]{2}{*}{ Seções } & \multicolumn{2}{|c|}{$\begin{array}{c}\text { Brasileiros } \\
2==\end{array}$} & \multicolumn{2}{|c|}{ 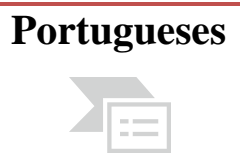 } & \multicolumn{2}{|c|}{$\begin{array}{c}\text { Espanhóis } \\
2=\end{array}$} & \multicolumn{2}{|c|}{$\begin{array}{c}\text { Franceses } \\
2= \\
= \pm\end{array}$} & \multicolumn{2}{|c|}{$\begin{array}{c}\text { Italianos } \\
=\overline{=}\end{array}$} & \multicolumn{2}{|c|}{$\begin{array}{c}\text { Ingleses } \\
=\overline{=}\end{array}$} & \multicolumn{2}{|c|}{$\begin{array}{c}\text { Alemães } \\
2=\end{array}$} & \multicolumn{2}{|c|}{$\begin{array}{l}\text { Russos } \\
\overline{=\Xi}\end{array}$} & \multicolumn{2}{|c|}{ Diversas } \\
\hline & $\mathbf{H}$ & $\mathbf{M}$ & $\mathbf{H}$ & $\mathbf{M}$ & $\mathbf{H}$ & $\mathbf{M}$ & $\mathbf{H}$ & $\mathbf{M}$ & H & $\mathbf{M}$ & $\mathbf{H}$ & $\mathbf{M}$ & $\mathbf{H}$ & $\mathbf{M}$ & H & M & H & M \\
\hline Administração & 35 & - & 11 & - & 1 & - & - & - & 3 & - & 4 & - & - & - & - & - & 1 & - \\
\hline Oficina de Motores & 43 & - & 5 & - & 1 & - & - & - & 8 & - & 3 & - & 2 & - & 3 & - & - & - \\
\hline Cardas e Fiação & 170 & 144 & 6 & - & 1 & - & - & - & 5 & - & 3 & - & 1 & 1 & 1 & 2 & - & - \\
\hline Tecelagem & 126 & 222 & 6 & 13 & 4 & 4 & - & 3 & 22 & 30 & 2 & 1 & 4 & 1 & 7 & 7 & 1 & 3 \\
\hline Alvejamento & 23 & 1 & - & - & - & - & - & - & 2 & - & - & - & - & - & - & - & - & - \\
\hline Preparo das Chitas & 67 & 5 & 4 & 1 & - & - & 2 & - & 1 & 1 & 6 & - & - & - & - & - & - & - \\
\hline Preparo dos Morins & 9 & 4 & - & - & - & - & - & - & 1 & - & - & - & - & - & - & - & - & - \\
\hline Enfardação & 14 & - & 2 & - & - & - & - & - & - & - & - & - & - & - & - & - & - & 1 \\
\hline Conservação de Imóveis & 23 & - & 4 & - & - & - & - & - & 4 & - & - & - & - & - & - & - & - & - \\
\hline Engenho e Lavoura & 25 & - & 7 & - & - & - & 1 & - & - & - & - & - & - & - & - & - & - & - \\
\hline Obras & 69 & - & 12 & - & 2 & - & - & - & 9 & - & - & - & - & - & - & - & - & 1 \\
\hline Subtotal & 604 & 376 & 57 & 14 & 9 & 4 & 3 & 3 & 55 & 31 & 18 & 1 & 7 & 2 & 11 & 9 & 3 & 5 \\
\hline Total & & & & & & & & & & & & & & & & & & \\
\hline
\end{tabular}

Fonte: Companhia Progresso Industrial do Brasil - Relatório da Assembleia Geral Ordinária, realizada em 2 de abril de 1903. 


\section{6 - A "greve geral" de 1903}

As greves pontuais, organizadas não só pelos operários da Fábrica Bangu, como das outras companhias têxteis do Rio de Janeiro, que visavam resolver uma situação específica de cada empresa, evidentemente, não integravam o que os historiadores chamam hoje de "movimento operário" ou sentimento de pertencimento a uma única "classe operária”. Os próprios intelectuais da época, como o advogado Evaristo de Moraes, reconheciam que não havia coesão, homogeneidade e até mesmo "erudição" entre os trabalhadores para se formar uma resistência forte e engajada contra os patrões: "Não houve, como não há, organização operária no terreno profissional, nem no terreno social. Os centros ou associações de classe, ultimamente fundados, vivem à custa dos esforços de meia dúzia de companheiros, que, por sinal, são sempre os mesmos dentro de cada classe". ${ }^{474}$

No entanto, este cenário começou a mudar a partir de 1902, com a fundação do Centro das Classes Operárias (CCO), pelo professor Vicente de Souza. Sua ideia era organizar o operariado sob a bandeira do socialismo. Vicente veio de Santos, onde colaborara na revista "A questão social", editada pelo Centro Socialista, em 1895. Estabelecendo-se no Rio, tornou-se professor de filosofia e lógica do Colégio Pedro II e começou a ter maiores contatos com o operariado. Para a historiadora Ângela de Castro Gomes:

É extremamente difícil avaliar a ação deste Centro, pois as notícias que o envolvem são
muito assistemáticas e geralmente ligadas à sua presença em episódios grevistas. Contudo,
justamente devido a este fato, pode-se perceber que o Centro era uma instituição de
referência, procurada por várias associações nos momentos de protesto.

Já no seu ano inaugural, o CCO "tomou parte saliente no movimento grevista por ele organizado no Lloyd Brasileiro, nada de prático logrando em proveito dos operários deste estabelecimento". ${ }^{476}$ Porém, utilizando o jornal "Gazeta Operária", que circulou entre outubro de 1902 e fevereiro de 1903, Vicente de Souza começou a espalhar suas ideias socialistas e virou um interlocutor dos operários. ${ }^{477}$

Os próprios trabalhadores da Fábrica Bangu chegaram a recorrer ao Centro em janeiro de 1903, reclamando de um italiano de nome Felippe que, no dia 21, agredira a dentadas no rosto o operário José Salazar, quando este voltava para casa. Vicente de Souza não perdeu a oportunidade e foi aos jornais chamar a atenção do Chefe de Polícia para o que acontecia naquela vila operária, onde "desordeiros promovem distúrbios, desacatando pacíficos operários quando de seu trabalho regressam às suas casas". ${ }^{478}$

\footnotetext{
474 Apud. GOMES, Ângela de Castro. A invenção do trabalhismo. $3^{a}$ edição. Rio de Janeiro: Editora FGV, 2005 , p. 66. 475 GOMES (2005), p. 70.

${ }^{476}$ HALL, Michael McDonald \& PINHEIRO, Paulo Sérgio. A classe operária no Brasil - documentos (1889 a 1930). Volume I - O movimento operário. São Paulo: Editora Alfa Ômega, 1979, p. 206.

${ }^{477}$ GOMES (2005), p. 65.

${ }^{478}$ CORREIO DA MANHÃ, 24 de janeiro de 1903, p. 3; JORNAL DO BRASIL, 24 de janeiro de 1903, p. 2.
} 
Naquele verão de 1903, como era costumeiro na cidade, graçava a febre amarela e os jornais publicavam o número de mortos sepultados no dia anterior, vítimas da enfermidade, sem especificar em qual bairro se deram os óbitos. Eis que a "Gazeta Operária", de $1^{\circ}$ de fevereiro, lançou a seguinte nota sob o título de "Pobre povo", direcionada à população operária de Bangu:

\begin{abstract}
A febre amarela está dizimando sem que os burgueses que vivem do seu trabalho se preocupem com isso. Sabemos que no último domingo faleceram cinco pessoas de febre amarela sem que ninguém tenha ainda procurado providenciar nada a respeito. Foge povo do Bangu, deixe esse matadouro! $!^{479}$
\end{abstract}

Se a propaganda socialista ainda não atingia em cheio ao operariado da Fábrica Bangu, a denúncia de Vicente de Souza sobre os casos de febre amarela corroborava com as cartas que alguns moradores costumavam mandar para a grande imprensa, preocupados com a má condição do saneamento na vila operária. "Se a higiene pública e privada desse lugar continuar a ser o que atualmente se verifica, o caso será para que em breve se torne o lugar salubérrimo de outrora em um verdadeiro lazarento" - reclamava o morador Joaquim Leandro Ribeiro. ${ }^{480} \mathrm{O}$ alarde fez com que o próprio Chefe do Distrito de Higiene, Dr. Frederico Fróes, fosse até o bairro verificar as condições sanitárias da fábrica, fazendo questão de publicar também nas páginas da grande imprensa que eram “infundadas as denúncias, pois, quanto às condições higiênicas da fábrica e suas dependências, nada deixam a desejar". 481

Com o intuito de se aproximar ainda mais da população operária de Bangu (a Companhia tinha 1.212 trabalhadores em 1903), ${ }^{482}$ Vicente de Souza e outros seis correligionários do CCO foram no domingo, 8 de fevereiro, até o longínquo subúrbio. Apesar de anteriormente terem comparado o bairro a um "matadouro", eles foram recebidos na casa do mestre geral da tecelagem, o inglês James Hartley, e fizeram uma "conferência de propaganda socialista" no "teatrinho do importante centro industrial", terminando com "vivas à emancipação operária, à igualdade social e à doutrina socialista!". ${ }^{483}$ Não há registros, no entanto, de quantos operários passaram o seu dia de folga ouvindo as suas teses.

Simultaneamente aos esforços de Vicente de Souza em prol da difusão do socialismo entre os trabalhadores, outro "agitador" daqueles tempos, Antônio Augusto Pinto Machado (da União dos Operários do Engenho de Dentro, composta basicamente por ferroviários), começou a organizar os trabalhadores das fábricas têxteis da Capital. Sob sua liderança, em maio de 1903, uma comissão de dirigentes operários foi ao Palácio do Catete agradecer ao presidente Rodrigues Alves por sua

\footnotetext{
${ }^{479}$ Apud. SANTOS, Ricardo Pinto dos. Entre rivais - Futebol, racismo e modernidade no Rio de Janeiro e em Buenos Aires (1897-1924). Rio de Janeiro: Editora Mauad X, 2012.

480 O PAIZ, 2 de junho de 1900, p. 1.

481 GAZETA DE NOTÍCIAS, 28 de março de 1903, p. 2.

482 OLIVEIRA, Márcio Piñon de. Bangu: de fábrica-fazenda e cidade-fábrica a mais uma fábrica da cidade. Instituto de Pesquisa e Planejamento Urbano e Regional (IPPUR) da Universidade Federal do Rio de Janeiro (UFRJ), 1991, p. 108.

${ }^{483}$ CORREIO DA MANHÃ, 9 de fevereiro de 1903, p. 2.
} 
cooperação nas festividades de $1^{\circ}$ de maio. Nessa mesma ocasião, foi entregue ao ministro dos Negócios da Indústria, Viação e Obras Públicas, Lauro Müller, uma petição assinada por 4 mil trabalhadores reivindicando a jornada de oito horas para adultos e seis horas para menores. ${ }^{484}$

Para o historiador Cláudio Batalha, a atitude ia além da "mera bajulação": era um exemplo de estratégia política que buscava comprometer moralmente as autoridades republicanas com as reivindicações dos trabalhadores. ${ }^{485}$

A redução da jornada de trabalho era uma ideia recente e representava uma "revolução" em termos de propostas trabalhistas no Brasil. Apenas uma década antes a jornada de oito horas tinha sido implantada na Inglaterra e, segundo os jornais, funcionava com bastante êxito, aumentando a produtividade do operário:

Tem produzido grande barulho a notável experiência que se acaba de praticar em Inglaterra, nas oficinas do sr. Mather, em Salford, com o regime das oito horas de trabalho.

Durante um ano, desde 20 de fevereiro de 1893 a 20 de fevereiro de 1894, a lei dos "três oito" (isto é, 8 horas de sono, 8 horas de trabalho e 8 horas de recreio e estudo) foi aplicada rigorosamente entre os 1.280 operários das fábricas Mather, dando os melhores resultados, tanto ao patrão como aos operários.

$\mathrm{O}$ trabalho útil aumentou numa proporção até ali desconhecida. Menos fatigado e mais feliz, o operário trabalhou mais e produziu melhor.

O patrão despendeu menos em combustível, em iluminação e em uso do maquinismo. A proporção do tempo perdido sem permissão, isto é, o momento de preguiça, diminuiu de dois terços.

Em resumo, segundo a opinião do diretor da fábrica, o regime das "três oito horas" é o verdadeiro meio de obter um aumento visível na produção e na potência produtiva das máquinas e dos operários. $\mathrm{O}$ operário não se fatiga e trabalha melhor, com mais gosto e com mais força.

Os socialistas estão muito satisfeitos, porque esta experiência é a demonstração prática da reivindicação que eles apresentam todos os anos no $1^{\circ}$ de maio. Os burgueses ingleses são menos insistentes que os burgueses do resto do continente. $\mathrm{O}$ dia legal das oito horas de trabalho está já empregado em grande número de fábricas. Nas manufaturas do Estado, isto é, nos arsenais, todos os operários trabalham apenas oito horas.

Em muito pouco tempo havemos de ver todas as fábricas admitir o dia legal de trabalho de oito horas. ${ }^{486}$

Em todas as fábricas do Rio de Janeiro, as jornadas estavam longe de se aproximar das oito horas inglesas. Mesmo em Bangu, onde havia uma significativa colônia de mestres têxteis britânicos, a jornada ainda era a mais exaustiva possível. $\mathrm{O}$ operário entrava às 6 horas da manhã e saía às 5 horas da tarde, muitas vezes fazendo serão até as 9 horas da noite nos dias úteis. ${ }^{487}$ Aos sábados, o expediente terminava às 3 horas da tarde para a limpeza das dependências, e as seções de estamparia, tinturaria e lavanderia não podiam parar de funcionar, nem aos domingos. ${ }^{488}$

\footnotetext{
${ }^{484}$ LOBO, Eulália Maria Lahmeyer. História do Rio de Janeiro. Do Capital Comercial ao Capital Industrial e Financeiro. $2^{\circ}$ Volume. Rio de Janeiro: IBMEC, 1978, p. 506.

485 BATALHA, Cláudio. "Cultura associativa no Rio de Janeiro da Primeira República" in: BATALHA, Cláudio; FORTES, Alexandre \& SILVA, Fernando Teixeira da (orgs.). Culturas de classe - identidade e diversidade na formação do operariado. Campinas: Editora da Unicamp, 2004, p. 111.

${ }^{486}$ O PAIZ, 27 de maio de 1894, p. 2.

${ }^{487}$ JORNAL DO BRASIL, 8 de janeiro de 1912, p. 5.

${ }^{488}$ Idem, 29 de setembro de 1901, p. 4.
} 
Mas não foi por causa de uma jornada menor que os trabalhadores se agitaram em 1903. Na Fábrica de Tecidos Cruzeiro, na rua Barão de Mesquita, no Andaraí, os seus 655 operários cruzaram os braços numa terça-feira, 11 de agosto, por não concordarem com a cobrança mensal pelo uso dos apetrechos individuais - espanadores, aventais e uma bolsa de coletar algodão. Por mais que fosse uma "retribuição módica", era mais um desconto no baixo salário dos tecelões. Parecia uma questão pontual, referente somente à fábrica do sr. Domingos Bebiano. 489

Não era. Como, em cada companhia, os operários apresentavam queixas diversas, na sextafeira, 14 de agosto, foi a vez da Fábrica de Tecidos Aliança, nas Laranjeiras, parar as máquinas. A greve teve início após o diretor ter se negado a readmitir uma operária dispensada pelo mestre dos teares. A operária, uma viúva polaca, havia sofrido abuso sexual por parte do mestre e fora por ele abandonada e demitida após o nascimento da criança. ${ }^{490}$

Aproveitando a paralisação de duas fábricas, os operários da Fábrica de Tecidos Carioca, no Jardim Botânico, reivindicaram algo bem maior: a jornada de 8 horas por dia. Organizados, eles logo conseguiram a adesão dos seus companheiros da Fábrica Bonfim, na Praia do Caju, e da pequena Fábrica Santa Heloísa. A decisão da "greve geral" foi tomada numa assembleia na sede da Federação dos Operários e Operárias em Fábricas de Tecidos, à rua de São Pedro ${ }^{\circ}{ }^{153}$, no próprio dia 14 de agosto.

Embora sem redigir o que realmente exigiam dos patrões, a Federação queria inicialmente o apoio de todos os trabalhadores, de todas as fábricas. Por isso, na reunião, foi nomeada uma comissão de seis operários de cada fábrica em greve para ir até Bangu, com o objetivo de convidar os trabalhadores da Companhia Progresso Industrial do Brazil a aderir ao movimento. ${ }^{491}$ Era impensável organizar uma greve geral sem o apoio dos milhares de operários da maior fábrica da cidade. No sábado, 15 de agosto, a Fábrica Bangu foi visitada por uma comissão de seis e depois, por outra de trinta grevistas. Segundo a grande imprensa, “os operários do Bangu, em número superior a 1.500, não quiseram aderir, dizendo-se por isso que seriam eles ameaçados por maior número de grevistas que os da comissão que lá foi". ${ }^{492}$

É provável que a derrota na "parede pacífica", que realizaram em 1901 contra os italianos, tenha influenciado na decisão de não entrar novamente em outro movimento grevista. Por mais que fosse tentador diminuir a jornada de trabalho para oito horas diárias, os operários da Fábrica Bangu sabiam que dificilmente conseguiriam êxito naquele momento. A solidariedade com os operários de outras empresas têxteis, que já estavam em greve por motivos pontuais, também não parecia ter

\footnotetext{
${ }^{489}$ Idem, 12 de agosto de 1903, p. 1.

${ }^{490}$ Idem, 15 de agosto de 1903, p. 2.

${ }^{491}$ GOLDMACHER, Marcela. A greve geral de 1903 - o Rio de Janeiro nas décadas de 1890 a 1910. Programa de Pós-graduação em História da Universidade Federal Fluminense. Niterói, 2009, pp. 125-126.

492 GAZETA DE NOTÍCIAS, 17 de agosto de 1903, p. 1.
} 
lógica para os trabalhadores da Companhia Progresso Industrial, o que vem a corroborar com o pensamento de anarquistas daquele início de século XX a respeito do trabalhador brasileiro: "aqui nunca houve uma sólida organização de classe - a única capaz de promover greves -, que atraindo para si os trabalhadores, fizesse deles homens verdadeiramente conscientes dos próprios direitos". 493

Em vista da ameaça dos grevistas das outras fábricas, na noite de domingo, 16 de agosto, a vila operária de Bangu viu desembarcar o delegado Domingues Bernardes e o tenente Santa Fé com 25 "praças embaladas" para fazer a segurança do estabelecimento. ${ }^{494}$

"Movimento grevista" e "repressão policial” eram expressões que caminhavam juntas na Primeira República. Amparadas pelo Código Penal de 11 de outubro de 1890, as direções das fábricas solicitavam o auxílio da polícia quando percebiam alguma agitação entre os trabalhadores. Os artigos 204, 205 e 206 do capítulo "Dos crimes contra a liberdade de trabalho" foram escritos de maneira propícia a responsabilizar criminalmente os líderes grevistas.

O artigo 204 catalogava como crime punível com prisão celular por um ou três meses o "constrangimento ou empecilho imposto a alguém" para "deixar de trabalhar em certos e determinados dias". Pelo artigo 205 era punível com pena de prisão celular por um a três meses e multa de $200 \$$ a $500 \$$ o aliciamento de operários para a greve, sob promessa de recompensa ou ameaças. O artigo 206 praticamente proibia as greves, de maneira pura e simples, punindo com prisão celular por um a três meses os que provocassem a suspensão do trabalho, para impor aos operários e patrões aumento ou diminuição de serviço ou salário. Para os líderes da greve a pena seria em dobro - prisão celular por dois a seis meses $\left(\S 1^{\circ}\right)$. Em caso de recurso à violência, a prisão celular se elevava para seis meses a um ano, além de outras penalidades $\left(\S 2^{\circ}\right){ }^{495}$

Somente na segunda-feira, 17 de agosto, os jornais tomaram conhecimento das reivindicações oficiais dos grevistas. Reunidos na sede da Sociedade dos Operários do Jardim Botânico, os trabalhadores da Fábrica de Tecidos Carioca colocaram no papel a pretensão pela jornada de 8 horas, o aumento de $40 \%$ no salário dos tecelões e o acréscimo de 500 réis na diária paga aos trabalhadores braçais, além de questões pontuais e referentes somente àquele estabelecimento, como a readmissão de dois operários grevistas, a repreensão a um contramestre que maltratava as crianças e a substituição dos cartões de abono (espécie de vales que só eram aceitos no armazém da localidade) por dinheiro. ${ }^{496}$ Neste mesmo dia, outra importante fábrica, a Companhia Confiança Industrial, em Vila Isabel, aderia à greve, além de outras menores, como a fábrica de tecidos Rink,

\footnotetext{
493 Apud. HALL \& PINHEIRO (1979), p. 131.

${ }^{494}$ CORREIO DA MANHÃ, 17 de agosto de 1903, p. 2

495 BEIGUELMAN, Paula. A formação do povo no complexo cafeeiro: aspectos políticos - $3^{a}$ edição. São Paulo: EdUSP, 2005, pp. 166-167.

496 CORREIO DA MANHÃ, 17 de agosto de 1903, p. 2.
} 
algumas de cigarros e de fósforos. No dia 18 de agosto, era a vez dos alfaiates, chapeleiros e sapateiros paralisarem os serviços, declarando-se solidários ao movimento por meio de suas respectivas associações de classe. ${ }^{497}$

Mesmo sem aderir à greve em um primeiro momento, a Fábrica Bangu sofreu as consequências dela e do clima de tensão que se instalou nos vários bairros proletários. No dia 17 de agosto, apesar de a vila estar policiada, mulheres e crianças foram aconselhadas a não irem trabalhar. Somente 700 homens compareceram, diminuindo consideravelmente a mão-de-obra naquela segunda-feira. Mesmo assim, não trabalharam em paz:

À tarde, avultaram os boatos sobre os supostos ataques da parte dos grevistas e por isso, para evitar que o trabalho fosse feito debaixo da apreensão de espírito, resolveram os operários da Bangu, de acordo com a sua diretoria, deixar o trabalho às 3 horas, volvendo todos às suas casas, onde aguardariam a volta de completa calma. ${ }^{498}$

A direção da Companhia percebeu logo. Antes que o movimento grevista influenciasse os ânimos do operariado de Bangu, era melhor fechar preventivamente o estabelecimento. Dessa forma, durante a semana, em meio a muitas notas de "distúrbios à ordem", prisões e "meetings operários", os jornais também noticiaram que "o apito da fábrica não foi ouvido naquela estação à hora de costume, 6 horas da manhã ${ }^{\prime 499}$ e que a fábrica estava fechada por deliberação da diretoria, para não expor os operários a supostas hostilidades. ${ }^{500}$

Não só na Bangu, mas outras fábricas da cidade - como a Corcovado e a São Félix, ambas no Jardim Botânico - também utilizaram desta estratégia para esvaziar as reivindicações que, por ventura, os operários daquelas companhias desejassem fazer. Ainda assim, a Federação dos Operários e Operárias em Fábricas de Tecidos recebeu uma declaração de que os tecelões da Bangu estavam solidários com a greve. ${ }^{501}$ Não há como saber quem eram os adeptos do movimento em Bangu, tampouco há como distinguir entre os 1.212 operários quantos realmente apoiavam a greve ou quantos estavam parados somente porque a própria fábrica tinha sido fechada por precaução.

As notícias na imprensa sobre a Fábrica Bangu são bem menores do que nas principais "cabeças" do movimento - Aliança, Cruzeiro e Carioca. Mesmo assim, entre telegramas que diziam que "continua inalterável a ordem no Bangu", 502 era possível encontrar notas que nos fazem crer que um pequeno grupo estava tentando barganhar também a diminuição da jornada e o aumento dos salários:

Permanece fechada a fábrica de tecidos do Bangu, cujos operários se conservam em atitude calma, poucos dentre eles aderindo ao atual movimento grevista. Esses procuram o auxílio dos companheiros para apresentarem à diretoria uma reclamação, solicitando

\footnotetext{
497 GOLDMACHER (2009), pp. 128-129.

${ }^{498}$ GAZETA DE NOTÍCIAS, 18 de agosto de 1903, p. 1.

${ }^{499}$ JORNAL DO BRASIL, 19 de agosto de 1903, p. 1.

500 GAZETA DE NOTÍCIAS, 20 de agosto de 1903, p. 1.

${ }^{501}$ Idem, 21 de agosto de 1903, p. 1.

${ }^{502}$ Idem, 22 de agosto de 1903, p. 2.
} 
diminuição de horas de trabalho e aumento de vencimentos. A fábrica está, porém, fechada, como medida preventiva, sendo guardada por uma força do $20^{\circ}$ batalhão de infantaria do exército. 503

Após uma semana de deflagrada, a "greve geral” já contava com 18.700 trabalhadores parados em toda a Capital Federal. Segundo os cálculos da imprensa, eram 12 mil tecelões, 3 mil operários em pedreiras, 1.200 chapeleiros, 600 carpinteiros, 500 alfaiates, 300 vidraceiros e outros 500 espalhados pelas mais diversas classes. ${ }^{504}$ Porém, para dar uma maior relevância à causa operária, o número total foi inflacionado dez anos depois. Num relatório apresentado pelo Sindicato dos Trabalhadores em Fábricas Tecidos durante o II Congresso Operário Brasileiro, em setembro de 1913, chegou-se à soma de 40 mil pessoas em greve, sendo que 25 mil eram tecelões. ${ }^{505}$ Números evidentemente fictícios, já que segundo o Recenseamento Industrial feito em 1907 (quatro anos após a "greve geral"), a Capital Federal tinha 8.117 trabalhadores ligados a 23 fiações e tecelagens de algodão ${ }^{506}$ e, no total, 34.850 operários espalhados em 662 estabelecimentos fabris. ${ }^{507}$

Alarmada com a rápida difusão da greve, a imprensa diária procurou saber quanto ganhava um operário no Rio de Janeiro. Segundo Maria Bárbara Levy, nessa época: "as informações censitárias são unânimes em apresentar os salários pagos pela indústria do Rio de Janeiro, os mais elevados do Brasil. Todas as informações confirmam que o custo da mão-de-obra no Rio de Janeiro era maior do que em outras regiões do país", 508 até porque o custo de vida também era maior. ${ }^{509}$

A Gazeta de Notícias chega a publicar quanto ganhavam por jornada os operários da Companhia de Fiação e Tecidos Aliança, nas Laranjeiras. Na dobação e nos carretéis, por exemplo, tirava-se $4 \$$ por dia, se fosse homem, e entre $3 \$$ e $4 \$$, se fosse mulher. Na seção de cardas, um operário poderia ganhar entre $4 \$$ a $7 \$$ diariamente, enquanto os aprendizes e ajudantes (no caso, os menores) recebiam entre $3 \$ 200$ a $3 \$ 700$. Nos teares, se o operário trabalhasse com quatro máquinas simultaneamente, poderia ganhar entre $4 \$ 600$ a $7 \$ 500$. No entanto, o jornal fazia questão de ressaltar que "os preços mínimos e máximos dependem da competência do operário e também da sua antiguidade no serviço", que o aluguel das casinhas na vila variava entre $25 \$$ e $50 \$$ e que por módicos $3 \%$ de seu ganho mensal era possível dispor de médico e farmácia. ${ }^{510}$

\footnotetext{
503 JORNAL DO BRASIL, 23 de agosto de 1903, p. 3.

${ }^{504}$ O PAIZ, 22 de agosto de 1903, p. 2.

${ }^{505}$ A VOZ DO TRABALHADOR, 20 de julho de 1914, p. 3.

506 Apud. GOLDMACHER (2009), p 35.

507 COLEÇÃO NOSSO SÉCULO - Volume I - 1900/1910 - A era dos bacharéis. São Paulo: Editora Abril Cultural, 1980, p. XIII.

${ }^{508}$ LEVY, Maria Bárbara. A indústria do Rio de Janeiro através de suas sociedades anônimas. Rio de Janeiro: Editora UFRJ, 1994, p. 212.

${ }^{509}$ Para o historiador Boris Fausto: "O motivo principal da maior taxa de salário no Rio de Janeiro residia no elevado preço do custo de alimentação da mão-de-obra na região, por força da inexistência de agricultura local e da precariedade agrícola da região fluminense. Isto significa, obviamente, que do diferencial de salários não se pode extrair qualquer afirmativa de melhores condições de vida dos trabalhadores do Rio de Janeiro com relação aos de São Paulo". Vide: FAUSTO, Boris. Trabalho urbano e conflito social (1890-1920). São Paulo: Difel, 1977, p. 29.

${ }^{510}$ GAZETA DE NOTÍCIAS, 21 de agosto de 1903, p. 2.
} 
Supúnhamos, então, que um operário cardador da Companhia Aliança trabalhasse exatamente os 30 dias de um mês, sem direito a folga, ignorando a "semana inglesa" de seis dias. Seu vencimento mensal ficaria entre $120 \$ 000$ e 210\$000. Caso conseguisse os $40 \%$ de aumento pretendido pelo movimento, seu vencimento poderia pular para $168 \$ 000$ a $294 \$ 000$ ao mês. Valores estes que realmente pareciam insatisfatórios, principalmente se comparados aos salários encontrados pela historiadora econômica Eulália Lobo referentes à Fábrica Bangu naquele mesmo ano de 1903. Com quatro amostras de cardadores, ela chegou à média mensal de 243\$360. Com sete amostras de outras seções têxteis, o valor subia para $283 \$ 920 .{ }^{511}$ E se o operário conseguisse galgar o posto de contramestre das cardas, ganharia mensalmente 360\$000, ainda distante do salário de um oficial gravador (a mesma profissão do português Manoel Pinto Gaspar do "caso das vacas" no capítulo 3.4), que recebia $569 \$ 040 .{ }^{512}$

O que se podia comprar com um salário de 243\$ em 1903? Para termos uma ideia, um cavalo custava 250\$, uma passagem de $3^{\mathrm{a}}$ classe para Lisboa era vendida a $140 \$$, um guarda-roupas custava $130 \$$ e um piano Pleyel era comercializado por $800 \$ .{ }^{513}$ Uma residência no bairro do Méier era vendida a 5:000\$, enquanto um prédio em São Cristóvão estava anunciado a 4:000\$. ${ }^{514}$ Se os bens de consumo eram quase inacessíveis, os gêneros alimentícios eram mais plausíveis: o queijo custava $6 \$ 000$ o quilo; a manteiga, 3\$500. É possível comprar um quilo de carne por $\$ 500$ e de açúcar por $\$ 400$. A lata de leite "Moça" custava $\$ 800$, o quilo do feijão preto, \$200; o de arroz, $\$ 220$; o quilo de banha em lata, $2 \$ 500$; o quilo de toucinho, $1 \$ 000 .^{515}$

No caso da Fábrica Bangu, só em 1903 as vendas atingiram o montante de 5.062:094\$. Descontados os impostos de consumo, o lucro líquido era de 4.796:744\$810, suficiente para comprar 959 casas no Méier. Ainda assim, o Conselho Fiscal reclamava, em 1904, do "decréscimo das vendas no ano findo, o que se deve atribuir em parte à paralisação dos trabalhos por ocasião da greve dos operários e à retração geral do nosso mercado, que em todo o ano se ressentiu de uma certa indecisão".516

Numa atmosfera capitalista e de busca incessante por lucros rápidos, as duas principais reivindicações dos operários têxteis - a redução para oito horas diárias e o aumento de $40 \%$ - foram severamente rebatidas pelo patronato em 1903. Mudar o cotidiano de longas jornadas e parcos salários seria conduzir as empresas à falência, segundo Plínio Soares, presidente do Centro Industrial de Fiação e Tecelagem de Algodão.

\footnotetext{
${ }^{511}$ LOBO (1978), p. 665.

512 Idem, p. 670.

513 JORNAL DO BRASIL, 7 de janeiro de 1903, pp. 5-6 e 29 de janeiro de 1903, p. 5.

${ }^{514}$ Idem, 17 de janeiro de 1903, p. 5 e 27 de janeiro de 1903, p. 5.

${ }^{515}$ COLEÇÃO NOSSO SÉCULO (1980), p. 24.

${ }^{516}$ DIÁRIO OFICIAL, 23 de abril de 1904, Seção 1, p. 16.
} 
(...) Essa nova questão, que agora surge como causa principal no movimento grevista, é a das horas de trabalho. Aqui, como normalmente em toda a parte do mundo, o dia de trabalho do operário é de 10 horas.

Pretendem os grevistas que ele seja reduzido a 8 horas. É de todo o ponto impossível atender a tal desejo, sem ferir de morte a indústria nacional, com prejuízo do próprio operário, que, pretendendo a redução do tempo de trabalho, não se apercebe que pede a sua própria ruína.

Ora, uma redução de duas em dez horas de trabalho, ou seja, de $20 \%$, corresponde a uma diminuição também de $20 \%$ na sua produção, e, portanto, um desequilíbrio tão considerável na economia da indústria nacional, que a colocaria fora das condições de suportar, como hoje faz, a concorrência estrangeira.

Tal circunstância acarretaria a ruína da nossa indústria de tecidos e fiação, o que representa, além da perda de grandes capitais empregados, um prejuízo considerável para o Estado e a falta de trabalho para dezenas de milhares de operários, que teriam sido eles mesmos os causadores da sua desgraça.

E não é só isso: ao lado desse pedido de diminuição do trabalho, pretendem ainda os grevistas o aumento de $40 \%$ em seus salários, proporção absurda se considerarmos a remuneração que já hoje têm.

Esse fato, a apreciação das duas pretensões dos grevistas de hoje, demonstra bem eloquentemente a inconsciência com que as suas reclamações são feitas. Ao mesmo tempo em que pretendem uma diminuição de trabalho, que importa na ruína da indústria, querem ainda que o salário seja aumentado em proporção excessiva. ${ }^{517}$

A carta do presidente do Centro Industrial ia além e culpava os "perturbadores e anárquicos" pela "desorganização do trabalho", exigindo o "direito incontestável de dispensar de seu pessoal aqueles cujo procedimento tenha sido irregular".

O Chefe de Polícia, Cardoso de Castro, conseguiu costurar um acordo com os industriais para que as fábricas reabrissem na segunda-feira, 24 de agosto. A pressão sobre os operários grevistas estava ficando mais forte, com dissolução à força de suas reuniões no Largo do Capim, fechamento de sedes de associações, por parte da polícia; demissões às centenas e intimação para os operários desocuparem suas casas nas vilas, por parte dos industriais. ${ }^{518}$

No dia marcado para a reabertura das fábricas, a frequência foi variável em cada tecelagem. Todas as vilas operárias eram bastante vigiadas pela polícia e a expectativa era de que, pelo menos, os trabalhadores que viviam nas casas das Companhias, iriam comparecer aos seus postos. Na Aliança (das Laranjeiras), somente metade dos 1.640 operários apareceu para trabalhar. Na Corcovado (do Jardim Botânico), apenas 360 pessoas bateram o ponto. Na Confiança (em Vila Isabel), compareceram 827 e faltaram 273. Na Cruzeiro (no Andaraí) - a fábrica que há mais dias estava em greve - 523 operários foram trabalhar e 132 não apareceram. E na Carioca (no Jardim Botânico) - a Companhia que deflagrou a "greve geral" -, meros 70 trabalhadores dos 1.450 empregados cumpriram a exigência do Chefe de Polícia. ${ }^{519}$

$\mathrm{Na}$ Bangu, os operários não puderam voltar ao trabalho porque algumas máquinas apresentaram problemas (teria sido algum tipo de sabotagem?). Somente após o conserto dos

\footnotetext{
${ }^{517}$ GAZETA DE NOTÍCIAS, 23 de agosto de 1903, p. 2.

${ }^{518}$ GOLDMACHER (2009), pp. 137-139.

${ }^{519}$ Idem, pp. 142-143.
} 
equipamentos é que a Companhia reabriu, já na terça-feira, 25 de agosto. ${ }^{520} \mathrm{E}$ assim foi feito. $\mathrm{O}$ delegado local, capitão Agostinho Coelho enviou telegrama à chefatura de polícia comunicando o retorno dos mais de 2.300 trabalhadores (número evidentemente avultado) às seções, na mais perfeita calma. ${ }^{521} \mathrm{Na}$ Companhia Progresso Industrial do Brazil, a suspensão dos trabalhos durou menos de uma semana - de 19 a 24 de agosto - e no relatório apresentado em 1904 estava incluído que "no ano findo, contramestres e operários portaram-se de modo o mais exemplar, pelo que lhes tributamos o nosso reconhecimento". 522

Em abril 1906, durante o Primeiro Congresso Operário Brasileiro, realizado na capital federal, a greve de 1903 foi analisada pelos integrantes daquele movimento, que constataram ter sido ela um grande fracasso, apesar de esta ter sido a primeira vez em que várias fábricas e diversos ofícios paralisaram suas atividades conjuntamente por tanto tempo, clamando por uma pauta unificada:

Esta greve que parecia vitoriosa em toda a linha terminou poucos dias depois com a vitória materialmente parcial para os operários, pois estes reclamavam o dia normal de oito horas e $40 \%$ de aumento sobre os salários existentes e obtiveram nove horas e meia e um aumento insignificante no preço da mão-de-obra.

Mas moralmente foi um fracasso completo, pois todas as fábricas despediram grande quantidade de operários atingindo a centenas de despedidos, principalmente nas Fábricas Carioca, Aliança e Confiança, cujos diretores foram os mais tiranos. ${ }^{523}$

A questão das demissões ressoou alto. No dia 28 de agosto, os diretores das fábricas Confiança, Corcovado, Aliança e Cruzeiro foram convocados pelo ministro da Justiça e Negócios Interiores do Brasil, José Joaquim Seabra, para esclarecimentos. "J. J. Seabra mostrou desejo que os operários despedidos e os grevistas não ficassem sem emprego". Porém, os industriais fizeram valer seu ponto de vista, alegando que "a anistia não podia ser geral" e que "o número de operários despedidos das fábricas em greve não atinge a 100, entre 12.000 dos que atualmente se acham trabalhando". ${ }^{24}$ Os diretores tomaram a decisão de não publicar na imprensa o nome dos empregados despedidos, embora dificilmente os "culpados" pelo movimento conseguissem vaga novamente nas fábricas têxteis da capital federal. A temível "lista negra" não estaria impressa nos jornais, mas é certo que os industriais já os reconheceriam facilmente se checassem seus antecedentes na polícia. ${ }^{525}$

A reunião entre governo e empresariado não trouxe nenhum alento aos trabalhadores. Para o historiador e ativista Edgard Carone, a falta de "garantias sociais" permitia que o operário perdesse seu emprego, figurasse em uma lista negra, não conseguisse trabalho na cidade, passando fome com

\footnotetext{
${ }^{520}$ GAZETA DE NOTÍCIAS, 25 de agosto de 1903, p. 4.

${ }^{521}$ O PAIZ, 26 de agosto de 1903, p. 1.

522 DIÁRIO OFICIAL, 23 de abril de 1904, Seção 1, p. 16.

${ }^{523}$ HALL \& PINHEIRO (1979), p. 133.

${ }^{524}$ GAZETA DE NOTÍCIAS, 29 de agosto de 1903, p. 1.

525 “O recrutamento passava a ser feito, não pelo departamento de pessoal da firma, mas diretamente pela delegacia de polícia regional, que preparava dossiês da vida pregressa do operário, sendo tudo anotado nas 'cadernetas operárias' e arquivado nas fábricas". Vide: HARDMAN, Foot Francisco \& LEONARDI, Victor. História da Indústria e do Trabalho no Brasil (das origens aos anos 20) - 2a edição. São Paulo: Editora Ática, 1991, pp. 161-162.
} 
sua família e até ser preso. "É assim que a legislação coercitiva vai arrochando na medida em que o movimento operário se torna mais atuante". 526

Diferentemente do que ocorreu com os operários das principais fábricas envolvidas na greve, em Bangu, a diretoria da Companhia Progresso Industrial do Brazil colocou um aviso no portão da fábrica, comunicando ao seu pessoal que, "por terem os operários se conservado em atitude calma durante a agitação operária, pagará a todos os dias em que deixaram de trabalhar". ${ }^{527} \mathrm{Na}$ medida, no entanto, não há nenhuma benevolência se lembrarmos que foi a própria direção que decidiu interromper preventivamente os trabalhos na fábrica.

${ }^{526}$ CARONE, Edgard. Classes sociais e movimento operário. São Paulo: Editora Ática, 1989, p. 43.

527 JORNAL DO BRASIL, 30 de agosto de 1903, p. 2. 


\section{IV - O Benemérito propugnador do progresso de Bangu}

Durante a greve de 1903, por mais que a Fábrica Bangu tivesse uma participação pequena no movimento, o diretor-gerente da Companhia, o português Eduardo Gomes Ferreira pediu exoneração do cargo no dia 17 de agosto, alegando problemas de saúde. Estranhamente, em um momento em que a fábrica mais precisava de um comando, o gerente se ausentou, sendo substituído por dois membros do conselho fiscal. ${ }^{528} \mathrm{Na}$ ocasião da greve, o próprio diretor-presidente, o Comendador Manoel Antônio da Costa Pereira, estava em viagem a Europa e a empresa foi administrada interinamente até o dia 31 de outubro, quando o tesoureiro espanhol João Ferrer foi elevado à condição de diretor-gerente da Companhia. ${ }^{529}$

Filho de Francisco Ferrer ${ }^{530}$ e Celeste Ferrer - comerciantes de coletes para senhoras estabelecidos na Rua da Carioca ${ }^{531}$-, João Ferrer já tinha ligações com os diretores da fábrica há muitos anos. O espanhol era sócio da Companhia Indústria e Comércio de Papéis Pintados, em que figuravam como associados o português Manoel Antônio da Costa Pereira e também Edmundo Bittencourt - fundador do jornal Correio da Manhã. A Companhia pediu liquidação em fevereiro de $1897^{532}$ e naquele mesmo ano, João Ferrer foi convidado para ser o tesoureiro da Fábrica Bangu, substituindo João Clemente de Carvalho. ${ }^{533}$

Em 1897, quando foi pela primeira vez a Bangu, João Ferrer encontrou um lugarejo com três ruas abertas, um clube recreativo, um reduto comercial e uma população estimada em 6.000 habitantes. Era tudo. As ruas eram a Estevão, a Fonseca e a Estrada do Engenho. Havia, também, a Estrada Real de Santa Cruz, mas que não era uma rua só de Bangu. Pertencia a todo o município e tinha o seu início dentro do Paço Imperial, na Quinta da Boa Vista, em São Cristóvão. O clube era a Sociedade Musical Progresso de Bangu. O reduto comercial era o Marco Seis, um conglomerado de imigrantes de várias nacionalidades, principalmente italianos, e, finalmente, uma população tão escassa, que o local podia muito bem ser chamado, com propriedade e acerto, de um deserto.

\footnotetext{
${ }^{528}$ JORNAL DO BRASIL, 18 de agosto de 1903, p. 2; GAZETA DE NOTÍCIAS, 18 de agosto de 1903, p. 2.

${ }^{529}$ DIÁRIO OFICIAL, 23 de abril de 1904, seção 1, pp. 15-16.

${ }^{530}$ Coincidentemente, o pai de João Ferrer, Francisco Ferrer era homônimo do anarquista espanhol Francisco Ferrer y Guardia, condenado ao fuzilamento em 13 de outubro de 1909, nos fossos da fortaleza de Montjuich, por supostamente participar do atentado ao Rei Alfonso XIII. Logo após o assassinato, Ferrer y Guardia se tornou um ícone dos anarquistas em todo o mundo, inclusive no Brasil. Vide: “À memória de Ferrer”, A VOZ DO TRABALHADOR, 15 de novembro de 1909, p. 3. Já o Francisco Ferrer que vivia no Brasil e morava na Rua Goulart nº 84, no Leme, faleceu em fevereiro de 1911, aos 72 anos. Vide: GAZETA DE NOTÍCIAS, 18 de fevereiro de 1911, p. 4.

531 ALMANAK, ADMINISTRATIVO, MERCANTIL E INDUSTRIAL DO RIO DE JANEIRO. Rio de Janeiro: Companhia Typographica do Brazil, 1901, p. 490.

532 DIÁRIO OFICIAL, 26 de fevereiro de 1897, seção 1, p. 16.

${ }^{533}$ OLIVEIRA, Márcio Piñon de. Bangu: de fábrica-fazenda e cidade-fábrica a mais uma fábrica da cidade. Instituto de Pesquisa e Planejamento Urbano e Regional (IPPUR) da Universidade Federal do Rio de Janeiro (UFRJ), 1991, p. 10.
} 
$\mathrm{Na}$ "parede pacífica" de 1901, quando era tesoureiro, Ferrer se mostrou ao lado dos italianos, argumentando que era "totalmente impossível a dispensa dos operários italianos que, no exercício do seu cargo, são bons e zelosos funcionários, e que a fábrica não podia se responsabilizar por fatos praticados fora do seu recinto". Além disso, parecia bem mais preocupado com o destino de grande quantidade de peças de fazenda que poderiam ficar inutilizadas se não fossem tratadas em tempo. ${ }^{534}$

No entanto, quando assumiu a gerência da Companhia, João Ferrer mudou sua linha de pensamento e com a experiência de quem já tinha vivenciado a "parede pacífica" de 1901 e a "greve geral" de 1903, adotou um estilo mais paternalista, procurando ao mesmo tempo desenvolver a vila operária e congraçar os mais diversos trabalhadores.

O fato de a Companhia ser proprietária, além da fábrica, de grandes extensões de terra, fazia com que o seu administrador fosse identificado não apenas como representante do capital, mas também como um benfeitor. Não podia ser diferente, pois era ele quem respondia por todas as coisas que ocorriam na propriedade da Companhia e quem interferia direta ou indiretamente na vida de todas as pessoas que ali viviam. Assim, ele respondia pela fábrica, pelo engenho, pela água, pela vila operária e pela criação/manutenção de todas as benfeitorias no núcleo urbano ao redor do edifício fabril.

Portanto, o administrador, um cargo abaixo do Presidente da Companhia, era a própria personificação da autocracia do capital no seu território. ${ }^{535}$ De um modo geral, as pessoas que dependiam dele, operários ou não, tendiam a manifestar uma reverência por tudo aquilo que ele fazia ou criava no lugar, atitude essa que se estendia, inclusive, ao universo das relações pessoais.

\subsection{1 - O Bangu Athletic Club}

Com o espanhol na direção, os mestres têxteis ingleses conseguiram apoio para uma antiga reivindicação. Desde 1897, os britânicos vinham tentando a ajuda da fábrica para a fundação de um clube de futebol, nos moldes dos que existiam em seu país. O antigo diretor-gerente, o português Eduardo Gomes Ferreira, barrou-lhes a pretensão, declarando-se inimigo de qualquer espécie de jogo, naturalmente confundindo o futebol com um jogo de azar, que poderia viciar os funcionários. Na concepção dele, os trabalhadores mais indisciplinados poderiam substituir as horas de trabalho pelo lazer de ficar no clube chutando uma bola. ${ }^{536}$

\footnotetext{
534 JORNAL DO BRASIL, 26 de setembro de 1901, p. 3.

${ }^{535}$ Segundo os estatutos da Companhia Progresso Industrial do Brasil, o diretor-gerente ganharia mensalmente o salário de um conto e quinhentos mil réis (1:500\$000), fora uma gratificação especial, cujo valor não estava especificado nos estatutos. Vide: DIÁRIO OFICIAL, 14 de novembro de 1898, seção 1, p. 15.

536 SILVA, Gracilda Alves de Azevedo. Bangu 100 anos: a fábrica e o bairro. Rio de Janeiro: Sabiá Produções Artísticas, 1989, p. 104.
} 
João Ferrer via o futebol de outra forma. O jogo da bola - uma recente novidade no país poderia servir para unificar aqueles trabalhadores em torno de um bem-comum: um clube próprio, que representasse a vila operária. Em 1904, dois anos após da fundação do Fluminense F. C., um clube de elite voltado para a prática do esporte no Rio de Janeiro, que mudou por completo a forma como o jogo bretão era visto na cidade, a Fábrica Bangu apoiou os ingleses na organização de uma associação esportiva. Desta forma, em 17 de abril de 1904 na casa do mestre têxtil John Stark, se reuniram dez chefes de seções na Companhia (oito ingleses, um italiano e um português), para fundarem o Bangu Athletic Club - o primeiro clube fabril do país.

Autores como Cláudio Batalha analisam a estratégia de organização de um clube como "mais um dos mecanismos de controle da empresa sobre seus operários". ${ }^{377}$ Joel Rufino dos Santos vai na mesma direção e crê que a Fábrica Bangu só instituiu a prática do futebol entre os trabalhadores sob o pretexto de proporcionar-lhes diversão -, para soltarem os excessos e queimarem energias consideradas perigosas quando não canalizadas corretamente. ${ }^{538}$ Margareth Rago diz que o futebol era desaconselhado pelos anarquistas, que viam o esporte como uma "prática degradante que embrutece o trabalhador e desperdiça suas energias, que deveriam ser canalizadas para a militância política". ${ }^{539}$ Em 1907, o jornal anarquista Terra Livre, publicado em São Paulo, chega ao limite da crítica: "É um jogo bom para os parasitas e os ociosos que precisam de exercitar os músculos em um trabalho inútil, desprezando ao mesmo tempo o trabalho útil e os que o fazem. Quanto a nós, temos exercício de sobra. Exercício até rebentar".540

Parece ser um exagero dos historiadores. No caso do Bangu Athletic Club, a organização criada sob as bênçãos de João Ferrer - que logo na sessão de fundação foi escolhido como "Presidente Honorário" - parecia servir mais para contemplar um desejo dos técnicos têxteis ingleses, saudosos das partidas que disputavam na Grã-Bretanha. Como afirma o historiador Leonardo Affonso de Miranda Pereira:

De início, o clube congregava parcelas muito restritas dos empregados da fábrica, compondo-se somente de trabalhadores especializados de origem estrangeira que ocupavam cargos de chefia. (...) A necessidade de apoio por parte da fábrica fez, porém, com que os fundadores do clube logo ampliassem esse impulso inicial, atendendo aos interesses da Companhia. ${ }^{541}$

\footnotetext{
537 BATALHA, Claudio. "Cultura associativa no Rio de Janeiro da Primeira República”. In: BATALHA, Cláudio; FORTES, Alexandre \& SILVA, Fernando Teixeira da (orgs.). Culturas de classe - identidade e diversidade na formação do operariado. Campinas: Editora da Unicamp, 2004, p. 114.

538 Apud. HERSCHMANN, Micael \& LERNER, Kátia. Lance de sorte: o futebol e o jogo do bicho na Belle Époque carioca. Rio de Janeiro: Diadorim, 1993, p. 127.

539 RAGO, Margareth. Do cabaré ao lar, a utopia da cidade disciplinar e a resistência anarquista - Brasil 1890-1930 - $4^{a}$ edição. São Paulo: Editora Paz e Terra, 2014, p. 152.

540 Apud. FAUSTO, Boris. Trabalho urbano e conflito social (1890-1920). São Paulo: Difel, 1977, p. 87.

${ }^{541}$ PEREIRA, Leonardo Affonso de Miranda. Footballmania: uma História Social do Futebol no Rio de Janeiro (19021938). Rio de Janeiro: Editora Nova Fronteira, 2000, pp. 32-33.
} 
Era notório que o clube não iria se restringir somente aos técnicos têxteis estrangeiros, seria preciso abrir as portas da nova associação aos demais trabalhadores que a ela desejassem se filiar, pagando taxas realmente módicas por mês: $2 \$ 000$ como joia para ingresso e $1 \$ 000$ de mensalidade 542 - valor inferior a uma diária de um operário de qualquer seção da fábrica.

Se havia algum interesse em controlar o operariado com o clube, este partia dos próprios mestres têxteis ingleses. De caráter disciplinador, logo na criação da associação esportiva, veio de James Hartley a proposta de que somente os empregados da fábrica pudessem ser sócios, excluindo, assim, qualquer pessoa de fora do bairro. Além disso, o inglês propôs que "se um sócio saísse da Companhia por mau comportamento, tem de deixar de fazer parte do $c l u b$, porém, se saísse por sua livre vontade, não havendo nada contra o seu caráter, pode continuar de ser sócio do club". 543

João Ferrer não participava diretamente do dia a dia do clube. O espanhol, no entanto, aparece citado nas atas de reunião do Bangu A. C. sempre que a diretoria precisasse do aporte financeiro do seu "patrono", como no caso da compra de um piano pela quantia de 2:800\$000, em 1911: "visto que o clube não tem esta quantia em caixa, o nosso Presidente Honorário, Sr. João Ferrer, ofereceu a quantia que falta para completar a compra do piano". ${ }^{444}$

Desta forma, oferecendo benesses ao clube criado pelos mestres têxteis com recursos provenientes da Companhia, João Ferrer aparecia aos olhos da comunidade como um benfeitor. Se as glórias alcançadas nas partidas de futebol eram fruto do esforço dos jogadores em campo, fossem eles ingleses ou brasileiros, nos dias de festas esportivas internas - espécie de gincanas onde se disputavam várias provas atléticas - era João Ferrer que aparecia como o grande nome a ser louvado: fosse ao patrocinar uma corrida com a participação de 60 meninos, na qual ele pagava ao segundo colocado $10 \$ 000$ e ao primeiro, $30 \$ 000^{545}$ - quantia que significava dez dias de trabalho árduo desses menores dentro da fábrica -; fosse na entrega dos prêmios aos vencedores, honraria reservada sempre à esposa do diretor-gerente, Georgeana Ferrer. ${ }^{546}$

Vale ressaltar que a iniciativa pioneira de um industrial como João Ferrer acabou sendo seguida por outras companhias têxteis da cidade. Desta forma, em 1907, a Companhia de Fiação e Tecidos Carioca, no Jardim Botânico, fundou o Carioca Football Club. Em 1909, com o apoio da família Bebiano, dona da Fábrica Cruzeiro, foi fundado o Andarahy Athletic Club. Em 1912, foi fundado o Paracamby Football Club por funcionários da Companhia Brazil Industrial, alguns deles antigos técnicos têxteis da Fábrica Bangu. Em 1915, a Companhia Confiança Industrial, de Vila

\footnotetext{
542 "Ata da sessão de 17 de abril de 1904". $1^{\circ}$ Livro de Atas das Sessões da Diretoria do Bangu A.C., 17 de abril de 1904 a 7 de fevereiro de 1905 .

543 "Ata da sessão de 24 de abril de 1904", $1^{\circ}$ Livro de Atas das Sessões da Diretoria do Bangu A.C., 17 de abril de 1904 a 7 de fevereiro de 1905 .

544 "Ata da sessão de 21 de junho de 1911", $3^{\circ}$ Livro de Atas das Sessões da Diretoria do Bangu A.C., 28 de fevereiro de 1909 a 12 de janeiro de 1915.

545 JORNAL DO BRASIL, 18 de junho de 1904, p. 5.

${ }^{546}$ Idem, 20 de novembro de 1906, p. 5.
} 
Isabel, apoiou a criação do Confiança Atlético Clube; mesmo ano em que a Fábrica Mavilis, na Ponta do Caju, patrocinou a criação do Mavilis Football Club - tendo a empresa e o clube as letras iniciais do nome de seu principal diretor: o português Manoel Vicente Lisboa.

\subsection{2 - A Escola Rodrigues Alves}

A segunda medida de grande vulto tomada por João Ferrer em Bangu ocorreu em 1905 com a construção da Escola da Companhia, que viria a servir aos filhos dos operários. Segundo o memorialista do bairro, Paschoal José Granado, na verdade, o prédio que abrigou a escola estava sendo erguido para ter outra função - iria ser uma cooperativa gigantesca - tendo sido alterada sua finalidade pela boa índole do diretor-gerente espanhol.

Graças à sua habilidade, Ferrer pôs fim a um conflito entre a Companhia e um grupo de comerciantes autônomos, que ameaçava ganhar grandes proporções. Desde 1891, imigrantes de nacionalidades distintas, especialmente italianos, vinham se estabelecendo em uma faixa de terra desapropriada pela prefeitura para a continuidade da estrada de ferro, paralela à Estrada Real de Santa Cruz, denominada Marco Seis. A Companhia não tinha poderes para interferir na área, mas insistia em fustigar os comerciantes ${ }^{547} \mathrm{E}$ começou a construir, em terrenos de sua propriedade, uma “cooperativa monstro" - tal como os atuais supermercados -, inclusive com prestações de serviços, como barbeiros, cabeleireiros, engraxates, com uma vantagem que se anunciava como capaz de liquidar, impiedosamente, com o comércio do Marco Seis: a venda à crédito, com desconto em folha de todos aqueles consumidores que tivesse vínculo empregatício com a fábrica. Tudo isso começou a ser feito na gestão do diretor-gerente anterior, o português Eduardo Gomes Ferreira.

Na visão romanceada de Paschoal José Granado:

'Seu' Ferrer não era homem de dividir. Considerou que destruir o comércio do Marco Seis não era programa de nenhum administrador sensato. Não somaria nada. Pelo contrário, iria, deste modo, abrir novas fontes de discórdias. Pensou de outro modo e deu destino diferente ao prédio que não seria nunca mais cooperativa, e nele fundou a Escola Rodrigues Alves para os filhos dos operários da Companhia Progresso Industrial do Brazil. Isso aconteceu em 1905. Era o seu segundo e prestimoso feito, além de preencher um lastimável vácuo, pois Bangu não tinha escola pública de espécie alguma. Pioneirismo puro, puro mesmo...548

Naquele momento, quando a Companhia criou, em 5 de julho de 1905, a escola - mantida com os próprios recursos - para os filhos dos funcionários da fábrica, é certo que muitas crianças ainda ficavam de fora das salas de aula, dedicando-se em tempo integral ao trabalho. Um relatório da própria Companhia, datado de 1903, enumera 31 crianças de até 10 anos (24 meninos e 7

\footnotetext{
547 ASSAF, Roberto. Bangu - Bairro operário, estação do futebol e do samba. Rio de Janeiro: Relume Dumará, 2001, p. 19.

${ }^{548}$ GRANADO, Paschoal José. João Ferrer-momentos históricos, esforço bibliográfico. Rio de Janeiro: s. d.
} 
meninas) e 205 menores de 11 a 15 anos (108 meninos e 97 meninas) trabalhando majoritariamente nas seções de cardas, fiação e tecelagem. Esses 236 menores representavam 19,4\% da mão de obra da fábrica, que contava com 1.212 empregados naquela ocasião. ${ }^{549}$

Em outubro de 1906, o presidente Rodrigues Alves compareceu ao bairro para visitar a fábrica e fazer uma solene inauguração do educandário, que passou a receber seu nome. Na ocasião, a Escola Rodrigues Alves - dividida em turmas para meninos e meninas - contava somente com 230 alunos e oferecia aulas de composição, geografia, português, aritmética e ditado. ${ }^{550}$

Em 1906, o número de alunos pulava para $350 .{ }^{551}$ Em 1908, já ampliava as matrículas, chegando a ter: "cerca de 400 alunos de ambos os sexos". ${ }^{552}$ Dois anos depois, em 1910, o número subia para 450. ${ }^{553}$ Pelo recenseamento de 1906, na freguesia de Campo Grande, onde estava situada a Fábrica Bangu, das 13.074 crianças e adolescentes até 15 anos, apenas 1.929 sabiam ler e escrever, ou seja, meros $14,75 \% .^{554}$

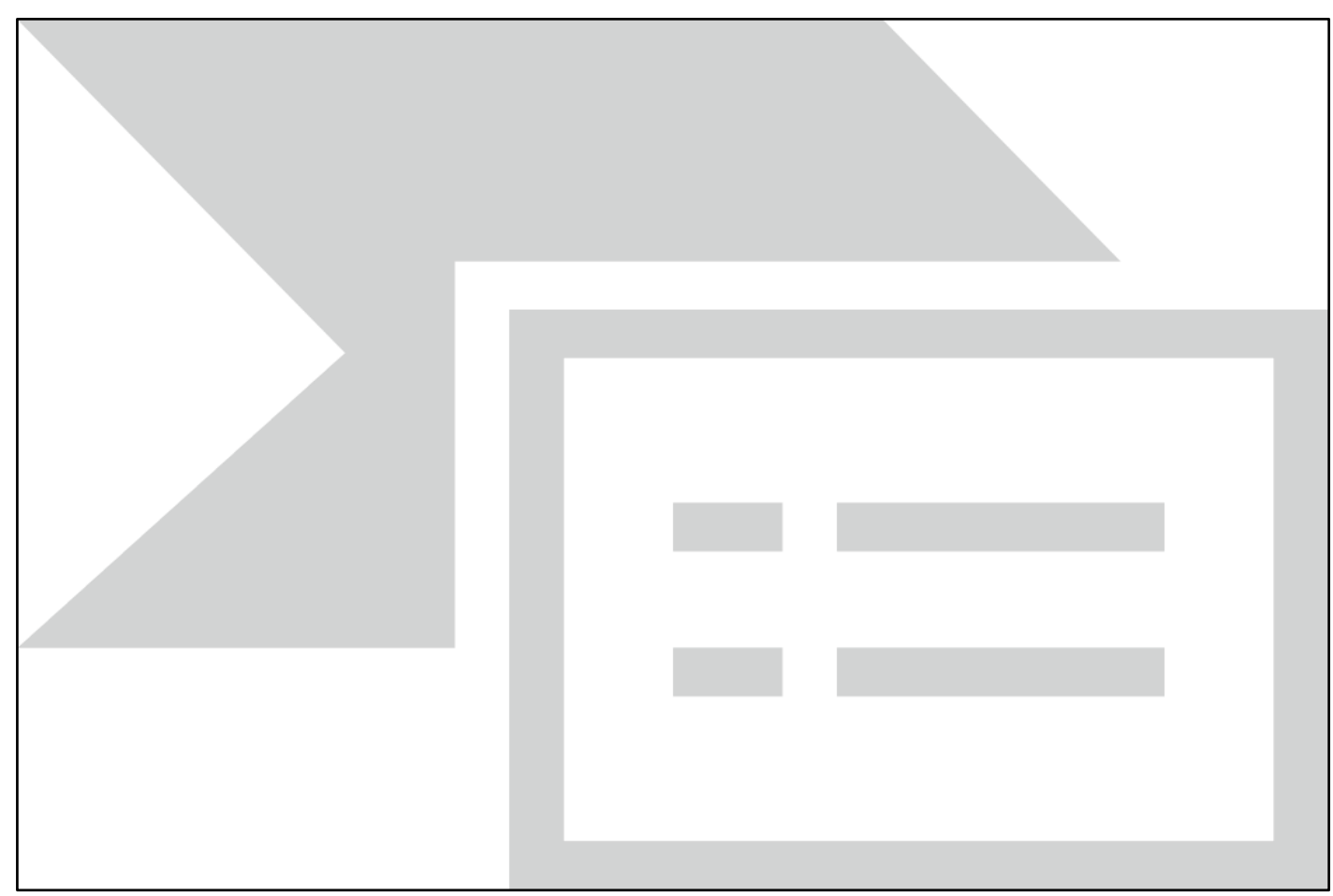

Figura 27 - Sala de aula exclusiva para as meninas da Escola Rodrigues Alves. Acervo: Grêmio Literário José Mauro de Vasconcelos.

\footnotetext{
549 OLIVEIRA (1991), p. 106.

${ }^{550}$ CORREIO DO BANGU, 6 de dezembro de 1908, p. 3

${ }^{551}$ DIÁRIO OFICIAL, 24 de fevereiro de 1906, seção 1, p. 22.

552 O PAIZ, 29 de abril de 1908, p. 2.

553 JORNAL DO BRASIL, 5 de outubro de 1910, p. 6.

${ }^{554}$ SENRA, Nelson de Castro. O Censo de 1906 do Rio de Janeiro. Rio de Janeiro: Publicações Pereira Passos, 2012, p. 343.
} 
No entanto, há ainda uma viva controvérsia entre letramento e trabalho industrial. Afinal, era ou não conveniente para uma fábrica ter operários alfabetizados? Alguns autores veem essas pequenas escolas fabris como uma arma adicional na mão dos patrões, pois se o pai perdia o emprego na Companhia por alguma falta grave, fatalmente, o filho também não teria mais como continuar seus estudos naquela instituição. A historiadora Margareth Rago aponta uma das razões ideológicas para que as fábricas têxteis investissem na educação das crianças:

O interesse pela educação dos operários desde a infância reflete a intenção disciplinadora de formar cidadãos adaptados que internalizassem a ética puritana do trabalho comportando-se de modo a não ameaçar a ordem social.

Formar o caráter da criança, incutindo-lhe o amor ao trabalho, o respeito pelos superiores em geral, as noções de bem e mal, de ordem e desordem, de civilização e barbárie; enfim, os princípios da moral burguesa. ${ }^{555}$

Para Stanley Stein, era útil aos patrões ter empregados que, ao menos, soubessem ler os regulamentos disciplinadores da própria Companhia: "A falta de escolas subvencionadas pelo governo ou pela comunidade deixou ao encargo dos fabricantes a tarefa de proporcionar educação primária aos empregados analfabetos. Assumiram-na porque era vantajoso para a fábrica ter empregados alfabetizados que soubessem ler instruções". 556

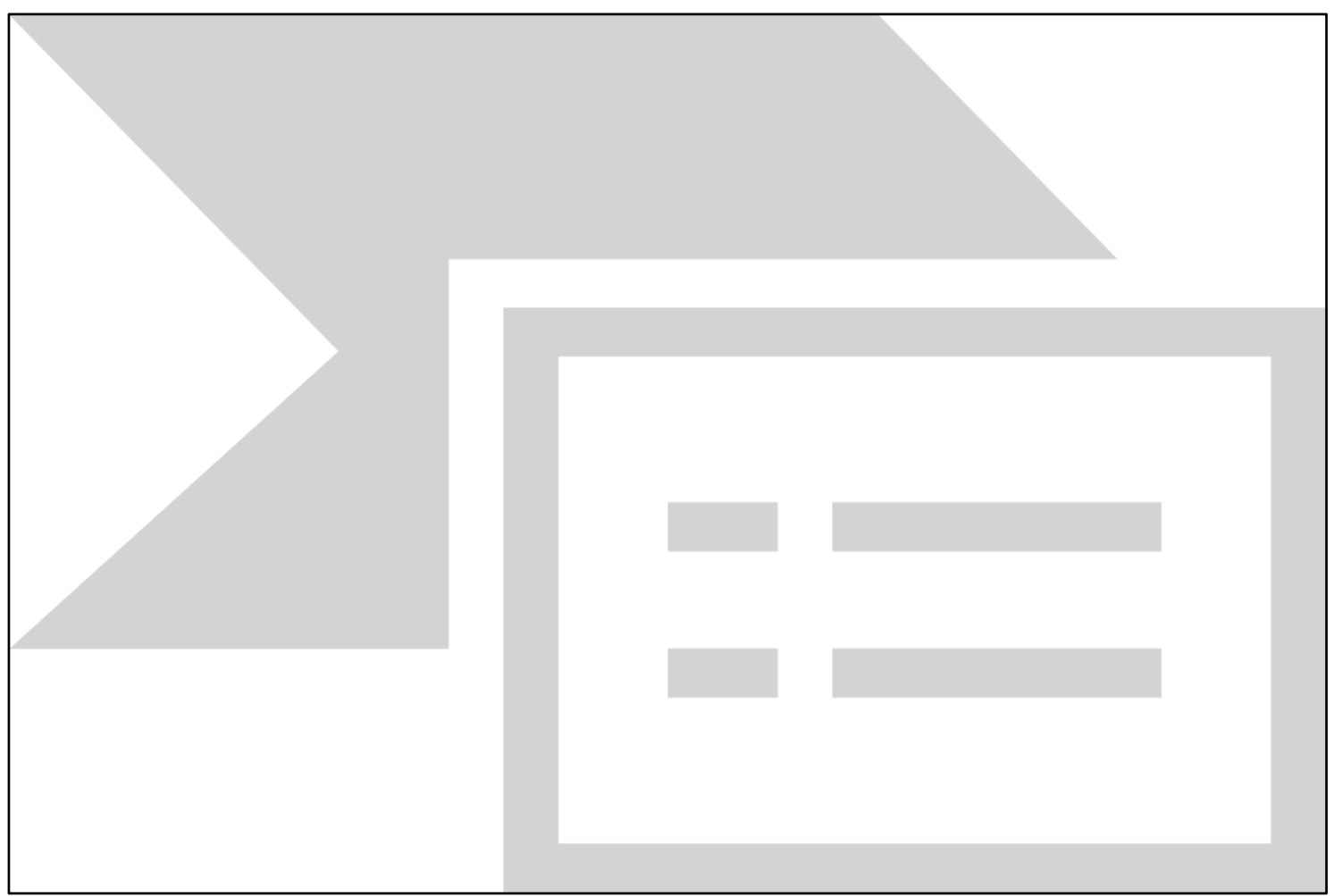

Figura 28 - Sala de aula exclusiva para meninos na Escola Rodrigues Alves. Acervo: Grêmio Literário José Mauro de Vasconcelos.

\footnotetext{
${ }^{555}$ RAGO (2014), pp. 159-161.

556 STEIN, Stanley Julien. Origens e Evolução da Indústria Têxtil no Brasil, 1850-1950. Rio de Janeiro: Editora Campos, 1979, p. 71.
} 
A preocupação da direção em prover a vila de benfeitorias era algo comum naquele início de século XX: a fábrica oferecia condições mínimas de vida e deixava "homens, mulheres e crianças, alegres, satisfeitos da sua sorte porque nada lhes falta: o médico, a farmácia, a escola, as diversões, o conforto"; 557 ao mesmo tempo em que completava lacunas que o próprio Estado deixava.

O relatório anual da Companhia não deixa dúvidas da importância atribuída à escola criada por João Ferrer no contexto daquela vila operária, valendo todo "sacrifício de sua criação e manutenção":

Com a máxima regularidade tem funcionado o nosso estabelecimento de instrução, de onde tantos bens dimanam para os nossos operários e seus filhos, que em sua falta teriam de ou deixar permanecer sua inteligência em trevas, ou de palmilhar longos caminhos em busca de instrução.

Essa escola, benemérita de toda a nossa atenção e carinhoso zelo, de sobra compensa com a sua crescente frequência de alunos, o sacrifício de sua criação e manutenção. ${ }^{558}$

Mas, a educação das crianças era feita aos poucos: os filhos dos mais pobres continuavam trabalhando na fábrica e excluídos da alfabetização, como atesta este depoimento de uma menina, “que tem no máximo 12 anos de idade” à Gazeta de Notícias, em 1918:

\section{(...) - E você já sabe ler?}

A menina ficou um tanto envergonhada para responder e depois de alguma relutância disse:

- O tempo é tão pouco para nós cavarmos a vida e se ainda perdermos horas em estudos, pior será. Enfim, se saber ler é muito bonito, nada nos adianta na fábrica, onde os mestres só dão valor à agilidade, aumentando os números dos teares conforme a ligeireza da trabalhadora. Há uma escola da fábrica, mas a sua frequência é muito diminuta relativamente ao número dos operários menores que a fábrica tem. ${ }^{559}$

Por mais que o discurso da "menina de 12 anos" esteja politizado demais e perfeito aos olhos de qualquer socialista da época - ainda mais em um período em que a fábrica estava em greve causando-nos dúvidas se ela é uma personagem real ou se apenas um meio do jornalista expressar o que via naquela comunidade operária. O fato é que, quando do Recenseamento de 1920, na freguesia de Campo Grande, das 2.743 pessoas que trabalhavam em indústrias têxteis, exatas 1.109 possuíam idades inferiores a 20 anos, totalizando 40,43\%. ${ }^{560}$ Uma reportagem de 1917 indica que a Companhia empregava 700 crianças, ${ }^{561}$ número elevado e que pode nos sugerir que havia maior número de menores nos teares do que nas salas de aula.

Ainda assim, na freguesia de Campo Grande, considerada uma área rural da capital federal, a população total que sabia ler e escrever alcançava o índice de 42,20\% (22.087 de 52.328

\footnotetext{
557 JORNAL DO COMMERCIO, 12 de outubro de 1906, p. 1.

${ }^{558}$ DIÁRIO OFICIAL, 24 de fevereiro de 1906, seção 1, p. 22.

${ }^{559}$ GAZETA DE NOTÍCIAS, 25 de novembro de 1918, p. 1.

${ }^{560}$ RECENSEAMENTO DE 1920 - $4^{\circ}$ Censo geral da população do Brazil, $1^{\circ}$ da agricultura e das indústrias e $11^{\circ}$ da população da cidade do Rio de Janeiro (Districto Federal). Rio de Janeiro: Typographia da Estatística, 1926, p. 598.

${ }^{561}$ GAZETA DE NOTÍCIAS, 21 de março de 1917, p. 1.
} 
habitantes), bem maior que o índice nacional, que era de apenas $24,45 \%$, incluindo brasileiros e imigrantes. ${ }^{562}$

Nos primeiros anos de sua administração, a reputação de João Ferrer estava em alta e suas obras não cessavam: em 1906, municiou o Bangu A. C. de um campo de futebol, num terreno contíguo à fábrica para que a associação dos ingleses pudesse disputar o primeiro Campeonato Carioca da história. Nos anos anteriores, o time jogava dentro do jardim da própria fábrica. Para o jornalista Mario Filho: “O Bangu era um prolongamento da Companhia Progresso Industrial do Brazil. A fábrica se disfarçando em clube. O campo pegado no jardim da fábrica. Não se sabia onde acabava a fábrica, onde começava o clube". 563

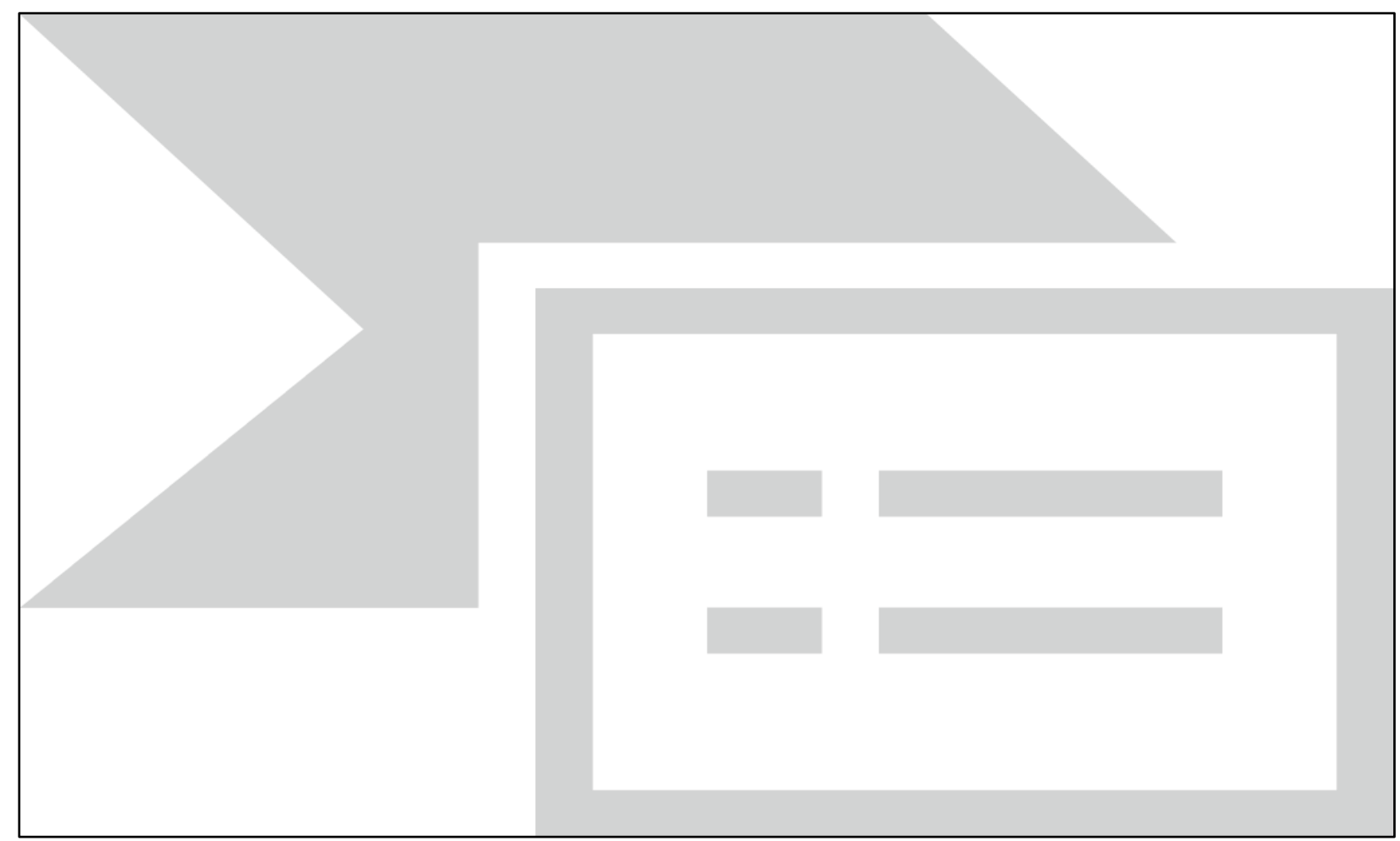

Figura 29 - "Como uma espécie de quintal da fábrica, o campo do Bangu aparecia como uma continuidade do espaço de trabalho. Tornando-se parte de suas instalações, parecia compor harmoniosamente o conjunto arquitetônico construído pela Companhia no distante bairro operário". 564

\footnotetext{
${ }^{562}$ RECENSEAMENTO de 1920, pp. 464-465.

${ }^{563}$ FILHO, Mário Rodrigues. O Negro no Futebol Brasileiro. $4^{a}$ edição. Rio de Janeiro: Editora Mauad, 2003, p. 90. Em relação à construção do campo de futebol numa área central do bairro, OLIVIERA (1991, p. 125) afirma que o local era anteriormente utilizado como uma feira de produtores rurais de Bangu, que funcionava somente aos domingos. João Ferrer teria destinado para esses rendeiros e pequenos produtores um mercado permanente para que eles pudessem continuar a vender seus produtos. FILHO (2003, p. 31) diz que com as sobras das verduras e legumes, o local acabara virando um depósito de lixo. Para ele: "o lixo era adubo, e do melhor, a grama pegou logo, e alastrou-se, cobrindo de verde o field do Bangu". GRANADO (1997, p. 40) chega até a identificar o jardineiro que trabalhou na confecção do campo: seria o português Augusto Ferreira. Ele e três irmãos teriam chegado a Bangu em 1889 para construírem o estabelecimento fabril.
}

${ }^{564}$ PEREIRA (2000), p. 259. 
A partir do momento em que passa a exercer um amplo domínio político sobre o bairro, promovendo a abertura de ruas e a urbanização da vila operária, o espanhol ganha uma "homenagem" da própria população local. O principal logradouro de Bangu - a rua que ficava no centro do bairro - chamava-se "Rua Estevão", em homenagem ao primeiro diretor-presidente da Companhia, Estevão José da Silva (1889-1895). Os tempos, porém, eram outros. Mais de uma década depois, ninguém se lembrava dos méritos do antigo português e os próprios moradores passaram a chamar a rua principal do bairro de "Rua Ferrer", ${ }^{565}$ mesmo que oficialmente, nos despachos da prefeitura do Distrito Federal, a rua ainda conservasse seu nome original. ${ }^{566}$

Na realidade, por ter comprado, em 1889, quatro imensas fazendas da região para ali construir uma fábrica e uma vila operária, a prefeitura do Distrito Federal entendia que Bangu era uma propriedade particular e os recursos destinados à freguesia de Campo Grande jamais deveriam ser utilizados naquele bairro. Só em 1917 é que a fábrica entregou Bangu à prefeitura. Por isso, até então, tudo o que o bairro possuía - incluindo a escola, a igreja, o teatro, o campo de futebol, o encanamento de água, iluminação das ruas - "era fruto do esforço de sua gente com uma colaboração intensiva da fábrica", como ressalta o memorialista Paschoal José Granado. ${ }^{567}$

João Ferrer, agindo como um verdadeiro prefeito, sabia que poderia não só "virar nome de rua", mas também mostrar ao operariado que a vida do trabalhador em Bangu era melhor do que em outros bairros do Rio de Janeiro.

Naquele específico ano de 1906 foi realizado entre os dias 15 e 22 de abril, no Centro Galego, à Rua da Constituição n ${ }^{\circ}$ 32, o Primeiro Congresso Operário Brasileiro, que pretendia alinhar o discurso dos trabalhadores e especificava quais pontos deveriam ser levantados na luta contra os patrões. Enquanto em Bangu, mestres, contramestres e operários estavam cada vez mais próximos, tendo a chance de participar do mesmo clube de futebol, o Congresso Operário, naturalmente, ia na direção oposta: "Considerando que os mestres e contramestres são, pelo lugar que ocupam, os verdadeiros representantes dos patrões, o Congresso entende que os mestres e contramestres devem ser excluídos dos sindicatos operários". 568

É provável que com os ânimos exaltados pelo Congresso, os operários das duas fábricas têxteis do Jardim Botânico - a Carioca e a Corcovado - tenham deflagrado um movimento grevista logo no mês de maio, que acabou perdurando por 22 dias. ${ }^{569}$

\footnotetext{
565 GUIMARÃES, Murillo. Uma rua chamada Ferrer. Rio de Janeiro: edição do autor, 1996, p. 15.

566 GAZETA DE NOTÍCIAS, 22 de julho de 1906, p. 10.

${ }^{567}$ GRANADO, Paschoal José. O alvorecer de Bangu. Rio de Janeiro: edição própria, 1997, p. 21.

${ }^{568}$ HALL, Michael McDonald \& PINHEIRO, Paulo Sérgio. A classe operária no Brasil - documentos (1889 a 1930). Volume I - O movimento operário. São Paulo: Editora Alfa Ômega, 1979, pp. 50-51.

${ }^{569}$ LOBO, Eulália Maria Lahmeyer (org.). Rio de Janeiro operário - natureza do Estado, conjuntura econômica, condições de vida e consciência de classe. Rio de Janeiro: Access Editora, 1992, p. 35.
} 
Por coincidência, justo neste período, os operários da Fábrica Bangu entraram em confronto com a polícia no dia 23 de maio. O conflito se deu porque o delegado local, Arthur Cherubim, devido às reclamações dos diretores da fábrica de tecidos, determinou que se detivessem alguns indivíduos conhecidos como "vagabundos". Na época, pelo artigo 399 do Código Penal de 1890 era possível recolher à prisão celular de 15 a 30 dias, quem não tinha profissão certa, ou seja, os chamados "vadios". ${ }^{570}$ Dessa forma, Jerônimo José da Silva, José Mariano Barbosa, Carlos de Oliveira Braga e Ângelo Corsetti, conhecidos como "desocupados”, estavam sendo levados pelos policiais em direção ao trem que os recolheria à delegacia de Campo Grande, "aos empurrões e aos pontapés". Segundo os jornais, "uma massa de cerca de 200 operários, não podendo assistir àquela cena sem um protesto, prorrompeu em uma vaia formidável. A polícia pretendeu atacar e prender mais operários. Isso valeu ser apedrejado o trem onde se achava a polícia com os presos". ${ }^{571}$

Segundo o delegado Arthur Cherubim, "a medida foi tomada de acordo com os diretores da fábrica, e que a polícia pretende unicamente sanear o lugar de vagabundos que ali perambulam, não tendo prendido operário algum". 572

O apedrejamento do trem e o conflito entre populares e policiais motivado pela prisão desses quatro homens, que não sabemos se eram realmente operários presos por engano ou se eram “desocupados" imputados no artigo 399, fez com que a imprensa logo entendesse que estava havendo uma greve em Bangu, tal como ocorria na Corcovado e na Carioca. Mas como? Afinal, Bangu era outro nas mãos do administrador João Ferrer. Como aquela massa operária poderia querer afrontar um diretor tão carismático com uma greve?

AS GREVES - Na Corcovado - Na Bangu - Requisição de forças - Prontidão de forças

(...) Bangu, a cidade operária onde os homens do trabalho saem de casa para as fábricas e só à tarde vão respirar o ar livre das praças e dos campos; Bangu, a localidade onde os operários são quase a totalidade da sua povoação, onde os operários são tão ordeiros e pacatos e unidos que têm o seu clube, o seu teatro, a sua banda de música, o seu campo de football; Bangu, com tudo isso de bom, foi anteontem à noite posto em estado de sítio pelo delegado da $3^{\mathrm{a}}$ suburbana. ${ }^{573}$

A notícia da greve acabou sendo infundada. A paz reinava na vila operária, mas João Ferrer estava atento às articulações do movimento operário. Sua mais nova obra era a construção de um gigantesco teatro que seria doado à Sociedade Musical Progresso de Bangu, que logo mudaria o nome, por sugestão do próprio Ferrer, para Casino Bangu. Apesar de já ter sido entregue à comunidade em 1906, o teatro não tinha sido oficialmente inaugurado. A festa de gala prevista para a chuvosa noite de 17 de novembro daquele ano realmente ocorreu, mas não contou com a presença

\footnotetext{
570 Sobre o Código Penal de 1890, vide o site do Senado Federal: http://legis.senado.gov.br/legislacao/ListaPublicacoes.action?id=66049

571 GAZETA DE NOTÍCIAS, 24 de maio de 1906, p. 3.

572 O PAIZ, 24 de maio de 1906, p. 3.

${ }^{573}$ GAZETA DE NOTÍCIAS, 24 de maio de 1906, pp. 2-3.
} 
de João Ferrer, que mandou um telegrama desde Petrópolis escusando-se de participar "por incômodo de sua saúde". 574

Como a inauguração de um prédio erguido pela própria Companhia sem a presença do principal nome daquela comunidade de nada valia, outra cerimônia foi marcada para, enfim, inaugurar o Casino Bangu sob os olhos de João Ferrer. A data foi, então, escolhida "a dedo": $1^{\circ}$ de maio de 1907.

O dia do trabalho já era comemorado no Rio de Janeiro desde 1891, em homenagem aos cinco líderes operários condenados à morte, em Chicago, em 1886. No entanto, com a realização do Primeiro Congresso Operário Brasileiro, em 1906, e sua decisão de desencadear a partir de $1^{\circ}$ de maio de 1907 uma campanha pelas oito horas, a data passou a ganhar uma conotação mais reivindicatória: anarquistas e sindicalistas revolucionários sustentavam tratar-se de uma jornada de luta, de reflexão e, até mesmo, de luto para a classe operária. 575

Em Bangu, numa fábrica que empregava 1.651 operários, ${ }^{576}$ no entanto, nenhuma reivindicação ocorreu. Muito pelo contrário. João Ferrer antecipou-se a qualquer manifestação, transformando o dia numa data festiva, com a inauguração de um jardim dentro da fábrica, banda de música executando "alegres marchas", jogo de futebol entre o Bangu e o Esperança ${ }^{577}$ e, à noite, a solene inauguração do teatro, desta vez com a presença do diretor-presidente Manoel Antônio da Costa Pereira e do diretor-gerente João Ferrer, evento noticiado com pompa pela Gazeta de Notícias:

O dia $1^{\circ}$ de maio, consagrado à festa do trabalho, não podia ter mais brilhante comemoração do que aquela que fizeram os operários da Fábrica de Tecidos de Bangu. Por lá o dia foi todo de uma festividade encantadora. A fábrica não trabalhou (...) e a alegria pairava por todo aquele recanto, onde impera o trabalho, onde a atividade tem o seu altar.

Começava a escurecer quando os srs. Comendadores Costa Pereira e João Ferrer chegaram ao vasto edifício do Casino, que ia ser inaugurado. O Casino é o teatro de Bangu. Construído pelos próprios operários da fábrica, ele representa o maior esforço que se pode imaginar daquela gente ativa e boa. O Casino é positivamente um excelente teatro, que obedece rigorosamente as construções modernas, cheio de conforto e de luz. O seu velarium de veludo negro-rubro esconde um palco chique em que se ostentam cenários do inteligente e hábil artista Dumiense. Toda a decoração foi inteligente e lindamente feita pelo sr. José Villas Boas, gravador da Fábrica de Tecidos.

Foi aí, nesse belíssimo teatro, que se celebrou a solenidade de inauguração. O professor Jacintho Alcides pronunciou um discurso alusivo ao ato, mostrando com aquele exemplo vivo o quanto podem a união e a amizade que reinam entre os operários de Bangu.

Em seguida, a graciosa menina Ermelinda Fernandes disse um lindo discurso, agradecendo aos dignos diretores da fábrica, em nome de seus companheiros e companheiras de trabalho, à boa vontade com que se houveram, apoiando e auxiliando a construção daquele edifício que se ia destinar às noites ao recreio e à instrução daqueles que, aos dias, se entregam ao trabalho e à luta pela vida.

\footnotetext{
574 JORNAL DO BRASIL, 19 de novembro de 1906, p. 4.

575 BATALHA, Cláudio. "Cultura associativa no Rio de Janeiro da Primeira República" in: BATALHA, FORTES, \& SILVA (2004), pp. 106-107.

576 OLIVEIRA (1991), p. 110.

${ }^{577}$ GAZETA DE NOTÍCIAS, 5 de maio de 1907, p. 4.
} 
(...) Depois tiveram lugar as danças. As bandas da fábrica e dos bombeiros tocavam sem cessar e no vasto salão do Casino era enorme a concorrência. Correu o baile no maior entusiasmo e as danças se prolongaram até alta madrugada.

E foi assim, com essa encantadora festa, que os operários da Fábrica de Tecidos de Bangu comemoraram a festa do trabalho. ${ }^{578}$

O editorial da Gazeta de Notícias era uma verdadeira antítese do que pregavam os anarquistas e socialistas do período. Conforme a jornal, na maior fábrica de tecidos da Capital Federal, os operários não tinham reivindicado nada no $1^{\circ}$ de maio. Muito pelo contrário, uma menina, das muitas que trabalhavam na Companhia, aparecia no palco para agradecer aos dignos diretores da fábrica pela boa vontade que tiveram ao auxiliarem na construção do teatro.

A “obra social” da fábrica continuou com o arruamento do bairro, que durou de 1907 a 1916, período em que a Companhia contratou os serviços do engenheiro mineiro Orozimbo do Nascimento. Em 1908, iniciou a captação das águas do rio da Prata - num longo percurso de 15 quilômetros - para movimentar uma pequena usina e gerar eletricidade, sendo Bangu o primeiro local da zona suburbana do Distrito Federal a contar com luz elétrica; tanto que entre 1910 e 1913 já com o apoio da Light and Power Company - a fábrica mudava todo seu maquinário a vapor pelo acionamento por energia elétrica. ${ }^{579}$

As ações de João Ferrer tentavam consolidar a imagem da Fábrica Bangu como a mais pujante da Capital Federal. Contratou o maestro Anacleto de Medeiros - o mais famoso do Rio de Janeiro - para comandar a banda de música dos operários entre 1904 e 1907; ${ }^{580}$ e participou da Exposição Nacional da Praia Vermelha, em 1908, ostentando um pavilhão próprio naquele evento, os demais ou eram de órgãos públicos (como o dos Correios e Telégrafos; da Inspetoria de Matas, Jardins, Arborização, Caça e Pesca; do Corpo de Bombeiros) ou dos estados da Federação (São Paulo, Bahia, Minas Gerais) ou de outro país (Portugal). ${ }^{581}$

O Pavilhão da Fábrica Bangu - Sem favor nenhum é um dos mais lindos da exposição. Parece uma pequena mesquita mourisca, com as suas cúpulas brilhando sob a ação do sol, e tendo nas flechas pequenas bandeirolas de cores vivas. Representação especial da afamada Fábrica Bangu. Foi projetado pelo sr. José Villas Boas e decorado pelo sr. Martinho Dumiense. Na parte interna forma um só salão, sendo as paredes e o teto revestidos de tecidos. Os produtos são ali expostos em vitrines simples e elegantes. ${ }^{582}$

Ao final da Exposição, surgiu a ideia de aproveitar as madeiras do gigantesco estande da Praia Vermelha, levá-las para Bangu e fazer nos fundos do campo do futebol um novo pavilhão, que servisse para municiar o Bangu A. C. de uma sede social, devidamente entregue em 24 de agosto de 1909. "Pavilhão capaz de fazer morrer de raiva o seu colega mourisco de Botafogo. Aí os seus

\footnotetext{
${ }^{578}$ Idem, 3 de maio de 1907, p. 3.

579 GRANADO, Paschoal José. João Ferrer-momentos históricos, esforço bibliográfico. Rio de Janeiro: s. d.

${ }^{580}$ DINIZ, André. O Rio musical de Anacleto de Medeiros. A vida, a obra e o tempo de um mestre do choro. Rio de Janeiro: Jorge Zahar Editor, 2007, pp. 66-69.

581 PEREIRA, Margareth da Silva. "A Exposição Nacional de 1908 ou o Brasil visto por dentro" in: PEREIRA, Margareth da Silva (org.). 1908 - Um Brasil em exposição. Brasília: Casa 12, 2011, pp. 35-43.

582 CORREIO DA MANHÃ, 2 de agosto de 1908, p. 3.
} 
sócios encontrarão, além de um luxuoso vestiário onde se preparam para a luta, salas espaçosas para palestra, refeições". 583

Com ações deste tipo, João Ferrer vinha conseguindo manter sob controle o operariado. Fora isso, contava também com o apoio maciço da imprensa, que enaltecia qualquer novo feito dos industriais. O jornalista Alcindo Guanabara era um dos seus mais ardorosos defensores:

(...) É justo tecerem-se encômios ao homem que tem acumulado esforços sobre esforços para fazer do Curato de Bangu um verdadeiro paraíso. (...) Novos prédios se levantam, novas ruas se rasgam e surgem, adiante, outros horizontes, que atestarão a grandeza deste recanto de terra americana. E um só homem, com a satisfação a florir-lhe nas faces e uma força de vontade extraordinária, que não recua diante de qualquer embaraço, é quem opera tanta transformação, como se uma vara mágica atuasse e fizesse surgir deste solo abençoado a futura cidade do Bangu. (...) Por isso, sr. João Ferrer, abraçamo-lo como quem abraça um herói das priscas eras. ${ }^{584}$

Críticas? Somente da imprensa operária, como a Voz do Trabalhador ${ }^{585}$ que, em 1909, abriu uma edição com a manchete "A escravidão em Bangu":

(...) Como a imprensa não se cansa de agitar o seu turíbulo, incensando a benemerência dos senhores de Bangu, tivemos vontade de conhecer a fábrica e saber as condições econômicas dos companheiros que ali trabalham. (...) Soubemos que o operário mais ágil não conseguia mais de $5 \$$ [por dia], que se trabalhava das 6 da manhã às 5 da tarde e que o aluguel das casas era de $45 \$$ por mês com direito à luz elétrica. Ficamos inteirados. A situação em Bangu era igual ou pior do que a das outras fábricas. Não havia liberdade, mas havia uma forte depressão mental para fazer esquecer e até louvar o cativeiro. (...) Parece que não há ali um só operário que conheça bem a obra dos senhores de Bangu. Pelo menos, vimos companheiros que proclamavam a benemerência dos exploradores. ${ }^{586}$

Quem fosse de fora de Bangu talvez tivesse a visão de que a fábrica explorava seus trabalhadores como qualquer outra, com salários baixos e jornadas exaustivas. Quem vivia em Bangu naquela época parecia ter outra visão do diretor-gerente, especialmente pela sua tenacidade em urbanizar todo o bairro. Paschoal José Granado, biógrafo de João Ferrer, via-o exageradamente como "um nome aureolado, ungido dos deuses". 587 O jovem $1^{\circ}$ secretário do Bangu A. C., Guilherme Pastor, intitularia Ferrer de o "benemérito propugnador do progresso de Bangu", numa publicação datada de 1916.

Em 1910, a diretoria da Companhia terminou por conquistar de vez o operariado ao entregar uma antiga reivindicação da comunidade: a Igreja de São Sebastião e Santa Cecília. A matriz começou a ser construída em 1908 com recursos provenientes de uma "subscrição" e "valiosos donativos" dos diretores da fábrica. Dessa forma, com uma grandiosa festa que durou de sábado até segunda-feira, o diretor-presidente Manoel Antônio da Costa Pereira, o diretor-gerente João Ferrer e o diretor-tesoureiro Francisco Ferreira Real entregaram o templo aos banguenses.

\footnotetext{
583 A IMPRENSA, 23 de maio de 1909, p. 4.

${ }^{584}$ Idem, 9 de junho de 1909, p. 4.

${ }^{585}$ O jornal teve duas fases: a primeira estendeu-se de $1^{\circ}$ de julho de 1908 a dezembro de 1909, quando se publicaram 21 números. A segunda iniciou-se a $1^{\circ}$ de janeiro de 1913 e, ao que parece, foi até julho de 1915, com edições quinzenais oscilando entre 3.000 a 4.000 exemplares. Vide: FAUSTO (1977), p. 94.

${ }^{586}$ A VOZ DO TRABALHADOR, 15 de novembro de 1909, p. 1.

${ }^{587}$ GRANADO (1997), p. 7.
} 
Coincidentemente, o último dia de festividades, 9 de maio, que contou com uma missa do Cardeal Dom Joaquim Arcoverde, uma procissão e uma grande queima de fogos, era também o aniversário natalício de João Ferrer. "A população de Bangu é calculada de 9 a 10 mil almas e sem medo de errar, pode-se afirmar que destes muito poucos foram os que não tomaram parte nas festas destes três últimos dias", dizia o Jornal do Brasil, numa longa matéria em que não foram poucos os elogios à diretoria da fábrica que "não se tem esquecido de seus operários, um dos mais poderosos fatores do seu atual estado de prosperidade. (...) A diretoria desse estabelecimento dispensa-lhes o carinho e o conforto de que eles tanto necessitam". 588

A imprensa operária via tudo isso com maus olhos: "A liberdade de Bangu consistia em permitir a adoração aos deuses das fábulas e o exercício dos cultos religiosos. Era preciso não deixar livre e vivo o instinto de análise e investigação e para isso não há nada melhor do que as religiões", dizia A Voz do Trabalhador. ${ }^{589}$

Outro jornal, O Amigo do Povo, editado em São Paulo por Neno Vasco, aberto às ideias do sindicalismo revolucionário, também pregava contra a relação operário-igreja: "compreendereis que é inteiramente inútil que confieis aos padres as vossas dores. Aconselhando-vos a resignação, o que eles fazem é impedir-vos de reagir contra quem vos oprime". 590

Para a historiadora Ângela de Castro Gomes, o anticlericalismo anarquista era uma forma específica de contestar a sociedade da época e o ataque à religião era um modo de criticar a autoridade política opressiva e uniformizadora. ${ }^{591}$

Com a igreja, João Ferrer encerrava um ciclo de grandes obras na vila operária e, evidentemente, inspirava outros industriais que procuravam soluções para conter a insatisfação de seus trabalhadores. Bastava investir na urbanização do próprio espaço, transformar parte dos lucros em ações sociais, cobrir lacunas que o Estado era incapaz de realizar para mostrar ao operariado que ali era um bom lugar para se viver e, mesmo que não fosse verdade, para se trabalhar também, mantendo-os "presos" a um laço de gratidão com este patrão tão bondoso. A imprensa diária corroborava essa opinião, enaltecendo a "obra social” desses homens tão generosos:

\footnotetext{
588 JORNAL DO BRASIL, 12 de maio de 1910, p. 7.

${ }^{589}$ A VOZ DO TRABALHADOR, 15 de novembro de 1909, p. 1.

${ }^{590}$ O AMIGO DO POVO, 17 de janeiro de 1904.

${ }^{591}$ GOMES, Ângela de Castro. A invenção do trabalhismo. $3^{a}$ edição. Rio de Janeiro: Editora FGV, 2005, p. 102.
} 


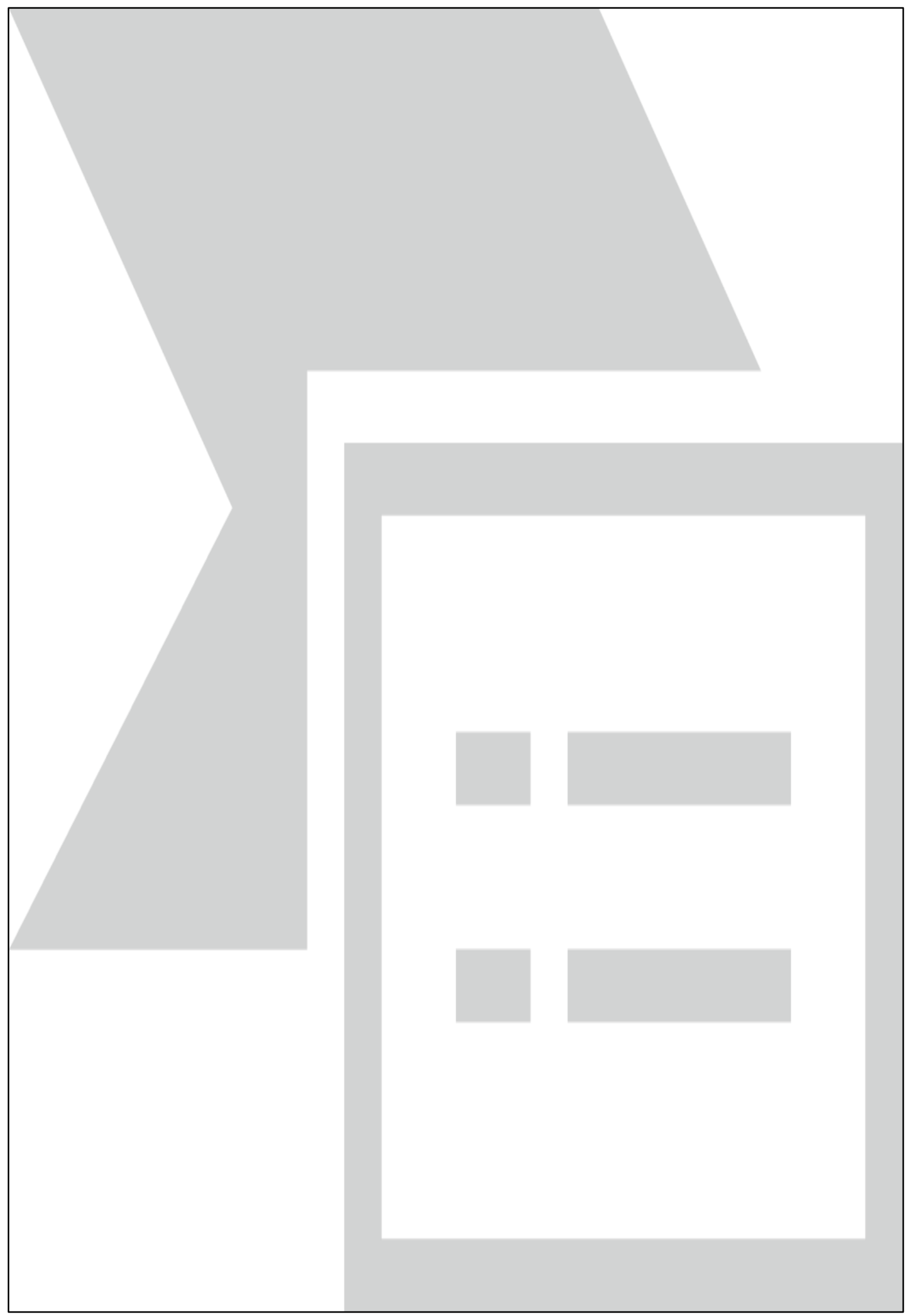

Figura 30 - A inauguração da igreja de Bangu ganhou destaque na imprensa. ${ }^{592}$

${ }^{592}$ REVISTA DA SEMANA n ${ }^{\circ}$ 525, 5 de junho de 1910, p. 20. 
"Sente-se a gente bem, respirando aquela atmosfera de trabalho honrado. E tem-se satisfação por viver em um país onde há homens como os srs. Costa Pereira, Real e Ferrer, verdadeiros beneméritos, que muito fazem pela nossa prosperidade" $" 593$ - dizia a Gazeta de Notícias, ainda em 1907, para complementar, em 1910: "Vamos apreciando como o capital protege o trabalhador e enche de comodidade, conforto e prazer a vida dos seus operários (...) os campos de football e outros gêneros de sport, a igreja, a Escola, o Casino-Teatro-Club (...) Fica-se com vontade de pedir um lugar de operário da Bangu". 594

Dessa forma, a resistência inicial dos operários e os pequenos conflitos eram substituídos pela resignação de viver em um lugar que parecia prover-lhes de tudo o que era necessário: moradia, médico, farmacêutico, sepultamento, "mediante um insignificante desconto mensal".

Em São Paulo, o industrial Jorge Street, dono da Companhia Nacional de Tecidos de Juta, no bairro do Belenzinho, seguiu a cartilha deixada pelos diretores da Companhia Progresso Industrial do Brazil, em Bangu, e construiu, entre 1911 e 1916, a Vila Maria Zélia para seus operários. Na sua expectativa utópica, municiou a vila de tanta coisa que o trabalhador não precisava sair de lá para nada.

Em redor da fábrica mandei construir casas para moradia dos trabalhadores, com toda a comodidade e conforto da vida social atual. Depois um grande parque com coreto para concertos, salão para representações e baile; escola de canto coral e música, um campo de football; uma grande igreja com batistério; um grande armazém com tudo o que o operário possa ter necessidade para sua vida, (...) uma sala de cirurgia-modelo e uma grande farmácia (...) uma escola para os filhos de operários e creches para lactantes (...) Quis dar ao operário a possibilidade de não precisar sair do âmbito da pequena cidade que fiz construir à margem do rio, nem para a mais elementar necessidade da vida. Consegui, assim, proporcionando, também, aos operários, distração gratuita dentro do estabelecimento, evitar que frequentem bares, botequins e outros lugares de vício, afastando-os especialmente do álcool e do jogo. ${ }^{595}$

A grande empresa têxtil, sobretudo quando localizada na periferia das cidades, tendeu a converter-se em um núcleo até certo ponto autônomo, com a implantação de serviços que revelam a mudança de comportamento de alguns industriais. Para o historiador Boris Fausto, é provável que os benefícios, envolvendo um cálculo mais complexo, fossem percebidos pelos trabalhadores como efetivas vantagens. De qualquer forma, a arregimentação resultou em fonte adicional de poder dos empresários sobre os trabalhadores. ${ }^{596}$ Margareth Rago tem um pensamento semelhante, acreditando que "a autoimagem paternalista que alguns industriais constroem, e que a historiografia incorpora sem questionar sua dimensão ideológica, visa reforçar sua autoridade, simbolizada na figura do pai, e assegurar a integração do trabalhador ao aparato produtivo".597

\footnotetext{
${ }^{593}$ GAZETA DE NOTÍCIAS, 10 de setembro de 1907, p. 1.

${ }^{594}$ Idem, 5 de outubro de 1910, p. 2.

595 Apud. RAGO (2014), p. 233.

${ }^{596}$ FAUSTO (1977), pp. 116-117.

${ }^{597}$ RAGO (2014), pp. 52-53.
} 
As obras e as doações feitas pela diretoria da fábrica, por mais que impressionassem positivamente o povo de Bangu, podem ser vistas também como uma retribuição pelos altos lucros da Companhia após 20 anos de funcionamento. Em 1910, cada ação da companhia (valor ao par: 200 mil-réis) foi cotada na Bolsa de Valores do Rio em 280 mil-réis. O agente especial do Departamento de Comércio e Trabalho dos Estados Unidos, William Alexander Graham Clark, concluiu logo: "se um antigo acionista vendesse suas ações em $1^{\circ}$ de janeiro de 1910, teria recebido de volta o seu investimento original com um lucro igual ou superior a $320 \%$ pelos vinte anos de uso do seu dinheiro, ou seja, $16 \%$ ao ano. Os dividendos médios pagos pela Companhia foram de, pelo menos, $10 \%$ em dinheiro, ao ano; como a Companhia apresentou também um grande superávit, os seus lucros líquidos efetivos, desde sua entrada em funcionamento até $1^{\circ}$ de janeiro de 1910 , devem ter sido, no mínimo, de $25 \%$ ao ano". 598

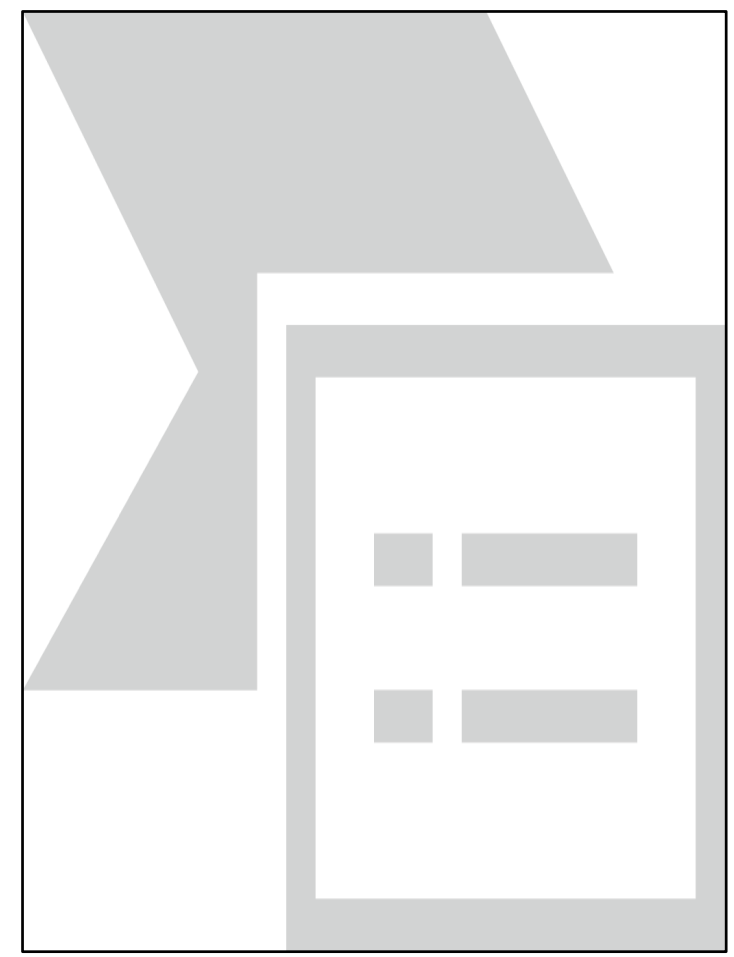

Figura 31 - O benemérito João Ferrer, em fotografia de 1905. Acervo: Grêmio Literário José Mauro de Vasconcelos. 


\section{1 - Apogeu e queda de João Ferrer}

Durante a primeira década de funcionamento da Companhia, sob a direção dos diretoresgerentes portugueses Antônio Xavier Carneiro e depois de Eduardo Gomes Ferreira, Bangu aparecia nos jornais em épocas de greves, paredes, protestos contra o capitão Jorge Estrella, alguns acidentes de trabalho envolvendo menores, brigas entre imigrantes e descarrilamentos na linha férrea de alguma composição que ia para a localidade. Não era uma imagem positiva.

João Ferrer mudou isso. Antes dele, o povoado de Bangu tinha recebido apenas um visitante realmente ilustre: o presidente Manoel Ferraz de Campos Salles, acompanhado do Ministro da Fazenda Joaquim Murtinho, em 19 de dezembro de 1899. ${ }^{599}$ No entanto, para o cronista João do Rio, a ida a Bangu teve outro intuito: "O sr. Murtinho e o sr. Campos Salles visitaram as fábricas para ver a maneira prática de aplicar o imposto de consumo", ${ }^{600}$ que passou a ser cobrado sobre catorze itens manufaturados, incluindo "os tecidos de lã e algodão que forem consumidos no território da República dos Estados Unidos do Brasil". ${ }^{601}$

Depois que João Ferrer começou a fazer a urbanização do bairro -, revogando, inclusive, uma “infeliz proibição do sr. Eduardo Gomes Ferreira" que impedia particulares de construir casas de alvenaria e cobertas de telhas em terrenos da fábrica ${ }^{602}$-, Bangu passou a servir de rota "turística" para visitantes ilustres e políticos nacionais e estrangeiros. Junto com os "figurões", no mesmo trem especial, vinham os fotógrafos e os representantes de jornais como O Paiz, Correio da Manhã, Jornal do Commercio, Jornal do Brasil, Gazeta de Notícias. Tratados com toda a amabilidade pelos diretores da Companhia, os jornalistas escreviam no dia seguinte que Bangu era "o recanto pitoresco desta Capital"603 e louvavam o quanto era bom ser operário da fábrica, sem se preocupar com as jornadas realmente longas, com o calor absurdo que fazia dentro das seções, dos riscos a que os menores se submetiam no trabalho têxtil. No mundo "cor de rosa" da grande imprensa, todos os operários "manifestam a sua satisfação para com a direção da Companhia, são pagos pontualmente e tratados com benevolência". ${ }^{604}$ Para os jornalistas da Belle Époque, em vez do suor de milhares de operários, foi "a varinha mágica do trabalho [quem] operou tudo aquilo que deslumbra e seduz o visitante!". 605

\footnotetext{
599 JORNAL DO BRASIL, 20 de dezembro de 1899, p. 1.

${ }^{600}$ GAZETA DE NOTÍCIAS, 24 de outubro de 1909, p. 1.

${ }^{601}$ BASTOS, Ana Marta Rodrigues \& WEID, Elisabeth von der. O Fio da Meada - Estratégia de expansão de uma indústria têxtil - Companhia América Fabril (1878-1930). Rio de Janeiro: Fundação Casa de Rui Barbosa, 1986, pp. 80-81. Para essas historiadoras, "Campos Salles e Joaquim Murtinho consideravam a industrialização brasileira uma perspectiva artificial diante da 'vocação agrária' do país"

602 GRANADO, Paschoal José. O alvorecer de Bangu. Rio de Janeiro: edição própria, 1997, p. 30.

${ }^{603}$ JORNAL DO BRASIL, 22 de maio de 1906, p. 4.

${ }^{604}$ GAZETA DE NOTÍCIAS, 21 de março de 1917, p. 1.

${ }^{605}$ CORREIO DA MANHÃ, 24 de outubro de 1909, p. 4.
} 
Dessa forma, a convite de João Ferrer, passaram por Bangu os presidentes Rodrigues Alves, em 11 de outubro de 1906, Nilo Peçanha, em 23 de outubro de 1909, Hermes da Fonseca, em 14 de novembro de 1910 (um dia antes de sua posse). Os ministros do governo Affonso Penna, David Campista (da Fazenda) e Miguel Calmon (da Viação e Obras Públicas), em 10 de novembro de 1908, o prefeito Souza Aguiar acompanhado de seu secretário Olavo Bilac, em 28 de abril de 1908. O político francês Paul Doumer, em 9 de setembro de 1907, o embaixador francês Georges Clemenceau, em 4 de outubro de 1910, os oficiais portugueses da Canhoneira "A Pátria", em 10 de outubro de 1905 e até mesmo a tripulação dos navios Lodore e Marion Joseph da Marinha Mercante Britânica, que foram ao bairro jogar uma partida de futebol contra o time do Bangu, em 10 de setembro de 1905.

Pela descrição dos jornais, era o próprio João Ferrer quem fazia questão de percorrer as seções da fábrica com cada visitante, explicando o funcionamento dos maquinismos e mostrando a pujança da Companhia. No fim, levantava brindes de champanhe ao governante. Dessa forma, o político, talvez deslumbrado ao ver a grande obra social daquela empresa, declarava "Que pena não ter conhecido este estabelecimento há mais tempo!" - como o fez o presidente Rodrigues Alves. ${ }^{606}$

O poeta Olavo Bilac, na função de secretário do prefeito Souza Aguiar, também "tirou o chapéu" para o que viu no bairro de João Ferrer:

\footnotetext{
Passei ontem o dia numa cidade que pouca gente conhece. É a cidade do Bangu, a uma hora de viagem do Rio de Janeiro. Verdadeira cidade, pela sua extensão, pela sua população, pela sua vida intensa e vibrante. O Bangu tem duas escolas, um cassino, um teatro, um parque, um campo de futebol, - e, para tudo dizer, dois automóveis! Há por aí muitas cidades que não possuem tanta cousa... Dos seis mil habitantes do Bangu, três mil são operários. A grande fábrica de tecidos, talvez a maior do Brasil, foi a criadora de todo aquele progresso. ${ }^{607}$
}

Dessa forma, cada visita à fábrica era uma propaganda a mais que a Companhia conseguia gratuitamente nas páginas dos jornais. Não à toa, o jornalista Alcindo Guanabara dizia, em 1909, que João Ferrer não poupava esforços para transformar Bangu em "um verdadeiro paraíso"! 608 Indo um dia apenas à vila operária, a impressão que se tinha era justamente esta, de que tudo ali funcionava na mais perfeita ordem.

Gilberto Freyre, posteriormente, ao analisar os comentários feitos pelo estadista francês Georges Clemenceau no livro "South America Today - A study of conditions, social, political and commercial in Argentina, Uruguay and Brazil", percebeu nos diretores da Fábrica Bangu resquícios dos velhos métodos de assistência patriarcal com que os senhores lidavam com os escravos:

(...) Daí o mérito que Clemenceau soube destacar nos particulares que no Brasil republicano, sem esperar pela ação dos governos, procuraram melhorar a condição dos indivíduos empregados nas suas indústrias. Esse mérito, encontrou-o ele em donos de

\footnotetext{
606 JORNAL DO BRASIL, 12 de outubro de 1906, p. 4.

${ }^{607}$ CORREIO PAULISTANO, $1^{\circ}$ de maio de 1908, p. 1.

${ }^{608}$ A IMPRENSA, 9 de junho de 1909, p. 4.
} 
fábricas situadas nos arredores da Capital da República, como a de Bangu. Eram industriais, os da Bangu, que, em 1910, tratavam seus operários com alguma coisa dos velhos métodos de assistência patriarcal desenvolvidos no Brasil por uma civilização que por ter sido escravocrata, não deixou de se conservar cristã no essencial da sua ética e nos seus ritos de convivência dos supostos superiores com os supostos inferiores.

"Os trabalhadores da Bangu, espalhado por toda a área, vivem em casas em que nenhuma das instalações de higiene está faltando, dando uma aparência agradável de saúde física e moral".

Não lhe faltava sequer o substituto de uma casa-grande patriarcal, adaptada às novas condições, já francamente industriais e quase urbanas, de trabalho:

"Um teatro para o encontro de toda a comunidade, onde os trabalhadores podem desfrutar os prazeres da música e do drama". ${ }^{609}$

A minúscula imprensa operária - total antítese do que era publicado na grande imprensa também via na generosidade dos industriais resquícios, evidentemente negativos, da antiga relação entre patrões e escravos. Se por um lado, os senhores davam pequenos agrados, por outro, mantinham os tecelões sob um rígido sistema fabril, em que não existiam direitos trabalhistas, tal qual no passado escravista:

Se o patrão atende a todas as suas necessidades pessoais, se lhe dá dinheiro, ou empresta quando querem casar, batizar um filho, enterrar um avô, engrinaldar um sobrinho - se o patrão atende a essas coisas, que pertencem à antiga situação de escravos, mas escapam ao moderno contrato de trabalho, é para essa pobre gente, um bom patrão, embora não cumpra pontualmente o contrato, isto é: não pague o salário como fora combinado e não trate o operário como pessoa igual. ${ }^{610}$

E de fato não eram pessoas iguais. Ferrer, que durante a semana morava numa residência destinada ao diretor-gerente, conhecido popularmente como "chalé dos ingleses", construído em 1900 nas terras da antiga Fazenda do Retiro, na Estrada do Engenho, nos finais de semana ia para sua casa na Rua Paysandu n ${ }^{\circ} 1$, de frente à praia do Flamengo. 611

Sua vida social fora de Bangu era das mais agitadas, podendo ser padrinho de casamento de noivos da alta sociedade carioca ou ser visto em missas de sétimo dia de familiares da elite do Rio de Janeiro. Como veranista, em janeiro, subia a serra e desfrutava do clima ameno de Petrópolis. ${ }^{612}$ Participava de almoço em prol da Beneficência Portuguesa, ${ }^{613}$ foi aceito sócio efetivo do Jockey Club, ${ }^{614}$ era convidado ilustre num banquete em homenagem ao senador Pinheiro Machado, ${ }^{615}$ ia ao Teatro Municipal assistir à estreia da Companhia Lírica ${ }^{616}$ e era presença certa numa garden party oferecida pelo presidente Nilo Peçanha aos representantes da indústria e do comércio da capital. ${ }^{617}$

É possível que a imagem de bem sucedido administrador e rico homem de negócios de João Ferrer, aliado ao fato de apresentar uma alternativa para a relação patrão/empregado que

\footnotetext{
${ }^{609}$ FREYRE, Gilberto. Ordem e Progresso. $4^{a}$ edição. Rio de Janeiro: Editora Record, 1990, p. 628.

${ }^{610}$ A VOZ DO TRABALHADOR, 15 de junho de 1909, p. 1.

${ }^{611}$ A ÉPOCA, 8 de abril de 1914, p. 6.

612 O PAIZ, 24 de janeiro de 1917, p. 3.

613 JORNAL DO BRASIL, 2 de maio de 1910, p. 7.

${ }^{614}$ Idem, 20 de setembro de 1910, p. 10.

615 O PAIZ, 5 de setembro de 1910, p. 2.

${ }^{616}$ Idem, 20 de setembro de 1918, p. 5.

${ }^{617}$ Idem, 21 de julho de 1910, p. 3.
} 
enfraquecia o movimento operário, tenha incomodado lideranças preocupadas com a questão social, como Vicente Piragibe ${ }^{618}$ e Mariano Garcia. ${ }^{619}$

Quando criou o jornal A Época, em 1912, Piragibe logo convidou Garcia para escrever uma "Coluna Operária” em suas páginas, em que combateria os industriais e alertaria os trabalhadores para seu estado de exploração. Natural, então, que o diretor-gerente da maior fábrica de tecidos da Capital fosse um dos alvos atingidos: "Não é possível que o sr. Ferrer, que, com certeza, gasta mais de $5 \$$ (cinco mil réis) por dia, queira que os operários, trabalhando como trabalham, possam viver com 3\$ (três mil réis) diários, que é o que ganha a maioria dos que trabalham no Bangu. As crianças são ali barbaramente exploradas, para ganharem uns miseráveis $\$ 800$ (oitocentos réis) por dia”, escrevia Mariano Garcia, já sabendo que a maioria dos operários não via o espanhol da mesma forma que ele: "Mas, descanse o sr. Ferrer, o grande e poderoso dono da Fábrica do Bangu, que os desgraçados que lá trabalham em sua bastilha não protestarão: eles estão embrutecidos pela escravidão e pela miséria, e estão muito convencidos de que ele é um benfeitor dos que trabalham". 620

Ato contínuo à publicação, um operário da Fábrica Bangu foi até a redação de $A$ Época e "nos pediu uma retificação em abono do sr. Ferrer e nos declarou que os operários ficaram molestados":

(...) Sobre os salários de 3\$ diários, nós sabemos que nem todos ganham isso, porém o nosso companheiro que veio defender a bondade do sr. Ferrer, com a sua retificação, veio nos confirmar que, de fato, alguns ganham esse salário, outros menos, e quanto à situação das crianças na fábrica, confirmou tudo quanto aqui dissemos, declarando embora, que é porque ainda os operários não reclamam do sr. Ferrer, porque este senhor tem atendido até hoje a todas as reclamações que lhes são feitas. ${ }^{621}$

Mariano Garcia, tratado nas páginas de A Época como "o único operário que pode servir de centro de convergência, em um partido socialista bem organizado", ${ }^{622}$ não iria desistir facilmente e sua "Coluna Operária" aparece outra vezes atacando a figura do diretor-gerente: "Esse sr. Ferrer, segundo os nossos informantes, prende os vencimentos dos operários, aos quais só paga com desconto de 20\%. Queixam-se ainda das multas e suspensões a torto e a direito, sem o menor critério nem escrúpulo", escrevia o líder socialista. ${ }^{623}$

\footnotetext{
${ }^{618}$ Vicente Piragibe, jornalista que já secretariara as redações do Cidade do Rio e do Correio da Manhã, ganha projeção após fundar o jornal A Época, no qual capitaneia um combate intransigente ao governo do Marechal Hermes. Tendo sido preso por isso, elege-se deputado pela Capital Federal no ano seguinte à sua libertação, notabilizando-se pela defesa da "classe proletária". Vide: PEREIRA, Leonardo Affonso de Miranda. Footballmania: uma História Social do Futebol no Rio de Janeiro (1902-1938). Rio de Janeiro: Editora Nova Fronteira, 2000, p. 301.

${ }^{619}$ Mariano Garcia, trabalhador de uma fábrica de cigarros em seus primeiros tempos de atividade, fundou em $1895 \mathrm{o}$ jornal $O$ Operário, lançando o programa e os estatutos de um partido socialista. Na primeira década do século XX, tentou seguidamente organizar um partido e esteve à frente da Gazeta Operária, jornal que combinou a defesa dos direitos dos trabalhadores com o ataque ao anarquismo. Vide: FAUSTO, Boris. Trabalho urbano e conflito social (1890-1920). São Paulo: Difel, 1977, p. 53.

${ }^{620}$ A ÉPOCA, 4 de março de 1913, p. 6.

${ }^{621}$ Idem, 7 de março de 1913, p. 7.

${ }^{622}$ Idem, 13 de junho de 1913, p. 4.

${ }^{623}$ Idem, 10 de dezembro de 1914, p. 2.
} 
Se havia uma política de rebater qualquer crítica da imprensa por parte da diretoria ou se os desagravos a João Ferrer vinham naturalmente dos próprios tecelões, não se sabe. O fato é que, novamente, um operário cujo nome ficou no anonimato, apressou-se em reparar a afronta ao diretorgerente:

Esteve em nossa redação um operário da Fábrica de Tecidos de Bangu, que nos declarou não serem verdadeiras as queixas e reclamações feitas em cartas enviadas a esta redação contra o sr. João Ferrer. O nosso informante afirmou que os pagamentos estão em dia e que absolutamente o sr. João Ferrer não paga com desconto aos operários, nem tampouco tem imposto, multas e suspendido operários. ${ }^{624}$

Para o povo de Bangu do início do século XX, João Ferrer realmente era um benfeitor, alguém que tinha se preocupado em trazer a urbanização para a localidade, além de demonstrar um apreço aos trabalhadores da fábrica. Essa imagem de um líder paternalista, um "benemérito propugnador do progresso" era mais forte do que qualquer crítica que socialistas, que sequer moravam na vila operária, poderiam fazer esporadicamente. Dessa forma, com o passar do tempo, o dono do jornal A Época, Vicente Piragibe, passou a entender que se quisesse os votos da população de Bangu na sua ambição pelo cargo de deputado, teria que abrir espaço não para as críticas ao diretor-gerente, mas para os constantes elogios que os operários achavam que Ferrer merecia, descaracterizando a linha inicialmente adotada pelo seu jornal.

Graças ao espanhol, lá os operários trabalhavam "satisfeitos e risonhos" e em nenhuma outra fábrica "se encontra tanta liberdade como na Bangu", era o que dizia um manifesto assinado por quatro rapazes e enviado à redação de $A$ Época.

O sr. João Ferrer é um industrial inteligente e ativo, dotado de um coração sensível e de uma alma simples, que the vale bem a estima de que goza no meio daquele núcleo de operários que satisfeitos e risonhos trabalham debaixo da sua administração.

O Bangu, que antes de ser confiado a esse benemérito, era um foco de sapos, mosquitos, cobras e miasmas, está hoje transformado, graças ao seu esforço, ao seu grande valor administrativo, em verdadeira cidade.

$\mathrm{O}$ sr. João Ferrer quando assumiu a direção daquela fábrica percorreu todo o local e notou o estado de miséria em que se achava Bangu.

Apenas encontrou dois armazéns funcionando em prédios completamente imundos, uma farmácia, um armarinho e em construção um prédio belíssimo, que se dizia ser uma cooperativa.

Porém, o sr. Ferrer, pondo em ação a sua inteligência ainda cedo salvou os operários de caminharem pela estrada da ignorância.

$\mathrm{O}$ sr. Ferrer analisou bem a falta de instrução em Bangu e assim fez desaparecer e fundou uma escola para operários e seus filhos. Demais, o sr. Ferrer jamais privou a liberdade do operariado e, ao contrário, em fábrica nenhuma se encontra tanta liberdade como na Bangu.

Os operários não só tem a fábrica para o trabalho como também todas as qualidades de diversões. ${ }^{625}$

\footnotetext{
${ }^{624}$ Idem, 11 de dezembro de 1914, p. 5.

${ }^{625}$ Idem, 8 de setembro de 1913, p. 6.
} 
É quase impossível imaginar que esse diretor-gerente tão poderoso e amado pelos seus próprios operários, pudesse perder rapidamente tudo o que vinha conquistando desde 1903. A crise econômica enfrentada pelas indústrias de tecidos durante a Primeira Guerra Mundial e as manobras fiscais feitas por João Ferrer para tentar mostrar que a Companhia não sofria os abalos do conflito na Europa, transformaram por completo a vida do espanhol.

Para a historiadora econômica Maria Bárbara Levy, o impacto do conflito mundial sobre a indústria no Rio de Janeiro provocou uma redução nos investimentos. Os dados levantados sobre a produção da indústria carioca entre 1914 e 1917 apontam taxas médias de crescimento anual significativamente inferiores à apresentada pela totalidade da indústria brasileira. Essas informações sugerem que, no quadro de crise, a região fosse mais prejudicada pela dificuldade de acesso às importações. O agravamento das dificuldades de transporte, com oferta insuficiente de tonelagem e elevação dos fretes marítimos, torna explícito dois aspectos da indústria carioca: de um lado, a maior dependência dessa indústria das matérias-primas localizadas fora de suas fronteiras e, de outro, o fato de ter enfrentado dificuldades em abastecer seus mercados tradicionais, em decorrência das mesmas dificuldades de transporte. ${ }^{626}$

A crise acabou envolvendo a diretoria da Companhia. O diretor-presidente, Manoel Antônio da Costa Pereira, pediu demissão em 14 de janeiro de 1919, alegando problemas de saúde, deixando o cargo que ocupava desde $1896 .{ }^{627}$ João Ferrer abandonou o seu posto em 27 de janeiro de $1919 .{ }^{628}$

Para a historiadora Gracilda Alves, esta crise foi o resultado da verificação de várias irregularidades, que vinham ocorrendo há vários anos e que estavam sendo encobertas pela diretoria através de vários recursos. A crise começou porque a Companhia vinha sofrendo graves prejuízos, que começaram com a grande seca que assolou a Capital Federal, e principalmente Bangu, nos anos de 1914 e 1915, acarretando a paralisação dos serviços da fábrica. Logo em seguida, ocorreu a superprodução de tecidos, depois, a retomada de grandes encomendas a preços baixos e, por último, a alta do algodão e das tintas, que subiram a preços sem precedentes.

Apesar desses problemas, a Companhia continuou a entregar aos compradores os seus tecidos, pelos preços contratados, mas, depois, não podendo mais continuar a cumprir esses contratos, reuniu os compradores e combinou alterar os preços para outros que, na ocasião, pareciam dar lucros. Como a Companhia não tinha estoque de algodão em quantidade suficiente, dentro em

\footnotetext{
${ }^{626}$ LEVY, Maria Bárbara. A indústria do Rio de Janeiro através de suas sociedades anônimas. Rio de Janeiro: Editora UFRJ, 1994, pp. 191-192.

${ }^{627}$ SILVA, Gracilda Alves de Azevedo. Bangu - a fábrica e o bairro: um estudo histórico, 1889-1930. Instituto de Filosofia e Ciências Sociais (IFCS) da Universidade Federal do Rio de Janeiro (UFRJ), 1985, pp. 431-432

${ }^{628}$ Idem, p. 428.
} 
pouco, viu-se obrigada a novamente reunir os compradores, para então, rescindir todos os contratos. Mas, esta medida não surtiu efeito porque finda a Guerra, sobreveio a paralisação dos negócios de tal forma que as vendas caíram assustadoramente.

Ferrer, então, escondeu de todos os acionistas a real situação da Companhia, porque, se esta fosse conhecida, seria um desastre financeiro. Por isso, por longo tempo, distribuía dividendos que na verdade não existiam, o que, juntamente com o aumento da conta de juros, agravou cada vez mais os encargos da Companhia.

A situação da Companhia, em 31 de dezembro de 1918, era péssima, e isso foi denunciado pelo Conselho Fiscal na Assembleia de acionistas. Constava o prejuízo de 6.268:135\$610 no balanço encerrado do ano findo. Estranhamente, o Conselho Fiscal só "descobriu” as falhas e fez um inventário completo sobre as mesmas quando da apresentação do prejuízo, apesar dessas irregularidades virem se processando há muito tempo. O ex-diretor-presidente Manoel Antônio da Costa Pereira foi chamado a prestar esclarecimentos na Assembleia Geral, em 18 de fevereiro de 1919, e culpou o seu ex-colega João Ferrer, que teria se deixado "alucinar por tão pernicioso processo":

(...) Por ter confiado em demasia em companheiro de vinte e tantos anos, desde os tempos áureos da Companhia, não que o possa considerar desonesto, mas pela orientação errônea por ele ultimamente adotada, em desacordo com todas as provas recomendáveis com a boa fé, que em tudo deve existir. Das consequências dessa orientação todos somos prejudicados.

(...) Nessa emergência, o colega, a que me referi, em vez de investigar a origem desse prejuízo para cortar logo o mal pela raiz, preferiu encobri-lo, na esperança talvez de se refazer com lucros em anos posteriores, para fazer desaparecer o passado; mas o mal agravava-se cada vez mais e ultimamente, por um exame feito pelo Conselho Fiscal, verificou-se a realidade. Lamento que este colega se deixasse alucinar por tão pernicioso processo.

(...) Devo declarar-vos que, ninguém mais do que eu lamenta este insucesso, de que me confesso culpado na parte que me pertence; nunca, porém, pensei que no fim da minha longa vida viesse passar por semelhante decepção e tamanho desgosto perante o meio social em que tenho vivido. ${ }^{629}$

Em outra assembleia extraordinária, os acionistas chamaram o guarda-livros Victorino Chouin, para ser ouvido, afinal ele era o responsável por toda a contabilidade da fábrica. Chouin mostrou que a situação da Companhia era muito grave e que os erros contábeis eram sempre propositais. Também afirmou que cometera estes erros a pedido de João Ferrer e Francisco Ferreira Real (o diretor-tesoureiro), na tentativa de salvar a Companhia. O acionista Herculano Rodrigues indagou Chouin se ele conhecia a responsabilidade do seu ato, se tinha conhecimento de que podia ter cassada a sua "carta de guarda-livros", além de estar sujeito a outras penalidades. Chouin respondeu que bem conhecia a sua responsabilidade e que o fizera por ordem superior. Revelou ainda que não podia determinar exatamente a época em que se iniciaram essas irregularidades, mas

${ }^{629}$ DIÁRIO OFICIAL, 11 de março de 1919, seção 1, p. 33-34. 
afirmou que estas começaram quando pela primeira vez utilizou-se o Fundo de Reserva para distribuição de dividendos aos acionistas. ${ }^{630}$

Demitido por justa causa, Victorino Chouin resolveu ir além da denúncia do uso do Fundo de Reserva para o pagamento de dividendos, o que dava uma falsa impressão de que a Companhia estava vivendo um período de lucros. Seu próximo passo foi denunciar João Ferrer às autoridades fiscais. O motivo: cartas enviadas pelo espanhol a fabricantes de máquinas na Inglaterra, nas quais constavam pedidos para que os valores a serem impressos nas notas fiscais fossem diminuídos em $50 \%$. Dessa forma, era possível ludibriar as autoridades alfandegárias do Brasil, fazendo com que a Companhia pagasse um menor imposto de importação, visto que as mercadorias tinham um valor bem inferior ao que realmente custavam. ${ }^{631}$

Era tudo verdade. A fraude fiscal era enorme. O total da sonegação chegava a 47:993\$290 entre 1913 e janeiro de 1919. O exame da correspondência da Companhia, feito pela comissão de inquérito do governo, revelou a existência de cartas dirigidas aos exportadores, assinadas por João Ferrer, nas quais se encontravam recomendações dirigidas à firma Lancaster Moore \& Cia., em 30 de agosto de 1916: “Todas as vezes que vossas senhorias despacharem para nós máquinas e maquinismos, reduzirem 50\% no valor declarado na fatura consular e respectivo conhecimento. Devemos explicar muito bem a vossas senhorias que em vista das constantes exigências da Alfândega, somos forçados a proceder deste modo, o que, aliás, é como fazem os nossos correspondentes na Inglaterra".

Em outra carta dirigida, na mesma data, ao London and Hanseatic Bank Ltd., de Londres, João Ferrer, textualmente, recomendava: “Que em virtude de exageradas exigências da Alfândega, e como já temos pedido por vezes, rogamos aos amigos tomarem nota do seguinte: todas as faturas que vossas senhorias despacharem para nós como máquinas e maquinismos devem reduzir 50\% no seu valor na respectiva fatura consular". ${ }^{32}$

Para piorar a situação de João Ferrer, além de fazer questão de assinar essas correspondências, quando alguma firma inglesa não cumpria a determinação - como foi o caso da Siessel Brothers e da Lancaster Moore, ambas de Manchester, o espanhol enviava outra carta dizendo-se estar

\footnotetext{
${ }^{630}$ SILVA (1985), P. 441.

631 "Victorino Chouin, brasileiro, residente à rua de S. Januário no 180 , vem perante V. S. denunciar a Companhia Progresso Industrial do Brazil, com sede à rua Primeiro de Março $\mathrm{n}^{\circ}$ 113, pelas faltas de pagamento de direitos de diversas mercadorias, vindas de diversos portos e em diversas datas, que sujeitas ao pagamento de direitos "ad valoren" sobre o valor real destas mercadorias, de acordo com os artigos 14, 15 e 16 das preliminares da tarifa vigente, deixaram de ser feitos sobre o referido valor devido às instruções da diretoria daquela Companhia aos seus correspondentes para serem os valores diminuídos nas faturas consulares na proporção de 50\%, mais ou menos (como poderá verificar-se no copiador de cartas da dita Companhia). E para prova do que alego, poderá V. S. mandar pedir aos srs. Diretores daquela Companhia as suas faturas comerciais, a fim de serem as mesmas confrontadas com as consulares apresentadas nesta Alfândega pela Companhia ora denunciada na ocasião de fazer-se o processo de desembaraço daquelas mercadorias. Caso V. S. precisar de melhores informações, encontrar-me-á sempre à sua disposição na minha residência já citada". Vide: GAZETA DE NOTÍCIAS, 28 de junho de 1920, p. 1.

${ }^{632}$ CORREIO DA MANHÃ, 3 de setembro de 1921, p. 2.
} 
"verdadeiramente surpreendido com o fato de ter essa firma contrariado as instruções e não reduzido de 50\% o valor declarado na fatura consular, referente à mercadoria embarcada no vapor Phindias (...), resultando disto pagar a Companhia direitos sobre o justo valor da mercadoria”. 633

Como afirmou o inspetor da Alfândega do Rio de Janeiro, Lindolpho Câmara, à Gazeta de Notícias: "Nem todos terão a ingenuidade de documentar as suas bandalheiras ao copiador. (...) A comissão encarregada do inquérito não esperava ser tão feliz como foi. Os srs. Luiz Affonseca e Soares Câmara encontraram logo no copiador a prova exuberante das fraudes sistemáticas da Progresso".634

O valor subtraído a essas mercadorias importava em 362:633\$600. A lei mandava que a multa aplicada à Companhia fosse o triplo, portanto 1.027:901\$400. Por fim, o Conselho de Fazenda, em decisão de 16 de julho de 1920, resolveu confirmar a multa imposta pela Alfândega do Rio de Janeiro na importância de impagáveis 1.087:901\$400 e proibir a entrada, nas repartições fiscais, dos diretores da Companhia. ${ }^{635}$

Se não podiam entrar nas repartições fiscais, os novos diretores da Fábrica Bangu - os portugueses Manoel Alves Velloso Júnior e Manoel Ribeiro Teixeira Neves ${ }^{636}$ - entraram no Palácio do Catete. A multa e os empréstimos que teriam que ser feitos para pagá-la seriam o fim da Companhia, o fim da vila operária e o fim do "ganha-pão" de milhares de pessoas que tiravam seus sustentos da produção de tecidos. Para desespero do jornalista da Gazeta de Notícia, que fazia oposição ao governo, os diretores conseguiram com o presidente Epitácio Pessoa uma redução do valor da dívida a menos de uma quinta parte do que foi estipulado, baseado numa brecha da legislação: "O processo foi requisitado pelo Palácio do Catete; o presidente designou pessoas de sua confiança para estudá-lo; estudaram de acordo com as ordens presidenciais, tão bem, que o processo desapareceu. Agora, protegida pelo Catete, a bandalheira vai ser abafada!"637

Por outro lado, defendendo a Companhia, naqueles tempos de um jornalismo nada imparcial, o Correio da Manhã declarava:

(...) Há uma circunstância a assinalar: quer a lei antiga, revogada, quer a lei nova, em vigor, só manda aplicar a multa quando a fraude é apurada no ato da conferência da Alfândega. Ora, essa particularidade não se verificou, porque o que houve foi a descoberta duma sonegação de direitos antiga, confirmada em exame de livros, mediante denúncia de uma pessoa que fora na mesma conivente, não só porque dela tivera conhecimento na ocasião oportuna, como ainda por a haver facilitado materialmente, sendo, como era, o guarda-livros da Companhia. ${ }^{638}$

\footnotetext{
${ }^{633}$ GAZETA DE NOTÍCIAS, 28 de junho de 1920, p. 1.

${ }^{634}$ Idem, 6 de julho de 1919, p. 3.

${ }^{635}$ Idem, 17 de setembro de 1920 , p. 1.

${ }^{636}$ OLIVEIRA, Márcio Piñon de. Bangu: de fábrica-fazenda e cidade-fábrica a mais uma fábrica da cidade. Instituto de Pesquisa e Planejamento Urbano e Regional (IPPUR) da Universidade Federal do Rio de Janeiro (UFRJ), 1991, p. 10.

${ }^{637}$ GAZETA DE NOTÍCIAS, 17 de setembro de 1920, p. 1.

${ }^{638}$ CORREIO DA MANHÃ, 26 de setembro de 1920, p. 2. Em outro editorial do CORREIO DA MANHÃ, 30 de setembro de 1920 , p. 2, sobre o assunto da anistia da multa, baseada em brechas da legislação, o articulador defende
} 
João Ferrer não teve a mesma sorte da Companhia. Arrolado no processo pela fraude fiscal junto com o diretor-presidente Comendador Manoel Antônio da Costa Pereira, com o diretortesoureiro Francisco Ferreira Real e o guarda-livros Victorino Chouin, um a um todos conseguiram fugir à detenção, menos o espanhol. O Comendador Costa Pereira acabou falecendo em 23 de janeiro de 1923, aos 83 anos, em sua suntuosa residência à praia de Botafogo, $\mathrm{n}^{\mathbf{o}} 348 .{ }^{639}$ Ferreira Real e Victorino Chouin (este como cúmplice) se viram definitivamente livres de qualquer sentença condenatória no Supremo Tribunal Federal, em 12 de setembro de $1923 .{ }^{640} \mathrm{Na}$ mesma data, João Ferrer foi condenado a um ano de prisão celular pelo artigo 265 do Código Penal (dos crimes contra a Fazenda Pública: do contrabando), corroborando a decisão do juiz da $1^{\text {a }}$ vara federal, Olympio de Sá e Albuquerque, proferida no dia 11 de abril de $1923 .{ }^{641}$

O advogado de João Ferrer era o conhecido Evaristo de Moraes que apelou de todas as formas ao ministro do STF, André Cavalcanti, pedindo a prescrição da ação penal baseada na exclusão de corresponsabilidade do tesoureiro Ferreira Real:

No inquérito policial, que precedera a denúncia, declarou sinceramente Ferrer o que toda a diretoria havia deliberado, fugindo - como, em geral, o fazem quase todos os industriais e comerciantes - à pressão das tarifas exageradas.

Nem era concebível que um ato de tal natureza, praticado no interesse da sociedade mercantil, resultasse da deliberação de um só dos seus diretores. Acresce a circunstância seguinte, e que é de fácil intuição: ao tesoureiro incumbia fornecer o dinheiro, não só para pagar os direitos como para pagar o preço das mercadorias importadas, não lhe podendo, portanto, escapar, repetidamente, a diferença entre o valor declarado nas faturas consulares, básico do pagamento à Alfândega, e o valor real, satisfeito, aqui, nos bancos, ou remetido para Europa nos fornecedores.

Entenderam os outros diretores deixar sozinho o companheiro; negaram.

Feito o sumário, insistiu o Dr. Procurador Criminal no pedido de pronúncia dos diretores, cuja criminalidade conjunta se lhe afigurou evidente.

Não foi, porém, a solução tal como reclamara o Ministério Público; dos diretores somente Ferrer se viu pronunciado. E só Ferrer está condenado! $!^{642}$

Não há detalhes exatos sobre o dia em que começou e quando terminou a pena de João Ferrer, entre 1923 e 1924. Sabe-se que em junho de 1924, João Ferrer já estava em liberdade, prestigiando a missa de sétimo dia de um inglês residente no Rio de Janeiro. ${ }^{643} \mathrm{Em} 1927$, adquiria um prédio na rua Cesário Alvim nº 10, no Humaitá, por 90:000\$, possivelmente sua última residência.

Para Paschoal José Granado, biógrafo de João Ferrer, nada disso ocorreu. Sua tentativa de distorcer a história e mantê-lo sempre como um "um nome aureolado, ungido dos deuses" fez com

que: "de tudo se evidencia que o governo agiu dentro das leis alfandegárias. Se estas leis não prestam, que as reforme o Congresso. Quanto ao dever propriamente da administração, um movimento enérgico de limpeza é necessário na Alfândega do Rio de Janeiro, mal dirigida, anarquizada, cega aos contrabandos e às fraudes de todo gênero que por lá transitam".

${ }^{639}$ O PAIZ, 24 de janeiro de 1923, p. 5.

${ }^{640}$ CORREIO DA MANHÃ, 13 de setembro de 1923, p. 3.

${ }^{641}$ Idem, 12 de abril de 1923, p. 4.

${ }^{642}$ MORAES, Evaristo de. Memorial Pró-João Ferrer - Apelação Criminal no 912 ao Ex. Sr. Ministro André Cavalcanti. Rio de Janeiro: Tipografia Leuzinger, 1923.

${ }^{643}$ JORNAL DO BRASIL, 19 de junho de 1924, p. 10. 
que escrevesse para a posteridade que Ferrer fora expulso da fábrica na época da Grande Guerra pelo fato de ser espanhol e a Espanha ter-se mantido neutra num conflito em que a neutralidade não era admitida. Para historiadores como François Xavier Guerra, estes textos de memorialistas locais acabam se prestando a diversos tipos de interesses: "É natural que esses documentos contenham uma parte de memória efetiva, mas são também um lugar de recriação do passado - feita com proporções variáveis de esquecimento, de invenção, mesmo de manipulação ou falsificação". ${ }^{444}$

Tal alteração deliberada dos fatos fez com que, anos depois, ao publicar um livro sobre a história das ruas do Rio, Brasil Gérson não entendesse porque não havia uma única homenagem a Ferrer em Bangu: "João Ferrer, cujo nome já não aparece mais, o que é uma tremenda injustiça, em coisa alguma do bairro que teve nele um dos seus maiores e melhores animadores". ${ }^{645}$

A principal rua do bairro, que liga a estação ferroviária até a igreja matriz, originalmente chamada de "Estevão", que os moradores do local resolveram mudar para "Ferrer" no início da década de 10, passara a ser chamada oficialmente, a partir de 1936, de "Avenida Cônego Vasconcelos", em homenagem ao vigário Dr. Augusto Alfredo Vasconcellos, por decisão do prefeito-interventor da cidade à época, o padre Olímpio de Melo. ${ }^{646} \mathrm{O}$ nome Ferrer foi, aos poucos, apagado da memória coletiva, principalmente após sua morte em 23 de agosto de $1934 .{ }^{647}$ Até porque, nesta época, outro "benfeitor” já administrava a fábrica e, com igual estilo paternalista, dava novo ânimo aos moradores do bairro: Manoel Guilherme da Silveira.

No entanto, quando ainda estava vivo, mesmo com todos os moradores sabendo de sua verdadeira saga, de rico administrador a presidiário por fraudes fiscais, João Ferrer foi homenageado com um grande baile na sede da Flor da Lyra.

Foi em 20 de outubro de 1929. A Sociedade Carnavalesca Flor da Lyra era uma agremiação recreativa frequentada pela população proletária do bairro, fundada em 1900 por Antônio Carreiro da Silva, que tinha o verde e o amarelo como cores oficiais. ${ }^{648}$ Naquele domingo, os operários estavam reunidos na sede do rancho quando "foi introduzido no recinto, por uma comissão de senhoritas, o sr. João Ferrer, sob prolongada salva de palmas e pétalas de rosas".

Um orador relembrou o passado de João Ferrer nos seus 16 anos de direção da fábrica como “emérito industrial, urbanista, educador, higienista. Fundou a escola mantida pela Companhia, sem exclusividade, não só para os filhos dos operários, como dos moradores do lugar. Atraiu a Bangu a

\footnotetext{
${ }^{644}$ GUERRA, François Xavier (org.). Mémoires em Devenir. Amérique Latine XVI-XX siècle. Bordeaux: Maison des Pays Ibériques, 1994, p. 5. Tradução de Jaime de Almeida para a Revista da Associação Nacional de Pesquisadores e Professores de História das Américas.

${ }^{645}$ GERSON, Brasil. História das ruas do Rio. Rio de Janeiro: Livraria Brasiliana Editora, 1965, p. 522.

${ }^{646}$ O GLOBO, Jornais de Bairro - Zona Oeste, 6 de novembro de 1988, p. 15.

${ }^{647}$ O PAIZ, 28 de agosto de 1934, p. 7.

${ }^{648}$ Idem, 9 de fevereiro de 1907, p. 3.
} 
visita de chefes de Estado e diplomatas. Foi o incondicional protetor dos operários, a quem sempre dedicou a mais sacrossanta amizade, na gripe de 1918".

O orador Altamiro de Oliveira, exageradamente, ainda pediu que os moradores se dirigissem aos poderes públicos para que fosse conseguida a mudança do nome da estação de Bangu para João Ferrer. Depois, "duas gentis senhoritas descerraram as cortinas e surge o retrato do homenageado sob vibrantes aplausos de todos os presentes". O médico da comunidade, Dr. Miguel Pedro, também tomou da palavra, até que chegou a vez de João Ferrer dizer alguma coisa para seus antigos funcionários, mas “o sr. João Ferrer não pôde proferir palavras de agradecimento, as lágrimas deslizavam-lhe pelas faces".

A reportagem do Jornal do Brasil, único órgão da imprensa que acompanhou a cerimônia, termina dizendo que "com a significativa homenagem, a Flor da Lyra, como intérprete do sentir do povo de Bangu, pagou uma dívida de honra para com o 'Passos' desse aprazível arrabalde". ${ }^{649}$

A referência a Pereira Passos era óbvia, afinal tinha sido ele o prefeito que dera nova faceta ao Rio de Janeiro na primeira década do século XX, tal qual João Ferrer tinha feito por Bangu praticamente na mesma época. Em 1929, a expectativa era de que vivessem no bairro em torno de 30.000 pessoas, ${ }^{650}$ das quais exatas 1.897 trabalhavam na fábrica. ${ }^{651}$

Por mais que a população do arrabalde tivesse mais do que triplicado desde a saída de Ferrer da localidade (em 1918, por exemplo, havia 12 mil habitantes em Bangu), ${ }^{652}$ ainda havia espaço para que os antigos moradores prestassem sua reverência a um homem que eles lembravam como um verdadeiro líder e organizador do espaço urbano nos primeiros tempos de existência da vila operária.

\footnotetext{
649 JORNAL DO BRASIL, 22 de outubro de 1929, p. 22.

${ }^{650}$ DIÁRIO OFICIAL, 19 de abril de 1929, seção 1, p. 70.

${ }^{651}$ OLIVEIRA (1991), p. 195.

${ }^{652}$ Idem, pp. 186-187.
} 


\section{V - A estratégia do football}

Em 1981, o historiador Joel Rufino dos Santos, fortemente influenciado pela literatura marxista - na qual maus patrões oprimiam operários humildes em busca de um maior lucro - e, ao mesmo tempo, observando a forma como as ditaduras militares da América do Sul se utilizavam do futebol como um lazer alienante, a ponto de ser chamado de "ópio do povo", escreveu o livro "História Política do Futebol Brasileiro", em que chega a uma conclusão "diabólica” sobre os times criados dentro de fábricas de tecidos no início do século XX: era uma invenção maquiavélica, um eficaz e inescapável meio de controle das classes populares. Operários que, sem vontade própria, tal como "crianças", eram induzidos a perderem suas energias com o jogo. O futebol seria um eficiente elemento disciplinador, usado diretamente pelos patrões que, com isso, além dos dias de trabalho, controlavam também as atividades de seus subordinados no domingo reservado ao lazer.

\footnotetext{
Como a uma criança que manda brincar "para queimar energias", os operários foram, então, mandados jogar futebol: os municípios isentaram os campos de impostos; os industriais se apressaram em construir grounds; a polícia parou de reprimir os rachas em terrenos baldios; os castigos aos estudantes de escolas públicas que fossem pegos jogando futebol, suspensos. ${ }^{653}$
}

Há muito de discurso ideológico - com um fraco suporte empírico - e pouca comprovação factual nesse tal intuito premeditado dos industriais, principalmente no caso do Bangu A. C. Quando a associação foi criada, em 17 de abril de 1904, o principal problema enfrentado pela Companhia em relação a seus operários não era a difusão de ideias anarquistas ou mesmo a ocorrência de muitas greves - o que poderia justificar a introdução do futebol para amansar ou até canalizar corretamente as energias dos trabalhadores. $\mathrm{Na}$ época, a questão a ser resolvida era como fazer com que tantos operários de nacionalidades tão diversas conseguissem viver num mesmo espaço de terra, em paz.

O clube, no entanto, não foi criado especificamente com esse propósito. Até porque ele sequer foi idealizado pelos principais diretores da Companhia (o presidente, o gerente ou o tesoureiro). A iniciativa de fundação partiu dos mestres têxteis britânicos que, muito embora, em posições privilegiadas dentro da fábrica, pareciam mais preocupados em reavivar o antigo jogo da bola que conheciam desde os tempos da Grã-Bretanha do que em criar um espaço para cercear e controlar o lazer dos demais trabalhadores. Tanto que, além do futebol, logo na sessão inaugural, fizeram questão de instituir outros dois esportes a serem praticados dentro do clube: o tênis e o críquete, ${ }^{654}$ que jamais cairiam no gosto popular dos brasileiros. O antropólogo José Sérgio Leite Lopes,

\footnotetext{
${ }^{653}$ SANTOS, Joel Rufino dos. História política do futebol brasileiro. São Paulo: Editora Brasiliense, 1981, p. 22. 654 “Ata da sessão de 17 de abril de 1904". 1 Livro de Atas das Sessões da Diretoria do Bangu A.C., 17 de abril de 1904 a 7 de fevereiro de 1905.
} 
acredita que no caso do Bangu A. C. havia uma conveniência de incentivar atividades de lazer coletivo:

Se de início o futebol é introduzido por iniciativa dos ingleses para o seu deleite e sociabilidade, logo a empresa percebe - atualizada que era com a prática internacional de outras empresas, na Europa, que promoviam o futebol como estímulo aos trabalhadores, aumentando seu sentido de pertencimento a uma comunidade de empresa - que aquele esporte se encaixava bem nas atividades e no emprego do tempo de uma vila operária de fábrica. ${ }^{65}$

Mais do que ocupar o tempo ocioso, desenvolver o físico ou desviar a mente de outros tipos de preocupação - especialmente ligadas a reivindicações sindicalistas - o futebol significou para aqueles trabalhadores um importante elemento de união em torno de um bem comum. Eles mostravam ver no jogo muito mais do que desejariam os industriais que financiavam a associação. O clube era um espaço de construção da solidariedade, onde os empregados da fábrica formavam laços que os ajudavam a solidificar ainda mais as experiências compartilhadas em sua vida cotidiana, como argumenta o historiador Leonardo Affonso de Miranda Pereira. ${ }^{656}$

Fundado apenas dois anos depois da criaçãodo Fluminense Football Club - time de elite voltado para a prática do esporte -, o Bangu A. C. parecia se inspirar no mesmo modelo fidalgo para "levar aos funcionários da fábrica a distinção e o refinamento que os sócios do Fluminense iam atribuindo ao jogo". 657

Dessa forma, quando a fundação do Bangu é noticiada pelos jornais, o clube parece ser o portador de uma função bem delineada: "destina-se ele ao cultivo de todos os exercícios atléticos conhecidos e todos os esportes tendentes a desenvolver o físico e o moral dos operários da Companhia a que pertencem". 658

Com mensalidades realmente baixas (2\$000 como joia para ingresso e $1 \$ 000$ mensais, contra os $5 \$ 000$ cobrados no Fluminense nesse período) - inferiores ao valor de uma jornada de um operário de qualquer seção da Companhia -, o Bangu inicialmente estava aberto somente aos trabalhadores da fábrica, sendo vedado a pessoas externas à Companhia. Logo na segunda sessão da diretoria - uma semana após a fundação - isso gerou um pequeno problema: aceitos os sóciosoperários João da Silva, Bernardino Brito, Roldão Maia, Onofre Lages, Gastão Bonfim, José Araújo e Antônio Bernardino (homens que já não tinham mais os nomes ingleses da maior parte dos

\footnotetext{
${ }^{655}$ LOPES, José Sérgio Leite. "Classe, etnicidade e cor na formação do futebol brasileiro" in: BATALHA, Cláudio; FORTES, Alexandre \& SILVA, Fernando Teixeira da (orgs.). Culturas de classe - identidade e diversidade na formação do operariado. Campinas: Editora da Unicamp, 2004, p. 131.

${ }^{656}$ PEREIRA, Leonardo Affonso de Miranda. Footballmania: uma História Social do Futebol no Rio de Janeiro (19021938). Rio de Janeiro: Editora Nova Fronteira, 2000, pp. 264-266.

${ }^{657}$ Idem, p. 33.

${ }^{658}$ JORNAL DO COMMERCIO, 17 de junho de 1904.
} 
fundadores), o italiano César Bochialini, no entanto, foi impedido de se filiar "porque não sendo ele operário da fábrica, não pode ser sócio do $c l u b " .{ }^{659}$

O italiano era um pequeno comerciante no local denominado Marco Seis, tinha uma relojoaria para vendas e pequenos consertos. ${ }^{660}$ Ao que tudo indica, diferentemente da maioria dos brasileiros, este imigrante sabia jogar futebol e, por isso, logo foi incorporado ao clube, aparecendo listado como sócio em junho daquele mesmo ano de 1904. ${ }^{661}$ Logo, Bochialini mudava-se, junto com suas duas irmãs e um cunhado, do Marco Seis para a Rua Estevam (ou Rua Ferrer) no 19, bem na estação de Bangu, e aparecia listado como "operário da fábrica de tecidos". ${ }^{662} \mathrm{O}$ episódio reforça a tese do historiador holandês Johan Huizinga de que grandes empresas que constituíam suas próprias associações esportivas, chegavam "até a contratar operários em função de sua habilidade para o futebol e não de sua competência profissional". 663

\subsection{1 - A questão disciplinar}

Da mesma forma que passou a fazer parte do quadro de funcionários da fábrica, satisfazendo uma exigência da diretoria do clube, César Bochialini logo se enquadrou em uma outra proposta rigorosa dos ingleses-fundadores, a de que "se um sócio saísse da Companhia por mau comportamento, tem de deixar de fazer parte do club". 664

Depois de jogar 21 partidas pelo time titular do Bangu entre 1904 e 1906, o italiano Bochialini não aparece mais nas escalações da equipe em 1907. ${ }^{665}$ Qual seria o motivo?

Nos meses de fevereiro e março de 1907, Bochialini estava às turras com seu próprio cunhado - um outro italiano de nome Rottini -, que morava na mesma casa de ${ }^{\circ} 19$. Depois de se atracarem, Bochialini feriu Rottini com uma facada na coxa esquerda. A residência foi, então, invadida pela polícia da fábrica que os levou "presos e apresentados ao gerente, que enviou, um para o Hospital de Misericórdia e outro para a detenção". ${ }^{666}$ Em agosto do mesmo ano, o juiz Raymundo Corrêa desqualificou o delito de "ferimentos graves" para "ferimentos leves", ${ }^{667}$ porém, é certo que a Companhia não o absolveu e o demitiu por mau comportamento. Consequentemente, o nome do

\footnotetext{
659 “Ata da sessão de 24 de abril de 1904". 1 Livro de Atas das Sessões da Diretoria do Bangu A.C., 17 de abril de 1904 a 7 de fevereiro de 1905.

${ }^{660}$ GRANADO, Paschoal José. Retratos, Espelho da Vida. In: Bangu Notícias. Ano I - nº 1 - Novembro de 1970, p. 17. 661 “Ata da sessão de $1^{\circ}$ de junho de 1904". $1^{\circ}$ Livro de Atas das Sessões da Diretoria do Bangu A.C., 17 de abril de 1904 a 7 de fevereiro de 1905.

662 O PAIZ, 27 de março de 1907, p. 3.

${ }^{663}$ HUIZINGA, Johan. Homo Ludens - $4^{a}$ edição. São Paulo: Editora Perspectiva, 2000, p. 143.

664 “Ata da sessão de 24 de abril de 1904". 1 Livro de Atas das Sessões da Diretoria do Bangu A.C., 17 de abril de 1904 a 7 de fevereiro de 1905.

${ }^{665}$ MOLINARI, Carlos. Almanaque do Bangu. Brasília: Editora Kiron, 2011, pp. 7-10.

666 O PAIZ, 2 de março de 1907, p. 2 e 27 de março de 1907, p. 3.

${ }^{667}$ Idem, 31 de agosto de 1907, p. 6.
} 
italiano não aparece mais nas atas do clube, nem em outros registros ligados à Bangu e é muito provável que tenha deixado de viver na vila operária.

A exigência de bom comportamento para ser sócio do clube e empregado da fábrica parecia clara, embora tivesse que estar escrita nos estatutos. O futebol era um esporte de elite, praticado com exceção do longínquo subúrbio de Bangu - por clubes que representavam a aristocracia da sociedade carioca, como o Fluminense, o Botafogo e o Paysandu. Dessa forma, os operáriosjogadores tinham de manter boa conduta dentro e fora de campo, garantindo elogios dos jornais, que valorizavam bem mais a fidalguia do que o mérito desportivo em si: "o team do club do Bangu, todo composto de empregados da fábrica de tecidos, que tomou o nome dessa localidade, é um eleven simpático, de homens do trabalho, fortes, alegres, bons companheiros, verdadeiros sportsmen". 668

Para manter este comportamento, os Estatutos do Bangu Athletic Club diziam que eram deveres dos sócios “conduzir-se com a máxima correção, quando uniformizados ou com o distintivo do $c l u b$ e quando estiverem no recinto deste. Os sócios que se desviarem dos deveres acima serão censurados pela diretoria e, na reincidência, suspensos ou eliminados". 669

Vendo o clube como uma forma de articular a união entre os operários, atitudes discrepantes não seriam toleradas pela diretoria, como a que o associado Climaco Teixeira protagonizou, no campo da Rua Ferrer, em 1917:

Por ocasião do jogo Esperança x Byron, o sr. Climaco Teixeira, um tanto alcoolizado, procurou por todos os meios, promover desordens, tendo provocado o sr. Benício de Oliveira, que também um tanto alcoolizado, sacou de um revólver ameaçando o provocador e mais os srs. Capitulino Tavares e Amasílio Bento. O sr. Teixeira proferia, em voz alta, palavras insultuosas, sendo a custo, retirado do campo. A diretoria, em vista dos fatos expostos e tendo o sr. Benício de Oliveira, solicitado demissão e sendo o seu procedimento sempre correto, resolveu apenas eliminar o sr. Climaco Teixeira e conceder a demissão ao sr. Benício. ${ }^{670}$

Climaco Teixeira não era mesmo o tipo de associado que o Bangu desejava, principalmente porque depois de ser expulso do clube em junho de 1917, ainda se envolveu num rumoroso caso de assassinado de Geraldina Corrêa, em agosto de 1918, na Estrada do Murundu. ${ }^{671}$

\footnotetext{
668 JORNAL DO COMMERCIO, 26 de julho de 1904.

${ }^{669}$ ESTATUTOS DO BANGU A. CLUB, aprovados em Assembleia Geral realizada em 20 de abril de 1915 , p. 3.

670 “Ata da sessão de 22 de junho de 1917”. 4 Livro de Atas das Sessões da Diretoria do Bangu A.C., 21 de janeiro de 1915 a 7 de setembro de 1917.

${ }^{671}$ Climaco Teixeira, excluído de sócio do Bangu em junho de 1917, por estar bêbado e arrumar confusão num jogo do Esperança, na Rua Ferrer, apareceria em agosto de 1918, envolvido num tenebroso caso de assassinato da Sra. Geraldina Corrêa, na Estrada do Murundu. Apelidado de "Neném", foi descrito pelos jornais como "desocupado, ébrio costumeiro" numa edição e em outra (GAZETA DE NOTÍCIAS, 19 de agosto de 1918, p. 3) como "Indivíduo atirado a valente, mal encarado, provocador de desordens, nunca abandona o seu revólver, com o qual ameaça todo o mundo". Era viúvo, tinha 30 anos e residia num sítio da localidade. Acabaria condenado à Casa de Correção, junto com outros dois homens: Bernardino Gonçalves da Silva e Francisco Barbosa. Preso em maio de 1919, Climaco foi absolvido em novembro de 1926, tendo neste período de tempo, ficado cego na cadeia. Por ser sócio fundador da sociedade recreativa "Prazer das Morenas de Bangu", passou a ser mantido com as arrecadações de alguns bailes a seu favor.
} 
Indisciplina não combinava com o ideal que o futebol queria propagar naqueles tempos de Belle Époque. Visto como um esporte salutar, o futebol - apesar de sua rápida difusão nas várias camadas da sociedade carioca - ainda guardava seus resquícios aristocráticos. E, para o Bangu, um clube operário que disputava a $1^{\text {a }}$ Divisão do Campeonato da Liga Metropolitana desde sua primeira edição, em 1906, era preciso controlar seus jogadores. Qualquer ato que pudesse envergonhar as cores do clube, era censurado energicamente. O caso do operário José de Andrade, o Juca, que trabalhava na sala de amostras da fábrica e era atacante do time banguense é um bom exemplo.

Em 9 de novembro de 1919, no campo da Rua Ferrer, com a partida já no $2^{\circ}$ tempo, o Bangu vencia o Fluminense por 2 a 1, quando Juca atingiu deslealmente o zagueiro tricolor Othelo, sendo expulso pelo juiz Eduardo Gibson. Com um a menos, o Bangu cedeu a virada ao Fluminense, perdendo o jogo por 3 a $2 .{ }^{672}$ A diretoria banguense, então, decidiu excluir Juca do quadro de jogadores do clube, além de fazer questão de comunicar ao clube das Laranjeiras a resolução tomada contra tão indisciplinado jogador:

O sr. José de Andrade, por ocasião do jogo com o Fluminense F. Club, em 9 do corrente, agrediu, sem nenhuma razão, um player desse. Considera isso um ato de condenável indisciplina e propõe, por isso, seja esse sócio excluído do quadro de jogadores e suspenso por 30 dias do quadro social.

Posta em discussão e depois a voto, é a proposta aprovada. O sr. Ary A. Franco propõe, sendo aprovado, que, como uma satisfação ao Fluminense F. Club, seja-lhe comunicada essa resolução da diretoria. ${ }^{673}$

É provável que a punição tenha interferido também na vida profissional de José de Andrade. Fora dos registros do clube em 1920, Juca reaparece na lista de sócios-prestantes em 1921 (ou seja, aqueles que prestavam algum serviço ao Bangu, no caso dele, jogando futebol) não mais como trabalhador da sala de amostras, mas como militar do $1^{\circ}$ Regimento de Artilharia Montada. ${ }^{674}$

O esporte era um instrumento de disciplinarização de jogadores e sócios que não se enquadravam em um determinado padrão esperado e o clube agia rapidamente nesses casos individuais. Porém, e quando a indisciplina era generalizada? Uma torcida inteira atuando fora da ética esperada pela elite da Belle Époque, o que fazer?

Por diversas vezes os jornais atentaram para o mau comportamento dos moradores de Bangu que iam ao campo da Rua Ferrer torcer pelo time da localidade. Em 1906, numa partida contra o Riachuelo, a Gazeta de Notícias percebeu que por ali, o operariado estava se exaltando mais do que o normal com uma simples partida de futebol, vaiando os adversários:

Os jornais à semana passada, verberaram um fato, que sendo verdadeiro é digno de lástima. No match de football ultimamente jogado entre os clubes Riachuelo e Bangu, sócios deste clube, como espectadores, vaiaram os jogadores. Seja-nos permitido dizer que

\footnotetext{
672 O PAIZ, 10 de novembro de 1919, p. 5.

673 “Ata da sessão de 11 de novembro de 1919". 6 Livro de Atas das Sessões da Diretoria do Bangu A.C., 13 de fevereiro de 1919 a 15 de dezembro de 1921.

${ }^{674}$ Juca não teria uma vida longa, falecendo precocemente em 3 de janeiro de 1923. "Ata da sessão de 11 de janeiro de 1923”. $7^{\circ}$ Livro de Atas das Sessões da Diretoria do Bangu A.C., 6 de janeiro de 1922 a 13 de novembro de 1930.
} 
estes espectadores não são sportsmen e apelamos para a diretoria do seu clube para que fatos iguais não se repitam. O verdadeiro sportman deve primar pela lhaneza, pela cortesia, pela lealdade e pela educação. Não acham os vaiadores que fariam figura muito mais bonita, mais cavalheirosa se dessem palmas aos vencidos? O menos que lhes adviria era a gratidão dos derrotados. Não se lembram eles que amanhã também podem ser vencidos? Absolutamente não culpamos o Bangu Athletic Club, nem a sua diretoria, mas achamos que, quanto antes, devem eliminar do seu seio esses vaiadores, que constituem elemento de discórdia, pernicioso e de muito mau efeito. Estamos certos que eles a esta hora acham-se arrependidos do ato que praticaram, porém, a nódoa ficou e, como eles não são conhecidos, ela recairá na coletividade, trazendo portanto vexames para os sócios do mesmo clube, que têm fina educação. Censurando estes fatos que constituem anomalia, estamos certos que não se repetirão. ${ }^{675}$

É claro que os apupos da torcida banguense se repetiram inúmeras vezes e até de forma mais agressiva. A defesa das cores do clube passou a representar a defesa dos interesses do bairro. Mesmo que o time ainda tivesse muitos estrangeiros (nesta partida contra o Riachuelo, em 1906, por exemplo, o Bangu jogou com cinco brasileiros, dois portugueses, dois italianos e dois ingleses $)^{676}$ os nacionais que ficavam em volta da cerca que separava o campo dos torcedores, deixavam as diferenças étnicas e de nacionalidade de lado para apoiar o Bangu. O inimigo não era mais o outro operário de um país diferente, o rival passava a ser o time adversário, aquele que vinha enfrentar o Bangu no campo da Rua Ferrer.

O clima esquentaria ainda mais em 1915, quando um sócio do São Cristóvão - Alexandre Moitinho - apitou uma partida entre Bangu e América, tendo favorecido o clube americano, em plena Rua Ferrer, em 16 de maio. Quando chegou a vez de o São Cristóvão vir até o bairro operário jogar sua partida de Campeonato contra o Bangu, no dia 4 de julho, a torcida queria se vingar do “tal” Moitinho, que era também jogador do primeiro quadro do São Cristóvão, como consta da notícia publicada pelo Jornal do Brasil:

(...) O sr. Alexandre Moitinho não compareceu ao match, por ter sábado à tarde, recebido um telegrama de pessoa amiga, que não quis revelar o nome, avisando-o de que, terminantemente, não fosse a Bangu no dia imediato, por correr risco à sua integridade física e à sua vida. (...) Acompanhados de diversos associados, chegaram a Bangu os times do São Cristóvão. A estação estava repleta de populares, que aguardavam a saída dos nossos players do comboio em que viajavam. Ao nosso desembarque ouvimos claramente de bocas em rosto ansioso de fúria: "Onde está o Moitinho? Quem é o tal Moitinho?". Evidentemente não o procuravam para fazer-lhe uma manifestação de simpatia... ${ }^{677}$

Manifestações dos torcedores-operários em defesa dos interesses do clube da localidade passaram a ser bem mais corriqueiras e, ao mesmo tempo, mostravam como aquela comunidade acreditava, de fato, que qualquer afronta ao Bangu A. C. era uma ofensa ao povo laborioso do bairro. Em meados da década de 10, foi ventilado proibir o operariado e outras classes que exerciam

${ }^{675}$ GAZETA DE NOTÍCIAS, 20 de maio de 1906, p. 7.

${ }^{676}$ MOLINARI (2011), p. 8. O Bangu entrou em campo com um time bastante diversificado neste dia 13 de maio de 1906: Manoel Maia (negro brasileiro), Justino Fortes (português), Roldão Maia (branco brasileiro), Oscar Lemos (branco brasileiro), Segundo Maffeu (italiano), Oscar Villas Boas (branco brasileiro), César Bochialini (italiano), William Procter (escocês, mestre eletricista da fábrica), Andrew Procter (escocês, chefe do almoxarifado da fábrica), Francisco Carregal (negro brasileiro) e Francisco de Barros (português, porteiro da fábrica).

${ }^{677}$ JORNAL DO BRASIL, 4 de agosto de 1915, p. 14. 
profissões "inferiores" de participar do Campeonato Carioca. O autor da proposta, o sr. Alberto Silvares, presidente do Vila Isabel F.C., defendia na revista "Sports" em que também era diretor, sua tese: "O football é um sport que só pode ser praticado por pessoas da mesma educação e cultivo". Para ele, um jogador tinha que ter, "entre os muitos predicados para sua prática regular, antes de mais nada, educação", ${ }^{678}$ ou seja, tudo o que os banguenses não teriam.

Em 1916, a proposta de impedir que os operários jogassem na $1^{\text {a }}$ Divisão do futebol carioca e que afetaria diretamente os times do Bangu e do Andarahy (este vinculado à Fábrica Cruzeiro) quase foi aprovada pela Liga. A divisão dos times pela profissão de seus jogadores (é bom lembrar que naquela época, todos os atletas eram amadores, ou seja, sócios-prestantes dos clubes) acabou não ocorrendo, principalmente porque o próprio presidente do Bangu, Noel de Carvalho, levantou a voz contra o que considerava uma injustiça, utilizando-se dos principais jornais para isto:

Mas não é uma pretensão abaixo de qualquer crítica o fato de qualificar a [Liga] Metropolitana de mau o elemento operário a ponto de negar-lhe coparticipação nas suas lides esportivas? Será possível que os membros da Metropolitana estejam convencidos de que a moralidade aumentará no seu seio com a exclusão do operário? (...) Será possível que um homem honesto e justo, seja qual for a sua posição na sociedade, sinta-se vexado e desonrado em ombrear com outro homem de qualidades idênticas, só pelo fato de ser este operário ${ }^{679}$

A defesa do elemento operário pelo presidente do clube suburbano reavivou ainda mais nos trabalhadores os "elos de sociabilidade": seus moradores e torcedores passaram a compartilhar de um modo muito particular de viver, trabalhar e torcer, formando assim uma identidade local. Morar na vila operária, ser empregado da Companhia e ir aos jogos do Bangu eram experiências compartilhadas que geravam uma sensação de pertencer a uma localidade e a um mesmo cotidiano, garantindo um clima de cumplicidade entre eles, como argumenta o historiador Nei Jorge dos Santos Jr. ${ }^{680}$

Essa união dos operários, esquecendo-se até mesmo das antigas divergências por questões de nacionalidade, aflorou ainda mais em 1917, ano marcado pelas grandes greves gerais de trabalhadores em São Paulo e no Rio de Janeiro, visto por muitos historiadores como um ponto de

\footnotetext{
${ }^{678}$ SPORTS, 6 de agosto de 1915. Na crônica intitulada “A Nossa Campanha” que faz em defesa da divisão das equipes de futebol do Rio de Janeiro de acordo com o nível social e a profissão de seus jogadores, Alberto Silvares escreveu uma "pérola" até hoje reproduzida por vários pesquisadores que se debruçam sobre o tema da discriminação na Belle Époque carioca: "De modo que nós que frequentamos uma Academia, temos uma posição na sociedade, fazemos barba no Salão Naval, jantamos na Rotisserie, frequentamos as conferências literárias, vamos ao five o'clock; mas quando resolvemos praticar sport entremos para o Icarahy, club distinto filiado à $3^{\text {a }}$ Divisão da Liga Metropolitana, somos obrigados a jogar com um operário, limador, com um corrieiro, mecânico, chauffeur e profissões outras que absolutamente não estão em relação ao meio onde vivemos. Nesse caso a prática do sport torna-se um suplício, um sacrifício, nunca uma diversão.

${ }^{679}$ GAZETA DE NOTÍCIAS, 30 de abril de 1916, p. 7.

${ }^{680}$ SANTOS Jr., Nei Jorge dos. A construção do sentimento local: o futebol nos arrabaldes de Bangu e Andaraí (19141923). Rio de Janeiro: Editora Multifoco, 2014, pp. 24-25.
} 
divisão entre um período de desorganização das associações sindicais e outro, no qual tais associações amadureceram em uma "estrutura consistente". 681

Em Bangu, porém, o foco do operariado continuava sendo as partidas de futebol. Em 10 de junho - um dia após o Cotonífero Crespi, situado no bairro da Mooca, em São Paulo, deflagrar uma greve que logo viraria uma paralisação geral de trabalhadores na capital paulista -, os banguenses tinham outra preocupação, provavelmente desconhecendo o movimento que começava no estado vizinho: iriam ver a partida entre o clube local e o Fluminense, lotando as arquibancadas do campo da Rua Ferrer.

O Bangu perdeu por 2 a 1 e o resultado gerou insatisfação generalizada, motivada tanto pela má atuação do árbitro, como pela maciça presença de torcedores do Fluminense no estádio do clube suburbano, já que o time tricolor tinha alugado um trem para levar seus adeptos até o longínquo bairro proletário. Ao final do jogo, na hora em que os sócios do clube mais aristocrático do Rio de Janeiro pretendiam embarcar no trem, foram surpreendidos por uma chuva de pedras, atiradas por enfurecidos moradores de Bangu:

Ao termos de fazer a crônica da partida realizada no campo da estação de Bangu, ficamos em dúvida sobre se a devemos incluir na seção esportiva ou se a devemos transferir para a seção dos casos policiais. Essa dúvida nasce da impressão com que nos retiramos ontem da longínqua estação suburbana, testemunha e quase vítima, o nosso representante, de uma saraivada de pedras, de paus, de tiros, lançada sobre o trem em que desciam os jogadores do Fluminense que ali foram disputar uma partida, simplesmente porque o quadro desse grêmio conseguiu vencer o antagonista do clube local. (...) $\mathrm{O}$ trem, conduzindo não só jogadores, mas pessoas de uma certa distinção e muitas famílias, foi apedrejado selvagemente. Os vidros das janelas foram partidos, as venezianas arriadas por prudência foram furadas a pedradas e porretadas. Muitas foram as pessoas feridas, algumas das quais senhoras e senhoritas. Chegaram a tentar um assalto ao comboio! O pânico estabelecido no seu interior é indescritível. ${ }^{62}$

Oficialmente, o Bangu A. C. tentou diminuir a ampla repercussão negativa que o apedrejamento teve na imprensa, divulgando a decisão de que "a diretoria resolveu d'ora para o futuro agir com a máxima energia nos dias de jogos. A assistência será ativamente fiscalizada e os que saírem da lei serão punidos severamente" ${ }^{683}$ O presidente Noel de Carvalho foi aos jornais "garantir que não há risco algum em se vir a Bangu, habitado como é, não por selvagens ou botocudos, como qualificou a imprensa, mas por uma honesta, laboriosa e pacífica população operária". 684

Ninguém foi punido no episódio das pedradas. Não se tratava de um sócio isolado ou do ato impensado de um torcedor. Era uma multidão que tinha tomado aquela decisão. Por mais reprovável

${ }^{681}$ BIONDI, Luigi. “A greve geral de 1917 em São Paulo e a imigração italiana: novas perspectivas” in HALL, Michael McDonald (org.). Cadernos Arquivo Edgard Leuenroth - Imigração, volume 15, $n^{\circ}$ 27. Campinas: UNICAMP/IFCH, 2009 , p. 264.

682 JORNAL DO BRASIL, 11 de junho de 1917, p. 10.

683 “Ata da sessão de 15 de junho de 1917". $4^{\circ}$ Livro de Atas das Sessões da Diretoria do Bangu A.C., 21 de janeiro de 1915 a 7 de setembro de 1917.

${ }^{684}$ O IMPARCIAL, 13 de junho de 1917, p. 8. 
que tivesse sido, é possível que a própria diretoria da fábrica têxtil compreendesse que, apenas 13 anos após a fundação, o clube conseguia "canalizar" os esforços dos trabalhadores. Nem mesmo nas greves e paredes as atitudes dos moradores da vila operária tinham sido tão violentas. No entanto, quando a questão envolvia o futebol e o destino do time - naquela ocasião contando com sete brasileiros e quatro britânicos - a comunidade parecia disposta a se unir em prol de uma associação que representava o nome do bairro.

De qualquer forma, a "selvageria" operária transplantada para os campos de futebol era, para os patrões, bem melhor do que a utilização dessa energia em protestos e piquetes contra a ausência de direitos trabalhistas de toda a classe. Apesar de o estopim ser a derrota no jogo, atirar pedras nos torcedores do Fluminense representaria um ressentimento dos trabalhadores do subúrbio chamados pelo jornal Lanterna de "pessoalzinho pé-rapado" 685 - contra uma elite socioeconômica, que vivia num dos melhores bairros da cidade. A "luta de classes", ilustrada neste episódio, pode revelar as tensões que o operariado vivia. Figurativamente, eles viam na agressão aos adeptos do clube das Laranjeiras uma forma de liberarem suas tensões e atingirem os membros da burguesia, responsáveis, mesmo que indiretamente, por sua dominação social.

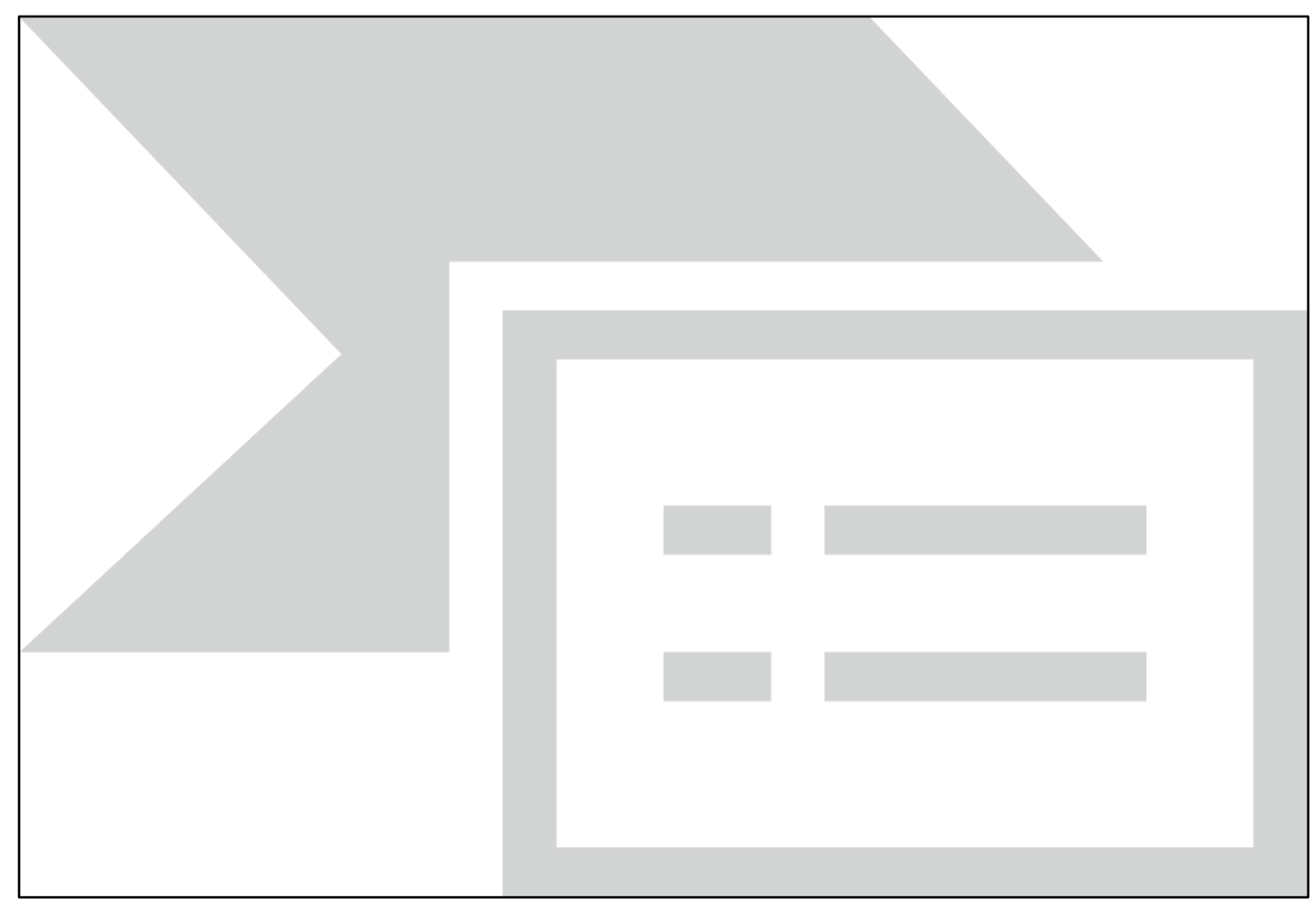

Figura 32 - O multifacetado time do Bangu no dia do jogo contra o Fluminense, em 1917. Negros brasileiros e filhos dos primeiros imigrantes britânicos vestiam a mesma camisa e despertavam a paixão dos moradores do bairro fabril. Acervo: Carlos Molinari.

\footnotetext{
${ }^{685}$ LANTERNA, 12 de junho de 1917, p. 4.
} 
No segundo semestre de 1917, os ânimos continuaram bem exaltados. No dia 30 de setembro, ou seja, quando as greves gerais já tinham cessado em São Paulo e no Rio de Janeiro, era ainda o futebol que colocava o nome de Bangu nas páginas dos jornais. Após uma partida contra o Sport Club Mangueira, na Rua Ferrer, o árbitro declarou aos diretores da Liga que apitar partidas na localidade era impossível pela ferocidade dos torcedores e as constantes invasões de campo. Jornais como $O$ Imparcial e $O$ Paiz, mesmo sem ter enviado cronistas ao campo, alimentavam a polêmica, publicando notas sobre o mau comportamento dos adeptos do Bangu: "Como juiz do encontro atuou o sr. Moura e Silva, que foi muito vaiado e ameaçado pela assistência, na sua maioria composta por adeptos do clube local". ${ }^{686}$ Os boatos aumentavam gradativamente: "Segundo se dizia ontem nas rodas esportivas, a Metropolitana vai interditar o campo do Bangu em virtude das cenas degradantes anteontem ali desenroladas durante o jogo com o Mangueira, na qual o time deste clube jogou sob uma atmosfera de terror, tendo mesmo o seu goleiro ameaçado de morte, caso não deixasse os rivais fazer gol!". 687

O resultado da confusão foi algo que a Liga há muito vinha tentando: interditar o campo da Rua Ferrer até o final da temporada de 1917, impedindo que outras partidas ocorressem em um local onde os torcedores eram por demais radicais. ${ }^{688}$ Era preciso punir exemplarmente aqueles que estavam destoando do padrão de conduta desejado para o esporte.

Por mais que os torcedores do clube operário pudessem reclamar nos jornais contra as “acusações injustas" que atingiam "um povo laborioso e, sobretudo, honesto como é o de Bangu", eles eram vistos como os suspeitos principais de quaisquer desordens que viessem a acontecer em seus jogos. Sem compartilhar dessa identificação profunda entre os sócios do clube operário, era natural que torcedores de outros times e jornalistas não se cansassem de condenar suas atitudes.

O Bangu A. C. não foi criado com a intenção de vigiar o momento de lazer do operariado da Companhia, mas acabou ganhando uma utilidade para os próprios diretores da Companhia: o de unir os trabalhadores em torno de uma mesma bandeira. A indisciplina generalizada que as partidas de fim de semana provocavam, acabaram servindo por aflorar um bairrismo inesperado e não eram reprimidas pela diretoria, ao contrário das faltas graves individuais, punidas com suspensão ou exclusão do quadro social. Pouco mais de uma década após sua fundação, o clube já era um incentivador de esforços dos moradores do bairro, que viam na defesa das suas cores uma forma de

${ }^{686}$ O PAIZ, $1^{\circ}$ de outubro de 1917, p. 8.

${ }^{687}$ O IMPARCIAL, 2 de outubro de 1917, p. 8.

688 Os jornais já faziam campanha para que o campo do Bangu fosse interditado, bem antes de 1917. Uma crônica publicada por O PAIZ, 8 de junho de 1909, p. 6, já fazia este "apelo” à Liga: “(...) Enquanto a Liga não se convencer de que deve, sob todos os títulos e razões, abolir os encontros que se tenham de dar no Bangu, obrigando-o a jogar em um dos muitos campos da cidade, que é o que não falta. Qualquer dos clubes que tenham de ir ao Bangu, cederá o seu campo de bom grado para a realização do match, evitando por esta forma as vaias das pessoas desconsideradas, que não sabem ou fingem não saber que o football, tal como aqui se pratica, é um divertimento de rapazes educados e que se prezam. Reflita a Liga sobre o caso e que tome uma resolução qualquer a respeito, de modo a sanar a imoralidade dos matches no Bangu". 
definirem sua identidade, compreendendo que o principal inimigo não era o operário que vinha de outro país e trabalhava ao seu lado diariamente ou até mesmo o contramestre; as rivalidades se estendiam a times de outros bairros - como o Fluminense, o Mangueira, o São Cristóvão - que vinham enfrentar o clube da localidade, representado em campo por jogadores que durante a semana eram seus próprios companheiros de tecelagem.

Pereira (2000) entende que qualquer sociedade composta por trabalhadores - tal como o Bangu A. C., o Andarahy A. C. ou o Carioca F. C. - era, ao mesmo tempo, uma forma de identidade classista. Para este historiador, quanto mais os trabalhadores iam formando sólidos laços de solidariedade, mesmo tendo inicialmente o campo de futebol como palco principal, mais eles iam participando ativamente de um processo amplo, que os ligava diretamente aos grandes enfrentamentos dos operários do período. ${ }^{689}$

É uma hipótese difícil de confirmar. A seleção dos sócios já representa um recorte - afinal, para fazer uma proposta de ingresso no clube, era preciso ser indicado por um associado mais antigo e, então, aprovado pela diretoria ${ }^{690}$-, restando à massa as manifestações passionais e sem propósito político.

Cláudio Batalha vai contra o pensamento de Leonardo Pereira, acreditando que o simples fato de existir uma sociedade composta basicamente por trabalhadores e destinada ao lazer, não expressa ainda uma identidade de classe, nem ajudaria a formar uma consciência política, que pudesse emergir nas grandes greves do final dos anos 10. Os adeptos do clube de futebol, dessa forma, não contribuiriam para reivindicações sociais, embora o "associativismo" fosse fundamental em qualquer vila operária do período. Batalha vê três grupos distintos de associações: as sociedades recreativas, carnavalescas, dançantes, esportivas; as sociedades mutualistas, culturais e educativas; e as sociedades profissionais, classistas e políticas - reservando a este último grupo a defesa dos interesses da classe trabalhadora. ${ }^{691}$

O clube de futebol, por mais que tenha servido para unir os operários da Fábrica Bangu, não parece mesmo ter sido palco de uma consciência maior de classe. O próprio artigo 50 dos Estatutos do Bangu A. C. de 1915 já restringia essa pretensão, ao estipular que eram "expressamente proibidas, no recinto do Club, as discussões de caráter político, religioso ou de nacionalidade". 692 Ademais, uma revista publicada pelo próprio clube, em 1916, confirmava que o número de sócios

\footnotetext{
${ }^{689}$ PEREIRA (2000), p. 278

${ }^{690}$ Art. 14 - A admissão de novos sócios será feita por proposta de um sócio quite, dirigida à diretoria, na qual serão declarados nome, idade, profissão e residência do proposto. Art. 15 - É condição essencial para ser admitido como sócio, possuir o proposto comprovada moralidade, a juízo da diretoria. Vide: ESTATUTOS DO BANGU A. CLUB, aprovados em Assembleia Geral realizada em 20 de abril de 1915, p. 3.

${ }^{691}$ BATALHA, Cláudio. "Formação da classe operária e projetos de identidade coletiva". In: DELGADO, Lucília de Almeida Neves \& FERREIRA, Jorge (org.). O Brasil Republicano: o tempo do liberalismo excludente - da Proclamação da República à Revolução de 1930. $3^{\text {a }}$ edição. Rio de Janeiro: Civilização Brasileira, 2008 , p. 180.

${ }^{692}$ ESTATUTOS DO BANGU A. CLUB (1915), p. 10.
} 
matriculados não ia além de 700 homens (mulheres e crianças abaixo de 15 anos não podiam ser admitidos como associados, embora pudessem tomar parte nas festas e partidas do clube se pertencessem à família de algum sócio). ${ }^{693}$ Como comparação, no mesmo ano, a Fábrica empregava 2.643 pessoas e um relatório da Companhia, de 1918, estimava em 12 mil o número de habitantes do bairro. ${ }^{694} \mathrm{Ou}$ seja, por mais que as arquibancadas da Rua Ferrer recebessem uma média de público de 2.914 pagantes a cada jogo, ${ }^{695}$ havia muito mais torcedores do time e moradores do bairro do que sócios contribuintes do clube. Dessa forma, pode-se concluir que a paixão que o futebol despertava serviu para unir diferentes grupos de trabalhadores da fábrica em prol de um mesmo ideal (acompanhar as partidas e torcer pelo time do bairro) do que o pouco provável fato de que o clube tenha servido para qualquer organização classista mais elaborada.

\footnotetext{
${ }^{693}$ Idem, p. 9.

${ }^{694}$ OLIVEIRA, Márcio Piñon de. Bangu: de fábrica-fazenda e cidade-fábrica a mais uma fábrica da cidade. Instituto de Pesquisa e Planejamento Urbano e Regional (IPPUR) da Universidade Federal do Rio de Janeiro (UFRJ), 1991, pp. $110,186,187,210$.

${ }^{695}$ Média feita com base em 39 registros de público pagante em partidas do Bangu realizadas no campo da Rua Ferrer entre 1924 e 1943, encontrados nos mais diversos órgãos de imprensa e catalogados pelo próprio autor em fichas técnicas.
} 


\section{1 - Futebol como meio de ascensão profissional}

Quais as vantagens que um operário tinha ao se tornar um jogador de futebol? Alguns historiadores, como Waldenyr Caldas, já se debruçaram sobre as benesses que um trabalhador teria se fizesse parte do time do Bangu A. C. Este autor acredita até mesmo que havia "uma verdadeira luta surda entre esses operários", ficando "todos na expectativa de uma possível convocação para participarem dos treinos do Bangu".

A tese de Caldas baseia-se no fato de que o Bangu nunca teve ingleses suficientes para formar dois times com 11 jogadores e que, logo cedo, o clube precisou incorporar elementos da massa operária nos seus quadros. Sem isso, não havia sequer jogo. Diferentemente de clubes exclusivos para britânicos, como o Rio Cricket (de Icaraí, Niterói) e do Paysandu, que tinham facilidade em atrair novos imigrantes para seus quadros, o Bangu, isolado no subúrbio, acabou obrigatoriamente tendo que fazer a "democratização" do futebol. Analisando esta época em que o jogador de futebol não era ainda um profissional do esporte, Caldas chega até mesmo a listar uma série de exigências, totalmente hipotéticas e sem comprovação nas fontes, que determinariam a escolha do operário que poderia figurar no time ao lado dos ingleses.

O critério de escolha do jogador baseava-se principalmente em três aspectos: no seu desempenho profissional, no tempo de serviço na empresa e no comportamento pessoal. Ao ser escolhido, o jogador-operário passaria imediatamente a desempenhar um tipo de trabalho mais leve, onde pudesse economizar suas energias para concentrá-las no futebol. Nos dias de treino, ele tinha autorização dos diretores da empresa para deixar o trabalho mais cedo, com uma condição: dirigir-se ao campo de futebol, a fim de realizar os treinos coletivos. $^{696}$

A teoria de Caldas tem pouco fundamento. Primeiro: era difícil crer que o desempenho profissional na tecelagem levasse um operário a figurar no time de futebol, se lhe faltasse a habilidade e o preparo físico para o esporte. Segundo: não necessariamente o tempo de casa parecia ser determinante para a escolha do jogador. Muitos operários jovens figuravam nas equipes que $\mathrm{o}$ Bangu A. C. montava e, talvez, fosse preferível um trabalhador mais novo do que um homem que já não dispusesse de tanta agilidade e condicionamento físico. Terceiro: como veremos ao analisarmos a trajetória do jogador Roldão Maia, o comportamento pessoal foi, neste caso, propositadamente deixado de lado. Por fim, nem todos obtinham o direito a um trabalho mais leve, embora seja importante ressaltar que o futebol propiciou a alguns deles a facilidade de se empregarem como "escriturário" (se fosse alfabetizado), como fiscal da sala de pano (caso do jogador Luiz Antônio, que atuou pelo clube entre 1912 e 1931) ou ainda como chefe do almoxarifado (caso do jogador Antenor Corrêa, que vestiu a camisa do time entre 1914 e 1928). A maioria, porém, continuava

\footnotetext{
${ }^{696}$ CALDAS, Waldenyr. O Pontapé Inicial - Memória do Futebol Brasileiro. São Paulo: IBRASA, 1990, p. 29.
} 
como tecelão. Essa "peculiaridade democrática" do time do Bangu não escapou a Mário Filho, atento observador do futebol carioca:

Nos teares os mestres não distinguiam um operário comum de um jogador de futebol. Tudo a mesma coisa. A distinção era feita na sala do pano. Depois de trabalhar muito, e, principalmente, de jogar muito, o operário-jogador ganhava o prêmio da sala do pano. E podia ainda melhorar se continuasse a merecer a confiança da fábrica, do Bangu. Havia o escritório, o trabalho mais suave do que na sala do pano. E o ordenado maior. ${ }^{697}$

Um registro das ocupações dos jogadores do clube alvirrubro entre 1918 a 1923, anotado a mão pelo secretário Guilherme Pastor em um grosso livro encadernado, mostra que 93 deles ainda trabalhavam como tecelões na fábrica, 44 eram escriturários da Companhia Progresso Industrial do Brazil, 31 eram estudantes da Escola Militar de Realengo, 30 eram escriturários em outras empresas, 24 eram comerciantes em Bangu, 22 eram estudantes em outras instituições que não a Escola Militar, 19 eram mecânicos da fábrica, 18 eram comerciantes em outros bairros, 16 eram gravadores da fábrica e 10 eram militares com alguma patente.

Como o número de jogadores inscritos a cada ano era relativamente alto (só em 1922, o Bangu registra na Liga 83 sócios-prestantes), era impossível dar bons cargos na fábrica a cada um deles. Se houvesse esta política, ela certamente estaria restrita aos titulares do $1^{\circ}$ time banguense e mesmo assim, a quem tivesse uma ficha de bons serviços prestados ao clube.

Quanto aos treinos coletivos, é correto afirmar que os jogadores-operários dos $1^{\circ}$ e $2^{\circ}$ times eram liberados do trabalho mais cedo às quintas-feiras. ${ }^{698}$ No entanto, sabe-se que era possível a qualquer sócio prestante, se dispusesse de tempo, aparecer no campo para treinar individualmente. Fato que fica evidente quando os membros do Ground Committee pretendem, em 1915, limitar o empréstimo da bola apenas às quintas-feiras, sábados e domingos. A diretoria se opõe à medida dizendo que isto atrapalharia o desenvolvimento do esporte e que os jogadores ficariam privados do já tradicional "shoot em goal diário". 699

Para Caldas, "a convocação significava prestígio junto aos diretores, privilégios, possíveis promoções e, sobretudo, a garantia de permanecer empregado, pelo menos enquanto satisfizesse as expectativas como jogador de futebol". ${ }^{700} \mathrm{O}$ cronista Mário Filho, no entanto, contradiz esta tese, desde a primeira edição do seu livro clássico O negro no futebol brasileiro, de 1947, entendendo que mesmo se atuasse no time principal do Bangu, o operário só subiria de cargo na fábrica se conseguisse se especializar:

O operário que jogava ao lado dos mestres, branco ou preto, não subia, não descia, ficava onde estava. Se quisesse subir tinha de trabalhar muito, de aprender muito, para

\footnotetext{
${ }^{697}$ FILHO, Mário Rodrigues. O Negro no Futebol Brasileiro. $4^{\text {a }}$ edição. Rio de Janeiro: Editora Mauad, 2003, p. 84.

698 "Ata da sessão de $1^{\circ}$ de maio de 1918". $5^{\circ}$ Livro de Atas das Sessões da Diretoria do Bangu A.C., 14 de setembro de 1917 a 29 de janeiro de 1919.

699 "Ata da sessão de 11 de março de 1915". 4 Livro de Atas das Sessões da Diretoria do Bangu A. C., 21 de janeiro de 1915 a 7 de setembro de 1917 .

${ }^{700}$ CALDAS (1990), p. 30.
} 
passar de tecelão a mestre. Como Francisco Carregal acabaria passando à custa de trabalho, e não de futebol. O futebol era divertimento. (...) No domingo dava seus pontapés na bola, corria em campo molhando a camisa, na segunda-feira cedinho, quando o portão da fábrica se abria, lá estava ele. Ia para os teares como os outros operários, trabalhava, só parava na hora do almoço, para voltar, depois, até às quatro horas. Nem tinha tempo de se lembrar do jogo da véspera. ${ }^{701}$

O caso de Francisco Carregal, citado por Mário Filho, é realmente dos mais emblemáticos. Primeiro jogador negro a vestir a camisa de um clube de futebol no Brasil, oportunidade dada a ele pelo Bangu em 1905, Carregal fez uma longa carreira dentro da fábrica, onde entrou como aprendiz de teares, aos 10 anos. Aos 20 anos, na mesma época em que passou a jogar futebol, tornou-se contramestre de teares. Aos 32 anos, virou contramestre geral e, em 1919, alcançou o posto de mestre geral. ${ }^{702}$

Havia, evidentemente, quem não queria esperar tanto. Claudionor Corrêa, brasileiro, negro, apesar de ter sido o artilheiro do Campeonato Carioca de 1920, não conseguia ir além de um simples tecelão dentro da fábrica nos anos em que defendeu o $1^{\circ}$ time do Bangu (entre $1918 \mathrm{e}$ 1921). Em 1922, quando surgiu uma oportunidade, trocou o Bangu pelo Vasco e o emprego de tecelão na Companhia Progresso Industrial pelo de encaixotador na Companhia Fábrica de Botões e Artefatos de Metal, um serviço mais leve arranjado por um dos diretores do clube vascaíno. ${ }^{703}$

O caso de Claudionor Corrêa - jogador-operário que chegou a ser convocado para participar da Seleção Brasileira que iria disputar o Campeonato Sul-Americano em Santiago, em 1920 - é emblemático. ${ }^{704}$ Mesmo sendo "bom de bola", ele acabou não subindo rapidamente dentro da empresa. Se as teorias que associam uma ascensão funcional graças ao futebol estivessem certas, Claudionor jamais teria largado a Companhia e o Bangu para trabalhar em outra fábrica e jogar por outro clube. Em suma: o fato de saber jogar futebol, no máximo, serviria para garantir um emprego nos teares. A ascensão profissional ia bem além do campo de jogo, e provavelmente passava pelo aprimoramento do conhecimento técnico e também das redes de relacionamento que o operário conseguisse tecer dentro da fábrica. Para alguns historiadores, como Anatol Rosenfeld e Fátima Antunes, no entanto, é inegável que "para uma parcela das camadas menos favorecidas, o futebol praticado no clube de fábrica trouxe uma nova possibilidade: a de fazer carreira como operáriojogador".

Por intermédio do clube de fábrica, homens simples tiveram acesso a um bem cultural desconhecido, o qual, uma vez apropriado e reelaborado, abriu-lhes outras oportunidades além da mera diversão. (...) Gerações de jovens foram admitidas não só porque trabalhavam bem, mas também porque jogavam bem. ${ }^{705}$

\footnotetext{
${ }^{701}$ FILHO (2003), p. 34.

${ }^{702}$ A ÉPOCA, 16 de outubro de 1919, p. 3.

${ }^{703}$ FILHO (2003), pp. 120, 138-139.

${ }^{704}$ GAZETA DE NOTÍCIAS, 7 de setembro de 1920, p. 5.

${ }^{705}$ ANTUNES, Fátima. “O futebol nas fábricas” In: Revista USP nº 22 - Dossiê Futebol. São Paulo, 1994, p. 106.
} 
Atentos ao fato de que, ao vestir a camisa do time, os jogadores-operários estavam, na verdade, representando a Companhia Progresso Industrial do Brazil, um deles chega a pedir à diretoria do Bangu A. C. que, caso ocorresse alguma lesão nos campos de futebol que o impedisse de trabalhar no dia seguinte, que ele fosse indenizado pelo próprio clube pelos dias em que ficassese recuperando. Assim, em 1912, o sócio prestante Arlindo Barbosa (que atuou entre 1905 e 1913) propõe que "sejam pelo club indenizados todos os prejuízos que o jogo de football pode acarretar num choque violento e que o impossibilite de frequentar, ou antes, comparecer ao trabalho. E se, por ventura, não for atendido convenientemente será obrigado a desistir de tal divertimento, porque já por diversas vezes o tem prejudicado". ${ }^{706}$ A proposta foi por unanimidade de votos rejeitada porque a diretoria entendia que já prestava proteção ao jogador-operário desde 1906, quando solicitou a presença do médico da Companhia, Dr. Borges Ramos, nos dias de jogos, "para prestar os seus serviços profissionais, caso que aconteça alguma desgraça pessoal". ${ }^{707}$

Da mesma forma, ciente de sua importância para o time, o jogador Alberto Vidal (que atuou entre 1914 e 1915) chega a pedir empréstimos à diretoria do clube, que eram concedidos e, posteriormente, anistiados: “A diretoria ainda resolveu auxiliar em $20 \$ 000$ (vinte mil réis) e perdoar em idêntica quantia de que era devedor ao sr. Alberto Vidal, tomando em consideração os relevantes serviços prestados ao B.A.C. pelo mesmo sr. como jogador de football e campeão de 1914". ${ }^{708}$ Não há registros da profissão de Alberto Vidal, mas provavelmente era uma pessoa que merecia e necessitava da generosidade da diretoria do Bangu., Em 1917, volta a pedir um empréstimo, desta vez de $50 \$ 000$ (cinquenta mil réis), obtendo da diretoria a metade desse valor. “Ao sr. Alberto Vidal foi concedida, tomando em consideração os serviços prestados ao club, a quantia de $25 \$ 000$ (vinte e cinco mil réis) como auxílio definitivo". 709

\subsection{2 - Roldão Maia: a trajetória de um jogador-operário}

Num domingo de outubro de 1958, um senhor foi recebido com uma salva de palmas no salão nobre do Bangu Atlético Clube. Era uma cerimônia festiva que pretendia homenagear em vida alguns dos grandes heróis da história banguense. O senhor, em questão, era Roldão Maia. Tinha sido jogador do clube nos seus primórdios, tinha sido diretor e, como era praxe, funcionário da

\footnotetext{
706 “Ata da sessão de 6 de março de 1912”. $3^{\circ}$ Livro de Atas das Sessões da Diretoria do Bangu A.C., 28 de fevereiro de 1909 a 12 de janeiro de 1915.

707 “Ata da sessão de 19 de janeiro de 1906". 2 Livro de Atas das Sessões da Diretoria do Bangu A. C., 24 de fevereiro de 1905 a 23 de julho de 1908 .

708 “Ata da sessão de 10 de fevereiro de 1916". 4 Livro de Atas das Sessões da Diretoria do Bangu A. C., 21 de janeiro de 1915 a 7 de setembro de 1917.

709 “Ata da sessão de 2 de março de 1917”. 4 Livro de Atas das Sessões da Diretoria do Bangu A. C., 21 de janeiro de 1915 a 7 de setembro de 1917.
} 
Fábrica Bangu. Aos 70 anos, ele já não ostentava o físico dos bons tempos. No entanto, com um atraso monumental, iria receber o título de sócio benemérito. ${ }^{710}$

Infelizmente, no caso da Fábrica Bangu, os chamados "cartões históricos", ou seja, as fichas de registros dos operários não estão mais disponíveis. Ali poderíamos ter acesso a dados completos sobre a trajetória profissional de jogadores-operários, como Roldão Maia. Além de sexo, idade, estado civil, instrução e nacionalidade, essas fichas mostravam as datas de entrada e saída, os cargos, os salários, a moradia, os acidentes, os motivos de punição e de desligamento, além de informar se o funcionário era ou não militante operário. No entanto, tentaremos reconstituir a trajetória desportiva e profissional de Roldão com outras fontes disponíveis: notícias de jornais e livros de atas do clube.

Pela data de seu alistamento militar, ${ }^{711}$ é provável que Roldão tenha nascido em 1889 (na época, os homens tinham que se apresentar ao Ministério da Guerra no ano seguinte após completar 20 anos $)^{712}$ e certamente começou a trabalhar na fábrica de tecidos quando ainda era menor. Isso porque, em 1904, logo ao saber da fundação do clube, resolveu ser sócio. Na segunda sessão da história do Bangu, junto com outros seis operários, Roldão Maia foi um dos primeiros sócios contribuintes. ${ }^{713}$

Roldão Maia gostava de esportes. Associado, poderia treinar, aperfeiçoar-se e quem sabe, jogar football. Pagou as mensalidades e teve sua primeira oportunidade em 1905. Um treino entre "brancos" e "encarnados". Jogou entre os "encarnados", ao lado de outros sócios brasileiros e portugueses. O treino era, na verdade, uma espécie de "peneira" que os ingleses faziam. Enquanto apitava o jogo, Clarence Hibbs - o mestre da estamparia - observava de perto quem tinha potencial para o jogo e quem não tinha. ${ }^{714}$ Roldão passou no teste.

No dia 22 de abril de 1906, Roldão vestiu o uniforme oficial pela primeira vez - camisa de algodão, com listras vermelhas bem grossas e listras brancas mais finas, bermudão azul escuro, meião preto de lã. Do outro lado estava o time do Riachuelo, verde e branco. Não foi difícil vencer: 5 a 0 . Naquele ano de 1906 ainda atuaria mais quatro vezes, sempre em partidas amistosas. ${ }^{715} \mathrm{O}$ Ground Committee - comissão formada por cinco membros da diretoria e que escalava as equipes -, não tinha confiança em lançar um jovem e ainda por cima brasileiro numa partida de Campeonato.

A partir de 1907, quando o número de ingleses no time principal foi reduzido - até porque o Bangu não estava disputando o Campeonato Carioca -, Roldão foi promovido à titular. Novamente,

\footnotetext{
${ }^{710}$ DIÁRIO DE NOTÍCIAS, 17 de outubro de 1958, segunda sessão, p. 7.

${ }^{711}$ DIÁRIO OFICIAL, 16 de outubro de 1910, seção 1, p. 33.

${ }^{712}$ Idem, 11 de novembro de 1910, seção 1, p. 18.

713 "Ata da sessão de 24 de abril de 1904". 1 Livro de Atas das Sessões da Diretoria do Bangu A.C., 17 de abril de 1904 a 7 de fevereiro de 1905.

714 JORNAL DO BRASIL, 24 de outubro de 1905, p. 5.

${ }^{715}$ MOLINARI, Carlos. Almanaque do Bangu. Brasília: Editora Kiron, 2011, pp. 8-10.
} 
para Waldenyr Caldas, a substituição da nacionalidade dos jogadores (britânicos por brasileiros) foi uma democratização do futebol, iniciada pelo Bangu:

Aqui, verdadeiramente, temos o início da democratização do futebol no Brasil. O critério classista dos técnicos ingleses já não tinha mais forças para se manter. Operário "bom de bola, o ás da pelota", como era chamado o bom jogador, tinha assegurado o seu lugar no time. Os próprios ingleses, agora, tinham interesse nisso. Atenua-se o conflito de classes (apenas na aparência) e com ele o preconceito de cor. O negro dribbler, por exemplo, poderia e até deveria integrar o eleven do Bangu, desde que evidentemente, trabalhasse para a Companhia Progresso. ${ }^{716}$

Roldão não era negro, nem driblador, mas era um jogador fisicamente mais forte que os demais - como comprovam as fotografias da época - e certamente soube se valer disso para levar vantagem. Em 1909, passou da conta em uma partida contra o Riachuelo, na Rua Ferrer: ${ }^{717}$

De fato, Roldão levava tudo de roldão. O aludido player já demonstrara a sua vocação para o "sarrafo", defendendo as cores do Bangu. Num prélio entre este quadro e o Riachuelo, Roldão deixou a marca de sua bicanca ferrada em quase todos os adversários. Terminado o prélio, os riachuelenses pareciam que não se retiravam de campo e sim, de Laguna [numa referência à famosa retirada de Laguna, na época da Guerra do Paraguai]: manquitolando, sangrando, gemendo. ${ }^{718}$

Em 1910, Roldão mudou de clube e vestiu o uniforme rubro do América (o Bangu não disputou o Campeonato Carioca daquele ano). Em 1911, voltou ao Bangu, ganhando logo a função de capitão do time. Foi campeão da 2a divisão em 1911 e em 1914 e, embora tentasse deixar de ser o capitão e líder do time, seu pedido de exoneração era sempre rejeitado pela diretoria. ${ }^{719}$

Como capitão, tomava atitudes polêmicas. Em 1912, chegou a ordenar que a equipe banguense abandonasse o campo, quando viu que o juiz tinha validado um gol irregular do São Cristóvão: "Não querendo o captain do Bangu se conformar com a decisão do referee, chamou seus companheiros para se retirarem do campo, o que fizeram sem objeção alguma" - registrou o Jornal do Brasil. $^{720}$

Essa liderança incontestável, com o passar dos anos experimentaria uma decadência. Em 1915, sem maiores explicações, Roldão não compareceu ao jogo contra o Botafogo, em General Severiano. Talvez, estivesse refletindo sobre uma notícia publicada no jornal A Época, que dizia: "Roldão, cujo jogo em priscas eras foi admirável e que, no entanto, hoje é diferente: sente-se pesado em demasia". ${ }^{721} \mathrm{O}$ Bangu perdeu por 4 a 1 . Roldão foi suspenso pela diretoria, como explicou o $1^{\circ}$ secretário Guilherme Pastor: “Quando o interroguei sobre se ia ou não jogar contra o Botafogo, ele

${ }^{716}$ CALDAS (1990), pp. 31-32.

717 A atuação de Roldão Maia neste jogo contra o Riachuelo, em 1909, também foi destaque negativo na edição de $O$ Paiz: "Roldão, o monstro, é inqualificável na expansão de sua brutalidade, só igualável à sua baixa condição moral. (...) Em suma, toda a equipe operária está no mesmo nível de seu capitão, o bate estacas Roldão Maia. (...) Juntem-se a isto as vaias de que foram alvo os jogadores do Riachuelo F. C., as ameaças que de fora lhes faziam os espectadores sem gravata". Vide: O PAIZ, 8 de junho de 1909, p. 6.

718 CORREIO DA MANHÃ, 5 de setembro de 1958, segundo caderno, p. 2.

719 “Ata da sessão de 2 de maio de 1912". $3^{\circ}$ Livro de Atas das Sessões da Diretoria do Bangu A.C., 28 de fevereiro de 1909 a 12 de janeiro de 1915.

${ }^{720}$ JORNAL DO BRASIL, 2 de junho de 1912, p. 13.

${ }^{721}$ A ÉPOCA, 16 de julho de 1915, p. 4. 
me respondeu com pouca cortesia. Resolvemos suspendê-lo, porque não estamos mais dispostos a dar braço forte à indisciplina". 722

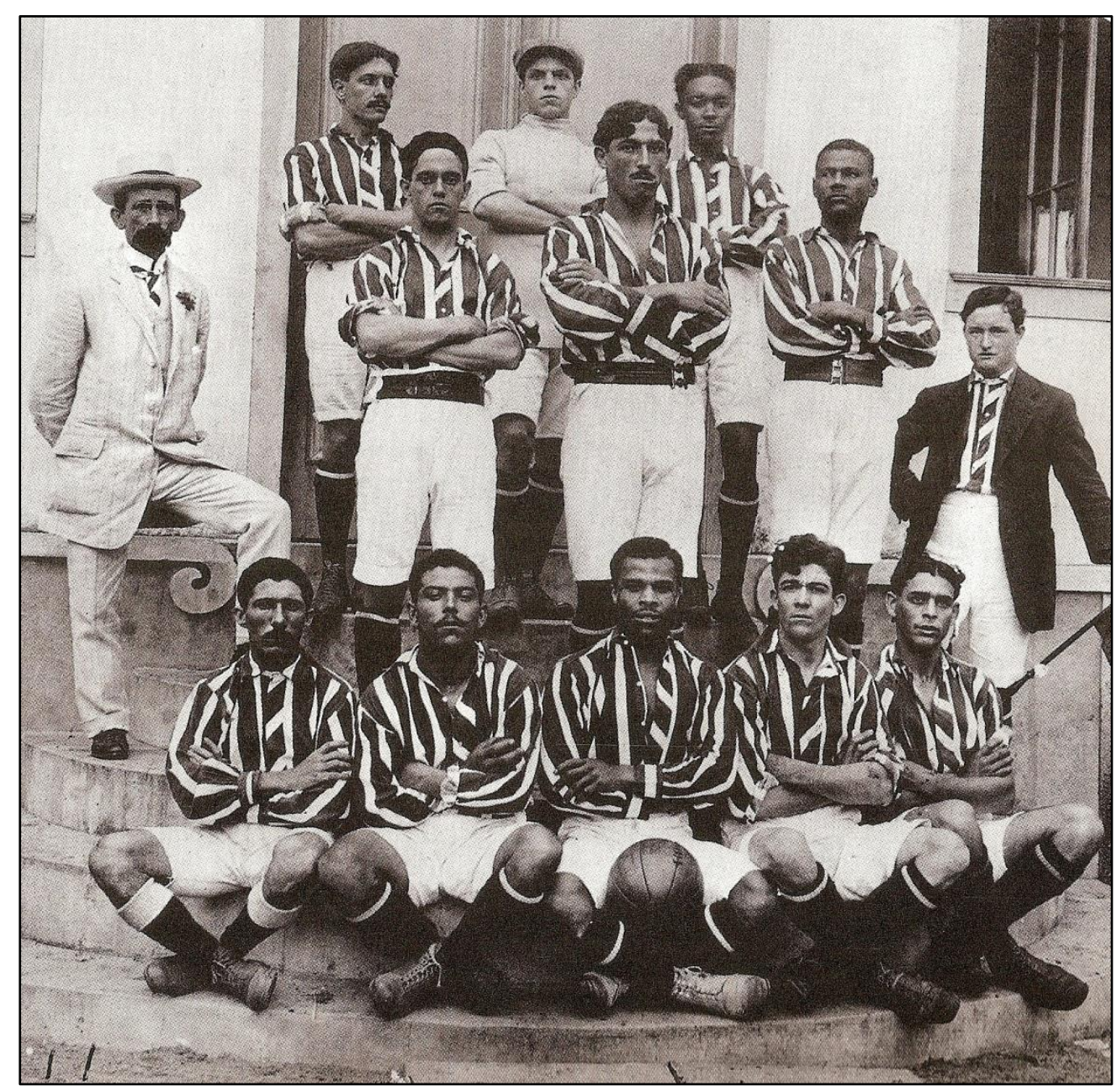

Figura 33 - Formação do Bangu A. C. em 1911. Na segunda fila, Roldão Maia é o segundo atleta da esquerda para a direita. Capitão do time, ele parecia ser maior e mais forte que os demais jogadores. De terno branco, à esquerda, o diretor escocês Andrew Procter. Atentemos também para a presença de vários atletas negros no elenco. Acervo: Carlos Molinari.

A suspensão terminou em 1916. Roldão colaborou substancialmente com o time que foi vicecampeão carioca, atrás apenas do América. Disputou todo o $1^{\circ}$ turno como titular, mas a partir do momento em que as vitórias pararam de vir, o Ground Committee achou que deveria mexer na equipe. Aos 27 anos, após ter feito 126 partidas pelo Bangu e marcado 11 gols, talvez fosse melhor dar a vez para alguém mais novo.

Em 1917, mudou de ares. Foi jogar pelo Esperança do Marco Seis, clube que era presidido pelo fundador do Bangu A. C., o escocês Andrew Procter. De lá foi para o Helênico. Certamente, já não era mais o grande center-half (centromédio) de outros tempos. Estava disputando a $3^{\text {a }}$ Divisão do Campeonato Carioca. Em 1919, voltou ao Bangu, aceitando jogar a preliminar de $2^{\text {os }}$ times. Sua

722 "Ata da sessão de 27 de agosto de 1915". 4 Livro de Atas das Sessões da Diretoria do Bangu A.C., 21 de janeiro de 1915 a 7 de setembro de 1917. 
reestreia foi noticiada pelos jornais: "O center-half Roldão, que por muito tempo jogou no $1^{\circ}$ team do Bangu, tendo depois se afastado das pugnas desportivas, voltou a jogar pelo mesmo club, ocupando a mesma posição, agora no $2^{\circ}$ team. Roldão fez sua reprise contra o Vila Isabel". ${ }^{723}$

Naquele mesmo ano de 1919, Roldão resolveu tumultuar um jogo do Esperança contra o Americano, na Rua Ferrer, impedindo a sua realização. Bangu e Esperança estavam de relações rompidas desde que o presidente do Esperança, Miguel José Pedro, denunciou o Bangu à Liga por ter cobrado entradas no amistoso contra a Seleção da Argentina. Na época, jogo amistoso não poderia vender ingressos. O Bangu sabia disso, mas precisava de dinheiro para terminar a construção de sua arquibancada social de ferro e madeira. $\mathrm{O}$ caso fora em maio. ${ }^{724}$ Em novembro, o Bangu perdoou o clube do Marco Seis e resolveu emprestar o campo para o clube vizinho. ${ }^{725}$ Roldão é que ainda não tinha perdoado o Esperança.

O jogador acabou suspenso por seis meses pela Liga Metropolitana e o clube ainda teve que pagar uma multa de $200 \$ 000$ por causa do incidente. ${ }^{726}$ Era o Roldão de sempre, um verdadeiro agitador, homem de temperamento forte. Parece evidente que, para a direção da fábrica, era melhor que este conhecido operário, de comportamento explosivo, estivesse ao seu lado.

Mecânico da Fábrica Bangu, Roldão Maia morava na Rua Fonseca. ${ }^{727}$ Segundo um jornalista chamado Augusto Rangel, que em 1919 andou publicando na Gazeta de Notícias vários insultos à Companhia e aos seus diretores (por causa da descoberta da já mencionada fraude aduaneira de João Ferrer), Roldão Maia ganhava $150 \$ 000$ semanais na fábrica, uma "nababesca compensação", mas não para trabalhar. Na visão de Augusto Rangel - costumeiramente perseguido e que se julgava ameaçado de morte -, Roldão era uma espécie de "capanga" do patronato e teria tentado lhe agredir na noite de 3 de julho. ${ }^{728}$

Não há como confirmar se a fábrica realmente utilizava o antigo jogador-operário, conhecido pela sua impulsividade, como meio para ameaçar quem desacatasse a diretoria da empresa. O jornalista Augusto Rangel era uma figura polêmica e pouco confiável. Naquele mesmo ano de 1919, foi preso por supostamente roubar um guarda-chuva com cabo de ouro ${ }^{729}$ e ser acusado de ter praticado "atos indignos" com um menor de 13 anos que morava com ele. ${ }^{730}$ Em 1924, enfim, foi denunciado à delegacia do $4^{\circ}$ distrito por aplicar golpes na praça, em que "lesava os incautos sob

\footnotetext{
${ }^{723}$ O IMPARCIAL, 11 de junho de 1919, p. 8.

724 “Ata da sessão de 31 de maio de 1919". $6^{\circ}$ Livro de Atas das Sessões da Diretoria do Bangu A.C., 13 de fevereiro de 1919 a 15 de dezembro de 1921.

725 “Ata da sessão de 28 de novembro de 1919". 6 Livro de Atas das Sessões da Diretoria do Bangu A.C., 13 de fevereiro de 1919 a 15 de dezembro de 1921.

${ }^{726}$ GAZETA DE NOTÍCIAS, 21 de fevereiro de 1920, p. 5; O PAIZ, 21 de fevereiro de 1920, p. 7.

${ }^{727}$ Informações referentes ao ano de 1919, apurado no livro de anotações de atletas, escrito a mão pelo $1^{\circ}$ secretário do Bangu A.C., Guilherme Pastor. Disponível para consulta na sede social do clube.

${ }^{728}$ GAZETA DE NOTÍCIAS, 7 de julho de 1919, p. 4.

${ }^{729}$ A ÉPOCA, 24 de fevereiro de 1919, p. 3.

${ }^{730}$ Idem, 19 de março de 1919, p. 8.
} 
promessas de emprego", pedindo uma fiança antecipada de $200 \$ 000$ a $400 \$ 000$ para garantir a vaga anunciada pela sua própria "Agência de Informações Comerciais". 731

O fato é que, enquanto Augusto Rangel tinha problemas com a Justiça, Roldão continuava sua vida na fábrica como mestre de seção. Se Roldão ascendeu por méritos profissionais, após muitos anos sendo mecânico, ou se pelo fato de ter sido jogador de futebol de certo renome no bairro ou até mesmo por ter prestado serviços à fábrica como capanga, não se sabe. Sua índole pessoal se confundia com suas atitudes nas oficinas e seu nome logo apareceu nas páginas do jornal proletário Voz do Povo, como um chefe de seção extremamente rude com seus funcionários:

Chegou ao nosso conhecimento um dos muitos desaforos que se passam no interior das fábricas. Um mestre de uma das seções da fábrica do Bangu, de nome Roldão Maia, abusando das suas atribuições, tentou anteontem praticar uma exploração, das muitas que se costumam fazer dentro das fábricas. Nas fábricas de tecidos há umas chapas que dão aos operários o direito de comprarem fazendas com certa percentagem vantajosa. Esse tal mestre, acariciando o projeto da ideia de um bom negócio, tentou comprar chapas aos operários que as quisessem vender. Na seção das moças, onde tentou a ideia, e como uma das moças a quem se dirigiu não lhe quis vender a chapa, indignou-se, praticando vários desaforos de tal forma obscenos, que resultaram em escândalo. Devido à interferência do gerente, que julgou o caso com parcialidade, esse tal mestre nada veio a sofrer. É sempre assim... já não é para estranhar. ${ }^{732}$

Com as fontes coletadas, podemos supor que Roldão tenha se valido de sua atuação nos campos de futebol para projetar sua imagem de um líder valente na comunidade de Bangu e que isso pode ter lhe ajudado a galgar postos na fábrica. Como muitos jogadores-operários da época, seu relacionamento com as chefias da Companhia era bem distinto do que o de qualquer outro trabalhador que não jogasse futebol.

Em 1921, aos 32 anos, ganhou a prova do arremesso de peso para atletas amadores numa festa esportiva disputada na Rua Ferrer, atirando o objeto a uma distância de 8m10 (algo insignificante em termos de recordes, especialmente se comparado com as marcas olímpicas da época) ${ }^{733}$. Mesmo assim, Roldão Maia, o vencedor da prova, ganhou dois prêmios entregues pessoalmente pelo diretor-gerente da Companhia, o inglês James Schofield: um litro de whisky "White Label” e uma caixa de charutos. ${ }^{734}$ Honraria maior, Roldão só viria a receber em 1958, já com 69 anos, quando subiu no palco do salão nobre para se tornar sócio honorário do clube.

\footnotetext{
731 O IMPARCIAL, 9 de abril de 1924, p. 8; O PAIZ, 9 de abril de 1924, p. 5.

732 VOZ DO POVO, 7 de fevereiro de 1920, p. 3.

${ }^{733}$ Em 1921, o recorde olímpico do arremesso de peso era do norte-americano Patrick McDonald que, nos Jogos de Estocolmo 1912, atirou a bola de ferro de 8 quilos a uma distância de $15 \mathrm{~m} 34$. Vide: LANCELOTTI, Silvio. Olimpíada 100 anos - História Completa dos Jogos. São Paulo: Nova Cultural, 1996, p. 70.

${ }^{734}$ O PAIZ, 29 de junho de 1921, p. 7.
} 


\section{VI - Greves: entre os fracassos e as conquistas de direitos}

Examinando 560 cartões históricos dos funcionários da Fábrica Bangu, numa época em que a Companhia tinha mais de 2.500 operários, ${ }^{735}$ a historiadora Eulália Lobo concluiu que, entre $1914 \mathrm{e}$ 1915, as médias salariais caíram na quase totalidade das categorias. ${ }^{736}$ O motivo foi a redução dos dias trabalhados por semana para apenas três, a partir de agosto de $1914 .{ }^{737}$. À época, ganhava-se por jornada e isso representava um sério abalo no ganho mensal dos operários.

Grande seca reduziu consideravelmente o volume dos mananciais, tornando crítico o abastecimento de água. "Uma seca, rebelde de debelar, e que obrigou a nossa fábrica quase a paralisar, sendo mesmo forçada a, por longo espaço de tempo, somente trabalhar meio dia, encarecendo extraordinariamente a produção" - registrou o Comendador Costa Pereira. ${ }^{738}$

Em setembro de 1914, a fábrica chega a paralisar os trabalhos porque há dois meses não chovia na região. ${ }^{739}$ Mais do que a queda na produção da Companhia, estavam em jogo os rendimentos de toda a população fabril. Acompanhando as notícias publicadas nos jornais, vê-se que a situação em outubro era gravíssima:

Estão completamente paralisados os trabalhos desta importante fábrica, onde ganham o pão dois mil operários agora privados de trabalho. Semelhante calamidade se deve unicamente ao imprevidente e inepto diretor ou inspetor das Águas, pela ausência do precioso líquido para a fábrica poder trabalhar. Tantas famílias privadas de pão, enquanto os magnatas passam a fiambre e champagne $!^{140}$

Apesar da nota claramente tentar jogar o operariado contra as autoridades públicas, não foi a prefeitura do Distrito Federal quem resolveu a situação. A própria Companhia mandou fazer a preparação de todos os encanamentos já existentes, construiu outro reservatório na Bacia do Guandu do Sena, com capacidade para armazenar aproximadamente 36 milhões de litros, e reforçou os mananciais do Rio da Prata, adquirindo mais algumas propriedades no local, em 1914 e $1915 .^{741}$

A crise nos rendimentos familiares em 1914 não impediu que, logo no início de 1915, os operários da Fábrica Bangu adotassem um gesto de solidariedade com os trabalhadores da Companhia de Fiação e Tecelagem Carioca, do Jardim Botânico, que estavam em situação bem pior.

Enquanto as outras fábricas diminuem os dias de trabalho, abatendo também os salários, a Companhia Carioca, menos feliz nas suas transações, teve de fechar o seu

\footnotetext{
735 OLIVEIRA, Márcio Piñon de. Bangu: de fábrica-fazenda e cidade-fábrica a mais uma fábrica da cidade. Instituto de Pesquisa e Planejamento Urbano e Regional (IPPUR) da Universidade Federal do Rio de Janeiro (UFRJ), 1991, p. 110.

${ }^{736}$ LOBO, Eulália Maria Lahmeyer. História do Rio de Janeiro. Do Capital Comercial ao Capital Industrial e Financeiro. $2^{o}$ Volume. Rio de Janeiro: IBMEC, 1978, p. 521.

${ }^{737}$ A ÉPOCA, 11 de agosto de 1914, p. 5.

${ }^{738}$ DIÁRIO OFICIAL, 11 de março de 1919, seção 1, p. 33.

${ }^{739}$ A ÉPOCA, 8 de setembro de 1914, p. 5.

${ }^{740}$ Idem, 28 de outubro de 1914, p. 4.

${ }^{741}$ OLIVEIRA (1991), p. 72.
} 
estabelecimento fabril, onde labutavam perto de 2.000 operários, entre homens, mulheres e crianças. A notícia daquela resolução repercutiu dolorosamente nos lares humildes daquela pobre gente, que se via, assim, diante de um abismo tenebroso, frente a frente com os dilacerantes espetáculos da fome.

Foram os companheiros da Companhia Corcovado os primeiros a correr em socorro daqueles infelizes.

Depois, o comércio local, algumas fábricas, e agora é o operariado da Fábrica de Bangu, que apesar de se debater também com a crise e a falta d’água e diminuição de dias de trabalho, acaba de tomar a iniciativa de promover alguns benefícios em favor de seus companheiros. ${ }^{742}$

Este exemplo pode demonstrar que, diante das dificuldades, a solidariedade entre pessoas de bairros diferentes, mas com a mesma profissão, começava a se aguçar. Em Bangu, a renda das sessões de cinema e de espetáculos teatrais, além de uma lista de assinaturas, foram revertidas aos operários da Carioca. ${ }^{743}$ Dois anos antes do início dos grandes movimentos grevistas, perceber a união e a ajuda mútua do operariado em tempos de crise, pode ser uma chave para explicar como esta "classe" alçou voos mais altos quando sentiu necessidade.

Em 1917, a Gazeta de Notícias fez uma visita a Bangu e lançou uma matéria na primeira página, ilustrada por duas fotografias. A impressão era francamente positiva, como nos melhores dias da Belle Époque. Os 2.800 operários (1.200 homens, 900 mulheres e 700 crianças) estavam felicíssimos com seus empregos e, após uma jornada que ia das 6 horas da manhã até as 5 horas da tarde (com intervalo de 10 às 11 horas para o almoço), quem saía pelos portões ainda encontrava forças para enaltecer a Companhia:

Todos eles manifestam a sua satisfação para com a direção da Companhia. São pagos pontualmente e tratados com benevolência. Alguns desses homens do trabalho nos disseram que há operários, em grande número, solicitando serviço nessa fábrica. Se houvesse vagas, até de outras fábricas viria, espontaneamente, gente, que aí deseja trabalhar. (...)

Todos os operários residem nas casas da Companhia, e grande número deles possui habitações próprias, pagando, apenas, o foro do terreno à empresa. Facilita ainda a Companhia, aos operários, a construção de prédios, adiantando-lhes dinheiro e materiais, adiantamentos esses que são pagos em pequenas prestações mensais. ${ }^{744}$

Visto desta forma, Bangu acabaria parecendo uma ilha de prosperidade em relação a todas as outras vilas operárias do eixo Rio-São Paulo. Os anos em que perduraram a Primeira Guerra Mundial (1914-1918) são anos de crise e, principalmente, de carestia de vida para as massas trabalhadoras das duas grandes cidades do país. Para Boris Fausto, neste período, "a especulação comercial, as pressões inflacionárias internas e as decorrentes da elevação dos preços internacionais atuam no sentido de provocar a forte elevação do custo de vida". ${ }^{745}$ Para Warren Dean, "a política inflacionária do governo, a escassez de tanta coisa causada pela guerra, as tentativas de fixar preços-teto e os níveis de ordenados atrasados deram origem a considerável inquietação social" ${ }^{746}$

\footnotetext{
${ }^{742}$ A ÉPOCA, 20 de fevereiro de 1915, p. 6.

${ }^{743}$ Idem, 6 de março de 1915, p. 5.

${ }^{744}$ GAZETA DE NOTÍCIAS, 21 de março de 1917, p. 1.

${ }^{745}$ FAUSTO, Boris. Trabalho urbano e conflito social (1890-1920). São Paulo: Difel, 1977, p. 166.

${ }^{746}$ DEAN, Warren. A industrialização de São Paulo (1880-1945). São Paulo: Difel, 1986, p. 103.
} 
Sheldon Leslie Maram conseguiu provar, por meio de índices econômicos, que o custo de vida para uma família crescera 46\% entre 1914 e 1919. Só o aumento com as despesas com alimentação representava $45 \%$ desse total. ${ }^{747}$ Para Eulália Lobo, “em 1917, o processo de proletarização e empobrecimento da mão-de-obra atingiu o auge com a inflação e o encarecimento dos gêneros alimentícios". ${ }^{748}$

Para o operariado, aumentavam os preços das necessidades mais básicas; para os patrões, a guerra na Europa trazia problemas, impedindo a expansão das fábricas, em decorrência da dificuldade das importações de máquinas. ${ }^{749}$ Fora isso, aumentava também o preço do quilo de algodão - desviado pela procura ultramarina e escasso para as fábricas locais ${ }^{750}$ - e das químicas necessárias ao preparo de tecidos estampados.

(...) Ultimamente, teve ela [a Fábrica Bangu] necessidade de elevar a produção, para poder fazer face às suas grandes despesas. E isso porque houve um aumento de $40 \%$ nos preços da matéria prima. $\mathrm{O}$ algodão, por exemplo, que custava 900 réis o quilo, custa, agora, $3 \$ 000$. As drogas aumentaram mais de dez vezes. E assim, tudo mais. ${ }^{751}$

Se houve aumento de produção, este foi obtido paradoxalmente com a diminuição constante do número de operários. Se em 1917, a Bangu tinha 2.879 trabalhadores; em 1918 empregava 2.733; em 1919 mantinha 2.600 postos; e, em 1920, ocupava 2.409 pessoas. ${ }^{752}$ Em suma, quem ficou empregado, trabalhou mais, pelo mesmo preço pago anteriormente.

Por causa da guerra, a importação de maquinários era mínima e, portanto, os operários, para enfrentar o aumento de produção exigido naqueles anos, e não podendo as fábricas aumentar seu número de máquinas, foram obrigados a trabalhar muito mais intensamente em turmas que se sucediam ao longo de um dia inteiro. ${ }^{753}$

Para historiadores de linha marxista, como Francisco Foot Hardman e Victor Leonardi, a crise veio bem a calhar para acender o ânimo das classes trabalhadoras e provocar as grandes greves desencadeadas após alguns anos de penúria:

Em 1914, o início da Primeira Guerra Mundial, veio agravar ainda mais o estado de penúria da classe trabalhadora, com a carestia crescente e o fantasma do desemprego. Porém, não houve uma reação imediata do movimento operário; pelo contrário, diminuíram as greves. Somente em julho de 1917, com a greve geral em São Paulo, se abriria um novo período de ascenso do movimento operário, que se estenderia até $1920 .{ }^{754}$

\footnotetext{
${ }^{747}$ MARAM, Sheldon Leslie. Anarquistas, imigrantes e o movimento operário brasileiro. Rio de Janeiro: Paz e Terra, 1979, p. 122.

${ }^{748}$ LOBO (1978), p. 940.

${ }^{749}$ LEVY, Maria Bárbara. A indústria do Rio de Janeiro através de suas sociedades anônimas. Rio de Janeiro: Editora UFRJ, 1994, p. 206.

${ }^{750}$ DEAN (1986), pp. 102-103.

${ }^{751}$ GAZETA DE NOTÍCIAS, 21 de março de 1917, p. 1.

752 OLIVEIRA (1991), pp. 110; 195.

753 BIONDI, Luigi. "A greve geral de 1917 em São Paulo e a imigração italiana: novas perspectivas”. In: HALL, Michael McDonald (org.). Cadernos Arquivo Edgard Leuenroth - Imigração, volume 15, $n^{o}$ 27. Campinas: UNICAMP/IFCH, 2009, p. 276.

${ }^{754}$ HARDMAN, Foot Francisco \& LEONARDI, Victor. História da Indústria e do Trabalho no Brasil (das origens aos anos 20) - $2^{a}$ edição. São Paulo: Editora Ática, 1991, p. 279.
} 
O movimento não começou no Rio de Janeiro, onde, apesar da crise, as médias salariais ainda eram mais altas do que em São Paulo. Em Bangu, naquele "paraíso laboral” descrito pela Gazeta de Notícias, não havia o mínimo sinal de levante operário no início de 1917. Um comício da Federação Operária contra a carestia de vida e também de propaganda das oito horas de trabalho, realizado no bairro, num domingo, 11 de fevereiro, teve "concorrência relativamente pequena, não obstante estar anunciado com larga antecipação". ${ }^{755}$ Insistentes, os sindicalistas voltariam em 25 de março, quando novamente foi "muito fraca a concorrência àquela assembleia". ${ }^{756}$ Só na terceira vez, em 29 de abril, data em que ocorreram meetings em diversos bairros do Rio de Janeiro - como Vila Isabel, Piedade, Largo de São Clemente, Gávea, Santa Cruz -, o público aumentou em Bangu e enfim “o comício teve regular assistência". 757

A greve começou timidamente em São Paulo num sábado, 9 de junho, com a paralisação de apenas 400 dos 1.305 operários do Cotonifício Crespi, na Mooca. Apoiado pela Liga Operária da Mooca, a greve se tornou generalizada a partir de 29 de junho, quando os trabalhadores exigiam aumentos em torno de 20\%. Logo, outras indústrias também aderiram ao movimento: a Fábrica de Tecidos Ipiranga, várias oficinas de fabricação de móveis, a Companhia Antarctica Paulista, a Fábrica de Tecidos Mariângela. Na primeira quinzena de julho, São Paulo era uma cidade ingovernável. A morte do sapateiro anarquista José Martínez, de 21 anos, em 9 de julho, por uma carga de cavalaria, acirrou ainda mais os ânimos. Seu cortejo fúnebre, em 11 de julho, foi acompanhado por 10 mil operários que empunhavam bandeiras pretas ou vermelhas. Numa capital com 400 mil habitantes, como era São Paulo em 1917, havia uma massa de 50 mil trabalhadores em greve. Na visão do militante Everardo Dias:

São Paulo é uma cidade morta: sua população está alarmada, os rostos denotam apreensão e pânico, porque tudo está fechado, sem o menor movimento. Pelas ruas, afora alguns transeuntes apressados, só circulavam veículos militares, requisitados pela Cia. Antártica e demais indústrias, com tropas armadas de fuzis e metralhadoras. Há ordem de atirar para quem fique parado na rua. Nos bairros fabris do Brás, Mooca, Barra Funda, Lapa, sucederam-se tiroteios com grupos de populares; em certas ruas já começaram fazer barricadas com pedras, madeiras velhas, carroças viradas. A polícia não se atreve a passar por lá, porque dos telhados e cantos partem tiros certeiros. Os jornais saem cheios de notícias sem comentários quase, mas o que se sabe é sumamente grave, prenunciando dramáticos acontecimentos. ${ }^{758}$

As diversas Ligas Operárias exigiam: aumento de 35\% nos salários inferiores a 5\$000 (por jornada) e de 25\% para os mais elevados; proibição do trabalho de menores de 14 anos; abolição do trabalho noturno de mulheres e menores de 18 anos; garantia de trabalho permanente; jornada de 8

\footnotetext{
755 CORREIO DA MANHÃ, 11 de fevereiro de 1917, p. 3.

756 A ÉPOCA, 26 de março de 1917, p. 2.

${ }^{757}$ Idem, 30 de abril de 1917, pp. 1-2.

758 Apud. GIANOTTI, Vito. Reconstruindo nossa história: 100 anos de luta operária no Brasil. Petrópolis: Editora Vozes, 1988, p. 95.
} 
horas, com acréscimo de 50\% nas horas extras e "semana inglesa"; respeito ao direito de associação; libertação dos grevistas presos e permanência no emprego dos participantes da greve. ${ }^{759}$

Alguns itens pareciam de impossível cumprimento para os industriais da época. Os empresários assinaram um acordo em 14 de julho, reconhecendo o direito de reunião, dando um aumento de $20 \%$, autorizando a libertação dos presos e concordaram em não demitir os operários grevistas. Fora isso, nada mais foi aceito. Durante um comício público, em 16 de julho, um Comitê de Defesa Proletária leu o acordo para uma massa de trabalhadores e, aos poucos, as fábricas foram voltando a funcionar. Estima-se que morreram, em decorrência dos conflitos urbanos, cerca de 200 pessoas. ${ }^{760}$

Analisando a greve 49 anos depois, o líder anarquista Edgard Leuenroth, chegou à conclusão que "A greve geral de 1917 foi um movimento espontâneo do proletariado sem interferência, direta ou indireta, de quem quer que seja. Foi uma manifestação explosiva, consequente de um longo período de vida tormentosa que então levava a classe trabalhadora". 761

Sem uma direção político-partidária ou mesmo sindical no comando das decisões, trabalhadores que vivenciavam a dura realidade do interior das fábricas e das oficinas reuniram-se nas ligas de bairro e adotaram a estratégia de ação direta para reivindicar melhorias nas condições de vida e de trabalho. Na medida em que suas solicitações não eram atendidas, as greves foram eclodindo até a generalização do movimento no mês de julho. ${ }^{762}$

Evidentemente, o ânimo inflamado dos paulistas incendiou os operários do Rio de Janeiro naquele mês de julho. Numa terça-feira, dia 17 de julho, na sede da Federação Operária, na Praça Tiradentes, compareceram 400 operários, muitos com tendência anarquista e deliberaram que era preciso iniciar o movimento na cidade: “A opinião dos anarquistas, externada em discursos violentos, era a de que o operariado carioca se declarasse em greve, para dar assim uma prova de franca e decisiva solidariedade aos seus companheiros de São Paulo, e, ao mesmo tempo, exigir e obter vantagens para a classe". ${ }^{763}$

Assim aconteceu. No dia seguinte, 18 de julho, a greve "estalou" em algumas marcenarias e foi "contaminando" diversos núcleos profissionais. Os sapateiros aderiram, depois os padeiros. Dia após dia, outras corporações de ofícios iam paralisando os trabalhos e escrevendo suas reivindicações aos patrões. A greve geral caminhava a passos largos. Evidente, que faltava a adesão dos operários em fábricas de tecidos, a parcela mais numerosa e, com certeza, mais ruidosa da greve. Quando os trabalhadores do cais do porto cruzaram os braços, em 23 de julho, não havia

\footnotetext{
${ }^{759}$ FAUSTO (1977), p. 198.

760 BIONDI (2009), pp. 293-294.

761 O ESTADO DE S. PAULO, 27 de março de 1966, p. 23.

${ }^{762}$ LOPREATO, Christina da Silva Roquette. O espírito da revolta - a greve geral anarquista de 1917. São Paulo: Annablume, 2000, p. 218.

${ }^{763}$ GAZETA DE NOTÍCIAS, 18 de julho de 1917, p. 5.
} 
mais dúvidas: todas as indústrias também iriam parar. No dia 24 de julho, enfim, os operários seguindo o exemplo dos tecelões da Carioca, que já estavam em greve - paralisam as fábricas de tecidos Andaraí, Confiança, Bonfim e Cruzeiro, em solidariedade com as demais categorias. No dia seguinte é a vez da Botafogo e da Aliança.

O centro da cidade já vivia momentos de tensão, com conflitos entre a polícia e os trabalhadores que para lá iam assistir os comícios. "O movimento paredista alastra-se a todas as classes", "Bandos populares percorrem as ruas", "Dois conflitos: no Largo de São Francisco e na Rua Camerino”, “A Polícia vai agir com energia” eram as manchetes dos jornais ${ }^{764}$, mostrando que, tal como anos atrás, a força repressiva parecia ser a única forma de tentar recrudescer os grevistas. Para Boris Fausto, "o Estado oligárquico parecia confirmar em larga medida a teoria anarquista, ao negar o reconhecimento dos mínimos direitos operários, ao optar pela repressão nos momentos de confronto aberto de classes". ${ }^{765}$

Porém, diferentemente da última "greve geral", em 1903, a grande imprensa diária passou a ver na luta do operariado uma causa justa e nas ações policiais um exagero constante. Houve uma clara mudança de opinião, as fábricas tão generosas, que ofertavam empregos, garantiam o sustento de milhares de famílias, apareciam, pelo menos em alguns editoriais, como culpadas pela fome dos trabalhadores e, até mesmo, culpadas por solicitarem proteção policial assim que a greve rondava sua vila operária:

Os pobres operários, com a alma abatida pelo esforço diário e o corpo vencido pela privação do alimento comprado à preço de ouro, desanimam, não sentindo em torno deles senão a ameaça do castigo imerecido da espada desembainhada da polícia, que devia protegê-los, e o gesto severo do governo, que devia resguardá-los. ${ }^{766}$

\subsection{1 - Uma semana de greve em Bangu (1917)}

Tal qual em 1903, a Fábrica Bangu demorou a entrar na "greve geral” de 1917. A participação dos trabalhadores da maior tecelagem do Rio de Janeiro foi pequena: pararam a fábrica de uma quinta-feira, 26 de julho a uma quarta-feira, $1^{\circ}$ de agosto.

Em 24 de julho, uma comissão de grevistas fora até a Fábrica Bangu dialogar com os mestres e contramestres das seções para que o trabalho fosse interrompido, mas não obtiveram sucesso. ${ }^{767}$ Com o restante das fábricas de tecido da cidade em greve, Bangu era a única tecelagem a funcionar na quarta-feira. Fazer com que os operários da Companhia aderissem ao movimento passou a ser uma questão de honra para os grevistas, que para Bangu se deslocaram em 25 de julho. Pouco antes, tinham conseguido a adesão dos operários da Fábrica de Tecidos de Linho Sapopemba e de uma

\footnotetext{
${ }^{764}$ O PAIZ, 25 de julho de 1917, p. 3.

${ }^{765}$ FAUSTO (1977), p. 69.

766 O PAIZ, 30 de julho de 1917, p. 1.

${ }^{767}$ GAZETA DE NOTÍCIAS, 25 de julho de 1917, p. 4.
} 
fábrica de vagões, em Marechal Hermes. Em Deodoro, nada ocorreu em paz, o grupo de grevistas praticou depredações, quebrando os vidros das janelas para exigir a adesão dos colegas.

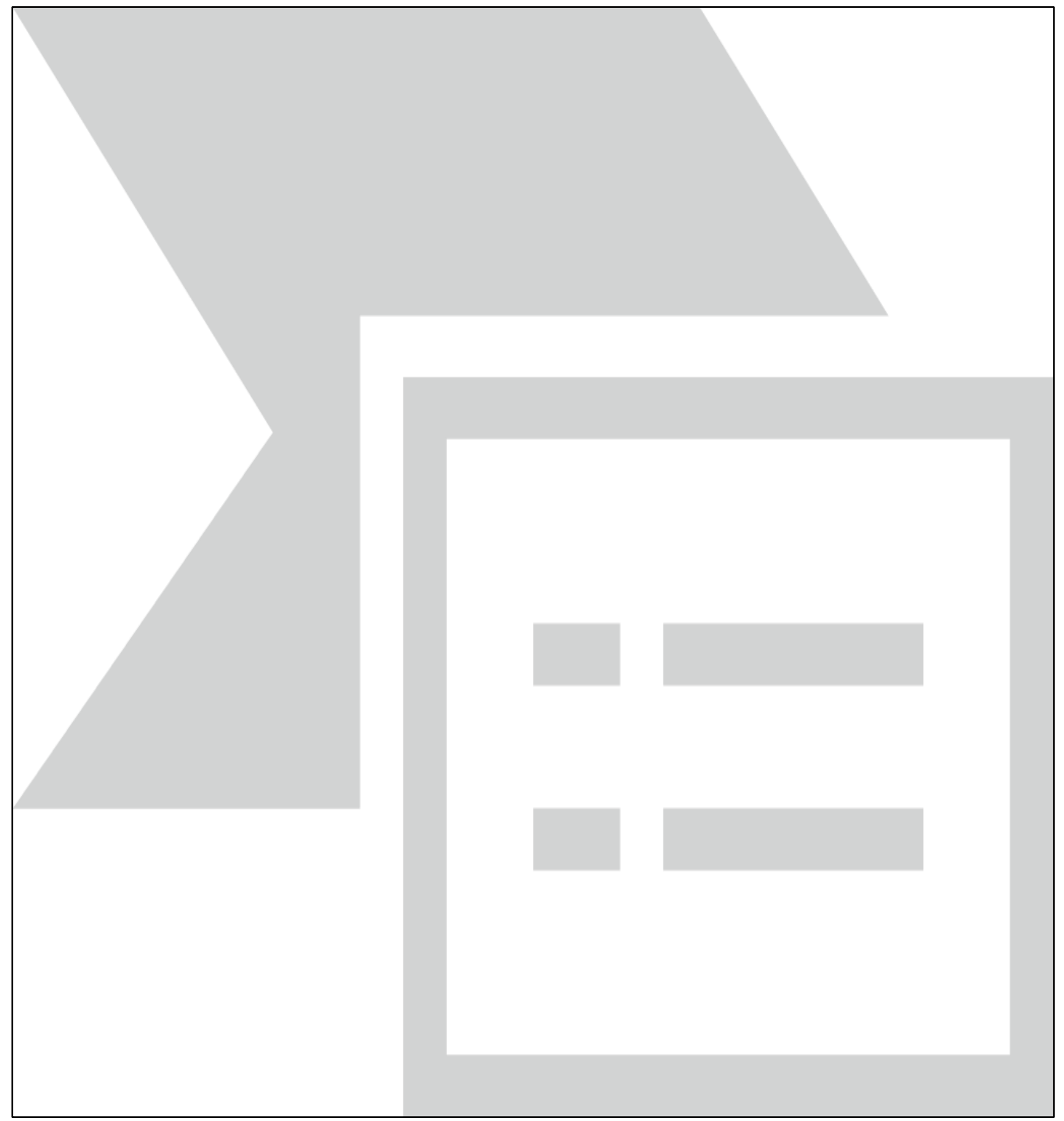

Figura 34 - As fotografias publicadas pelas revistas ilustradas mostram a atuação da polícia contra os grevistas no Centro do Rio de Janeiro. ${ }^{768}$

Em Bangu, a comissão foi logo "recepcionada" pelo comissário Teixeira e um forte contingente de praças, alertando que, se ocorresse qualquer ato semelhante ao de Deodoro, a polícia agiria com severidade. "Três dos grevistas mais exaltados gritaram que os companheiros não 
deviam submeter-se às exigências da polícia, o que provocou forte alarido e a imediata prisão dos três". O delegado Ribeiro Gonçalves, do $25^{\circ}$ distrito, foi chamado. À tarde, os presos foram soltos e os grevistas solicitaram autorização para realizar um meeting para os operários às 5 horas.

Quando os operários deixaram o serviço, ouviram os pedidos dos ativistas para "serem solidários com os demais companheiros que já estavam em greve desde há dias”. Perto das 6 horas, um dos operários da Fábrica Bangu pediu a palavra, dizendo-se em nome de todos os outros, que a greve estava declarada naquela Companhia. ${ }^{769}$

No dia 26 de julho, como era de costume, o apito da fábrica soou conclamando os trabalhadores a seus postos. Um número muito reduzido de operários compareceu e os trabalhos foram suspensos. Uma comissão de empregados foi se entender com os mestres e contramestres, garantindo que em Bangu não haveria desordens e agressões. ${ }^{770} \mathrm{O}$ delegado do $25^{\circ}$ distrito passou a pernoitar no bairro e a fábrica foi "guardada" por um contingente de 30 praças. $^{771}$

Os jornais especularam que entre 31 e 38 mil operários em fábricas de tecidos tinham cruzado os braços, mas os números parecem avultados. ${ }^{772} \mathrm{Um}$ levantamento feito pelo Correio da Manhã, também com números estimados, mostrou que havia, no máximo, 29 mil tecelões empregados em toda a cidade. ${ }^{773}$ Para os grevistas, a adesão da Bangu era importante pelo seu elevado número de trabalhadores. Porém, distantes do Centro do Rio, isolados em sua própria vila operária, vivendo sob o regime paternalista de João Ferrer, e ouvindo constantemente que os demais tecelões de todas as outras fábricas adorariam trabalhar ali, a força de mobilização em Bangu foi pequena. Fora isso, se realizassem ações maiores, certamente, sofreriam com a repressão policial.

Normalmente, os grevistas se reuniam para meetings na estátua de Benedito Ottoni, nas proximidades da estação Central da Estrada de Ferro. Na noite de 26 de julho, correu o boato que um trem chegaria repleto de operários da Bangu, o que animou os "paredistas" e pôs em alerta as autoridades policiais, que "guarneceram a gare da Estrada de Ferro Central do Brasil com praças embaladas, a fim de evitar que ali penetrassem os grevistas". No fim, era só um boato. Os banguenses sequer embarcaram no trem, frustrando os trabalhadores da região central da cidade. ${ }^{774}$

Se os milhares de operários da Bangu não saíam dos limites da sua própria vila, logo nas primeiras horas da manhã de sexta-feira, 27 de julho, o comício foi até Bangu. Líderes grevistas das

\footnotetext{
${ }^{769}$ GAZETA DE NOTÍCIAS, 26 de julho de 1917, p. 4.

${ }^{770}$ Idem, 27 de julho de 1917, p. 3.

${ }^{771}$ O PAIZ, 27 de julho de 1917, p. 3.

772 GAZETA DE NOTÍCIAS, 28 de julho de 1917, p. 1.

773 CORREIO DA MANHÃ, 31 de julho de 1917, p. 1. Pelos números - avultados e arredonados - do jornal, as principais fábricas têxteis tinham os seguintes números de empregados: Bangu (3.000), Confiança (2.800), Carioca (2.500), Aliança (2.500), Corcovado (2.500), Cruzeiro (2.500), Sapopemba (2.000), Bonfim (2.000) e Mavilis (2.000).

774 O PAIZ, 27 de julho de 1917, p. 3.
} 
fábricas Sapopemba (Deodoro) e Aliança (Laranjeiras) foram solicitar que seus colegas se conservassem afastados do trabalho para ganho de causa da categoria. ${ }^{775}$

Nessa ocasião, já se conhecia exatamente as reivindicações dos operários têxteis: 1) a redução do trabalho diurno para oito horas; 2) aumento de $30 \%$ sobre os vencimentos em vigor, sem distinção de classe; 3) reconhecimento das associações operárias pelos industriais; 4) não demitir quem tivesse tomado parte na greve; 5) trabalho noturno não superior a seis horas, sendo feito por turmas diferentes; e 6) responsabilidade dos patrões pelos acidentes de trabalho. ${ }^{776}$ Era, com certeza, uma pauta de reivindicações que importava uma mudança muito significativa em relação a anos anteriores. As fábricas São Félix, Carioca e Corcovado, sediadas na zona sul da cidade, apresentaram a seus patrões uma lista com 13 itens, incluindo a abolição do trabalho do menor de 14 anos e uma licença maternidade de seis meses (três antes e três depois do parto). ${ }^{777}$

A direção da fábrica esperava normalizar o expediente logo na segunda-feira, 30 de julho. Segundo o Correio da Manhã, a Gazeta de Notícias e $O$ Imparcial, a Fábrica Bangu funcionou normalmente, com um número de funcionários superior a 1.000 e muita fiscalização policial ao redor. ${ }^{778}$ Segundo $O$ Paiz, o expediente terminou no horário do almoço, quando os operários saíram para não regressar, descobrindo do lado de fora que ainda não havia nenhum acordo entre as partes. “Os vários oradores afirmaram terem sido seus colegas iludidos de que o acordo entre patrões e operários tinha sido feito e que assim, levados às fábricas, foram impedidos de se retirarem pelos mestres e contramestres". 779

Segundo os jornais, os operários das fábricas Cruzeiro, Confiança, Botafogo, São Félix, Carioca, Corcovado, Bangu, Sapopemba e a de Chapéus Mangueira caíram nesta armadilha. Os tecelões da Aliança (em Laranjeiras), Aurora (em Botafogo), Bonfim e Esperança (ambas em São Cristóvão), mais resistentes, sequer compareceram aos postos de trabalho. No mesmo dia, os patrões se reuniram no Centro Industrial do Brasil - o tesoureiro Francisco Ferreira Real representou a Fábrica Bangu - e deliberaram “ouvir e estudar quaisquer pedidos trazidos por comissão constituída exclusivamente por operários, desde que restabelecido o trabalho normal" 780

É certo que no dia $1^{\circ}$ de agosto, uma quarta-feira, as oficinas da Bangu já funcionavam normalmente, sendo, junto com a fábrica de chapéus Mangueira, uma das primeiras a restabelecer o serviço, enquanto que em Deodoro, São Cristóvão, Vila Isabel e Andaraí, as Companhias existentes nestes bairros funcionavam com pessoal "reduzidíssimo". Na Gávea e Jardim Botânico, os

\footnotetext{
${ }^{775}$ GAZETA DE NOTÍCIAS, 28 de julho de 1917, p. 4.

776 O PAIZ, 28 de julho de 1917, p. 3; GAZETA DE NOTÍCIAS, 28 de julho de 1917, p. 1.

777 A ÉPOCA, 28 de julho de 1917, p. 2.

778 GAZETA DE NOTÍCIAS, 31 de julho de 1917, p. 2.

779 O PAIZ, 31 de julho de 1917, p. 4.

${ }^{780}$ O IMPARCIAL, 31 de julho de 1917, p. 5.
} 
operários da Carioca, São Félix e Corcovado continuavam de braços cruzados. ${ }^{781}$ Apesar de a greve ser "geral", em Bangu havia pouca experiência nesse tipo de movimento contra os patrões. Suportar uma semana sem atender ao apito da chaminé às 6 horas da manhã, provavelmente, incomodava também os tecelões, que apesar de necessitarem de aumentos salariais e ansiarem uma diminuição da jornada, temiam sobremaneira a perda do emprego e a consequente saída da casa em que viviam, e às vezes, até mesmo a extinção da vaga do filho na escola da Companhia.

Por isso, não é de assustar o rápido retorno ao trabalho por parte dos banguenses. Segundo Eulália Lobo, entre o movimento que tomou conta da cidade em agosto de 1903 e este, em julho de 1917, ocorreram várias greves de algumas Companhias isoladamente. Neste período de 14 anos, a Fábrica de Tecidos de Linho de Sapopemba paralisou suas atividades cinco vezes, um verdadeiro recorde. A Corcovado e a Carioca pararam duas vezes. A Cruzeiro e a Confiança fizeram uma greve cada, respectivamente em 1908 e $1909 .^{782}$ Por mais que a catalogação seja incompleta, o nome da Bangu não aparece envolvido em nenhuma greve nesse longo período, que coincide com a administração do espanhol João Ferrer.

Insatisfeitos com o retorno dos tecelões da Bangu, um pequeno grupo de 13 indivíduos foi até o bairro na manhã do dia $1^{\circ}$ de agosto, segundo a polícia, para "cometer depredações a fim de evitar que os operários da Fábrica de Bangu continuassem a trabalhar". Os comissários Odon e Ferreira agiram rápido e, apesar da fuga de oito deles, conseguiram prender cinco homens. É significativo que nenhum deles pertencesse à Companhia Progresso Industrial do Brasil: Antônio Joaquim de Mesquita, Júlio Paiva e Francisco Pessoa eram operários da Fábrica de Tecidos Sapopemba, em Deodoro; e Ovídio Sampaio e Carivaldo de Andrade eram da Fábrica de Tecidos Botafogo. ${ }^{783}$

No dia 2 de julho foram conhecidas as bases do acordo entre patrões e empregados, com mínimas conquistas para o proletariado: 1) as fábricas de tecidos de algodão e lã trabalharão até 56 horas por semana; 2) todos os operários que vencem salários terão um adicional de $10 \%$ sobre os preços atuais; 3) quando houver necessidade de trabalho noturno, este não poderá exceder de sete horas, sendo pago como um dia; quando o mesmo trabalho for apenas de três horas e meia, será pago como meio dia; 4) as questões relativas às 8 horas de trabalho, responsabilidade dos patrões nos acidentes das oficinas e o trabalho dos menores serão resolvidos por lei do Congresso Nacional; 5) sendo garantido pela Constituição o direito de todos se associaram, os operários poderão fundar sociedades destinadas a melhorar as condições da classe e com fins beneficentes, comprometendo-

\footnotetext{
${ }^{781}$ O PAIZ, 2 de agosto de 1917, p. 4.

${ }^{782}$ LOBO, Eulália Maria Lahmeyer (org.). Rio de Janeiro operário - natureza do Estado, conjuntura econômica, condições de vida e consciência de classe. Rio de Janeiro: Access Editora, 1992, pp. 34-42.

${ }^{783}$ A NOITE, $1^{\circ}$ de agosto de 1917, p. 4.
} 
se a não admitir nas mesmas pessoas estranhas; 6) nenhum operário será dispensado de qualquer fábrica de tecidos de algodão e lã por motivo da presente greve. ${ }^{784}$

De acordo com o item 4, ao passar algumas decisões importantes para as mãos dos deputados e senadores, os patrões tinham a certeza de que, graças a morosidade do Estado, tudo continuaria como estava por muito mais tempo. A jornada continuaria longa, a culpa pelos acidentes continuaria recaindo no colo do trabalhador e os menores permaneceriam como mão-de-obra superexplorada. De fato, nos anos subsequentes, o Congresso Nacional evoluiu bem pouco nas questões trabalhistas, como nos mostra Boris Fausto:

Um reduzido grupo, quase limitado a Nicanor Nascimento e Maurício de Lacerda, pretendia a adoção de uma legislação trabalhista que representava um efetivo progresso nas condições da época, integrando-a em um conjunto de iniciativas cujo alcance ia além das relações de trabalho. No outro extremo, encontravam-se os deputados que, com variável fundamento ideológico, adotavam uma postura retrógrada, rejeitando a necessidade de qualquer legislação do trabalho moderadamente inovadora ou mesmo simples consagradora das relações vigentes. ${ }^{785}$

Não cabe aqui discutir até que ponto os congressistas estavam mais preocupados com os ônus para os industriais do que com a vida dos operários, mas por falta de interesse ou até mesmo por divergências políticas, muito se debateu e poucos avanços foram obtidos:

\footnotetext{
Apenas a lei sobre acidentes de trabalho (lei $n^{\circ} 3724$, de 15-01-1919), em torno da qual havia um razoável consenso, veio a ser aprovada. No mais, a Comissão Especial realizaria longas e inúteis reuniões, enquanto o movimento operário perdia o ímpeto: o projeto do Código do Trabalho nestas condições não chegou sequer a ser votado. ${ }^{786}$
}

A greve, que envolveu de 50 a 70 mil trabalhadores de diversas categorias em todo o Rio de Janeiro, ${ }^{787}$ não foi além da primeira semana de agosto de 1917. Em Bangu, logo no domingo, dia 5, os operários já demonstravam outra preocupação: acompanhar a partida do Campeonato Carioca contra o Vila Isabel. Segundo O Paiz, "este belo e emocionante encontro realizou-se no amplo field do Bangu e para assisti-lo teve uma numerosa e escolhida assistência". ${ }^{788} \mathrm{Na}$ época, ainda não se divulgavam público e renda das partidas, mas dados estatísticos mostram que, a cada jogo no campo da Rua Ferrer, naquele ano de 1917, os torcedores-operários do Bangu deixavam nas bilheterias a soma de 629\$666, em média, superando em compra de ingressos os adeptos do Carioca (ligados à fábrica de mesmo nome no Jardim Botânico) e do Vila Isabel (muitos deles operários da Companhia Confiança Industrial), que geravam rendas médias de 401\$900 e 251\$061, respectivamente. ${ }^{789}$

\footnotetext{
784 CORREIO DA MANHÃ, 3 de agosto de 1917, p. 3.

785 FAUSTO (1977), p. 230.

786 Idem, p. 233.

787 SCHWARCZ, Lilia Moritz. "População e sociedade" in: SCHWARCZ, Lilia Moritz (org.). História do Brasil Nação - A Abertura para o Mundo (1889-1930). Rio de Janeiro: Editora Objetiva, 2012, p. 59. FAUSTO (1977), p. 179, chega a sustentar que 100 mil operários participaram da greve de 1917.

788 O PAIZ, 6-7 de agosto de 1917, p. 6.

789 SANTOS Jr., Nei Jorge dos. A construção do sentimento local: o futebol nos arredores de Bangu e Andaraí (19141923). Rio de Janeiro: Editora Multifoco, 2014, p. 76.
} 


\section{1 - A epidemia e a greve andam juntas (1918)}

Em tempos de ânimos exaltados, mesmo na pacata vila operária da Companhia Progresso Industrial do Brazil, havia riscos de que qualquer fagulha provocasse uma explosão. Mas, em 1918, não foi um simples estalo que despertou a classe trabalhadora para a greve, foi uma verdadeira catástrofe, que percorreu todos os bairros do Rio de Janeiro.

Os meses de outubro e novembro foram marcados pela "influenza hespanhola", uma epidemia gravíssima que chegou pelos navios atracados no porto e contaminou toda a cidade. ${ }^{790}$

Numa quinta-feira, 16 de outubro, tanto a fábrica de tecidos quanto o Bangu A. C. decretaram o fechamento de suas atividades até que a situação voltasse ao normal - quase todos os operários estavam doentes. ${ }^{791}$ A América Fabril, a São Félix, a Carioca e a Corcovado tomaram idêntica decisão do mesmo dia. Não há o número de mortos na Fábrica Bangu, mas sabe-se que oito sócios do Bangu A. C. morreram em decorrência da gripe espanhola, ${ }^{792}$ entre eles o ex-jogador Archibald French, que atuou entre 1915 e $1917 .{ }^{793}$

Em apenas dois meses, 65\% dos habitantes da Capital Federal adoeceram (ou seja, aproximadamente 745 mil pessoas). Pelos números oficiais, 12.221 pessoas morreram na pior enfermidade que o Rio de Janeiro já tinha enfrentado. A população estava dizimada.

Aterrava a velocidade do contágio e o número de pessoas que estavam sendo acometidas. Nenhuma de nossas calamidades chegara aos pés da moléstia reinante: o terrível não era o número de casualidades - mas não haver quem fabricasse caixões, quem os levasse ao cemitério, quem abrisse covas e enterrasse os mortos. O espantoso já não era a quantidade de doentes, mas o fato de estarem quase todos doentes, a impossibilidade de ajudar, tratar, transportar comida, vender gêneros, aviar receitas, exercer, em suma, os misteres indispensáveis à vida coletiva. ${ }^{794}$

Para alguns historiadores, a maior parte desses óbitos atingiu a população pobre dos subúrbios, completamente desassistida do ponto de vista de uma política sanitária. Para a classe trabalhadora, além das agruras da carestia de vida, veio se juntar "num quadro verdadeiramente apocalíptico, a peste e a morte". ${ }^{795}$

\footnotetext{
${ }^{790}$ DIÁRIO OFICIAL, 26 de setembro de 1918, seção 1, p. 6.

791 "Em vista da epidemia que atualmente reina, de um modo assustador, impedindo que haja regularidade em serviços os mais simples, sejam suspensos todos os divertimentos deste club, bem como o expediente. Vide: "Ata da sessão de 16 de outubro de 1918". 5 Livro de Atas das Sessões da Diretoria do Bangu A. C., 14 de setembro de 1917 a 29 de janeiro de 1919. "Em virtude de ter adoecido quase todo o pessoal da fábrica de tecidos Bangu, esta fechou ontem". Vide: A ÉPOCA, 17 de outubro de 1918, p. 8.

792 "Ata da sessão de 27 de novembro de 1918". 5 Livro de Atas das Sessões da Diretoria do Bangu A. C., 14 de setembro de 1917 a 29 de janeiro de 1919.

${ }^{793}$ O PAIZ, 31 de outubro de 1918, p. 6.

794 NAVA, Pedro. Chão de ferro. São Paulo: Ateliê Editorial, 2001, p. 208.

795 ADDOR, Carlos Augusto. A insurreição anarquista no Rio de Janeiro. Rio de Janeiro: Dois Pontos Editora, 1986, pp. 65-66.
} 
É certo que Bangu foi bem afetado pela "influenza", mas até que ponto? A historiadora Gracilda Alves, que escreveu o livro oficial do centenário da fábrica, em 1989, afirma que a Companhia, neste momento de crise, suspendeu a cobrança dos aluguéis das suas casinhas ocupadas por funcionários e transformou a escola em um hospital para atender as vítimas da gripe. ${ }^{796}$ No entanto, o jornal A Noite dá a entender que a iniciativa foi da própria diretora da escola, a professora Angelina Bellosta Moreira e de seu marido, Dr. Alberto Moreira, que providenciaram junto às autoridades sanitárias para que no local fosse instalado um hospital para 150 doentes e um serviço de socorro a domicílio. ${ }^{797}$

No auge da epidemia, no entanto, parecia que essas medidas não funcionaram. No início de novembro, por exemplo, A Noite denunciava que o Comissariado tinha entregue poucos donativos ao posto de Bangu, que contava com 252 doentes internados. ${ }^{798}$ Uma comissão formada por cinco operários - João Alves, Joaquim Martins, Hemetério Gomes, Antônio Salvaterra e José da Costa Fernandes - percorreu as redações dos grandes jornais no Centro do Rio para informar que "o operariado nada deve ao sr. João Ferrer e funcionários daquela Companhia, porquanto, os mesmos coisa alguma fizeram em proveito na atual emergência". 799 Além de não receberem o "menor auxílio", a comissão ainda reclamou o não pagamento da última quinzena trabalhada. ${ }^{800}$

Até então chamado de o "benemérito propugnador do progresso de Bangu”, João Ferrer foi o alvo das reivindicações dos operários durante e após a gripe espanhola. Um deles declarou, ao término da epidemia, que "o sr. Ferrer não nos deu nem um pouco de ar, quando estivemos espanholados". 801

A Gazeta de Notícias que, em março de 1917, colocara na primeira página uma reportagem enaltecendo a Fábrica Bangu; em novembro de 1918, mudou completamente de opinião provavelmente influenciada pelos movimentos grevistas que escancaravam a realidade operária - e, também na primeira página, abriu espaço para uma denúncia bombástica: “A fome nos meios operários - Bangu e a profunda miséria dos seus moradores - A impressionante visita da Gazeta às residências dos tecelões famintos". Naturalmente, além da fome, a questão da gripe espanhola também foi colocada pelos moradores entrevistados:

Todos os empregados sofrem o desconto de $1 \%$ para pagamento ao médico, Dr. Borges Ramos, que quando é chamado para socorrer qualquer doente, só aparece às vezes, e assim mesmo fazendo reclamações. (...) A fábrica, que anunciou que mandara suspender o desconto de medicamentos, fornecidos aos doentes da peste, ordenou que se fizesse o

\footnotetext{
796 SILVA, Gracilda Alves de Azevedo. Bangu 100 anos: a fábrica e o bairro. Rio de Janeiro: Sabiá Produções Artísticas, 1989, pp. 67; 89.

${ }^{797}$ A NOITE, 5 de novembro de 1918, p. 4.

${ }^{798}$ Idem, 7 de novembro de 1918, p. 4.

${ }^{799}$ CORREIO DA MANHÃ, 6 de novembro de 1918, p. 3.

${ }^{800}$ O IMPARCIAL, 6 de novembro de 1918, p. 4.

${ }^{801}$ GAZETA DE NOTÍCIAS, 19 de novembro de 1918, p. 3.
} 
desconto este mês, o que prova que aquele gesto foi apenas uma "fita" dos diretores para impressionar bem a população. ${ }^{802}$

Fato curioso, para mostrar a dualidade das opiniões, outro jornal, A Época, noticiou - ao término da epidemia de gripe - a realização de uma festa promovida pelos banguenses em homenagem ao médico Borges Ramos, ao farmacêutico Altamiro Oliveira e ao cônego Alfredo de Vasconcellos pela dedicação aos doentes durante a epidemia. $\mathrm{Na}$ ocasião, foi servido um "assado com o couro à moda rio-grandense", regado a chopes e vinho capitoso. No corpo da matéria, são elencadas as ações benéficas feitas pelo trio à população de Bangu:

O sr. Dr. Borges Ramos agradeceu as referências feitas pelo vigário e terminou dizendo que parte daquela manifestação era de justiça que lhe pertencesse, pois que ele havia sido o médico do corpo e que o vigário foi o médico da alma.

Realmente somos testemunhas, porque assistimos o sr. Dr. Alfredo de Vasconcellos por ocasião da epidemia, distribuir aos pobres dezenas de sacos de açúcar, arroz, farinha, feijão, pão, fazendas, leite e ainda dinheiro para remediar, enquanto o sr. Dr. Borges Ramos, o homenageado, ardendo em febre, não abandonava o lar dos seus doentes. ${ }^{803}$

O Dr. Borges Ramos foi o médico da Companhia até abril de $1919,{ }^{804}$ mas é certo que outros profissionais atenderam a população de Bangu durante a "influenza", como o Dr. Ricardo Barreto, ligado à ordem religiosa dos vicentinos, que chegou a treinar diversos moços para serem enfermeiros, levando assim o socorro à domicílio. "Quem conhece o abandono de médicos em que estão as populações dos subúrbios bem pode avaliar o serviço que esse caritativo clínico está prestando aos infelizes e desprotegidos que moram por ali". 805

Podemos entender, então, que, dificilmente a fábrica deixaria de prestar assistência aos doentes do bairro, embora seja perfeitamente compreensível que nem todas as famílias tenham ficado satisfeitas com o tratamento recebido, afinal eram poucos médicos (oficialmente a fábrica só tinha um médico e um farmacêutico) para muitos enfermos. Nos dois meses do surto de gripe, a situação econômica se agravou ainda mais para os operários que não podiam trabalhar. Para quem ganhava o pagamento por diárias, faltar ao serviço significava ficar sem ordenado. 806 "Há perto de dois meses que estou doente e quando trabalhava já ganhávamos pouco, que mal dava para viver, e agora, com esta moléstia que ainda não sei qual é, mas que me ataca o peito e as costas, nem sei como se vive" - reclamava um operário à Gazeta de Notícias. ${ }^{807}$

\footnotetext{
${ }^{802}$ Idem, 25 de novembro de 1918, p. 1.

${ }^{803}$ A ÉPOCA, 19 de fevereiro de 1919, p. 6.

${ }^{804}$ Idem, 28 de abril de 1919, p. 6.

${ }^{805}$ Idem, 28 de outubro de 1918, p. 6.

${ }^{806}$ NÉBIAS, Wellington Barbosa. A greve geral e a insurreição anarquista de 1918 no Rio de Janeiro: um resgate da atuação das associações de trabalhadores. Instituto de Filosofia e Ciências Sociais (IFCS) da Universidade Federal do Rio de Janeiro (UFRJ), 2009, p. 184.

${ }^{807}$ GAZETA DE NOTÍCIAS, 25 de novembro de 1918, p. 1.
} 
O ano de 1918 foi de crise para ambos os lados. A Fábrica amargava um prejuízo acumulado de 6.218:135\$610. ${ }^{808}$ Os operários de todas as indústrias têxteis do Rio, ao voltarem ao trabalho após um longo período de doença e sem dinheiro, pretendiam reivindicar aos patrões o pagamento de $50 \%$ dos salários aos operários que tinham sido forçados a faltar ao serviço por causa da gripe; o perdão de um mês de aluguel das casas que muitas empresas forneciam aos trabalhadores e o aumento das horas de trabalho. Com o início da recessão, o trabalho se reduzira em média a 28 horas semanais, representando um corte de $50 \%$ nos salários. ${ }^{809}$

Os salários estavam realmente baixos, principalmente pela redução compulsória das horas trabalhadas: um operário da fiação recebia $174 \$ 480$ por mês; quem fosse dos teares ganhava $184 \$ 800 .{ }^{810}$ Uma maçaroqueira explicou matematicamente sua situação financeira a um jornalista:

Eu, por exemplo, levo uma hora para fazer um ponto que é pago à razão de 460 réis. Antigamente trabalhávamos 10 horas, mas de algum tempo a esta parte só temos serviço para 7 horas, o que equivale a dizer que ganhamos $3 \$ 200$ por dia de trabalho. No fim da quinzena recebemos menos de $40 \$ 000.811$

Depois de ficar fechada desde o dia 16 de outubro, a fábrica tinha reaberto as portas no dia 11 de novembro. No entanto, a escala estava reduzida. Os operários entravam às 8 horas da manhã (duas horas mais tarde que o normal), tinham o descanso de uma hora de almoço e saíam às 4 da tarde (uma hora a menos que o corriqueiro) e trabalhavam apenas quatro dias por semana.

Assim, uma nova greve irrompeu à 1 hora e 40 minutos da tarde de 18 de novembro de 1918, quando os operários paralisaram as máquinas e foram saindo ordeiramente do edifício fabril. "Foi um ato repentino, inesperado e que causou geral surpresa, segundo nos afirmou um morador de Bangu”. Na realidade, não tão repentino assim. Havia um acordo tácito entre a União dos Operários em Fábricas de Tecidos e representantes oficiais espalhados nas várias fábricas do Rio. Assim que os destinatários recebessem um telegrama, era a hora de paralisar os serviços, ${ }^{812}$ o que foi feito nas fábricas Carioca, Corcovado, Manchester (Tijuca), Covilhã, São Félix, Campista, Andaraí, Sapopemba e Confiança Industrial. ${ }^{813}$

Segundo Nébias, "muitos trabalhadores não sabiam explicar com clareza as razões que tinham motivado a greve. Alguns afirmaram que interromperam o serviço porque receberam ordens. Outros alegaram que iniciaram a greve por solidariedade de classe". 814

\footnotetext{
${ }^{808}$ OLIVEIRA, Márcio Piñon de. Bangu: de fábrica-fazenda e cidade-fábrica a mais uma fábrica da cidade. Instituto de Pesquisa e Planejamento Urbano e Regional (IPPUR) da Universidade Federal do Rio de Janeiro (UFRJ), 1991, p. 185.

${ }^{809}$ FAUSTO, Boris. Trabalho urbano e conflito social (1890-1920). São Paulo: Difel, 1977, p. 214.

${ }^{810}$ LOBO, Eulália Maria Lahmeyer. História do Rio de Janeiro. Do Capital Comercial ao Capital Industrial e Financeiro. $2^{o}$ Volume. Rio de Janeiro: IBMEC, 1978, p. 667.

${ }^{811}$ GAZETA DE NOTÍCIAS, 25 de novembro de 1918, p. 1.

812 Idem, 19 de novembro de 1918 , p. 3.

${ }^{813}$ A ÉPOCA, 19 de novembro de 1918, p. 1

${ }^{814}$ NÉBIAS (2009), p. 6.
} 
Na realidade, junto com a greve geral, havia a tentativa dos anarcossindicalistas da União dos Operários em Fábricas de Tecidos de uma greve insurrecional, ou seja, um levante anarquista contra o governo. Tendo como inspiração a Rússia soviética, iriam realizar a revolução social naquela tarde. Os anarquistas acreditavam que o mundo estava passando por grandes transformações, a Guerra Mundial, a Revolução Russa, a gripe espanhola e os problemas econômicos enfrentados por diversos países era um sinal desses tempos, em que era necessário derrubar o sistema social existente e substituí-lo pela nova sociedade libertária. Esta crença incentivou e mobilizou muitos anarquistas no Rio de Janeiro em 1918 e para realizar a "revolução", eles iriam precisar dos trabalhadores, que seriam influenciados pelos sindicatos a aderirem à insurreição, ${ }^{815}$ incluindo os operários da Fábrica Bangu.

Segundo o depoimento do tenente Jorge Elias Ajus, militar infiltrado no movimento, o plano mirabolante tinha sido organizado por José Oiticica, um dos líderes anarquistas da época:

(...) Entre os operários o movimento já estava completamente organizado, dispondo ele e os seus companheiros, de todos os tecelões e metalúrgicos, dispostos a tudo, já armados com grandes quantidades de bombas de dinamite, de explosão com contato, aguardando apenas que fosse feita a designação do dia para a greve geral. descendo os operários de Botafogo que se aproximariam do Palácio do Catete e em momento dado matariam a sentinela e invadiriam o Palácio, aprisionando o Presidente e içando uma bandeira vermelha, enquanto no mesmo momento, outros operários se reuniriam no Campo de São Cristóvão, onde seria fácil o ataque à Intendência da Guerra a fim de se apossarem de armas, munições e equipamentos; enquanto que os operários de Bangu, em número de 2 mil, saltariam em Realengo, se apoderariam das armas e munições existentes na Fábrica de Cartuchos, que incendiariam, partindo para a cidade. ${ }^{816}$

Para Boris Fausto, "parece inútil ressaltar que a insurreição anarquista não tinha nenhuma viabilidade de êxito". 817 A maioria dos trabalhadores não estava interessada em revolução social; isso era uma expectativa dos anarquistas, que representavam uma parcela pequena do movimento operário. As principais preocupações do operariado eram econômicas. Os tecelões queriam recuperar o poder aquisitivo perdido devido à carestia, além de lutar por melhores condições dentro das fábricas.

Em uma conversa com um operário bastante politizado, dentro de um trem que ia para Bangu, um jornalista pode apurar o grau de insatisfação do trabalhador:

- E a revolução?

- Já era tempo, mas ainda não chegou a hora. Ela virá, porém, terrível e insopitável. A fome há mais de dois anos invadiu o lar do pobre. A resignação do povo está terminando e a revolução da fome tem que estourar. Antes morrer de balas dos soldados inconscientes, sofredores como nós, do que ver os filhos, a esposa e nós mesmos definhar à falta de alimentação e conforto. ${ }^{818}$

\footnotetext{
${ }^{815}$ Idem, pp. 154-156.

${ }^{816}$ ARCHIVO VERMELHO - REVISTA POLICIAL ILLUSTRADA, ano 1, $\mathrm{n}^{\circ}$ 13, 16 a 31 de dezembro de 1918 , p. 21.

${ }^{817}$ FAUSTO (1977), p. 213.

${ }^{818}$ A ÉPOCA, 19 de novembro de 1918, p. 1.
} 
Se a revolta anarquista foi um fiasco - houve apenas um conflito entre operários e praças policiais no Campo de São Cristóvão -, para Maram, a greve de 1918 também foi. "A greve geral em si atraiu poucos participantes de fora da indústria têxtil, da metalúrgica e da construção". 819 Segundo estimativas, foram mais de 20 mil trabalhadores que cruzaram os braços, número relativamente pequeno se comparado ao movimento do ano anterior. ${ }^{820}$

No entanto, a greve de 1918 foi, pelo menos na Fábrica Bangu, mais agitada que a de 1917, com várias prisões e até demissões. A infeliz ideia de um levante insurrecional logo no início do movimento fez com que a repressão policial aos grevistas fosse maior, qualquer atitude que fosse considerada suspeita, qualquer tentativa de organização de um comício, era suficiente para levar um indivíduo preso. A nota divulgada pela Polícia Central não deixa a menor dúvida sobre isto:

\footnotetext{
Num momento como este, a autoridade tem o dever de ser franca, e por isso, declara que será inflexível nas providências necessárias ao restabelecimento da ordem. Todos os grupos suspeitos serão dissolvidos. Serão presos todos os desordeiros e agitadores conhecidos. Nenhuma associação poderá reunir-se sem comunicá-lo à polícia. Pede-se à população ordeira que evite aglomerar-se em qualquer ponto onde irrompam conflitos porque as ordens de reação são terminantes. ${ }^{821}$
}

Logo no primeiro dia do movimento, 18 de novembro, correu pelo bairro o boato de que graves ocorrências se dariam à noite, o que fez o delegado do $25^{\circ}$ distrito, Augusto Mendes, pedir reforço de praças para a localidade. Não houve mobilização alguma à noite para sorte da polícia, já que o reforço pedido à tarde, só chegou a Bangu depois das 22 horas. ${ }^{822}$ No dia 19, os comissários João Odon, Geminiano Labre, Raymundo e Trajano começaram a ter trabalho: dissolverem um comício e prenderam cinco operários que protestaram contra a proibição do meeting. Eram eles: Olívio Francisco de Mendonça, João Francisco de Mendonça, João Ataliba, Amasílio Crespo e José da Costa, que seria o orador oficial do grupo. ${ }^{823}$

No dia 20, a polícia continuou efetuando prisões. Sendo avisada de que os operários se reuniam num casebre abandonado na área rural "Saco do Viegas", já nas proximidades do bairro de Campo Grande, os comissários Odon e Labre cercaram o casebre e conseguiram deter sete “conspiradores": Diogo Espardo Moreno, Donato Teixeira Santos, Agostinho de Azevedo, Raymundo de Carvalho, Emílio de Menezes, Felippe de Mattos e Bernardo de Mattos. Para provar que as autoridades seguiam uma pista certa, dentro da casa "encontraram-se em profusão, boletins sediciosos, dos que foram espalhados nas proximidades dos quarteis, há dias, e que convidavam os soldados e marinheiros a apoiá-los". ${ }^{824}$

\footnotetext{
${ }^{819}$ MARAM, Sheldon Leslie. Anarquistas, imigrantes e o movimento operário brasileiro. Rio de Janeiro: Paz e Terra, 1979 , p. 95.

${ }^{820}$ GIANOTTI, Vito. História das lutas dos trabalhadores no Brasil. Rio de Janeiro: Mauad Editora, 2007 , p. 70.

${ }^{821}$ A ÉPOCA, 19 de novembro de 1918, p. 1.

822 JORNAL DO BRASIL, 19 de novembro de 1918, p. 5.

${ }^{823}$ Idem, 20 de novembro de 1918, p. 5.

${ }^{824}$ A ÉPOCA, 21 de novembro de 1918, p. 6.
} 
Ao que tudo indica, pela primeira vez, havia em Bangu, grupos de operários que viam na greve, nos comícios, e até mesmo nos motins, uma forma legítima de reivindicar seus direitos. $\mathrm{O}$ tema da revolução social, por mais que parecesse utópico, certamente inflamava esses homens, insatisfeitos com a queda do poder aquisitivo de seus salários e a penúria em que viviam, apesar de estarem empregados. Segundo o relatório da Companhia, em 1918, dos 12 mil moradores do bairro, 2.733 tinham emprego na fábrica. ${ }^{825}$ Além desses, segundo a Gazeta de Notícias, havia 1.300 pessoas desempregadas vivendo "na mais completa miséria, passando fome" em Bangu. ${ }^{826}$ Dessa forma, com um grande excedente de desempregados, era mais fácil para os patrões jogar, nos períodos de greve, com a ameaça de demissão e a substituição de um trabalhador por outro, ávido por conseguir emprego.

No dia 21, o comissário João Odon efetuou mais seis prisões de elementos "instigadores da greve", que estavam rondando por Bangu: Armindo Gomes, Ovídio Sampaio, Antônio Damião, Sebastião Pereira, José Alves e Carivaldo de Andrade. Todos foram enviados para a Polícia Central. ${ }^{827}$ Ovídio Sampaio e Carivaldo de Andrade eram reincidentes, já tendo sido presos por ocasião da greve de 1917. Na época, trabalhavam para a Fábrica de Tecidos Botafogo.

Os industriais esperavam reabrir as fábricas na segunda-feira, dia 25 de novembro, mesmo sem nenhum tipo de acordo firmado entre as partes. Em Bangu, 1.800 operários (66\%) se apresentaram ao trabalho. Segundo a grande imprensa diária, estavam ansiosos para retornar às máquinas: "Entre os obreiros notava-se a melhor boa vontade para a volta ao serviço, chegando mesmo grande número deles a, antes do apito de chamada, ir estacionar nas proximidades da fábrica, aguardando a hora da entrada no estabelecimento".

No entanto, a União dos Operários em Fábricas de Tecidos denunciava em uma nota como foi que os patrões da Bangu conseguiram rapidamente a volta dos tecelões ao trabalho:

O motivo que forçou estes trabalhadores a irem às oficinas foi o seguinte: o gerente da fábrica ameaçou os operários que os faltosos ao apito ontem para o trabalho ficavam sem crédito nem fiança para as casas dadas pela fábrica. Só sob tão vergonhosa pressão e ainda ameaçados de serem expulsos das casas onde moram, que pertencem à Companhia proprietária da fábrica, forçou-os a quebrarem os seus compromissos com a União. ${ }^{828}$

Na mesma nota, a União mostrava-se confiante porque, apesar da Bangu, todas as outras fábricas permaneceram em greve: Sapopemba, Santa Heloísa, São Félix, Carioca (apenas seis operários apresentaram-se ao trabalho), Corcovado, Esperança (somente 20 operários compareceram ao trabalho), Mavilis, Bonfim, Confiança (só 80 operários trabalharam), Botafogo, Manchester, Covilhã, Minerva (apenas três menores compareceram ao serviço), Bom Pastor, Aurora e Todos os Santos. Na Aliança e na Cruzeiro aproximadamente 200 operários entraram para

${ }^{825}$ OLIVEIRA (1991), pp. 186-187.

${ }^{826}$ GAZETA DE NOTÍCIAS, 19 de novembro de 1918, p. 3.

827 JORNAL DO BRASIL, 22 de novembro de 1918, p. 5.

${ }^{828}$ Idem, 26 de novembro de 1918, p. 5. 
as oficinas, sendo que nesta última, os grevistas foram convencê-los a abandonar o serviço, conseguindo seu intento.

Mas, a greve estava mesmo acabando. Na terça-feira, 26 de novembro, a Fábrica Bangu funcionou em sua totalidade e, pelos cálculos, 8.940 operários compareceram às mais diversas Companhias têxteis espalhadas pela cidade. No mesmo dia, porém, a Confiança e a Corcovado fizeram questão de passar para os jornais a lista nominal dos funcionários demitidos. Eram 52 na fábrica de Vila Isabel e 29 na do Jardim Botânico. A Carioca e a São Félix, juntas, anunciaram a demissão de 80 grevistas, a Sapopemba rescindiu contrato com 50 deles, enquanto que, "pela administração da Fábrica Bangu foram dispensados os serviços de mais de 50 operários". ${ }^{829} \mathrm{O}$ serviço completo em todo o Distrito Federal só foi restabelecido na segunda-feira, 2 de dezembro.

Os operários, que reivindicavam, através da União dos Operários em Fábricas de Tecidos (UOFT), a completa liberdade de pensamento, os seis dias de trabalho por semana, a criação de um salário mínimo e a regulamentação das oito horas diárias, não obtiveram nada com esta greve. "Os operários retornaram completamente derrotados, sem conquistar nenhuma das reivindicações pretendidas", afirma Carlos Augusto Addor. ${ }^{830} \mathrm{Em}$ Bangu, continuou o regime de apenas quatro dias por semana (não se trabalhava sexta-feira nem sábado), enquanto durasse a abundância de estoque. $^{831}$

Com a fama de serem eternos "fura-greves", sempre retornando docilmente ao trabalho antes das demais fábricas, os operários da Bangu chegaram a escrever um manifesto aos jornais, conclamando a continuidade da luta. A carta parece mais uma tentativa de se livrar da reputação a eles atribuída e "do mau conceito em que nos encontramos" do que uma ameaça real do operariado contra os patrões:

Os operários do Bangu, deveras compungidos com a situação em que se colocaram, voltando ao trabalho antes disso ser resolvido pela União dos Operários em Tecidos, concorrendo por essa foram para o fracasso das suas reclamações, aconselham a todos os que se encontram trabalhando que abandonem o trabalho e só o retornem depois que as reclamações que a União formulou sejam atendidas e todos os companheiros que estão presos sejam soltos e readmitidos nos seus lugares. É um procedimento que, estamos certos, nos reabilitará do mau conceito em que nos encontramos, não só na nossa classe, como nas demais em geral. ${ }^{832}$

Para o advogado Evaristo de Moraes, que acompanhou o movimento operário à época e escreveu suas memórias em 1922, uma fábrica, como a Bangu, repleta de brasileiros negros, muitos deles vindo de áreas rurais e contratando sempre imigrantes portugueses, ${ }^{833}$ estava formando um

\footnotetext{
${ }^{829}$ Idem, 27 de novembro de 1918, p. 5.

${ }^{830}$ ADDOR (1986), p. 174.

${ }^{831}$ JORNAL DO BRASIL, 30 de novembro de 1918, p. 5.

${ }^{832}$ Idem, 3 de dezembro de 1918, p. 7.

${ }^{833}$ Analisando os dados deixados pela historiadora Gracilda Alves que, nos anos 1980, teve acesso às fichas funcionais da Fábrica Bangu, é possível perceber que dos 233 estrangeiros contratados entre 1893 e 1930, 158 eram portugueses, enquanto apenas 31 eram italianos e 13 eram espanhóis. Evidentemente, nem todas as fichas foram encontradas, porém,
} 
contingente de operários de características bem peculiares: mais afeiçoados ao patrão e extremamente reticentes em relação a greves muito longas:

O português é o "pior grevista, no sentido da falta de tenacidade. Em se demorando a solução para o conflito, não se devia contar com ele. Empolga-o a nostalgia do trabalho. Aproxima-se irresistivelmente do patrão à espera de um sinal".

Quanto aos brasileiros “ora davam provas de um espírito de abnegação que ia até o heroísmo, ora se entregavam ao primeiro chamado patronal, ou à primeira pressão da polícia. Nisto, como em muitas outras relações de nossa vida social, patenteava-se a índole indecisa, contraditória, cheia de imprevistos, do brasileiro. Acrescia em certas classes operárias a circunstância de predominar o elemento negro, da geração que, anda, por desgraça, alcançara o cativeiro, de regime de trabalho sob o chicote, sem horário nem remuneração". 834

a quantidade de lusitanos em relação ao total de imigrantes chega a 67\%. Vide: SILVA, Gracilda Alves de Azevedo. Bangu - a fábrica e o bairro: um estudo histórico, 1889-1930. Instituto de Filosofia e Ciências Sociais (IFCS) da Universidade Federal do Rio de Janeiro (UFRJ), 1985, pp. 783-819.

${ }^{834}$ Apud. CARONE, Edgard. Classes sociais e movimento operário. São Paulo: Editora Ática, 1989, pp. 45-46. 


\section{2 - A maior greve e a jornada de 8 horas (1919)}

Inegável que o ânimo dos trabalhadores, das mais diversas categorias, das principais capitais do país estavam em polvorosa naquele final de anos 10. Em 1919, outras greves ocorreriam no Distrito Federal, São Paulo, Porto Alegre e Salvador. Desta vez, pareceu impossível aos industriais negar o que o operariado pretendia há tempos: a jornada de 8 horas, reduzindo significamente o tempo em que se ficava nas fábricas.

$\mathrm{O}$ ano começou agitado. A morte do presidente eleito, Rodrigues Alves, em 16 de janeiro vítima tardia da gripe espanhola -, obrigou a realização de novas eleições, com a disputa entre o paraibano Epitácio Pessoa (do Partido Republicano Mineiro) e o baiano Ruy Barbosa (do Partido Republicano Paulista). Ruy Barbosa perderia o pleito de 13 de abril por uma significativa diferença de 169.959 votos. ${ }^{835}$ Entretanto, durante a campanha, o candidato aproximou-se dos sindicatos e prometeu, se eleito, defender as causas dos trabalhadores com a criação de uma legislação operária, garantindo, assim, a simpatia da classe e vencendo, ao menos, na contagem de votos do Distrito Federal, Estado do Rio de Janeiro e Pará. ${ }^{836}$

Durante a campanha, em 19 de março de 1919, alguns jornais publicaram uma espécie de "manifesto operário" pedindo votos ao senador Ruy Barbosa, intitulado o "extraordinário operário do pensamento". Dentre os que assinam o manifesto estão 111 operários da Fábrica Bangu, 91 homens e 20 mulheres, incluindo imigrantes como o casal Miguel Starzinski e Bertha Sranke Starzinski, Manoel Borgueiro e Violeta Borgueiro e sete membros da família Spirito. Apesar do apoio no abaixo-assinado, estrangeiros e mulheres não tinham direito de ir às urnas.

Além desses, é possível reconhecer o nome de três jogadores-operários do Bangu A. C.: Thomaz Franco, tecelão; Avelino de Souza, tecelão; Anchyses Carrilho, gravador. Naquele ano, 36 jogadores do elenco banguense também trabalhavam na fábrica, mas os demais 33 não firmaram suas assinaturas no manifesto. ${ }^{837}$ Os motivos podem ser vários, desde o não alinhamento com a campanha de Ruy Barbosa, ao distanciamento da vida política do país.

O próprio presidente do Bangu A. C., o jovem Firmino de Carvalho claramente apoiava a candidatura de Ruy. No comício realizado na praça da Matriz numa sexta-feira, 11 de abril, Firmino fez a apologia de Ruy e também da campanha de Octacílio de Carvalho Camará para o cargo de senador, terminando por conclamar os operários a seguir os oradores Caio Monteiro de Barros e o advogado Evaristo de Moraes até a estação de trem. ${ }^{838}$

\footnotetext{
${ }^{835}$ PORTO, Walter Costa. Dicionário do voto - $3^{a}$ edição revista e atualizada. Rio de Janeiro: Lexicon, 2013.

${ }^{836}$ MATOS, Hebe. "A vida política” in: SCHWARCZ, Lilia Moritz (org.). História do Brasil Nação - A Abertura para o Mundo (1889-1930). Rio de Janeiro: Editora Objetiva, 2012, p. 123.

${ }^{837}$ A ÉPOCA, 19 de março de 1919, p. 3.

${ }^{838}$ Idem, 12 de abril de 1919, p. 2.
} 
Ruy Barbosa tinha conquistado a simpatia do operariado com uma conferência emblemática no dia 20 de março de 1919 e que foi transformada até mesmo em livro: "A questão social e política no Brasil". Qualquer trabalhador em fábrica de tecidos se identificaria com as mazelas relatadas pelo candidato, que criticou duramente o Estado por não agir em benefício dos operários. Em uma das muitas partes da conferência, lembrou-se dos adoecidos tecelões da Fábrica Bangu que, segundo ele, viviam tuberculosos:

(...) O Dr. Domingos Marques de Oliveira, em uma conferência de que aquele seu colega transcreve trechos notáveis, e que o orador pronunciara na própria fábrica do Bangu, declarava que todos os tísicos, de que havia tratado naquela localidade, onde ele clinicava, havia seis anos, eram tecelões, e atribuía a dilatação desse mal, em grande parte, à lançadeira de chupar, singular utensílio usado nos teares (não sei se ainda agora), e de que o operário se serve com a boca, sugando. Esse instrumento perigoso, a esse tempo já condenado na Europa, obrigava os tecedores e tecedeiras a esforços persistentes de aspiração, havendo operários que deviam exercer a sucção cada um em trezentas lançadeiras; e, passando, sucessivamente, de boca em boca, transmitia, pela comunicação bucal, o contágio da tuberculose, de que era, segundo o testemunho desses dois facultativos, "o mais poderoso auxiliar" e "o maior propagador". ${ }^{839}$

O fim da chamada "lançadeira de chupar" era uma reivindicação antiga dos operários, tendo as fábricas Corcovado, Carioca e São Félix incluído esta exigência durante a greve de julho de $1917{ }^{840}$ O próprio Congresso Operário de 1912 - patrocinado por Mário Hermes, deputado federal, filho do presidente Hermes da Fonseca e realizado dentro do Palácio Monroe ${ }^{841}$ - já pedia o fim da lançadeira e sua substituição por um sistema auto-mecânico, utilizado na Alemanha, Inglaterra e Portugal. $^{842}$

O novo presidente eleito, Epitácio Pessoa - representante das oligarquias de São Paulo e Minas Gerais -, sequer fez campanha pelo Brasil e acompanhou à distância sua vitória nas urnas. Estava na França por ocasião da Conferência de Paz do pós-guerra e participou da fundação da Organização Internacional do Trabalho no dia 11 de abril de 1919. A criação da OIT era uma exigência do Tratado de Versalhes para responder às principais reivindicações do movimento sindical em todo o mundo. Na mesma data, Epitácio Pessoa telegrafou ao Ministro do Exterior, Domício da Gama, informando que no Tratado, seriam incluídas as principais bandeiras de luta do operariado, incluindo a jornada de 8 horas diárias, o limite máximo semanal de 48 horas e a proibição do emprego de menores de 14 anos. ${ }^{843}$ Ou seja, o Brasil, como um dos 52 signatários, deveria adotar a mesma política trabalhista.

Os países da Europa logo transformaram a chamada "convenção I" da OIT em lei. A Assembleia Nacional francesa aprovou a lei da jornada de oito horas em 23 de abril de 1919,

${ }^{839}$ BARBOSA, Ruy. A questão social e política no Brasil. Rio de Janeiro: Centro Edelstein de Pesquisas Sociais, 2010, p. 23.

${ }_{840}$ A ÉPOCA, 28 de julho de 1917, p. 2.

${ }^{841}$ GOMES, Ângela de Castro. A invenção do trabalhismo. $3^{a}$ edição. Rio de Janeiro: Editora FGV, 2005, p. 114.

${ }^{842}$ Idem, 13 de novembro de 1912, p. 4.

${ }^{843}$ BEIGUELMAN, Paula. A formação do povo no complexo cafeeiro: aspectos políticos $-3^{a}$ edição. São Paulo: EdUSP, 2005, pp. 258-259. 
embora tenha dado um prazo de dois anos para todas as indústrias se adaptarem. Na Espanha, o Real Decreto previa que, a partir, de $1^{\circ}$ de outubro de 1919, nenhum trabalhador podia ser obrigado a ficar no emprego além das oito horas, limite de tempo reconhecido como justo, por razões de "higiene moral". ${ }^{844}$ Em Portugal, o Ministério do Trabalho estipula, a partir do decreto $\mathrm{n}^{\circ}$ 5516, de 7 de maio de 1919, o período máximo de oito horas diárias e 48 horas semanais. ${ }^{845}$ No Brasil, o governo não impôs nenhum decreto, a regulamentação da jornada deveria surgir ainda naquele ano, pelo menos na Capital Federal, de um acordo entre o Centro Industrial de Fiação e Tecelagem de Algodão (que representava o interesse patronal de 17 empresas) e a União dos Operários em Fábricas de Tecidos.

\subsection{1 - Comícios para inflamar o povo}

O clima era propício a mudanças. Mesmo em Bangu, onde o operariado havia sido pacífico nas greves anteriores, já se percebia uma agitação.

Num domingo, 30 de março, o Partido Trabalhista Brasileiro fez um comício no bairro. Falaram João Leuenroth - irmão do famoso anarquista paulista Edgard -, Marcelino de Oliveira e o jornalista Augusto Rangel. Leuenroth criticou fortemente a recém-promulgada lei sobre acidentes de trabalho (lei n 3724, de 15 de janeiro de 1919), chamando-a de "conto do vigário". De acordo com sua interpretação, "a nova lei só auxilia os obreiros vítimas de acidentes durante os dois primeiros anos de sua invalidez, depois do que será forçado a pedir esmolas, a implorar a caridade pública, porque nada mais terá que lhe proporcione meios de subsistência".

Já o polêmico jornalista Rangel explicou que os meios buscados para garantir a vitória dos trabalhistas não passavam "pela dinamite, nem pelo punhal, mas simplesmente pela declaração pacífica de greve, com abandono imediato do trabalho". Ao fim, quando os operários começaram a dispersar, surgiram dois anarquistas - Theóphilo Ferreira e Antônio Pook - criticando a plataforma "pacifista" dos trabalhistas. Para Ferreira, era preciso "combater de armas na mão a burguesia. (...) Tudo isso só terminará pela dinamite, pela revolução, que é uma fatalidade aqui no Rio e não demorará muitos dias". ${ }^{846}$

A bravata de Theóphilo Ferreira aos operários da Fábrica Bangu enquadra-se na análise que o historiador Sheldon Leslie Maram faz do movimento anarquista depois da frustrada greve insurrecional de 1918: “Aumentaram simplesmente o volume da retórica revolucionária sem ter em mãos qualquer plano objetivo de revolução e nem mesmo os homens necessários para alimentá-la.

\footnotetext{
${ }^{844}$ CARMONA, Álvaro Soto. El trabajo industrial en la España contemporánea (1874-1936). Barcelona: Anthropos, 1989, p. 586

${ }^{845}$ MARTINEZ, Pedro Romano. Código do Trabalho - $3^{a}$ edição. Estoril: Principia Editora, 2006, p. 13.

${ }^{846}$ GAZETA DE NOTÍCIAS, 31 de março de 1919, p. 2.
} 
Muitos dos líderes das fileiras anarcossindicalistas eram revolucionários apenas da boca para fora" ${ }^{847}$

Para Maram, o operariado estava mais preocupado com a conquista do "pão diário" e pela permissão de se afiliarem aos sindicatos do que seguir o discurso radical dos anarquistas.

Principal representante dos têxteis, a União dos Operários em Fábricas de Tecidos abrira uma sucursal no bairro e decidiu se reunir toda terça-feira, sob as ordens do presidente José Pereira de Oliveira. ${ }^{848}$ Logo no início dos trabalhos, num domingo, 6 de abril de 1919, Pereira de Oliveira se remeteu à Revolução Russa para agitar o ânimo dos tecelões, que se estivessem pouco atentos aos fatos internacionais, dificilmente compreenderiam seu discurso. Citou os Romanoffs, que "estavam a serviço da burguesia, sugando gota a gota o sangue do trabalhador", salientou o papel de Lênin, "o maior batalhador em prol dos direitos dos humildes" e enalteceu Trotsky, para ele, "o herói da nova era". 849

A disseminação das ideias da Revolução Russa no eixo Rio-São Paulo corria rápida. Ainda em 1919, os anarquistas paulistas Edgard Leuenroth e Hélio Negro publicaram o livro "O que é maximalismo ou bolchevismo?", no qual, além das questões ideológicas, explicavam financeiramente a precariedade da vida de um operário, pai de família, com esposa e dois filhos para sustentar. Mensalmente, com alimentação (89\$900), aluguel da casinha da vila (45\$000), vestuário e calçados (40\$750) e outras necessidades que por ventura aparecessem (32\$000), este operário deveria ganhar $207 \$ 650$ para poder se manter. ${ }^{850}$

Por mais que os salários fossem extremamente variáveis, dependendo da função, do número de horas ou dias trabalhados e às vezes até da produtividade, podemos ter uma ideia do quanto pagava a Fábrica Bangu em 1919, segundo as fichas catalogadas por Eulália Lobo: um operário da fiação ganhava, em média, apenas $85 \$ 440$; enquanto um cardador recebia $189 \$ 600$. No entanto, quem trabalhasse na seção de dobação percebia $240 \$ 000$ e o ofício de mecânico - uma profissão especializada - era remunerado com $444 \$ 000$ mensais. ${ }^{851}$

Quando chegou o dia $1^{\circ}$ de maio, a multidão de trabalhadores da Capital Federal estava no ápice da agitação. Em Bangu, ainda tentou-se utilizar as mesmas fórmulas de anos anteriores: banda de música na rua, jogo de futebol e o lançamento da "pedra fundamental" das arquibancadas do

\footnotetext{
${ }^{847}$ MARAM, Sheldon Leslie. Anarquistas, imigrantes e o movimento operário brasileiro. Rio de Janeiro: Paz e Terra, 1979, p. 96.

${ }^{848}$ Além de Bangu, a União dos Operários em Fábricas de Tecidos abriu sucursais no Andaraí, Laranjeiras, Gávea, Sapopemba, Petrópolis, Niterói e Santo Aleixo. Apud. ADDOR, Carlos Augusto. A insurreição anarquista no Rio de Janeiro. Rio de Janeiro: Dois Pontos Editora, 1986, p. 151.

${ }^{849}$ A RAZÃO, 7 de abril de 1919, p. 5.

${ }^{850}$ HARDMAN, Foot Francisco \& LEONARDI, Victor. História da Indústria e do Trabalho no Brasil (das origens aos anos 20) - $2^{a}$ edição. São Paulo: Editora Ática, 1991, p. 156.

${ }^{851}$ LOBO, Eulália Maria Lahmeyer. História do Rio de Janeiro. Do Capital Comercial ao Capital Industrial e Financeiro. $2^{o}$ Volume. Rio de Janeiro: IBMEC, 1978, pp. 667; 672.
} 
Bangu A. C., ${ }^{852}$ mas é pouco provável que além dos sócios e suas famílias, o grosso do operariado tenha assistido a esses passatempos. Muitos dos banguenses devem ter tomado o trem e ido até o Centro da cidade, onde participaram de uma passeata gigantesca, da Praça Mauá até o Teatro Municipal. Estima-se que as ruas estavam tomadas por 50 a 60 mil manifestantes, entre trabalhadores industriais, líderes anarquistas e simpatizantes do comunismo. ${ }^{853}$ "Na mais completa ordem e com uma imponência nunca vista até hoje, os operários comemoraram o $1^{\circ}$ de maio formando um enorme cortejo que circulou pela Avenida Rio Branco e ruas próximas". ${ }^{854}$

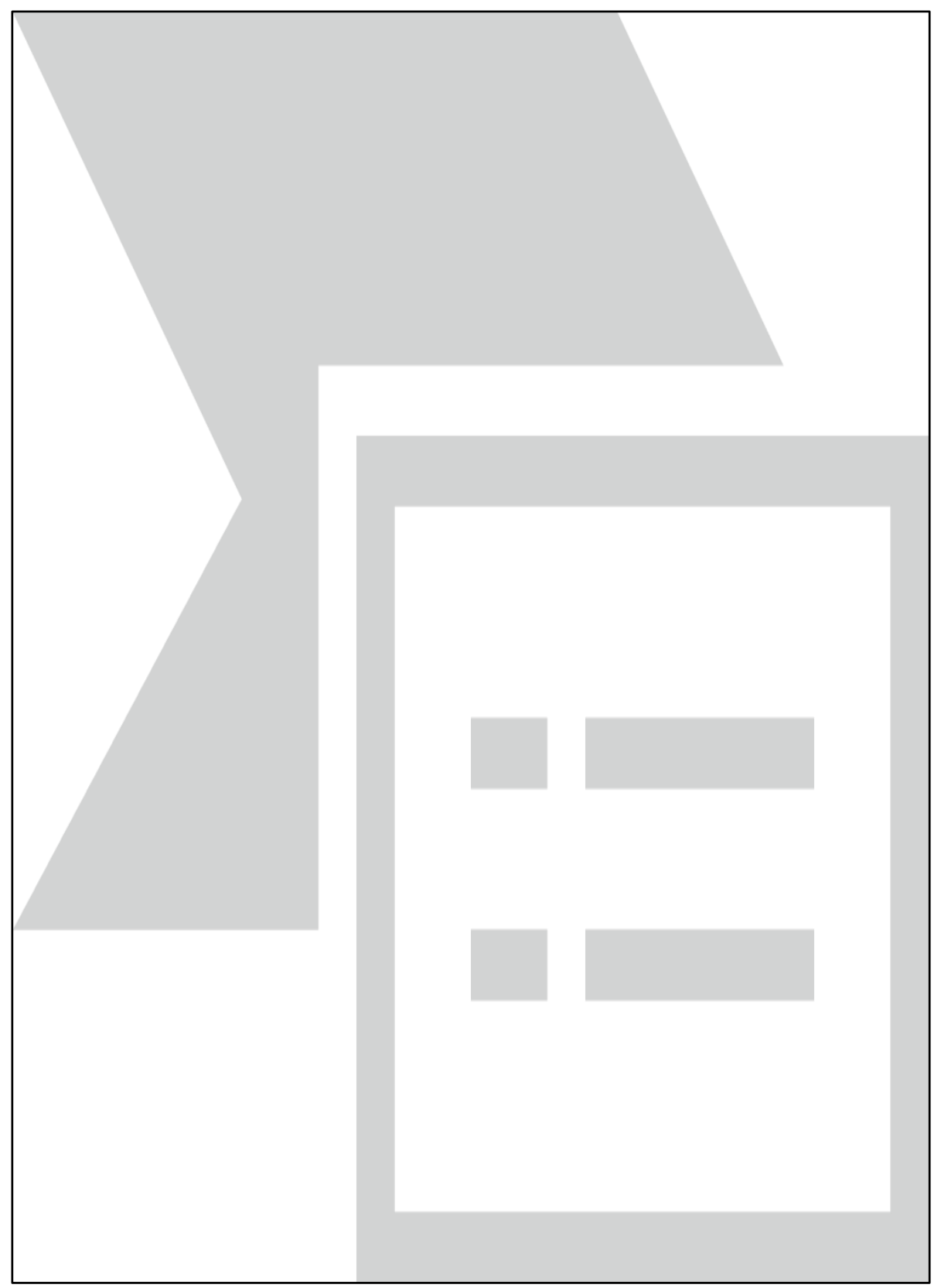

Figura 35 - Flagrantes da multidão que lotou as ruas do Centro do Rio em $1^{\text {o }}$ de maio de 1919. Fonte: Fon-Fon.

\footnotetext{
${ }^{852}$ A ÉPOCA, 3 de maio de 1919, p. 6.

${ }^{853}$ SCHWARCZ, Lilia Moritz. "População e sociedade" in: SCHWARCZ (2012), p. 59.

${ }^{854}$ FON-FON, ano XII, no 19, 10 de maio de 1919, p. 23.
} 
Segundo o Censo Industrial publicado em 1920, a capital paulista já tinha ultrapassado o Distrito Federal em número de operários, atingindo a significativa marca de 84 mil trabalhadores. $\mathrm{O}$ Rio contava com $56.517,{ }^{855}$ sendo que destes, 19.264 (34\%) estavam empregados na indústria têxtil. ${ }^{856}$

E como sempre acontecia, foi por São Paulo que as greves começaram em 1919. Logo no dia 2 de maio, eclodindo na Tecelagem Mariângela, uma fábrica de Francisco Matarazzo, no bairro do Brás, ${ }^{857}$ e rapidamente contanto com a adesão de outras indústrias, os paulistanos assistiram a uma nova "greve geral", que envolveu além dos têxteis, os chapeleiros, operários da construção civil, os gráficos, os sapateiros, as costureiras, os tipógrafos e os padeiros. ${ }^{858}$ A meta era só voltar quando conseguissem além da redução da jornada para oito horas, um aumento percentual significativo no valor de cada hora trabalhada (os sindicatos pediam reajustes que iam entre $40 \%$ e $70 \%$, enquanto os patrões ofereciam 20\%) para que o decréscimo da jornada não prejudicasse o rendimento mensal do operário. "Que importam os $20 \%$ do passado se a soma do que se obtém nas oito horas é inferior à que se percebia antes da greve atual?" 859

No Rio, até então, apenas os funcionários do Lloyd tinham cruzado os braços e, no início de junho, com o arrefecimento do movimento em São Paulo, a grande imprensa carioca limitava-se a informar a existência de greves na Europa: anunciava-se a greve de estudantes em Lisboa e uma greve geral em Vladivostok, na Rússia. ${ }^{860}$ Era como se ignorassem que a própria Capital Federal estava sob um barril de pólvora, a partir do momento em que o Centro Industrial descartou a União dos Operários como mediadora dos conflitos internos entre patrões e operários. Uma nota suscinta dos industriais foi o estopim de uma grande greve, que paralisaria as fábricas da cidade durante todo o mês de junho.

Em resposta ao ofício de VV. SS., no qual pedem que a União dos Operários em Fábricas de Tecidos seja reconhecida como órgão direto e representante da classe, com plenos poderes para se entender com os industriais sempre que houver dúvidas entre patrões e operários, temos de declarar que não podemos conceder tais prerrogativas, porquanto a administração e a disciplina das fábricas continuam exclusivamente a cargo dos diretores e seus prepostos. Saudações. ${ }^{861}$

Na segunda-feira, dia 2 de junho, as operários já não atendiam ao apito que partia das chaminés, nos mais diversos bairros fabris da Capital, incluindo os quase 3.000 operários da Bangu.

\footnotetext{
${ }^{855}$ NETO, José Miguel Arias. "Primeira República: economia cafeeira, urbanização e industrialização" in: DELGADO, Lucília de Almeida Neves \& FERREIRA, Jorge (orgs.). O Brasil Republicano: o tempo do liberalismo excludente - da Proclamação da República à Revolução de 1930. Rio de Janeiro: Civilização Brasileira, 2008, p. 221.

${ }^{856}$ LOBO, Eulália Maria Lahmeyer. (org.). Rio de Janeiro operário - natureza do Estado, conjuntura econômica, condições de vida e consciência de classe. Rio de Janeiro: Access Editora, 1992, p. 20.

${ }^{857}$ TOLEDO, Roberto Pompeu de. A capital da vertigem - Uma história de São Paulo de 1900 a 1954. Rio de Janeiro: Objetiva, 2015, pp. 106, 175.

${ }^{858}$ GOHN, Maria da Glória. História dos movimentos e lutas sociais - A construção da cidadania dos brasileiros. São Paulo: Edições Loyola, 1995, p. 75.

${ }^{859}$ Apud. BEIGUELMAN, Paula. Os companheiros de São Paulo. São Paulo: Edições Símbolo, 1977, p. 104.

${ }^{860}$ CORREIO DA MANHÃ, $1^{\circ}$ de junho de 1919 , p. 1.

${ }^{861}$ Idem, 7 de junho de 1919, p. 6.
} 
Esta foi a mais longa paralisação de que os banguenses tomaram parte, até então. Suportaram, longamente, três semanas inteira longe dos teares. Para Boris Fausto, parecia que a sorte da associação têxtil de massas e o próprio destino das lutas da categoria estava em jogo nesta greve de 1919. Ela envolvia uma série de reivindicações acerca de salários, condições de trabalho, readmissão de operários demitidos na greve de novembro de 1918, mas tinha como eixo o reconhecimento da organização sindical por parte dos empresários. ${ }^{862}$

A jornada de 8 horas era consenso entre os dois lados e inevitavelmente estava bem próximo o dia em que essa antiga reivindicação seria posta em prática. Porém, as divergências começavam em relação a percentagem de aumento a ser concedido, passavam pela equidade salarial entre homens e mulheres, a proibição do trabalho noturno para as operárias, a diminuição do serão noturno de 8 para 6 horas, a proibição de contratação de menores de 14 anos e o pagamento de $50 \%$ a mais por hora-extra (os industriais acenavam com um acréscimo de 20\%). ${ }^{863}$ A resposta do empresariado em relação ao trabalho do menor - visto naquela época como mão-de-obra barata e por isso, imprescindível - beirava o deboche. "Tudo que diz respeito ao bem-estar já está em vigor nos nossos regulamentos, a não ser o trabalho das crianças, que é concedido para atender à solicitação dos próprios pais, que são também operários das fábricas". 864

A situação do trabalho do menor já tinha sido alvo dos chargistas do período. Num suposto encontro entre um casal da elite carioca e um menino operário, surgia o diálogo que, claramente, responsabilizava os pais pela exploração da mão-de-obra infantil e não o industrial:

- Eu estou desocupado porque a fábrica aderiu à greve. Os operários são contra o trabalho das crianças, dizia o menino.

- E quem foi que te empregou na fábrica? - perguntava o burguês da avenida

- Foi meu pai, que é o chefe dos grevistas... ${ }^{865}$

Nessa questão específica, a União dos Operários saiu derrotada. Temos como exemplo a Fábrica Bangu, que em 1920, contratou 43 operários com menos de 17 anos - o menor deles tinha nove anos -, de um total de 79 admitidos, ou seja, $54 \%$ da nova mão-de-obra. ${ }^{866}$

Após a primeira semana de greve, as pequenas fábricas têxteis da cidade acabaram concordando em assinar a tabela de reajuste proposto pela União dos Operários. No entanto, as gigantes do setor afiliadas ao Centro Industrial, não cediam às exigências dos trabalhadores. ${ }^{867}$ Para Boris Fausto:

As suas concessões limitavam-se ao oferecimento de um pequeno aumento salarial que seria anulado pela fixação das oito horas de trabalho, enquanto a recusa ao reconhecimento

\footnotetext{
${ }^{862}$ FAUSTO, Boris. Trabalho urbano e conflito social (1890-1920). São Paulo: Difel, 1977, p. 186.

${ }^{863}$ O ESTADO DE SÃO PAULO, 3 de junho de 1919, p. 3.

${ }^{864}$ CORREIO DA MANHÃ, 7 de junho de 1919, p. 6.

${ }^{865}$ CARETA, ano X, no 475, 28 de julho de 1917, p. 15.

${ }^{866}$ SILVA, Gracilda Alves de Azevedo. Bangu - a fábrica e o bairro: um estudo histórico, 1889-1930. Instituto de Filosofia e Ciências Sociais (IFCS) da Universidade Federal do Rio de Janeiro (UFRJ), 1985, p. 808.

${ }^{867}$ A ÉPOCA, 9 de junho de 1919, p. 8.
} 
do sindicato - uma das razões básicas da divisão dos industriais - era frontal. O Centro Industrial de Fiação e Tecelagem de Algodão tinha consciência do alcance da luta e seguiu uma linha de crescente intransigência; a ponto de negar uma oferta mediadora do Chefe de Polícia. Não obstante a intensa mobilização operária, expressa em manifestações de rua com cerca de 15.000 participantes, os têxteis acabaram por ceder aos golpes de uma intensa repressão. ${ }^{868}$

Mesmo que o movimento estivesse condenado a ter pouco sucesso, outras categorias de trabalhadores foram aderindo à causa dos tecelões. Assim, na Capital Federal durante aquele mês de junho, os sapateiros, os padeiros, os alfaiates, os marmoristas, as costureiras e os ladrilheiros também cruzaram os braços e passaram a negociar diretamente com seus patrões.

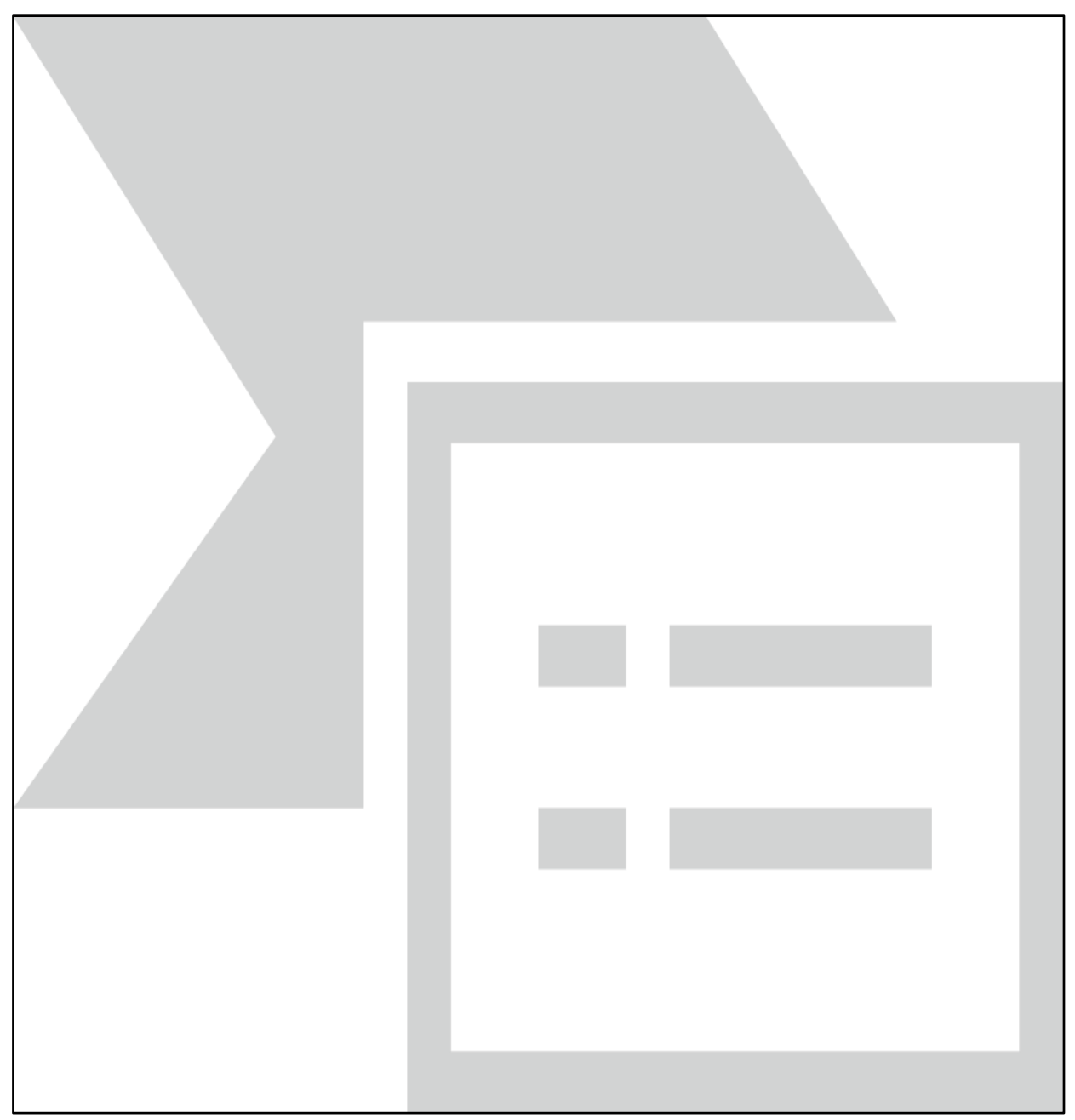

Figura 36 - Charge da revista Careta atribuindo a culpabilidade do trabalho do menor a seus próprios pais.

Com o passar dos dias, a grande imprensa foi se desinteressando de informar a seus leitores o desenrolar das ações nos bairros mais periféricos. Sabe-se que houve prisões e conflitos, especialmente na turbulenta fábrica de Deodoro. Em Bangu, mais distante ainda do Centro, houve 
alguns comícios, ${ }^{869}$ e a ação do Dr. Augusto Mendes, delegado do $25^{\circ}$ distrito, pareciam aconselhar aos operários “a maior prudência para que não se desse nenhum fato desagradável". 870

A fábrica anunciou que abriria os portões a quem quisesse voltar ao trabalho numa quartafeira, 18 de junho. ${ }^{871}$ Evidente que a decisão incutiu uma reação dos demais operários do bairro, que não aceitavam retornar aos trabalhos sem um acordo assinado. Na manhã do dia 19, os ânimos na porta do estabelecimento estavam acirrados com os manifestantes tentando impedir a entrada dos companheiros. A ordem só veio com a chegada da polícia. “Compareceu ao local o delegado Dr. Augusto Mendes que fez ver aos grevistas que, assim como a polícia não obrigava os operários grevistas a voltar ao trabalho, não podia consentir que esses impedissem de trabalhar aqueles que o desejassem". É provável que nada tenha se dado com tamanha cordialidade, mas O Imparcial se limitou a dizer que: "as palavras da criteriosa autoridade demoveram os operários dos seus violentos intuitos e todos eles se retiraram em paz". ${ }^{872} \mathrm{O}$ Paiz, mais atento à famosa truculência policial para com os operários, informava que: “Os delegados receberam ordens para autuar em flagrante todo aquele que violar o artigo $2^{\circ}$ do decreto $\mathrm{n}^{\circ} 1.162$ de 1890, derrogatório do artigo 206 do Código Penal. Esse dispositivo estabelece para os contra-fatores as penas de prisão celular por dois a seis meses e a multa de $200 \$$ a $500 \$ 000 " .873$

Segunda-feira, 23 de junho, seria um dia-chave. Houve um reforço de mais oito praças de cavalaria para vigiar o edifício fabril. ${ }^{874}$ Os operários da Fábrica Bangu aceitavam voltar ao trabalho, na mesma ocasião em que terminava a greve nas fábricas Confiança (Vila Isabel), Sapopemba (Deodoro), Cruzeiro (Andaraí), Santa Heloísa (Matoso) e Esperança (São Cristóvão). Não era o fim do movimento ainda, outras indústrias, como a Aliança (Laranjeiras), a Carioca, a Corcovado, a São Félix (situadas entre a Gávea e Jardim Botânico), a Bonfim e a Mavilis (ambas na Ponta do Caju) continuavam resistindo, permanecendo, assim, por mais uma semana sem atender aos apitos das chaminés. ${ }^{875}$

No caso específico da Bangu, após três semanas em casa, os tecelões foram vencidos pelas privações que estavam passando:

Os operários dessa fábrica volveram ao serviço, segundo declaravam, premidos pelas necessidades, pela falta absoluta de recursos para sua manutenção. Muitos deles, segundo adiantavam, há muitos dias que vinham se alimentando a pão e café. E, assim, não viram outro recurso senão volverem à fábrica, desistindo de prosseguirem na greve. ${ }^{876}$

\footnotetext{
${ }^{869}$ O PAIZ, 7 de junho de 1919, p. 6.

${ }^{870}$ GAZETA DE NOTÍCIAS, 3 de junho de 1919, p. 4.

${ }^{871}$ A NOITE, 18 de junho de 1919, p. 5.

${ }^{872}$ O IMPARCIAL, 20 de junho de 1919, p. 5.

${ }^{873}$ O PAIZ, 22 de junho de 1919, p. 11.

${ }^{874}$ CORREIO DA MANHÃ, 25 de junho de 1919, p. 5.

${ }^{875}$ O PAIZ, 24 de junho de 1919, p. 5.

${ }^{876}$ A ÉPOCA, 24 de junho de 1919, p. 2.
} 
A falta de dinheiro e a fome eram realmente ótimos argumentos para justificar o término da luta. Jornais, como A Razão, atribuíam que, além das privações, a repressão policial também pesou na decisão do operariado que, assim, coagidos, rompiam mais facilmente os laços que os mantinham a União dos Operários:

A perseguição e as violências, totalmente descabidas, pela falta de pretextos, foram relegadas para os pontos longínquos, como Bangu, onde desde o primeiro momento, imperou um verdadeiro terrorismo, ficando os operários sem a mínima garantia, constantemente provocados pelos esbirros do sr. Aurelino [Leal] e pelos capangas e desordeiros promovidos a auxiliares da polícia, que lhes fornecia armas e munições. Tudo fez ali em Bangu a polícia unida à capangada conta os operários, para quebrar-lhes a solidariedade com a União, demonstrando assim a parcialidade do Chefe de Polícia. ${ }^{877}$

Para as indústrias têxteis do Rio de Janeiro, a greve de 1919 acabou sendo a mais importante. Depois dela, ao menos, a jornada de oito horas passou a ser implementada, muito embora, de quando em quando, uma fábrica tentasse voltar ao sistema antigo. A tabela salarial da União dos Operários acabou não sendo aceita. Na época, um operário de $1^{a}$ classe ganhava $9 \$ 000$ por dia. Se cumprisse 26 dias de trabalho por mês (folgando apenas nos domingos), esse "abonado" das tecelagens receberia $234 \$ 000$. No entanto, poucos ganhavam o teto máximo diário. Havia até quem fosse considerado operário de $5^{\mathrm{a}}$ classe, recebendo $5 \$ 000$ por dia. Nesse caso, mesmo que comparecesse ao serviço de segunda a sábado, não ganharia mais do que $130 \$ 000$ ao término de um mês. A União esperava aprovar uma tabela audaciosa, que previa o salário mensal de 360\$000 a um operário dito de $1^{\mathrm{a}}$ classe; $330 \$ 000$ ao de $2^{\mathrm{a}} ; 300 \$ 000$ ao de $3^{\mathrm{a}} ; 270 \$ 000$ ao de $4^{\mathrm{a}}$ e $240 \$ 000$ ao de $5^{\mathrm{a}}$. Ou seja, no final das contas, um trabalhador ainda no início da carreira já iria receber $6 \$ 000$ a mais do que recebia um operário de $1^{\text {a }}$ classe antes da greve. ${ }^{878}$ Evidente que o sindicato saiu frustrado no seu intento.

\footnotetext{
${ }^{877}$ A RAZÃO, 26 de junho de 1919, p. 5.

${ }^{878}$ O IMPARCIAL, 20 de junho de 1919, p. 5.
} 


\section{3 - Mr. Schofield: "um macaco numa loja de louças"}

Quando João Ferrer pediu demissão do cargo de diretor-gerente, em janeiro de 1919, logo foi substituído pelo inglês Thomas Bradshaw. Segundo os jornais, um homem "cujo tino administrativo promete muito concorrer para a grande progressão da Companhia, assim como para o bem-estar do operariado daquela fábrica". ${ }^{879}$ No entanto, Bradshaw não duraria muito no cargo e pouco se sabe sobre sua gerência ou sobre sua atuação na longa greve de junho de 1919. Em outubro, outro inglês surgiu em seu lugar: James Schofield, um homem cuja dualidade de informações nos permite supor que era odiado por uns e amado por outros, quase na mesma proporção.

O comerciante James Schofield chegara ao Brasil em 6 de julho de 1888, vindo na primeira classe do paquete Potosi, um vapor que saira de Liverpool vinte e três dias antes. Na época, tinha 32 anos e ainda era solteiro. ${ }^{880}$ Em 1890, fundaria, com dois imigrantes franceses importadores de fazendas, a Fábrica de Fiação e Tecidos Andorinhas em Santo Aleixo, segundo distrito de Magé. ${ }^{881}$ Concomitantemente, também era diretor da Companhia Manufactureira Linha Estrella, ${ }^{882}$ algo que desgostava o presidente da Andorinhas: "Nosso gerente continua a prestar e tem prestado bons serviços à nossa Companhia, apesar de ter empregado parte de sua atividade no serviço de outra empresa", dizia no relatório de $1893{ }^{883}$

Em 1905, James Schofield participou da fundação de outra Companhia: a Nova Fábrica de Fiação e Tecidos Santo Aleixo, onde em 1918 foi guindado ao cargo de diretor-presidente para "debelar dificuldades que ameaçavam o bom andamento do serviço em nossa fábrica". ${ }^{884}$ Convidado a administrar a Fábrica Bangu em 1919, provavelmente pelo novo diretor-secretário da Companhia, o português Manoel Ribeiro Teixeira Neves, ex-tesoureiro da Nova Fábrica Santo Aleixo, James Schofield foi fincando raízes no bairro. Em 9 de outubro, seu nome já aparecia entre os pedidos de filiação ao Bangu A. C. ${ }^{885}$ e $\operatorname{logo}$ os jornais noticiam sua mudança para a vila operária, estabelecendo-se na Rua Ferrer $n^{\circ}$ 43. Sua chegada teve uma "significativa manifestação de apreço, promovida pelos sócios da União dos Operários em Fábricas de Tecidos" ${ }^{886}$ mostrando que, inicialmente, o novo diretor-gerente tinha o apoio do principal sindicato têxtil da época.

\footnotetext{
${ }^{879}$ A ÉPOCA, $1^{\circ}$ de fevereiro de 1919, p. 6.

${ }^{880}$ Relação de passageiros do vapor Potosi. Arquivo Nacional, BR.AN.RIO.OL.0.RPV.PRJ 3635.

${ }^{881}$ LUCA, Tania Regina de \& VIDAL, Laurent. Franceses no Brasil - século XIX-XX. São Paulo: Editora UNESP, 2009, pp. 187-188.

882 DIÁRIO OFICIAL, 19 de novembro de 1894, seção 1, p. 16.

${ }^{883}$ Idem, 2 de dezembro de 1893, seção 1, p. 13.

${ }^{884}$ Idem, $1^{\circ}$ de outubro de 1918, seção 1, p. 51.

885 “Ata da sessão de 9 de outubro de 1919”. $6^{\circ}$ Livro de Atas das Sessões da Diretoria do Bangu A.C., 13 de fevereiro de 1919 a 15 de dezembro de 1921.

${ }^{886}$ A ÉPOCA, 25 de outubro de 1919, p. 3.
} 
Mas, os tempos da resignação do operariado frente ao paternalismo de João Ferrer já tinham ficado para trás. Schofield lidaria com um movimento operário mais coeso, que sabia se organizar, realizar greves e protestar veementemente nas páginas dos novos jornais "radicais" que surgiam: $A$ Razão e a Voz do Povo.

No início de 1920, Schofield tentaria alterar um dos pilares básicos do movimento operário de então: a conquista da jornada de oito horas. Desde o fim da greve de 1919, a Companhia tinha acordado com o Chefe de Polícia que o trabalho se iniciaria às 7 horas da manhã e terminaria às 4 horas da tarde, com direito a uma hora de almoço. Pela nova decisão do diretor-gerente, o turno continuaria começando às $7 \mathrm{~h}$, mas todos sairiam às $4 \mathrm{~h} 40$, sem que ninguém ganhasse nada a mais por isso. ${ }^{887}$ Foi o estopim para o início de uma "parede". Na segunda-feira, 5 de janeiro, os tecelões e os estampadores abandonaram o serviço rigorosamente às 4 horas e cruzaram os braços contra o aumento compulsório da jornada.

\begin{abstract}
A Bangu tem sido uma das fábricas que mais tem oprimido os seus trabalhadores. Uma nova exploração está sendo ali posta agora em prática. Foi alterado o horário de entrada e saída, de formas a anular ainda mais a concessão das oito horas. Diante dessa exploração, os operários dos teares e da estamparia resolveram reagir. Dirigiram-se à gerência e manifestaram o seu descontentamento. Não foram atendidos e, em represália, abandonaram o serviço, mantendo-se em greve pacífica. ${ }^{88}$
\end{abstract}

Foi uma greve bem curta. $\mathrm{Na}$ sexta-feira, 9 de janeiro, os operários aceitaram voltar ao trabalho, após a União mediar um acordo que estipulava a entrada às $6 \mathrm{~h} 30$ da manhã e saída às $4 \mathrm{~h}$ da tarde, descontando esta meia hora a mais no horário que deveriam fazer aos sábados. ${ }^{889} \mathrm{~A}$ grande imprensa pouco noticiou o andamento da paralisação, apenas o jornal $A$ Razão escreveu longas matérias sobre esses três dias em que a fábrica ficou fechada, todas elas culpando o diretor-gerente pelo impasse. Para este órgão, James Schofield, ao aumentar a jornada em 40 minutos, tinha decidido provocar a ira nos trabalhadores. Dessa forma, poderia demitir mais de cem funcionários grevistas, enxugando o quadro da fábrica. Nas palavras do jornalista, "ter o pretexto de atirar na miséria mais de cem operários". 890

A Razão estranhava o fato de a fábrica não ter apitado convocando os seus trabalhadores na manhã de terça-feira, 6 de janeiro, e de o diretor-gerente ter pedido grande reforço policial, incluindo a cavalaria, ao delegado Mathias Costa, do $25^{\circ}$ distrito, por conta de um boato de que os operários praticariam violências e depredações. Por decisão do Chefe de Polícia, a cavalaria sequer apareceu por Bangu e, além das 25 praças de que dispunha o distrito, foram enviados mais dez homens para controlar uma situação que, em momento algum, deixou de ser calma. Na visão do anônimo jornalista de $A$ Razão era benéfico para a Companhia paralisar o serviço por alguns dias,

\footnotetext{
${ }^{887}$ GAZETA DE NOTÍCIAS, 6 de janeiro de 1920, p. 4. A RAZÃO, 8 de janeiro de 1920, p. 4.

${ }^{888}$ A RAZÃO, 6 de janeiro de 1920, p. 2.

${ }^{889}$ JORNAL DO BRASIL, 9 de janeiro de 1920, p. 9. A RAZÃO, 9 de janeiro de 1920, p. 4.

${ }^{890}$ A RAZÃO, 7 de janeiro de 1920, p. 5.
} 
afinal, a Companhia estava "sem encomendas e dispondo de um grande estoque e fazendas" ${ }^{891}$ Um raciocínio pouco lógico, afinal se não havia quem comprasse os tecidos, para quê aumentar a jornada de trabalho?

Ao Ministro da Justiça, Alfredo Pinto, os diretores da Fábrica Bangu comunicaram que não houve necessariamente uma greve, mas uma "desinteligência entre os operários e o gerente" ${ }^{892} A$ Razão, no entanto, insitia em denunciar que tudo não passou de um "plano maquiavélico e perverso da diretoria daquela fábrica". 893

Foi a quarta e última greve pela qual passou a Fábrica Bangu naquele conturbado período de quatro anos, desde o início das reivindicações em São Paulo, em 1917, até alguns movimentos isolados em 1920, o qual os historiadores chamam de momento de "ascenso do movimento operário". 894

Nos dias que sucederam à rápida greve de 1920, o jornal $A$ Razão recebeu cartas de alguns operários da Fábrica Bangu criticando durantemente o diretor-gerente. Para Joaquim Aleixo da Silva, Schofield era o responsável direto pela diminuição da produção fabril, citando que em dezembro de 1919, foram produzidos apenas 800 mil metros de pano, quando o normal era produzir 2 milhões de tecidos por mês. "O novo e famoso administrador, em má hora trazido de Santo Aleixo, tem-se revelado um verdadeiro macaco em loja de louças e as consequências não se farão esperar", dizia. ${ }^{895}$

Outro operário, Egeu de Lima Filho, lembrou uma "crueldade" feita por Schofield que, com "um sorriso demasiadamente cínico" demitiu um senhor de 70 anos que trabalhava na Companhia desde a fundação: "Esse inglês desnaturado, ex-tecelão e hoje quase milionário, por cuja alma jamais passara um sopro de piedade humana, que revelara a baixeza de seu caráter, deu também provas de sua feroz animalidade, lançando à miséria um velho de 70 anos, que na fábrica Bangu trabalhava quase há 30 anos", escreveu. ${ }^{896}$

Dias depois, José Daniel, o “infortunado velho", procurou o jornal, contando sua versão dos fatos e inocentando de culpa o diretor-gerente, provavelmente uma estratégia para conseguir o emprego de volta:

Trabalhava há longos anos na Fábrica Bangu, sempre benquisto por todos os companheiros e chefes. Há tempos, porém, seus companheiros dirigiam-lhe gracejos que, embora sem intenção maldosa, não lhe agradavam, visto ser já um velho de quase 70 anos e não se acostumar às brincadeiras dos seus companheiros.

No dia 27 do corrente, porém, não tolerando uma brincadeira promovida por um de seus companheiros, protestou com veemência, dando lugar a que fossem informar ao sr. James

\footnotetext{
${ }^{891}$ Idem, 8 de janeiro de 1920, p. 4.

${ }^{892}$ O JORNAL, 10 de janeiro de 1920, p. 3. CORREIO DA MANHÃ, 10 de janeiro de 1920, p. 6.

${ }^{893}$ A RAZÃO, 9 de janeiro de 1920, p. 4.

${ }^{894}$ HARDMAN, Foot Francisco \& LEONARDI, Victor. História da Indústria e do Trabalho no Brasil (das origens aos anos 20) - $2^{a}$ edição. São Paulo: Editora Ática, 1991, p. 279.

${ }^{895}$ A RAZÃO, 24 de janeiro de 1920, p. 6.

${ }^{896}$ Idem, 2 de fevereiro de 1920, p. 5.
} 
Schofield ter ele reagido com um canivete contra seu companheiro. Acredita, porém, que o sr. James não o tenha despedido com intenção malévola, apenas por ter acreditado nas informações prestadas, sem sindicar da verdade, pois há já quase trinta anos que trabalha na fábrica referida, sem nunca ter usado quaisquer armas. ${ }^{897}$

O lado dúbio das opiniões dificulta uma tomada de posição sobre o real caráter de James Schofield. Outro operário, Júlio Cézar de Oliveira, remete uma carta ao mesmo jornal defendendo o gerente e revelando que os nomes que criticaram o inglês simplesmente não existiam em Bangu, tratando-se, obviamente, de pseudônimos, subterfúgio para evitar qualquer perseguição ou demissão. Para Júlio Cézar, “estas pessoas que escrevem tais cartas são despeitadas por terem os seus negócios cortados, medidas tomadas por várias razões muito justas e por este motivo fazemnos intrigar com o nosso administrador, sr. James Schofield, contra o qual nada temos a dizer". 898

Para o historiador norte-americano Stanley Stein, as críticas ao gerente britânico tinham uma justificativa: “o nacionalismo estava em ascensão no Brasil na década de 1920 e os estrangeiros recebiam muito mais críticas do que mereciam. Era fácil isolar os industriais de nacionalidade estrangeira dos brasileiros". ${ }^{899}$ Schofield, de fato, vivia em um bairro cuja predominância inglesa tinha decrescido rapidamente em apenas 14 anos. Pelo censo de 1906, existiam na região 28 homens e 9 mulheres de nacionalidade britânica, totalizando 37 moradores na freguesia de Campo Grande. ${ }^{900}$ Segundo o recenseamento de 1920, esse número caíra para 18 (12 homens e 6 mulheres). ${ }^{901}$ Este declínio da população estrangeira no Rio de Janeiro, especialmente dos britânicos, estava relacionado ao fim de um longo período de predominância inglesa no Brasil, que tinha ocorrido por causa do início da Primeira Guerra Mundial, em 1914.902

Desta forma, era possível encontrar outros trabalhadores brasileiros criticando a presença inglesa em alguns ramos, como na Estrada de Ferro Leopoldina e na companhia de eletricidade Light - uma visão completamente distinta do respeito e admiração que marcou a contratação dos técnicos têxteis britânicos na última década do século XIX. A justificativa de importar esses técnicos, com salários bastante altos, para ensinar os ofícios industriais à nascente mão-de-obra nacional já não tinha mais lógica. Naquele mesmo ano de 1920, o inglês era visto apenas como alguém que, ao amealhar os melhores salários, atrapalhava o crescimento econômico do operariado local, como bem demonstra este relato de um funcionário da Leopoldina Railway, em greve no mês de março:

\footnotetext{
${ }^{897}$ Idem, 6 de fevereiro de 1920, p. 6.

${ }^{898}$ Idem, 9 de fevereiro de 1920, p. 4.

${ }^{899}$ STEIN, Stanley J. Origens e Evolução da Indústria Têxtil no Brasil, 1850-1950. Rio de Janeiro: Editora Campos, 1979 , p. 135.

${ }^{900}$ SENRA, Nelson de Castro. O Censo de 1906 do Rio de Janeiro. Rio de Janeiro: Publicações Pereira Passos, 2012 , p. 344.

${ }^{901}$ RECENSEAMENTO DE 1920 - $4^{\circ}$ Censo geral da população do Brazil, $1^{\circ}$ da agricultura e das indústrias e $11^{\circ}$ da população da cidade do Rio de Janeiro (Districto Federal). Rio de Janeiro: Typographia da Estatística, 1926, p. 100.

902 GRAHAM, Richard. Grã-Bretanha e o início da modernização no Brasil. São Paulo: Editora Brasiliense, 1973 , p. 331.
} 
Pedimos um aumento dos nossos minguados ordenados com o qual a Companhia não concorda, por achar que somos muito bem remunerados. No entanto, há entre nós, companheiros com mais de 20 anos de serviço com o irrisório ordenado de $200 \$$, não obstante as grandes e graves responsabilidades de seu cargo, ao passo que um inglês estúpido e ignorante, desconhecendo por completo o nosso idioma, é importado dos confins de Judas, apenas aqui chegados com toda a sua estupidez e ignorância, é elevado a chefe de seção com ordenado superior a 1:000\$000, somente para dormir na seção na hora do expediente..$^{903}$

Críticas assim eram facilmente encontradas em jornais como a Voz do Povo, que era o "órgão da Federação dos Trabalhadores do Rio de Janeiro e do proletariado em geral". Na grande imprensa diária, James Schofield ainda merecia todo o crédito. Desta forma, o Jornal do Brasil destaca as festas que ocorriam todo dia 3 de janeiro - data do aniversário natalício do inglês - em frente a sua casa na Rua Ferrer. ${ }^{904}$ Nesta ocasião, ele se tornava o "chefe de serviço exemplar e cavalheiro de qualidades excepcionais", que gozava de "geral estima entre os operários". ${ }^{905}$ Em 1926, por exemplo, além dos discursos, foram recitadas poesias e canções, houve concerto de piano e encenação teatral dos meninos da Escola Evangélica de Bangu. Por fim, uma comissão de dez homens - nenhum tecelão e sim figuras das mais proeminentes do bairro, como o advogado e $1^{\circ}$ secretário do Bangu A. C., Guilherme Pastor, e os jogadores José de Mattos e Antenor Corrêa, escriturários da Companhia - entregou um retrato emoldurado com um artístico cartão de prata, onde se lia: "Homenagem dos operários da fábrica ao seu administrador-geral". 906

Fugindo das críticas e tentando se aproximar do operariado, James Schofield foi eleito presidente do Bangu A. C. em 1922, ${ }^{907}$ sendo reeleito para o cargo em 1923, ${ }^{908} \mathrm{em} \mathrm{1924,},{ }^{909}$ para o biênio $1925 / 1926^{910}$ e para o biênio $1927 / 1928 .{ }^{911}$ Ao mesmo tempo, era presidente de honra do Grêmio Carnavalesco Prazer das Morenas de Bangu e homenageado pela Sociedade Carnavalesca Flor da Lyra. As duas agremiações disputavam a atenção do inglês, promovendo festas por ocasião de seu embarque para a Inglaterra, em 1927, no mesmo domingo, e laureando-o como "verdadeiro amigo da classe proletária e o maior incentivador do recreativismo banguense".912 Para a historiadora Maria Clementina Pereira da Cunha, o fato de imigrantes "endinheirados" financiarem sociedades carnavalescas poderia funcionar como um meio de legitimação social. ${ }^{913}$

\footnotetext{
${ }^{903}$ VOZ DO POVO, 19 de março de 1920, p. 1.

${ }^{904}$ JORNAL DO BRASIL, 5 de janeiro de 1922, p. 8.

${ }^{905}$ Idem, 4 de janeiro de 1925, p. 10.

${ }^{906}$ Idem, 5 de janeiro de 1926, p. 13.

907 O MALHO, ano XXI, no 1.012, 4 de fevereiro de 1922, p. 34

908 O PAIZ, 21 de fevereiro de 1923, p. 8.

909 JORNAL DO BRASIL, 10 de abril de 1924, p. 16.

${ }^{910}$ O PAIZ, 16-17 de março de 1925, p. 8.

911 JORNAL DO BRASIL, 2 de março de 1927, p. 7.

912 Idem, 29 de maio de 1927, p. 12.

${ }^{913}$ CUNHA, Maria Clementina Pereira. Ecos da Folia - Uma História Social do Carnaval Carioca entre 1880 e 1920.

São Paulo: Companhia das Letras, 2001, p. 108.
} 


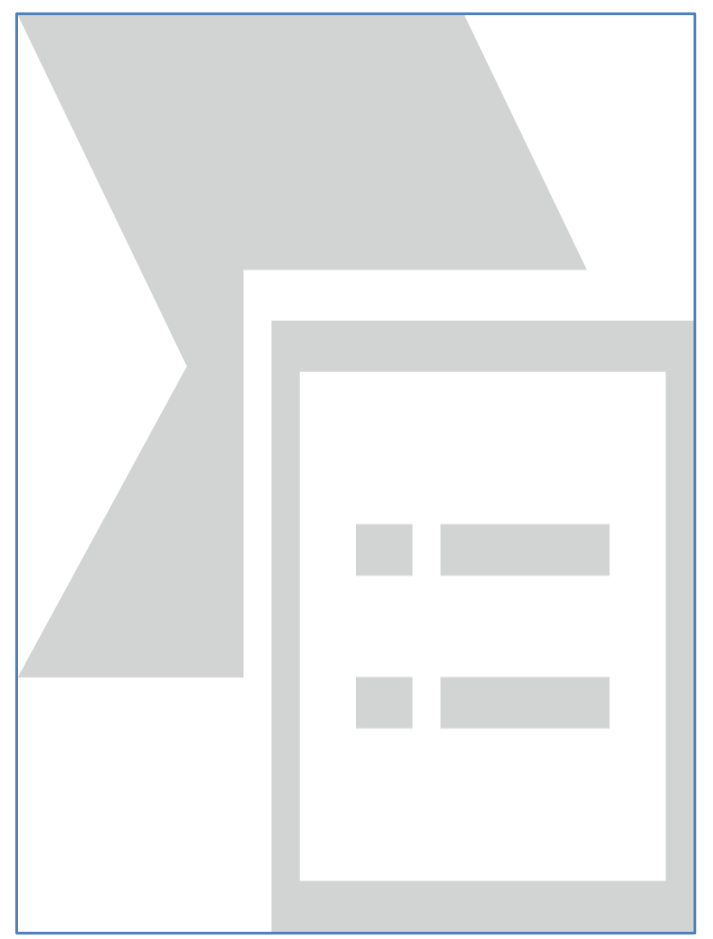

Figura 37 - O impopular diretor-gerente inglês James Schofield

Não é de admirar, então, que no Carnaval de 1923, o diretor-gerente tenha oferecido um lanche aos foliões das sociedades banguenses na varanda de sua residência, "querendo demonstrar o seu entusiasmo pelo efêmero reinado de Momo". Logo, se formou uma festa de grandes proporções em plena Rua Ferrer, onde o "o povo, estacionado em frente à vivenda do sr. Schofield, não se cansava de aplaudir o magnífico espetáculo proporcionado pelas queridas sociedades". 914 Astuto e influente, ao mesmo tempo em que abria sua casa aos foliões, Schofield também ofereceu um banquete ao prefeito do Distrito Federal, Alaor Prata, quando este visitou a Fábrica Bangu, em $1925 . .^{915}$

914 JORNAL DO BRASIL, 15 de fevereiro de 1923, p. 9.

915 Idem, 27 de agosto de 1925, p. 12. 


\subsection{1 - No fim, um homem impopular}

Durante os anos 20, a presidência da Companhia mudou de mãos: do português Manoel Alves Velloso Júnior, que ficou no cargo entre 1919 a 1922, para o médico brasileiro Manoel Guilherme da Silveira, porém, James Schofield continuou como diretor-gerente. ${ }^{916}$ Aos poucos, contando com a valiosa anistia da dívida aduaneira no governo Epitácio Pessoa ${ }^{917}$ e buscando empréstimos no mercado, ${ }^{918}$ a fábrica foi conseguindo se estabilizar economicamente, a ponto de receber elogios do presidente eleito, mas ainda não empossado, Washington Luís, quando de sua visita a Bangu, em 1926: "Uma empresa que há bem poucos anos não encontrava quem lhe emprestasse dinheiro, vale hoje mais de 40.000 contos e vende, por ano, mais de $20.000 \$$ ". 919

No entanto, a política de demitir mais do que contratar continuava vigorando durante os anos 20, cabendo a responsabilidade sobre os cortes a Schofield. Entre 1920 e 1928, o número de operários baixou de 2.409 para 2.223, um decréscimo de $8 \% .^{920}$

A fama do inglês de demitir funcionários acabou sendo eternizada para a posteridade. Em 1967, quando o escritor José Mauro de Vasconcelos - nascido em Bangu, em 1920 - escreveu o clássico livro infantil "O meu pé de laranja lima”, um relato autobiográfico de sua infância pobre no bairro, lembrou-se de Schofield (embora tenha usado um nome muito parecido com o do diretorgerente na sua obra), que seria o responsável pela penúria e por uma mudança estrutural na família de Zezé, o personagem principal da história:

\footnotetext{
- Você que quer saber tudo não desconfiou o drama que vai lá em casa. Papai está desempregado, não está? Ele faz mais de seis meses que brigou com Mister Scottfield e puseram ele na rua. Você não viu que Lalá começou a trabalhar na Fábrica? Não sabe que Mamãe vai trabalhar na cidade, no Moinho Inglês? Pois bem, seu bobo. Tudo isso é pra juntar um dinheiro e pagar o aluguel dessa nova casa. A outra, Papai já está devendo bem oito meses. Você é muito criança para saber dessas coisas tristes. ${ }^{921}$
}

A imagem de uma fábrica vilã, que explorava os trabalhadores e que tinha desempregado seu pai, impedindo assim que o menino Zezé (o próprio José Mauro de Vasconcelos quando criança) pudesse ganhar um presente no Natal, está bem ilustrada em algumas passagens do livro. Quem era o principal culpado? Evidentemente, o tal do "Mister Scottfield":

\footnotetext{
${ }^{916}$ OLIVEIRA, Márcio Piñon de. Bangu: de fábrica-fazenda e cidade-fábrica a mais uma fábrica da cidade. Instituto de Pesquisa e Planejamento Urbano e Regional (IPPUR) da Universidade Federal do Rio de Janeiro (UFRJ), 1991, p. 10.

${ }^{917}$ A multa total de 1.125:488\$860 (mil cento e vinte e cinco contos de réis) imposta pelo Conselho da Fazenda foi transformada em uma dívida de 72:000\$000 (setenta e dois contos de réis). Vide: A RAZÃO, 25 de setembro de 1920, p. 3.

918 A ÉPOCA, 24 de abril de 1919, p. 7. A Companhia tencionava obter um empréstimo de 9.000:000\$, dividido em 45 mil debêntures. O prazo para pagamento seria de 30 anos e a amortização começaria em 1921, à razão de $1 \%$ ao ano. Pelo que se lê em O PAIZ, 14 de abril de 1926, p. 2, foi obtido um empréstimo por debêntures no valor de 6.000:000\$.

919 O PAIZ, 14 de abril de 1926, p. 2; GAZETA DE NOTÍCIAS, 14 de abril de 1926, p. 10.

${ }^{920}$ OLIVEIRA (1991), p. 195.

${ }^{921}$ VASCONCELOS, José Mauro de. O meu pé de laranja lima. $3^{a}$ edição; $22^{a}$ impressão. São Paulo: Editora Melhoramentos, 2009, p. 16.
} 
Pensei na Fábrica um momento. Não gostava dela. O seu apito triste de manhã tornavase mais feio às cinco horas. A Fábrica era um dragão que todo dia comia gente e de noite vomitava o pessoal muito cansado. Não gostava ainda porque Mister Scottfield fizera aquilo com Papai... ${ }^{922}$

James Schofield, sua esposa Mary Ellen e seu filho Cecil se ausentariam de Bangu em 2 de junho de 1927. Partiram pelo paquete "Alcântara" para uma longa viagem de recreio a Inglaterra. ${ }^{923}$ Seu regresso ocorreria no dia 3 de novembro, pelo mesmo navio. ${ }^{924}$ Durante este tempo, a direção da fábrica passou para as mãos do português José Villas Boas, que tinha sido por muitos anos, o chefe da oficina de gravura.

No início de 1928, Schofield pensou que poderia voltar ao cargo de diretor-gerente. Assim que foi reconduzido ao posto, os operários decidiram paralisar o serviço. Não aceitavam o inglês de jeito nenhum. Logo na segunda-feira, 2 de janeiro, a fábrica não funcionou.

O motivo da greve foi a modificação feita na gerência pela alta administração do estabelecimento.

Desde há alguns dias que os referidos operários vieram a saber que a gerência da fábrica ia ser confiada novamente ao sr. James Schofield, que já exercera esse cargo e dele se achava afastado e substituído pelo sr. Villas Boas.

Segundo as informações que obtiveram, o sr. Schofield reassumiria as suas funções ontem e por isso, os operários entraram para o trabalho com o objetivo de o abandonarem, caso isso se confirmasse.

Por volta das 8 horas, estando a fábrica em pleno movimento, os trabalhadores tiveram notícia de que o sr. Schofield assumira a gerência e a visto disso paralisaram o serviço, abandonando o estabelecimento.

À tarde verificou-se um entendimento entre os paredistas e a alta administração da fábrica, ficando resolvida a volta ao trabalho hoje pela manhã. ${ }^{925}$

A "parede" durou apenas 24 horas e embora alguns jornais tenham dito que um dos motivos era o não cumprimento da nova Lei de Férias (decreto $n^{\circ} 4.982$, de 24 de dezembro de 1925), um operário mandou uma carta ao A Manhã dizendo não se tratar disso. "Não se trata de protesto contra a não execução da lei das férias, pois os operários sabem perfeitamente que jamais terão esse benefício, visto o governo reacionário que aí está achar-se perfeitamente bem, de mãos dadas com os magnatas da indústria”.

Coincidentemente, foi neste ano de 1928 que a fábrica passou a cumprir a Lei de Férias, pagando-as em dinheiro, embora isso não ocorresse com todos os operários. Muitos foram dispensados sem recebê-las e outros entraram com processo judicial, recebendo o dinheiro referente às férias algum tempo após a demissão. A lei só passou a ser regularmente cumprida pela fábrica a partir de $1930 .{ }^{926}$

\footnotetext{
922 Idem, ibidem, p. 61.

${ }_{923}$ O IMPARCIAL, 25 de maio de 1927, p. 9.

924 JORNAL DO BRASIL, 3 de novembro de 1927, p. 16.

${ }^{925}$ Idem, 3 de janeiro de 1928, p. 12.

${ }^{926}$ SILVA, Gracilda Alves de Azevedo. Bangu - a fábrica e o bairro: um estudo histórico, 1889-1930. Instituto de Filosofia e Ciências Sociais (IFCS) da Universidade Federal do Rio de Janeiro (UFRJ), 1985, p. 737.
} 
Schofield, que completou 72 anos exatamente no dia 3 de janeiro de 1928, data em que os jornais estamparam seu nome como motivo principal da greve, ainda teve o desgosto de ler na mesma carta do anônimo tecelão alguns impropérios. "Há alguns anos já a Companhia teve a infeliz lembrança de entregar a gestão da fábrica a um senhor, James Schofield, inglês velho, que vem desde menino trabalhando em fábricas de tecidos e de uma ignorância tão sólida que, apesar de residir há quarenta anos no Brasil, não fala o nosso idioma". ${ }^{927}$

Sem o cargo de diretor-gerente na Fábrica Bangu, Schofield devolveu a casa em que vivia à Companhia, licenciou-se da presidência do Bangu A. C. em 16 de janeiro ${ }^{928}$ e foi morar na rua Coronel Guimarães Júnior $n^{\circ} 88$, em Niterói. Praguejado pelos operários, o velho inglês estava mesmo sem sorte naquele ano. No dia 26 de março, no cruzamento da Avenida Rio Branco com a Rua da Alfândega, foi atropelado por um auto-ônibus, recebendo ferimentos e contusões generalizadas. ${ }^{929}$ Guindado ao posto de diretor-presidente interino da Nova Fábrica de Fiação e Tecidos Santo Aleixo em outubro de $1928,{ }^{930} \operatorname{logo}$ é obrigado a dar a notícia de que a Companhia passava por uma crise sem precedentes. Em maio de 1929, pediu a moratória aos credores ${ }^{931}$ e em novembro daquele mesmo ano, a falência era publicada nos principais jornais. Schofield aparece na lista de credores, com um prejuízo calculado em 383:400\$000. ${ }^{932}$

James Schofield faleceu, em Niterói, em abril de 1931, aos 75 anos, 43 dos quais vividos no Rio de Janeiro, dirigindo fábricas de tecidos. ${ }^{933}$

\footnotetext{
927 A MANHÃ, 6 de janeiro de 1928, p. 7.

928 “Ata da sessão de 16 de janeiro de 1928". $7^{\circ}$ Livro de Atas das Sessões da Diretoria do Bangu A.C., 6 de janeiro de 1922 a 13 de novembro de 1930.

${ }^{929}$ O IMPARCIAL, 27 de março de 1928, p. 14.

${ }^{930}$ DIÁRIO OFICIAL, 14 de outubro de 1928, seção 1, p. 35.

${ }^{931}$ Idem, 21 de maio de 1929, seção 1, p. 53.

932 GAZETA DE NOTÍCIAS, $1^{\circ}$ de novembro de 1929 , p. 6.

${ }^{933}$ CORREIO DA MANHÃ, 30 de abril de 1931, p. 8; “Ata da sessão de 30 de abril de 1931". $8^{\circ}$ Livro de Atas das Sessões da Diretoria do Bangu A.C., 27 de novembro de 1930 a 12 de setembro de 1935.
} 


\section{4 - Arrefecimento do movimento operário (1920)}

Entre a greve de três dias, em janeiro de 1920 e a greve de um dia, em janeiro de 1928, não há notícia de nenhum outro movimento paredista neste longo intervalo de oito anos. Não foi um arrefecimento exclusivo da Companhia Progresso Industrial do Brazil. Para a historiadora Eulália Lobo, “o número de greves se reduzia consideravelmente na década de 20. De 1922 a 1927 foi instaurado o estado de sítio que visava coibir as rebeliões militares, mas que serviu para reprimir os operários". 934 Warren Dean segue a mesma linha, acreditando que, talvez, mesmo que houvesse alguma paralisação, nem mesmo os jornais noticiavam: "Parece que o número de greves diminuiu depois de 1922, mas isso pode ser ilusório, visto que os jornais relutavam em publicar notícias de greves durante o estado de sítio, que durou até 1927". 935 Para Boris Fausto, “o movimento operário entra em uma longa depressão, impossível de ser medida apenas quantitativamente pelo decréscimo do número de greves. A contestação das camadas dominadas reflui a um nível secundário, deixando de ser fonte de alarme para os círculos dirigentes"936

Mas para tal "depressão" após três anos sucessivos de embates diretos é necessário que tenha havido algum fator que viesse esmagar os clamores do operariado. A explicação está no aumento da violência policial nos momentos de confronto aberto de classes. Para Sheldon Maram, houve um “esforço repressivo conjunto das autoridades municipais, estaduais e federais que culminou com a extinção definitiva do primeiro movimento operário brasileiro". ${ }^{937}$ Dando nomes aos responsáveis, a historiadora Ângela de Castro Gomes assinala 1920 como o ano em que a luta por melhores condições de vida e trabalho foi totalmente sufocada:

Em 1920, nos maiores combates a derrota acontecia de forma fragorosa. Para tanto, muito contribuiu a repressão montada pelo presidente Epitácio Pessoa. As novas autoridades nomeadas para o cargo de Chefe de Polícia, Geminiano da França, e para o cargo de terceiro delegado auxiliar, Nascimento Silva, receberam ordens de intensificar a luta contra o anarquismo, incumbindo-se pessoalmente desta tarefa. É bem perceptível, quando se lê o jornal Voz do Povo, o aumento da violência e da eficácia da ação policial contra os anarquistas, sobretudo a partir de meados do ano. ${ }^{938}$

Sequer foram realizadas grandes greves naquele ano de 1920. O que aumentou mesmo foi a repressão. Na Companhia América Fabril - dona de cinco fábricas no Rio de Janeiro - foi publicada uma cartilha com instruções sobre "o sistema adotado com relação ao trabalho". Logo na primeira página do folheto, um aviso, "se cumprirdes com as suas instruções, evitareis desgostos e aborrecimentos". Dentro dele, 53 motivos de punição ao operário, entre os quais inconformar-se

\footnotetext{
934 LOBO, Eulália Maria Lahmeyer. História do Rio de Janeiro. Do Capital Comercial ao Capital Industrial e Financeiro. $2^{o}$ Volume. Rio de Janeiro: IBMEC, 1978, p. 549.

935 DEAN, Warren. A industrialização de São Paulo (1880-1945). São Paulo: Difel, 1986, p. 179.

${ }^{936}$ FAUSTO, Boris. Trabalho urbano e conflito social (1890-1920). São Paulo: Difel, 1977, p. 248.

${ }^{937}$ MARAM, Sheldon Leslie. Anarquistas, imigrantes e o movimento operário brasileiro. Rio de Janeiro: Paz e Terra, 1979, p. 167.

${ }^{938}$ GOMES, Ângela de Castro. A invenção do trabalhismo. $3^{a}$ edição. Rio de Janeiro: Editora FGV, 2005, p. 135
} 
com a punição ou com a suspensão, ser "incorrigível”, ser grevista, ser agitador, frequentar a União dos Operários em Fábricas de Tecidos e até mesmo "demorar na privada" - o $37^{\circ}$ pecado capital que o trabalhador poderia cometer. ${ }^{939}$ Até mesmo no Bangu A. C., foi instituído um regimento interno, que "amordaçava" os sócios do clube. Pelos artigos $10^{\circ}$ e $11^{\circ}$, eram "proibidas frases indecentes no recinto social e quaisquer discussões em voz alta" e era "proibido aos sócios criticar os atos da diretoria, salvo quando reunidos em Assembleia Geral". ${ }^{940}$

$\mathrm{Na}$ Fábrica Bangu, as greves deixaram de existir, mas o clima estava tenso. Nas páginas do jornal A Razão eram constantes as publicações de que a direção da empresa utilizava capangas para coagir o operariado, função que 25 anos atrás era feita exclusivamente pelo Capitão Jorge Estrella. Neste novo cenário de maior número de trabalhadores e crescimento populacional do bairro, o número de "vigias" também aumentou, seriam seis: Oscar Silva, Júlio Silva, Joaquim Vianna, Celestino Barros, José Antônio de Barros e Alfredo Silva, o "China", todos ganhando salários que variavam entre $180 \$ 000$ e $300 \$ 000$ (remuneração paga ao chefe "Oscarzinho"). ${ }^{941}$

Evidente que isso geraria algum tipo de problema mais sério. No dia 5 de março de 1920, uma sexta-feira, quando saía da fábrica, o operário Manuel da Silva, brasileiro, 20 anos, teve uma discussão com Alfredo "China" após ser revistado. Manuel saía com um embrulho que continha um retalho de fazenda de dois metros. O vigia acusava o operário de haver praticado um furto; Manuel repelia a acusação, afirmando ter adquirido o retalho por compra. Exasperado, "China" sacou um revólver e disparou contra a coxa do trabalhador, fugindo em seguida, sendo acobertado pelos outros vigias para que a polícia não o capturasse. ${ }^{942}$ Pela crônica dos jornais, os policiais entraram na fábrica e ficaram "presos" lá dentro porque os vigias fecharam o portão principal, impedindo a saída deles, enquanto Alfredo "China" desaparecia. Foi preciso que dois praças que passavam pelo local, com a ajuda de populares, abrissem o portão, desarmassem os cinco vigias, para que eles, enfim, fossem presos e conduzidos à delegacia. ${ }^{943}$

"Furtar pano ou qualquer material da fábrica" era um dos motivos de punição estipulados pela cartilha da América Fabril. No caso da Companhia Progresso Industrial do Brasil, a historiadora Gracilda Alves da Silva encontrou fichas de vários funcionários, que nos anos 1930, foram sumariamente demitidos por furto de pano. ${ }^{944}$ Porém, ser alvejado por este motivo, ao que tudo indica, só ocorreu com o operário Manuel da Silva. O incidente pode ter sido o fim da utilização de

\footnotetext{
939 BASTOS, Ana Marta Rodrigues \& WEID, Elisabeth von der. O Fio da Meada - Estratégia de expansão de uma indústria têxtil - Companhia América Fabril (1878-1930). Rio de Janeiro: Fundação Casa de Rui Barbosa, 1986, pp. $192,283-284$.

940 “Ata da sessão de 12 de fevereiro de 1920”. 6 Livro de Atas das Sessões da Diretoria do Bangu A.C., 13 de fevereiro de 1919 a 15 de dezembro de 1921.

${ }^{941}$ A RAZÃO, 2 de fevereiro de 1920, p. 5.

942 Idem, 6 de março de 1920, p. 4. CORREIO DA MANHÃ, 6 de março de 1920, p. 4.

943 JORNAL DO BRASIL, 6 de março de 1920, p. 10. O PAIZ, 6 de março de 1920, p. 6.

${ }^{944}$ SILVA (1985), pp. 799, 812, 818.
} 
capangas na Companhia, já que em outras emergências, o diretor-gerente, James Schofield, passou a pedir auxílio da própria força policial.

Com o movimento operário cada vez mais sufocado, houve apenas uma grande greve em 1920, a dos trabalhadores da Estrada de Ferro Leopoldina. A partir dela, os sindicatos pensaram em estourar uma "greve geral" a partir do dia 24 de março. Na véspera, a sucursal da União dos Operários em Fábricas de Tecidos, em Bangu, se reuniu às 7 horas da noite para discutir a atitude a ser tomada pelos tecelões. ${ }^{945}$

James Schofield estava apreensivo. Na tarde do dia 24 de março foi confabular com o Chefe de Polícia, Geminiano da França, pedindo garantias de vida. Temia que, quatro dos empregados por ele despedidos naquela semana, por vingança, o agridissem ou o matessem, conforme chegou ao seu conhecimento. ${ }^{946}$ Não passava de mais um boato, mas em uma época em que as empresas ainda não tinham pensado na possibilidade de criar um departamento de recursos humanos, tal como hoje conhecemos, o ônus das demissões recaía no diretor-gerente, responsável direto pelos cortes. Schofield saiu da delegacia mais calmo. Um escrivão o acompanhou do Centro do Rio até a delegacia do $25^{\circ}$ distrito e de lá, duas praças o escoltaram e passaram a guardar sua residência na Rua Ferrer. Para o bairro, foram destacadas dez praças de infantaria da Brigada Policial para "que a Fábrica fique ao abrigo dos excessos dos grevistas e que o trabalho livre daqueles que não estiverem em solidariedade com as resoluções da classe seja também garantido". 947

Apesar dos distúrbios no Centro do Rio, as fábricas de tecidos não paralisaram suas atividades. Pelo que consta do boletim apresentado pela entidade patronal, o Centro Industrial de Fiação e Tecelagem de Algodão, apenas a Fábrica Andarahy e o Moinho Inglês paralisaram suas atividades em solidariedade aos ferroviários. Na nota divulgada, um sarcástico comentário: "Podese, pois, dizer que os maximalistas ainda não conseguiram infeccionar o operariado de algodão". ${ }^{948}$ Segundo uma verificação feita pelo Correio da Manhã, apenas as fábricas menores, como a Aurora, a Bom Pastor, a Manufatora Progresso, a Manchester e a Tijuca, aderiram à greve. ${ }^{949}$

Para alívio do inglês James Schofield a fábrica não paralisou os trabalhos. Para azar do italiano Francesco Ferrara, de 33 anos, a greve não foi deflagrada. No sábado, 27 de março, quando operava a máquina de estampar, o operário ficou com quatro dedos da mão direita esmagados. ${ }^{950}$ Era mais uma vítima dos tão corriqueiros acidentes, que permeavam o dia-a-dia de qualquer fábrica de tecidos...

\footnotetext{
945 A RAZÃO, 23 de março de 1920, p. 5.

946 JORNAL DO BRASIL, 25 de março de 1920, p. 10.

${ }_{947}$ CORREIO DA MANHÃ, 25 de março de 1920, pp. 3-4.

${ }^{948}$ Idem, 27 de março de 1920, p. 1.

${ }^{949}$ Idem, 28 de março de 1920 , p. 3.

950 JORNAL DO BRASIL, 28 de março de 1920, p. 8. O JORNAL, 28 de março de 1920, p. 4.
} 


\subsection{1 - A caça aos anarquistas}

No dia 25 de janeiro de 1920, discursando no Teatro Municipal de São Paulo, o candidato à governador, Washington Luís teria pronunciado uma frase que ficaria eternamente marcada na sua biografia: "a questão social é um caso de polícia". ${ }^{951}$ Por mais que negasse que tivesse dito isso tão claramente, atribuindo o axioma a uma "deformação violenta da verdade", 952 era dessa forma que as elites dirigentes realmente pensavam, principalmente naqueles tempos em que o movimento operário tinha ganho as ruas tanto de São Paulo, quanto do Rio de Janeiro.

No mesmo discurso, Washington Luís ainda reservaria outras surpresas ao público, ao afirmar que as recentes agitações eram obra de uma minoria de trabalhadores estrangeiros e não do operariado brasileiro. Na visão do político paulista, esses europeus eram:

Homens vindos de outros climas, habituados a outras leis, martirizados por sofrimentos por nós desconhecidos, exacerbados por males que aqui não medram, agitam-se e agitam, no momento propício, como seja o da carestia de vida, intercorrentemente produzida pela guerra europeia, a falar de reivindicações de direitos, que lhes não foram negados, a reclamar contra situações que não existem.

O problema a resolver, aqui, não direi que seja diametralmente oposto, mas é incontestavelmente diferente do europeu.

Aqui, leis liberais aboliram de direito as castas e os privilégios que, a bem examinar, de fato nunca existiram. ${ }^{953}$

Portanto, esses europeus agitadores - os anarquistas - é que tinham incutido na cabeça de trabalhadores nacionais, dóceis e ordeiros, a luta de classes. ${ }^{954}$ Estranho paradoxo bem lembrado pela historiadora Ângela de Castro Gomes: qualquer reclamação que os operários formulassem era vista como obra de "agitador estrangeiro", mas não se dizia que, na verdade, era estrangeira a maioria dos patrões que exploravam o braço produtor no país, fosse ele nacional ou não. ${ }^{955}$

A conjuntura dos anos 1919 e 1920 é especialmente reveladora dos termos do confronto que se estabeleceu entre as elites políticas, a imprensa em geral e o patronato, de um lado, e os anarquistas, de outro. O tema do nacionalismo forneceu o ideário da acusação, que combinava uma forte repressão com a consagração da imagem do anarquista como o estrangeiro indesejável. ${ }^{956}$

Desta forma, a grande imprensa comprou a ideia do combate aos anarquistas. Uma notícia publicada pelo jornal A União, após um comício na Praça da República, no Centro do Rio, transforma a polícia em uma força "moralizadora", com a qualidade de ser "paciente ao extremo" e os estrangeiros em "falsos operários":

\footnotetext{
${ }^{951}$ LOPREATO, Christina da Silva Roquette. O espírito da revolta - a greve geral anarquista de 1917. São Paulo: Annablume, 2000, p. 209.

${ }^{952}$ NETO, Lira. Getúlio - Dos anos de formação à conquista do poder (1882-1930). São Paulo: Companhia das Letras, 2012, p. 300.

${ }^{953}$ Apud. GELADO, Viviana. Poéticas da transgressão - Vanguarda e cultura popular nos anos 20 na América Latina. São Carlos: EdUFSCar, 2006, pp. 177-178.

${ }_{954}$ ADDOR, Carlos Augusto. A insurreição anarquista no Rio de Janeiro. Rio de Janeiro: Dois Pontos Editora, 1986, p. 178.

${ }^{955}$ GOMES (2005), p. 105

${ }^{956}$ Idem, p. 109.
} 
Quarta-feira passada, a Praça da República foi teatro de acontecimentos muito graves. Ali se reuniram algumas associações operárias, cujos oradores oficiais, das janelas das respectivas sedes, falavam ao povo em termos desabridos para os poderes constituídos.

A polícia, paciente em extremo, foi permitindo o desabafo dos nossos "Lenines", até ao ponto em que a manifestação do pensamento se fez com uma exortação ao povo para destruir o existente e derrubar as instituições.

Imediatamente a polícia ordenou o encerramento do comício, ao que os anarquistas se opuseram violentamente. Daí o choque, uma luta cerrada entre policia e operários, ou falsos operários, que terminou assim: alguns policiais feridos a tiro e pedradas, e o comissário Bolívar em estado grave; danificadas algumas casas comerciais; cadeiras, quadros e mesas das sedes operárias destruídos; populares contundidos; e, finalmente, 32 anarquistas presos, na maioria, italianos, portugueses e espanhóis.

A polícia, é justo que se declare, foi de uma correção admirável, só agindo numa ocasião e circunstâncias em que não podia deixar de fazer. O Chefe de Polícia, de acordo com o Dr. Alfredo Pinto, ministro da Justiça, declarou aos representantes da imprensa que está firmemente resolvido a:

1) reprimir toda e qualquer agitação de caráter anarquista;

2) fechar todas as associações em que tome parte anarquistas;

3) processar e expulsar do território nacional esses indesejáveis. ${ }^{957}$

Se em um único comício em 1919, 32 anarquistas foram presos, com o passar do tempo e o recrudescimento das ações repressivas, este número ia aumentando consideravelmente. Ao término da greve da Leopoldina Railway, deflagrada em março de 1920, muitos outros indivíduos, "alguns deles suspeitos, outros comprovadamente turbulentos" tinham sido presos, entre os quais vários espanhóis e portugueses. ${ }^{958} \mathrm{O}$ historiador Sheldon Leslie Maram, baseado em jornais da época, chegou à estimativa de 1.500 a 2.000 presos, $80 \%$ eram operários estrangeiros. ${ }^{959}$ As fotografias dos incidentes ocorridos no Centro do Rio são indícios claros de que a cidade viveu dias tumultados, com a depredação de bondes e o esperado confronto entre manifestantes e policiais.

Tratados ironicamente pela imprensa como os "apóstolos das ideias salvadoras", sempre usando "citações de arrevezados nomes russos", os anarquistas estavam sendo moldados como elementos de alta periculosidade; estrangeiros nos quais o operariado nacional já reconhecia como maléficos para liderar suas reivindicações. ${ }^{960}$ Vistos como inimigos dos trabalhadores nas páginas de qualquer jornal ou revista de grande circulação, os anarquistas fundaram seu próprio órgão de imprensa. De orientação anarcosindicalista, a Voz do Povo surgiu a 5 de fevereiro de 1920, em fins do período de ascensão do movimento operário e durou menos de um ano - a última edição saiu a 6 de dezembro - sob a sucessiva direção de Carlos Dias, Afonso Schmidt, Álvaro Palmeira e a presença ativa de Astrojildo Pereira. ${ }^{961}$ É provável que tivesse tiragem bastante limitada, ${ }^{962}$ dificuldade de circulação e distribuição e quando, enfim, chegasse às mãos de um operário, pelo

\footnotetext{
${ }^{957}$ A UNIÃO, 14 de setembro de 1919, p. 3.

958 A RUA, 30 de março de 1920, p. 2.

${ }_{959}$ MARAM, Sheldon Leslie. Anarquistas, imigrantes e o movimento operário brasileiro. Rio de Janeiro: Paz e Terra, 1979, pp. 19, 25.

960 CARETA, ano XII, no 577, 12 de julho de 1919, p. 28.

${ }^{961}$ FAUSTO (1977), p. 159.

962 Em um editoral do jornal, lê-se que "Precisamos de máquinas de linotipo para mais rapidamente desenvolvermos a nossa tiragem e podermos, assim, alargar a nossa circulação”. Vide: VOZ DO POVO, 12 de março de 1920, p. 2.
} 
preço de 100 réis, causase-lhe problemas se fosse pego pelo mestre ou contramestre lendo material tão "subversivo".

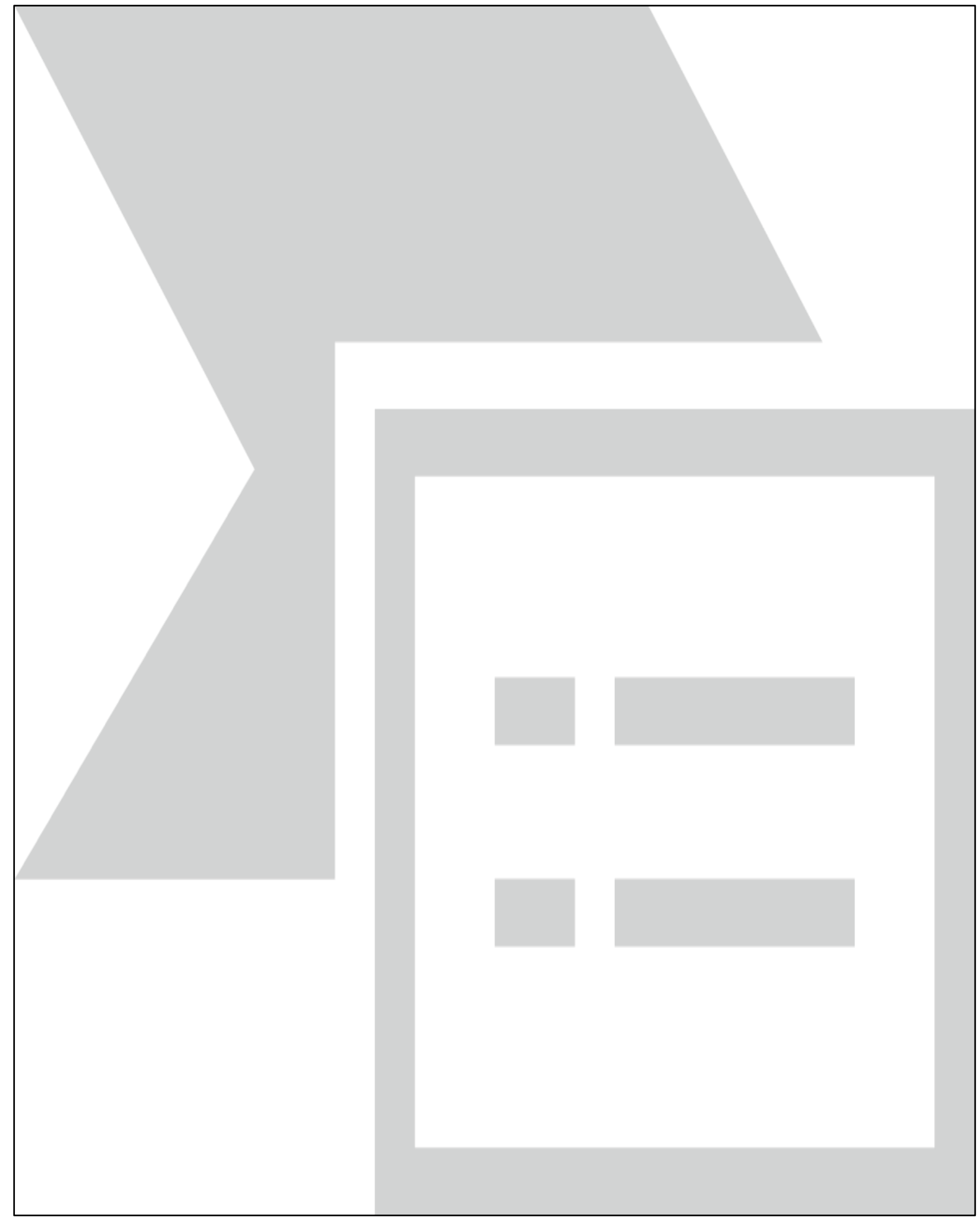

Figura 38 - Os tumultos no Centro do Rio decorrentes da greve deflagrada em março de $1920 .{ }^{963}$

${ }^{963}$ CARETA, ano XIII, n ${ }^{\circ}$ 615, 3 de abril de 1920, p. 16. 
No entanto, dos muitos jornais consultados, é o único a tomar parte na defesa das mulheres que eram assediadas dentro das fábricas de tecidos. No caso da Companhia Progresso Industrial do Brazil, por três vezes saíram notícias relatando maus tratos às operárias. Numa delas, um chefe de seção, João Augusto Couto, era denunciado por um "camarada" que teria ido até a redação contar o que viu. "A arrogância do tal mestre chega ao ponto de em um mandado qualquer, sem motivo justificável, insultar as moças, como se elas fossem suas filhas e suas escravas", dizia. ${ }^{964}$

Efêmero como todas as publicações operárias cariocas do período, o jornal se destacava por sua grande vivacidade, realizando festivais em bairros operários para arrecadar dinheiro e viabilizar sua precária continuidade. Um desses festivais ocorreu em Bangu, num sábado, 10 de abril de 1920 e, como não poderia deixar de ser, acabou servindo para dar mais uma amostra da forte repressão ao anarquismo na cidade.

O festival, com início às 8 horas da noite, teria o seguinte programa: execução da "Internacional", conferência sobre a questão social, declamação de versos, quermesse de donativos, leilão de prendas e baile até a madrugada. O jornal pedia que "os camaradas daqui da cidade" subissem no trem das 6 h50 na Central. ${ }^{965}$

Foi o que fizeram nove homens, sete portugueses e dois brasileiros, que embarcaram no trem, "visivelmente alcoolizados", portando revólveres e canivetes. Em determinado momento começaram a "perturbar a ordem, dando vivas ao anarquismo, à liberdade, à igualdade e morras ao governo". Chegando à estação de Madureira, um guarda civil que viajava no comboio pediu auxílio à polícia do $23^{\circ}$ distrito e conseguiu prender seis deles: Jerônimo Silva (português), Nicolau Gimenez (brasileiro), Paulino Gimenez (brasileiro), Jerônimo Rodrigues Pereira (português), José Teixeira (português) e João Caetano (português). Os outros três conseguiram escapar e continuaram viagem. Ao desembarcarem na estação de Bangu, Joaquim Nunes, César Fernandes e Antônio Gonçalves foram surpreendidos com a presença da polícia, que os recolheu imediatamente ao xadrez. Para a polícia, eram todos anarquistas que queriam "perturbar a ordem em Bangu". 966

Num editorial da Voz do Povo, os camaradas tinham sido enquadrados pelo "crime único de cantarem num trem para Bangu a Internacional" e se questionava: "Cresce a violência governamental. Sobe a onda da tirania, que nos ameaça submergir. Para onde se vai?". 967

A resposta parecia óbvia. A Lei de Expulsão de Estrangeiros (Decreto $\mathrm{n}^{\circ}$ 4.247, de 6 de janeiro de 1921), proposta pelo senador Adolpho Gordo e sancionada pelo presidente Epitácio Pessoa era uma versão mais dura das leis de 1907 e 1913, que já versavam sobre o assunto. Agora,

\footnotetext{
964 VOZ DO POVO, 22 de março de 1920, p. 3.

965 Idem, 10 de abril de 1920, p. 3.

966 JORNAL DO BRASIL, 11 de abril de 1920, p. 8.

${ }^{967}$ VOZ DO POVO, 14 de abril de 1920, p. 1.
} 
com a aprovação dessa lei, era possível mais rapidamente expulsar o imigrante considerado "nocivo á ordem publica ou á segurança nacional", ou seja, o anarquista. ${ }^{968}$

A grande imprensa noticiava com alegria a deportação desses homens "indesejáveis", que nos últimos anos tantas perturbações tinham causado à cidade. Havia a esperança de que, livres do elemento estrangeiro e amedrontados pela força do aparato repressivo, o operariado nacional parasse de questionar a sua condição de vida e de trabalho. Logo numa das primeiras levas pósaprovação da Lei, o Correio da Manhã exultava:

Noticiamos há dias que o Dr. Nascimento Silva iniciará os processos de expulsão contra os anarquistas presos no último movimento paredista. Os processados são indivíduos reconhecidamente perturbadores da ordem pública e na sua maioria faziam parte dos comitês de greve, isto é, eram os incumbidos da propaganda grevista.

Mais ou menos uma dezena desses indesejáveis - e quase todos os presos eram de nacionalidade estrangeira, portuguesa principalmente - vai ser remetida às suas terras de origem, não podendo mais voltar ao Brasil. Todos eles já estão devidamente "encomendados". Os processos estão prontos, as portarias de expulsão vão ser lavradas. Entre esses "indesejáveis" figuram alguns dinamiteiros envolvidos em casos recentes.

Todas as providências para a expulsão já foram dadas, inclusive na parte que tocava aos cônsules dos países de origem dos expulsos.

Ao que parece os dez anarquistas devem embarcar a bordo do "Demerara", a 5 do mês próximo, com destino a Vigo e Lisboa. As passagens pagas custarão à polícia, mais ou menos, 4:500\$. ${ }^{969}$

Analisando a listagem do Ministério da Justiça e Negócios Interiores, com dados entre 1907 e 1930, os sete portugueses "indesejáveis" que foram presos indo para Bangu não aparecem entre os extraditados. ${ }^{970}$ Cantar a "Internacional" dentro de um trem, talvez, fosse um crime menor. Porém, só em 1920, dos 75 extraditados, 42 eram lusos (56\%). ${ }^{971}$

O governo tinha conseguido: a forte repressão policial praticada contra os trabalhadores reduziu a possibilidade de greves e enfraqueceu a movimentação dos sindicatos. ${ }^{972} \mathrm{E}$, apesar do apelo lançado pela Voz do Povo, no seu último número, em 6 de dezembro de 1920: “(...) Se cruzarmos os braços, seremos esmagados. O proletariado deve lembrar-se de que não pode ficar calado nesta hora que soa, há que tudo fazer para que a nossa voz volte a se fazer ouvir. Não desanimar, pois, porque estas emergências é que retemperam as nossas energias", 973 tanto o jornal quanto o movimento operário já não tinham mais forças para lutar contra a resposta coercitiva e triunfante do Estado. ${ }^{974}$ Pelo menos, pelos próximos anos... ${ }^{975}$

\footnotetext{
968 GOMES (2005), p. 135.

${ }^{969}$ CORREIO DA MANHÃ, 26 de fevereiro de 1921, p. 3.

${ }^{970}$ Apud. MENEZES, Lená Medeiros. "Os processos de expulsão como fontes para a história da imigração portuguesa no Rio de Janeiro (1907-1930)". In: MARTINS, Ismênia de Lima \& SOUSA, Fernando. Portugueses no Brasil: migrantes em dois atos. Niterói: Muiraquitã, 2006, pp. 86- 117.

${ }^{971}$ MARAM (1979), p. 43.

972 SCHWARTZ, Lilia Moritz \& STARLING, Heloísa Murgel. Brasil: uma biografia. São Paulo: Companhia das Letras, 2015, p. 337.

${ }^{973}$ VOZ DO POVO, 6 de dezembro de 1920, p. 1.

${ }^{974}$ FAUSTO (1977), p. 211.
} 


\section{Conclusão}

Nesta dissertação, restringindo o espaço geográfico à maior fábrica do Rio de Janeiro em número de operários, teares e produção, e restringindo também o espaço cronológico ao período de trinta anos, conseguimos analisar o movimento operário sob a lente da micro-história. Percebemos ações específicas, como a personificação da coação aos trabalhadores mediante a existência de um Capitão (estratégia utilizada na última década do século XIX para controlar os tecelões tal como se fazia anteriormente com os escravos). A repressão não gerou os resultados esperados. Ao contrário, aumentaram os conflitos internos e a insatisfação, principalmente, dos trabalhadores brasileiros. A partir de 1903, com a nomeação de um novo diretor-gerente, a estratégia mudou, passando a ser mais paternalista, oferecendo diversas benfeitorias ao bairro, que deveriam ser utilizadas pelos tecelões, como igreja, campo de futebol, teatro. Incutiu-se, então, na mentalidade do operário que, mesmo que as condições de trabalho fossem tão difíceis como em outras Companhias, era melhor viver em Bangu e obedecer as normas vigentes daquela localidade.

Durante nossa análise, também percebemos ações mais amplas, que ocorriam em diversas fábricas do Rio de Janeiro simultaneamente, como a "importação" de tecelões britânicos que se transformaram em mestres têxteis quando chegaram ao Brasil e a valorização do trabalhador imigrante em detrimento ao nacional. Essas conclusões a historiografia do período já realçava. $\mathrm{O}$ que faltava era identificar nomes e trajetórias pessoais.

Com a análise micro-histórica obtivemos exemplos reais, encontrando personagens que vão além de um modelo padrão que serviria a todas as fábricas do eixo Rio-São Paulo. Os homens que viveram em Bangu deixaram seus vestígios para que, mediante uma busca incessante nas fontes, pudéssemos reconstruir este período bastante conturbado em que a palavra "operário" passou a criar as bases de uma nova identidade de classe. Suas ações, mesmo que analisadas isoladamente, estavam plenamente inseridas no contexto da industrialização, prioritariamente têxtil, que surgia no país. Graças às várias notícias de jornais olhamos de forma microscópica para esses trabalhadores. Vimos como os operários se relacionavam entre si, como vivenciavam as experiências de um novo sistema de trabalho e como se comportavam na hora de reivindicarem seus direitos. $\mathrm{O}$ comportamento variava em cada situação e não há como classificar todos os operários da Fábrica Bangu simplesmente como engajados ou como acomodados. Certamente, no entanto, eram resilientes, enfrentando constantemente as adversidades, apesar das muitas derrotas conhecidas nas greves.

975 “Com a subida de Washington Luís ao governo, sucedendo a Artur Bernardes, o estado de sítio é suspenso e o país vive dias de liberdade. Vide: CARONE, Edgard. Classes sociais e movimento operário. São Paulo: Editora Ática, 1989, p. 238. 
Para a elite dirigente, era melhor que, em vez de eles serem resilientes, eles fossem pacatos. Um diálogo rápido, captado pelo repórter do Jornal do Brasil, dá uma pequena amostra do que estava em jogo no início da industrialização no país e que permeia boa parte da discussão desta dissertação:

Em setembro de 1904, o arcebispo Dom Joaquim Arcoverde visitou a vila de Bangu. Ao se despedir, na estação de trem, falou ao diretor-gerente da Companhia, João Ferrer:

- O senhor tem bons operários.

O espanhol concordou:

- É que nos corações generosos desses homens do trabalho cintila a luz da fé. ${ }^{976}$

O que era ser um bom operário? O conceito de "bons operários" ia além da produtividade que eles poderiam obter. Era, principalmente, ser um elemento ordeiro, que aceitasse o ritmo de trabalho imposto, que visse a fábrica como uma dádiva, afinal era dali que ele tiraria o seu sustento e o de toda sua família. O bom operário imaginado e desejado era dócil e resignado.

Essa foi a questão que pontuou os primeiros anos após a inauguração da Fábrica Bangu. Os imigrantes foram trazidos justamente para serem assim. Aos olhos do empregador, eram famílias inteiras acostumadas à nova rotina urbana, brancos, civilizados, disciplinados, laboriosos e que precisavam tanto do emprego quanto os nacionais, levando evidente vantagem nessa luta pelos cargos. Os brasileiros, mesmo que não estivessem afeiçoados às máquinas, foram contratados como a mão-de-obra mais barata possível, um elemento ainda não adaptado à moderna indústria. As fotografias dos primeiros operários mostram uma grande quantidade de mulheres e crianças, que apesar de ser assalariados, certamente viviam na mais completa pobreza.

A dissertação mostrou a divisão étnica-profissional que pontuou a indústria têxtil no seu período inicial. O inglês era o mestre da seção, visto com um expert, justificando cada Libra paga a ele. Os portugueses e os italianos ganhavam espaço e chegavam a contramestres. Ao brasileiro, sem especialização, analfabeto, restava ser o "chão da fábrica", como se diz. As "castas" do trabalho estavam formada. No modelo ideal, não haveria disputas por cargos, cada um entenderia seu lugar.

Por pensarem assim, os diretores foram surpreendidos com a primeira greve, em 1894, quando os trabalhadores brasileiros reivindicavam questões básicas relativas somente àquela fábrica, incluindo a redução do alto preço dos bens de consumo do armazém. Não se comunicavam ainda com os operários de outras Companhias, mas já sabiam que poderiam barganhar alguma vantagem se paralisassem o serviço. Não era esse o trabalhador ideal que a fábrica esperava ter encontrado nas famílias pobres da região.

Seguiram-se as reações do patronado. A direção compreendeu que não era possível que aquela massa de operários vivesse livremente pelo seu perímetro. Era preciso que houvesse alguma

\footnotetext{
976 JORNAL DO BRASIL, 23 de setembro de 1904, p. 5.
} 
forma de reprimir atitudes destoantes do padrão estipulado. Surgiu, assim, o cargo de "administrador dos assuntos externos", entregue a dedo ao ex-delegado Jorge Estrella. O capitão representaria o braço forte da empresa sobre os trabalhadores, coagindo, amendrontando, expulsando da vila quem ousasse agir de forma distinta do que era esperado.

Por mais que tentasse controlar seu espaço geográfico, a Companhia sabia que, dia a dia, chegavam novos moradores na região. Poucos tinham acesso às casinhas da vila operária, mas muitos passaram a viver nas redondezas, num local chamado "Marco Seis". Desavenças entre pessoas de nacionalidades diferentes se tornaram normais. Um brasileiro desempregado poderia se achar vingado se xingasse um contramestre português ("ô Gaspar, a tua vaca partiu os chifres, antes fossem os do dono da vaca!'”) e acabaria assassinado por esta ofensa, afinal, o lusitano fazia questão de andar armado em um lugar que considerava inóspito. $\mathrm{O}$ estremecimento das relações chegou ao ápice quando um italiano assassinou um negro brasileiro. Poucos choraram a morte de Emygdio; os operários aproveitaram a situação para decretar uma "parede", que visava a expulsão de todos os italianos de Bangu. Se acabasse a colônia, talvez os nacionais pudessem ascender e ocupar suas vagas. Todas as estratégias adotadas pelos grevistas nestes primeiros anos falharam.

Nesta primeira fase, até 1901, as greves eram em prol de alguma causa exclusiva daquela Companhia. O sentimento de pertencer a uma classe operária, ao lado de milhares de "infelizes" de outros bairros, não existia. No caso específico da Bangu, isso explica porque eles tenham relutado tanto em participar do movimento de 1903. Quando foi deflagrada uma "greve geral" na cidade, os banguenses pareciam não ter o que reivindicar, não sabiam se aderiam ou não. A direção da fábrica decidiu por eles, fechando o estabelecimento por alguns dias para evitar tumultos.

É visível a mudança que ocorre na fábrica a partir daquele ano com a nomeação de João Ferrer ao cargo de diretor-gerente. Tratava-se de um homem de ideias avançadas, de estilo paternalista, que diferentemente dos portugueses que o antecederam e dos ingleses que o substituíram, postou-se como um "prefeito" daquela localidade. Na visão do espanhol era preciso aparelhar o bairro, municiá-lo das mais diversas benfeitorias, dotar a vila operária de espaços de convivência, lazer e educação. Sob seu comando, Bangu - que não tinha nada além da fábrica e das casinhas - viveu dias de progresso, com a inauguração da escola, do campo de futebol, do teatro, da igreja. Viu obras importantes como o encanamento, trazendo água desde o Rio da Prata até a fábrica, a chegada da eletricidade, que propiciou trocar o maquinismo a vapor e a abertura de novas ruas. Ferrer também estreitou os laços com a imprensa e trouxe homens públicos ao seu "quintal" para mostrar os avanços que tinha feito ali. Na comitiva vinham os repórteres, todos recepcionados com a maior pompa, banda de música, banquete, ruas enfeitadas. Passar um dia em Bangu era, para os articulistas da Belle Époque, uma maravilha. Tinham descoberto o paraíso laboral, onde era 
possível manter operários ordeiros e felizes graças a um diretor-gerente generoso. Quando voltavam para as redações, publicavam "pérolas" como esta:

Toda a vez que via passar um operário para a oficina, onde tinha de demorar-se oito horas trabalhando para o engrandecimento do nosso meio artístico e industrial, aumentava em meu coração uma adoração sincera pela classe que ele representa e perguntava a mim mesmo se poderia haver classe mais sacrificada, mais digna de lástima do que a operária.

Que engano, felizmente, o meu!

Há um lugar, que bem se poderia chamar "paraíso", onde o operário é feliz, inteiramente feliz, porque tem tudo quanto deseja: o pão, a tranquilidade, a educação e diversões de todo o gênero, desde o violento football até um belíssimo teatro, onde pode ser representada qualquer peça de grande movimento.

É um lugar encantador, que não fica em país, que para visitá-lo seja preciso gastar dinheiro às mancheias: quarenta minutos! Parece um sonho: quarenta minutos - e podereis envolver com o vosso olhar carinhoso, o núcleo operário de Bangu, a cuja entrada do belíssimo e florido jardim bem se poderia ler: "Paraíso da vida".

Ali não há política, não há ódios, não há perturbações de espécie alguma.

À tarde, quando terminados os labores, há risos de felicidade, de toda aquela grande e nobre família, unida na aldeia tranquila, pelos mesmos sentimentos de fraternidade e pela mesma aspiração de paz e de trabalho. ${ }^{977}$

Fora do mundo "cor de rosa" idealizado pela grande imprensa, o operariado de Bangu tinha os mesmos problemas de outros bairros fabris: a jornada exteunante de 10 horas em salas mal ventiladas, máquinas perigosas que requeriam o máximo de atenção, o rigor de um contramestre impedindo as conversas e, claro, a remuneração parca. Os anarcosindicalistas percebiam isso facilmente. Em visita à vila em 1909, admiravam-se do trabalhador não perceber quão precária era sua condição de vida: "Parece que não há ali um só operário que conheça bem a obra dos senhores de Bangu. Vimos companheiros que proclamavam a benemerência dos exploradores". ${ }^{978}$ A pequena imprensa operária, porém, não tinha o alcance dos jornais diários. A impressão que ficava para um leitor que vivia em outro ponto da cidade era de que a Fábrica Bangu oferecia tudo para os seus trabalhadores. Mesma impressão tem um leitor contemporâneo quando vê o livro do centenário da Companhia, escrito pela historiadora Gracilda Alves e publicado em 1989: parecia que ali tudo funcionava perfeitamente. Essa é a memória que se desejou perpetuar da fábrica e entrou no imaginário dos próprios moradores do bairro.

Para um operário da primeira década do século XX, por mais que vivesse a dualidade entre a exploração e a proteção, é provável que se sentisse amparado por poder alugar uma casinha da vila para abrigar sua família e ver o filho estudando na Escola Rodrigues Alves. Se suas perspectivas não fossem maiores, talvez se visse numa posição privilegiada em relação a um sem número de brasileiros desempregados ou aos que não tivessem aprendido um ofício fabril, tal como ele.

A maioria das pessoas que vivia ali não tinha nascido no bairro, relativamente novo, surgido a partir da construção da fábrica, em 1889. Elas vinham de outros estados ou até mesmo de outros países. Por isso, é até surpreendente a identificação que tiveram com o clube da localidade, 
defendendo suas cores e apoiando os jogadores-operários que faziam a diversão do povo nos finais de semana. Visto por historiadores marxistas como uma espécie de dominação e controle do lazer do trabalhador, concluímos que o futebol não foi implantado ali com este propósito, isso seria o mesmo que, nos dias de hoje, acusar uma emissora de TV de alienar seus telespectadores simplesmente por transmitir partidas de futebol, por exemplo.

Nesta dissertação, demonstramos que as ideias imputadas ao Bangu A. C., muitas das vezes, são errôneas. Não se tratava de mais um método disciplinador - a Companhia admitia jogadores rudes dentro de campo e não coibia apedrejamentos à torcida adversária. O futebol, instituído pelos ingleses para seu próprio lazer e deleite, foi rapidamente apropriado pelos brasileiros, que logo formavam uma das torcidas mais bairristas de que se tem notícia na cidade.

Um cronista de $O$ Paiz, em visita ao bairro, percebeu que o esporte, mais do que dominação, propiciava uma "válvula de escape" no domingo do trabalhador:

Aos domingos a estação do Bangu, sobre ser o sítio aprazível e pitoresco de sempre, oferece o aspecto de um arraial em festa. Ali há um vasto campo para o football e outro para cricket. Os sportmen são destros e hábeis. Além disso, os operários mantêm diversas sociedades recreativas, de música e dança.

As ruas enchem-se da multidão em trajes domingueiros.

Da cidade também vai muita gente para assistir às partidas disputadíssimas de football. Assim corre o dia alegremente.

Só à noite, quando a lembrança do trabalho da segunda-feira sugere a necessidade de dormir para acordar cedo, é que as ruas se despovoam e a grande vila operária reentra na monotonia de sua vida normal. ${ }^{979}$

O problema não era o lazer, mesmo que ele fosse estipulado pela Companhia. O problema era a segunda-feira, o recomeço da longa jornada. Nem todos os dias corriam calmos para os milhares de operários. Na opinião do escritor José Mauro de Vasconcelos, “a fábrica era um dragão que todo dia comia gente e de noite vomitava o pessoal muito cansado". ${ }^{980}$ Depois do frenesi da Belle Époque, onde tudo era sorridente e onde não se encontram notícias de vítimas das máquinas, propositalmente ocultada de suas páginas; a mesma imprensa, na década de 1910, passou a publicar, corriqueiramente, notas sobre acidentes de trabalho. Particularmente, o dia 10 de agosto de 1916 deve ter sido permeado por uma atmosfera terrível para todos os operários, especialmente para a operária Maria de Sá, mãe do menino Waldemar, de apenas oito anos:

Horrível desastre o que ocorreu ontem na Fábrica de Tecidos do Bangu.

Ontem, quando o infeliz menino esperava o elevador em que subiria ao pavimento em que trabalha sua mãe, distraiu-se, sendo apanhado pelo elevador que descia, ficou imprensado entre as grades, falecendo instantaneamente.

O horrível desastre causou geral consternação entre os operários e a infeliz Maria de Sá, ao deparar com seu filho morto, foi presa de uma crise de nervos. ${ }^{981}$

\footnotetext{
${ }^{979}$ O PAIZ, 16 de setembro de 1906, p. 8.

980 VASCONCELOS, José Mauro de. O meu pé de laranja lima. $3^{a}$ edição; $22^{a}$ impressão. São Paulo: Editora Melhoramentos, 2009, p. 61.

${ }^{981}$ O PAIZ, 11 de junho de 1916, p. 6.
} 
Morrer dentro da fábrica era uma tragédia possível, principalmente para os menores. A lei de 1891 que estipulava regras para o emprego de crianças na indústria era descumprida. Por muitos anos, os acidentes de trabalho eram imputados na conta da própria vítima. Só a partir de 1919 é que foi aprovada pelo Congresso uma lei que obrigava o empregador a indenizar o acidentado, mesmo assim tratava-se de uma lei feita para acalmar o movimento operário que se agitava em greves sucessivas. Antes era ainda pior: por exemplo, os operários Rômulo Labonde, de 17 anos, e Miguel Rangel, de 50 anos, que ficaram com as mãos esmagadas pela engrenagem em dois acidentes distintos em 1917, nada receberiam. ${ }^{982}$ Não há como falar em um pouco mais de sorte. Porém, em 1920, Bernardino de Macedo, Anthero Queiroz e Custódio Pires, atingidos por uma polia de uma máquina de fiar, ao menos, teriam direito a alguma indenização da Companhia pelo triplo acidente. ${ }^{983}$ Mesmo assim, ainda vivia-se numa época em que o regulamento interno de cada fábrica mandava mais na vida do operário do que o Estado, omisso, que não interferia nas relações de um empreendimento particular.

A eclosão da Primeira Guerra Mundial, na Europa, veio alterar a rotina industrial até mesmo aqui no Brasil. A crônica "carestia" que afligia o país era agravada pelas consequências da guerra. Falava até pão. A Argentina deixara de vender ao Brasil o trigo que, em condições mais vantajosas, agora exportava para os países litigantes. Havia também o caso de indústrias brasileiras que, a exemplo das argentinas, desviaram para a Europa produtos por lá escassos, gêneros alimentícios especialmente, provocando o desabastecimento interno. Como resultado o preço por aqui duplicou, triplicou, quadruplicou. O preço do feijão, por exemplo, subiu 160\% entre julho de 1916 e julho de $1917 .{ }^{984}$ O operariado podia reclamar, com razão, que o custo de vida em 1916 era $16 \%$ mais alto que em 1914, enquanto os salários tinham subido apenas $1 \%$ em dois anos. ${ }^{985}$

A carestia de vida foi o motor que impulsionou a ação dos sindicatos e movimentos, espotâneos ou não, que deflagaram as "greves gerais" de 1917, 1918 e 1919. Em Bangu, o operariado foi bastante modesto e temeroso em se opor ao patronato. Normalmente, entrava nas greves depois das outras fábricas e regressava ao trabalho antes. $\mathrm{O}$ medo maior era de perder o emprego, ser substituído por outro, afinal o que não faltava era mão-de-obra barata disponível. Em seguida, vinha o medo da repressão policial. A resposta dos industriais era buscar apoio no Chefe de Polícia. Era ele quem negociava com os grevistas. A repressão era violenta, principalmente no centro do Rio, onde os operários se aglomeravam em meetings.

\footnotetext{
982 GAZETA DE NOTÍCIAS, 18 de abril de 1917, p. 6. A RAZÃO, 19 de julho de 1917, p. 4.

983 A NOITE, 25 de maio de 1920, p. 4.

984 TOLEDO, Roberto Pompeu de. A capital da vertigem - Uma história de São Paulo de 1900 a 1954. Rio de Janeiro: Objetiva, 2015, pp. 165-166.

${ }_{985}$ MARAM, Sheldon Leslie. Anarquistas, imigrantes e o movimento operário brasileiro. Rio de Janeiro: Paz e Terra, 1979, pp. 120-121.
} 
Em 1918, quando os anarquistas tentam se aproveitar do movimento operário para impor uma "greve insurrecional”, tudo ficou ainda pior, com maior número de prisões. Qualquer atividade que gerasse suspeita era coibida pela polícia. Na ocasião, tudo o que os trabalhadores têxteis queriam era uma reparação pelos dias em que ficaram em casa, afastados do serviço, porque estavam quase todos infectados pela gripe espanhola. As ideias anarquistas, inflamadas pelo sucesso da Revolução Russa, por mais que fossem fartamente propagadas nas vilas operárias, não tinham penetração entre a classe. O levante de 18 de novembro foi um fiasco e só serviu para alertar os patrões que o operariado nacional corria risco de ser contaminado por ideias vindas de fora, como o "maximalismo" e o "bolchevismo"

Dentre as muitas derrotas nas greves anteriores, pelo menos, em 1919, os operários dos dois grandes centros urbanos - Rio de Janeiro e São Paulo - puderam obter o direito à jornada de 8 horas e um relativo aumento salarial que compensaria trabalhar duas horas a menos, mesmo àqueles que ganhassem por hora ou empreitada. No caso específico da Fábrica Bangu, foi preciso cruzar os braços por longas três semanas para que, enfim, um acordo fosse firmado pelo Centro dos Industriais. Em termos gerais, o arrefecimento do movimento ocorre a partir de 1920, asfixiado por uma política estatal de repressão aos sindicatos e de caça aos anarquistas, especialmente os estrangeiros. O operariado, que tinha despertado de um longo período de letargia em 1917, teve que voltar a aceitar sua situação de vulnerabilidade sem poder realizar novas greves no período presidencial de Epitácio Pessoa e Arthur Bernardes.

No caso da Fábrica Bangu, apesar de os trabalhadores terem muitas críticas ao novo diretorgerente - o inglês James Schofield tinha fama de homem severo, que demitia qualquer um pela mínima falta -, os operários não tiveram sequer como lançar mão da paralisação dos serviços, ficando entre janeiro de 1920 e janeiro de 1928 sem realizarem uma única greve. Certamente não faltava insatisfação, como mostram algumas cartas publicadas por jornais trabalhistas, como a $V o z$ do Povo, mas o movimento operário estava desarticulado e bastante vigiado durante a década de 1920. 


\section{Bibliografia}

\section{1 - Jornais e Revistas}

A Época, 1912-1915; 1917-1919

A Estrella, 1884

A Folha Nova, 1883

A Imprensa, 1901; 1909

A Manhã, 1928

A Noite, 1917-1920; 1945

A Notícia, 1896

A Razão, 1917; 1919-1920

A Rua, 1920

A União, 1919

A Voz do Trabalhador, 1909; 1914

Archivo Vermelho - Revista Policial Illustrada, 1918

As Ocurrências da Semana, 1895

Careta, 1917; 1919-1920

Cidade do Rio, 1896; 1899

Correio da Manhã, 1901; 1903-1904; 1907-1909; 1917-1921; 1923-1924; 1931-1932; 1958

Correio do Bangu, 1908

Correio Paulistano, 1908

Diário de Notícias, 1891; 1893; 1930-1931; 1954-1955; 1958

Diário do Commercio, 1891

Diário Oficial, 1892-1894; 1897-1898; 1901; 1904-1906; 1910; 1918-1919; 1922-1923; 1928; $1930 ; 1932 ; 1934-1935 ; 1939$

Fon-Fon, 1919

Gazeta da Tarde, 1891; 1895-1896

Gazeta de Notícias, 1888; 1890-1896; 1898-1899; 1901; 1903; 1906-1907; 1909-1911; 1916-1920; $1923 ; 1929$

Gazeta de Petrópolis, 1896

Jornal do Brasil, 1891-1893; 1896-1897; 1899-1906; 1910; 1912-1913; 1915; 1917-1918; 1920; 1922-1929; 1931; 1934-1935; 1937

Jornal do Commercio, 1892-1893; 1895; 1904; 1906

Lanterna, 1917 
Novidades, 1890

O Amigo do Povo, 1904

O Apóstolo, 1895

O Estado de São Paulo, 1910; 1919; 1966

O Globo, 1938; 1948; 1988-1989; 2014

O Imparcial, 1917-1919; 1924; 1927-1928

O Jornal, 1920; 1925; 1932

O Malho, 1922

O Paiz, 1891; 1893-1896; 1898-1900; 1903; 1906-1910; 1913; 1916-1921; 1923-1926; 1934

O Teтpo, 1891-1892

Revista da Semana, 1901; 1905-1906; 1910

Sports, 1915

The Brazilian Review, 1906

The Rio News, 1891-1893; 1895; 1898-1899

Voz do Povo, 1920

\section{2 - Manuscritos}

\section{1 - Livros de atas}

$1^{\circ}$ livro de atas das reuniões do Bangu A. C.: 17 de abril de 1904 a 7 de fevereiro de 1905 $2^{\circ}$ livro de atas das reuniões do Bangu A. C.: 24 de fevereiro de 1905 a 23 de julho de 1908 $3^{\circ}$ livro de atas das reuniões do Bangu A. C.: 28 de fevereiro de 1909 a 12 de janeiro de 1915 $4^{\circ}$ livro de atas das reuniões do Bangu A. C.: 21 de janeiro de 1915 a 7 de setembro de 1917 $5^{\circ}$ livro de atas das reuniões do Bangu A. C.: 14 de setembro de 1917 a 29 de janeiro de 1919 $6^{\circ}$ livro de atas das reuniões do Bangu A. C.: 13 de fevereiro de 1919 a 15 de dezembro de 1921 $7^{\circ}$ livro de atas das reuniões do Bangu A. C.: 6 de janeiro de 1922 a 13 de novembro de 1930 $8^{\circ}$ livro de atas das reuniões do Bangu A. C.: 27 de novembro de 1930 a 12 de setembro de 1935

\section{2 - Documentos pessoais}

Carteira profissional de James Stirling, emitida em 21 de setembro de 1934.

Census of Scotland 1881 - página relativa à família Donohoe, na vila de Busby, em Means.

Census of Scotland 1891 - página relative à família Donohoe, na vila de Busby, em Means.

Census of England and Wales 1911 - página relativa à família Stirling 
Certidão de casamento de Thomas Donohoe e Elizabeth Montagne, em 6 de junho de 1890.

Certidão de casamento de Andrew Procter e Mary Johnston Cameron, em 22 de janeiro de 1898.

Certidão de casamento de James Hartley e Margaret Montagne, em 29 de outubro de 1898.

Certidão de casamento de James Stirling e Doris Procter, em 22 de janeiro de 1923.

Certidão de nascimento de Thomas Donohoe, em 25 de janeiro de 1863, em Means, Escócia.

Certidão de nascimento de John Donohoe, em 30 de junho de 1891, em Busby, Escócia.

Certidão de nascimento de Patrick Donohoe, em 20 de fevereiro de 1894, em Busby, Escócia.

Certidão de nascimento de John Hartley, em 20 de março de 1901, na freguesia de Campo Grande.

Certidão de nascimento de Sybil Hartley, em 11 de janeiro de 1906, na freguesia de Campo Grande.

Certidão de óbito de Patrick Donohoe, em 28 de abril de 1948, na freguesia de Madureira.

Certidão de óbito de Angelina Pinto, em 23 de novembro de 1965, na freguesia de Inhaúma.

Certidão de óbito de Hermínio Donohoe, em 30 de abril de 1969, na freguesia de Madureira.

Certidão de óbito de João Pinto Donohoe, em 4 de janeiro de 1979, na freguesia de Madureira.

Salvo-conduto concedido à Sarah Hanna Hellowell, em 8 de agosto de 1894, em Londres.

Título eleitoral de João Pinto Donohoe (2a via), expedido em 22 de outubro de 1966.

\section{3 - Relação de navios desembarcados no porto do Rio de Janeiro}

Relação de passageiros do vapor Potosi (procedente de Liverpool), em 6 de julho de 1888.

Relação de passageiros do vapor Britannia (procedente de Liverpool), em 25 de março de 1891.

Relação de passageiros do vapor Liguria (procedente de Liverpool), em 4 de setembro de 1894.

Relação de passageiros do vapor Oravia (procedente de Liverpool), em 26 de outubro de 1897.

Relação de passageiros do vapor Ibéria (procedente de Liverpool), em 9 de novembro de 1898.

Relação de passageiros do vapor Atlantique (procedente de La Plata), em 12 de março de 1901.

Relação de passageiros do vapor Oravia (procedente de Liverpool), em 17 de julho de 1901.

Relação de passageiros do vapor Victoria (procedente de Liverpool), em 2 de novembro de 1904.

\section{3 - Livros, artigos e trabalhos acadêmicos}

ABREU, Maurício. Evolução Urbana do Rio de Janeiro. $4^{a}$ edição. Rio de Janeiro: Instituto Pereira Passos, 2010.

ADDOR, Carlos Augusto. A insurreição anarquista no Rio de Janeiro. Rio de Janeiro: Dois Pontos Editora, 1986.

ALENCASTRO, Luiz Felipe de (org.). História da vida privada no Brasil-Império: a corte e a modernidade nacional. São Paulo: Companhia das Letras, 2010. 
ALMEIDA, Paulo Roberto de. Formação da diplomacia econômica no Brasil - as relações econômicas internacionais no Império. $2^{a}$ edição. São Paulo: Editora Senac, 2001.

ANTUNES, Fátima. “O futebol nas fábricas” In: Revista USP nº 22 - Dossiê Futebol. São Paulo, 1994.

ARAÚJO, Marco Antônio de. Administração de produção e operações - uma abordagem prática. Rio de Janeiro: Brasport, 2009

ASSAF, Roberto. Bangu: bairro operário, estação do futebol e do samba. Rio de Janeiro: Relume Dumará, 2001.

\& MARTINS, Clóvis. História dos Campeonatos Cariocas de Futebol (1906-2010). Rio de Janeiro: Maquinária, 2010.

ÁVILA, Fernando Bastos de. Antes de Marx. As raízes do humanismo cristão: textos e comentários. Rio de Janeiro: Ed. PUC-Rio, 2002.

BARBOSA, Ruy. A questão social e política no Brasil. Rio de Janeiro: Centro Edelstein de Pesquisas Sociais, 2010.

BASBAUM, Leôncio. História sincera da República - De 1889 a 1930. $2^{a}$ edição. São Paulo: Edições L. B., 1962.

BASTOS, Ana Maria Rodrigues \& WEID, Elisabeth Von Der. O fio da meada: estratégia de expansão de uma indústria têxtil. Rio de Janeiro: Fundação Casa de Rui Barbosa, 1986.

BATALHA, Cláudio. "Limites da liberdade: trabalhadores, relações de trabalho e cidadania durante a Primeira República” in: FURTADO, Júnia Ferreira \& LIBBY, Douglas Cole (orgs.). Trabalho livre, trabalho escravo - Brasil e Europa, séculos XVIII e XIX. São Paulo: Editora Annablume, 2006.

; FORTES, Alexandre \& SILVA, Fernando Teixeira da (orgs.). Culturas de classe - identidade e diversidade na formação do operariado. Campinas: Editora da Unicamp, 2004.

BEIGUELMAN, Paula. A formação do povo no complexo cafeeiro: aspectos políticos. $3^{a}$ edição. São Paulo: EdUSP, 2005.

Os companheiros de São Paulo. São Paulo: Edições Símbolo, 1977.

BERTONHA, João Fábio. Os italianos. $2^{a}$ edição. São Paulo: Contexto, 2005.

BIONDI, Luigi. “A greve geral de 1917 em São Paulo e a imigração italiana: novas perspectivas". In: HALL, Michael McDonald (org.). Cadernos Arquivo Edgard Leuenroth Imigração, volume 15, $n^{\circ}$ 27. Campinas: UNICAMP/IFCH, 2009.

BUADES, Josep. A guerra civil espanhola - O palco que serviu de ensaio para a Segunda Guerra Mundial. São Paulo: Editora Contexto, 2013.

BUESCU, Mircea. Evolução econômica do Brasil. Rio de Janeiro: APEC Editora, 1977. 
BURKE, Peter. A Escrita da História: novas perspectivas. São Paulo: Editora Unesp, 1992.

CALDAS, Waldenyr. O Pontapé Inicial - Memória do Futebol Brasileiro. São Paulo: IBRASA, 1990.

CARMONA, Álvaro Soto. El trabajo industrial en la España contemporánea (1874-1936). Barcelona: Anthropos, 1989.

CARONE, Edgard. Classes sociais e movimento operário. São Paulo: Editora Ática, 1989.

CARVALHO, José Murilo de (org.). História do Brasil Nação - A Construção Nacional (18301889). Rio de Janeiro: Editora Objetiva, 2012

CARVALHO, Lia; LOBO, Eulália \& STANLEY, Myrian. Questão habitacional e o movimento operário. Rio de Janeiro: Editora UFRJ, 1989.

CENNI, Franco. Italianos no Brasil: Andiamo in Merica. São Paulo: Edusp, 2003.

CHALOUB, Sidney. "Trabalho escravo e trabalho livre na cidade do Rio: vivência de libertos, galegos e mulheres pobres”. In: Revista Brasileira de História, v. 55, nº 8/9. São Paulo, 1985 Trabalho, lar \& botequim: o cotidiano dos trabalhadores no Rio de Janeiro da Belle Époque. $2^{a}$ edição. Campinas: Editora da Unicamp, 2001.

CLEMENCEAU, Georges. South America Today - A study of conditions, social, political and commercial in Argentina, Uruguay and Brazil. Londres: The Knickerbocker Press, 1911.

COLEÇÃO NOSSO SÉCULO - Volume I - 1900/1910 - A era dos bacharéis. São Paulo: Editora Abril Cultural, 1980.

CUNHA, Maria Clementina Pereira. Ecos da Folia - Uma História Social do Carnaval Carioca entre 1880 e 1920. São Paulo: Companhia das Letras, 2001.

DEAN, Warren. A industrialização de São Paulo (1880-1945). São Paulo: Difel, 1986.

DECCA, Edgar Salvadori de. O Nascimento das Fábricas. $10^{a}$ edição. São Paulo: Editora Brasiliense, 1996.

DELGADO, Lucília de Almeida Neves \& FERREIRA, Jorge (org.). O Brasil Republicano: o tempo do liberalismo excludente - da Proclamação da República à Revolução de 1930. $3^{a}$ edição. Rio de Janeiro: Civilização Brasileira, 2008.

DIMAS, Antônio. Bilac, o jornalista: crônicas - Volume 2. São Paulo: Edusp, 2006.

DINIZ, André. O Rio musical de Anacleto de Medeiros. A vida, a obra e o tempo de um mestre do choro. Rio de Janeiro: Jorge Zahar Editor, 2007.

EDMUNDO, Luiz. O Rio de Janeiro do meu tempo. Brasília: Edições do Senado Federal, 2003.

FARIA, Fernando Antônio. "Companhia Progresso Industrial do Brasil: empresa e empreendedores". In: História Revista - Revista da Faculdade de História e do Programa de PósGraduação em História da Universidade Federal de Goiás (Vol 4: Nos 1 e 2). Goiânia: Universidade Federal de Goiás, 1999. 
FAUSTO, Boris. Trabalho urbano e conflito social (1890-1920). São Paulo: Difel, 1977.

FILHO, Mário Rodrigues. O Negro no Futebol Brasileiro. $4^{a}$ edição. Rio de Janeiro: Editora Mauad, 2003.

FREIRE, Américo. Augusto de Vasconcellos, o Dr. Rapadura - Um estudo sobre liderança e negociação política na Capital Federal. Rio de Janeiro: Fundação Getúlio Vargas - Texto CPDOC $\mathrm{n}^{\mathrm{o}} 35,1999$.

FREITAS, Adriana Oliveira de. A Fábrica Bangu e a República nascente (1889-1914). Programa de pós-graduação em História do Centro de Ciências Humanas e Naturais da Universidade Federal do Espírito Santo (UFES), 2005.

FREYRE, Gilberto. Ordem e Progresso. $4^{a}$ edição. Rio de Janeiro: Editora Record, 1990. Ingleses no Brasil. Aspectos da influência britânica sobre a vida, a paisagem e a cultura do Brasil. $3^{a}$ edição. Rio de Janeiro: UniverCidade Editora, 2000.

GAZE FILHO, Humberto. Casino Bangu - Um século em revista (1892-1992). Rio de Janeiro: Síntese Propaganda, 1992.

GELADO, Viviana. Poéticas da transgressão - Vanguarda e cultura popular nos anos 20 na América Latina. São Carlos: EdUFSCar, 2006.

GERSON, Brasil. História das ruas do Rio. Rio de Janeiro: Livraria Brasiliana Editora, 1965.

GIANOTTI, Vito. Reconstruindo nossa história: 100 anos de luta operária no Brasil. Petrópolis: Editora Vozes, 1988 . História das lutas dos trabalhadores no Brasil. Rio de Janeiro: Mauad Editora, 2007.

GINZBURG, Carlo. A Micro-história e outros ensaios. Rio de Janeiro: Bertrand Brasil, 1989 Mitos, emblemas, sinais. São Paulo: Companhia das Letras, 2001.

GOHN, Maria da Glória. História dos movimentos e lutas sociais - A construção da cidadania dos brasileiros. São Paulo: Edições Loyola, 1995.

GOLDMACHER, Marcela. A greve geral de 1903 - o Rio de Janeiro nas décadas de 1890 a 1910. Programa de Pós-graduação em História da Universidade Federal Fluminense. Niterói, 2009.

GOMES, Ângela de Castro. Burguesia e trabalho - Política e legislação social no Brasil 19171937. Rio de Janeiro: Editora Campus, 1979.

"A guardiã da memória". In: Acervo - Revista do Arquivo Nacional, Rio de Janeiro, volume 9, nos 1 e 2, 1996.

A invenção do trabalhismo. $3^{\text {a }}$ edição. Rio de Janeiro: Editora FGV, 2005.

GONÇALEZ, Márcio Carbaca. Publicidade e Propaganda. Curitiba: IESDE Brasil S.A., 2009. 
GRAHAM, Richard. Grã-Bretanha e o início da modernização no Brasil. São Paulo: Editora Brasiliense, 1973.

GRANADO, Paschoal José. "Retratos, espelho da vida”. In: Bangu Notícias. Ano I - no 1 Novembro de 1970, p. 17.

“O primeiro e o mais". In: Revista Comemorativa do $70^{\circ}$ aniversário do Bangu A.C., Rio de Janeiro, abril de 1974. O alvorecer de Bangu. Rio de Janeiro: edição própria, 1997. Histórias e estórias de Bangu. Material avulso mimeografado, s. d. João Ferrer - momentos históricos, esforço bibliográfico. Rio de

Janeiro: s. d.

GUERRA, François Xavier (org.). Mémoires em Devenir. Amérique Latine XVI-XX siècle. Bordeaux: Maison des Pays Ibériques, 1994.

GUIMARÃES, Murillo. Uma rua chamada Ferrer. Rio de Janeiro: edição do autor, 1996.

HALL, Michael McDonald \& PINHEIRO, Paulo Sérgio. A classe operária no Brasil documentos (1889 a 1930). Volume I - O movimento operário. São Paulo: Editora Alfa Ômega, 1979.

HARDMAN, Foot Francisco \& LEONARDI, Victor. História da Indústria e do Trabalho no Brasil (das origens aos anos 20). $2^{a}$ edição. São Paulo: Editora Ática, 1991.

HEILBRON, Julio \& BARBOSA, Elmer Corrêa. CNI: 200 Anos de Indústria no Brasil. Rio de Janeiro: EMC Edições, 2008.

HERSCHMANN, Micael \& LERNER, Kátia. Lance de sorte: o futebol e o jogo do bicho na Belle Époque carioca. Rio de Janeiro: Diadorim, 1993.

HOLANDA, Sérgio Buarque de. Raízes do Brasil. São Paulo: Companhia das Letras, 2006

HUIZINGA, Johan. Homo Ludens. $4^{a}$ edição. São Paulo: Editora Perspectiva, 2000.

KELLER, Paulo Fernandes. Fábrica \& Vila Operária - A vida cotidiana dos operários têxteis em Paracambi-RJ. Engenheiro Paulo de Frontin: Editora Solon Ribeiro, 1997.

LANCELOTTI, Silvio. Olimpíada 100 anos - História Completa dos Jogos. São Paulo: Nova Cultural, 1996.

LEAL, Cláudia Feienrabend Baeta. "De primos, cunhados e anarquistas perigosos: repressão a imigrantes italianos (São Paulo, 1893)" In: HALL, Michael McDonald (org.). Cadernos Arquivo Edgard Leuenroth - Imigração, volume 15, $n^{\circ}$ 27. Campinas: UNICAMP/IFCH, 2009.

LE GOFF, Jacques. A História Nova. São Paulo: Editora Martins Fontes, 2005. História e Memória. $7^{a}$ edição. Campinas: Editora Unicamp, 2013.

LEOPOLDI, Maria Antonieta. Política e interesses na industrialização brasileira - as associações industriais, a política econômica e o Estado. São Paulo: Editora Paz e Terra, 2000. 
LETIERE, Róbson. Rio Bairros - Uma breve história dos bairros cariocas, de A a Z. Rio de Janeiro: edição própria do autor, 2013.

LEVI, Giovanni. A herança imaterial: trajetória de um exorcista no Piemonte do século XVII. Rio de Janeiro: Civilização Brasileira, 2000.

LEVY, Maria Bárbara. A indústria do Rio de Janeiro através de suas sociedades anônimas. Rio de Janeiro: Editora UFRJ, 1994.

LEVY, Maria Stella Ferreira. “O papel da migração internacional na evolução da população brasileira (1872 a 1972)”. In: Revista Saúde Pública, no 8. São Paulo, 1974.

LOBO, Eulália Maria Lahmeyer. História do Rio de Janeiro. Do Capital Comercial ao Capital Industrial e Financeiro. $2^{\circ}$ Volume. Rio de Janeiro: IBMEC, 1978.

(org.). Rio de Janeiro operário - natureza do Estado, conjuntura econômica, condições de vida e consciência de classe. Rio de Janeiro: Access Editora, 1992.

LOPREATO, Christina da Silva Roquette. O espírito da revolta - a greve geral anarquista de 1917. São Paulo: Annablume, 2000.

LUCA, Tania Regina de \& VIDAL, Laurent. Franceses no Brasil-séculos XIX-XX. São Paulo: Editora UNESP, 2009.

LUZ, Nícia Vilela. A luta pela industrialização no Brasil. São Paulo: Difel, 1981

MARAM, Sheldon Leslie. Anarquistas, imigrantes e o movimento operário brasileiro. Rio de Janeiro: Paz e Terra, 1979.

MARQUES, Teresa Cristina de Novaes \& MELO, Hildete Pereira de. "Imigrantes portugueses no Brasil a partir dos recenseamentos populacionais do século XX: um estudo exploratório de gênero" In: Revista Gênero, volume 9, nº 1. Niterói, 2008

MARTINEZ, Pedro Romano. Código do Trabalho - $3^{a}$ edição. Estoril: Principia Editora, 2006.

MATTOS, Hebe. "História Social”. In: CARDOSO, Ciro Flamarion \& VAINFAS, Ronaldo. Domínios da História: Ensaios da Teoria e Metodologia. Rio de Janeiro: Editora Campus, 1997.

MAUAD, Ana Maria. “Através da imagem: fotografia e história interfaces”. In: Revista Tempo - volume 1, no 2. Rio de Janeiro, 1996.

MENDES JR., Leonardo \& ROSSI, Jones. Guia politicamente incorreto do futebol. São Paulo: Leya, 2014.

MENEZES, Lená Medeiros. "Os processos de expulsão como fontes para a história da imigração portuguesa no Rio de Janeiro (1907-1930)”. In: MARTINS, Ismênia de Lima \& SOUSA, Fernando. Portugueses no Brasil: migrantes em dois atos. Niterói: Muiraquitã, 2006.

MOLINARI, Carlos. Almanaque do Bangu. Brasília: Editora Kiron, 2011. 
MONTEIRO, Ana Maria Ferreira. Empreendedores e investidores em indústria têxtil no Rio de Janeiro (1878-1895): uma contribuição para o estudo do capitalismo no Brasil. Niterói: Universidade Federal Fluminense, 1985.

MORAES, Evaristo de. Memorial Pró-João Ferrer - Apelação Criminal no 912 ao Ex. Sr. Ministro André Cavalcanti. Rio de Janeiro: Tipografia Leuzinger, 1923.

NAVA, Pedro. Chão de ferro. São Paulo: Ateliê Editorial, 2001.

NÉBIAS, Wellington Barbosa. A greve geral e a insurreição anarquista de 1918 no Rio de Janeiro: um resgate da atuação das associações de trabalhadores. Instituto de Filosofia e Ciências Sociais (IFCS) da Universidade Federal do Rio de Janeiro (UFRJ), 2009.

NEIRA, Luz Garcia \& WAIN, Sarah. Teaching arts and crafts or the technology transfer: Ernest Bower and textile design practice in Brazil. São Paulo: Editora Edgard Blucher, 2012.

NETO, Lira. Getúlio - Dos anos de formação à conquista do poder (1882-1930). São Paulo: Companhia das Letras, 2012. . Getúlio - Da volta pela consagração popular ao suicídio (1945-1954). São Paulo: Companhia das Letras, 2014.

NIVEN, Thomas Eric. East Kilbride: the history of parish and village. Escócia: Wilson, Guthrie and Lang, 1965.

OLIVEIRA, Luís Henrique de. "Dos Annales à Micro-História: alguns apontamentos sobre os avanços da História Social”. In: Revista Virtú, Instituto de Ciências Humanas (ICH) da Universidade Federal de Juiz de Fora (UFJF) - $1^{\mathrm{a}}$ edição, 2005.

OLIVEIRA, Márcio Piñon de. Bangu: de fábrica-fazenda e cidade-fábrica a mais uma fábrica da cidade. Instituto de Pesquisa e Planejamento Urbano e Regional (IPPUR) da Universidade Federal do Rio de Janeiro (UFRJ), 1991.

ORGANIZAÇÃO INTERNACIONAL DO TRABALHO. Combatendo o trabalho infantil Guia pra educadores. Brasília: IPEC, 2001.

PEREIRA, Leonardo Affonso de Miranda. Footballmania: uma História Social do Futebol no Rio de Janeiro (1902-1938). Rio de Janeiro: Editora Nova Fronteira, 2000.

PEREIRA, Margareth da Silva (org.). 1908 - Um Brasil em exposição. Brasília: Casa Doze, 2011.

PORTO, Walter Costa. Dicionário do voto $-3^{a}$ edição revista e atualizada. Rio de Janeiro: Lexicon, 2013.

PRIORE, Mary del. Do outro lado - A história do sobrenatural e do espiritismo. São Paulo: Editora Planeta, 2014.

QUEIRÓS, Eça de. Obra completa - volume 3. Rio de Janeiro: Editora Nova Aguilar, 2000. 
RABAÇA, Silvio. De pai para filho: imigrantes portugueses no Rio de Janeiro. Rio de Janeiro: Documenta Histórica, 2010.

RAGO, Margareth. Do cabaré ao lar, a utopia da cidade disciplinar e a resistência anarquistaBrasil 1890-1930. $4^{a}$ edição. São Paulo: Editora Paz e Terra, 2014.

RECENSEAMENTO Geral da República dos Estados Unidos do Brasil em 31 de dezembro de 1890 - sexo, raça, estado civil, nacionalidade, filiação, culto e analfabetismo. Rio de Janeiro: Officina da Estatística, 1898.

RECENSEAMENTO DE 1920 - $4^{\circ}$ Censo geral da população do Brazil, $1^{\circ}$ da agricultura e das indústrias e $11^{\circ}$ da população da cidade do Rio de Janeiro (Districto Federal). Rio de Janeiro: Typographia da Estatística, 1926.

REVEL, Jacques (org.). Jogos de Escalas - A experiência da microanálise. Rio de Janeiro: Editora Fundação Getúlio Vargas, 1998.

RIBEIRO, Maria Alice Rosa. Condições de trabalho na indústria têxtil paulista (1870-1930). Campinas: Editora da Unicamp, 1988.

RODRIGUEZ, Hélio Suêvo. A formação das estradas de ferro no Rio de Janeiro - o resgate da sua memória. Rio de Janeiro: Memória do Trem, 2004.

SANTOS, Joel Rufino dos. História política do futebol brasileiro. São Paulo: Editora Brasiliense, 1981.

SANTOS, Ricardo Pinto dos. Entre rivais - Futebol, racismo e modernidade no Rio de Janeiro e em Buenos Aires (1897-1924). Rio de Janeiro: Editora Mauad X, 2012.

SANTOS Jr., Nei Jorge dos. A construção do sentimento local: o futebol nos arredores de Bangu e Andaraí (1914-1923). Rio de Janeiro: Editora Multifoco, 2014.

SÁ PINTO, Surama Conde. Só para iniciados - o jogo político na antiga Capital Federal. Rio de Janeiro: Mauad Editora, 2011.

SCHULZ, John. O Exército na Política - origens da intervenção militar (1850-1894). São Paulo: EdUSP, 1994.

SCHWARCZ, Lilia Moritz (org.). História do Brasil Nação - A Abertura para o Mundo (18891930). Rio de Janeiro: Editora Objetiva, 2012.

\& STARLING, Heloísa Murgel. Brasil: uma biografia. São Paulo:

Companhia das Letras, 2015.

SENRA, Nelson de Castro. O Censo de 1906 do Rio de Janeiro. Rio de Janeiro: Publicações Pereira Passos, 2012.

SEVCENKO, Nicolau (org.). História da Vida Privada no Brasil-República: Da Belle Époque à Era do Rádio. São Paulo: Companhia das Letras, 1998. 
SILVA, Alberto da Costa e (org.). História do Brasil Nação - Crise colonial e independência (1808-1830). Rio de Janeiro: Editora Objetiva, 2011.

SILVA, Gracilda Alves de Azevedo. Bangu - a fábrica e o bairro: um estudo histórico, 18891930. Instituto de Filosofia e Ciências Sociais (IFCS) da Universidade Federal do Rio de Janeiro (UFRJ), 1985.

Bangu 100 anos: a fábrica e o bairro. Rio de Janeiro: Sabiá

Produções Artísticas, 1989.

STEIN, Stanley Julian. Origens e Evolução da Indústria Têxtil no Brasil, 1850-1950. Rio de Janeiro: Editora Campos, 1979.

STONE, Lawrence. "Proposografia". In: Revista de Sociologia e Política, volume 19, n 39, junho de 2011.

SUZIGAN, Wilson. Indústria brasileira: origem e desenvolvimento. São Paulo: Editora Brasiliense, 1986.

THOMPSON, Edward Palmer. A Formação da Classe Operária Inglesa. Volume II - A maldição de Adão. São Paulo: Editora Paz e Terra, 2012.

TOLEDO, Roberto Pompeu de. A capital da vertigem - Uma história de São Paulo de 1900 a 1954. Rio de Janeiro: Objetiva, 2015.

URBIM, Carlos. Zamprogna: a história da imigração italiana e a industrialização no Rio Grande do Sul. Porto Alegre: Nova Prova Editora, 2009.

VASCONCELOS, José Mauro de. O meu pé de laranja lima. $3^{a}$ edição; $22^{a}$ impressão. São Paulo: Editora Melhoramentos, 2009.

VEIGA. José Eli da. O Desenvolvimento Agrícola: uma Visão Histórica. São Paulo: EdUSP, 2007.

WEID, Elisabeth von der. A indústria têxtil no Brasil. Estudo de caso de uma empresa do Rio de Janeiro. Fontes documentais. Rio de Janeiro: Editora Fundação Casa de Rui Barbosa, 1995.

WRIGHT, Arnold. Impressões do Brazil no Século Vinte - Sua História, seo povo, commercio, indústrias e recursos. Londres: Lloyd’s Greater Britain Publishing Company Ltd., 1913. 


\section{Declaração de Autenticidade}

“Eu, Carlos Molinari Rodrigues Severino, declaro para todos os efeitos que o trabalho de conclusão de curso intitulado "Mestres estrangeiros; operariado nacional: resistências e derrotas no cotidiano da maior fábrica têxtil do Rio de Janeiro (1890 - 1920)" foi integralmente por mim redigido, e que assinalei devidamente todas as referências a textos, ideias e interpretações de outros autores. Declaro ainda que o trabalho é inédito e que nunca foi apresentado a outro departamento e/ou universidade para fins de obtenção de grau acadêmico, nem foi publicado integralmente em qualquer idioma ou formato". 